\author{
UNIVERSIDADE DE SÃO PAULO \\ FACULDADE DE ARQUITETURA E URBANISMO
}

Philippe Arthur dos Reis

Canstruir, marar e viver para além da centra de Sãa Paula: as setares médias entre a urleanizaçãa e as relaçães saciais da Brás (1870-1915)

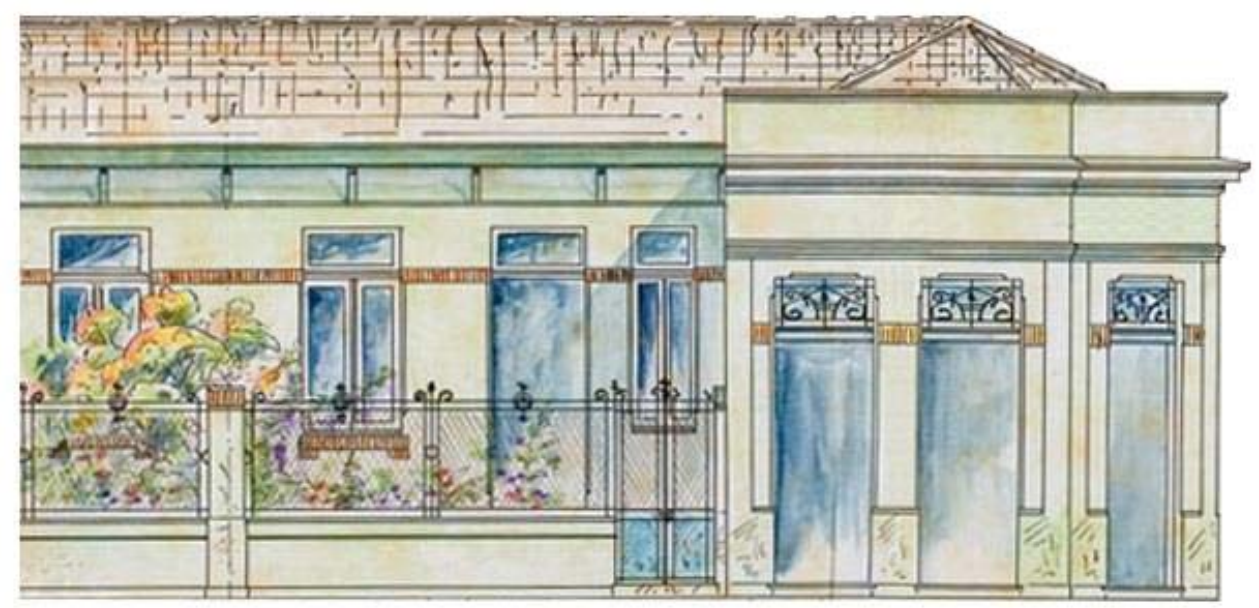

São Paulo, maio de 2017. 


\section{UNIVERSIDADE DE SÃO PAULO \\ FACULDADE DE ARQUITETURA E URBANISMO}

Philippe Arthur dos Reis

Construir, morar e viver para além do centro de São Paulo: os setores médios entre a urbanização e as relações sociais do Brás

(1870-1915)

Dissertação de Mestrado apresentada ao

Programa de Pós-Graduação da

Faculdade de Arquitetura e Urbanismo da Universidade de São Paulo como parte dos requisitos necessários à obtenção do título de Mestre em Arquitetura e Urbanismo.

Área de Concentração: História e Fundamentos da Arquitetura e do Urbanismo

Orientadora: Prof ${ }^{\mathrm{a}}$ Dra. Beatriz Piccolotto Siqueira Bueno

\section{EXEMPLAR REVISADO E ALTERADO EM RELAÇÃO À VERSÃO ORIGINAL, SOB RESPONSABILIDADE DO AUTOR E ANUENCIA DO ORIENTADOR.}

$\mathrm{O}$ original se encontra disponível na sede do programa

São Paulo, 07 de junho de 2017. 
Autorizo a reprodução e divulgação total ou parcial deste trabalho, por qualquer meio convencional ou eletrônico, para fins de estudo e pesquisa, desde que citada a fonte.

Catalogação na Publicação Serviço Técnico de Biblioteca

Faculdade de Arquitetura e Urbanismo da Universidade de São Paulo

Reis, Philippe Arthur dos
R375c Construir, morar e viver para além do centro de São Paulo: Os setores médios entre a urbanização e as relações sociais do Brás (1870-1915) / Philippe Arthur dos Reis ; orientadora Beatriz Piccolotto Siqueira Bueno. - São Paulo, 2017. $383 \mathrm{p}$.

Dissertação (Mestrado) - Faculdade de Arquitetura e Urbanismo da Universidade de São Paulo. Área de concentração: História e Fundamentos da Arquitetura e Urbanismo

1. História Urbana. 2. Urbanização. 3. Arquitetura. 4. Setores Médios. 5. São Paulo. 6. Brás. 7. Zona Leste. I. Bueno, Beatriz Piccolotto Siqueira, orient. II. Título. 
Aos movimentos sociais que lutam por uma cidade mais igualitária.

À minha família e meus amigos que regem a sinfonia que é a minha vida. 


\section{Agradecimentas}

Este trabalho é fruto de um intenso trabalho que envolveu indiretamente inúmeras pessoas, as quais o enriqueceram com debates, indicação de caminhos, disponibilização de materiais, apoio financeiro e emocional. Sem todo este processo, este trabalho não teria nascido, e assim, agradeço aos anônimos que contribuíram para a realização desta dissertação.

Agradeço à Coordenação de Aperfeiçoamento de Pessoal de Nível Superior CAPES - pelo apoio financeiro, sem o qual essa empreitada não teria sido realizada, ainda mais neste período turbulento ao qual vivemos, de golpes em nosso processo democrático, e de cortes nos setores educacionais de nosso país, além do desmonte do Estado social que sobreviveu até aqui.

À minha orientadora, Beatriz Bueno, que foi peça inestimável para que tudo isso se concretizasse, desde os tempos de trabalho no Arquivo Histórico Municipal, que com elegância e firmeza me ajudou a caminhar por entre os caminhos da história da urbanização, indicando bibliografia, possibilidades de leitura documental, e sempre aberta ao diálogo para que esse trabalho fosse concretizado.

Agradeço às professoras Maria Luiza Ferreira de Oliveira e Maria Lúcia Caira Gitahy pelas valiosas contribuições advindas com o exame de qualificação, que sem as quais muito do que apresentamos não teria sido realizado. Agradeço também ao professor Paulo César Garcez Marins, que com suas aulas e conversas um leque de História se abriu; à professora Flavia Brito do Nascimento que acompanhou parte deste trabalho e foi peça importante na minha formação; aos professores de minha banca de defesa, o professor Fernando Atique, que além de mestre no ensinar, foi uma pessoa que teve um grande papel em minha trajetória acadêmica desde a graduação, e à professora Cristina Campos, pelas indicações bibliográficas e pelo debate em torno do higienismo sanitário. Não posso deixar de estender meus sinceros agradecimentos aos professores José Lira e Fábio Marins, sobretudo nos momentos a que precisei recorrer. 
Agradeço aos professores Luís Ferla e Janes Jorge do grupo HÍMACO pela cessão dos vetores para confecção dos mapas finais deste trabalho. Ao professor Jaime Rodrigues, que despertou em mim muitas das inquietações enquanto historiador, orientando caminhos desde a graduação. Meu agradecimento sem medidas à todas as funcionárias e funcionários dos acervos e arquivos pesquisados: Arquivo Público do Estado de São Paulo; Faculdade de Arquitetura e Urbanismo da Universidade de São Paulo (em especial à Ivany e à Dina); Faculdade de Filosofia, Letras e Ciências Humanas da Universidade de São Paulo; ao Museu da Cidade de São Paulo; ao Museu Paulista (e em especial à Flávia); à Biblioteca Pública Mário de Andrade (no qual muito agradeço à Norma); aos funcionários da Biblioteca e Acervo da Câmara dos Vereadores de São Paulo, muito obrigado pela disponibilização das atas legislativas.

Um agradecimento especial a todos aqueles que trabalham no Arquivo Histórico Municipal. Nesta instituição dei meus primeiros passos enquanto historiador, e pude conhecer in loco o processamento técnico e arquivístico do tratamento documental, sobretudo com a Cidinha e Marlene. À Vera e Helenice, pessoas dispostas a me ajudar no que fosse (im)possível, são um exemplo do profissionalismo do atendimento público. Agradeço sobremaneira à uma pessoa que foi peça fundamental na coleta bibliográfica, de materiais, informações e intercâmbio com outros pesquisadores: Tomico! Sem ela, muito do que aqui se coletou não teria vindo, e eu sou grato pela disposição com que teve ao me auxiliar neste processo.

Meus agradecimentos e abraços aos meus amigos e colegas pós-graduandos, Diego Becker, Hennan Gessi, Diógenes Sousa, Leonardo Novo, Monique Borin, Paola Pascoal, Michele Dias, Paula Broda, Sheila Schnek e Lindener Pareto. À Maíra Rosin, meus agradecimentos pelas conversas e ter participado de algumas das indagações deste trabalho, além de caminhar comigo nos processos de confecção dos mapas. À Renata Geraissati minha gratidão pelas conversas sobre história de São Paulo, e ser a amiga que é, atenciosa, objetiva e com um grande coração. Estendo meus agradecimentos aos meus amigos e colegas historiadores: Vanessa Lima, Lucas Florêncio, Carlos Moura, Raíssa Marcondes e Janaína Lopes.

Ao Fabio Donato pela entrevista e pela disponibilização do material para consulta sobre a antiga Confeitaria Guarany. 
Meus agradecimentos ao Gabriel Toledo, especialmente pelo auxílio no processo de confecção das fachadas dos imóveis do Brás.

Ao Bryan Pitts pelas conversas historiográficas à distância.

Ao Joshua Dowling pela amizade e companheirismo mesmo que longe.

Às minhas amigas e amigos da Escola Estadual Carlos Gomes, espaço que aprendi e vivenciei o campo da Educação, em especial à Lorena Freitas, Rafael D’avilla, Josafá Crisóstomo, Willian Fernandes, Robéria Freitas, Camila Freitas, Elaine Dias e Cintia Oliveira. Não menos importante, estendo minha gratidão às minhas alunas e alunos desta escola.

À Fernanda Sueni, amiga para todas as horas e momentos, sempre pronta para ouvir, e que nos acalma em momentos de aflição. Da mesma forma, agradeço aos meus queridos amigos Edilson Cruz, Alex Fessel e Bruno Freitas pelo companheirismo e partilharem de muitas das emoções do "longo ano" de 2016.

A todos participantes e envolvidos do projeto Passeando pelas Ruas: Histórias do meu bairro e da minha cidade que proporcionam longos debates e aprofundamentos sobre o patrimônio cultural paulistano, em especial à Yasmin Darwich, que me auxiliou em diversas questões conceituais do campo da Arquitetura e Urbanismo, e hoje partilhamos de uma amizade que extrapola as discussões do patrimônio cultural.

$\mathrm{Na}$ mesma medida estendo um sincero agradecimento ao Escritório DBM\&F Advogados pelo apoio recebido em questões pessoais, e que influíram sobre a produção deste trabalho.

E por fim, mas não menos importante, à minha família. Sem ela, este trabalho não teria sido concretizado e levado até o final. Foram as conversas, partilhas de angústias e desesperos e muito amor que me revestiram durante essa trajetória. Aos meus avós, Etelvina e José Cardoso de Almeida (também conhecido como seu Salim osodrac), pessoas brilhantes e que me ensinaram o quanto a vida é bela nos momentos mais simples do cotidiano. Aos meus irmãos, pela diversão e apoio em momentos cruciais deste trabalho: À Paloma e Paola que foram peças fundamentais desse quebra cabeça; Ao Pablo pelas idas e vindas e encontros no metrô. Às pequenas Pietra e Pérola por serem a alegria e o amor que revestem a família. 
Aos meus pais eu não tenho palavras para descrever o quanto foram primordiais no processo de constituição desse trabalho. Foram os conselhos, conversas, diálogos e entusiasmo deles que me proporcionaram forças para que prosseguisse adiante, mesmo com todos os percalços e dificuldades vivenciadas. Meu pai, Paulo, figura ímpar da família, que sabe na prática o que é o "construir a cidade", e minha mãe, Márcia, figura do laço e do companheirismo, sempre pronta para me ouvir e partilhar emoções.

A todas e todos, muito obrigado! 
É necessário examinar os pormenores mais negligenciáveis

(GINZBURG, 1989, pág. 144). 


\section{Resuma}

Desde finais do século XIX São Paulo vivenciou um intenso processo de mudanças, atreladas à transição da mão de obra escrava para a livre, o incentivo à imigração, a Proclamação da República, e a disponibilidade de capitais oriundos da riqueza gerada pelo café, o que permitiu sua expansão para outras áreas além do "Triângulo". Chácaras foram loteadas, novas ruas foram abertas, as ações governamentais que regulavam a cidade aprimoravam-se, e uma série de diferentes atores sociais entraram em cena, produzindo e vivenciando novos bairros. É a partir dessa perspectiva que o bairro do Brás surge.

Procuramos estudar o bairro do Brás reconstituindo sua materialidade entre os anos de 1870 a 1915, com atenção ao seu processo de feitura, e principalmente aos seus agentes produtores, pondo luz especialmente nos setores médios que também envolveram-se na produção das cidades. Ao entrecruzarmos diferentes fontes, podemos imaginar os personagens e seus cenários de ação no passado, essencialmente a materialidade dos imóveis construídos, suas tipologias, seus programas edilícios, entrevendo alguns dos seus usos em seus respectivos endereços.

Analisando a Série Obras Particulares do Arquivo Histórico de São Paulo, juntamente a cartografia, fotografias e outras fontes, podemos vislumbrar quem seriam os proprietários e construtores desses imóveis, bem como os agentes públicos que estiveram debruçados sobre cada pedido de construção solicitada à Prefeitura Municipal, ampliando a compreensão sobre o processo de urbanização do bairro atrelado às próprias mudanças que a cidade de São Paulo estava vivenciando.

Palavras chave: História urbana; Urbanização; Arquitetura; Setores médios; São Paulo; Brás; História Social, Sociabilidade. 


\section{Alestract}

At the close of the 19th century, São Paulo underwent intense changes as a result of the transition from slave labor to free, state-sponsored immigration, the overthrow of Brazil's empire and establishment of a republic, and increased capital availability due to the wealth generated by coffee production. These transformations allowed the city to urbanize beyond the historic "Triangle" that had been its center since the colonial era. Farms were divided into lots, new streets were laid out, government regulation was improved, and new social actors appeared on the scene. It was in this context that the neighborhood of Brás, so important to São Paulo's industrialization, was born.

This study reconstructs the materiality of the construction of the neighborhood of Brás between 1870 and 1915. It focuses on the human agents who produced the neighborhood, especially the role of the middle classes, who were also involving themselves in the production of cities. By placing a variety of sources in dialogue with one another, it enables us to imagine us a series of characters and the stage they built as they played their roles on it - the materiality of the buildings, their typologies, and their blueprints, envisioning, albeit imperfectly, some of the uses to which they were put.

By analyzing the Obras Particulares series from the Historical Municipal Archive of São Paulo, along with cartography, photographs, and other sources, we can catch a glimpse of the buildings' owners and constructors, along with civil servants as they leaned over each request for a building permit submitted to the city government. In so doing, this study enhances our understanding of Brás's urbanization, linking it to the broader processes of change that the city of São Paulo was experiencing.

Keywords: Urban history; Urbanization; Architecture; Middle classes; São Paulo; Brás; Social History; Sociability 


\title{
Aceruas e instituiçães pesquisadas
}

\author{
Acervo Fábio Donatto \\ Arquivo do Estado de São Paulo \\ Biblioteca do Arquivo Histórico Municipal \\ Biblioteca e Acervo da Câmara dos Vereadores de São Paulo \\ Biblioteca Digital Luso Brasileira - Biblioteca Nacional \\ Biblioteca Pública Mário de Andrade \\ Faculdade de Arquitetura e Urbanismo da Universidade de São Paulo \\ Faculdade de Economia, Administração e Contabilidade da Universidade de São Paulo \\ Faculdade de Filosofia, Letras e Ciências Humanas \\ Fundação Seade \\ Hemeroteca Digital Nacional - Biblioteca Nacional \\ Seção de Manuscritos do Arquivo Histórico Municipal \\ Museu da Cidade de São Paulo \\ Museu Paulista, Universidade de São Paulo
}




\section{Lista de Figuras}

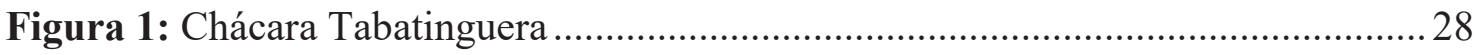

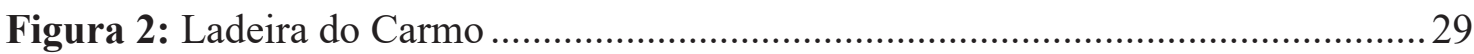

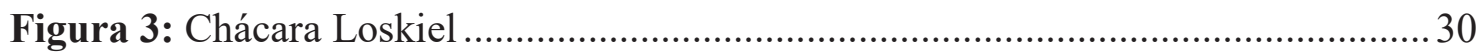

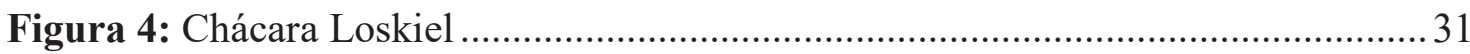

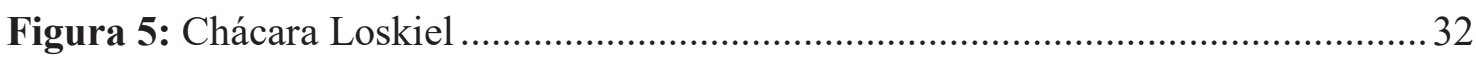

Figura 6: Anúncio do jornal Correio Paulistano sobre o Colégio

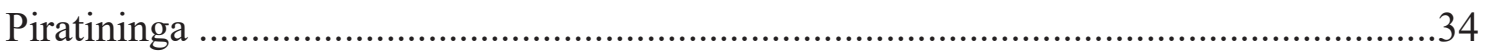

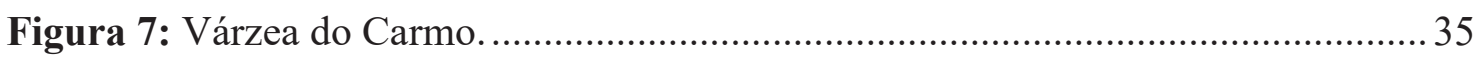

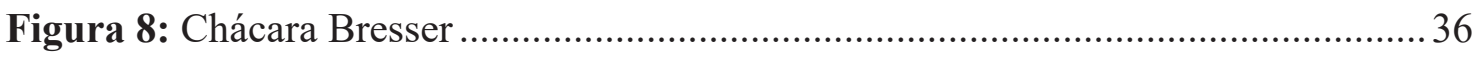

Figura 9: Anúncio do jornal Correio Paulistano ...................................................... 41

Figura 10: Anúncio do jornal Correio Paulistano ..................................................... 51

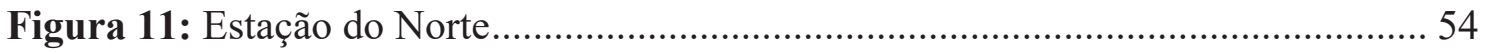

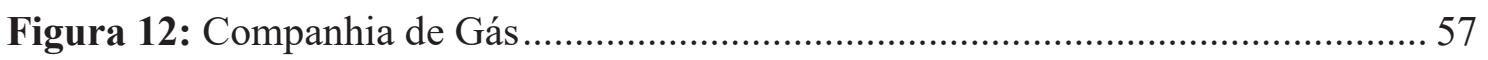

Figura 13: Uma das propriedades de Francisco Sampaio Moreira ..............................59

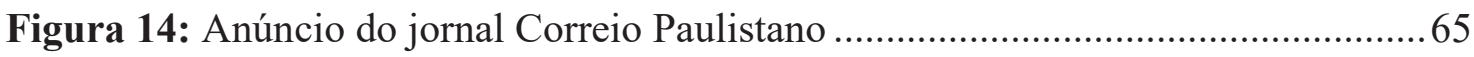

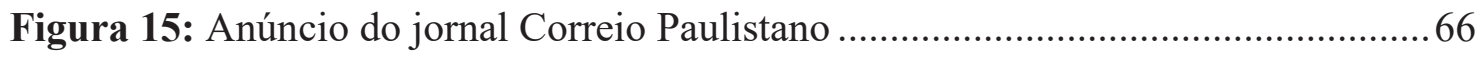

Figura 16: Anúncio do jornal Correio Paulistano .........................................................66

Figura 17: "Casas operarias. Herdeiros de Carlos de Campos"- Rua Jutahy, atual rua 
Figura 18: "Planta do terreno onde deverão ser construídas as casas operarias conforme autorizado pela Prefeitura Municipal”, Rua Jutahy

Figura 19: "Projecto de uma pequena casinha no terreno da rua Uruguayana $n^{\circ} 93$ de propriedade de Jm. Carlos Augusto Cavalheiro" 68

Figura 20: "Projecto de construção de uma casinha a edificar-se na rua Uruguayana junto a casa $n^{\circ} 46$ de propriedade de Jm, Carlos Augusto Cavalheiro" .68

Figura 21: "Projecto de construcção de uma casa a rua Uruguayana $\mathrm{n}^{\mathrm{o}}$, um augmento no barracão do fundo do terreno $\mathrm{p}^{\mathrm{a}}$ uma fabrica de carroças de propriedade de $\mathrm{D}^{\mathrm{a}}$ Ernestina Cavalheiro Ferreira." 68

Figura 22: "Projecto de uma cocheira $\mathrm{p}^{\mathrm{a}}$ um cavalo de (...) a edificar-se no terreno do fundo da casa da rua Uruguayana de propriedade de Jm. Carlos A. Cavalheiro” 68

Figura 23: "Projecto de um augmento a fazer-se no puchado da casa de $n^{0} 57$ da rua Uruguaya aygmentando banheiro e quarto, de propriedade de Jm. Carlos Augusto Cavalheiro"

Figura 24: "Projecto de uma modificação a fazer-se no puchado da casa $n^{0} 59$ da rua Uruguayana de cosinha e dispensa (...) banheiro e cosinha de propriedade de Jm. Carlos Augusto Cavalheiro" 69

Figura 25: Monumento à Celso Garcia, Lorenzo Petrucci .73

Figuras 26, 27 e 28: Herma de Celso Garcia; "Homenagem de amigos e sociedades operárias"; na lateral direita do busto a identificação de "L. Petrucci" .73

Figura 29: Estação do Norte. 102

Foto 30: Várzea do Carmo, 1887 103

Foto 31: Várzea do Carmo, 1887 104

Figura 32: Várzea do Carmo, 1916 104

Figura 33: Várzea do Carmo, 1919 105 
Figura 35: Várzea do Carmo, 1919 106

Figura 36: Largo do Brás, 1862 107

Figura 37: Largo do Brás, 1887 108

Figura 38: Largo do Brás, 1914 108

Figura 39: Igreja do Senhor Bom Jesus, 1920 109

Figura 40: Largo do Brás, 1914 109

Figura 41: Rua Visconde de Parnaíba [e a entrada da Hospedaria dos Imigrantes], 19001930 110

Figura 42: Área a ser desapropriada entre o beco do Lucas e a rua Assunção. 111

Figura 43: "Propriedade de Abel Augusto Salles", rua Almirante Barroso, s/n 126

Figura 44: "Propriedade de Miguel d'Elia" 131

Figura 45: "Antonio Regas" 134

Figura 46: "Propriedade de Francisco Guedes". 140

Figura 47: "Rua Visconde de Parnaíba n 592”, Benedito J. Duarte, 1939 143

Figura 48: "Rua Visconde de Parnaíba no 592”, Benedito J. Duarte, 1939 143

Figura 49: "Rua Visconde de Parnaíba no 592”, Benedito J. Duarte, 1939 144

Figura 50: "Rua Visconde de Parnaíba n ${ }^{\circ}$ 592", Benedito J. Duarte, 1939 144

Figura 51: "Rua Visconde de Parnaíba no 592”, Benedito J. Duarte, 1939 145

Figura 52: "Rua Carneiro Leão", Benedito Junqueira Duarte, 1929 147 
Figura 53: "Rua Carneiro Leão", Sebastião de Assis Ferreira, 1942. .148

Figura 54: "Rua Carneiro Leão", Sebastião de Assis Ferreira, 1942. .149

Foto 55: "Rua Carneiro Leão", Sebastião de Assis Ferreira, 1942. 150

Foto 56: "Rua Carneiro Leão", Sebastião de Assis Ferreira, 1942. 151

Foto 57: "Rua Carneiro Leão", Sebastião de Assis Ferreira, 1942. 152

Figura 58: "Projecto de uma casa para Trabalhadores", rua Azevedo Junior, entre os números 9 e 11 154

Figura 59: "Projecto para construcção de 2 casas operarias nos fundos do terreno sito á rua Barão de Ladário n $18 \mathrm{C}$ para o Sr. Pedro Gomes da Silva" 154

Figura 60: "Construcção de duas casas de Operarios de propriedade do Sr. Luiz Golfieri. Travessa Joly (Braz)" 156

Figura 61: Conjunto de "11 casas operarias" a serem construídas na rua Visconde de Parnaíba número 377. 156

Figura 62: "Projecto de 1 casa para empregado na fabrica do Belenzinho", situada na Avenida Celso Garcia, 499. 157

Figura 63: "Projecto para transformar uma cocheira em uma casa de operário, levantando as paredes na altura que manda o Padrão, de propriedade do Snr. Servulo Gonçalves Junior" 157

Figura 64: "Propriedade de José Sehiafoni”, rua Miler sem número. 159

Figura 65: "Planta de casinha a construir sobre o terreno pertencente ao Snr. Frederico Fortunato", rua Miler número186. .159

Figura 66: "Propriedade de Alexandre Barbosa", rua da Concórdia número 50. 160

Figura 67: "Propriedade de José Casagrande", rua Gomes Cardim número 67 .160

Figura 68: "Propriedade de Luiz Fraga", rua Elisa Whitaker número 458. 161 
Figura 69: "Projecto de uma modificação a faserse na casa $n^{\circ} 178$ da rua do Gasometro. .162

Figura 70: Projeto de construção de uma cocheira de Cesario Magri, na rua Claudino Pinto número 8.

Figura 71: "Propriedade de Cesari Magri”, rua Claudino Pinto número 8. 163

Figura 72: "Propriedade da Snra. D. Geltrudes de Andrade Alves", rua Uruguaiana número 36. 165

Figura 73: "Propriedade de João Bernardi”, rua Américo Brasiliense número 66. 165

Figura 74: "Propriedade de Luigi Baldi”, rua Américo Brasiliense número 69. 166

Figura 75: "Propriedade de Ernesto Venturini”, rua Maria Marcolina número 120... 166

Figura 76: "Manoel José de Freitas Rua Mixta, 42, canto Barão de Ladário" 169

Figura 77: “Propriedade do Sr. José Rodrigues”, rua Miler número 48. 169

Figura 78: "Projecto de casa para o Sr. J. Lopes de Figueiredo à rua Chavantes, 36 tinta" 158

Figura 79: "Casa de propriedade do Illmo. Snr. Dario Balthar”, rua Santa Rosa número 24 . 158

Figura 80: "Projecto de casas operárias para a C. N. de Tecidos de Juta". 175

Figura 81: "Projecto de casas operárias para a C. N. de Tecidos de Juta".... 175

Figura 82: Localização da Vila Operária da Companhia Nacional de Tecidos de Juta entre as ruas Conselheiro Belisário e Barão de Ladário, defronte ao conjunto fabril...176 Figura 83: "Villa Operaria do Snr. Costabile Matarazzo" 177

Figura 84: "Projecto de Villa Operaria de Propriedade do Snr. João Ferreira". 178

Figura 85: Conjunto de residências da antiga Vila Operária de João Ferreira, na atual rua 
Vieira Martins, entre a rua Bresser e Inácio de Araújo.

Figura 86: "Projecto de Villa para o Snr. Abel A. Salles" 179

Figura 87: "Projecto para construcção de 3 casas á rua Almirante barroso junto ao $\mathrm{N}^{\circ} 84$ tinta e mais 5 casas nos fundos do mesmo terreno para o Exmo. Snr. Dr. José Antonio Nogueira" 180

Figura 88: "Propriedade do Snr. José Giaffoni" 181

Figura 89: "Projecto para construcção de uma vila nos fundos do terreno sito à rua Almirante Barozo $n^{\circ}$ junto ao 84 e 2 garages na frente 181

Figura 90: "Propriedade de Paschoal Diorio" 182

Figura 91: "Propriedade de Manoel de Souza Costa" 182

Figura 92: "Propriedade da Illma Sra. Lydia Augusta Saraiva" 183

Figura 93: "Propriedade do Snr. Álvaro Ramos" 183

Figura 94: "Alipio Henrique de Souza" 185

Figura 95: Propriedade do Snr. Alipio Henrique de Souza. 186

Figura 96: "Propriedade do Snr. Albino de Moraes" 186

Figura 97: "Propriedade do Snr. João Cupertino" 187

Figura 98: "Projecto de 5 casas para o Snr. João Ferreira". 188

Figura 99: "Antonio M. Sobrinho" 188

Figura 100: "Proprietario Snr. João Bento Collaço" 189

Figura 101: Projeto de 10 casas com um forno 190

Figura 102: "Propriedade do Snr. José Maria Duarte" 190 
Figura 103: "Planta para 4 casas de moradia" 191

Figura 104: "Projecto de Três Casas e um Armazém" 192

Figura 105: "Propriedade de Arthur Wrigg". 193

Figura 106: "Propriedade do Snr. Francisco Marengo" 194

Figura 107: "Casas Bolognani”. 195

Figura 108: "Construcção de uma casa dupla na rua Bresser n ${ }^{\circ}$ 145, de propriedade da Sra. Filomena Gozza". 197

Figura 109: "Propriedade do Snr. Nicola Gambini" 197

Figura 110: Casa com jardim 198

Figura 111: "Propriedade do Exm. Snr. Ismael Bresser" 199

Figura 112: "Propriedade do Exmo. Dr. Ismael Bresser" 199

Figura 113: "Propriedade do Comendador José Monteiro Pinheiro" .200

Figura 114: "Casa a construir-se para o Exmo. Sig. Comm. José Monteiro Pinheiro" 201

Figura 115: Casa a construir-se para o Exmo. Sig. Comm. José Monteiro Pinheiro" 201

Figura 116: "Propriedade do Snr. José Senna" .202

Figura 117: "Casa de propriedade do Snr. Jacomo Coletti” .203

Figura 118: "Projecto d'uma habitação que o Snr. Natal Boni pretende mandar construir na rua Bresser n ${ }^{\circ} 423$ ” 203

Figura119: Projecto para construcção de uma casa ................................................206

Figura 120: Projecto para Snr. Felice Mollica 207 
Figura 121: Projecto para a Snra. Ambrosina Amalia Franco de Macedo. .207

Figura 122: "Propriedade de José Glete" 208

Figura 123: "Illmo. Sr. Dr. Mario Gracco". 208

Figura 124: "Ilmmo. Sr. Dr. Mario Gracco". 209

Figura 125: "Propriedade do Snr. João Grass" 209

Figura 126: Propriedade do Snr. João Grass 210

Figura 127: Propriedade do Snr. João Grass 210

Figura 128: “Snr. Miguel D’Elia” 212

Figura 129 : "Propriedade do Exmo. Snr. João de Miranda" 213

Figura 130: "João Alves Carneiro" 213

Figura 131: $O$ Mercado do Brás no Largo da Concórdia 235

Figura 132: Açougue de "José de Souza Oliveira" 243

Figura 133: "Planta do augmento do predio $n^{\circ} 28$ da Av. Celso Garcia de propriedade do Illmo Snr. Benedicto José de Lima" 244

Figura 134: "Reforma na propriedade do Coronel Antonio Baptista da Costa", na Avenida Celso Garcia número 389. .245

Figura 135: "Propriedade do Snr. Raphael Zimbardi”, na Avenida Celso Garcia número 462 .245

Figura 136: Anúncio da "Fratelli Secchi" no Almanaque Laemmert do ano de 1918. 246

Figura 137: Anúncio do "Moinho Matarazzo" 
Figura 138: "Industrias Reunidas F. Matarazzo São Paulo - Aumento do moinho"

Figura 139: "Industrias Reunidas F. Matarazzo São Paulo - Fachada da fabrica para produção de goma de arroz" .248

Figura 140: "F. Matarazzo \&amp; C. São Paulo - Projeto de modificação dos depósitos anexos ao moinho Matarazzo" .248

Figura 141: "F. Matarazzo \&amp; C. São Paulo - Projeto de assentamento de um silo do Moinho Matarazzo" .249

Figura 142: "Projecto de casa (sobrado) com armazém para padaria 251

Figura 143: "Projecto de forno para a Snra. Angela Cocco" 252

Figura 144: "Projecto de um forno com seu respectivo galpão [...]" .253

Figura 145: "Propriedade do Illm. Snr. Miguel Antonio Ferreira .255

Figura 146: "Projecto de uma padaria para ser construída á rua Almt. Barroso - 76 Capital de propriedade do Snr. Domingos Alterio" .255

Figura 147: "Propriedade de Francisco Richardo" .256

Figura 148: "Snr. Jose Re - Avenida Selso Garcia n. 142" 256

Figura 149: "Propriedade de Luiz Cervino" 257

Figura 150: "Projecto de um aumento a fazer-se no armazém da Avenida Celso Garcia n. $11 \%$ .257

Figura 151: "Projecto de uma casa com padaria" .257

Figura 152: "Propriedade do Snr. Salvatore Nasti" .257 
Figura 153: "Projecto de um quarto a construir e acrecimo de paredes na seccao da massa e substituição de telhas"

Figura 154: Anúncio da bebida "Bohorques" no jornal O Estado de São Paulo, edição de 25 de março de 1915. 260

Figura 155: Anúncio da “Confeitaria Guarany”, Arquivo do Estado de São Paulo, Jornal O Braz, edição de 22 de outubro de 1902. 262

Figura 156: "Projecto de um prédio para o Snr. Emilio Siniscalchi" .264

Figura 157: "Forno a construir-se no Laboratorio da Confeitaria Guarany" .265

Figura 158: Cartaz da "Confeitaria Guarany”, começo do século XX 265

Figura 159: A Pizzaria Castelões 266

Figura 160: Forno a lenha da Pizzaria Castelões, com porta de ferro produzida pela Companhia Mechanica e Importadora de São Paulo. 267

Figura 161: "Projecto de casa, fábrica e casas operárias", 268

Figura 162: "Augmento de commodos no interno da fabrica e de propriedade do Snr. José M. Gaia" .269

Figura 163: "Augmento de um commodo - Prop. Do Snr. José Gaia .269

Figura 164: "Projecto para reconstrução da frente do armazém no 229 da Avn. Rangel Pestana". 271

Figura 165: Depósitos da "Casa Tolle". Societé de Publicité Sud-Américaine, Monte Domecq' \&amp; Cie .273

Figura 166: Depósitos da "Casa Tolle". Societé de Publicité Sud-Américaine, Monte Domecq' \&amp; Cie .273 
Figura 167: Depósitos da "Casa Tolle". Societé de Publicité Sud-Américaine, Monte Domecq' \&amp; Cie .273

Figura 168: Depósitos da "Casa Tolle". Societé de Publicité Sud-Américaine, Monte Domecq' \&amp; Cie .274

Figura 169: Fachada da Companhia Wilson Sons \&amp; Cie. 277

Figura 170: Anúncio da agência de seguros Alliança, que contava com a Wilson Sons and Company como representante. 277

Figura 171: "São Paulo Alpargatas Co". 278

Figura 172: Anúncio da "Fabrica Brazileira de Alpargatas e Calçados" 278

Figura 173: "Armazéns de Palaride Mortari.” 278

Figura 174: "Projecto de uma cocheira a rua da Concordia n 18", Arquivo Histórico Municipal, Fundo "Diretoria de Obras. 278

Figura 175: "Projecto para construcção de um barracão na Serraria Oriente de Palaride Mortari” 279

Figura 176: Anúncio do complexo industrial de "Palaride Mortari" 279

Figura 177: "Armazéns de propriedade do Snr. Martins Ferreira" 279

Figura 178: Depósitos da "Martins Ferreira \&amp; Cia" 280

Figura 179: Fachada dos depósitos da "Martins Ferreira \&amp; Cia" 280

Figura 180: Depósitos e seção de encaixotamento e expedição da "Martins Ferreira \&amp; Cia”. 281 
Figura 181: Depósitos da "Martins, Ferreira \&amp Cia". .281

Figura 182: Depósitos da "Martins, Ferreira \&amp; Cia" 282

Figura 183: Vista geral dos armazéns e depósitos da "Martins, Ferreira \& Cia" .......282

Figura 184: "Propriedade dos Srs. Machado, Mello e Cia" 283

Figura 185: Anúncio da "José Refinetti, Irmão \&amp; Co". 291

Figura 186: Anúncio da Fábrica de Móveis dos "Irmãos Refinetti". 292

Figura 187: Projeto da serraria de José Monteiro Pinheiro 294

Figura 188: "Reforma de cocheira J. Monteiro \&amp; Cia." 294

Figura 189: Desvio na serraria da Avenida Celso Garcia, 110. 294

Figura 190: "Cocheira para a Serraria Santa Isabel" .295

Figura 191: "Planta duma serraria" 295

Figura 192: "Planta dum barracão para uma serraria na Avenida Celso Garcia n 254" .296

Figura 193: Anúncio da Fundição "Craig \& Martins"... 300

Figura 194: Anúncio da "Fundição do Braz"..... 301

Figura 195: Anúncio da "Fundição do Brás 301

Figura 196: Escritório da "Fundição do Brás" 302

Figura 197: Escritório da "Fundição do Brás" 303 
Figura 198: "Funcionários da "Fundição do Bráz" 303

Figura 199: Depósito da fábrica de ferro fundido e esmaltado da "Fundição do Bráz" 304

Figura 200: Depósito da fábrica de ferro fundido e esmaltado da "Fundição do Bráz" 304

Figura 201: Interior da fábrica de ferro fundido e esmaltado da "Fundição do Bráz" 305

Figura 202: Operários trabalhando nos fornos de esmaltação da "Fundição do Bráz" 305

Figura 203: Operários da "Fundição do Bráz" 306

Figura 204: "Cia. Mechanica e Importadora de S. Paulo - Aumengto do depósito" 307

Figura 205: "Projecto para a construção de um galpão para reparações de automóveis da Companhia Mecânica e Importadora de S. Paulo à Rua Américo Brasiliense" .308

Figura 206: "Projecto para o aumengto das oficinas da Cia. Mechanica e Importadora de São Paulo." 308

Figura 207: "Modificação em cocheiras e water closets nas offic da Comp a Mechanica Importadora de São Paulo. Construção de depósito para (...) e fundição"..... 309

Figura 208: Entrada da atual Escola Estadual Romão Puiggari, antigo Primeiro Grupo Escolar do Brás. 311

Figura 209: Alto relevo alusivo à uma parte da bandeira nacional contido numa das extremidades externas do antigo Primeiro Grupo Escolar do Brás 
Figura 210: Antigo edifício da Escola Normal do Brás, atual sede da São Paulo Escola de Teatro.

Figura 211: A Escola Profissional Feminina do Brás em 1940. 312

Figura 212: Antigo edifício da Escola Profissional Feminina do Brás, atual Escola Técnica Estadual Carlos de Campos 313

Figura 213: Charge satirizando a instalação do Teatro Colombo envolvendo o vereador Celso Garcia e o prefeito Antônio Prado 327

Figura 214: Palco e plateia do Teatro Colombo. 328

Figura 215: Foto da caixa do teatro nos anos 1950-60. 329

Figura 216: Anúncio do Teatro Colombo 329

Figura 217: Fachada do Teatro Colombo na década de 1920 com os arcos voltaicos instalados em 1914 330

Figura 218: A reforma dos camarotes do Teatro Colombo.

Figura 219: Plateia do Teatro Colombo em 1921. 332

Figura 220: Plateia do Teatro Colombo em 1928 332

Figura 221: Interior do Teatro Colombo em 1908 333

Figura 222: Proposta de placar para anúncio do Teatro Colombo. 333

Figura 223: O incêndio do Teatro Colombo. 334

Figura 224: O final do incêndio do Teatro Colombo, com o que restou de suas paredes 


\section{Lista de gráficas}

Gráfico 1: Augmento anual de construcções de S. Paulo e Augmento annual de construcções no Rio de Janeiro.

Gráfico 2: Pedidos de alinhamento e construção em ruas do Brás (1872-1899)..... .84

Gráfico 3: Pedidos de particulares das Avenidas Rangel Pestana e da Intendência encaminhados para aprovação da Intendência Municipal (18721899) .88

Gráfico 4: Pedidos de particulares de ruas abaixo das Avenidas Rangel Pestana e da Intendência encaminhados para aprovação da municipalidade (18721899).......

Gráfico 5: Pedidos de particulares de ruas acima das Avenidas Rangel Pestana e da Intendência encaminhados para aprovação da municipalidade (18721899). .94

Gráfico 6: Quantidade de lotes por proprietários do Brás.

Gráfico 7: Projetos assinados por construtores, práticos-licenciados e arquitetos no

Brás

Gráfico 8: Número de sobrados construídos no Brás (19061915) .205 


\section{Lista de Mapas}

Mapa 1: São Paulo - chácaras, sítios e fazendas, ao redor do centro desaparecidos com o crescer da cidade. .38

Mapa 2: Pormenor do mapa "São Paulo - chácaras, sítios e fazendas, ao redor do centro desaparecidos com o crescer da cidade" .39

Mapa 3: Planta da Cidade de São Paulo e seus Subúrbios - cópia de 1918 de uma planta datada de 1841

Mapa 4: Pormenor da Planta da Cidade de São Paulo e seus Subúrbios. Cópia de 1918 de uma planta datada de 1841

Mapa 5: Planta da cidade de São Paulo, 1868. 50

Mapa 6: Planta da cidade de São Paulo 1868 - recorte. .51

Mapa 7: Mappa da capital da Pcia. de S. Paulo seos Edifícios públicos, Hotéis, Linhas ferreas, Igrejas, Bonds, Passeios, etc. publicado por Frco. De Albuquerque e Jules Martin em julho de 1877.

Mapa 8: Planta da Cidade de São Paulo levantada pela Companhia Cantareira e Esgotos, 1881 55

Mapas 9: Pormenores da Planta da Cidade de São Paulo levantada pela Companhia Cantareira e Esgotos, em 1881 60

Mapa 10: Planta da capital do Estado de S. Paulo e seus arrebaldes desenhada e publicada por Jules Martin em 1890

Mapa 11: Planta da cidade de São Paulo de 1895 63

Mapa 12: Pormenor da Planta da cidade de São Paulo (...) - 1895 .64

Mapa 13: Perímetros da cidade de São Paulo em 1916 sob os perímetros de 2007.....81

Mapa 14: Mapa da cidade de São Paulo em 1916 com destaque para o Brás...... .82 


\section{Lista de takelas}

Tabela 1: Descritivo das chácaras existentes em São Paulo no século XIX.

Tabela 2: Capitalistas e proprietários que atuaram na região do Brás na década de 1870 46

Tabela 3: Distritos de paz da cidade de São Paulo em 1908 .76

Tabela 4: Evolução numérica da população residente em São Paulo entre os anos de 1872 a 1940 .78

Tabela 5: Relação de projetos de obras particulares referentes a ruas do Brás entre 19061915.

Tabela 6: Relação de cortiços do Brás em 1892 138

Tabela 7: Relação de vilas do Brás anunciadas no Almanack Laemmert. 172

Tabela 8: Relação de vilas operárias construídas por particulares encontradas na Série Obras Particulares.

Tabela 9: Aumento populacional dos distritos de São Paulo entre 1872-189)

Tabela 10: Imigrantes na cidade de São Paulo entre 1882 e 1891)

Tabela 11: Números de óbitos de prováveis moradores do Brás segundo suas origens nacionais (1901-1908)

Tabela 12: Residentes do Brás que atuavam no bairro e em áreas centrais da cidade (1901$1915)$

Tabela 13: Profissionais liberais que atuavam no Brás (1897-1914). 223

Tabela 14: Relação dos estabelecimentos comerciais do Brás especializados em alimentos (1897-1915) 
Tabela 15: Relação dos estabelecimentos comerciais do Brás especializados no ramo vestuário e de armarinhos e fazendas (1897-1915) 288

Tabela 16: Relação dos estabelecimentos comerciais do Brás especializados no ramo madeireiro (1897-1915) 292

Tabela 17: Relação dos estabelecimentos comerciais do Brás especializados no ramo da construção civil (1897-1915) .296

Tabela 18: Relação dos estabelecimentos comerciais do Brás especializados no ramo da fundição e funilaria (1897-1915) 298

Tabela 19: Distribuição dos estabelecimentos educacionais do Brás (18971916)

Tabela 20: Lojas especializadas em objetos escolares do Brás (1906-1914).

Tabela 21: Estabelecimentos de interesse social do Brás. .322

Tabela 22: Pedidos de licença para construção ou reforma de cinemas no Brás (19101915) .335

Tabela 23: Fotografias e aparelhos para cinematógrafos do Brás (1908-1914). 336 
Lista de anexas - Perfis arquitetânicas das ruas

Avenida Rangel Pestana.

356

Avenida Celso Garcia

.361

Rua Bresser.

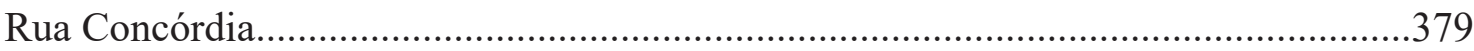

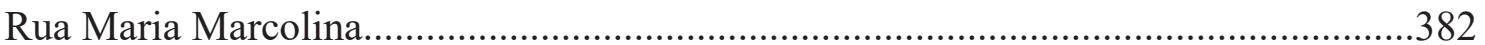

Rua Miller. 


\section{Sumária}

Introdução

01

Capítulo 1: Uma cidade entre chácaras: (des)costurando um bairro para além do centro - entre projetos, loteamentos e serviços públicos 23

1.1 A Várzea do Carmo e suas chácaras a partir do olhar de Militão Augusto de Azevedo. 26

1.2 Entre a cartografia histórica e a toponímia: chácaras e nomes que deram origem ao bairro 38

1.3 A configuração de um bairro para além do centro entre finais do século XIX e o começo do século XX.

Capítulo 2 - Um canteiro de obras a céu aberto: novo olhar sobre um bairro - entre cortiços, casas, vilas operárias e sobrados

2.1 Habitação: um debate para além da edificação

2.2 Entre casas, vilas e sobrados, um bairro para morar

2.3 Os cortiços da cidade de São Paulo: os embates entre a cidade oficial e a cidade clandestina

2.4 Um ponto temporal fora da curva: uma análise das fotografias de cortiços do Brás a partir dos anos 1930.

2.5 Entre as casas de operários, as casas de padrões mínimos e a máxima ocupação do lote

2.6 As casas em série e vilas como alternativa ao mercado imobiliário 
2.7 Entre jardins, garagens e quartos para empregados: exceções das casas dos setores médios

2.8 Sobrado: um espaço para a morada e o trabalho dos setores médios

Capítulo 3 - Se non è vero, è ben trovato: não só italiano e fabril - Espaços de sociabilidade num bairro não exclusivamente operário

3.1 Nem tudo era italiano e operário

3.2 Fábricas e comércios em perspectiva: um bairro se construindo na São Paulo dos anos 1910 226

3.3 Entre armazéns e fábricas de alimentos

$3.4 \mathrm{O}$ cotidiano em questão: armazéns, açougues e quitandas .241

3.5 As padarias ocupando o cenário do Brás 250

3.6 Entre as confeitarias, doces e os cafés: espaços de sociabilidade e lazer no Brás. 258

3.7 Botequins e bilhares x Bares e bebidas. 270

3.8 Os fios e os rastros da moda: O Brás e a produção de tecidos para São Paulo ....284

3.9 Produzir a cidade, alimentar as fábricas e mobiliar as casas 290

3.10 Italianidade e nacionalismo: uma análise sobre as escolas italianas do Brás.....310

3.11 Equipamentos urbanos e entretenimentos modernos: os estabelecimentos de interesse social, o Teatro Colombo, cinemas e fotografias 322 
Referências bibliográficas.

Anexos: Fachadas das ruas do Brás 
Mapa 16: Planta Geral da Capital de São Paulo, 1897. 86

Mapa 17: Pormenor da Planta Geral da Capital de São Paulo, 1897 86

Mapa 18: Pormenor da Planta Geral da Capital de São Paulo, de 1897, simbolizando em laranja as ruas "acima” do eixo das avenidas Rangel Pestana e Intendência (em vermelho), e em amarelo as ruas "abaixo" do referido eixo, relação ao centro da cidade de São Paulo em azul claro. 95

Mapa 19: Planta Geral da cidade de São Paulo, 1905 98

Mapa 20: Pormenor da Planta Geral da Cidade de São Paulo, 1905 .99

Mapa 21: Planta da cidade de São Paulo com as redes de esgotos, 1901 100

Mapa 22: Pormenor da Planta da cidade de São Paulo com as redes de esgotos, 1901 .101

Mapa 23: Grandes Estabelecimentos industriais do Brás.

Mapa 24: Área de influência entre fábricas, bares e botequins. 276

Mapa 25: Escolas e estabelecimentos de venda de objetos escolares do Brás. 321

Mapa 26: Repartições, associações, órgãos públicos, urbanos e de interesse social do Brás. 324

Mapa 27: Diversões e Lazer: Cinemas, Teatros e Fotografias. 337 


\section{Intraduçãa}

“O Brás era um bairro cinzento, com ruas de paralelepípedo e poucos automóveis. Ao meio-dia as sirenes anunciavam a hora do almoço nas fábricas. Como não existiam prédios, de toda parte viam-se chaminés e as torres da igreja de Santo Antônio apontando para o céu. (...)

Os operários saíam cedo, com a marmita embrulhada no jornal e o guarda-chuva preto. Garoava muito em São Paulo; a cidade era cercada por matas e conhecida como "terra da garoa". Entre os trabalhadores, muitos eram adolescentes, mas não havia mais crianças: o trabalho antes dos catorze anos tinha sido proibido. Essas imagens marcaram a minha infância: para ser homem precisava acordar cedo e ir para a fábrica com a marmita.

Nem todos eram operários, no entanto. Havia barbeiros, alfaiates, marceneiros, sapateiros e ambulantes que passavam com a carrocinha. Entre eles, um napolitano com um latão cilíndrico nas costas anunciava com a voz musical:

- Olha a pizza! A pizza! Mozzarella i pomarolla'n copa!

Queria dizer que a pizza tinha tomate em cima da mozarela. Ele forrava o latão com um pano branco e ali dentro os discos de pizza vinham cuidadosamente empilhados, separados uns dos outros por folhas de papel-manteiga. Eram preparados pela mulher dele no forno a lenha. Não custavam caro, mas poucos compravam, porque os imigrantes eram pessoas econômicas. Napolitanos como esse foram os precursores das pizzarias que surgiram no Brás, nos anos 50."1

A pequena história contada pelo médico Drauzio Varela, sobre sua infância e adolescência vividas nas ruas do bairro do Brás na década de 1940, além de um convite ao mundo da imaginação, nos traz em perspectiva uma série de questões relacionadas ao processo de urbanização de uma cidade como São Paulo. O livro registra as lembranças que o pequeno "neto do Varella" (como então Drauzio era conhecido em referência ao seu avô espanhol) aos poucos revela as práticas do cotidiano de um bairro, seus personagens, seus modos de vida, suas relações sociais, permitindo vislumbrar aspectos da materialidade ali presente.

O trecho apresentado acima vai de encontro à algumas das questões que procuramos levantar e respondê-las a partir de um conjunto documental que vem ganhando destaque na comunidade científica, em especial aos estudos da História de São Paulo: as permissões de construção da Série Obras Particulares, bem como outras correlatas pertencentes ao Arquivo Histórico Municipal da Cidade de São Paulo. Associadas à iconografia, cartografia antiga e aos almanaques comerciais, as fontes nos revelam facetas desconhecidas do

\footnotetext{
${ }^{1}$ VARELLA, Drauzio. Nas ruas do Brás. São Paulo: Companhia das Letras, 2000, pág. 25-27.
} 
processo de formação e transformação de certas áreas, permitindo-nos tatear a materialidade e entrever alguns dos agentes produtores desse espaço, especialmente sobre a formação da zona leste da cidade a partir de finais do século XIX.

Tais materiais entram em convergência com um dos nossos propósitos: oferecer uma contribuição ao processo de urbanização da Zona Leste da cidade de São Paulo, região que foi preterida da historiografia, vem ganhando destaque com intensos trabalhos, mas que ainda carece de maiores olhares de como se desenvolveram as relações entre seus diversos habitantes, suas intensões e aspirações políticas e econômicas, bem como um processo mais acurado de análise de sua relação com outras porções da cidade e de regiões que outrora viriam a tornar-se cidades. Separada essencialmente pelo rio Tamanduateí, a porção leste da cidade é aberta pelo Brás, bairro que por estar geograficamente mais próximo do centro da cidade que se urbanizava desde o último quartel do século XIX, passará por intensas transformações correlatas ao que acontecia em outras partes de São Paulo e de cidades do mundo capitalista.

Procuramos, assim, estudar o bairro do Brás, reconstituindo sua materialidade entre os anos de 1870 a 1915, período que coincide com uma série de transformações no centro da cidade de São Paulo, e em áreas próximas dele que viriam a formar bairros, como a Vila Mariana, Santana, Bexiga e a Barra Funda, e ao mesmo tempo, este é o período que coincide com o principal corpus documental por nós trabalhado. Ao contrário de outros trabalhos sobre a História dos bairros da cidade de São Paulo, estivemos preocupados com a dimensão material do Brás, seu processo de feitura, e principalmente seus agentes produtores, pondo luz especialmente nos setores médios que também se envolveram na produção das cidades.

A reconstituição da materialidade do Brás é lida como um processo, com ritmos, compassos e descompassos, visível no entrecruzar minucioso de diferentes fontes, essencialmente as manuscritas, permitindo que se imaginem personagens e seus cenários de ação no passado. Esta reconstituição, que não pretende e não se espera ser totalizante, se faz a partir da análise de fontes como, por exemplo, os almanaques comerciais, que trazem em suas páginas as lojas, os envolvidos com as atividades mercantis, os profissionais que atuavam em seus escritórios, repartições públicas, e mesmo aqueles que prestavam serviços cotidianamente, contando com a uma informação riquíssima para os estudos de História da Urbanização: os endereços de cada item publicado, rua a rua, com seus números, e às vezes, telefones, telégrafos e caixas postais, permitindo uma análise do perfil da região em estudo. 
Tais materiais, quando analisados conjuntamente com as fontes cartográficas permitem imaginar e melhor compreender o passado de uma das regiões da cidade de São Paulo que se desenvolveu desde o final do século XIX paralelamente a outros espaços e cujo crescimento pode ser acompanhado por meio do rol de construções do período. A série Obras Particulares, depositada no acervo do Arquivo Histórico Municipal², permite então conhecer a materialidade dos imóveis, suas tipologias, seus programas edilícios, entrevendo alguns dos seus usos em seus respectivos endereços. Esta série, analisada em conjunto, permite portanto reconstituir o perfil de certas ruas, e a tessitura - planimetria e volumetria - dos bairros da cidade.

Pondo luz nas suas entrelinhas, é possível verificar quem seriam os proprietários e construtores desses imóveis bem como identificar os agentes públicos que estiveram debruçados sobre cada pedido de construção solicitada à Prefeitura Municipal entre os anos de 1870 a 1915, além de seus respectivos pareceres. Nosso trabalho parte, assim, de uma metodologia de cruzamento e ensaio de espacialização de dados heterogêneos mas conexos, que permitem realizar cartografias regressivas e reconstituir certos bairros de São Paulo, como a pesquisa desenvolvida por Sheila Schneck sobre o bairro do Bexiga ${ }^{3}$, o trabalho de Monique Felix Borin sobre a Barra Funda ${ }^{4}$, e o de Clara Cristina Valentin Anaya de Carvalho sobre a Vila Mariana ${ }^{5}$.

Este não é um trabalho convencional de história de bairro, pois procura focar em suas análises o processo de produção a partir da dimensão cotidiana, pondo luz no papel dos setores médios paulistanos na produção da cidade na passagem do século XIX para o XX. Tido até então como um bairro exclusivamente operário, imigrante (italiano) e fabril, pudemos perceber que o Brás ia muito além deste estereótipo, com personagens que aos poucos foram sendo resgatados do esquecimento, atuando lado a lado dos grupos eleitos pela historiografia. O presente trabalho insere-se no grupo de pesquisa liderado pela Professora Beatriz Bueno, ao qual formaram-se Sheila Schneck, Lindener Pareto Júnior,

\footnotetext{
${ }^{2}$ Instituição que já fora conhecida como Arquivo Histórico Municipal Washington Luís, Arquivo Histórico de São Paulo, e atualmente Arquivo Histórico Municipal.

3 SCHNECK, Sheila. Formação do bairro do Bexiga em São Paulo: loteadores, proprietários, construtores, tipologias edilícias e usuários (1881-1913). Dissertação (Mestrado em Arquitetura e Urbanismo), Faculdade de Arquitetura e Urbanismo, Universidade de São Paulo, São Paulo, 2010.

${ }^{4}$ BORIN, Monique Felix. A Barra Funda e o fazer da cidade: experiências da urbanização em São Paulo (1890-1920). Dissertação (Mestrado em História), Faculdade de Filosofia, Letras e Ciências Humanas, Universidade de São Paulo, São Paulo, 2014.

${ }^{5}$ CARVALHO, Clara Cristina Valentin Anaya de. Os setores médios e a urbanização de São Paulo: Vila Mariana, 1890-1914. Dissertação (Mestrado em História), Escola de Filosofia, Letras e Ciências Humanas, Universidade Federal de São Paulo, Guarulhos, 2016.
} 
Jorge Lody, Elisângela Maria da Silva, Nelson Braghittoni, entre outros alunos e alunas que se dedicaram a estudar São Paulo. Atenta ao mercado imobiliário rentista então vigente, os estudos de Bueno e seus alunos vem pondo luz no processo de produção de São Paulo.

Construir, morar e viver num bairro como Brás entre finais do oitocentos até meados da Primeira Guerra Mundial, significou a inserção de novos grupos na dinâmica espacial e social da cidade de São Paulo, na época a segunda maior cidade do país em número de habitantes e a que apresentava uma economia em ascensão, essencialmente pelo capital advindo das plantações de café do interior do estado. Em resposta às demandas de seu franco crescimento demográfico, edificações avolumaram-se e espraiavam-se em todas as direções da cidade.

Os setores médios foram alvo de intensas pesquisas no decorrer do século $\mathrm{XX}$, tornando-se objeto de estudo de diferentes áreas do conhecimento. Décio Saes, em seu livro Classe média e política na Primeira República Brasileira (1889-1930) ${ }^{6}$ nos forneceu algumas indicações sobre o perfil econômico e social deste grupo no cenário brasileiro da passagem do século XIX para o XX, destacando sua heterogeneidade e um grupo que se encontrava no meio termo entre aqueles que possuíam altos índices rentistas e a classe operária, mas que não necessariamente possuíam um envolvimento enquanto um grupo unificado como os demais.

Já Edgar Carone, nos alerta que muitos dos personagens que formariam os setores médios das cidades adviriam das inúmeras transformações que a economia interiorana vinha sofrendo desde o final da primeira metade do século XIX, grupos que aos poucos tornavamse empobrecidos e viam na capital um melhor espaço para angariar novos fundos de investimento, tal como observamos ao longo do primeiro capítulo deste trabalho. Segundo o autor,

A avaliação do processo urbano é mais visível, no caso da cidade de São Paulo, através da taxa demográfica, que quadruplica entre 1890 e 1930. Como consequência, cresce o número de bairros novos, sobressaindo-se as novas construções em alvenaria - inexistem ainda os arranha-céus -, e as diferenças sociais entre eles ${ }^{7}$

${ }^{6}$ SAES, Décio. Classe média e política na Primeira República Brasileira (1889-1930). Petrópolis: Vozes, 1975.

${ }^{7}$ CARONE, Edgard. A evolução industrial de São Paulo (1889-1930). São Paulo: SENAC, 2001, pág. 54. 
Atento à explosão industrial do estado, e essencialmente na capital, Carone observa que os grupos imigrantes teriam um destacado papel no processo de formação da cidade, sendo que muitos atuariam em diversos ramos de produção e venda de artigos de primeira necessidade, como nos setores de alimentação e vestuário, atendendo quase que exclusivamente ao seu grupo social ${ }^{8}$.

Esses homens e mulheres dos setores médios da população compuseram parte significativa do mercado imobiliário rentista então vigente em São Paulo, por meio da construção de casas para aluguel como uma de suas rendas. Maria Luiza Ferreira de Oliveira mostrou em sua tese como os "setores médios e intermediários" foram ativos personagens que teceram relações sociais entre si, por meio de lojas, casas e armazéns, estabelecendo contatos com os setores mais remediados e precarizados da sociedade paulistana da segunda metade do século XIX, estando também atentos aos fundamentos da legislação urbanística que estava em discussão e aplicação ${ }^{9}$. Muitos desses personagens dos setores médios e intermediários atuaram no centro da cidade de São Paulo, e de forma parecida em bairros situados em suas franjas, como o Brás. Foi nesse bairro que muitos constituíram suas relações com imigrantes que buscavam residências mais baratas para residir, tecendo relações de confiança por meio do crédito em seus armazéns, e mesmo relações com aqueles que financiavam a construção de novos imóveis em diferentes lotes do bairro. Encarado inicialmente como uma forma de diversificação das fontes de renda, o mercado imobiliário rentista foi alvo de investimento de diferentes personagens, tais como imigrantes, operários, construtores, políticos, engenheiros que atuavam continuamente nestes e noutros espaços de formação da cidade, participando do processo inclusive "famílias pobres que exploravam essas brechas no mercado que se adaptava à crescente demanda"10.

O papel dos setores médios e a produção imobiliária foi objeto de estudo da arquiteta Luciana Além Gennari, que, partindo da análise da produção das "casas em série" nos bairros da Móoca e do Brás, a autora mapeou-as no corpus documental Obras Particulares do AHM e as reconstituiu espacialmente na Planta da Cidade de São Paulo de 1930 (Sara Brasil), trazendo ao debate os seus proprietários e construtores que investiram nessa forma de morar para obter lucro com sua venda ou aluguel, aproveitando a carestia de moradias que pairava sobre a cidade de São Paulo no começo do século XX. Gennari observa o

\footnotetext{
${ }^{8}$ Idem, pág. 99 e 107.

9 OLIVEIRA, Maria Luiza Ferreira de. Entre a casa e o armazém: Relações sociais e experiência da urbanização. São Paulo, 1850-1900. São Paulo: Alameda, 2005.

${ }^{10}$ Idem, pág. 57.
} 
potencial de lucro de rendimento para as camadas médias e baixas da população no começo do começo do século, entendendo as dinâmicas daqueles proprietários em meio ao mercado imobiliário rentista então vigente e ao processo de descentralização da cidade com a instalação de moradias populares em regiões junto das ferrovias e fábricas. Trabalho semelhante foi realizado por Sheila Schneck ${ }^{11}$ para o Bexiga, no qual a autora, também por meio de pesquisa na Série Obras Particulares do AHM, estuda o processo de formação do bairro a partir do desmembramento de seus lotes, e a consequente venda dos mesmos para diferentes usuários ali construírem imóveis e comercializá-los para a população que se estabelecia na cidade, trazendo à luz os diferentes atores sociais envolvidos no seu processo de formação, como seus proprietários, construtores, políticos e usuários. Outro ponto de destaque que a autora realiza é o de mapear ruas com distintos usos e especificidades, de acordo com a posição geográfica das mesmas. À exceção desses estudos, raros foram os trabalhos que verticalizaram a análise à escala do lote urbano e, mesmo o delas, circunscrevem-se no estudo de determinados tipologias, em detrimento das demais edificações dos bairros em questão, que podem igualmente ser levantadas por meio de pesquisa no AHM, demonstrando a existência de outras tipologias e modos de morar.

A bibliografia sobre a questão da habitação não se encerra: Eva Alterman Blay pontuou as relações entre operários-inquilinos e os proprietários de vilas operárias, visto nelas ser "possível armazenar a força de trabalho livre necessária à produção" fabril da cidade, sendo este um "investimento privado que se concentrará na aplicação de rendimentos em vilas operárias e mesmo cortiços" ${ }^{12}$, ampliando a discussão em torno dos personagens que atuavam no contexto de urbanização, crescimento demográfico e investimento imobiliário que ocorriam na cidade de São Paulo naquele período. Já Raquel Rolnik estudou o papel da legislação no desenho de São Paulo, e como este projeto beneficiava certas camadas sociais e certas áreas da cidade, promovendo conflitos entre aqueles que pleiteavam ou eram estigmatizados, desenvolvendo a tese de que os usos e disputas da terra em São Paulo remontam sobretudo ao último quartel do século XIX, com a sistematização de leis urbanísticas na capital, a partir do Código de Posturas de 1875, revisto e ampliado em 1886. Com relação ao bairro do Brás, a autora coloca que este pode ser considerado um bairro com uma "cartografia heterogênea dos modos de habitar"13, visto

\footnotetext{
${ }^{11}$ SCHNECK, Op. Cit.

12 BLAY, Eva Alterman. Eu não tenho onde morar: vilas operárias na cidade de São Paulo. São Paulo: Nobel, 1985, pág. 40.

${ }^{13}$ ROLNIK, Raquel. A cidade e a lei: legislação, política urbana e territórios na cidade de São Paulo. São Paulo: Studio Nobel: Fapesp, 1997, pág. 60.
} 
que entre 1886 e 1890, são 10.809 os novos habitantes e 117 os pedidos de construção ou reforma, dados estes que para nós podem ser questionados quando contabilizados todos os pedidos que particulares encaminharam para aprovação de obras à prefeitura entre $1870 \mathrm{e}$ 1914.

A falta de moradia e os investimentos privados em habitação foram intensamente observados pela historiografia, existindo similitudes em outros países. Michelle Perrot coloca que tal problema social era algo recorrente também na Paris de finais do século XIX, enfatizando que a discussão entrelaçou as questões do higienismo e da política urbana promovida desde as reformas promovidas pelo Barão de Haussmann entre os anos de 1850 e 1873, acompanhados "pelo duplo movimento das aberturas de vias de circulação e alta dos aluguéis gerados pelas demolições" na porção central da capital francesa ${ }^{14}$.

Tais preceitos higienistas de controle e de ordenamento das políticas de habitação e de construções em geral na cidade estão em consonância com as transformações dos métodos de produção da arquitetura das cidades europeias e norte-americanas ocorridos em fins da segunda metade do século XIX com profundas relações com a indústria e com os profissionais que compunham seu quadro de empregados. Tanto nos Estados Unidos ${ }^{15}$ (WOODS, 1999) como em diversos países europeus pode-se verificar uma tendência à racionalização dos espaços produtivos, e mesmo da atuação de instituições e atores no planejamento territorial das cidades em processo de transformação na virada do século XIX para o XX, em favor da higiene urbana representados no slogan das políticas de “embelezamento e melhoramentos urbanos" a exemplo da Paris remodelada por Haussmann ou Barcelona por Ildefonso Cerdá ${ }^{16}$, e levadas a cabo em outras partes do mundo, demonstrando o "verdadeiro ciclo de urbanização" ocorrido neste período ${ }^{17}$.

Os ideais de higienismo e de planejamento urbano seriam assim um dos campos privilegiados de atuação de determinados profissionais que buscavam afirmar-se diante das mudanças que o próprio sistema capitalista da época evidenciava. $\mathrm{O}$ engenheiro civil e o arquiteto, por exemplo, seriam encarados como profissionais preparados para resolver os

\footnotetext{
${ }^{14}$ PERROT, Michelle. "Os operários, a moradia e a cidade no século XIX". In: Os excluídos da história: operários, mulheres e prisioneiros. Rio de Janeiro: Paz e Terra, 2006, pág. 120.

15 WOODS, Mary N., From Craft to Profession. The Practice of Architecture in Nineteenth- Century America. Berkeley/Los Angeles/London, University of California Press, 1999.

${ }^{16}$ CALABI, Donatella. História do urbanismo europeu: questões, instrumentos, casos exemplares. São Paulo: Perspectiva, 2015, pág. 25-26.

${ }^{17}$ ZUCCONI, Guido. A cidade do século XIX. São Paulo: Perspectiva, 2009, pág. 16.
} 
problemas infra-estruturais das cidades que se industrializavam e que cresciam em grandes proporções populacionais, sendo considerados capazes de agenciar e administrar as grandes obras necessárias no século XX, entregando com protagonismo e liderança os principais postos de burocracia municipal e regional no que tange às obras públicas. Figuras emblemáticas do pensamento urbano da São Paulo que crescia para além dos seus limites do Triângulo, foram temas abordados pela historiografia, e assim, devem ser trazidos à tona quando pensamos bairros que estão surgindo neste ínterim. Antônio Francisco de Paula Souza $^{18}$, Orville Derby ${ }^{19}$, Victor da Silva Freire, Antoine Bouvard ${ }^{20}$ dentre outros, formaram uma ampla rede que se descortinou deste o último quartel do século XIX, estabelecendo as bases para a expansão da cidade e sua ordenação diante do cenário de remodelação urbana. Coube a estes arquitetos e engenheiros o gerenciamento da transformação dessas cidades capitalistas, ensejando conflito e convergência com os interesses de particulares, sendo eles próprios muitas vezes "empresários e capitalistas" partícipes do processo.

Em recente pesquisa doutoral que mapeou as transformações arquitetônicas em curso na cidade de São Paulo nos anos iniciais da República até a eclosão da Primeira Guerra Mundial, o pesquisador Jorge Lody analisou as solicitações de permissão de construção encaminhadas à Prefeitura municipal, bem como a atuação daqueles profissionais envolvidos. Ao computar bairro por bairro da cidade e o total de solicitações encaminhadas aos órgãos públicos municipais, Lody constatou que o bairro do Brás foi o que apresentou o maior número de solicitações, perfazendo um total de 4.603, mais que o dobro do segundo bairro, o Bexiga, com 2.088 solicitações $^{21}$, o que nos confere uma garantia de entrever que esta área da cidade sofreu intensas transformações num curto período de menos de dez anos (1906-1915), e que se constituiu como espaço de estabelecimento da massa trabalhadora da cidade.

\footnotetext{
${ }^{18}$ CAMPOS, Cristina. Ferrovias e saneamento em São Paulo: o engenheiro Antonio Francisco de Paula Souza e a construção da rede de infraestrutura territorial e urbana paulista. Tese (Doutorado em Arquitetura e Urbanismo) - FAUUSP, São Paulo, 2007.

19 FIGUEROA, Silvia Fernanda de Mendonça. Modernos Bandeirantes: a Comissão Geográfica e Geológica de São Paulo e a exploração científica do território paulista (1886-1931). Dissertação (Mestrado em História). FFLCH, São Paulo, 1987.

${ }^{20}$ D’ELBOUX, Roseli Maria Martins. Joseph-Antoine Bouvard no Brasil. Os melhoramentos de São Paulo e a criação da Companhia City: ações interligadas. Tese (Doutorado em Arquitetura e Urbanismo) - FAUUSP, São Paulo, 2015.

${ }^{21}$ LODY, Jorge. Arquitetura e cidade: obras particulares em São Paulo, 1906-1915. Tese (Doutorado em Arquitetura e Urbanismo), FAUUSP, São Paulo, 2015, pág. 92.
} 
A formação urbana do bairro do Brás que se iniciou a partir do loteamento de suas chácaras, acarretou um processo de abertura de ruas que se desenharam por meio de contínuos pedidos de alinhamento solicitados pelos proprietários desses lotes, para que então se pudessem realizar as novas edificações (armazéns, fábricas e especialmente residências). Ao atentar para o processo de produção e uso do bairro, percebemos o conjunto dos diferentes agentes ali atuantes (proprietários, construtores, usuários), e ao fim e ao cabo da pesquisa, podemos afirmar que o Brás era um bairro não exclusivamente operário, nem exclusivamente fabril, tampouco italiano. Comparativamente ao bairro do Bexiga, no Brás o número de fábricas, casas e vilas operárias é muito maior, mas pode-se perceber que o número de comércios e imóveis destinados à prestação de serviços não é de se excluir, e os variados profissionais de diversos ramos e a predominância dos moradores nacionais sobre os estrangeiros são dados que permitem uma nova compreensão da formação do bairro até o final da década de 1910.

Pretendemos, assim, ensaiar um novo olhar sobre as narrativas construídas para o bairro ("bairro italiano", "espaço fabril", etc.), um universo mais complexo, plural e heterogêneo do que se parecia à primeira vista. Procuramos, então, trazer em perspectiva a dimensão material do processo de feitura do bairro, colocando luz na pluralidade de tipologias, diversidade de atividades e de atores, sobretudo naqueles que se envolveram no processo de produção do bairro, indiretamente da cidade como um todo.

Tais narrativas não se circunscreveram ao bairro, mas alcunhas foram criadas para a própria cidade, como "vila jesuítica", "cidade bandeirante", "cidade dos barões do café", “capital do café", "burgo dos estudantes", dentre outras que remetem à eleição de certos personagens e grupos em detrimento de outros cujas vozes foram silenciadas pela historiografia.

Obras seminais sobre a História de São Paulo e o desenvolvimento da cidade foram produzidas na primeira metade do século XX e tiveram ampla repercussão, formando um discurso continuamente reiterado, no qual foi se moldando uma imagem da cidade centrada na ideia do "pioneirismo" dos seus "modernos bandeirantes", com vistas a estabelecer laços entre o passado colonial e a oligarquia econômica que comandava os quadros institucionais da Primeira República. Esse discurso, arquitetado por intelectuais vinculados ao Instituto Histórico e Geográfico de São Paulo (IHGSP), ao Museu Paulista e a outras instituições de ensino e pesquisa como a Escola Politécnica e a Faculdade de Direito do Largo São Francisco, moldou um certo olhar sobre a história da cidade de São Paulo, formando assim 
uma narrativa sob a lente do "progresso" e do "desenvolvimento", de forma que o estudo do passado pudesse servir aos anseios daquele presente ${ }^{22}$, legitimando o poder das elites que detinham os meios de produção e de projeção dos destinos intelectuais e políticos do país.

Ernani Silva Bruno, um dos egressos deste movimento, nos anos 1950 encontrou respaldo intelectual para dar cabo a análises gerais sobre a cidade, sob um viés memorialístico, e sobre o Brás teve um papel de demarcá-lo como um local marcado pela pobreza e preterido da cidade. Ao colocar em evidência a existência de palacetes e chalés que vieram a existir na cidade a partir da década de 1870, o autor cita que "havia o outro lado das construções suntuosas ou bizarras e dos primeiros ensaios de crescimento vertical: as edificações modestas e mesmo miseráveis dos primeiros bairros proletários" "23, indo ao encontro das declarações feitas por Antônio Francisco Bandeira Júnior em seu livro A Indústria no Estado de São Paulo em 1901, o qual relata a existência de "casas infectas que se estendiam pelas pobres ruas do Brás, do Bom Retiro, da Água Branca, da Lapa, do Ipiranga. Casinhas e cortiços - sobretudo as do Brás, do Bexiga e do Cambuci - que sofreram em 1910 a crítica de um viajante italiano: Cusano"24, personagem que também teria um peso nas declarações de Bruno, evidenciando a existência de grandes cortiços e casinhas, e os perigos da "promiscuidade" ${ }^{25}$, como facilitando o contágio das doenças ${ }^{26}$.

A própria construção da ideia de um lugar não aprazível, fora dos padrões de higiene impostos pela legislação, e de conter grande parte do operariado da cidade se faz sentir em tais palavras, essencialmente no tocante ao uso do conceito de "promiscuidade" que remeteria ao universo da sexualidade, prostituição e do crime presente em regiões mais afastadas da área central, e que estaria atrelado às camadas mais pobres.

As obras publicadas com apoio da Comissão do IV Centenário do Aniversário da Cidade de São Paulo configuraram amplo imaginário sobre a cidade, como aquela vinculada ao mundo do trabalho e das oportunidades geridas por meio de sua indústria nascida em especial nas primeiras décadas do século XX. A obra de Ernani Silva Bruno não foge à regra, pois além de ser reiterada ao longo do tempo, obteve grande sucesso, ao ser agraciada

\footnotetext{
${ }^{22}$ REIS, Philippe Arthur dos. "O passado servindo aos anseios do presente: Orville Derby e a historiografia bandeirante”. Epígrafe, V. 1, nº 1, 2014.

${ }^{23}$ BRUNO, Ernani Silva. História e Tradições da Cidade de São Paulo. São Paulo: Comissão do IV Centenário da Cidade de São Paulo, Livraria José Olympio Editora, 1954, pág. 956.

${ }^{24}$ Idem.

${ }^{25}$ Idem, pág. 1032.

${ }^{26}$ Ibidem, pág. 1194.
} 
como componente das publicações dos festejos da cidade em $1954^{27}$, e merecer uma terceira edição trinta anos mais tarde, demonstrando a vitalidade de suas ideias, e a incorporação de um discurso reiterado em análises documentais que só hoje, vem sendo alvo de intensas pesquisas e revisões.

Atrelada a este rol de obras que se apresentam como constituidoras da formação do imaginário sobre o bairro do Brás e da dinâmica da cidade de São Paulo, outra vem se somar e possuir destaque desde que fora publicada. Da série "História dos Bairros de São Paulo", O Bairro do Brás, de Maria Celestina Teixeira Mendes Torres, publicado inicialmente no ano de 1969, e recebendo uma segunda edição em 1985, o livro tornou-se referência obrigatória na bibliografia sobre a história do bairro formado para além da colina histórica, oferecendo um amplo panorama de análise, que remonta ao período da colonização portuguesa, utilizando-se de muitos documentos para possam respaldar e ilustrar as suas assertivas.

Paulista da cidade de Piracicaba, Maria Celestina Teixeira Mendes Torres, foi professora comissionada junto à antiga Faculdade de Filosofia e Letras da USP, local em que cursou Geografia e História em 1937. Suas atividades ligadas à universidade deram prosseguimento como $3^{\text {a }}$ assistente de Psicologia Educacional, e também na cadeira de História Moderna e Contemporânea, transferindo-se posteriormente para a área de História Econômica da Faculdade de Ciências Econômicas da USP ${ }^{28}$.

Com a pretensão de ser um trabalho de reconstrução histórica, Maria Celestina Mendes Torres, logo nas páginas iniciais do livro, coloca grande ênfase na lentidão dos primeiros séculos, e na grande e "estranha rapidez" a partir da segunda metade do século XIX. Diferente de outros centros e cidades brasileiras, São Paulo teria crescido com uma "fisionomia própria" que, desde sua fundação em 1554, já ofereceria indícios para se "pressentir a futura metrópole em que se transformaria no século XIX"29, por apresentar “um clima bem mais agradável do que o do Nordeste ou o Rio de Janeiro, mais agradável

\footnotetext{
${ }^{27}$ Sua primeira publicação deu-se um ano antes daquela patrocinada pelo serviço de comemorações culturais dos festejos do IV Centenário da Cidade de São Paulo, o que não se exclui a ideia do autor saber da existência de um projeto de publicação de livros referentes à história e ao desenvolvimento da cidade naqueles tempos. 28 TORRES, Maria Celestina Teixeira Mendes. O bairro do Brás. São Paulo: Série História dos Bairros de São Paulo. Departamento de Cultura. São Paulo: Gráficas Bisordi S.A., 1968, pág. 7.

${ }^{29}$ Idem, pág. 24.
} 
particularmente ao europeu, em virtude de sua semelhança com o de certas regiões da Europa, em contraste com o litoral carioca, bahiano ou pernambucano ${ }^{30}$.

Nossa autora ao trazer dados que pudessem comprovar o desenvolvimento do bairro do Brás a partir da segunda metade do século XIX, alinha-se aos preceitos já desenvolvidos pela geração de intelectuais anteriores a ela. Para o ano de 1865, ano da conclusão do lançamento de impostos municipais sobre portas e janelas dos prédios das freguesias da Sé, Santa Ifigênia e Brás, Torres contabiliza o seguinte número de imóveis existentes no perímetro urbano:

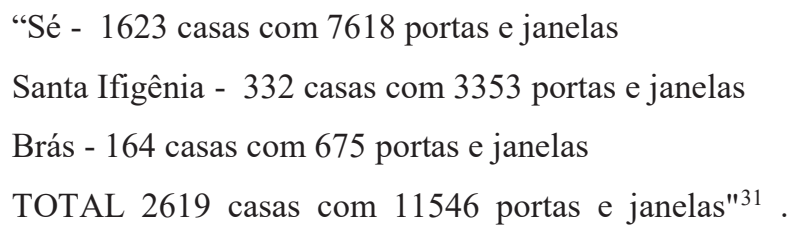

Os dados corroboram as descrições feitas pelo viajante Saint Hilaire quando da sua passagem por São Paulo, em 1819, de existência de uns poucos casebres no Brás, narrativa apropriados por Ernani Silva Bruno ${ }^{32}$, e reproduzida infinitamente.

Torres contabiliza que poucas seriam as indústrias que existiam no bairro do Brás na segunda metade do século XIX, como a de licores do alemão Carlos Augusto Bresser e a de cerveja de João Bohemer, ambas localizadas no Marco da Meia Légua, mas, que com a instalação da ferrovia nas proximidades, margeando o rio Tamanduateí (tanto a São Paulo Railway como a Estrada de Ferro Pedro II) iriam

\footnotetext{
“exercer decisiva influência no povoamento e na valorização dos terrenos dos bairros do Brás e da Mooca, onde se instalara a maioria dos trabalhadores, atraídos pela oferta de trabalho e pelo baixo preço de terrenos considerados insalubres em virtude das inundações a que estavam sujeitos" ${ }^{\prime 3}$,
}

Para a autora, comparar a população residente em São Paulo daria a dimensão da expansão e crescimento "industrial e comercial" que a cidade, e em especial, o bairro do Brás, tiveram no último quartel do século XIX.

\footnotetext{
${ }^{30}$ Idem.

${ }^{31}$ Idem, pág. 87-88.

32 BRUNO, Op. Cit., pág. 202.

33 TORRES, Op. Cit., pág. 105-107.
} 
Este aumento populacional da cidade não passaria desapercebido por Torres sem que ela tocasse assim na iniciativa do imigrante como personagem povoador da cidade e do bairro do Brás, o responsável pela introdução e formação das primeiras fábricas. Para Torres, “a imigração, trazendo o espírito de iniciativa e a necessária mão de obra à indústria, particularmente a têxtil que encontra mercado certo na produção nacional"34, conferiu ao Brás seu caráter industrial e como local propício para a implantação futura de suas indústrias, forjando-se como um bairro fabril e de típica residência operária. Tendo como fonte as Atas da Câmara Municipal de 1891, relata o seguinte episódio:

\footnotetext{
"Misturam-se fábricas e residências. Em 1878 os italianos Ludovico Dal Porto e Francisco Casini fundam a primeira fábrica de massas alimentícias na rua Monsenhor Andrade, em meio a modestas casas construídas nas antigas datas de terras. Nem sempre, porém, são as fábricas instaladas sem protestos de antigos moradores. Em 1891 os moradores da rua do Brás pedem a Câmara Municipal que não permita a construção de 'fábricas naquela rua', da 'Companhia de Fumos Paulista, em centro tão populoso'. Ouvido o Dr. Inspetor de Higiene, este, em virtude do parecer do Dr. Adjunto daquela inspetoria, resolveu que o maquinismo para manipulação seja montado a 100 metros afastados do estabelecimento da administração e depósitos" 35 .
}

Para Torres o desenvolvimento do bairro do Brás se dá num processo conjunto com o próprio desenvolvimento da cidade e assim, pode ser verificado por meio da série de plantas cartográficas editadas e reproduzidas pelo Atlas da Comissão do IV Centenário da Cidade de São Paulo, que "permite uma visão da expansão urbana paulistana durante todo o século XIX", bem como servir de ilustração para o seu trabalho ${ }^{36}$, sem que fizesse uma crítica à própria produção material desta cartografia ${ }^{37}$. Do conjunto publicado em 1954, duas plantas da cidade foram escolhidas para uma análise mais detida sobre o Brás: uma publicada por Jules Martin em 1890, e outra realizada pela Companhia Cantareira e Esgotos em 1881. Na sua leitura visual desta cartografia, a autora evidencia o caminho "na direção de suas novas funções - comercial e industrial - não perde[ndo o] Brás a sua antiga função

\footnotetext{
${ }^{34}$ Idem, pág. 113.

${ }^{35}$ Idem, pág. 113-114.

${ }^{36}$ Idem, pág. 123.

${ }^{37}$ Vide o trabalho desenvolvido por REIS Filho, Nestor Goulart. São Paulo: Vila, Cidade, Metrópole. São Paulo: Bank Boston, 2004.
} 
de abastecedor do mercado miúdo de São Paulo, nem deixara ainda, de ter inúmeras hortas, pomares e chácaras, 'agricultura miúda', na pitoresca linguagem de então" ${ }^{38}$. Enquanto a de 1881, cadastral, para a autora é a planta mais completa pois oferece uma ideia da distribuição dos prédios pelas diversas ruas e travessas existentes na cidade, a de Jules Martin revela as ruas abertas no Brás até a praça da Concórdia, e à rua da Mooca e ao bairro do Pari, sendo "particularmente interessante observar como se aglomeram as casas nas proximidades da estação do Norte e do Gasômetro"39.

Caracterizando o bairro em fins do século XIX como "dos italianos, principalmente napolitanos", e "pela presença de cocheiros italianos substituindo os portugueses", Torres acrescenta que este movimento faz parte da

\footnotetext{
“nova metrópole que substitui, definitivamente, o velho colégio jesuítico (...) Ao contrário da maioria das cidades sulamericanas, que se desenvolveram, principalmente, como centros de cultura, burocráticos ou comerciais, a capital paulista torna-se, no século XX, o maior centro industrial da América Latina"40
}

e não por acaso, relaciona esse processo de formação da indústria paulista ao desenvolvimento do bairro do Brás.

Ao citar Bandeira Junior, o mesmo a que se refere Ernani Bruno, Torres lista uma série de fábricas que eram em grande parte, pertencentes a italianos:

\footnotetext{
"Fábrica de Móveis, fundada em 1888 pertencente aos Irmãos Rafinetti (Rua Piratininga), Fábrica a vapor de massas alimentícias, de Romali \& Cia., fundada em 1896 (Rua do Gasômetro), Fábrica de massas alimentícias, a vapor, de Alexandre Ranzini, fundada em 1897, no Belenzinho, Fábrica de massas, de João Christofani, a mais antiga no Estado, fundada em 1878 (rua Monsenhor Andrade), Fábrica Italiana de Material Antiséptico, de Giacomo Mattia, fundada em 1900 (Avenida Intendência), Premiada Destilação Italiana a vapor, de Luiz Trevisan \& Irmão, fundada em 1886 (rua Visconde de Parnaíba), no Marco da Meia Légua, Funilaria Mecânica a vapor, de Dorico Michele, fundada em 1893 (rua Almirante Wandenkolk), Fábrica de Construções de Ferro, de Lenisa \& Mirati, fundada em 1895 (rua do Gasômetro). Bandeira Jr. refere-se ainda a outras: Fundição de Ferro e Bronze de Craig \& Martins, fundada em 1895 (rua Monsenhor Andrade), Fábrica de Carros, fundada em 1891, dos Rodovalho (rua da Mooca), Cristalaria
}

38 TORRES, Op. Cit, pág. 128.

${ }^{39}$ Idem, pág. 123.

40 TORRES, Op. Cit., pág. 158 e 162. 
Germânia, fundada em 1890, de Conrado Sorgenicht \& Cia (Avenida Intendência), Fábrica a vapor de massas alimentícias - A industrial, de Jose Pinto da Fonseca fundada em 1892 (rua do Gasômetro), Fabrica a vapor de graxa para calcados, de Alexandre Sekmer (rua Martin Afonso), Grande Fábrica a vapor de Águas Minerais e Outras Bebidas, Christoffel Stupakoff, fundada em 1871, de Augusto Tolle (rua Piratininga), e, ainda uma Casa de Flores, de Manuel Garcia da Silva, fundada em 1883 - o Japão - à rua São Bento, com filial em Santos, mas recebendo o material de um grande estabelecimento floro-agricultor situado à rua Piratininga, onde plantas nacionais e estrangeiras são cultivadas com preceitos e cuidados necessários, onde se fazem as experiências de cultivo, enxerto e cruzamento de qualidades" 41 .

Em muitos aspectos pode-se verificar uma aproximação da obra de Maria Celestina Mendes Torres com a obra de Ernani Silva Bruno, seja pela escolha das fontes documentais anteriormente já trabalhadas, seja pelos marcos de transição da história da cidade, ou pela eleição de certos personagens como o imigrante que teria impulsionado o desenvolvimento do bairro junto ao da cidade. Neste cenário de produção historiográfica, é de se entrever que O Bairro do Brás foi o primeiro livro publicado em coleção patrocinada pelo Departamento do Patrimônio Histórico da Secretaria Municipal de Cultura da Prefeitura de São Paulo no ano de 1968, projeto que tinha como premissa anualmente publicar trabalhos que remetessem à história dos bairros da cidade. Mas ainda assim uma pergunta paira no ar quando nos indagamos sobre a possibilidade de um trabalho como este ter sido agraciado com tal premiação.

A obra de Torres não apenas dialoga com autores que já se firmavam como consagrados na literatura de São Paulo, mas é de se perceber nitidamente que seu trabalho pode ter sido o que mais se aproximou das leituras (e por que não dizer grupos intelectuais) daqueles que compunham a comissão julgadora do prêmio do I Concurso Municipal de História dos Bairros de São Paulo: Myriam Ellis, filha de Alfredo Ellis Júnior, e na época professora da Faculdade de Filosofia, Letras e Ciências Humanas da Universidade de São Paulo (FFLCH USP); Pedro Brasil Bandecchi, egresso da Faculdade de Direito, e na época, professor de História do Brasil no SENAC ${ }^{42}$; e por fim, nada menos que a própria figura de Ernani Silva Bruno.

${ }^{41}$ Idem, pág. 164.

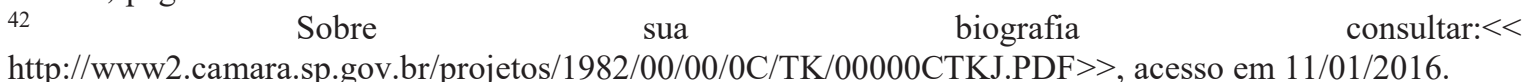


Sua obra tornou-se material de referência sobre o Brás, por conter inúmeros dados que pudessem evidenciar as transformações que o bairro passou entre o final do oitocentos e os anos de 1920, e assim, servissem de respaldo para a compreensão de um bairro que auxiliou na formação da cidade que "em 1554 [não] poderia relegar ou apenas pressentir a futura metrópole em que se transformaria no século XIX" ${ }^{\prime 4}$, predominando em grande parte uma linguagem ufanista e de glória diante das transformações da cidade.

Por meio de um grande número de fontes iconográficas, Torres as utiliza de forma que pudessem conferir um tom de "veracidade" àquilo que escrevia em seu texto, como se pela evidência das fotografias que retratam paisagens rurais, em detrimento de outras que complementavam sua rápida transformação com novos imóveis; ou também pelo constante uso da cartografia, a qual pudesse demonstrar a "evolução" do bairro a partir do surgimento de novas ruas, evidenciando sua expansão junto à cidade.

Convém trazer à tona alguns dados que interligam os componentes da comissão julgadora deste trabalho: a filha de Alfredo Ellis Júnior (Myriam Ellis), na época já morto, levava com afinco a produção intelectual que seu pai deixou, principalmente na escolha e eleição de temas que redundassem na história do povoamento e da economia paulista; Pedro Brasil Bandecchi, ex-aluno da Faculdade de Direito, ligado à Academia Paulista de História, tendo ocupado diversas funções e cargos públicos, dentre eles o de vereador da Câmara Municipal de São Paulo e de Secretário da Educação e Cultura, bem como ser professor da Universidade de São Paulo; e por fim, Ernani Silva Bruno, jornalista curitibano, e também radicado da Faculdade de Direito da USP, sendo que na época ocupava posição de destaque no cenário intelectual, pois seus livros despertavam grande interesse do público, além de estar prestes a assumir a direção do Museu da Casa Brasileira, cargo que ocuparia de 1970 a 1979, instituição a qual teve íntima relação desde sua formação a partir da guarda de muitos dos móveis expositivos constantes nas exposições dos festejos do IV Centenário da cidade de São Paulo. Três representantes de uma vertente historiográfica que estava em curso desde o começo da segunda metade do século XX, notadamente levada a cabo com as comemorações dos 400 anos da fundação da vila de São Paulo, e que procurava manterse alinhada às fontes documentais já observadas por outros autores, mas, com a evidente marca de filiar-se à escola de escrita da história de São Paulo, do grupo de intelectuais ligados à Faculdade de Direito da USP, e mesmo do empresariado industrial que financiava tais obras, como bem observou Rodrigo Silva em sua dissertação de mestrado acerca das

${ }^{43}$ TORRES, Op. Cit., pág. 23. 
representações construídas no século XVIII e reatualizadas no século XIX, ganhando força em diferentes espaços da escrita da história em São Paulo ao longo da primeira metade do século XX. ${ }^{44}$

Para Maria Celestina Torres pode não ter sido fácil ganhar o concurso, mas, fica evidente sua filiação à tradição de elaboração de uma história que se remeta à escola de Ellis Junior (que assim como muitos intelectuais da primeira metade do século XX, reiterava a ideia de decadência paulista no século XVIII), por meio do contato com a filha dele, na época, professora da USP. Seu envolvimento com Pedro Bandecchi parece-nos ter sido menor quando comparado com a tradição de Ellis Junior, mas ainda assim, demonstra sua filiação e preocupação em demarcar a instalação da Faculdade de Direito como um marco para o próprio desenvolvimento do bairro do Brás, dado este que firma sua aproximação cronológica com ele, e Ernani Silva Bruno, dois egressos das Arcadas, este com uma produção intelectual que vigorou por longo tempo.

Além de sua obra sobre o Brás, a autora também foi agraciada com outros dois prêmios da série "História dos Bairros de São Paulo": o segundo prêmio do II concurso, realizado no ano de 1970, dedicado ao bairro de Santana, e que contava em sua banca com o professor Ernesto Leme, radicado da Faculdade de Direito e ex-reitor da Universidade de São Paulo entre os anos de 1951 a 1953; José Pedro Leite Cordeiro, médico da Faculdade de Medicina na mesma universidade, e membro do IHGSP; e o jornalista Fernando Goes ${ }^{45}$; e o primeiro prêmio no VIII concurso, ocorrido em 1977 sobre o bairro do Ibirapuera, no qual não encontramos informações referentes aos membros da banca de escolha desta obra. $^{46}$

Nossa preocupação não se baseia em menosprezar os memorialistas e a historiografia que nasceu na segunda metade do século XX, mas ressaltar a importância da convergência de diferentes fontes documentais que não apenas ilustrem ou possuam um caráter de veracidade, mas capaz de ampliar nossa compreensão sobre o processo de

\footnotetext{
${ }^{44}$ Rodrigo Silva, em recente trabalho desenvolvido no Departamento de História da Faculdade de Filosofia, Letras e Ciências Humanas da USP, defendeu que muitos dos discursos que caracterizavam a cidade de São Paulo, como ser pacata e ser restaurada (ou não) pelo Morgado de Matheus no século XVIII, corresponderia aos próprios interesses da intelectualidade que escreveu sobre, de modo a resignificarem tais eventos e em muitas vezes, colocarem-se como os novos atores sociais da história da cidade. SILVA, Rodrigo. Sobre taipas e textos: um estudo sobre as narrativas a respeito da cidade de São Paulo. São Paulo: Alameda, 2013.

${ }^{45}$ TORRES, Op. Cit., pág. 05.

${ }^{46}$ Ainda não há um estudo que mapeie as indagações e debates historiográficos na produção da coleção "Histórias dos bairros de São Paulo", a fim de compreendermos seu processo de idealização, divulgação e de propagação intelectual por meio dos agentes envolvidos, como os atores, membros das comissões julgadoras e políticos.
} 
urbanização do bairro atrelado às próprias mudanças que a cidade de São Paulo e outras do mundo capitalista estavam vivenciando, com uma marcada imigração, mudança nos contextos políticos e uma burguesia que ascendia socialmente.

A coleta e espacialização da documentação processada, em sua maioria os pedidos de reformas ou construção de obras por particulares, demandaram um tempo além do esperado, impedindo que pudéssemos debruçar muito mais em torno de questões intuídas pela pesquisa. Convém destacar que se tata de uma documentação vasta, e sistematizá-la num banco de dados não foi tarefa fácil. Esta sistematização de dados referentes aos loteadores, construtores e proprietários, só para darmos os exemplos de alguns dos agentes do processo de urbanização do Brás foi penosa, mas muito válida também, pois o que nos permitiu precisar aspectos característicos do Brás e desmistificar os estereótipos supracitados. Tampouco foi fácil especializar as relações sociais e posteriormente estabelecer o cruzamento com diversas outras fontes, como fotografias, anúncios de revistas e jornais, relatos de história oral, relatos memorialísticos, e a mencionada cartografia com os almanaques comerciais.

É de se ressaltar que a coleta e sistematização da série Obras Particulares fora proporcionada pelo meu contato anterior com a documentação no Arquivo Histórico Municipal. Como funcionário, pude conhecer e trabalhar in loco com toda a organização arquivística de tratamento, higienização, catalogação, sistematização das informações no banco de dados da instituição, e mesmo com outras séries e coleções depositadas no vasto acervo ali contido. A formação foi além, pois a série em questão fora contemplada com um projeto financiado pela FAPESP, que teve como principal objetivo sua informatização juntamente com o Fundo Particular Severo e Villares, séries documentais que incluem mais de 65 mil projetos arquitetônicos de obras públicas e projetos de particulares (edifícios comerciais, de serviços, residenciais etc.), submetidos à aprovação da Prefeitura entre 1906 a 1915. O Prof. Dr. Nestor Goulart Reis Filho coordenou o projeto, constituído por Professores e Pesquisadores do Laboratório de Estudos sobre Urbanização, Arquitetura e Preservação - LAP da FAUUSP, e a Prof ${ }^{a}$. Dra. Beatriz Piccolotto Siqueira Bueno esteve à frente da sua concepção e execução, supervisionando os trabalhos no Arquivo Histórico Municipal. 
Outros trabalhos já se debruçaram sobre a série Obras Particulares, como os desenvolvidos por Carlos Lemos $^{47}$, Heloisa Barbuy ${ }^{48}$, Lindener Pareto Júnior ${ }^{49}$ e Jorge $\operatorname{Lody}^{50}$, além dos citados anteriormente ${ }^{51}$, porém, com a recente informatização do mesmo no site www.projetosirca.com.br, uma nova geração de pesquisadores vem podendo se debruçar em torno do rico material que são as obras particulares.

As obras particulares, no momento de sua produção, configuraram-se como materiais que garantiam a observação das transformações da cidade pelo poder público, que regulava as construções novas e aquelas que passariam por reformas. Assim, todo particular que desejasse construir na cidade a partir de 1893, era obrigado a apresentar Diretoria de Obras e Viação um memorial descritivo das obras que desejasse fazer, de forma que estivesse de acordo com os padrões higiênico-sanitários da época (respaldados pela legislação), e de desenhos arquitetônicos que demonstrassem visualmente as obras a serem realizadas. Assim, a cidade oficial era orquestrada e regulada, desde a região central aos bairros que surgiam em suas franjas, e assim podemos vislumbrar os interesses de particulares e os pareceres do poder público diante das tramas de transformação da cidade de São Paulo nos finais do século XIX. Tal material, analisado em conjunto sobre uma determinada área, nos são uma rica fonte de informações para analisarmos a história de produção da cidade de São Paulo e mesmo de outras do mundo capitalista.

A partir da seleção das ruas a serem pesquisadas, com base na Planta Geral da Capital de São Paulo, organizada por Gomes Cardim em 1897, organizamos todos os projetos remetidos para aprovação da Prefeitura entre os anos de 1906 a 1915, formando um banco de dados com mais de 2.500 pedidos de particulares da área do Brás. Na amostragem pesquisada, predominam residências, espalhadas por todas as ruas do bairro. O banco de dados nos serviu então de referência para toda a dissertação e mostrou-nos, por meio de planilhas, que não havia apenas casas operárias no Brás, um estereótipo a se desconstruir.

Nosso trabalho conta com três capítulos, sendo o primeiro deles dedicado aos primeiros sinais de parcelamento do solo da área da então Várzea do Carmo, a porção de terras que se desdobrava para além do rio Tamanduateí, e que posteriormente seria

${ }^{47}$ LEMOS, Carlos Alberto Cerqueira. Cozinhas, etc. São Paulo: Perspectiva, 1978; A República ensina a morar (melhor). São Paulo: Hucitec, 1999.

48 BARBUY, Heloisa. A cidade-exposição: Comércio e cosmopolitismo em São Paulo, 1860-1914. São Paulo: Edusp, 2006.

49 PARETO JÚNIOR, Lindener. O cotidiano em construção: os "práticos licenciados" em São Paulo. Dissertação (Mestrado em Arquitetura e Urbanismo), Faculdade de Arquitetura e Urbanismo, Universidade de São Paulo, 2011.

${ }^{50}$ LODY, Op. Cit.

${ }^{51}$ SCHNECK, Op. Cit.; BORIN, Op. Cit.; CARVALHO, Op. Cit. 
oficializada como Brás a partir da segunda metade do século XIX, com o loteamento das chácaras e o papel de diversos personagens ligados ao mundo econômico, social, político e econômico desta região da cidade. Muitos desses personagens estariam ligados a um inicial processo de parcelamento do solo do bairro do Brás, aparecendo nos pedidos de alinhamento para a Câmara Municipal de São Paulo. Tais personagens, possuidores de extensões de terra que variavam entre si, conferiram nomes às principais ruas do bairro, permanecendo como um marco toponímico de longa duração, que perdura até os nossos dias. Atrelado a tal questão, procuramos trazer em discussão a implantação de alguns dos equipamentos urbanos existentes nesta porção da cidade até o começo do século $\mathrm{XX}$, de modo que servissem à população ali residente e mesmo a outras porções da cidade, como o Gasômetro e as linhas de bondes.

O segundo capítulo vai de encontro à nossa principal discussão proposta, em torno da atuação dos setores médios da população na região leste da cidade de São Paulo, analisando os primeiros pedidos de construção obrigatórios pela então Intendência Municipal no ano de 1893, estendendo-se até 1915, data limite da nossa documentação. Iniciamos com a explanação da questão da moradia em São Paulo debatida a partir da figura do vereador Afonso Celso Garcia da Luz, que trouxe em suas falas algumas das propostas de melhoria das condições de habitação da população de São Paulo. Posteriormente, procuramos discutir o principal programa arquitetônico construído nas ruas do Brás, as residências, destrinchando as múltiplas formas de habitação, como as casas mínimas, casas em série, vilas operárias, casas para os setores médios, palacetes e os cortiços. Sobre esta última forma de morar, estendemos a discussão para duas décadas à frente, a fim de que o debate se ampliasse, e pudéssemos aferir as formas de morar diante da cidade não oficial, e que perduraram até pelo menos os anos 1940, quando os registros por nós utilizados foram feitos.

Por fim, o terceiro capítulo procura tecer as relações de sociabilidade e consumo presentes nas ruas do Brás, mapeadas a partir do cruzamento dos pedidos de construção e reformas de obras particulares, com os anúncios do Almanaque Laemmert, publicado desde o ano de 1844, e que trazia em suas páginas uma variada gama de comércios, profissionais, endereços de repartições públicas, dentre muitos outros pontos de interesse da cidade que podiam ser vislumbrados ano a ano, rua por rua. Desta forma, procuramos entrever quem seriam os usuários dos imóveis construídos, o que vendiam, com quem se relacionavam, os motivos de determinados gêneros de comércio estarem instalados em determinadas vias em detrimento de outras, exclusivamente residenciais. Além disso, procuramos vislumbrar as 
opções de lazer e diversão da época, com seus cinemas e teatros, e mapearmos as instituições educacionais, que não se encerravam em escolas financiadas pelo Estado, mas por uma série de outras fundadas por grupos imigrantes.

Como um exercício de espacialização, procuramos elaborar mapas que trouxessem em discussão a formação e a materialidade do bairro, com base na cartografia histórica e na cartografia atual, cotejando aproximações de onde localizavam-se alguns dos espaços estudados por nós. Com apoio da Planta Industrial e Commercial da Cidade de São Paulo, produzida cerca de $1911^{52}$, editada por Thomas \& Cia, e depositada no Arquivo Aguirra do Museu Paulista, pudemos inferir a localização de muitos dos estabelecimentos aqui trabalhados. Visto que se trata de uma planta pictórica, a mesma não possui um desenho fiel ao tamanho das ruas e lotes. Desta forma, procuramos trabalhar com um mapa produzido dentro de nossa temporalidade: a Planta da Cidade de São Paulo levantada pela Divisão Cadastral, de 1916, e depositada no Núcleo de Acervo Cartográfico do Arquivo Público do Estado de São Paulo. O mapa, possui delimitações mais “exatas” do período em questão, e vislumbra uma área que não consta na Planta Industrial e Commercial.

A espacialização se deu por meio de uma metodologia denominada SIG (Sistemas de Informações Geográficas), a qual auxilia no processo de compreensão espacial, e no nosso caso, a entrever o processo de urbanização do Brás. Segundo Ian Gregory,

\footnotetext{
“O SIG permite que informações geográficas sejam usadas de maneira mais poderosa que qualquer outro meio permita. Ele traz um conjunto de ferramentas que permitem ao historiador estruturar, integrar, manipular, analisar e dispor informações de maneiras completamente novas". 53
}

Atrelado a este exercício, e como forma de vislumbrar uma possível paisagem de como se configurou o Brás entre os anos de 1906 a 1915, elaboramos um perfil de algumas das ruas do bairro, com as fachadas dos seus edifícios. Inspirados no trabalho desenvolvido por Heloisa Barbuy, a qual estudou as circulações, o consumo, as sociabilidades do Triângulo histórico ${ }^{54}$, a autora produziu um infográfico com o perfil dos edifícios e fachadas reconstruídos nesta área entre os anos de 1880 a 1914, a partir dos desenhos arquitetônicos da Série Obras Particulares, depositadas no Acervo de Manuscritos do Arquivo Histórico

\footnotetext{
52 BARBUY, Op. Cit., pág. 208.

${ }^{53}$ GREGORY, Ian e ELL, Paul. Historical GIS. Cambridge: Cambridge University Press, 2007, pág. 1-17

(Tradução minha).

${ }^{54}$ Região formada pelas ruas Direita, 15 de Novembro, São Bento e adjacências.
} 
Municipal. Para a localização dos imóveis, a autora utilizou-se da numeração contida nos desenhos arquitetônicos, juntamente com a Planta Industrial e Commercial.

No nosso caso, procuramos nos basear no mesmo material utilizado pela autora, e com apoio da coleção cartográfica SARA Brasil, de 1930, também sob a guarda do Arquivo Histórico Municipal. Apresentamos desta forma, o perfil das ruas Miler, Concórdia, Bresser, Maria Marcolina e das avenidas Rangel Pestana e Celso Garcia, todas (com exceção da primeira) atendidas por bondes e que evidenciaram ao longo da pesquisa serem algumas das ruas com maior dinamismo comercial e de moradia dos setores médios. Alguns dos edifícios não apresentavam numeração, mas sua localização foi aferida por meio das informações contidas nos processos, como esquinas, ruas próximas ou entre outros prédios. Assim, cada edifício pôde contar com seu número na época, e quando possível o proprietário ( 


\title{
Capítula 1: Uma cidade entre chácaras: (des)casturanda um lairra para além da centra - entre prajetas, lateamentas e serviças públicas
}

\begin{abstract}
"Atravessei a cidade de São Paulo, incontestavelmente a mais bela de todas por mim visitadas desde que estava no Brasil. Chegado ao Convento do Carmo, de onde se descortina uma belíssima vista, desci por uma rua calçada, a qual, por uma ladeira bastante íngreme, estende-se até o córrego do Tamanduateí, e que é cercada de um lado por pequenas casas e do outro pelo terraço do convento. O córrego corre abaixo da cidade, constituindo ali um dos limites da mesma; é o mesmo transposto por uma ponte de pedra, de um só arco. Além dessa ponte, apresenta-se uma vasta planície, que apesar de uma mudança de nível muito pronunciada, deve, contudo, ser considerada como a continuação da de Piratininga, e que, muito pantanosa nas vizinhanças do córrego, apresenta mais longe, uma alternativa de pastagens e de capões de mato pouco elevados. Num espaço de algumas centenas de passos a partir da ponte, o caminho é bordado e embelezado pelos tufos espessos de uma grande seneceonácea de flores de um amarelo doirado; depois, além dessa parte do caminho, vêem-se várias casas de campo." 55
\end{abstract}

É com essa visão de impressionismo que o viajante francês Auguste de Saint-Hilaire descreve a cidade de São Paulo em 1819, às vésperas da Independência do Brasil. Com um relato de um típico viajante do século XIX, suas expressões denotam descrever por minúcias uma cidade que circunscrevia seus limites à localização de três igrejas: a de São Bento, São Francisco e de Nossa Senhora do Carmo, sendo a partir desta última possível vislumbrar toda a região que se descortinava adiante, com o rio Tamanduateí, as casas e a natureza que se estendia.

São Paulo é uma cidade que desde sua fundação como vila em 1554, até a segunda metade do século XX possuiu íntima relação com seus rios, riachos e ribeirões, cursos d'água que garantiam a subsistência aos lavradores e moradores que habitavam suas margens, ou mesmo servissem de rota como via de ligação para outras regiões interioranas do Brasil. Dois rios tiveram notável importância no desenvolvimento da vida social de São Paulo: o Anhangabaú e Tamanduateí, sendo este um rio que demarcou por mais de 300 anos

55 SAINT HILAIRE, Auguste. Viagem à província de São Paulo. São Paulo: Martins, 1940. p. 148, apud OLIVEIRA, Maria Luiza Ferreira de. "O registro dos limites da cidade: imagens da várzea do Carmo no século XIX”. Anais do Museu Paulista, N. Sér. v. 6/7, (1998-1999), editado em 2003, pág. 51. 
os limites da vila que se circunscrevia às ruas da colina histórica e nas primeiras décadas do século XIX teria parte de seu curso alterado, propiciando que houvesse uma expansão da cidade para além da Várzea do Carmo, a região compreendida após a descida da ladeira do Convento das Carmelitas, conforme descrita por Saint Hilaire.

Bastava cruzar as águas do chamado "rio dos tamanduás verdadeiros" "56, segundo a terminologia tupi guarani, que uma vasta área se descortinava, repleta de chácaras, cortadas apenas por uma estrada que levava ao Rio de Janeiro, passando pelas freguesias da Penha e pela região de São Miguel. Esta área, comumente fora identificada por ser um espaço dividido entre imensas chácaras, que, na realidade, circundavam a cidade de São Paulo, e até o começo do século XX muitas delas ainda podiam ser encontradas. Pois é no último quartel do século XIX que estas mesmas chácaras passariam a ser retalhadas, como um tecido cortado entre vários pedaços, partes estas que seriam compradas por diferentes personagens do mundo político, religioso, econômico e social da São Paulo oitocentista.

No entanto, um certo tipo de discurso teleológico persiste em marcar esse espaço do rio e além como uma região que se desenvolveu graças ao progresso industrial, e que encontrava-se preterido da cidade civilizada e moderna que se almejava na passagem do século XIX para o XX, imagem de metrópole que São Paulo acabou por perseguir e se tornar, mas que não fora uniforme para toda sua dimensão territorial, e nem mesmo igualitária no que concerne à disponibilização de espaços e áreas para seus mais diversos extratos sociais.

Muitos são os relatos que caracterizam São Paulo em finais do século XIX como uma cidade ladeada por chácaras, sítios, fazendas, nas quais havia uma produção a ser vendida na cidade ou em localidades próximas, cujo destino foi dar origem a novos bairros fabris e residenciais. O processo de retalhamento das áreas além do rio Tamanduateí foi abordado por memorialistas, os quais debruçaram suas impressões sobre diversas partes de São Paulo em épocas posteriores, como as obras de Ernani Bruno, Jacob Penteado e Alcântara Machado. Tais obras denotam uma visão de cidade que merece ser revista, e que pode ir além da simples descrição dos espaços na qual se referem, e, portanto, procuramos não as encarar como um referencial concreto da materialidade da cidade nas épocas a que se referem. Tal material pode ser considerado basilar para os estudos de impressões de como

\footnotetext{
${ }^{56}$ Segundo Maria Vicentina Dick, "a etimologia de Tamanduateí não é pacífica; pode ser um composto de tamanduá + (t)eyra, "multidão de tamanduás". Theodoro Sampaio anota que o vocábulo também significa "rio do tamanduá grande". DICK, Maria Vicentina de Paula do Amaral. A dinâmica dos nomes na cidade de São Paulo: 1554-1897. São Paulo: Annablume, 1996, pág. 37.
} 
era a cidade, e quando utilizadas em conjunto com outros materiais, como a iconografia, a cartografia e a fotografia, é possível uma visão mais acurada dos espaços a que ela descreve, como a Várzea do Carmo na segunda metade do século XIX.

Ernani Silva Bruno fora um dos que mais se debruçou sobre a região da Várzea do Carmo, traçando aspectos que remontam ao tempo em que a cidade era um "Arraial dos Sertanistas" (1554-1828) entendendo que este era um local sem importância econômica e social, e que no futuro, teve sua ascensão juntamente com a cidade que se modernizava. Remontando informações de um artigo de Teodoro Sampaio na Revista do Instituto Histórico e Geográfico de São Paulo, Bruno evoca trechos que enfatizam a insalubridade e mal-estar em viver numa área como aquela em princípios do século XIX, constatando que a Várzea do Carmo contava "com habitações dispersas, ranchos toscos com uma venda anexa (...) e grupos de pequenas casas mal edificadas ao longo da estrada para o Rio de Janeiro" ${ }^{57}$. Tal descrição estaria de acordo com sua compreensão histórica da dinâmica de São Paulo, que não passava de um arraial marasmático que só mereceu mudanças a partir de meados do século XIX. Para Bruno,

\footnotetext{
“Com a proclamação da República quase todos os donos de chácaras antigas dos bairros de Santa Ifigênia, Bom Retiro, Brás, Consolação, Liberdade e Cambuci escreveu Antonio Egidio Martins - mandaram abrir ruas, avenidas, alamedas e largos em suas terras. Não só desses bairros, podia-se dizer. Mas também do Higienópolis, Avenida Paulista, Mooca, Pari, Ipiranga, Barra Funda e Água Branca, onde enormes áreas descampadas foram recebendo arruamento e loteação" $"$.
}

Segundo a cronologia estabelecida por Bruno, entre os anos de 1828 e 1872 São Paulo tornou-se o então "burgo dos estudantes", tempo que corresponderia à implantação da Academia de Direito, e para o jornalista servia como outro marco balizador das transformações que assolaram a cidade desde então, com desdobramentos urbanísticos que se espraiariam para além dos seus limites, indo de encontro ao que seus administradores e investidores (quase em sua maioria advindos dessa escola), desejavam: aumentar seus rendimentos por meio do uso de suas terras.

\footnotetext{
${ }^{57}$ BRUNO, Op. Cit, pág. 198-199.

${ }^{58}$ Idem, pág. 1027.
} 
A venda das chácaras acompanha o ritmo de transformações de cidade que, sem parada, irradia seus tentáculos em todas as direções. Aos olhos de Silva Bruno e tantos outros memorialistas, "arruamento e loteação" eram sinônimos de progresso, o que não necessariamente correspondiam à população da época, mesmo aos setores médios, muitos deles proprietários destas terras que estavam prestes a serem colocadas na praça para serem vendidas. Ao nos depararmos com muitos dos anúncios de jornais de finais do século XIX, percebemos que os discursos eram de venda de lugares com vegetação, plantações, mas com fácil localização, por estarem próximos da estrada do Brás, e da linha da Estrada de Ferro Dom Pedro II, com sua Estação do Norte pairando nas proximidades de chácaras que passavam por pequenos retalhamentos.

\subsection{A Várzea do Carmo e suas chácaras a partir do olhar de Militão Augusto de Azevedo}

A partir do último quartel do século XIX, tornam-se perceptíveis as mudanças que São Paulo apresentava, especialmente com relação a determinados personagens e seus espaços: no cenário, surgem novos atores, como os imigrantes que na cidade se estabeleceram, viajantes que relatavam suas impressões, negros que cada vez mais ocupavam as ruas a fim de obterem dinheiro com a venda de doces e frutas, ou mesmo em áreas próximas aos rios, espaço onde lavavam as roupas e as estendiam na relva do rio Tamanduateí ${ }^{59}$. As áreas próximas à então cidade, passaram a ser alvo constante de atenção, tanto do poder público, como de proprietários. Ernani Silva Bruno relata que

\footnotetext{
Feitas de taipa eram também as sedes de chácaras antigas existentes nos bairros ou nas imediações da cidade," [sendo que] "para muitas famílias abastadas de fazendeiros, então fixadas na cidade, essas chácaras e casas de campo representavam um fenômeno de meia urbanização. O paulista da roça - que desde os tempos coloniais quando tinha casa na cidade era só para passar domingos ou dias de festa - urbanizava-se, mudando-se para a capital da província ${ }^{60}$ [grifo nosso].
}

\footnotetext{
${ }^{59} \mathrm{~A}$ historiadora Maria Odila fora uma das pioneiras em trazer em perspectiva a vida e o cotidiano de diferentes personagens antes deixados à margem pela historiografia, essencialmente no que concerne à cidade de São Paulo oitocentista. DIAS, Maria Odila Leite da Silva. Quotidiano e poder em São Paulo no século XIX. São Paulo: Brasiliense, 1984.

${ }^{60}$ BRUNO, Op. Cit., pág. 478-479.
} 
Ao trazermos em perspectiva o olhar de Militão Augusto de Azevedo, como um fotógrafo que registrou sobremaneira a cidade de São Paulo entre 1862 e 1887, percebemos que sua produção se estendeu para além das ruas centrais da cidade, registrando também a porção leste da capital paulista, com suas chácaras, o rio Tamanduateí, alguns de seus personagens e suas relações sociais com esses espaços, principalmente na década de $1860^{61}$.

No que diz respeito à Chácara Tabatinguera, localizada na margem esquerda do rio Tamanduateí, conta-nos Egydio Martins que esta era também conhecida como Chácara da Dona Ana, que anteriormente pertencia ao Tenente-Coronel Francisco de Assis Lorena (Conde de Sarzedas), até ser de propriedade de D. Ana Maria de Almeida Lorena Machado, onde havia uma famosa fonte de água chamada Santa Luzia e que servia a diversos viajantes que estavam a caminho da $\mathrm{Sé}^{62}$. Pouco depois da época do registro fotográfico feito por Militão Augusto de Azevedo, conta-nos outro memorialista, que os nadadores do rio Tamanduateí corriam para as matas do interior da chácara, fugindo dos policiais que cercavam "as duas margens do Tamanduateí, no trecho da rua do Glicério"63, dada a proibição do divertimento que talvez tenha surgido por todos estarem nus e ou do perigo que podia ocorrer por menores praticarem o esporte. Esta chácara daria origem às ruas Conselheiro Furtado, Conde de Sarzedas, Tomás de Lima e Santa Luzia. ${ }^{64}$ Um anúncio de 27 de março de 1860 do jornal Correio Paulistano, faz alusão a um dos primeiros sinais da venda desta chácara:

\footnotetext{
"Vende-se uma rica chácara com boa casa de sobrado construída toda de novo com pilares de tijolos, sita na rua da Tabatinguera... a qual tem muitos e bons arvoredos, de diversas qualidades, como peras, maçãs, ameixas, grandes parreiras, etc., plantações de chá, capim e um grande pasto para animais, riquíssima água dentro"65.
}

\footnotetext{
${ }^{61}$ Solange Ferraz Lima em seu mestrado explorou as transformações da cidade vista pela lente de diferentes fotógrafos, em especial de Militão Augusto de Azevedo. LIMA, Solange Ferraz. São Paulo na virada do século. As imagens da razão urbana: a cidade nos álbuns fotográficos de 1887 a 1919. (Mestrado em História) FFLCH, São Paulo, 1995.

${ }^{62}$ OLIVEIRA, Op. Cit., pág. 54.

${ }^{63}$ FREITAS, Afonso A. de. Tradições e reminiscências paulistanas. Apud, BRUNO, 1954, pág. 1246.

${ }^{64}$ BRUNO, Idem, pág. 1029.

${ }^{65}$ Idem, pág. 577.
} 


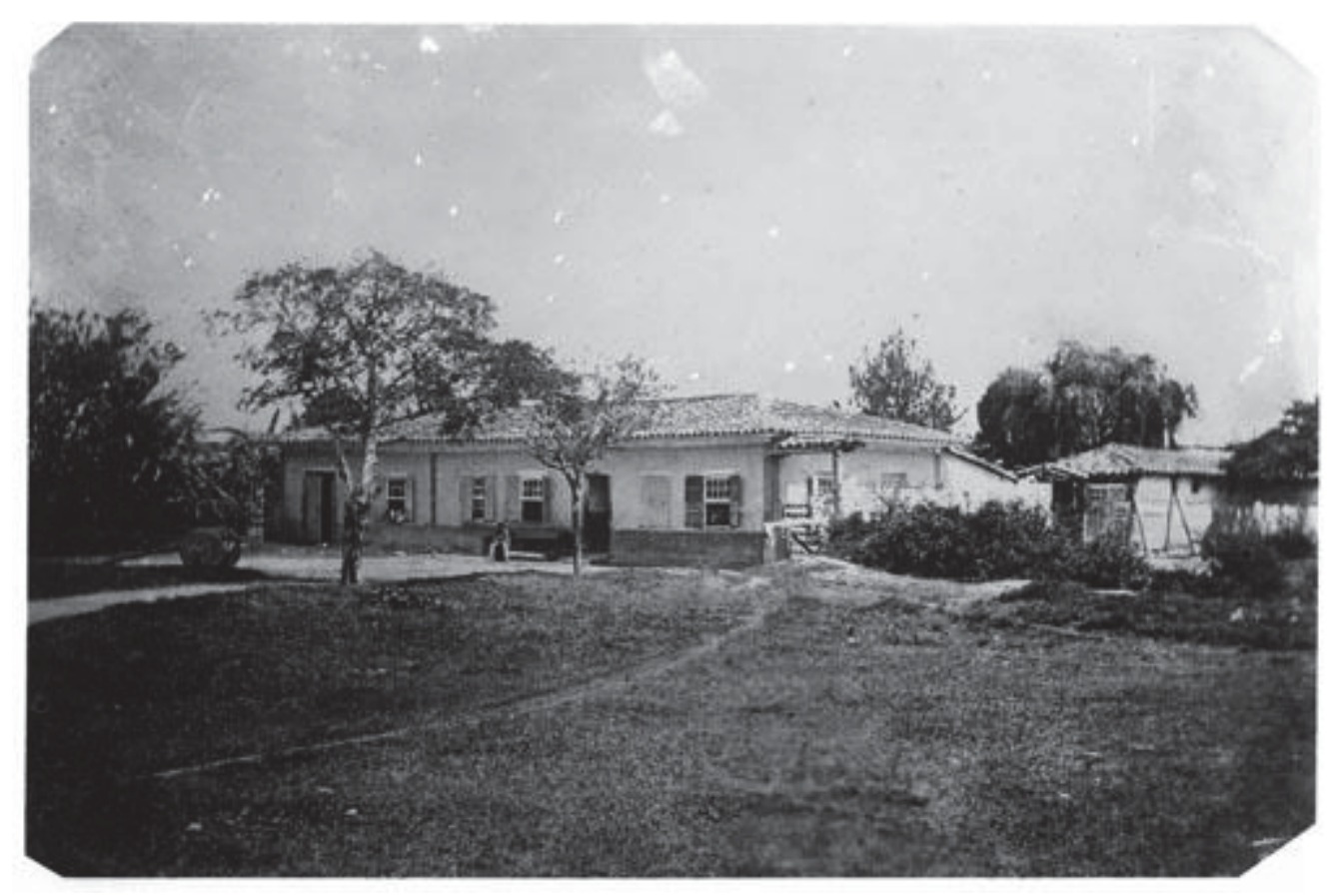

Figura 1: Chácara Tabatinguera, por Militão Augusto de Azevedo, 1860, Acervo Fotográfico do Museu da Cidade de São Paulo.

A casa rústica e de taipa e seu entorno, denotam um universo tipicamente rural, embora muito contíguo à cidade. Um utensílio não identificado no canto esquerdo da fotografia parece indicar que servia à produção agrícola da chácara, ideia que pode ser corroborada quando analisamos o outro lado da imagem, onde parece uma plantação de verduras com suas folhas escuras que se destacam das gramas do terreno. Ao fundo, um conjunto de árvores, possivelmente aquelas descritas por Afonso Freitas onde os nadadores corriam para fugir da polícia. Apesar de a propriedade não estar na margem direita do rio Tamanduateí, além Várzea do Carmo, é interessante notar que mesmo áreas lindeiras à colina onde concentrava "a cidade", tinham feições contrastantes.

Se a chácara de dona Ana Machado se encontrava junto à colina, na outra margem do rio Tamanduateí constavam uma série de outras chácaras acessadas por um dos caminhos disponíveis oriundos da ponte do Carmo. Militão registra o panorama da Várzea do Carmo na década de 1860, tal como podia ser visualizada a partir da Ladeira do Carmo, de onde se avistava a mencionada ponte e o caminho dela derivado que adentrava esse mundo das chácaras. 


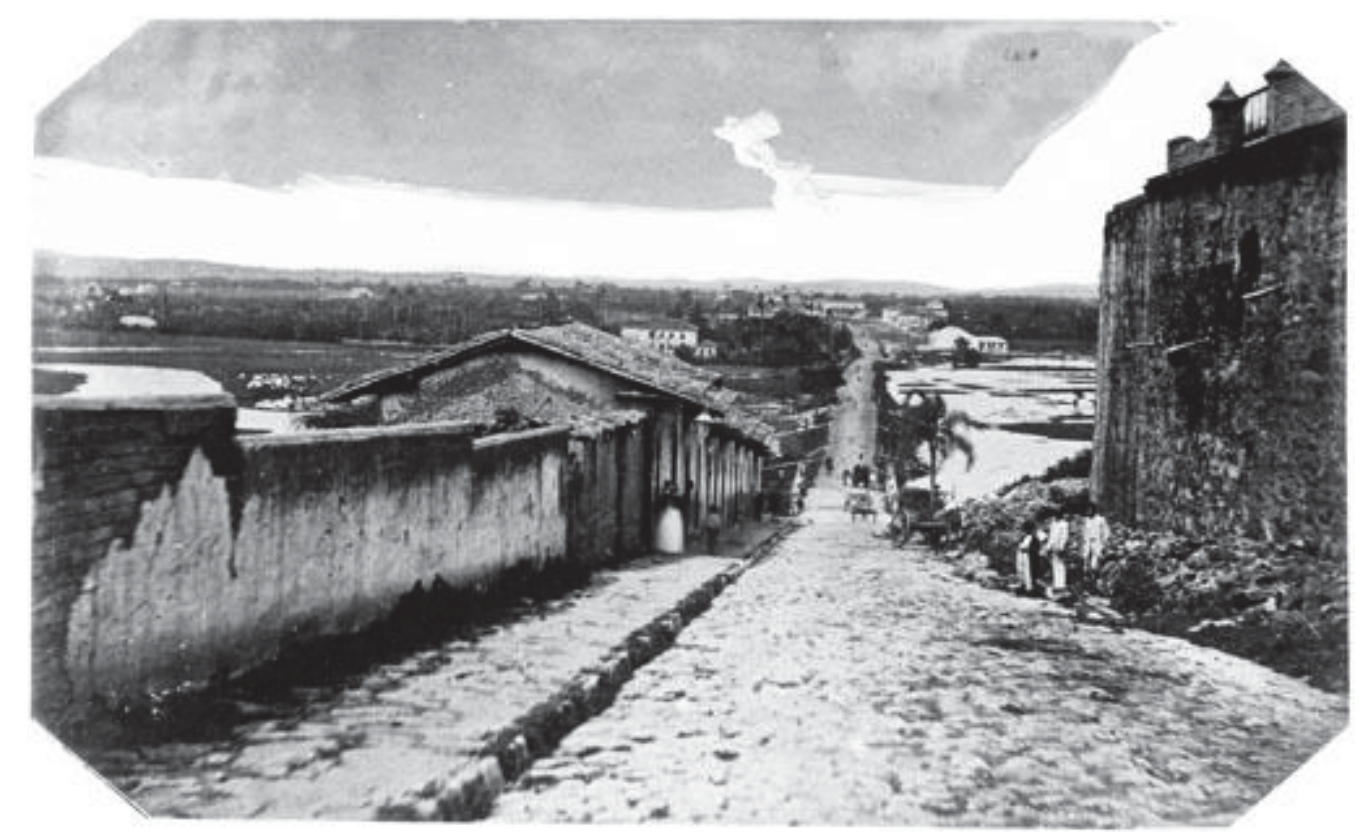

Figura 2: Ladeira do Carmo, Militão Augusto de Azevedo, 1862 c., Acervo Fotográfico do Museu da Cidade de São Paulo

Do lado direito da foto, vê-se a muralha do convento das carmelitas e, do lado esquerdo, um expressivo conjunto de casinhas lindeiras à ponte, as quais refletem a natureza do tipo de ocupação que marcava esse espaço de transição entre a "cidade" propriamente dita e seus "subúrbios". Serviam àqueles que chegavam ou saíam da cidade, vendendo cereais, farinha, toucinho e outros gêneros, podendo servir inclusive de estalagem para quem estivesse de passagem. Ao final da ladeira, a Ponte do Carmo, sobre o rio Tamanduaté́, e adiante outras duas: a Ponte do Meio e a Ponte do Ferrão, que davam acesso à então Estrada do Brás, também conhecida como Caminho da Penha.

Ao fundo insinua-se o rio que serpenteia a região, o que não parece ter sido um impeditivo às ocupações que se fizeram em suas proximidades, denotando assim ser um espaço de crescente número de pessoas, e que não era circunscrito única e exclusivamente às chácaras, mas rodeados de espaços que vinham ganhando força, como os pequenos comércios e vendas que se alastravam pela principal rua da região. Duas grandes construções se destacam na paisagem, e parecem colocar-se como um "portal" de entrada à região do Brás. De quem elas seriam? Militão pode nos oferecer indicativos de quem seriam os seus proprietários, a partir do cruzamento com outras fotos suas, tiradas de outros ângulos. 


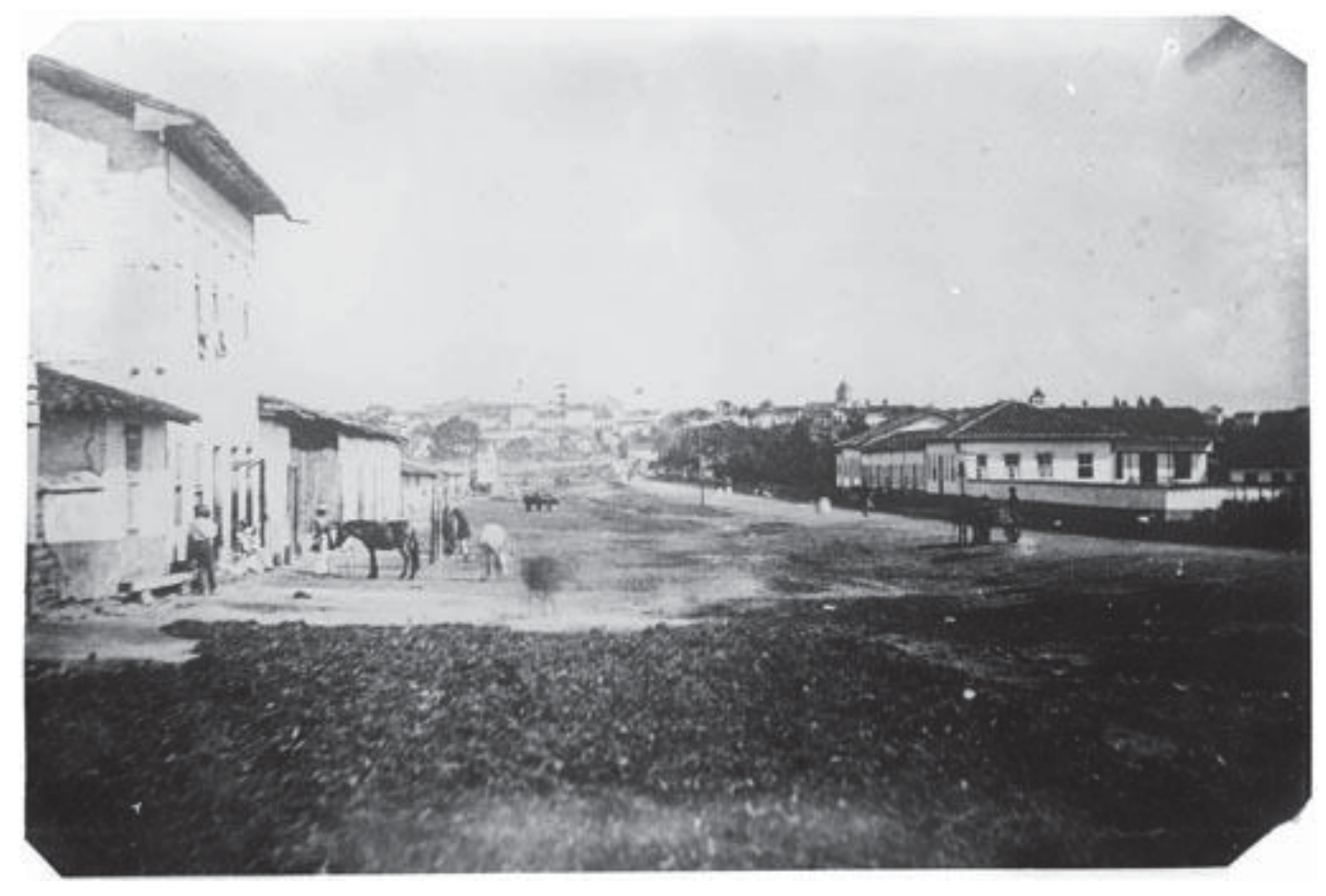

Figura 3: Chácara Loskiel, Militão Augusto de Azevedo, década de 1860, Acervo Fotográfico do Museu da Cidade de São Paulo

A foto acima, tirada de algum ponto próximo à então rua da Figueira, leva-nos de volta à ladeira do Carmo, só que vista do ângulo oposto ao da imagem anterior. Ao fundo, vê-se a cidade, com destaque para as torres das igrejas ali localizadas, ícones da paisagem urbana do oitocentos. Do lado direito, temos a casa grande da Chácara Loskiel, que quase não aparece na fotografia anterior. Após ela, o grande arvoredo da então Chácara da Figueira, ou do Ferrão, de propriedade de Domitila de Castro Canto e Melo, a então Marquesa de Santos.

O movimento parece ser contínuo, intenso, no qual pessoas transitam por ambos os lados da rua rumo à cidade ou com vistas a sair em direção ao leste, podendo ir para a Penha, São Miguel, Conceição dos Guarulhos ou ao Rio de Janeiro. No sobrado, à esquerda, uma sequência de portas atesta tratar-se de uma venda. As mulas ali paradas remetem à ideia de vendas destinadas ao abastecimento, carregando gêneros no seu lombo em direção a outras localidades.

Em 02 de abril de 1862 o jornal Correio Paulistano anunciava com destaque que Pedro Loskiel pretendia "retirar-se para a Europa no fim do corrente mez, por isso prevene á todos aquelles que se julgarem seus credores, queirão apresentar as suas contas no praso de 15 dias". Seria o proprietário da chácara que estaria viajando? Uma nova referência à 
propriedade aparece no mesmo jornal, em 09 de novembro do mesmo ano, num anúncio no qual Leonardo Loskiel passaria na freguesia do Senhor Bom Jesus do Brás dia 13 de novembro, a fim de que se cumpra o requerimento postulado ao juiz de paz para que se arremate "os bens móveis penhorados de Jorge Mathias Krautter". Ao que tudo consta, Leonardo Loskiel vivia uma fase de maus negócios, pois em 11 de fevereiro de 1863, assinou um recibo da quantia de $600 \$ 000$ réis à Isack Kuão ${ }^{66}$. Pouco tempo depois, em 31 de março, perdeu seu escravo Marcellino, por $4 \$ 000$, além de outros $3 \$ 000$ réis pagos à Margarida Juenque da Silva, referentes à uma dívida contraída com ela ${ }^{67}$.

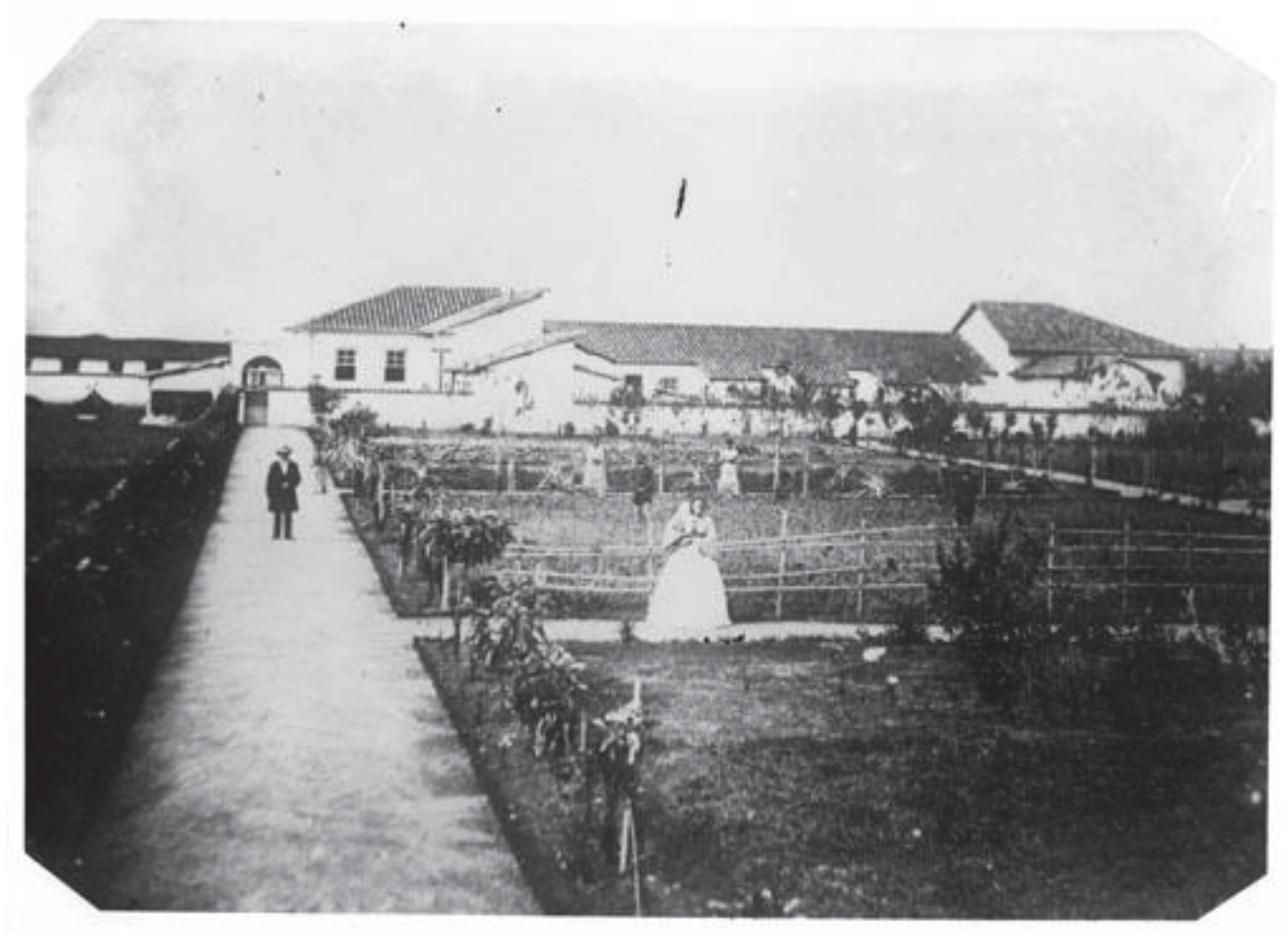

Figura 4: Chácara Loskiel, Militão Augusto de Azevedo, década de 1860, Acervo Fotográfico do Museu da Cidade de São Paulo

Leonardo Loskiel parece ter pago suas dívidas, pois ainda continuava como proprietário de sua chácara nos idos de 1864, quando anuncia no Correio Paulistano que precisa "de um jardineiro e um negro chacareiro que entenda de horta e jardim" ${ }^{68}$. Loskiel, assim como vários outros personagens da cidade de São Paulo, fazia parte dos chamados setores médios que possuíam rendas, podiam usufruir de alguns luxos, mas ainda assim viviam na contradição de em determinados momentos estarem em alta e depois em baixa.

${ }^{66}$ Jornal Correio Paulistano, edição de 12 de fevereiro de 1863.

${ }^{67}$ Jornal Correio Paulistano, edição de 31 de março de 1863.

${ }^{68}$ Jornal Correio Paulistano, edição de 23 de novembro de 1864. 
As coisas parecem não ter ficado tão boas para a família Loskiel, pois Leonardo, perdeu seu filho Jacob Loskiel, esposo de Francisca Emilia Loskiel, em 15 de setembro de 1867, convidando "parentes e amigos para o enterro dos seus restos mortaes hoje 17 do corrente, ás quatro horas da tarde, acompanhando o cadáver, de carro do Braz ao cemitério publico". ${ }^{69}$

Militão parece ter se interessado pela chácara Loskiel, ao retratar não apenas a grande residência que ficava entre plantações, cultivadas possivelmente por escravos, como contemplar algumas das personagens, como negros entre as plantações e uma mulher com vestido branco, possivelmente a senhora, Francisca Loskiel, esposa de Jacob. Em 1869, os Loskiel não deviam mais morar na chácara, pois o Correio Geral anunciava o nome de Leonardo como um dos que constavam na lista de" cartas atrazadas do mês de janeiro que deixaram de ser entregues por ignorar-se a residência dos destinatários". ${ }^{70} \mathrm{Ou}$ seja, a chácara deve ter sido vendida como tantas outras ao longo das décadas seguintes.

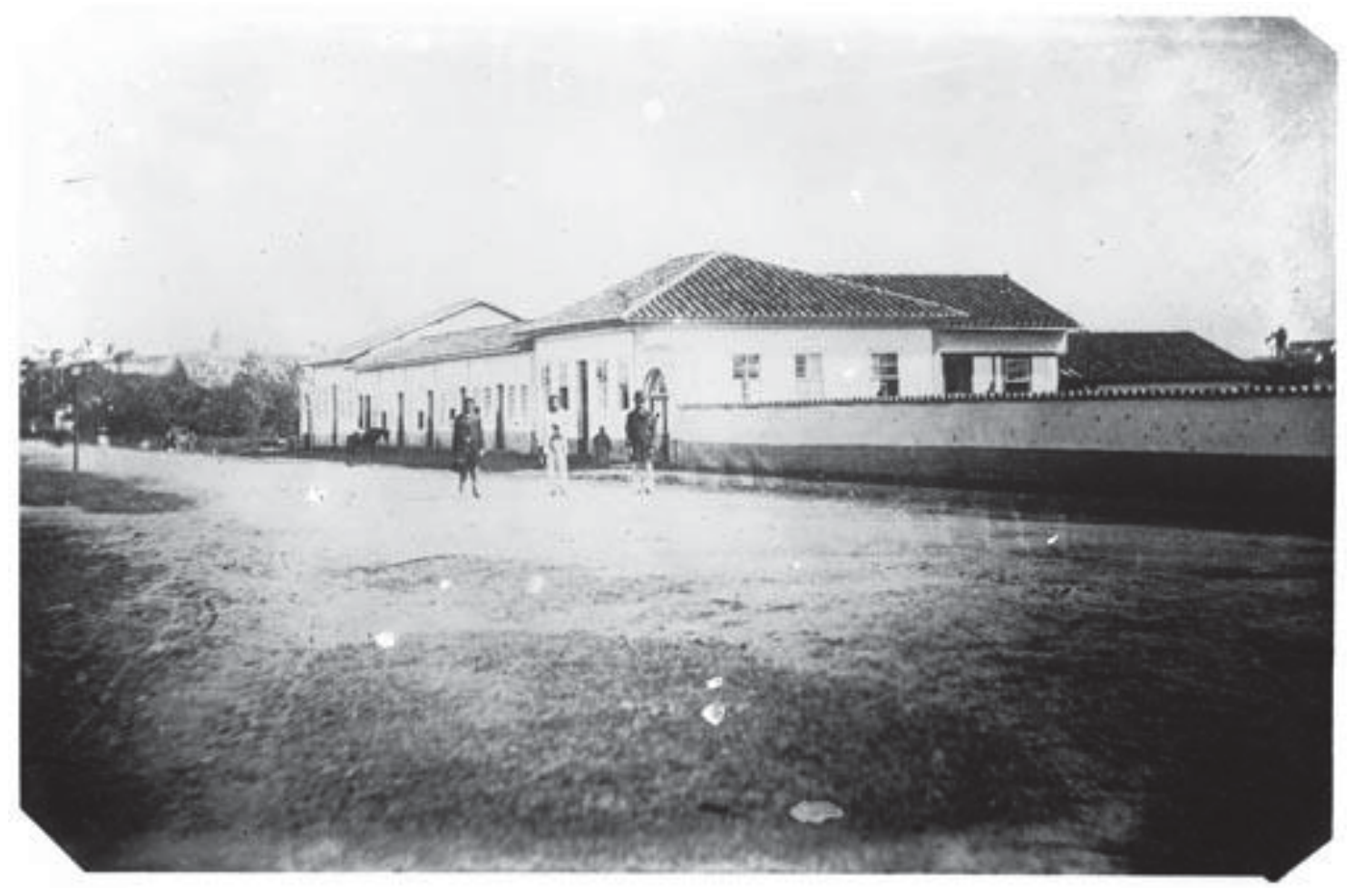

Figura 5: Chácara Loskiel, Militão Augusto de Azevedo, década de 1860, Acervo Fotográfico do Museu da Cidade de São Paulo.

Outra chácara que passou pelos olhos de Militão Augusto de Azevedo fora a Chácara da Figueira, representada na foto acima junto do arvoredo vizinho à Chácara Loskiel. A

69 Jornal Correio Paulistano, edição de 16 de setembro de 1867.

${ }^{70}$ Jornal Correio Paulistano, edição de 02 de fevereiro de 1869. 
chácara, resistiu na paisagem do Brás até a década de $1890^{71}$. Nestes quase trinta anos que separam o registro do fotógrafo e o seu loteamento, era alugada "para morada, [com] acommodações próprias para escravos, com jardim, horta, capinsaes e grande terreno cultivado para plantações, com cocheira e pasto para animaes", sendo que aqueles que desejassem aluga-la deveriam dirigir-se à rua de Santa Tereza número 4. ${ }^{72}$ Segundo Maria Vicentina Dick, a partir de informações de Nuto Santana, em 1785, estas terras eram pertencentes a viúva de José da Sylva Ferrão, D. Maria Leite da Silva, advindo do sobrenome do falecido esposo o nome da chácara ${ }^{73}$. Já Ernani Silva Bruno, coloca que o único resquício que teria sobrado da mesma chácara seria o nome da rua da "Figueira", que fazia referência à uma grande árvore existente na entrada da chácara até o ano de 1905 , quando foi derrubada ${ }^{74}$.

Se a situação dos Loskiel parecia não estar favorável entre finais do século XIX, o mesmo se aplica à Marquesa de Santos, o que se pode inferir dos inúmeros anúncios que figuravam nas páginas do Correio Paulistano, que mostram que seu sobrado foi alugado para o Collégio Pyratininga, no anúncio destacando-se os benefícios da chácara, como sua situação geográfica, a beleza do edifício, as ditas qualidades higiênicas, sem contar a "atividade e zêlo, do exforço e dedicação dos seus Directores em diversas epochas"75.

Ou seja, nesse tempo intermédio entre as décadas de 1860 a 1890, as chácaras foram ou vendidas ou alugadas, desde que não mais atendiam às necessidades de seus antigos proprietários, muitos deles endividados.

\footnotetext{
${ }^{71}$ Sebastião Pagano, "São Paulo Antigo", Diário de São Paulo, de 29 de janeiro de 1950, apud, BRUNO, 1954, pág. 1031.

72 Jornal Correio Paulistano, edição de 20 de outubro de 1863.

73 SANTANNA, Nuto. São Paulo histórico. V. $2^{\circ}$, p. 123, apud, DICK, Op. Cit., pág. 244.

${ }^{74}$ BRUNO, Op. Cit., pág. 1031.

75 Jornal Correio Paulistano, edição de 26 de maio de 1864.
} 


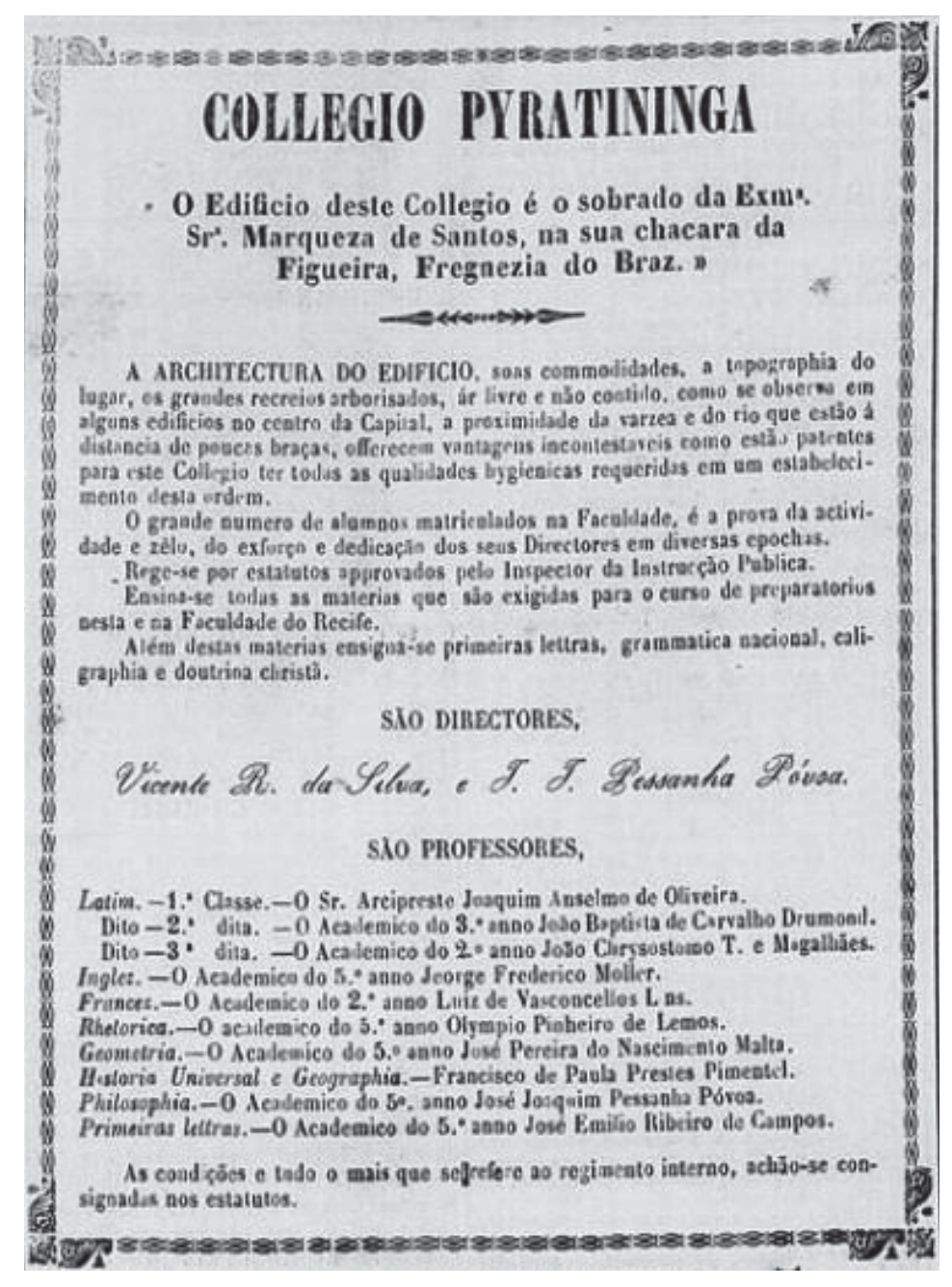

Figura 6: Anúncio do jornal Correio Paulistano sobre o Colégio Piratininga, em edição de 26 de maio de 1864. Acervo Hemeroteca Digital Brasileira.

A Chácara da Figueira fazia parte do imaginário daqueles que se despediam da cidade, saindo pela Várzea do Carmo. Conferia boas vindas àqueles que passavam pelo lugar rumo à estrada do Brás, visto ser aquela que abrangia uma extensa área territorial em ambos os lados da estrada e estar defronte ao rio Tamanduateí, onde logo depois havia a Ponte do Carmo anteriormente mencionada. O registro que Militão faz da Várzea do Carmo nos oferece algumas pistas do tamanho da Chácara da Figueira, pois, ao centro está localizado o sobrado anunciado anteriormente pelo Colégio Piratininga, e à sua frente uma extensa área alongada até o rio Tamanduateí. Nas margens do rio, percebemos inúmeras lavadeiras que em grupo realizam suas atividades e mais à frente, algumas roupas secando ao sol. Na estrada, uma carroça com uma mula conferem dinâmica ao registro e, apesar de parada, indica estar em trânsito. Seria esta carroça que teria trazido as inúmeras roupas deixadas ao lado da árvore da esquerda? 


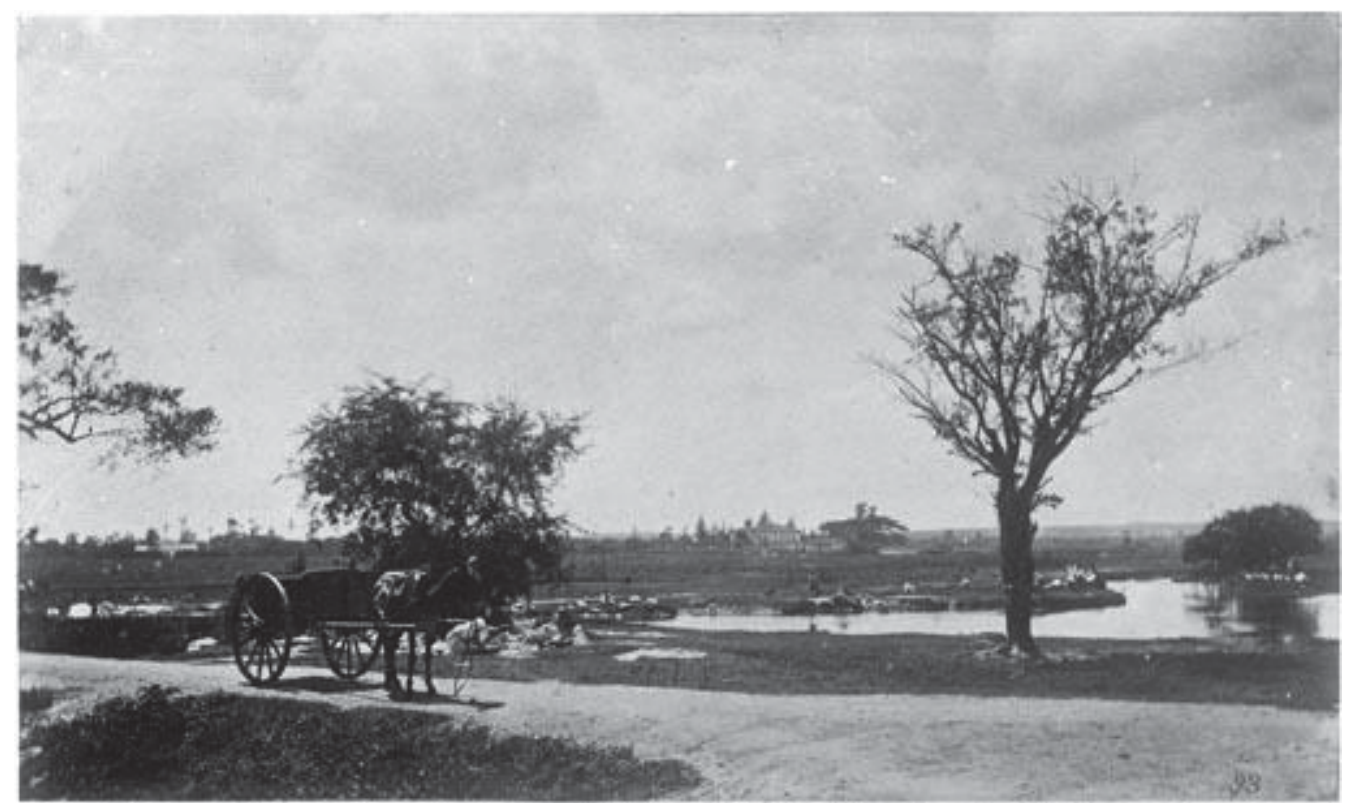

Figura 7: Várzea do Carmo, Militão Augusto de Azevedo, década de 1860, Acervo Fotográfico do Museu da Cidade de São Paulo

Ernani Bruno coloca que as chácaras da cidade continuaram com sua função de abastecimento e produção alimentícia até os finais do século XIX, quando foram progressivamente retalhadas por um processo de abertura de ruas, avenidas, alamedas e largos em suas terras" ${ }^{" 76}$, marcando assim o início do loteamento destas áreas, processo descrito como linear e sem volta.

Suas feições se repetiam. As chácaras além da Várzea do Carmo, tinham em geral, uma casa grande voltada à rua do Brás, quase sempre com um comércio anexo (espécie de venda) que atendia aos viajantes com seus animais. A chácara de Carlos Augusto Bresser seguia a mesma lógica, e Militão não deixa escapar de seus registros as pessoas que conferiam vida ao cenário, desta vez, quase todas posando diante do muro da casa grande. 


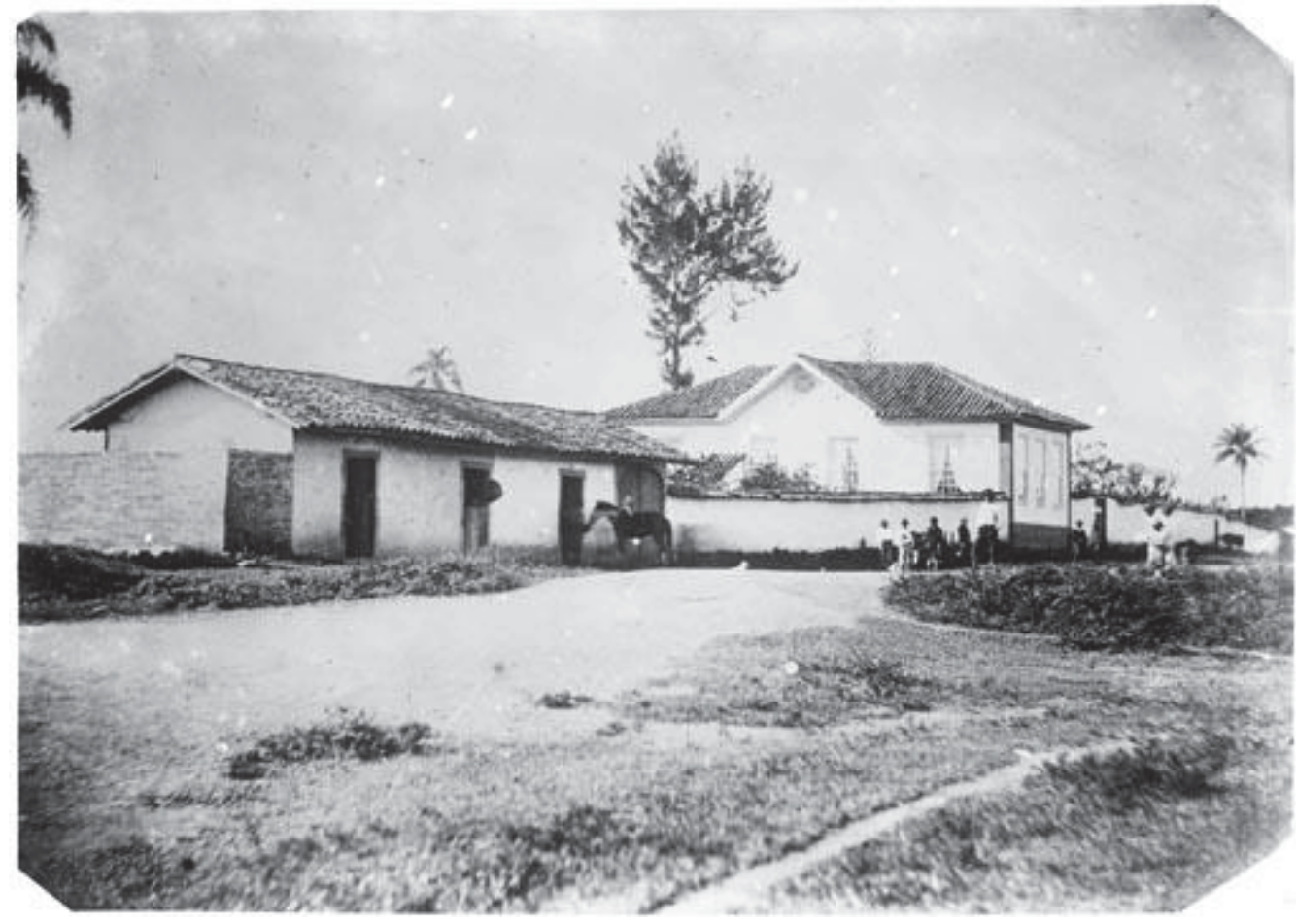

Figura 8: Chácara Bresser, Militão Augusto de Azevedo, década de 1860, Acervo Fotográfico do Museu da Cidade de São Paulo

Karl Abraham Bresser era alemão nascido em 1804. Contraiu casamento com Anna Clara Müller e tiveram cinco filhos: Carlos Alberto (morto na Alemanha), Carlos Adolfo, Clara Albertina, Carolina Augusta e Carlos Augusto. Além de proprietários de escravos ${ }^{77}$, segundo o registro de terras da família, a chácara dos Bresser fora adquirida dos monges franciscanos por 7 contos de réis, em $1^{\circ}$ de outubro de 1854, "do lado esquerdo da estrada que segue da cidade à freguesia de Nossa Senhora da Penha". O terreno ficava entre a Ponte Preta e a Ponte de São Nicolau e nos fundos, fazia divisa outra chácara, a do inglês Horácio Fogas. Por outro lado, margeava o caminho que levava ao Pari e fazia divisa com as terras de Manuel Joaquim do Espírito Santo, além de terras devolutas, passando a ter 142 metros e 80 centímetros de frente, por 1083 metros e 78 centímetros de fundo do lado esquerdo, e 625 metros do lado direito ${ }^{78}$.

Com a morte de Carlos Augusto Bresser, em 1856, sua esposa, também conhecida como Madame Bresser, tornou-se locatária de várias propriedades, incluindo a chácara que

\footnotetext{
77 Jornal Correio Paulistano, edições de 06 de maio de 1863 e 11 de julho de 1863.

${ }^{78}$ As informações referentes aos limites da Chácara Bresser foram baseadas no livro idealizado por Diva Bresser, tetraneta de Carlos Bresser. UNZELTE, Celso (org.). A família Bresser na história de São Paulo. São Paulo: Campo Visual, 2003, pág. 48-51.
} 
se localizava na região da rua Bresser e do Marco da Meia Légua ${ }^{79}$. Acompanhado a tudo isso, podemos perceber que a situação da família Bresser parece ter seguido o mesmo destino das outras famílias supracitadas, vendendo parte dos terrenos e das casas contidas no lote, como atesta o jornal Correio Paulistano, que descreve um posicionamento favorável da Câmara Municipal ao "novo proprietário da casa que foi da Viúva Bresser, afim de que seja permittido collocar mais um degrao de cantaria na porta da esquina do referido predio" $"$. Para preencher a renda da família, Ana Müller passou a vender o que era produzido na parte que restou da chácara na rua das Casinhas, número 2: "bom leite fresco á 240 rs o quartilho" e "legumes de todas as qualidades, como repolho e couve-flor", todos os dias a partir das 7 horas da manhã. ${ }^{81}$

Conta sua tetraneta, que Anna Clara realizava reuniões mensais na casa da chácara, na qual compareciam membros da sociedade paulistana ${ }^{82}$. Quem seriam os membros que frequentavam essas reuniões? Disto não sabemos, mas podemos dizer que aos poucos a chácara tornou-se um ponto de referência além do rio Tamanduateí, sendo inclusive atendida pelo serviço de transporte de cocheiras de Joaquim Marcellino da Silva, com saídas possivelmente da estação do Brás ${ }^{83}$. Em 1882, Anna Clara Müller vendeu metade da chácara ao seu filho mais velho, Carlos Augusto Bresser, por 20 contos de réis. ${ }^{84}$

O conjunto de fotografias elaborado por Militão Augusto de Azevedo nos confere algumas aproximações sobre a ocupação da Várzea do Carmo, seus personagens e proprietários das chácaras da Várzea do Carmo antes de serem integrados às transformações da cidade de São Paulo. Quando aliadas a outras fontes documentais, as séries de fotografias de Militão Augusto de Azevedo tornam-se um rico material para se visualizar o processo de urbanização da parte leste da cidade de São Paulo ocorrido notadamente a partir do último quartel do século XIX, como especial atenção para a estrada do Brás, que nas fotos aparece como um ponto de interesse para o exercício do comércio, inclusive parte dos proprietários das chácaras que procuraram diversificar suas rendas, alugando espaços antes dedicados apenas ao lazer e descanso de suas famílias, ou colocando à venda parte de suas propriedades.

\footnotetext{
79 Jornal Correio Paulistano, edição de 23 de novembro de 1863.

${ }^{80}$ Jornal Correio Paulistano, edição de 26 de junho de 1863.

${ }^{81}$ Jornal Correio Paulistano, edição de 23 de junho de 1864.

${ }^{82}$ UNZELTE, Op. Cit., pág. 48.

${ }^{83}$ Jornal Correio Paulistano, edição de 04 de janeiro de 1865.

84 UNZELTE, Idem, pág. 51.
} 
1.2 Entre a cartografia histórica e a toponímia: chácaras e nomes que deram origem ao bairro

A partir da análise das fotografias registradas por Militão Augusto de Azevedo na década de 1860, podemos perceber um conjunto de nomes de personagens envolvidos com o processo de urbanização da Várzea do Carmo e suas chácaras, os quais tiveram expressivo papel no processo de urbanização desta porção da cidade, como Maria Domitila do Canto e Melo e Carlos Augusto Bresser.

João Campos Aguirra (1871-1962), legou-nos expressivo conjunto documental, hoje sob a guarda do Museu Paulista, constituído por uma série de fichas, mapas, cadastros, fotografias, e diversos outros itens, que, nos permitem uma ideia das várias propriedades rurais que rodeavam a cidade, bem como sobre dados biográficos dos seus proprietários, registros de sesmarias, registros paroquiais, etc ${ }^{85}$. Do seu material, interessa-nos particularmente uma planta na qual estão registradas as "chácaras, sítios e fazendas ao redor do centro desaparecidos com o crescer da cidade", certamente uma obra da primeira metade do século XX.

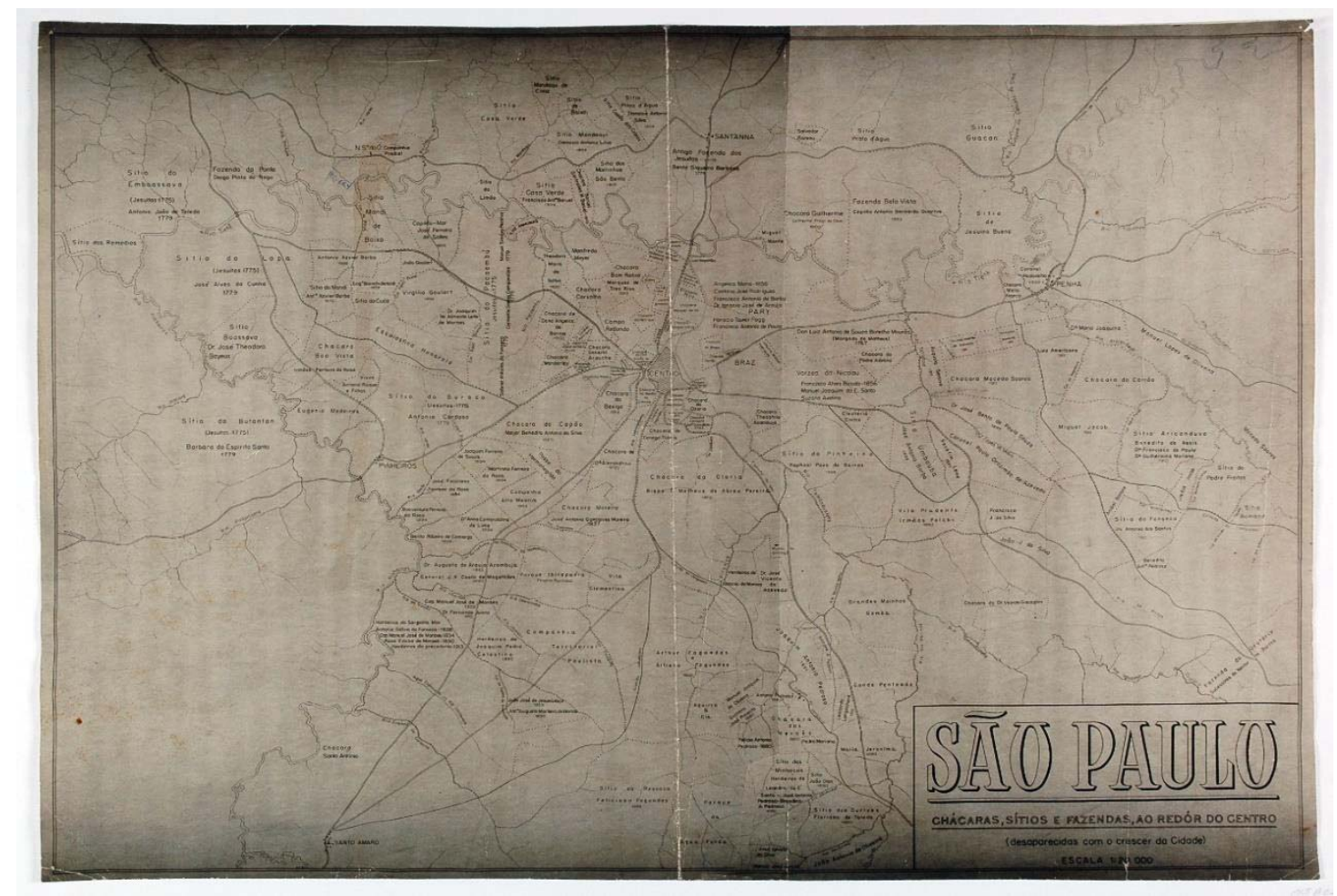

Mapa 1:"São Paulo - chácaras, sítios e fazendas, ao redor do centro desaparecidos com o crescer da cidade. Escala 1:20.000", s/d, Acervo do Museu Paulista.

${ }^{85}$ PIRES, Walter. "Arquivo Aguirra. Fonte documental sobre a formação territorial de São Paulo". Anais do Museu Paulista. São Paulo. N. Sér. v. 10/11. p. 61-78 (2002-2003), pág. 61. 


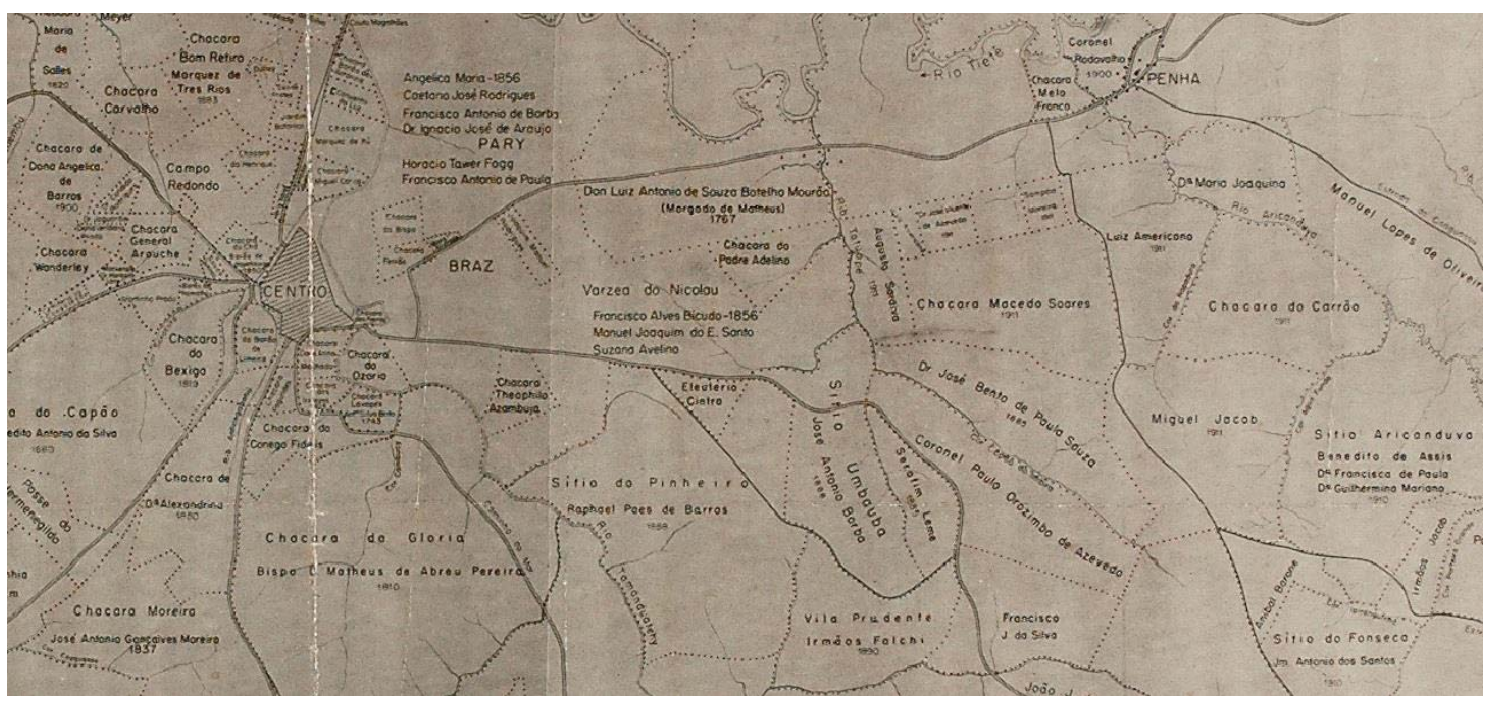

Mapa 2: Pormenor do mapa "São Paulo - chácaras, sítios e fazendas, ao redor do centro desaparecidos com o crescer da cidade. Escala 1:20.000", s/d, Acervo do Museu Paulista.

O Brás tornou-se um ponto intermediário entre aqueles que vinham do Rio de Janeiro, e mesmo de regiões da própria cidade, como a Penha, fato que se concretizou pela grande movimentação da estrada que interligava a colina à capital do país por meio da chamada Estrada do Brás, posteriormente dividida em Avenida Rangel Pestana e Estrada da Intendência (sendo esta última rebatizada, em 1908, como Celso Garcia). Aos poucos a área se caracterizaria como parada e descanso para aqueles que chegavam à cidade de São Paulo, ou mesmo para aqueles que seguiam viagem estrada afora. Ao longo da estrada, podem-se verificar as inúmeras chácaras que a ladeavam de ambos os lados, com gigantescas extensões de terra que podiam até mesmo alcançar o rio Tietê, sob propriedade de algumas famílias e membros do clero local.

Com um mercado imobiliário que se aquecia entre a passagem do século XIX para o XX, a cidade de São Paulo foi alvo de um intenso processo de retaliação de suas chácaras, sítios e fazendas situadas ao seu redor. O mapa acima, apesar de não conter data, parece ter sido produzido pela firma de João Campos Aguirra, homem ligado à área comercial paulistana e que acumulou um notável acervo de cadastros imobiliários da cidade, produzindo assim certo conhecimento acerca das terras que podiam ser adquiridas na capital. Sobre o Brás, pode-se verificar que se trata de chácaras além do centro, voltadas para o eixo da estrada do Brás: Chácara do Bispo, Ferrão, de Horácio Tamer Fogg, Chácara do Padre Adelino, dentre outras que nos auxiliam a compreender o processo de parcelamento e divisão territorial que a área passou principalmente a partir da segunda metade do século XIX. 
Muitos dos nomes desses proprietários permanecem na toponímia da região, e podem ser encontrados nas ruas existentes ainda nos dias de hoje. Afinal, quem seriam algumas das pessoas que dão nomes às ruas do Brás, como Maria Marcolina, Monsenhor Andrade, Celso Garcia, Bresser? Por que estes e outros nomes foram dados a muitas das vias desta porção da cidade? Quais são os traços deste passado chacareiro que permaneceram na paisagem urbana contemporânea que se formaria em finais do oitocentismo? O uso da cartografia antiga, bem como recortes de jornais, permissões de construção e fotografias nos auxiliam na resposta a tais questionamentos.

Como bem observou Maria Elisângela da Silva ${ }^{86}$, entre os anos de 1860 e 1869 a maior parte dos pedidos de solicitação de datas de terras por particulares à Câmara Municipal de São Paulo concentravam-se nas regiões do Brás e da Mooca, sendo distribuídas em larga escala nesta década. Analisando as chácaras desenhadas no mapa de João Aguirra, vemos que muitas delas estiveram envolvidas neste processo de retalhamento da cidade de São Paulo. São elas: Chácara do Major Manoel Rodrigues Jordão; Chácara do Monsenhor Andrade; Chácara do Bispo; Chácara do Ferrão (também conhecida como da Figueira, ou da Marquesa); Chácara Theophilo Azambuja; Chácara do Osório; Chácara do Padre Adelino; Várzea do Nicolau; e grandes extensões territoriais que pertenciam a Horácio Tamer Fogg, um dentista estadunidense ${ }^{87}$; a Francisco Antonio de Paula; ao Morgado de Matheus (terras em seu poder desde 1767); Eleuteria Cintra; e o Sítio do Pinheiro, pertencente à Raphael Paes de Barros. Todas estas áreas estavam próximas ou fronteiras à estrada do Brás.

${ }^{86}$ SILVA, Maria Elisângela da. Práticas de apropriação e produção do espaço em São Paulo: a concessão de terras municipais através das Cartas de Datas (1850-1890). Dissertação (Mestrado em Arquitetura e Urbanismo). São Paulo: FAUUSP, 2012, pág. 188.

${ }^{87}$ BRUNO, Op. Cit, pág. 1115-1116 


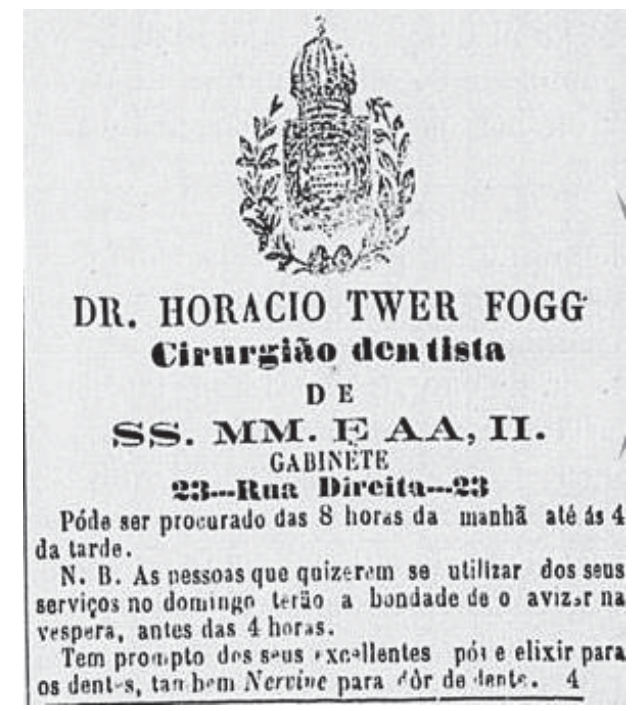

Figura 9: Anúncio do jornal Correio Paulistano sobre o dentista Fogg, edição de 13 de janeiro de 1890.

Maria Celestina Torres nos lembra os longos debates ocorridos na Câmara Municipal referentes às doações de terras e loteamentos da cidade. Numa sessão ordinária de 26 de janeiro de 1860, discutiu-se o parecer da concessão de datas de terras a 181 cidadãos que solicitavam "terrenos contíguos e por detrás da Freguesia do Brás":

\footnotetext{
"Há bem sabido que esta cidade se vai consideravelmente augmentando, e que os terrenos se achão sobremaneira escassos para a edificação; e pelo que se tem visto vender terras e propriedades por um preço fabulozo; e como o progresso hé constante, segue-se q. não se alargando os terrenos pa. edificação com os que se achão devolutos, aparece hum verdadeiro monopólio excuzado e desnecessário p. q. existem em grande quantidade terrenos á disposição da Camara para serem repartidos por moradores" $\$ 8$
}

Se nos atentarmos ao tamanho e detalhes de algumas dessas chácaras, percebemos que seus limites não eram fatores impeditivos da subdivisão dos terrenos em quadras e ruas posteriormente fossem revendidas. Tais áreas revelam fios e rastros $^{89}$ que nos permitem uma melhor compreensão histórica dos processos de loteamentos das chácaras, sítios e fazendas listadas acima que também pode ser vislumbrada em outras séries cartográficas,

88 TORRES, Op. Cit, pág. 84-85

${ }^{89}$ Expressão e título de um clássico do historiador italiano, Carlo Ginzburg. 
sobretudo entre 1860 e 1869 e depois da década de 1870, segundo Elisângela Maria da Silva ${ }^{90}$.

Com apoio do mapa "São Paulo - chácaras, sítios e fazendas, ao redor do centro desaparecidos com o crescer da cidade", e de relatos de memorialistas tais como de Ernani Silva Bruno e Antônio Egídio Martins, elaboramos a seguinte tabela com as chácaras existentes em São Paulo até finais do século XIX:

\begin{tabular}{|c|c|c|c|c|}
\hline \multicolumn{5}{|c|}{ Descritivo das chácaras existentes em São Paulo no século XIX } \\
\hline CHÁCARA & REGIÃO & $\begin{array}{l}\text { PROPRIETÁRIO } \\
\text { INICIAL }\end{array}$ & $\begin{array}{c}\text { PROPRIETÁRIO } \\
\text { FINAL } \\
\end{array}$ & REFERÊNCIA \\
\hline $\begin{array}{l}\text { Campo } \\
\text { Redondo }\end{array}$ & Bom Retiro & $\begin{array}{l}\text { Visconde de } \\
\text { Mauá? }\end{array}$ & $\begin{array}{l}\text { Frederico Glette a } \\
\text { adquire em } 1879\end{array}$ & $\begin{array}{l}\text { MARTINS, } \\
\text { 2003, pág. } 228\end{array}$ \\
\hline $\begin{array}{l}\text { Miguel } \\
\text { Carlos, de }\end{array}$ & $\begin{array}{l}\text { Ao norte, além } \\
\text { da ponte da } \\
\text { Constituição }\end{array}$ & & & $\begin{array}{l}\text { BRUNO, 1954, } \\
\text { pág. } 205\end{array}$ \\
\hline $\begin{array}{l}\text { Monte } \\
\text { Carmelo, } \\
\text { Cônego Dr. }\end{array}$ & $\begin{array}{l}\text { Margem do rio } \\
\text { Tamanduateí }\end{array}$ & $\begin{array}{l}\text { Cônego Monte } \\
\text { Carmelo }\end{array}$ & & $\begin{array}{l}\text { MARTINS, } \\
\text { 2003, pág. } 55\end{array}$ \\
\hline Ferrão & $\begin{array}{l}\text { Pala leste, } \\
\text { depois do } \\
\text { Tamanduateí }\end{array}$ & & $\begin{array}{l}\text { Domitila de Castro } \\
\text { Canto e Melo }\end{array}$ & $\begin{array}{l}\text { BRUNO, 1954, } \\
\text { pág. } 205\end{array}$ \\
\hline Osório & $\begin{array}{l}\text { Para leste, } \\
\text { depois do rio } \\
\text { Tamanduateí }\end{array}$ & Menezes & Viúva do Osório & $\begin{array}{l}\text { BRUNO, 1954, } \\
\text { pág. } 205\end{array}$ \\
\hline $\begin{array}{l}\text { Ana Machado, } \\
\text { Dona }\end{array}$ & $\begin{array}{l}\text { Sul da rua } \\
\text { Tabatinguera }\end{array}$ & $\begin{array}{ll}\text { Ana } & \text { Maria } \\
\text { Machado } & \\
\end{array}$ & & $\begin{array}{l}\text { BRUNO, 1954, } \\
\text { pág. 205, } 1246\end{array}$ \\
\hline Glória & $\begin{array}{l}\text { Sudeste, entre } \\
\text { os rios } \\
\text { Tamanduateí, } \\
\text { Cambuci e } \\
\text { Ipiranga. } \\
\text { Segundo } \\
\text { Antonio Egidio } \\
\text { Martins, era } \\
\text { pertencente à } \\
\text { Fazenda } \\
\text { Nacional. }\end{array}$ & $\begin{array}{l}\text { Cap. Manuel } \\
\text { Pinto Guedes }\end{array}$ & $\begin{array}{l}\text { Sargento-Mor } \\
\text { Manuel de Oliveira } \\
\text { Cardoso }\end{array}$ & $\begin{array}{l}\text { PIRES, } 2003 . \\
\text { BRUNO, 1954, } \\
\text { pág. 205; pág. } \\
572 \\
\text { MARTINS, } \\
\text { 2003, pág. 49; } \\
\text { pág. 53. }\end{array}$ \\
\hline
\end{tabular}

${ }^{90}$ SILVA, Op. Cit, pág. 36. 


\begin{tabular}{|c|c|c|c|}
\hline $\begin{array}{l}\text { Sítio do } \\
\text { Tapanhoim }\end{array}$ & $\begin{array}{lr}\text { Entre o rio } \\
\text { Cambuci, } \\
\text { córrego do } \\
\text { Lavapés e a } \\
\text { Estrada do Mar. }\end{array}$ & & $\begin{array}{l}\text { BRUNO, 1954, } \\
\text { pág. } 205\end{array}$ \\
\hline Fagundes, do & Sul da cidade & & $\begin{array}{l}\text { BRUNO, } 1954 \text {, } \\
\text { pág. } 205\end{array}$ \\
\hline $\begin{array}{l}\text { Cônego } \\
\text { Fidélis }\end{array}$ & Sul da cidade & & $\begin{array}{l}\text { BRUNO, } 1954, \\
\text { pág. } 205\end{array}$ \\
\hline $\begin{array}{l}\text { Campos do } \\
\text { Estalajadeiro } \\
\text { Bexiga }\end{array}$ & $\begin{array}{l}\text { Sudeste, } \\
\text { beirando o rio } \\
\text { Anhangabaú }\end{array}$ & & $\begin{array}{l}\text { BRUNO, } 1954 \\
\text { pág. } 205\end{array}$ \\
\hline Sítio Sertório & $\begin{array}{l}\text { Sudeste, } \\
\text { beirando o rio } \\
\text { Anhangabaú }\end{array}$ & & $\begin{array}{l}\text { BRUNO, } 1954, \\
\text { pág. } 205\end{array}$ \\
\hline $\begin{array}{l}\text { Martinho da } \\
\text { Silva Prado }\end{array}$ & $\begin{array}{l}\text { Oeste da } \\
\text { cidade, onde } \\
\text { ficava o Tanque } \\
\text { Reúno ou do } \\
\text { Bexiga }\end{array}$ & $\begin{array}{l}\text { Martinho da Silva } \\
\text { Prado }\end{array}$ & $\begin{array}{l}\text { BRUNO, } 1954, \\
\text { pág. } 205\end{array}$ \\
\hline $\begin{array}{l}\text { Arouche de } \\
\text { Toledo } \\
\text { Rendon, do } \\
\text { Marechal }\end{array}$ & $\begin{array}{lr}\text { Adiante } & \text { do } \\
\text { campo } & \text { dos } \\
\text { Curros, } & \text { Vila } \\
\text { Buarque } & \\
\end{array}$ & $\begin{array}{l}\text { Arouche de } \\
\text { Toledo Rendon }\end{array}$ & $\begin{array}{l}\text { BRUNO, 1954 } \\
\text { pág. 205; pág. } \\
576\end{array}$ \\
\hline $\begin{array}{l}\text { Itapetinga, do } \\
\text { Barão de }\end{array}$ & $\begin{array}{l}\text { Entre o riacho } \\
\text { do Acu e o } \\
\text { Piques }\end{array}$ & $\begin{array}{ll}\text { Barão } & \text { de } \\
\text { Itapetininga }\end{array}$ & $\begin{array}{l}\text { BRUNO, } 1954 \\
\text { pág. } 205\end{array}$ \\
\hline $\begin{array}{l}\text { Campo } \\
\text { Redondo }\end{array}$ & \begin{tabular}{ll} 
A noroeste & da \\
cidade, & na \\
direção & de \\
\multicolumn{2}{l}{ Santa Ifigênia } \\
\end{tabular} & & $\begin{array}{l}\text { BRUNO, } 1954, \\
\text { pág. } 205\end{array}$ \\
\hline $\begin{array}{l}\text { Anastácio de } \\
\text { Freitas } \\
\text { Trancoso, do } \\
\text { Coronel }\end{array}$ & $\begin{array}{lr}\text { Distante } & \text { do } \\
\text { centro, que } & \text { se } \\
\text { originou } & \text { o } \\
\text { bairro } & \text { do } \\
\text { Anastácio. } & \\
\end{array}$ & $\begin{array}{l}\text { Anastácio de } \\
\text { Freitas Trancoso }\end{array}$ & $\begin{array}{l}\text { BRUNO, 1954, } \\
\text { pág. } 571\end{array}$ \\
\hline Palmeiras, das & $\begin{array}{l}\text { Zona que se } \\
\text { abriu mais tarde } \\
\text { a Avenida } \\
\text { Angélica }\end{array}$ & & $\begin{array}{l}\text { BRUNO, } 1954, \\
\text { pág. } 576\end{array}$ \\
\hline $\begin{array}{l}\text { Charpe, Mauá } \\
\text { ou dos } \\
\text { Campos } \\
\text { Elíseos }\end{array}$ & & & $\begin{array}{l}\text { BRUNO, 1954, } \\
\text { pág. } 576\end{array}$ \\
\hline
\end{tabular}




\begin{tabular}{|c|c|c|c|c|}
\hline Carvalho, do & Barra Funda & & & $\begin{array}{l}\text { BRUNO, 1954, } \\
\text { pág. } 576\end{array}$ \\
\hline Bresser & Brás & & $\begin{array}{l}\text { Carlos Abraão } \\
\text { Bresser }\end{array}$ & $\begin{array}{l}\text { BRUNO, 1954, } \\
\text { pág. 577; pág. } \\
1442\end{array}$ \\
\hline Loskiel & $\begin{array}{l}\text { Brás } \\
\text { Localizada } \\
\text { logo depois da } \\
\text { rua da Figueira, } \\
\text { na rua do Brás }\end{array}$ & & Leonardo Loskiel & $\begin{array}{l}\text { BRUNO, 1954, } \\
\text { pág. } 573 \text {; pág. } \\
577 \text {; pág. } 1442\end{array}$ \\
\hline $\begin{array}{l}\text { Falcão, do } \\
\text { Conselheiro }\end{array}$ & Mooca & & & $\begin{array}{l}\text { BRUNO, 1954, } \\
\text { pág. } 607\end{array}$ \\
\hline $\begin{array}{l}\text { Clemente } \\
\text { Falcão de } \\
\text { Souza Filho }\end{array}$ & $\begin{array}{l}\text { Rua da Glória, } \\
106\end{array}$ & $\begin{array}{l}\text { Clemente Falcão } \\
\text { de Souza Filho }\end{array}$ & & $\begin{array}{l}\text { MARTINS, } \\
\text { 2003, pág. } 155\end{array}$ \\
\hline $\begin{array}{l}\text { Albuquerque, } \\
\text { do Dr. }\end{array}$ & Bexiga & & & $\begin{array}{l}\text { BRUNO, 1954, } \\
\text { pág. } 1030\end{array}$ \\
\hline Levy & Liberdade & & & $\begin{array}{l}\text { BRUNO, 1954, } \\
\text { pág. } 1030\end{array}$ \\
\hline $\begin{array}{l}\text { Dr. Clímaco } \\
\text { Barbosa, do }\end{array}$ & $\begin{array}{l}\text { Caminho do } \\
\text { Ipiranga }\end{array}$ & Clímaco Barbosa & & $\begin{array}{l}\text { BRUNO, 1954, } \\
\text { pág. } 1030\end{array}$ \\
\hline Quebra Bunda & Liberdade & $\begin{array}{l}\text { Jose veloso de } \\
\text { Oliveira }\end{array}$ & & $\begin{array}{l}\text { MARTINS, } \\
\text { 2003, pág. } 157\end{array}$ \\
\hline $\begin{array}{l}\text { Rafael de } \\
\text { Barros, do Dr. }\end{array}$ & Mooca & Rafael de Barros & & $\begin{array}{l}\text { BRUNO, 1954, } \\
\text { pág. } 1030\end{array}$ \\
\hline Tatuapé & Tatuapé & & & $\begin{array}{l}\text { BRUNO, 1954, } \\
\text { pág. } 564\end{array}$ \\
\hline
\end{tabular}

Tabela 1: "Descritivo das chácaras existentes em São Paulo no século XIX", elaborada pelo autor com base em relatos memorialísticos.

A tabela acima, com boa parte das chácaras existentes na São Paulo oitocentista, serve de subsídio para compreendermos o processo de parcelamento do solo e, mudança de proprietários ocorrida no período supracitado. Ao notarmos os nomes destes proprietários, e comparando com o mapa "São Paulo - chácaras, sítios e fazendas, ao redor do centro desaparecidos com o crescer da cidade", percebemos grandes extensões de terras (talvez as maiores ao redor da cidade), além de grande parte destas propriedades estarem nas mãos de um pequeno grupo de sujeitos. 
Os memorialistas nos conferem um amplo panorama de como eram essas chácaras da porção leste da cidade, além do Tamanduateí, no último quartel do século XIX: locais de descanso, lazer, e de produção agrícola que atendia à cidade. Como podemos ampliar esta compreensão, e enxergarmos novos atores diante deste cenário "chacareiro"? Os almanaques comerciais servem de subsídio para mapearmos alguns desses personagens que participavam na ativa vida da região da Várzea do Carmo e do Brás, seja com suas residências, seus comércios, suas profissões, seja por meio dos laços existentes uns para com os outros. Segundo Antonio Celso Ferreira, os almanaques "formavam um modelo muito apreciado de publicação, tendo aparecido em várias versões e diferentes lugares (...) vinculados a tipografias e empresas jornalísticas, evidenciando uma dependência em relação à grande imprensa." "91 A partir do Almanak da Província de São Paulo para $1873^{92}$ e do Indicador de São Paulo administrativo, judicial, industrial, profissional e comercial para o ano de 1878, pudemos aferir uma série de outros personagens não citados pelos memorialistas que, a nosso ver, podem oferecer um novo panorama de como eles interferiram no processo de urbanização da cidade de São Paulo, exercendo forte influência em torno dos loteamentos das chácaras citadas, principalmente por residirem e / ou possuírem uma ampla rede comercial que não se circunscrevia à colina histórica, mas nos baixos da cidade, além Tamanduateí.

O Indicador ainda nos traz algumas aproximações do aspecto geral da cidade em 1878: a Companhia Carris de Ferro percorria "a parte central da Cidade, dando commodo e fácil transito até á estação da estrada de ferro Ingleza; e á noite acende-se uma excelente iluminação a gaz"; "notão-se bons prédios, e tendência para introdução do gosto moderno nas construcções" durante a gestão de João Xavier como Presidente da Província de São Paulo entre os anos de 1872 a 1875.

Na ocasião, a cidade estava dividida em quatro freguesias - a da Sé, a de Santa Ifigênia, a da Consolação e a do Senhor Bom Jesus do Braz - sendo que ao redor da cidade haviam outras quatro freguesias: a de Nossa Senhora da Conceição dos Guarulhos, distante 16,6 quilômetros; a de Nossa Senhora da Penha, a 9,7 quilômetros; a de São Bernardo a

${ }^{91}$ FERREIRA, Antonio Celso. A epopeia bandeirante: letrados, instituições, invenção histórica (18701940). São Paulo: Editora Unesp, 2002, pág. 39.

92 "Trata-se de uma publicação de caráter estatístico, contendo informações sobre a capital e os núcleos do interior, com uma parte cultural de pequeno porte.” In: FERREIRA, Idem.

${ }^{93}$ MARQUES, Abílio A. S. Indicador de São Paulo administrativo, judicial, industrial, profissional e comercial para o ano de 1878. São Paulo: Imprensa Oficial do Estado; Arquivo do Estado, 1985, pág. 103 . 
19,3 quilômetros; e a mais distante, Juquery, a 27,7 quilômetros. Nos subúrbios da cidade, diz o Indicador,

\begin{abstract}
"existem boas chácaras, que produzem frutas, hortaliças, chá, e em algumas fabrica-se vinho nacional em quantidade que promete tornar-se uma importante indústria. Nos sítios e fazendas, cultiva-se mantimentos, algodão, café, e cria-se gado. Possue actualmente algumas fabricas importantes, e em breve terá uma de tecidos, cuja edificação acha-se já bem adiantada." 94
\end{abstract}

Com base no Indicador de São Paulo, elaboramos a seguinte tabela contendo “capitalistas e proprietários" que atuaram na região do Brás na década de 1870:

\begin{tabular}{|c|c|c|c|}
\hline \multicolumn{4}{|c|}{$\begin{array}{l}\text { “Capitalistas e proprietários” que atuaram na região do Brás na década de } 1870, \\
\text { segundo o Indicador de São Paulo de } 1878 .\end{array}$} \\
\hline $\begin{array}{c}\text { TÍTULO / } \\
\text { ESTABELECIMENTO }\end{array}$ & NOME & ENDEREÇO & $\begin{array}{l}\text { REFERÊN- } \\
\text { CIA }\end{array}$ \\
\hline Bacharel & $\begin{array}{l}\text { Ignácio José de } \\
\text { Araújo }\end{array}$ & Rua do Brás, 71 & Pág. 110 \\
\hline Brigadeiro & $\begin{array}{l}\text { Luiz Joaquim de } \\
\text { Castro Carneiro } \\
\text { Leão }\end{array}$ & Rua da Móoca (chácara) & Pág. 114 \\
\hline Doutor & $\begin{array}{l}\text { Américo } \\
\text { Brasiliense de } \\
\text { Almeida e Mello }\end{array}$ & $\begin{array}{l}\text { Travessa de Santa } \\
\text { Teresa, } 17\end{array}$ & Pág. 114 \\
\hline Monsenhor & $\begin{array}{l}\text { Anacleto José } \\
\text { Ribeiro Coutinho }\end{array}$ & Rua do Carmo, 75 & Pág. 114 \\
\hline \multirow[t]{2}{*}{ Dona } & $\begin{array}{l}\text { Carolina Amalia } \\
\text { da Silva Rangel }\end{array}$ & Rua do Carmo, 81 & Pág. 114 \\
\hline & $\begin{array}{l}\text { Lucas Queiroz de } \\
\text { Assumpção }\end{array}$ & Rua do Braz, 49 & Pág. 114 \\
\hline Bacharel & $\begin{array}{l}\text { Miguel Antunes } \\
\text { de Moraes }\end{array}$ & Rua do Brás, 18 & $\begin{array}{l}\text { Págs. } 114 \text { e } \\
115\end{array}$ \\
\hline $\begin{array}{l}\text { Compositores } \\
\text { Tipográficos }\end{array}$ & $\begin{array}{l}\text { Diogo José } \\
\text { Machado }\end{array}$ & Rua do Carmo, 81 & Pág. 115 \\
\hline Médicos Homeopatas & Carlos Marquois & Rua do Carmo, 85 & Pág. 116 \\
\hline $\begin{array}{l}\text { Loja de ferragens, } \\
\text { couros, arreios, etc. }\end{array}$ & $\begin{array}{l}\text { Francisco Gomes } \\
\text { dos Santos Lima }\end{array}$ & $\begin{array}{l}\text { Ladeira de São } \\
\text { Francisco, } 15\end{array}$ & Pág. 119 \\
\hline \multirow[t]{4}{*}{$\begin{array}{l}\text { Armazéns de louça e } \\
\text { molhados }\end{array}$} & $\begin{array}{l}\text { Antonio José de } \\
\text { Azevedo Júnior }\end{array}$ & Largo do Brás & Pág. 119 \\
\hline & $\begin{array}{l}\text { Francisco } \\
\text { Gregório } \\
\text { Rodrigues } \\
\end{array}$ & Largo do Brás, 119 & Pág. 119 \\
\hline & $\begin{array}{l}\text { José } \\
\text { Affutauchugg }\end{array}$ & Campo da Luz, 17 & Pág. 119 \\
\hline & $\begin{array}{l}\text { José Alves da } \\
\text { Silva Porto }\end{array}$ & Rua da Imperatriz, 15 & Pág. 119 \\
\hline
\end{tabular}

${ }^{94}$ LUNÉ, Antônio José Batista de. Almanak da Província de São Paulo para 1873. São Paulo: Imprensa Oficial do Estado; Arquivo do Estado, 1985, págs. 103 e 104. 


\begin{tabular}{|c|c|c|c|}
\hline & $\begin{array}{l}\text { José Gregório } \\
\text { Rodrigues }\end{array}$ & Rua do Brás, 64 & Pág. 119 \\
\hline & $\begin{array}{l}\text { José Manoel da } \\
\text { Costa }\end{array}$ & Marco da Meia Légua & Pág. 119 \\
\hline & Mello \& Comp. & Rua São Bento, 39 & Pág. 119 \\
\hline & $\begin{array}{l}\text { Mello, Irmão \& } \\
\text { Leal }\end{array}$ & Rua do Comércio, 23 & Pág. 120 \\
\hline & $\begin{array}{l}\text { Manoel José } \\
\text { Soares }\end{array}$ & Largo do Braz & Pág. 120 \\
\hline $\begin{array}{l}\text { Armazéns de } \\
\text { molhados, fazendas, } \\
\text { etc. }\end{array}$ & $\begin{array}{l}\text { Salvador José } \\
\text { Barreiros }\end{array}$ & Marco da Meia Légua & Pág. 120 \\
\hline \multirow[t]{13}{*}{$\begin{array}{l}\text { Armazéns de molhados } \\
\text { e gêneros do país }\end{array}$} & $\begin{array}{l}\text { Antônio José de } \\
\text { Azevedo Júnior }\end{array}$ & Rua do Brás & Pág. 120 \\
\hline & $\begin{array}{l}\text { Antonio José } \\
\text { Pereira } \\
\text { Guimarães }\end{array}$ & Rua do Brás, 183 & Pág. 120 \\
\hline & $\begin{array}{l}\text { Firmino Antônio } \\
\text { da Silva } \\
\text { Whitacker }\end{array}$ & $\begin{array}{l}\text { Rua da Esperança, 23, e } \\
\text { Lavapés }\end{array}$ & Pág. 120 \\
\hline & $\begin{array}{l}\text { Francisco } \\
\text { Gregório } \\
\text { Rodrigues }\end{array}$ & Rua do Brás & $\begin{array}{l}\text { Pág. } 120 \\
\end{array}$ \\
\hline & $\begin{array}{l}\text { Gabriel Antonio } \\
\text { Fernandes }\end{array}$ & Rua do Brás & Pág. 120 \\
\hline & $\begin{array}{l}\text { José Francisco } \\
\text { Nazareth }\end{array}$ & Rua do Brás, 76 & Pág. 120 \\
\hline & José Kauer & Marco da Meia Légua & Pág. 122 \\
\hline & $\begin{array}{l}\text { Josepha Maria de } \\
\text { Oliveira }\end{array}$ & Marco da Meia Légua & Pág. 122 \\
\hline & $\begin{array}{l}\text { Manoel José } \\
\text { Soares }\end{array}$ & Rua do Brás & Pág. 122 \\
\hline & Maria Ferreira & Marco da Meia Légua & Pág. 123 \\
\hline & $\begin{array}{l}\text { Messias Egydio } \\
\text { dos Santos }\end{array}$ & Rua do Brás, 143 & Pág. 123 \\
\hline & $\begin{array}{l}\text { Miguel Antonio } \\
\text { Chaves }\end{array}$ & Rua do Brás, 86 & Pág. 123 \\
\hline & $\begin{array}{l}\text { Salvador José } \\
\text { Barreiros }\end{array}$ & Marco da Meia Légua & Pág. 123 \\
\hline \multirow{3}{*}{$\begin{array}{l}\text { Cocheiras de alugar } \\
\text { animais carros, seges, } \\
\text { etc. }\end{array}$} & Donato Severino & Rua do Brás, 84 & Pág. 126 \\
\hline & João Bresser & Brás (chácara) & Pág. 126 \\
\hline & $\begin{array}{l}\text { Manoel José dos } \\
\text { Santos }\end{array}$ & Rua do Brás, 157 & Pág. 126 \\
\hline $\begin{array}{l}\text { Irmão da Mesa da } \\
\text { Santa Casa de } \\
\text { Misericórdia, Bacharel }\end{array}$ & $\begin{array}{l}\text { João Carlos da } \\
\text { Silva Teles }\end{array}$ & Braz & $\begin{array}{l}\text { Pág. } 107- \\
\text { Almanaque } \\
\text { de } 1873\end{array}$ \\
\hline
\end{tabular}

Tabela 2: "Capitalistas e proprietários" que atuaram na região do Brás na década de 1870, elaborada pelo autor com base no Indicador de São Paulo de 1878. 
É de se notar que grande parte dos chamados "capitalistas e proprietários" que atuavam na região do Brás fossem advogados, o que não exclui membros da Igreja e comerciantes envolvidos com o ramo das ferragens, com armazéns de secos e molhados, e até médicos e compositores. Dos nomes citados, apenas João Bresser era proprietário de uma chácara, sendo os demais proprietários de porções de terras menores. Os personagens acima listados podem ter conquistado suas terras por solicitações encaminhadas à Câmara Municipal, as tais "Cartas de Datas" analisadas em pormenor e especializadas por Elisângela Maria da Silva. Exemplo dessa prática são os proprietários da região do Marco da Meia Légua, os quais podem ter adquirido estas terras a partir do processo de venda que Anna Müller realizou após a morte do seu marido, Carlos Bresser.

Esse processo de loteamento das chácaras pode ser mais bem compreendido quando cruzamos os nomes de alguns destes personagens com outras fontes, como a cartografia histórica. Podemos perceber que, em muitos mapas, há a referência a nomes de proprietários de chácaras, com seus limites e vizinhanças, nomes estes que batizaram ruas e becos, permanecendo na toponímia da região. Maria Vicentina de Paula do Amaral Dick, em artigo publicado em 1984 sobre as relações da História e Toponímia, procurou convergir diferentes fontes para traçar a origem dos nomes de algumas das ruas de São Paulo, baseando-se em relatos de viajantes, memorialistas, bibliografia e principalmente nos "Fichários do Arquivo Municipal", fichas que sistematizam informações gerais sobre a história das ruas de São Paulo 95 .

Analisemos a planta de 1841, executada pelo engenheiro-civil Karl Abraham Bresser, então proprietário da chácara da região do Marco da Meia Légua, um dos limites do Brás. Trata-se da primeira carta cadastral da cidade e confere grande atenção aos lotes existentes, suas quadras e mesmo aos espaços ocupados pelos edifícios, como nos atenta Nestor Goulart Reis ${ }^{96}$. Na região além do rio Tamanduateí, pode-se verificar uma vasta área com três principais artérias viárias representadas: a Estrada da Mooca, o Caminho da Mooca e um caminho não identificado, mas que por abrigar em seu percurso a chamada Ponte do Ferrão e Igreja do Bom Jesus, deduzimos ser a antiga Rua do Brás, posteriormente Rangel Pestana / Celso Garcia.

\footnotetext{
${ }^{95}$ Hoje disponíveis em $<<\mathrm{http}: / /$ www.dicionarioderuas.prefeitura.sp.gov.br $>>$.

${ }^{96}$ REIS Filho, Op. Cit., p. 239.
} 


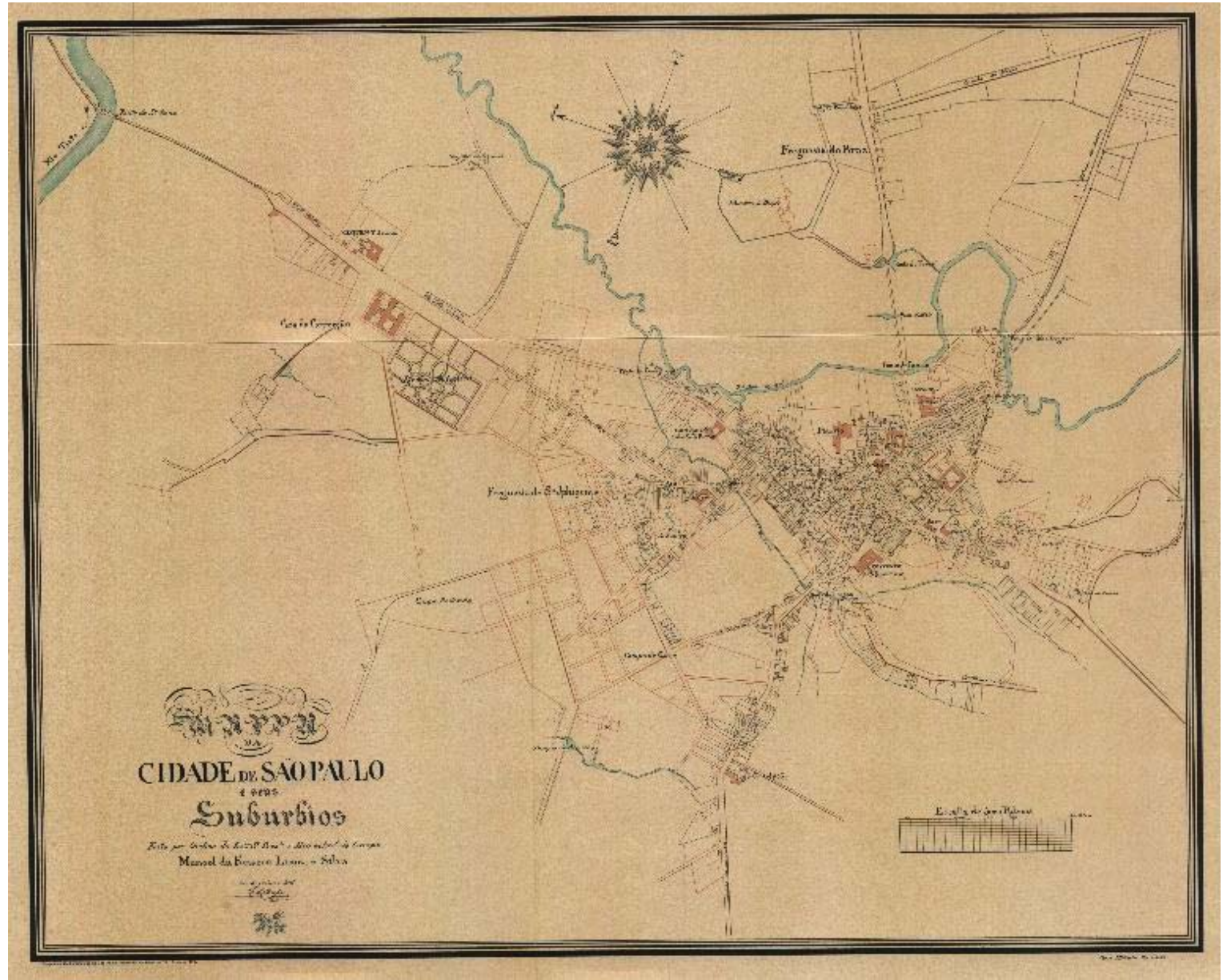

Mapa 3: Planta da Cidade de São Paulo e seus Subúrbios - cópia de 1918 de uma planta datada de 1841. Acervo Cartográfico do Arquivo Histórico Municipal.

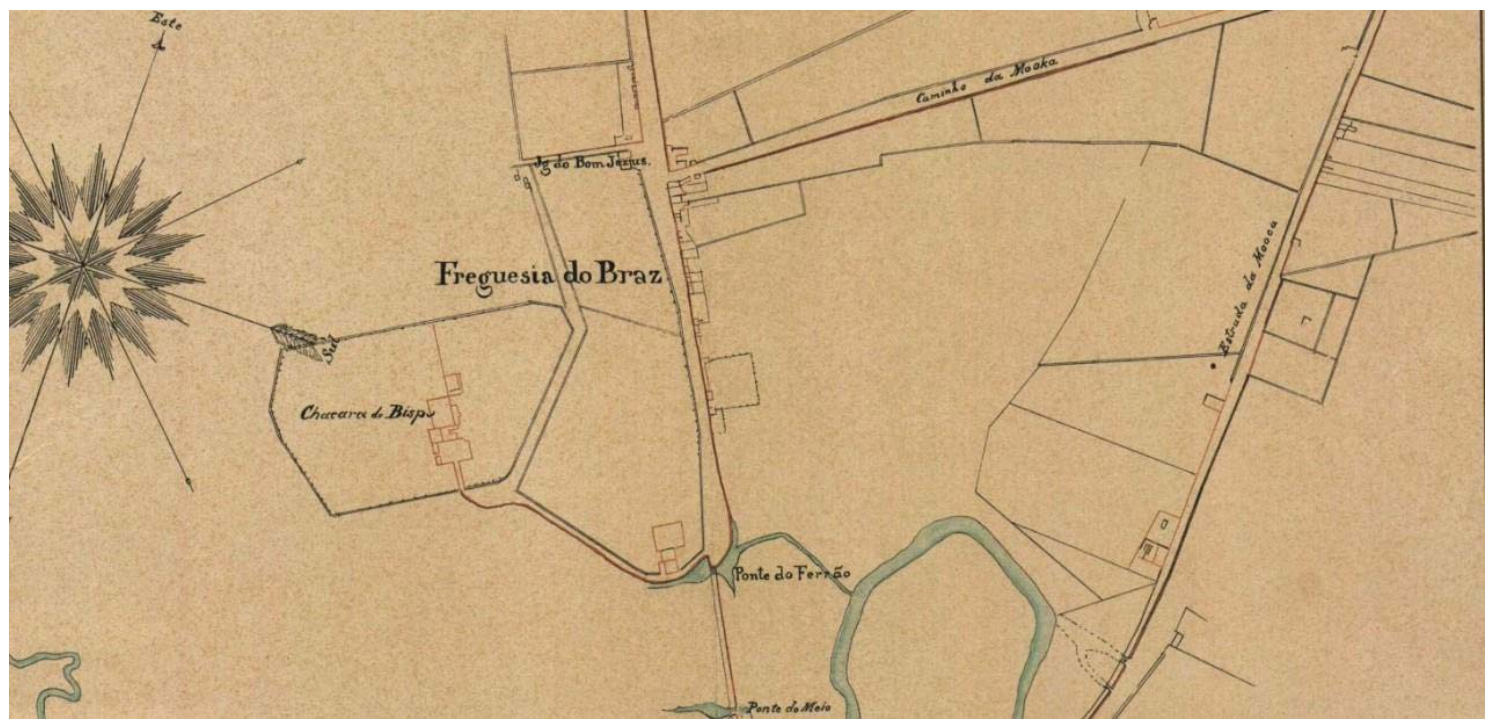

Mapa 4: Pormenor da Planta da Cidade de São Paulo e seus Subúrbios. Cópia de 1918 de uma planta datada de 1841. Acervo Cartográfico do Arquivo Histórico Municipal. 
Abaixo da "rosa dos ventos" desenhada na planta, vê-se a Chácara do Bispo, com possivelmente algumas construções em seu interior, e separada de outra possível chácara por um simples caminho que levava aos fundos da Igreja Bom Jesus de Matosinhos, esta, quase defronte ao Caminho da Mooka. Afinal, de quem seria essa chácara vizinha à propriedade do bispo? Ao que nos indica, esta chácara seria a do Ferrão, pertencente à Domitila de Castro Canto e Melo, a Marquesa de Santos, informação corroborada quando analisamos a Planta da Cidade de São Paulo, de 1868, atribuída por Nestor Goulart a Carlos $\operatorname{Rath}^{97}$.

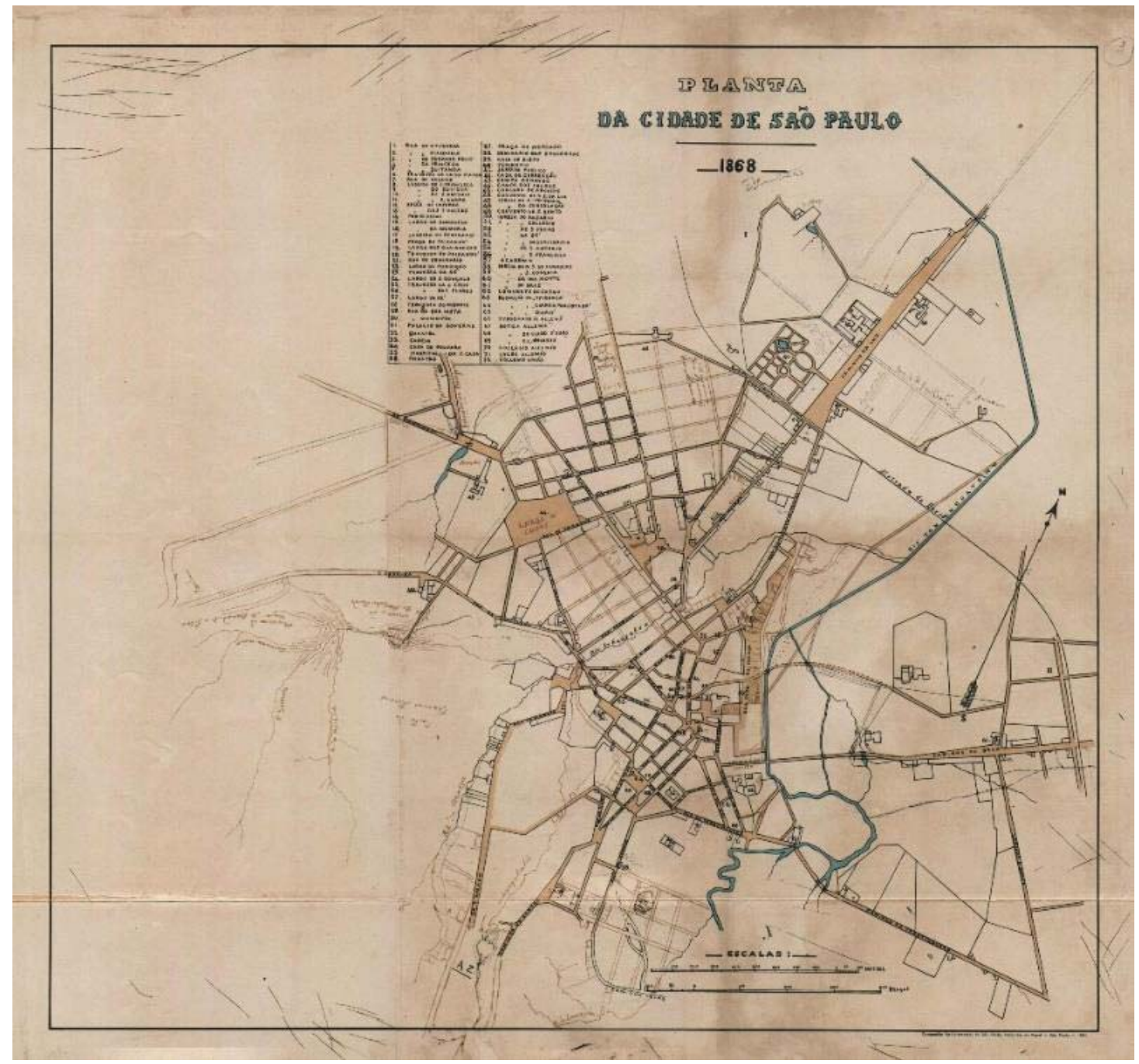

Mapa 5: Planta da cidade de São Paulo, 1868, Acervo Cartográfico do Arquivo Histórico Municipal.

${ }^{97}$ Idem, p. 241. 


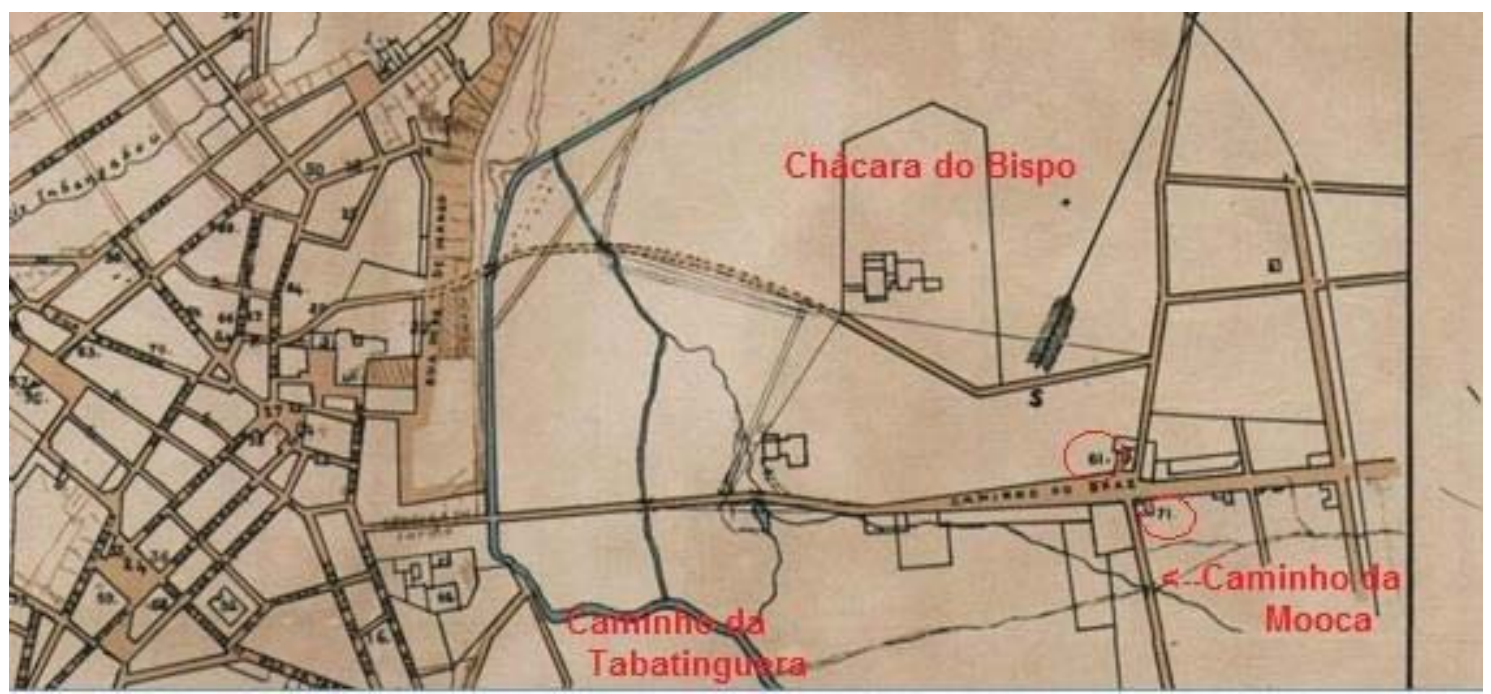

Mapa 6: Planta da cidade de São Paulo 1868 - recorte (atentar para os números referentes à região do Brás: 61: Igreja do Brás; 71: Liceu Alemão.

Podemos perceber que a chácara do Bispo permaneceu com seus limites demarcados entre 1841 e 1868, separada da chácara abaixo pelo caminho que levava aos fundos da igreja do Brás (número 61). O Caminho da Mooca permanece ligando o Caminho do Braz à Estrada da Mooca, agora chamada de Caminho da Tabatinguera, que também acompanha a Estrada de Ferro São Paulo Railway. Além disso, dois números podem ser observados como pontos de interesse nesta porção da cidade: o número 61, indicando a Igreja do Brás (também conhecida como Igreja do Bom Jesus de Matosinhos), e o número 71, local do Liceu Alemão. Na Chácara do Bispo, pode-se perceber a existência de um caminho que é traçado entre os limites do lado esquerdo das duas chácaras, ligando-as à Rua Vinte e Cinco de Março.

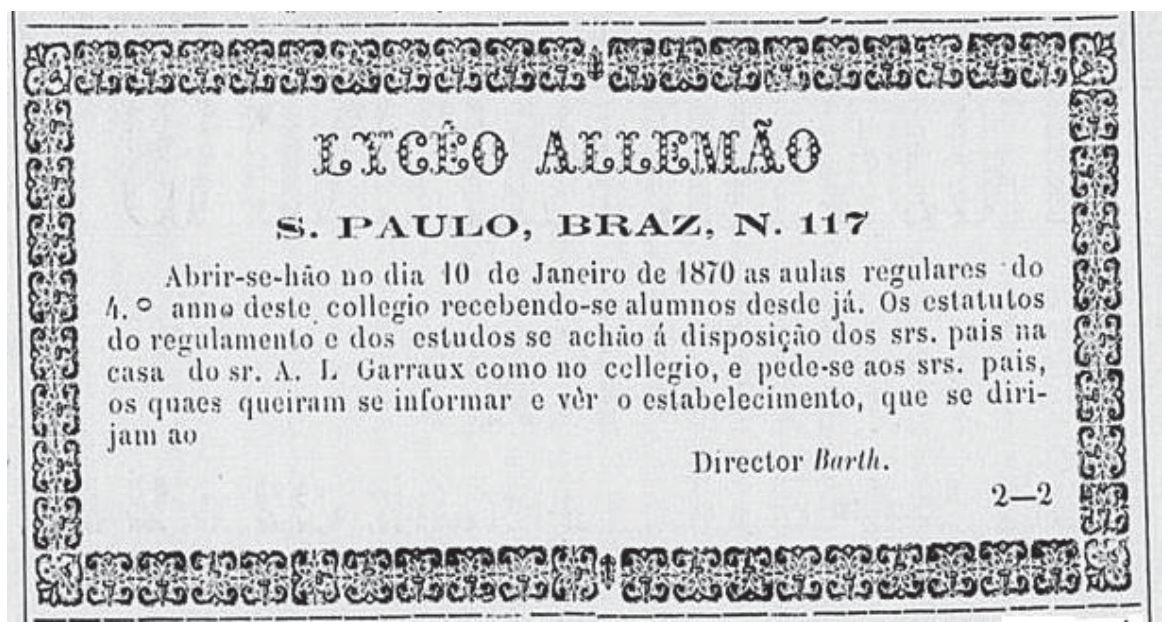

Figura 10: Anúncio do jornal Correio Paulistano, edição de 13 de janeiro de 1870, sobre o Lycêo Allemão do Bráz. Acervo Hemeroteca Digital Brasileira. 
O primeiro mapa turístico de São Paulo, intitulado Mappa da capital da Pcia. De S. Paulo seos Edifícios públicos, Hotéis, Linhas ferreas, Igrejas, Bonds, Passeios, etc. publicado por Frco. De Albuquerque e Jules Martin em julho de 1877, representa os atrativos urbanos da cidade no início do seu processo de urbanização. No canto superior esquerdo da planta, uma legenda descreve uma sequência de igrejas e conventos existentes na cidade e em algarismos romanos, os edifícios que se situavam fora da cidade (ou melhor, do perímetro urbano de 1877). À direita do mapa, encontramos um segundo guia de localização da cidade, com edifícios simbólicos, que versam sobre diferentes tipologias e usos, como estações de trens, a cadeia, o hospício e o mercado. O terceiro e último guia, no canto inferior esquerdo, nos dá a dimensão dos edifícios de uso comercial, como lojas, institutos, colégios, hotéis, e latitude e longitude da cidade, bem como "estações de urbanos" (bondes), e as futuras linhas a serem implantadas.

Enquanto a grande maioria dos edifícios demonstrados no mapa circunscrevem-se à área da colina histórica, entre as ruas do Triângulo, os olhos do leitor são convidados a se ater ao que se passa nas franjas da cidade: na área da Luz podemos verificar a estação de trem recém-inaugurada e bondes em pleno funcionamento, bem como o Jardim Público com sua torre de observação, chamando a atenção o desenho simétrico do Jardim da Luz e a avenida que lhe margeava ${ }^{98}$. O Seminário Episcopal na rua dos Lázaros, muito próximo da antiga casa do Bispo (n. 55), parecem ser próximos da Fábrica de Tecidos (n. 74) que margeia o rio Tamanduateí, revelando a convivência de tipologias antigas e novas nesse espaço de transição.

Toda a área da várzea que ladeia o rio Tamanduateí se mostra praticamente desabitada, com um verde que ocupa boa parte da planta. Mas a presença dos tílburis que passam pelo aterrado do Gasômetro (um antigo caminho que cortava as chácaras do Bispo e do Ferrão) e o próprio edifício do Gasômetro (n. 22) - contratação que iniciou-se em 1863, e se concretizou em 1872 em terrenos da Chácara da Figueira, armazenando e distribuindo o gás hidrogênio para o abastecimento de lampiões das ruas e residências da cidade indicam as mudanças nos usos e deslocamentos a serem feitos na cidade.

${ }^{98}$ Hoje Avenida Tiradentes. 


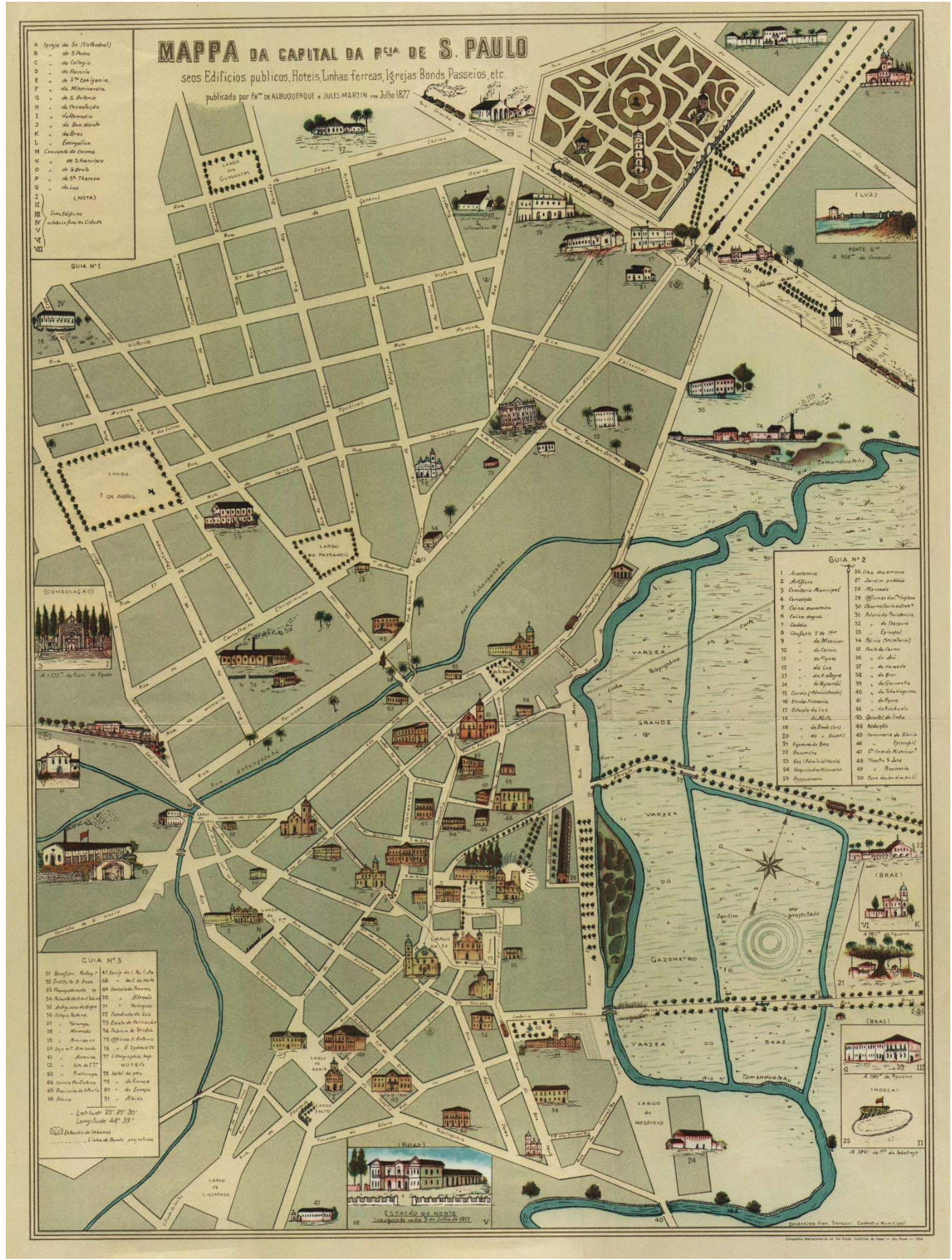

Mapa 7: Mappa da capital da Pcia. de S. Paulo seos Edifícios públicos, Hotéis, Linhas ferreas, Igrejas, Bonds, Passeios, etc. publicado por Frco. De Albuquerque e Jules Martin em julho de 1877, 1877, Acervo Cartográfico do Arquivo Histórico Municipal. 
Vizinho a este complexo, a Igreja do Brás (letra K), que estaria segundo o mapa a 390 metros da grande figueira do Brás (número 21), e próxima ao Palácio Episcopal (número 33) e ao Hipódromo (25, II). Separando este cenário urbano, um "Jardim a ser projectado", muito próximo da Ilha das Amores (n. 26), parte de um jardim público projetado ainda no governo de João Teodoro, demonstrando o interesse em transformar esta área da cidade em uma outra área própria para passeios e diversões, segundo os princípios urbanísticos da época.

Nos chama a atenção o fato da Estação do Norte, situada para além deste conjunto urbano citado, vir desenhada no lado de "dentro" da cidade, na margem esquerda do rio Tamanduateí, citando inclusive sua data de inauguração no dia 03 de julho de 1877, pouco antes da publicação da referida planta. A estação, parece ser assim o símbolo da expansão da cidade para além do seu limite na colina histórica, demarcando a nova fase da cidade que podia ser interligada ao Rio de Janeiro, e da projeção de São Paulo no contexto capitalista de então ${ }^{99}$, construída na margem direita do rio Tamanduateí, e não no lado da cidade, como dava a impressão o mapa de 1877.

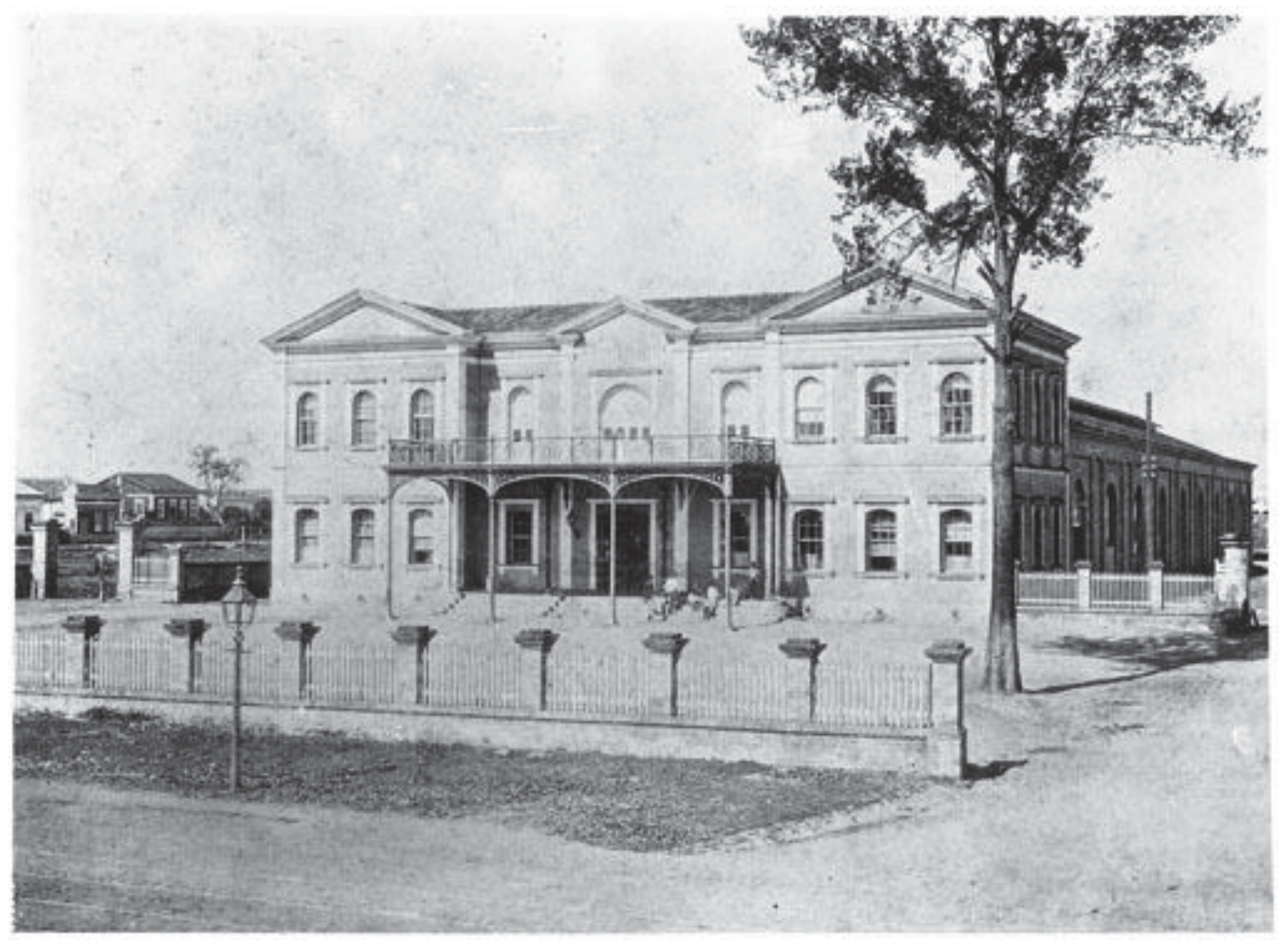

Figura 11: Estação do Norte, Fotógrafo não identificado, 1889 c., Acervo Fotográfico do Museu da Cidade de São Paulo

\footnotetext{
${ }^{99}$ Segundo Eric Hobsbawm, as ferrovias “faziam parte da inovação de maior impacto do século” XIX, não apenas por sua grande extensão, mas pelo impacto no campo de empregos, visto que detinha muito mais braços trabalhando para sua construção e manutenção que qualquer outro empreendimento antes realizado. HOBSBAWN, Eric. A era dos impérios, 1875-1914. São Paulo: Paz e Terra, 2010, pág. 52.
} 
Com apenas quatro anos de diferença da publicação anterior, a Planta da Cidade de São Paulo levantada pela Companhia Cantareira e Esgotos em 1881, pelo engenheiro chefe da companhia Henry B. Joyner, procurava cadastrar o número de imóveis existentes na cidade para sistematizar a futura rede de águas e esgotos que estava instalando em São Paulo, dando a ver a sua dimensão naquele momento. A atenção especial é dada aos edifícios públicos, e igrejas, fábricas e estações de trens distribuídas na cidade e demarcados com números e uma tonalidade mais intensa sobre o desenho.

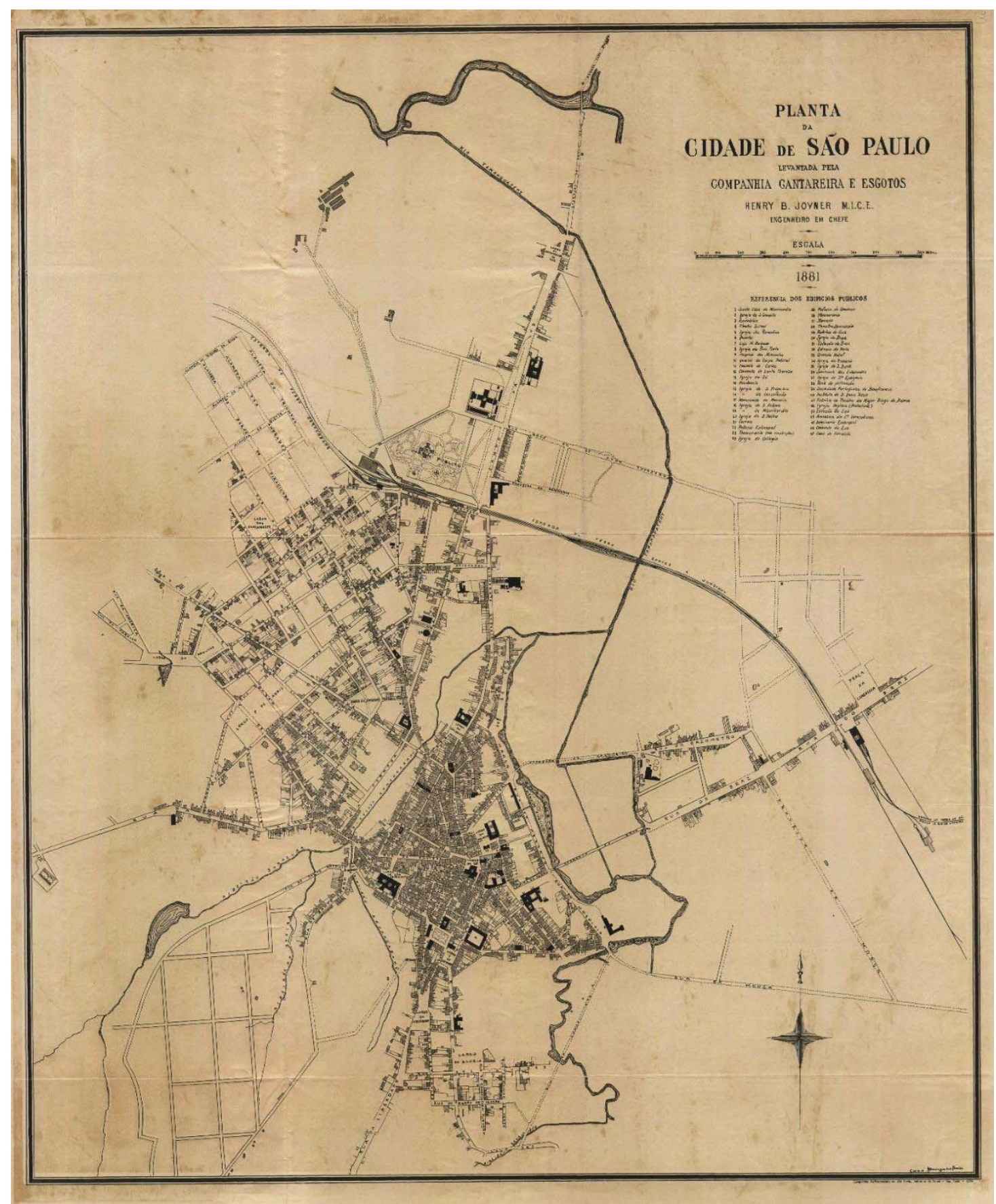

Mapa 8: Planta da Cidade de São Paulo levantada pela Companhia Cantareira e Esgotos, 1881, Acervo Cartográfico do Arquivo Histórico Municipal. 
Parte do rio Tamanduateí já parece estar retificado e canalizado, desembocando no rio Tietê. Se nos atermos aos equipamentos urbanos situados na porção leste da cidade, podemos vislumbrar as duas estações de trens (do Norte n. 31 e do Brás n.32), o Gasômetro (n. 29), a Igreja do Brás (n. 30), em meio a muitos imóveis que se estabeleceram essencialmente na rua do Gasômetro e do Brás, marcando a paisagem como um local intermediário para aqueles que entravam e saíam da cidade. Há uma continuidade nas construções capitaneadas nesta via, contando inclusive com uma praça que recepcionava aqueles que desembarcavam na Estação do Norte, a praça da Concórdia, demonstrando ser um "ponto final" para a região do Brás, com construções que margeavam seus dois lados. A praça era vizinha da propriedade do Comandante Superior da Guarda Nacional da Capital, o Coronel Inácio José de Araújo ${ }^{100}$, bacharel mencionado no Indicador de 1878 como residente à rua do Brás número 78 que, em 1865, começava a ser loteada e continha um “parreiral enorme em sua chácara da Avenida Rangel Pestana ${ }^{101}$, esquina do Largo da Concórdia, com possibilidade de fabricar de oitenta a cem pipas de vinho"102. Em 1865, a chácara foi loteada e uma das ruas da região fora batizada com o nome de seu proprietário.

Os fotógrafos do período, ao registrarem os novos ícones da paisagem urbana em transformação, acabam por revelar nas entrelinhas do discurso visual as contradições e ambiguidades em curso. Por exemplo, o fotógrafo do registro abaixo, ao destacar o complexo da Companhia de Gás nas proximidades da rua do Gasômetro em direção ao Brás, ainda coloca em foco os traços da antiga chácara da Figueira, com o arvoredo nos fundos e à direita um caminho separando duas faixas de terra, certamente a Chácara Loskiel ao lado direito.

\footnotetext{
${ }^{100}$ Quem atesta sua profissão é o periódico humorístico Cabrião, editado por Ângelo Agostini, um dos grandes precursores da caricatura e ilustração da época, juntamente com dois jornalistas, Américo de Campos e Antônio Manoel dos Reis, o qual relata que circulava entre "ocupantes de cargos e funções políticoadministrativas de maior importância, e figuras do alto clero", dentre eles o Dr. João Tobias de Aguiar e Castro, filho de Rafael Tobias de Aguiar e Domitila de Castro do Canto e Melo, Subdelegado da Freguesia do Brás, e morador da chácara do Ferrão. Cabrião semanário humorístico editado por Ângelo Agostini, Américo de Campos e Antônio Manoel dos Reis, 1866-1867 / introdução de Délio Freire dos Santos. São Paulo: Editora UNESP: Imprensa Oficial do Estado, 2000, pág. XXIII.

${ }^{101}$ Bruno leva em consideração a toponímia de sua época, e não rua do Brás, como a via era conhecida em idos da década de 1860 .

${ }^{102}$ BRUNO, Op. Cit, pág. 1115-1116
} 


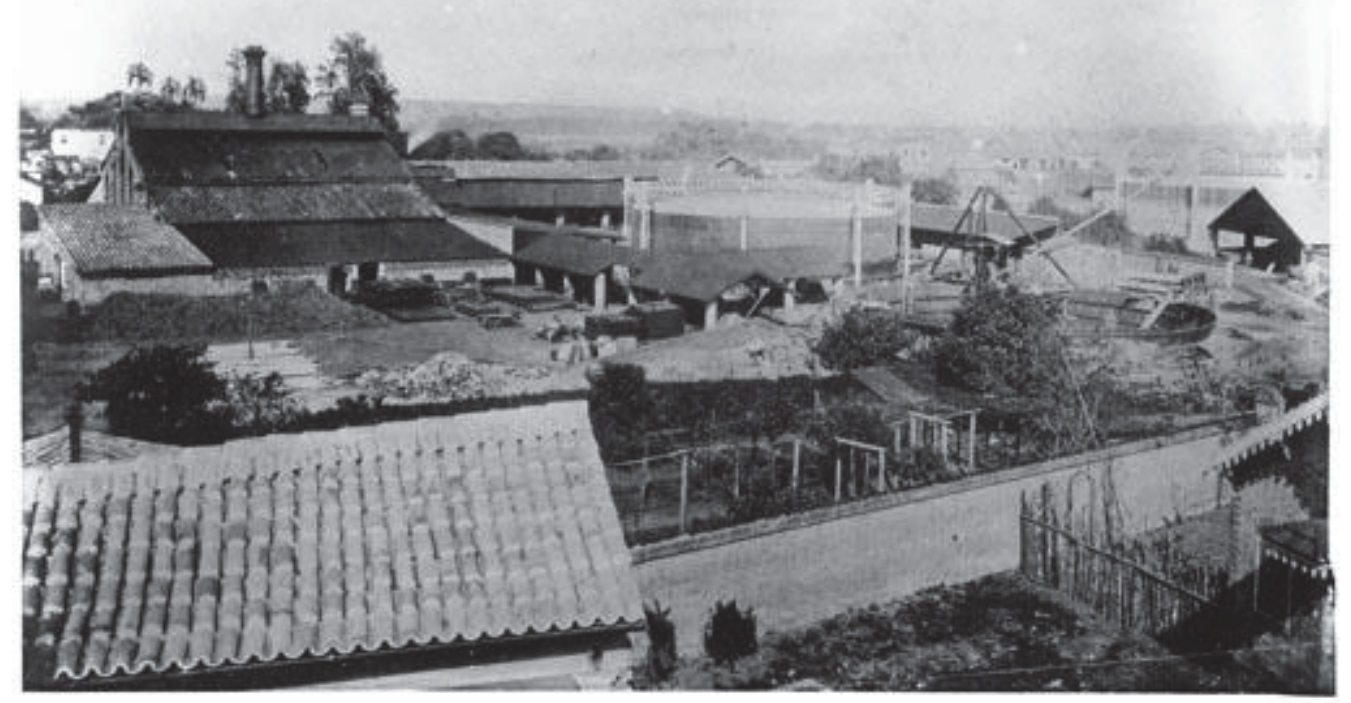

Figura 12: Companhia de Gás, fotógrafo não identificado, 1888 c., Acervo Fotográfico do Museu da Cidade de São Paulo.

Sobre a produção de bebidas na região, outro personagem com uma chácara se destaca: João Boemer. Sobre o viticultor, Ernani Silva Bruno lembra o viticultor além de um sítio na região do Belenzinho, "Bohemer fundara outra no Marco da Meia Légua"103, tornando-se também proprietário de uma fábrica de cerveja na "estrada que ia ter no Santuário da Penha" 104 (avenida Intendência, e posterior Celso Garcia), além de ter deixado um grande número de prédios e terrenos no bairro de sua residência, quando veio a falecer. ${ }^{105} \mathrm{Um}$ dos seus bisnetos, Wagner Boemer, esclarece que seu bisavô fora

\footnotetext{
“a terceira pessoa a ser enterrado no cemitério do Brás, em 1894. Sua esposa morreu dois meses antes $\mathrm{D}^{\mathrm{a}}$ Maria Tereza, em um túmulo perpétuo, conhecido como Quarta Parada e que por sinal é no Belém. Ele foi proprietário de terras no Brás e no bairro da Penha. O terreno onde está construída a igreja S. João na av. Celso Garcia esquina com a rua João Boemer foi sua doação. Foi o primeiro fabricante de cerveja em São Paulo, conhecida como cerveja da Penha. Teve sete filhos entre homens e mulheres. Dois deles emigraram para os Estados Unidos no fim do século XIX mas entraram como alemães e não como brasileiros. Tem o Pedro Boemer, junto com a família Schunck não sei se irmão ou seu filho foram os primeiros moradores e fundadores de Santo Amaro. O ramo da minha família
}

\footnotetext{
${ }^{103}$ BRUNO, Op. Cit, pág. 1117.

${ }^{104}$ MOURA, Carlos Eugênio Marcondes de (Org.). Vida cotidiana em São Paulo no século XIX: memórias, depoimentos, evocações. São Paulo: Editora UNESP, 1999, pág. 206.

${ }^{105}$ Disponível em: http://www.dicionarioderuas.prefeitura.sp.gov.br, acesso em 30/10/2016.
} 
começa com o João, Julio Boemer meu avô, Newton Boemer meu pai, todos falecidos." $" 106$

O escritor cearense Raimundo de Menezes nos confere uma visão da relação que esse personagem tinha com a região em que viveu:

\footnotetext{
“O Marco constituía uma espécie de recanto campestre. Havia por lá umas chácaras, numa das quais morava um pacato e bonachão germânico, o João Boemer, que possuía uma fábrica de cerveja chamada “cerveja da penha", a 500 réis a garrafa! A estrangeira ou a do rio - marcas Pá, Viena, Franzizkaner - eram vendidas a $1 \$ 500$ (um mil e quinhentos contos de réis), vejam: coisa só para rico..." 107
}

A planta de 1881 revela especificidades do processo de formação do Brás, dá a ver a existência de novas ruas que no mapa de 1877 não eram encontradas: a travessa da Móoca (hoje rua Piratininga), e a rua que se inicia na travessa do Gasômetro ${ }^{108}$ (atual rua Maria Domitila), desembocariam na atual rua Vasco da Gama. Apesar do Dicionário de Ruas denotar que esta última rua só vem aparecer no mapa da cidade de 1890, podemos perceber que se trata de uma abertura da década de 1860, quando a chácara da então Marquesa de Santos iniciou seu processo de loteamento.

Além destas, pode-se perceber a existência de um conjunto de ruas projetadas, com cinco construções espalhadas entre elas: do lado esquerdo da linha férrea podemos verificar o alinhamento das ruas Monsenhor Andrade, Sampaio Moreira e Flórida ${ }^{109}$, e ao norte da Praça da Concórdia, a rua Barão de Ladário cortada pelas ruas Xavantes ${ }^{110}$ e Oriente, e a rua Rodrigues dos Santos, que desembocava na rua João Teodoro. A primeira rua referia-se a um prolongamento do limite da então Chácara do Bispo (uma homenagem ao monsenhor Manuel Joaquim Gonçalves de Andrade, natural da Ilha da Madeira e que se estabelece na cidade no ano de 1796, elegendo-se bispo da diocese de São Paulo em 1826, atuando inclusive como deputado provincial de 1835 a 1845, morrendo dois anos depois). Sobre a rua Sampaio Moreira, percebemos que este fora um dos proprietários de terras na região, antigo comerciante em São Paulo e detentor de propriedades que se espalhavam entre as ruas da Concórdia, do Comércio, da Quitanda e Correia de Andrade, famoso por batizar um

\footnotetext{
${ }^{106}$ Disponível em: http://conhecidos1.rssing.com/chan-15748585/all p3.html, acesso em 30/11/2016.

${ }^{107}$ MENEZES, Raimundo de. São Paulo dos nossos avós. São Paulo: Saraiva, 1969.

108 Atual rua da Figueira.

109 Atual rua do Bucolismo.

${ }^{110}$ Hoje este trecho corresponde à rua Ministro Firmino Whitaker.
} 
edifício homônimo na rua Líbero Badaró. Sobre a figura de Brasilio Rodrigues dos Santos, o Dicionário de Ruas o descreve como bacharel da Faculdade de Direito do Largo São Francisco, em 1877, ocupando o cargo de juiz na cidade de Bragança Paulista. Republicano, fora eleito senador, e em 1892 nomeado deputado federal, falecendo em 30 de março de 1901.

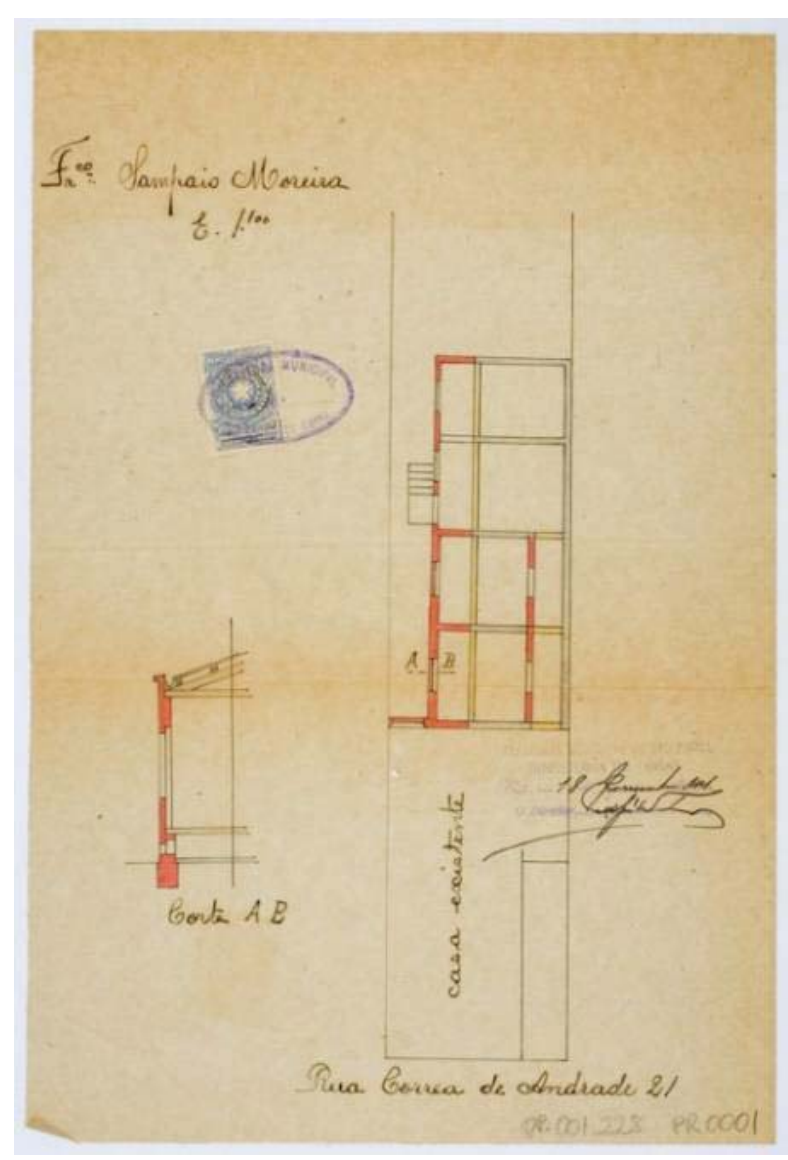

Figura 13: Uma das propriedades de Francisco Sampaio Moreira, na rua Correia de Andrade, 2, Brás. Arquivo Histórico Municipal; Série Obras Particulares do Arquivo Histórico Municipal, OP.1911.001.228.

A planta, produzida em 1881 pelo Engenheiro-chefe da Companhia Cantareira e Esgotos, Henry B. Joyner, nos fornece interessantes dados de como a região além do rio Tamanduateí teve seu perfil alterado nesses trezes anos desde a época da produção da Planta da Cidade de São Paulo, atribuída a Carlos Rath em 1868. Nela, é evidente o número de construções que surgiram nessa época, alinhadas essencialmente ao longo da rua do Gasômetro e da rua do Brás, via que então contava com duas estações de trens, identificadas na planta com os números 31 (Estação do Brás) e 32 (Estação do Norte), junto da Igreja do Brás (número 30). Entre as duas ruas mencionadas, aparece a Fábrica de Gás (número 29), com entrada pela travessa do Gasômetro, e do outro lado um antigo braço do rio Tamanduateí que servia à Chácara do Bispo e pode ser observada na planta de 1847. Como 
mencionado anteriormente, o Gasômetro fora instalado na Chácara do Ferrão (também conhecida como Chácara da Figueira) entre as ruas da Figueira e Maria Domitila. Com esses dados em mãos, podemos tecer algumas considerações a respeito do arruamento que fora se desenhando a partir desta chácara e da pertencente ao Bispo.
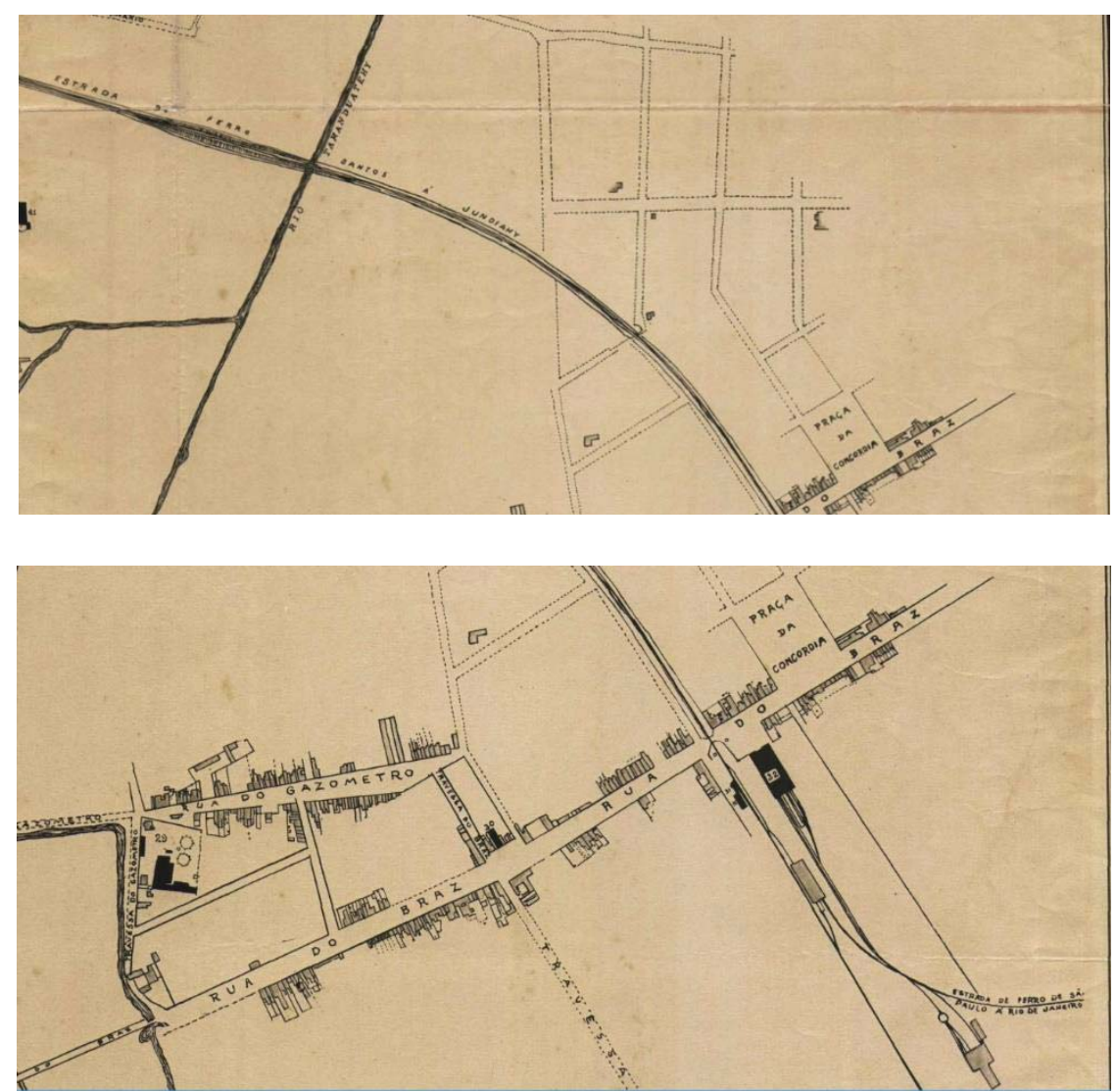

Mapas 9: Pormenores da Planta da Cidade de São Paulo levantada pela Companhia Cantareira e Esgotos, em 1881. Acervo Cartográfico do Arquivo Histórico Municipal.

Por meio da comparação cartográfica, podemos verificar que a entrada da Chácara do Ferrão deu origem à rua da Figueira em sua parte sul e ao norte à rua Santa Rosa, conforme se verifica por meio do caminho que ligava a área à Chácara do Bispo. Em 1890 pode-se perceber que a região além rio Tamanduateí já continha muito mais ruas, e que o processo de loteamento das chácaras estava por findar-se. O dado pode ser vislumbrado por meio da Planta da capital do Estado de S. Paulo e seus arrebaldes desenhada e publicada por Jules Martin em 1890. O novo arruamento se deu nas proximidades da Estrada de ferro: 
rua do Norte ${ }^{111}$, a avenida Martim Burchard ${ }^{112}$; e por fim a avenida (posterior "rua") Américo Brasiliense ${ }^{113}$

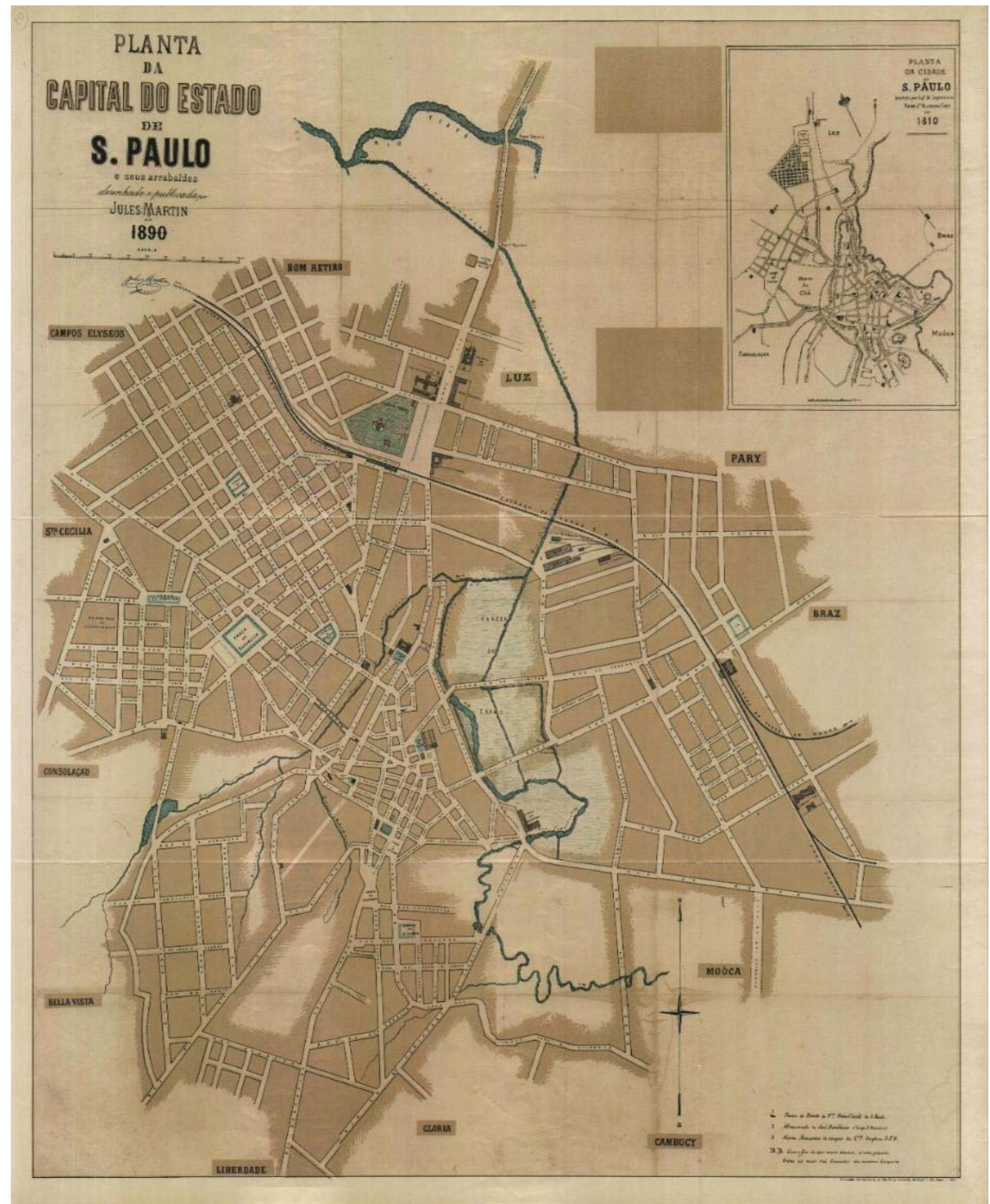

Mapa 10: Planta da capital do Estado de S. Paulo e seus arrebaldes desenhada e publicada por Jules Martin em 1890, Acervo Cartográfico do Arquivo Histórico Municipal

\footnotetext{
${ }^{111}$ Posterior rua Domingos Paiva, uma homenagem a Domingos de Paiva Azevedo, proprietário da Casa Paiva, distribuidora de "tecidos e roupas feitas, [que] comercializava também artigos de armarinho, miudezas e mais outras mercadorias de ocasião" atendendo especialmente ao público feminino da região central. BARBUY, Op. Cit., pág. 189

${ }^{112}$ Homenagem ao industrial e comerciante alemão que juntamente com Victor Nothmann loteou o bairro de Higienópolis. BUENO, Beatriz Piccolotto Siqueira. Aspectos do mercado imobiliário em perspectiva histórica: São Paulo (1809-1950). São Paulo: Edusp, 2016, pág. 132.

${ }^{113}$ Homenagem ao paulistano formado pela Faculdade de Direito em 1855, que em 1857 ocupou o cargo de juiz de paz, e fora deputado provincial. Como republicano, foi o primeiro secretário da Convenção de Itu, e já na década de 1890 presidente do Estado de São Paulo. Posteriormente ocupou o cargo de Ministro do Supremo Tribunal. Hoje este nome batiza uma via na região do bairro de Santo Amaro, e a que nos referimos chama-se Professor Eurípedes Simões de Paula, ex-diretor da Faculdade de Filosofia, Letras e Ciências Humanas da Universidade de São Paulo. Disponível em: http://www.dicionarioderuas.prefeitura.sp.gov.br/, acesso em $30 / 10 / 2016$.
} 
Passados cinco anos da publicação da planta de Jules Martin, Hugo Bonvicini publica a Planta da cidade de São Paulo de 1895, que divide a cidade em cinco distritos, indicando os principais edifícios públicos e casas comerciais e industriais, atendendo assim ao visitante que deseja conhecer mais a cidade. Interessante notar que, nesta planta, as indicações comerciais se limitam quase que exclusivamente à porção central, cabendo ao Brás a citação da Companhia Mechanica de Depósitos (8E), situada na rua Monsenhor Andrade e, nas suas proximidades, a Fábrica Bavaria de Cerveja e Gelo na Mooca $(10 \mathrm{H})$. Dos edifícios públicos apresentados, além das já citadas Estação do Norte e Estação do Brás (ambas localizadas entre as quadrantes 9F), um novo edifício figura sobre a carta no quadrante 10 G: "Emigração", correspondendo à hospedaria dos imigrantes inaugurada em 1887. A Igreja do Brás, apesar de desenhada e estando no quadrante $8 \mathrm{~F}$, não é apresentada na legenda. Sobre o Gasômetro, apesar de estar representado sob o número 57 da legenda, consta com seu endereço a rua 15 de Novembro, 3. 


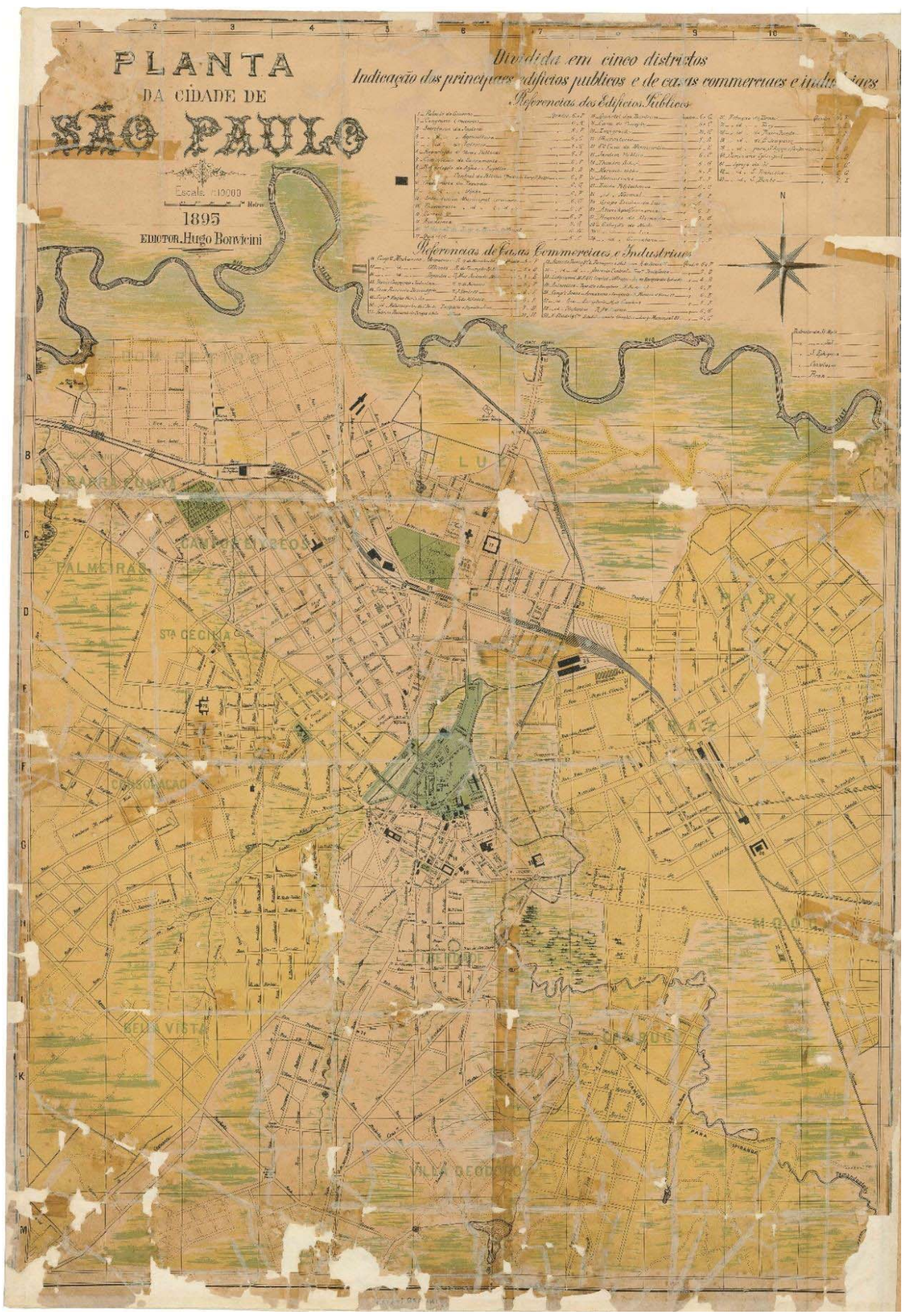

Mapa 11: Planta da cidade de São Paulo de 1895, Hugo Bonvicini, Acervo Cartográfico do Arquivo Histórico Municipal 
Outro dado interessante de se notar é a existência de traços que contornam as futuras ruas Monsenhor Andrade, Oriente, Florida, Sampaio Moreira, Cruz Preta, Concórdia e Maria Marcolina ${ }^{114}$.

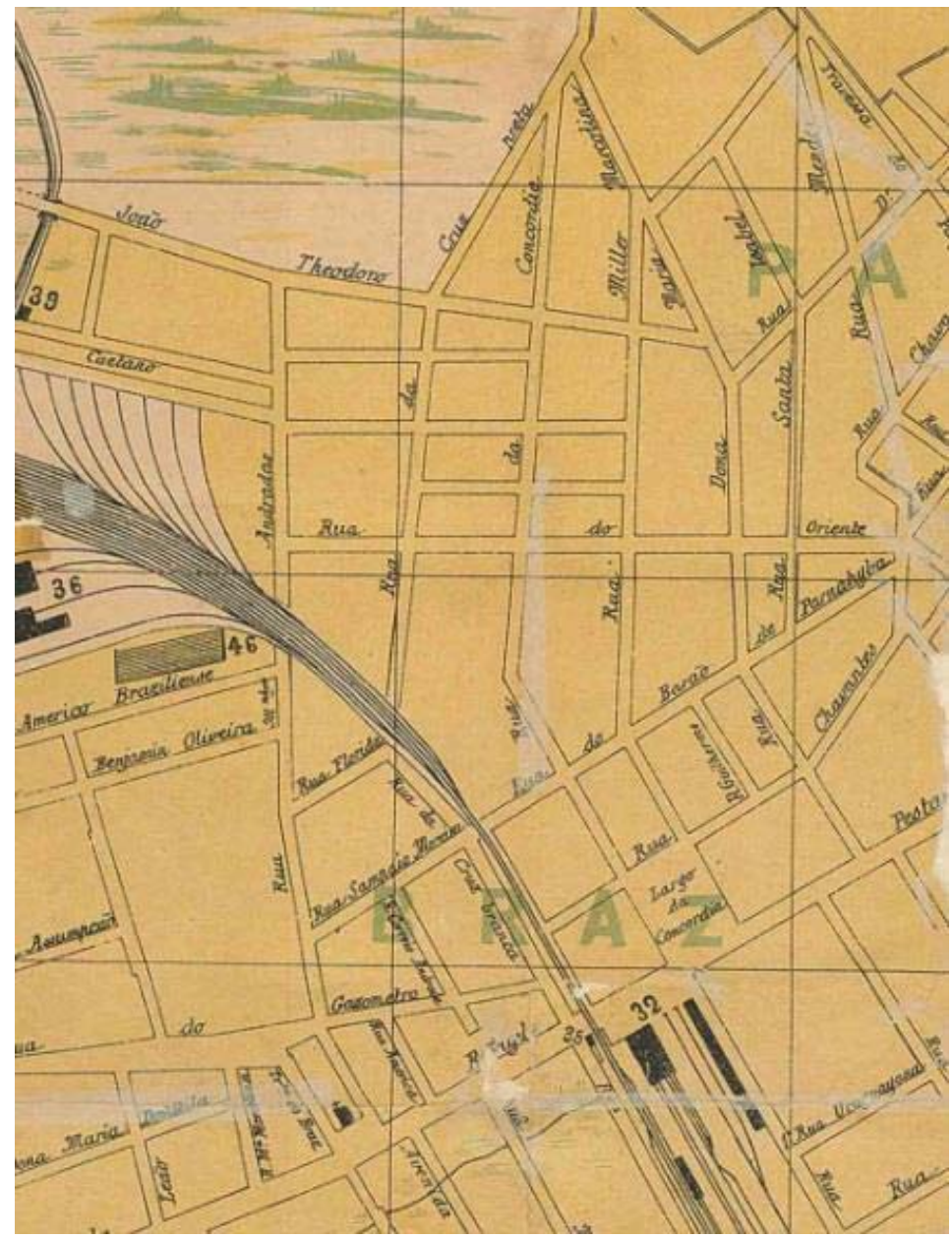

Mapa 12: Pormenor da Planta da cidade de São Paulo (...) indicando o traçado de ruas da região do Brás existentes em 1895.

Os traços das antigas Chácara da Figueira e da Chácara do Bispo parecem ter permanecido na região, delineando a "curva" que a rua Santa Rosa realiza no encontro com a Avenida Rangel Pestana. Se nos atentarmos para as ruas Assunção e do Lucas, verificaremos que neste espaço outro morador se destacava: Lucas Queiroz de Assunção,

\footnotetext{
${ }^{114}$ Sobre esta personagem, podemos perceber que era uma antiga moradora da região do Brás, proprietária de uma porção de terras que haviam pertencido à família Paes de Barros. Filha de Rodrigo Antonio Monteiro de Barros (1831-1884) e de D. Ana Francisca da Silva Prado (1837-1908), sendo sua avó materna Maria Marcolina Prado Monteiro de Barros. Maria Marcolina casou-se com Alfredo Claudio da Silva no ano de 1879 em São Paulo e teve dois filhos: Alfredo Claudio da Silva (falecido solteiro em Recife, quando cursava a Faculdade de Direito) e Rodrigo Claudio da Silva, que se casou em Paris com Cecília Carmen Monteiro de Barros em 1910. Biografia baseada no Dicionário de Ruas, o qual tomou como base a Genealogia Paulistana de Luiz Gonzaga da Silva Leme.
} 
negociante do Brás, desde pelo menos a década de 1870, residente à rua do Brás número 49, o qual, assim como Maria Domitila e Anna Müller, alugava sua chácara "com casa forrada e assoalhada [com] muitas árvores fructíferas, agua de poço boa, e cocheira"115.

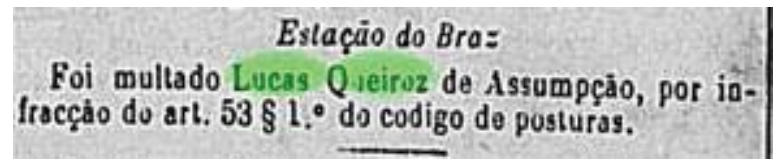

Figura 14: Anúncio do jornal Correio Paulistano, edição de 06 de fevereiro de 1877. Acervo Hemeroteca Digital Brasileira.

Talvez muitas das ruas apresentadas por Bonvincini em 1895 já existissem, mas não foram desenhadas em mapas anteriores. Aqui vemos claramente que as antigas chácaras não mais existem, sobrando possivelmente amplos terrenos que ainda mantém suas funções agrícolas, abastecendo grande parte da cidade e o bairro. Esta planta, quando comparada com a Planta Geral da capital de São Paulo organizada sob a direção do Dr. Gomes Cardim - Intendente de obras - 1897, nos fornece uma medida da expansão urbana ocorrida em São Paulo em finais do século XIX. Sobre todos os lados irradiaram-se ruas, retalhando antigas chácaras e terrenos que antes limitavam a colina histórica. Sobre a região da Várzea do Carmo e Brás, os arruamentos parecem ter se consolidado, permanecendo muito do traçado presente na contemporaneidade. Se nos atermos mais para à porção leste, diversos são os loteamentos existentes, como no Belém, a Vila Bernardino de Campos e a Vila Gomes Cardim. Chácaras, como a do Monsenhor Anacleto José Ribeiro Coutinho, foram inclusive revendidas para outros loteadores, neste caso, ao Barão de Souza Queiroz. Já as propriedades do negociante Antonio Azevedo Júnior, Squire Sampson, Júlio Joli e Behring foram demolidas e transformadas em lotes menores, permanecendo apenas os respectivos nomes de cada um desses proprietários na toponímia local. Sobre a família Joli, Ernani Silva Bruno coloca que esta era uma família que há tempos estava radicada em São Paulo e que da sua chácara vinham as flores para as demais chácaras e jardins da cidade,

com sementes e com mudas, eram em 1880 e anos seguintes três casas: a Casa da China; a do rio-grandense Frederico de Albuquerque, redator da Revista de Horticultura; e a do velho francês J. J. Joly, contando Von Koseritz que o jardim deste ultimo foi uma das coisas mais notáveis que viu no arrebalde do Brás. Houve logo depois, para os lados do Marco da Meia Légua, (em 1886-1887) uma

115 Jornal Correio Paulistano, edição de 11 de fevereiro de 1871. 
outra chácara de floricultura: a de Roberto Kirten. Essa chácara de Kirsten era mencionada no Almanach do Estado para 1891, como também a chácara de Julio Joly, além de outros estabelecimentos de horticultores: Guilherme Carlos Opel, na Avenida Rangel Pestana; Francisco Nemitz, na Vila Mariana, e A. J. Serafana

\& Cia e M. Garcia, na rua de São bento, este último com depósito na Chácara Japonesa" ${ }^{116}$.

\section{Attenção}

J. Joly, pai, tac sempre para vender na sua chacara do Braz n. 90 , um sortimento immenso e escolhido de arvores fructiferas e de laxo, cebollas de flores, trepadeiras, e de todas as plantas mais bellas e mais modernas da Europa, que recebo cada anno em tempo opportuno, que ficam aclimatadas $\theta \mathrm{em}$ bom estado. Os amadores de jardim e pomi res desta provincia, podem dirigir-se pessosimente ou por cartas ao mesmo, na cer teza que encontrarão tudo quanto podem desejar. 0 mesmo encarrega-se do bom arranjo das modas, e de remettel-as pelo caminho de ferro de Jundlahy ao correspondente designado, sendo toda via toda despeza do transporte a custa do comprador.

Espera no mez proximo futaro uma collecça completa de cinco teil pés de muda de arvoredos de toda especie, $\theta$ entre ellas uma krands poręăo de vinhas para fazer vinho de qualidade superior, assim como se mentes muito frescas d'hortsliças o de flores, cojas no seu recebimento dará novo aviso ao publico. $3-3$

Figura 15: Anúncio do jornal Correio Paulistano, de 11 de fevereiro de 1870 .

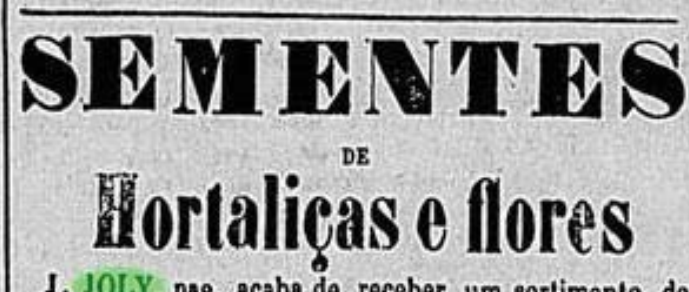

J. JOLY, pae, acaba de receber um sortimento de sementes muito novas de horlaliças e de flores de todas as qualidades as quaes se acham a venda no deposito em casa do sr. capitào José Philippe Salnian, rua da Imperatriz n. 17, espera brevemente uma gran le collecçảo de arbustos, arvoredos fructifuros, plantas a ce. bolas de flores. $5-1$

Figura 16: Anúncio do jornal Correio Paulistano de 08 de fevereiro de 1877.

Podemos perceber que o grande número de homenagens conferidas às ruas do Brás referem-se a antigos proprietários de chácaras ou lotes da região. Em alguns outros casos, proprietários de imóveis também foram agraciados, batizando vias da região, como a Carlos de Campos, homenagem à um dos diretores do Jornal Correio Paulistano, e que tendo concluído a Faculdade de Direito em 1887, exerceu diferentes cargos públicos em São Paulo, como a Secretaria da Justiça, Senador e Deputado Federal. Além dos seus cargos, podemos observar que era um dos capitalistas atuantes na região, atuando no mercado imobiliário rentista por meio da construção de "casas operárias".

O construtor Joaquim Carlos Augusto Cavalheiro fora outro personagem homenageado em uma das ruas do Brás. Com destacada atuação em diversos bairros da cidade (ao menos 445 projetos entre obras novas e reformas). Lindener Pareto Júnior o 
classifica como "proprietário" e "capitalista" com atuação substantiva nas ruas do Brás e da Móoca desde 1890"117.

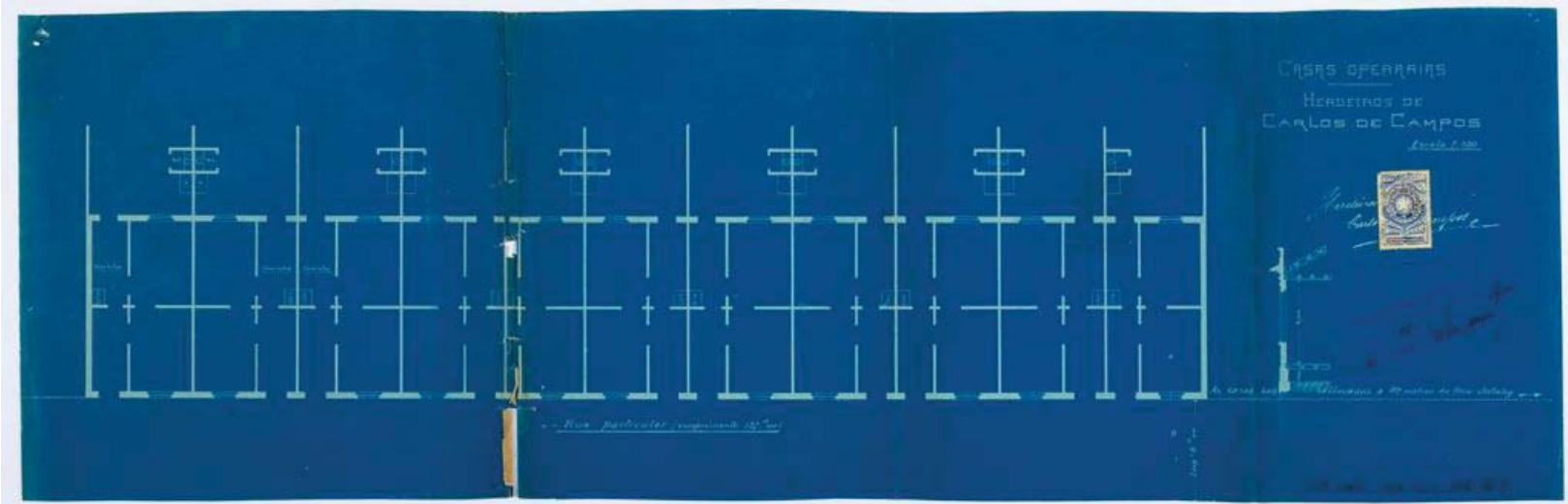

Figura 17: “Casas operarias. Herdeiros de Carlos de Campos"- Rua Jutahy, atual rua Visconde de Laguna. Arquivo Histórico Municipal, Fundo "Diretoria de Obras” OP1910.001.973.

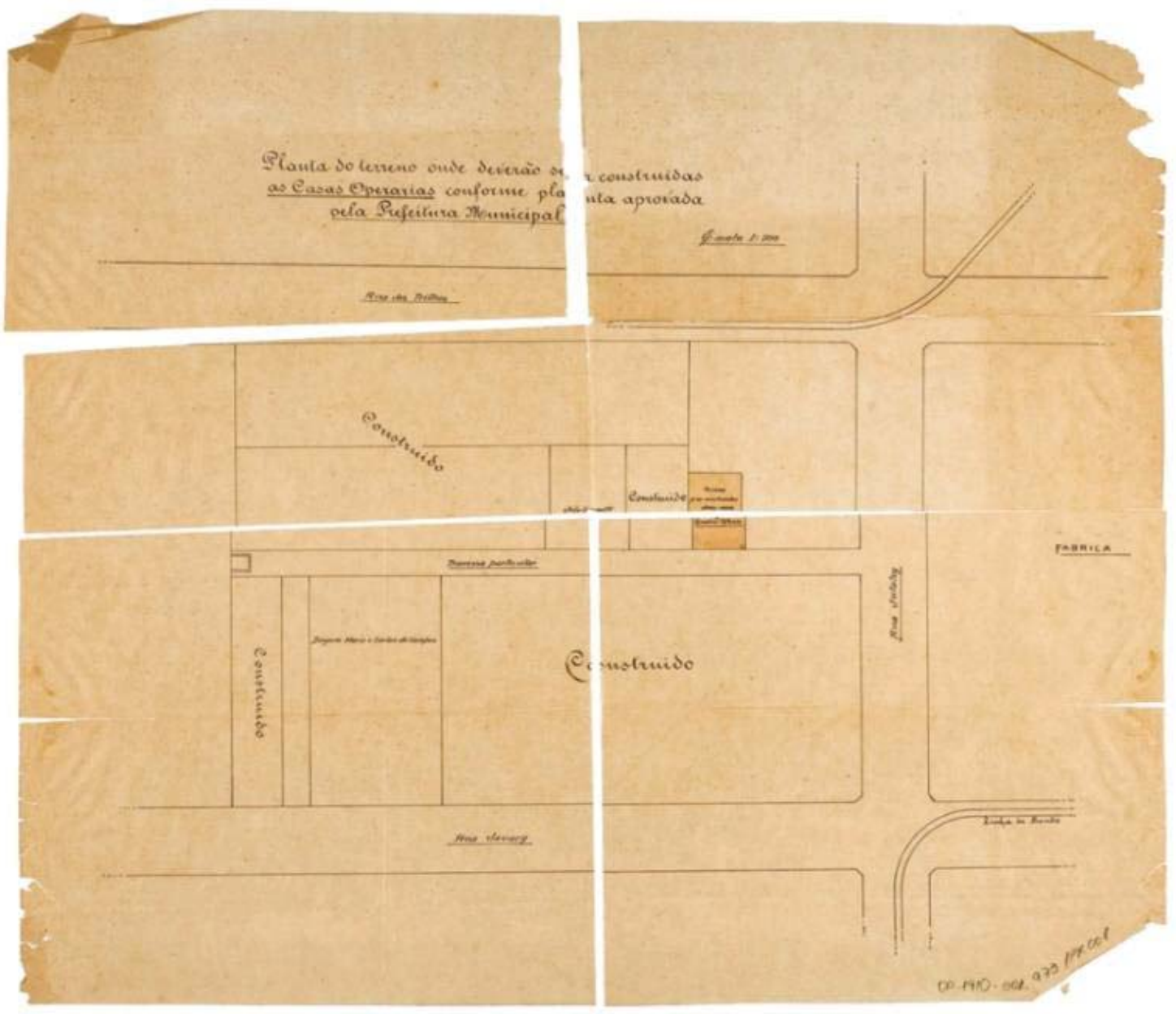

Figura 18: "Planta do terreno onde deverão ser construídas as casas operarias conforme autorizado pela Prefeitura Municipal", Rua Jutahy. - Arquivo Histórico Municipal, Fundo "Diretoria de Obras" OP1910.001.973

117 PARETO JUNIOR, Lindener. Joaquim Cavalheiro: um "arquiteto-construtor no Brás e na Móoca. São Paulo: Cultura Acadêmica, 2015, pág. 76. 


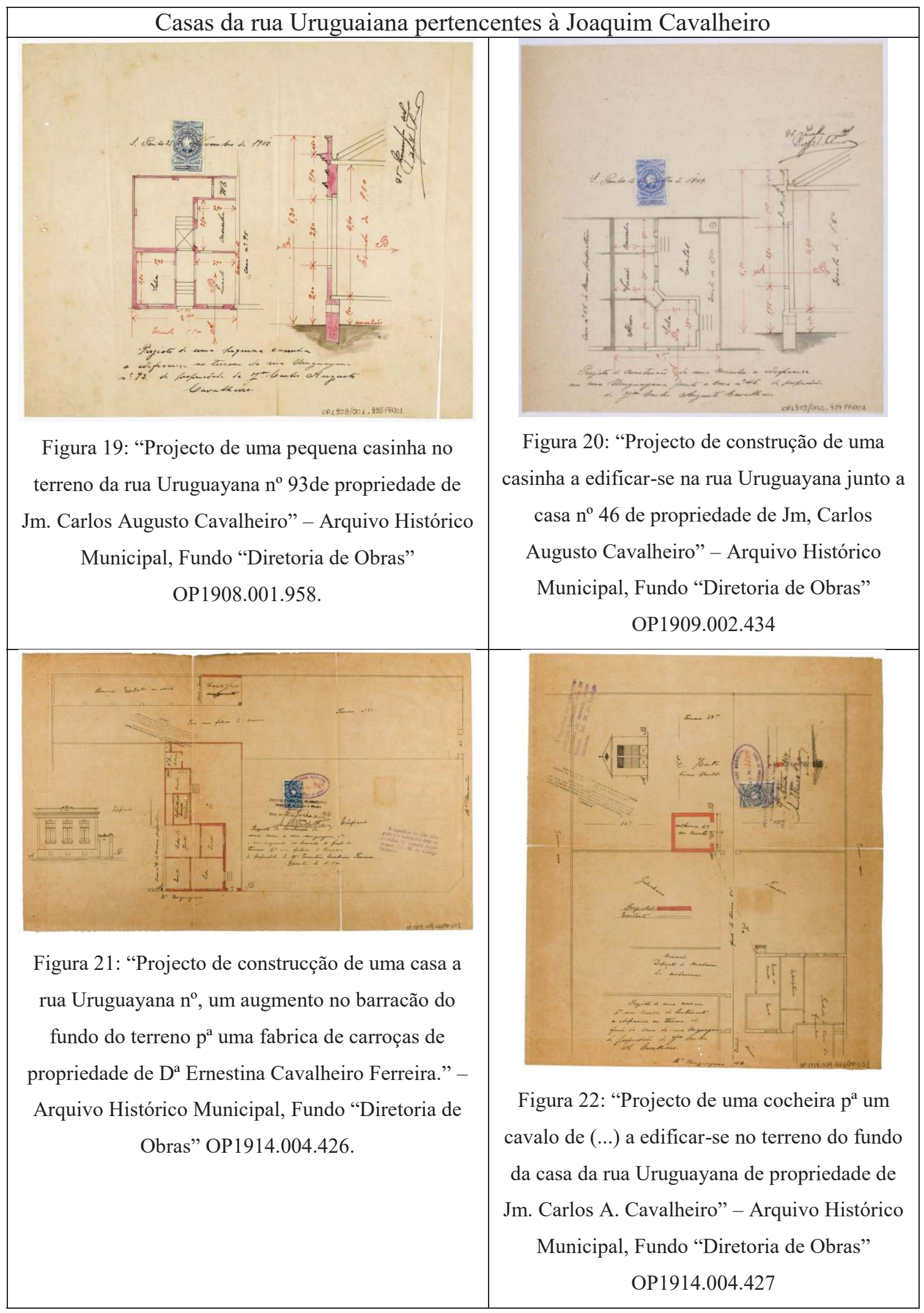




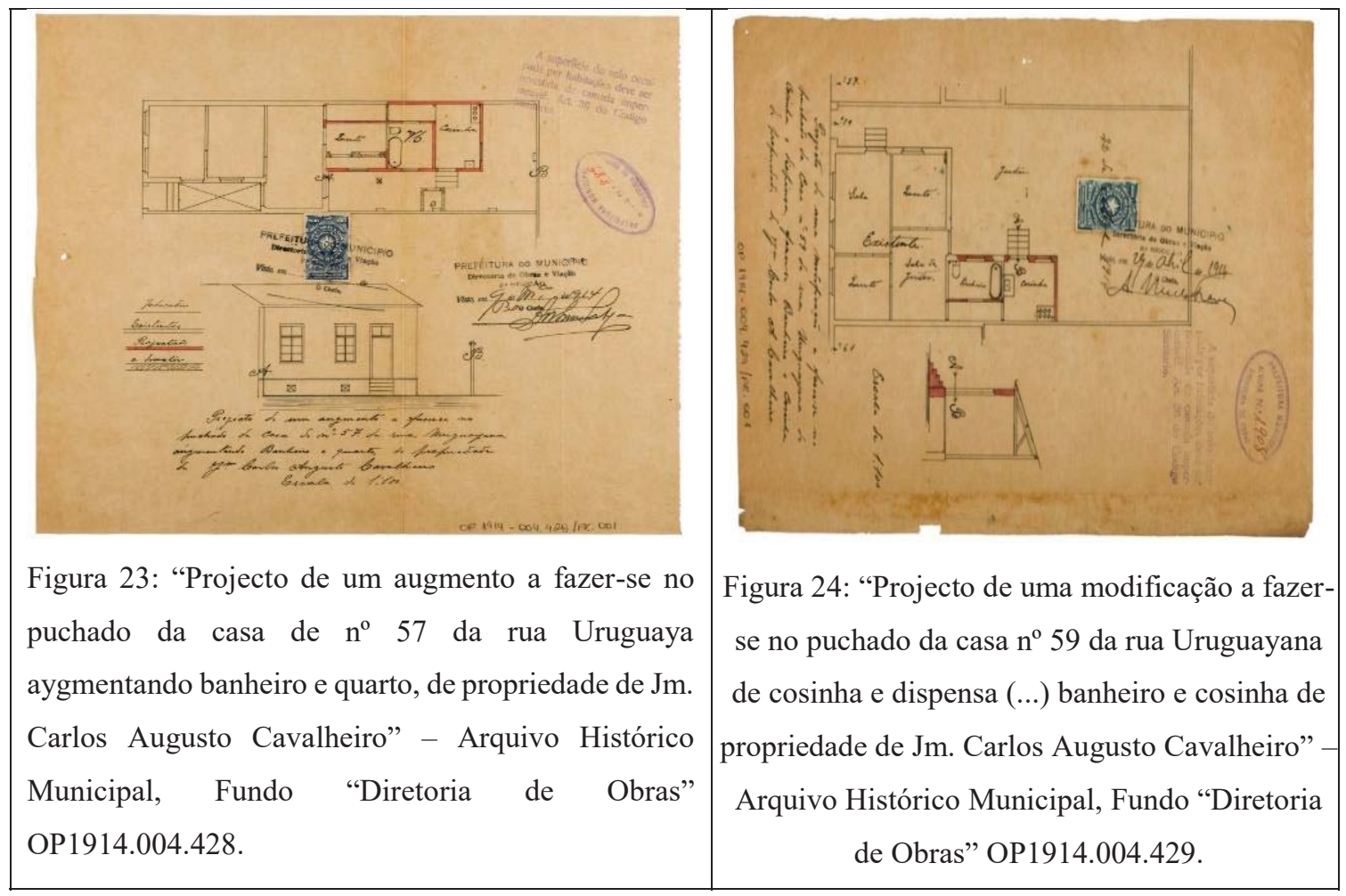

Outro personagem de destaque com propriedades na região norte da Várzea do Carmo, fora Augusto Carlos da Silva Telles, proprietário de uma vasta chácara na região do Pari $^{118}$. Já as figuras de Caetano Pinto Homem, que fora proprietário de terrenos espalhados pela cidade de São Paulo, e Carneiro Leão pode-se deduzir que era o brigadeiro Luiz Joaquim de Castro Carneiro Leão, "proprietário e capitalista" anunciado no Indicador de 1878, como proprietário de uma chácara na rua da Mooca, ou poderia também referir-se a Honório Hermeto Carneiro Leão, Ministro da Justiça a partir de 1831, conforme indica o Dicionário de Ruas da Prefeitura, mas pelas vinculações com o Brás, acreditamos tratar-se do primeiro.

Enquanto a grande maioria das ruas do Brás faz uma referência direta a antigos proprietários das chácaras que ali existiram, e que estes personagens possuem intrínseca relação com a Faculdade de Direito e com os meios político e econômico de São Paulo de finais do século XIX, em outras ruas as homenagens se circunscrevem a pessoas com menos propriedades, mas que não estavam inseridas no rol de chacareiros ou ligados diretamente

\footnotetext{
118 Silva Telles formou-se na Faculdade de Direito do Largo São Francisco em 1834, ocupando diversos cargos públicos, dentre eles o de procurador fiscal entre os anos de 1847 a 1851; Secretário do Governo Provincial em 1848; juiz da cidade de Bragança em 1853 e secretário da caixa filial, do Banco do Brasil em São Paulo, em 1856. Seu filho, Augusto Carlos da Silva Telles, além de professor catedrático na Escola Politécnica de São Paulo, fora engenheiro da cidade de Santos, diretor de obras no Rio de Janeiro e vereador de São Paulo entre os anos de 1905 a 1911, contando com amplo reduto eleitoral no Brás, como pode-se verificar a partir dos Anais da Câmara dos Vereadores de São Paulo
} 
ao mundo das decisões da cidade. Um dos exemplos é José Monteiro, proprietário de uma serraria no bairro do Belenzinho, a "Serraria do Marco", e outros imóveis distribuídos nas ruas Oriente e Maria Marcolina. Outra figura de destaque fora o Major Octaviano, um antigo chefe político do bairro do Belenzinho.

A rua Luiz Gama, um prolongamento da rua Carneiro Leão, homenageia o personagem com presença destacada no Brás em finais do século XIX. Segundo o Dicionário de Ruas, esta rua começou a ser aberta em princípios do ano de 1882, sendo que dois anos depois os vereadores receberam um abaixo-assinado dos moradores da região da Glória e da Mooca para que a via fosse denominada "Luiz Gama", em homenagem à Luiz Gonzaga Pinto da Gama, um dos maiores líderes abolicionistas brasileiros, ex-escravo, que trabalhou a favor da libertação dos escravos, auxiliando nas alforrias e promovendo processos em prol de pessoas livres e ilicitamente escravizadas, mesmo não possuindo o diploma de bacharel, o que não o impediu de obter conhecimento jurídico suficiente para que auxiliasse essas pessoas ${ }^{119}$.

Alguns personagens apesar de não serem proprietários de terras na região do Brás também foram homenageados com algumas das futuras vias ali abertas: personagens da literatura nacional, como Casimiro de Abreu, autor de Canção do Exílio; José de Alencar, autor de clássicos indianistas do Romantismo, como Iracema; e Álvares de Azevedo ${ }^{120}$, conhecido por declamar poesias na Faculdade de Direito de São Paulo, instituição da qual era aluno, e ter vasta produção literária do período Romântico; Prudente de Moraes e Campos Sales, serem ex-presidentes do Brasil; Visconde de Parnaíba, ex-presidente da Província de São Paulo, que em seu governo inaugurou-se o edifício da Hospedaria dos Imigrantes; Pedro Augusto Gomes Cardim, formado na Faculdade de Direito, jornalista e político, fora Intendente de São Paulo; Henrique Dias, personagem do século XVI que lutou contra a presença holandesa no Pernambuco. Sobre as figuras de Maria Joaquina, Fernandes Silva e Elisa Whitacker infelizmente não encontramos referências sobre quem teriam sido.

Por fim, dois logradouros merecem atenção por batizarem o caminho mais importante do Brás ao longo do tempo, divididas em dois logradouros distintos: as avenidas Rangel Pestana e Celso Garcia. Anteriormente conhecido (e seus limites não bem definidos)

\footnotetext{
${ }^{119}$ Com base em: AZEVEDO, Elciene. Orfeu de carapinha: a trajetória de Luís Gama na imperial cidade de São Paulo. Campinas: Editora da Unicamp, 1999. SCHWARZ, Roberto. "Autobiografia de Luiz Gama". Revista Novos Estudos. CEBRAP. N. 25, out/1989, pág. 136-141.

${ }^{120}$ Hoje este nome batiza uma via na região do bairro de Santo Amaro, e a que nos referimos chama-se Polignano à Mare, cidade italiana que conta com uma abadia dedicada a San Vito, padroeiro do bairro do Brás.
} 
como ladeira do Carmo, caminho do Brás, estrada da Penha, caminho para o Rio de Janeiro, avenida da Intendência, a via concentrou grande número de residentes e comerciantes, notadamente ao final do século XIX com o processo de desmanche das chácaras que existiam dos seus dois lados.

Francisco Rangel Pestana, fluminense da cidade de Iguaçu, nasceu em 26 de novembro de 1839, matriculando-se vinte anos mais tarde na Faculdade de Direito de São Paulo, e concluindo o curso em 1863. Como jornalista, fundou o Timbira em 1860, e escreveu em outros jornais de circulação, como o Futuro e Época. Em 1866, juntamente com Limpo de Abreu e Monteiro da Silva, fundou o jornal Opinião Liberal, e dois anos depois o Correio Nacional. No final de 1874, junto com Américo de Campos, trabalhou como redator chefe do jornal A Província de São Paulo. Com a Proclamação da República, assumiu a direção da Província de São Paulo juntamente com Prudente de Morais e Coronel Souza Mursa ${ }^{121}$. Em 1890, o Governo Provisório o nomeou membro da comissão encarregada de elaborar o projeto e a Constituição da República, sendo que neste mesmo ano foi eleito senador, voltando a residir em São Paulo em 1896. De 1899 em diante, foi eleito deputado federal do Rio de Janeiro, vice-presidente deste Estado e Senador, falecendo no ano de 1903.

Tanto o Dicionário de Ruas, como as Atas da Câmara não fazem referência direta à data de mudança do nome de parte da Ladeira do Carmo e rua do Brás para Avenida Rangel Pestana, porém, presumimos que ocorrera em princípios da década de 1890, visto que pedidos de particulares foram encaminhados para aprovação da Intendência Municipal a fim de construírem na via em questão.

Sobre a figura de Affonso Celso Garcia da Luz, podemos dizer que a homenagem se estende à uma avenida que não se circunscreve apenas ao Brás, mas a bairros adjacentes como o Belém e o Tatuapé, alcançando a região da Penha, dada a sua dimensão de mais de 6 quilômetros de comprimento. Nascido na cidade de Batatais em 1869, Celso Garcia formou-se em Direito pela Faculdade de São Paulo, e teve intensa atuação como jornalista em diversos veículos, como o jornal O Estado de São Paulo. Na cidade de São Paulo, foi eleito vereador no ano de 1905, sendo reeleito na gestão seguinte, bem como membro da Comissão de Higiene e Saúde Pública e membro da Comissão de Justiça e Polícia. Sua atuação na Câmara Municipal quase sempre ia de confronto com os demais vereadores e mesmo com o prefeito Antônio Prado, destacando-se por trazer à tona questões que

${ }^{121}$ Nome este que também batiza uma das ruas do Brás. 
versavam sobre a condição de vida dos habitantes de diversos bairros de São Paulo, em especial do Brás e do Belenzinho, como habitação, o asfalto de ruas, a velocidade dos automóveis, questionando o fato de grande parte do capital levantado pela Câmara ser destinado a outros bairros que não os mais populosos da época. Vítima de uma "congestão pulmonar" (pneumonia), faleceu na madrugada de 30 de maio de 1908, na cidade de São João da Boa Vista. Sua morte repercutiu num amplo debate no interior da Câmara Municipal, iniciado pelo vereador Joaquim Marra, que indicou que a Câmara fosse a responsável pelo traslado do corpo e realizasse todos arranjos para o funeral. ${ }^{122}$ Em sessão de 06 de junho de 1908, o mesmo vereador indica que a homenagem ao falecido vereador fosse dada à rua dos Imigrantes ${ }^{123}$, o que se confirma pelo parecer de Arthur Guimarães, o qual relata que a "existe nesta Camara uma representação dos moradores do Bom Retiro, especialmente da rua dos Immigrantes, pedindo, já há tempos, para ser dado áquella rua o nome de Celso Garcia”. Ambos vendo o posicionamento dos demais colegas Almeida Lima, Bernardo de Campos, Sampaio Vianna, Goulart Penteado, Azevedo Soares, José Oswald, Mário do Amaral, Álvaro da Rocha Azevedo, Silva Telles, Raymundo Duprat e Gomes Dias da Silva, conferem à Avenida Intendência o nome de Avenida Celso Garcia, como resposta outro encaminhamento feito pela população, e que contava com 891 assinaturas ${ }^{124}$, o que indica a relação do vereador com a população do Brás.

Na Praça Major Guilherme Rudge, defronte à avenida em questão, um monumento de bronze e granito feito pelo escultor italiano Lorenzo Petrucci, homenageia o então vereador Celso Garcia. Segundo o Inventário de Obras de Arte em Logradouros Públicos da Cidade de São Paulo, o mesmo esteve localizado inicialmente no Largo dos Guaianases provavelmente entre os anos de 1911 e 1912, até ser transferido para sua atual localização entre os anos de 1938 e $1945 .{ }^{125}$

\footnotetext{
${ }^{122}$ Anais da Câmara Municipal de São Paulo, Sessão de 06 de junho de 1908, Biblioteca da Câmara Municipal de São Paulo, pág. 137.

${ }^{123}$ Atual rua José Paulino, no Bom Retiro.

${ }^{124}$ Anais da Câmara Municipal de São Paulo, Sessão de 06 de junho de 1908, Biblioteca da Câmara Municipal de São Paulo Sessão de 06 de junho de 1908, pág. 138

125 O Inventário de Obras de Arte em Logradouros Públicos da Cidade de São Paulo fora elaborado pelo Departamento do Patrimônio Histórico da Prefeitura de São Paulo, e está disponível online pelo site: $<<$ http://www.prefeitura.sp.gov.br/cidade/upload/Inventario_de_Esculturas_1261586685.pdf $>>$, acesso em $02 / 01 / 2017$.
} 


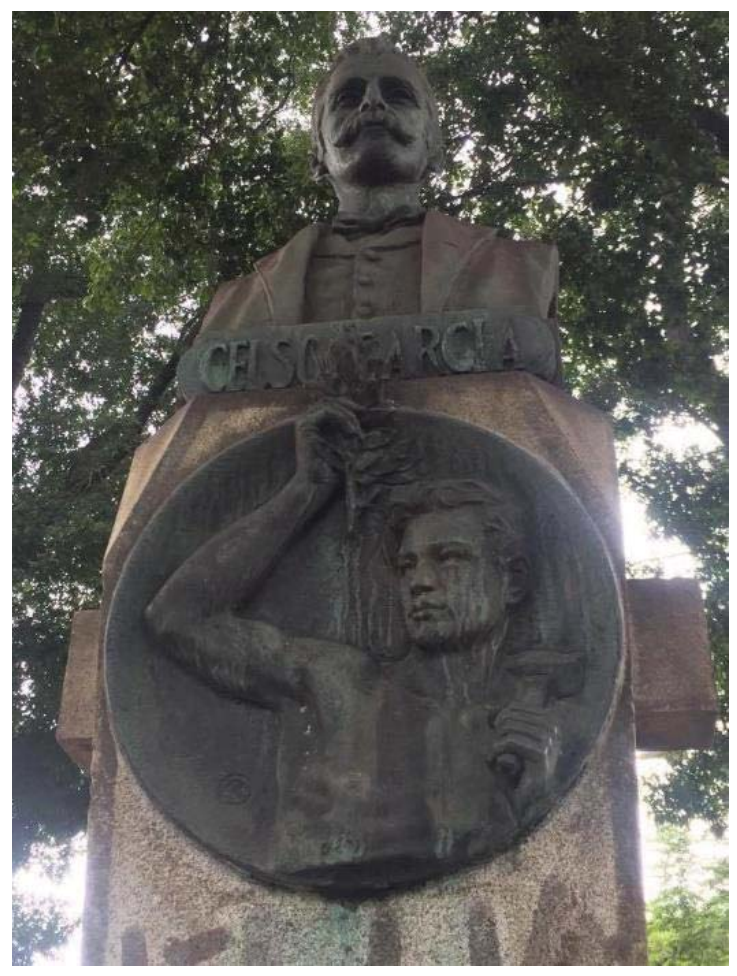

Figura 25: Monumento à Celso Garcia, Lorenzo Petrucci, s/d, foto do autor.
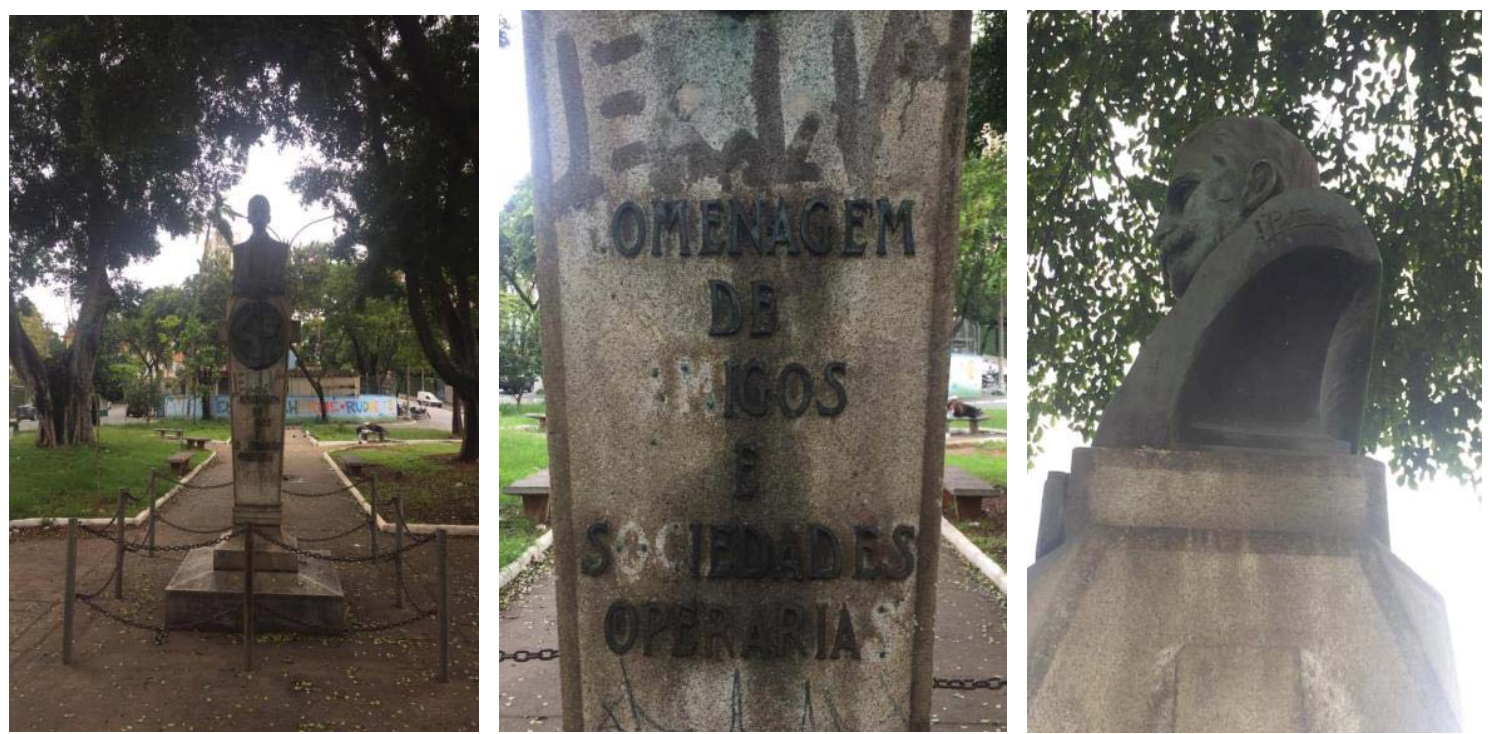

Figuras 26, 27 e 28: Herma de Celso Garcia; "Homenagem de amigos e sociedades operárias"; na lateral direita do busto a identificação de "L. Petrucci". Fotos do autor. 
1.3 A configuração de um bairro para além do centro entre finais do século XIX e o começo do século $X X$

Com o crescimento populacional e a demanda cada vez maior por serviços, a cidade de São Paulo passou por uma série de reorganizações distritais a fim de que houvesse uma melhor dinâmica da administração municipal e, ao mesmo tempo, orientasse o crescimento que a capital do Estado vinha passando através das construções capitaneadas por particulares, sejam elas casas, comércios ou fábricas, tendo como parâmetro observações das transformações de outras cidades do mundo capitalista. A cidade e o Estado de São Paulo vinham passando por uma reorganização territorial desde a segunda metade do século XIX, fato que pode ser observado à luz da "expansão para o oeste", para que assim facilitasse na expansão da lavoura cafeeira, e aos novos núcleos urbanos que se firmavam a partir das ferrovias. ${ }^{126}$

Com o regime republicano, uma nova forma de administração política se instaura nos municípios, racionalizando e compreendendo as dinâmicas individuais deles, objetivando a construção de uma máquina executiva eficaz e abrangente, dotando o poder público municipal de poderes para atuar nas dinâmicas que se realizavam nas cidades. Em São Paulo, a partir de janeiro de 1890, o município passou a ser governado por um Conselho de Intendências, para assim zelar e ter atenção às atribuições específicas da cidade ${ }^{127}$. Nove anos depois, a cidade passaria por uma nova reorganização política, com a organização do Poder Executivo, que seria exercido por um único vereador, sob a denominação de Prefeito Municipal, estando a administração dos Serviços Municipais divididos pelo Prefeito em quatro seções: Justiça, Polícia e Higiene, Obras e Finanças, assim regidos pela Lei $n^{\circ} 374$ de 29 de novembro de 1898.

Em 07 de janeiro de 1899, seria eleito o primeiro prefeito da cidade, Antônio da Silva Prado, cafeicultor e político com destacada atuação que remontava ao período imperial

\footnotetext{
${ }^{126}$ Sobre o assunto, ver: LOVE, Joseph. A locomotiva: São Paulo na federação brasileira - 1889/1937. Rio de Janeiro: Paz e Terra, 1982; FERREIRA, Op. Cit.;

${ }^{127}$ A Lei Imperial de $2^{\circ}$ de outubro de 1828 serviu de Regimento para a Câmara Municipal de São Paulo por mais de sessenta anos, organizando a administração municipal em três esferas subordinadas 'Câmara: Procuradoria, Comissões e Secretaria. Segundo o ornanograma elaborado por Liliane Schrank Lemann de Barros e Rosana Pires Azanha Moizo, "na prática, um pequeno conjunto de vereadores, juízes, procuradores e funcionários tinham atribuições que mais tarde seriam objeto de intendências, diretorias, divisões, departamentos e secretarias". Ver: BARROS, Liliane Schrank Lehmann de. MOIZO, Rosana Pires Azanha. "Formação administrativa da cidade de São Paulo, 1554-1954". In: Revista do Arquivo Municipal. São Paulo: Departamento do Patrimônio Histórico, v. 199, 1991.
} 
juntamente com sua família. Seu governo (entre os anos de 1899 e 1911), juntamente com os dois sucessores (Raimundo da Silva Duprat, entre os anos de 1911 e 1914; e Washington Luís Pereira de Souza, entre os anos de 1914 e 1918), além de moldarem o aparelhamento administrativo da cidade que se formava, com seu quadro técnico de funcionários, estiveram atrelados e atentos ao debate da cidade ideal que se pretendia representar na construção de novos edifícios e nas operações urbanísticas em curso na capital paulista.

Neste processo de reorganização municipal, em 1908 uma divisão administrativa é estabelecida para todo o Estado de São Paulo, e segundo o diretor da "Repartição de Estatística e Archivo do Estado de S. Paulo”, Adolpho Botelho de Abreu ela:

\footnotetext{
"satisfaz, plenamente, os seus principaes interessados que são as camaras municipaes do Estado, no interesse de quem, especialmente, foi elaborada e a quem é destinada, Ahi encontrarão consubstanciada toda a legislação sobre as divisas de todos os municípios do Estado, por districtos de paz, desde os tempos coloniaes até os nossos dias. Já não dependerão de consultar-nos, nem ao governo, para ficarem instruídas em relação as suas divisas administrativas. Aos estudiosos, a não ser por curiosidade puramente histórica, já não será preciso, irem beber nas fontes, quando os manaciaes ahi estão odos captados e reunidos.

Constitue, além disso, um orgam de consulta, promto e fácil aos poderes constituídos do Estado, na emergência em que se encontram, frequentemente, de derimir questões de divisas municipaes, hoje muito frequentes no regimem de autonomia em que vivem os municípios. Oxalá seja tão útil quanto desejei que o fosse, ao menos emquanto outros com mais competência, não empreenderem trabalho idêntico melhor concebido e de mais folego." ${ }^{128}$
}

A partir do relatório anteriormente apresentado, elaboramos o seguinte quadro descritivo dos distritos de paz da cidade de São Paulo em 1908:

${ }^{128}$ Divisão administrativa e divisas municipaes do Estado de S. Paulo. São Paulo: Typ. Mont’ Alverne, 1908, pág. 1 e 2. 


\begin{tabular}{|l|l|l|}
\hline \multicolumn{3}{|c|}{ Distritos de paz da cidade de São Paulo em 1908 } \\
\hline $\begin{array}{l}\text { NÚMERO DO } \\
\text { DISTRITO }\end{array}$ & \multicolumn{1}{|c|}{$\begin{array}{c}\text { DISTRITOS DE } \\
\text { PAZ }\end{array}$} & \multicolumn{1}{c|}{ LEIS E DATAS DA CRIAÇÃO } \\
\hline 1 & Belenzinho & Lei n. 623 de 26 de junho de 1899 \\
\hline 2 & Braz & Alvará de 8 de junho de 1818 \\
\hline 3 & Cambuci & $\begin{array}{l}\text { Lei n. 1.040 B. de 19 de dezembro de } \\
1906\end{array}$ \\
\hline 4 & Sé (Norte) & $\begin{array}{l}\text { Ato da Câmara Municipal de 14 de } \\
\text { março de 1833 e de 4 de agosto de 1863 } \\
\text { e Lei n. 975 de 20 de dezembro de 1905 }\end{array}$ \\
\hline 5 & Liberdade(Sul da Sé) & $\begin{array}{l}\text { Ato de 14 de março de 1833. Lei n. 975 } \\
\text { de 20 de dezembro de 1905 }\end{array}$ \\
\hline 6 & Consolação & Lei n. 33 de 23 de março de 1870 \\
\hline 7 & Butantã & Lei n. 1.082 de 13 de setembro de 1907 \\
\hline 8 & Santa Cecília & Lei n. 622 de 26 de junho de 1899 \\
\hline 9 & Santa Ifigênia & Alv. de 21 de abril de 1809 \\
\hline 10 & Vila Mariana & Lei n. 370 de 3 de setembro de 1895 \\
\hline 11 & Santana & Lei n. 99 de 4 de abril de 1889 \\
\hline 12 & Nossa Senhora do Ó & Alv. de 26 de março de 1796 \\
\hline 13 & Penha de França & Alv. de 26 de março de 1796 \\
\hline 14 & São Miguel & $\begin{array}{l}\text { Provisão Régia de 21 de junho de 1739, } \\
\text { extinta e depois restaurada pela lei n. 1 } \\
\text { de 1 de fevereiro de 1871 }\end{array}$ \\
\hline
\end{tabular}

Tabela 3: "Distritos de paz da cidade de São Paulo em 1908”, elaborada pelo autor com base no relatório de Divisão administrativa e divisas municipaes do Estado de S. Paulo.

As reformas iniciadas na gestão do Presidente da Província de São Paulo, João Teodoro Xavier, entre os anos de 1872 a 1875, marcaram o cenário paulistano, ecos dos primeiros lucros advindos da exportação do café, e foco na região central da cidade e algumas áreas envoltórias como a $\mathrm{Luz}^{129}$. Aos poucos, a capital paulista se transformou num canteiro de obras: prédios de taipa foram substituídos pelos de alvenaria, ruas foram alargadas, imponentes construções de edifícios públicos foram financiadas em nome do cosmopolitismo de São Paulo, inserido assim no rol de cidades capitalistas de então, à luz do que em anos anteriores correra em cidades europeias como Londres e Paris. Todas estas mudanças só poderiam encontrar respaldo numa legislação firme e rigorosa, que conferisse novos parâmetros para a cidade que se desejava. O Código de Posturas de 1875 inaugurou, assim, uma nova fase para os habitantes da cidade, regulando e trazendo ditames que a estruturassem. Mas seria apenas com o Código Sanitário de $1894^{130}$ que a cidade iria

129 Sobre a gestão de João Teodoro Xavier à frente da Província de São Paulo, ver: FRANCO, Herta. Modernização e melhoramentos urbanos em São Paulo: a gestão do presidente de província João Theodoro (1872-1875). São Paulo: FAUUSP (Tese de Doutorado em Arquitetura e Urbanismo), 2002.

${ }^{130}$ Disponível em: $<<$ https://www.al.sp.gov.br/norma/?id=137356 $>>$, acesso em 10/01/2017. 
intensificar seus trabalhos de adequação aos ditames impostos pela legislação. Segundo Paulo Garcez Marins, é neste período que “o privado passa a ser, portanto, controlado não apenas pelos desígnios do indivíduo, mas pela ordem imposta pelo Estado"131, neste caso representado pelos códigos e leis regidos em âmbito estadual e municipal.

Para qualquer construção ou execução de reforma, tornou-se obrigatório, a partir de 1893, apresentar à municipalidade um projeto e memorial descritivo das obras a serem executadas, com vistas a regular e controlar o crescimento que a cidade passava, passando assim pelo crivo de "fiscais engenheiros, e a partir de 1899, pelo diretor da Diretoria de Obras, o Engenheiro Victor da Silva Freire"132. Até então, a vida urbana da cidade de São Paulo estava concentrada entre o espaço convencionalmente chamado de Triângulo histórico, definido pelas ruas São Bento, Direita e Quinze de Novembro, e todo tipo de construção que se desejasse realizar na cidade, fazia-se necessário pedir autorização à Câmara Municipal, preceitos exigidos pelas Posturas Municipais desde $1830^{133}$. Nestas e em ruas das proximidades, os bondes circulavam, lojas de artigos de luxo, armazéns e bancos se estabeleciam, hotéis foram erguidos, restaurantes traziam em seus cardápios pratos de requinte da cozinha europeia, num processo que, em menos de vinte anos, transformou esse espaço em nome dos interesses de uma burguesia cafeicultora endinheirada.

São Paulo crescia em população e em construções! Não apenas a região central foi alvo da renovação urbanística da passagem do século XIX para o XX, mas também áreas próximas que estavam sob jurisdição da municipalidade. A Avenida Paulista, um empreendimento imobiliário de Joaquim Eugênio de Lima esteve neste rol de transformações, ao serem vendidos extensos lotes de terra para a elite paulista ali se estabelecer. Os Campos Elíseos, Higienópolis ${ }^{134}$, a Barra Funda ${ }^{135}$ e mesmo a Vila Mariana ${ }^{136}$ não fugiriam à regra da expansão da cidade.

Ao analisarmos o número de solicitações de pedidos de construções e reformas de obras particulares encaminhadas para a Prefeitura de São Paulo entre os anos de 1906 e

\footnotetext{
131 MARINS, Paulo César Garcez. "Habitação e vizinhança: limites da privacidade no surgimento das metrópoles brasileiras". In: História da vida privada no Brasil. V. 3. São Paulo: Companhia das Letras, 1999, pág. 136.

132 PARETO JUNIOR, Op. Cit., pág. 28.

${ }^{133}$ Idem.

${ }^{134}$ HOMEM, Maria Cecília Naclério. Palacete paulistano: o processo civilizador e a moradia da elite do café (1867-1914-18). Tese (doutorado em Arquitetura e Urbanismo). Faculdade de Arquitetura e Urbanismo da Universidade de São Paulo. São Paulo, 1992.

135 BORIN, Op. Cit.

${ }^{136}$ CARVALHO, Op. Cit.
} 
$1915^{137}$, pudemos perceber que as cifras são altas, totalizando um conjunto de mais de 35 mil documentos, mesmo que correspondentes a uma parcela da chamada cidade "oficial". A intensa urbanização observada desde o último quartel do século XIX, o aumento populacional, bem como o anseio de São Paulo se identificar com outros centros industriais foram fatores decisivos que reverberavam no cotidiano da cidade. Jorge Lody em recente pesquisa, demostrou que o número dos pedidos de particulares encaminhados para a prefeitura se intensificou neste período, mas que ao mesmo tempo "os números não correspondiam à cidade real" e "um grande número de obras clandestinas estava em andamento e posteriormente continuou a existir" ${ }^{138}$. Assim, ao trabalharmos com essa série documental, estamos cientes de estar trabalhando com uma parcela da cidade, daquela que a municipalidade esteve envolvida e aprovou as edificações.

\begin{tabular}{|c|c|c|}
\hline \multicolumn{3}{|c|}{ Evolução numérica da população residente em São Paulo entre os anos de 1872 a 1940 } \\
\hline ANO & $\begin{array}{c}\text { POULCÇ̃̃O RESIDENTE EM } \\
\text { SÃO PAULO }\end{array}$ & $\begin{array}{c}\text { TAXA DE } \\
\text { CRESCIMENTO }\end{array}$ \\
\hline 1872 & 31.385 & $106 \%$ \\
\hline 1890 & & $269 \%$ \\
\hline & 64.934 & $141 \%$ \\
\hline 1900 & 239.820 & $129 \%$ \\
\hline 1920 & 579.033 & \\
\hline & & \\
\hline 1940 & 1.326 .261 & \\
\hline
\end{tabular}

Tabela 4: "Histórico demográfico da cidade de São Paulo", elaborada pelo autor com base nas informações da Secretaria Municipal de Desenvolvimento Urbano.

${ }^{137}$ Período que o Sistema de Registro, Controle e Acesso ao Acervo (SIRCA) compreende em sua base de dados online (www.projetosirca.com.br)

${ }^{138}$ LODY, Op. cit, p. 55. 

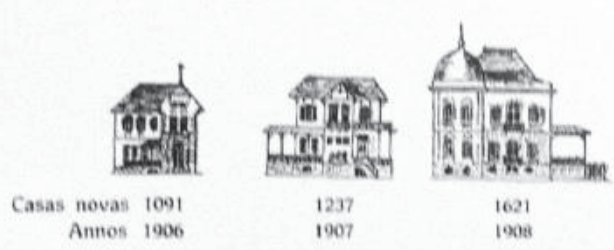

1237
1007

1621

1908
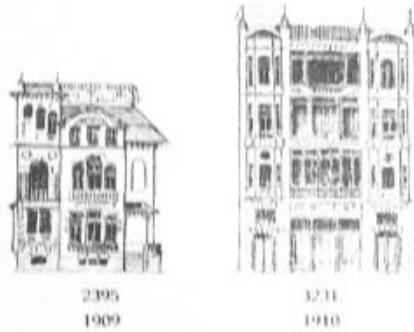

Augmento annual de construç̧ões no Rio de Janeiro
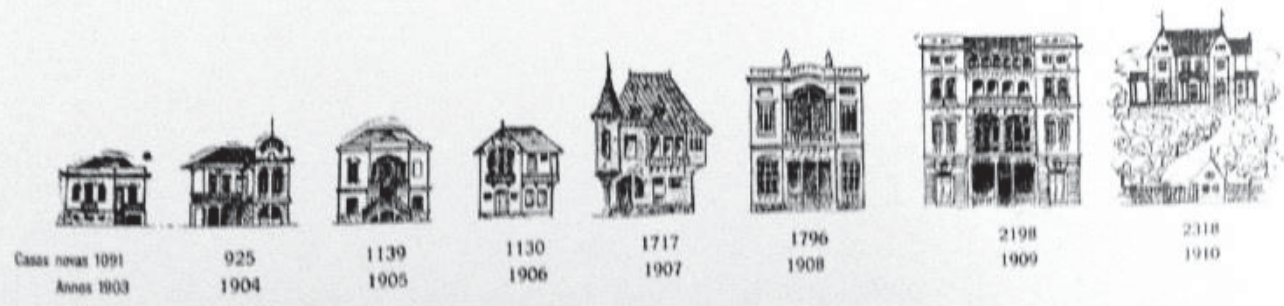

Revista de Engenharia, vol. 1, n. 1, p. 25, 10.71911.

Gráfico 1: Gráfico elaborado por Victor da Silva Freire, demonstrando numericamente o número de construções capitaneadas nas cidades de São Paulo e Rio de Janeiro entre os anos de 1903 a 1910. Apud LODY, 2015, pág. 88.

Para a região leste da cidade não foi um caso diferente. Entre os anos de 1872 e 1899, ou seja, antes desta explosão de construções que marcou a cidade posteriormente, pôde-se verificar que o número de pedidos de alinhamento e edificações, bem como o de autorização para fazer passeios (ou reformar calçadas) foi crescente, especialmente entre as ruas que já passavam os bondes puxados à burro, instalados a partir da gestão do Presidente da Província João Teodoro. Aos olhos do mercado imobiliário esta era uma região a ser explorada financeiramente, e, que aliada às transformações em curso na cidade com a presença cada vez maior de novos habitantes, de um mercado consumidor interno que se expandia velozmente, e a disponibilidade de capitais, a urbanização poderia atender os desejos e demandas de construção de novas habitações, armazéns, cocheiras e fábricas.

A partir da pesquisa nos livros encadernados da Série Obras Particulares do Arquivo Histórico Municipal, e percebemos que das ruas do Brás presentes no mapa da cidade de São Paulo, organizado por Gomes Cardim em 1897, muitas delas tiveram um alto número de solicitações de alinhamento e construção encaminhadas para aprovação da Intendência Municipal. Os limites do bairro podem ser vislumbrados a partir dos seguintes 
mapas produzidos por nós: Perímetros da cidade de São Paulo em 1916 sob os perímetros de 2007, o qual levou em consideração a dimensão da cidade de São Paulo em data próxima de nosso limite temporal com o atual tamanho da cidade; Mapa da cidade de São Paulo em 1916 com destaque para o Brás, traçado a partir divisão administrativa da cidade até o ano de 1914; e os Perímetros do Brás em 1916, com sua delimitação identificada a partir da divisão da cidade até o ano de 1914. Tais mapas foram produzidos com apoio da cartografia antiga, bem como do Mapa Digital da Cidade de São Paulo, especializando os limites do que era o bairro do Brás dentro da cidade até o ano de 1916, e do que era a área da cidade em comparação à área da cidade na contemporaneidade, auxiliando na compreensão dimensional da cidade e do bairro do Brás. 


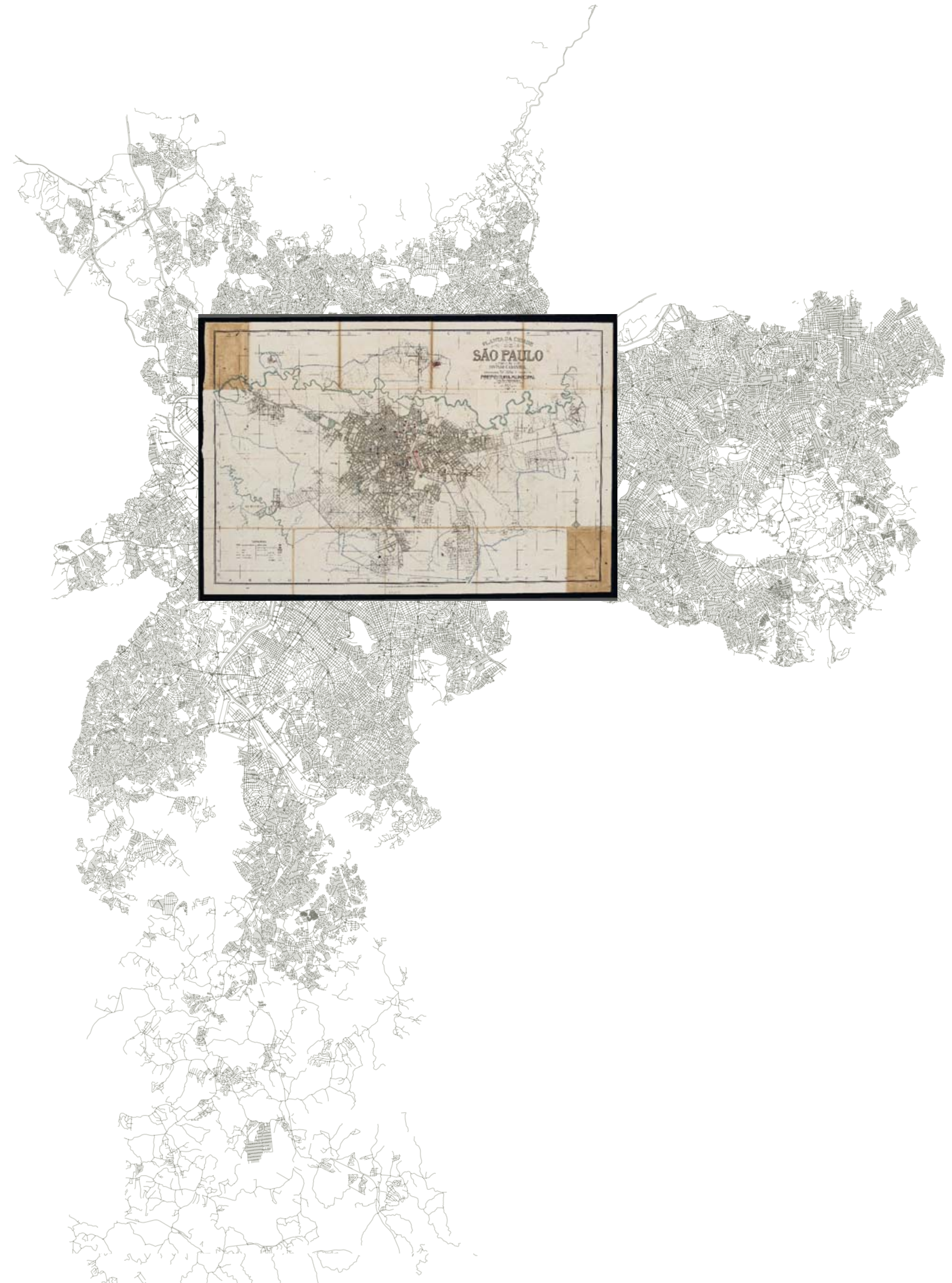

Perímetros da cidade de São Paulo em 1916 sob os perímetros de 2007

Planta da Cidade de São Paulo (1916)

Cidade de São Paulo - MDC (2007) São Paulo levantada pela Divisão Cadastral" (1916). 


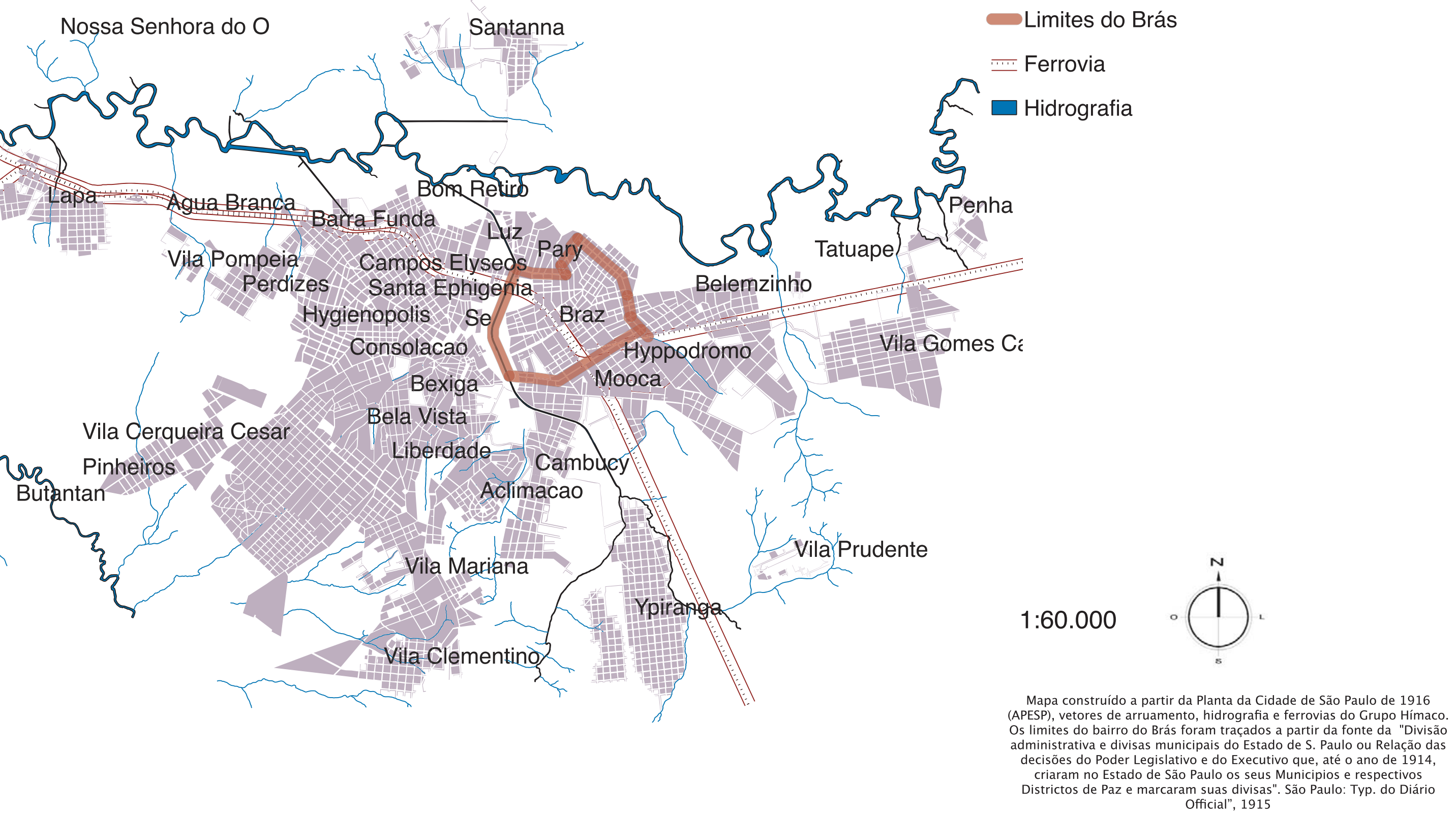




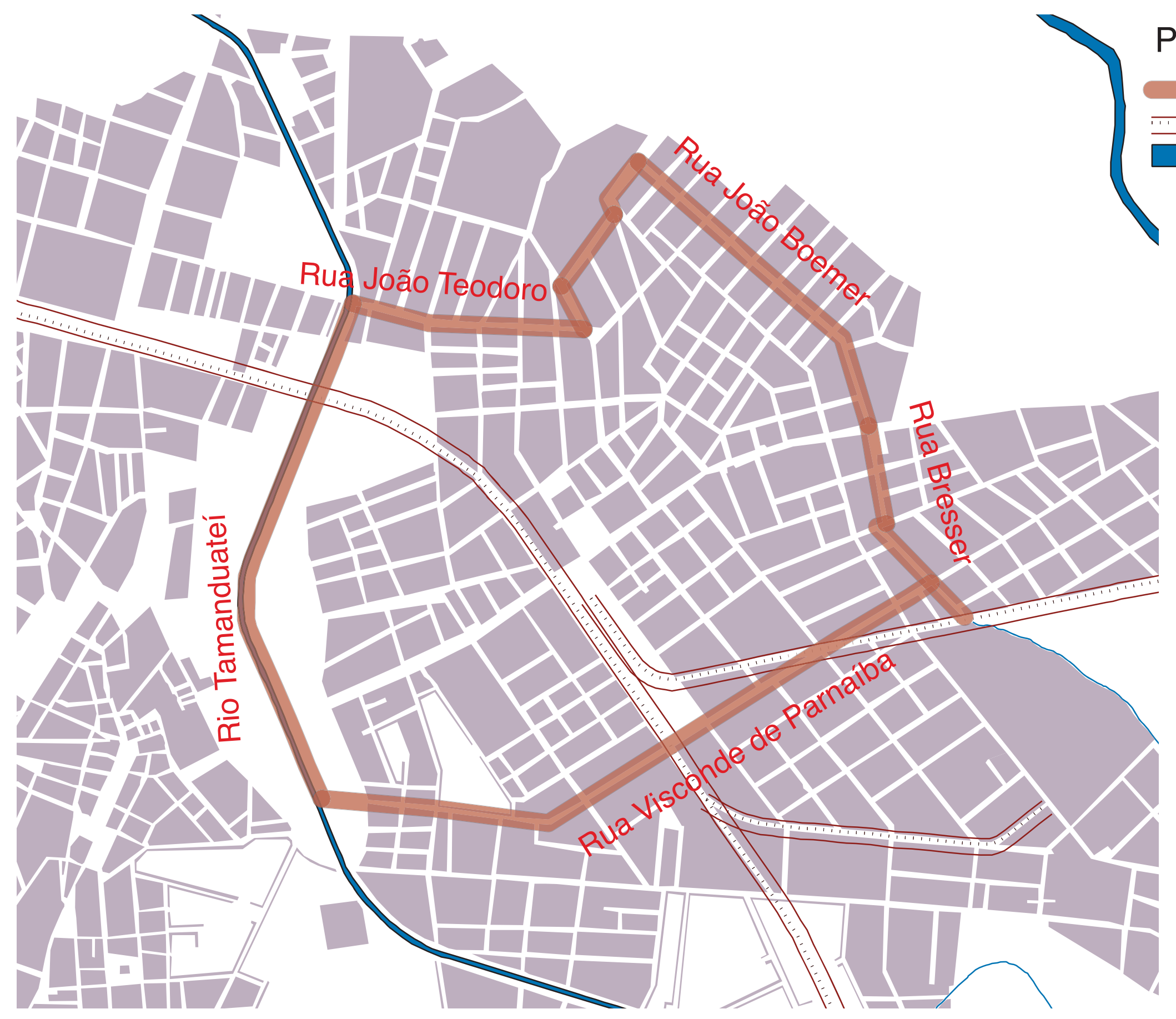

Perímetros do Brás em 1916

Limites-Bras

$\ldots$ Ferrovias

Hidrografia

LIMITE LESTE: Rua Major

Otaviano, Rua José Monteiro, Rua João Boemer

LIMITE NORTE: Rua Carlos de Campos, Rua Paraíba,

Rua João Teodoro

LIMITE OESTE: Rio

Tamanduateí

LIMITE SUL: Rua Visconde

de Parnaíba

$1: 20.000$

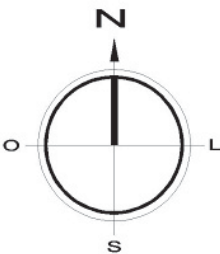

Mapa construído a partir da Planta da Cidade de São Paulo Planta (APEstral Commercial da Cidaco de São Paúlo de 1911 (Museu Paulista) vetores do arruamento, hidrografia ferrovias do Grupo Hímaco. Limites retirados da "Divisão administrativa e divisas municipais do Estado de $S$. Paulo ou Relação das decisões do Poder Legislativo e do Executivo que, até o ano de 1914, criaram no Estado de São Paulo os seus Municipios e respectivos Districtos de Paz e marcaram suas divisas". São Paulo: Typ. do Diário Official", 1915 
Pedidos de alinhamento e construção em ruas do Brás (1872-1899)

120

100

80

60

40

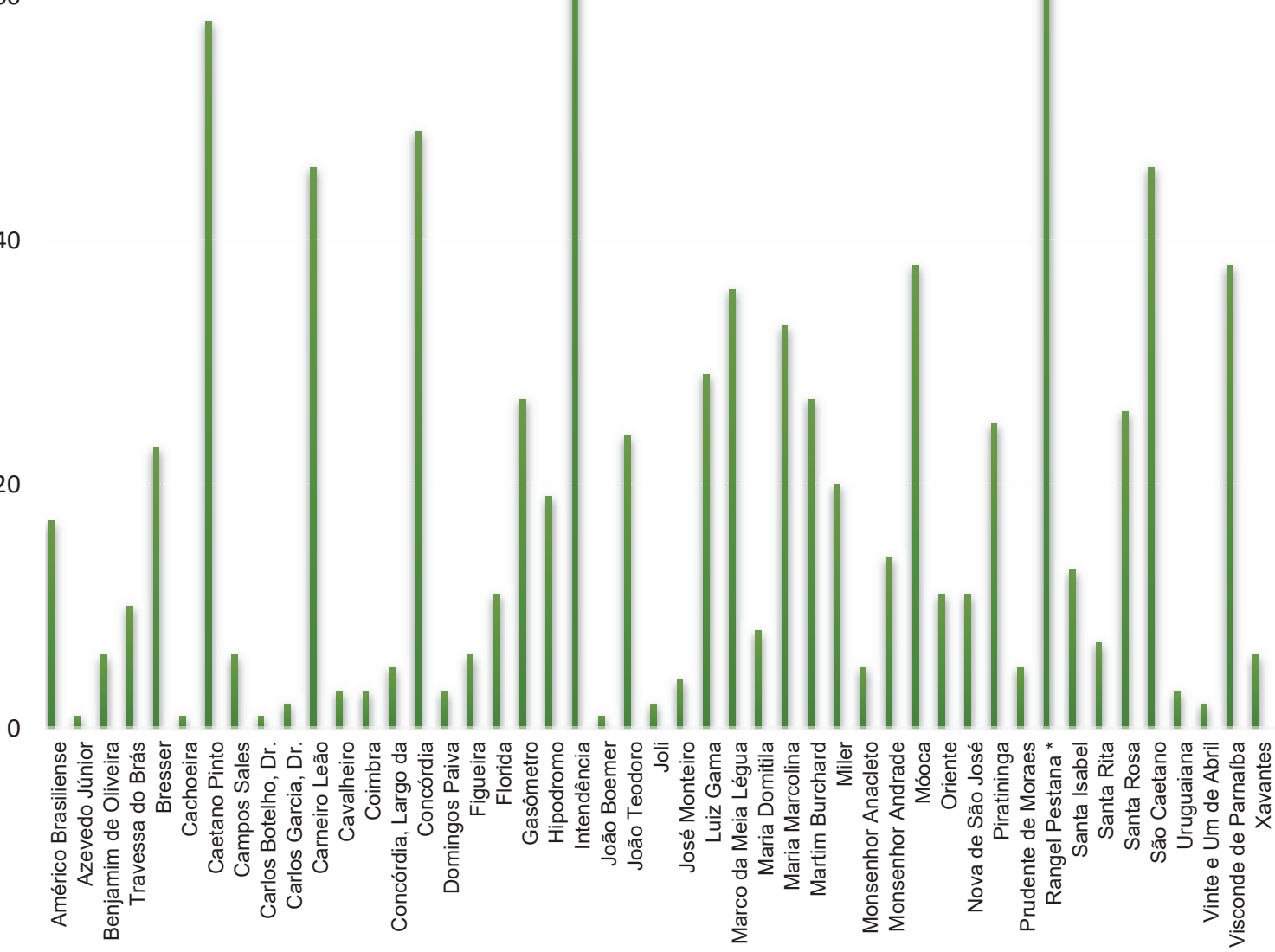

Gráfico 2: "Pedidos de alinhamento e construção em ruas do Brás ocorridas entre 1872 e

1899”, elaborado pelo autor, com base na Série Obras Particulares (volumes encadernados) do Arquivo Histórico Municipal, Fundo "Diretoria de Obras". 
Percebe-se a partir dos números levantados acima, que a média de solicitações de particulares para alinhar ou construir em cada uma das ruas levantadas foi entre 10 e 20 pedidos, sendo considerável a parcela das vias que ultrapassaram este valor. Nos chama a atenção a discrepância que as Avenidas da Intendência e Rangel Pestana ${ }^{139}$ apresentam diante das demais (111 e 82 pedidos, respectivamente) provavelmente em decorrência dessas vias serem, dede o período colonial, um importante eixo de ligação da cidade de São Paulo com o Rio de Janeiro, de cidades próximas como Nossa Senhora da Conceição dos Guarulhos, e regiões vizinhas ligadas administrativamente ou politicamente a São Paulo, como os bairros de São Miguel e Penha, sendo este último inclusive servido pelo sistema de bondes puxados à burro, e desde 1901 pelos bondes elétricos. Os pedidos para alinhamento e construção decorrem, portanto, do intenso fluxo de viajantes, negociantes, tropeiros que passavam por essas ruas, fenômeno que perdurou mesmo com a chegada da linha férrea em 1867.

Em outras ruas do Brás também pode ser observado uma mediana quantidade de pedidos de alinhamento e construção, como nas ruas Bresser, Caetano Pinto, Carneiro Leão, Concórdia, do Gasômetro, João Teodoro, Luiz Gama, no Marco da Meia Légua, Maria Marcolina, Martim Burchard, Miler, da Móoca, Piratininga, Rangel Pestana, Santa Rosa, São Caetano e Visconde de Parnaíba, todas com ao menos 20 pedidos encaminhados à Intendência Municipal. Essas ruas, que quando observadas em conjunto, mostram-se paralelas, outras perpendiculares, quase sempre separadas pelo eixo formado pelas avenidas Rangel Pestana e da Intendência.

${ }^{139}$ A avenida Rangel Pestana fora contabilizada juntamente com os pedidos da rua do Brás, o primeiro trecho após a colina do Carmo, e que posteriormente fora integrada em uma só via. 


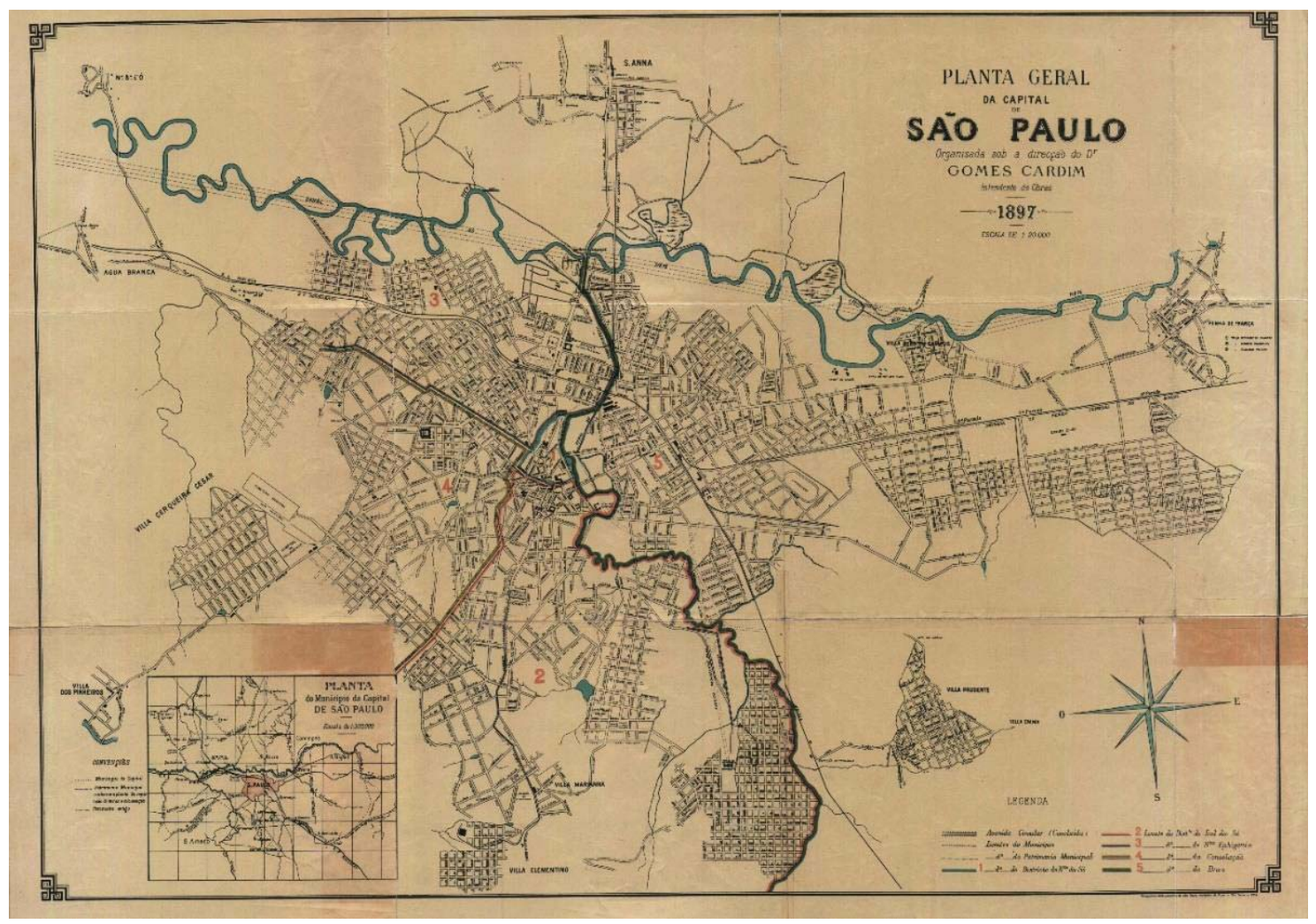

Mapa 16: Planta Geral da Capital de São Paulo, 1897. Acervo Cartográfico do Arquivo Histórico Municipal.

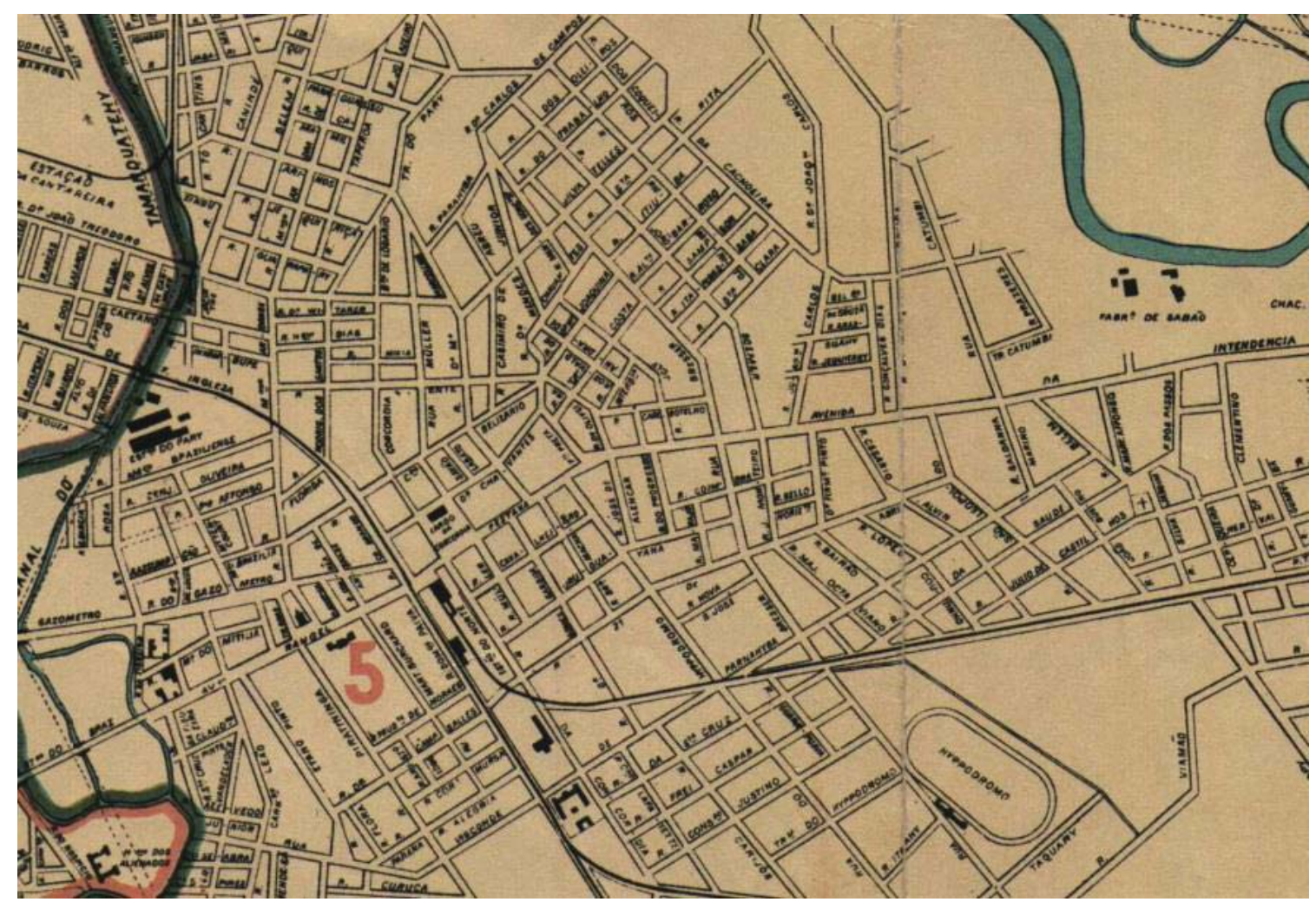

Mapa 17: Pormenor da Planta Geral da Capital de São Paulo, 1897. Acervo Cartográfico do Arquivo Histórico Municipal. 
Procuramos, então, separar o conjunto de ruas com maior número de solicitações encaminhadas para a Intendência Municipal em dois grupos separados geograficamente pelo eixo das Avenidas Rangel Pestana e da Intendência: um com as ruas "acima" do eixo, e outro grupo com as ruas "abaixo" do eixo. Dessa forma, as componentes do primeiro grupo eram as ruas: do Gasômetro, João Teodoro, o Marco da Meia Légua, Maria Marcolina, Miler, Santa Rosa e São Caetano. Por sua vez, as ruas do segundo grupo eram: Bresser $^{140}$, Caetano Pinto, Carneiro Leão, Concórdia, Luiz Gama, Martim Burchard, da Móoca, Piratininga e Visconde de Parnaíba. Este conjunto de ruas, que ultrapassava o número de 20 solicitações cada uma, torna-se, assim, uma amostra do processo de ocupação e relação do poder público com os particulares de então. Ao esmiuçarmos cada um desses pedidos, conseguimos ter uma aproximação de como (nestes quase trinta anos) a região se transformou, tecendo algumas considerações sobre o principal questionamento que orienta a pesquisa: Houve um processo uniforme sobre a urbanização do Brás?

Chama a atenção, especialmente, o número de novas construções feitas na Avenida da Intendência num primeiro momento. São 88 pedidos encaminhados, solicitando a construção de casas e armazéns que somados, aos pedidos da Avenida Rangel Pestana, totalizam 105. Tais construções eram constantemente observadas pelos fiscais municipais, para que seguissem as normas impostas pela legislação, e não houvesse desacordo com a imagem de cidade que se planejava construir.

\footnotetext{
${ }^{140}$ Apesar de a rua Bresser atravessar a avenida da Intendência, seu maior prolongamento encontra-se na parte "baixa" que aqui procuramos convencionar.
} 


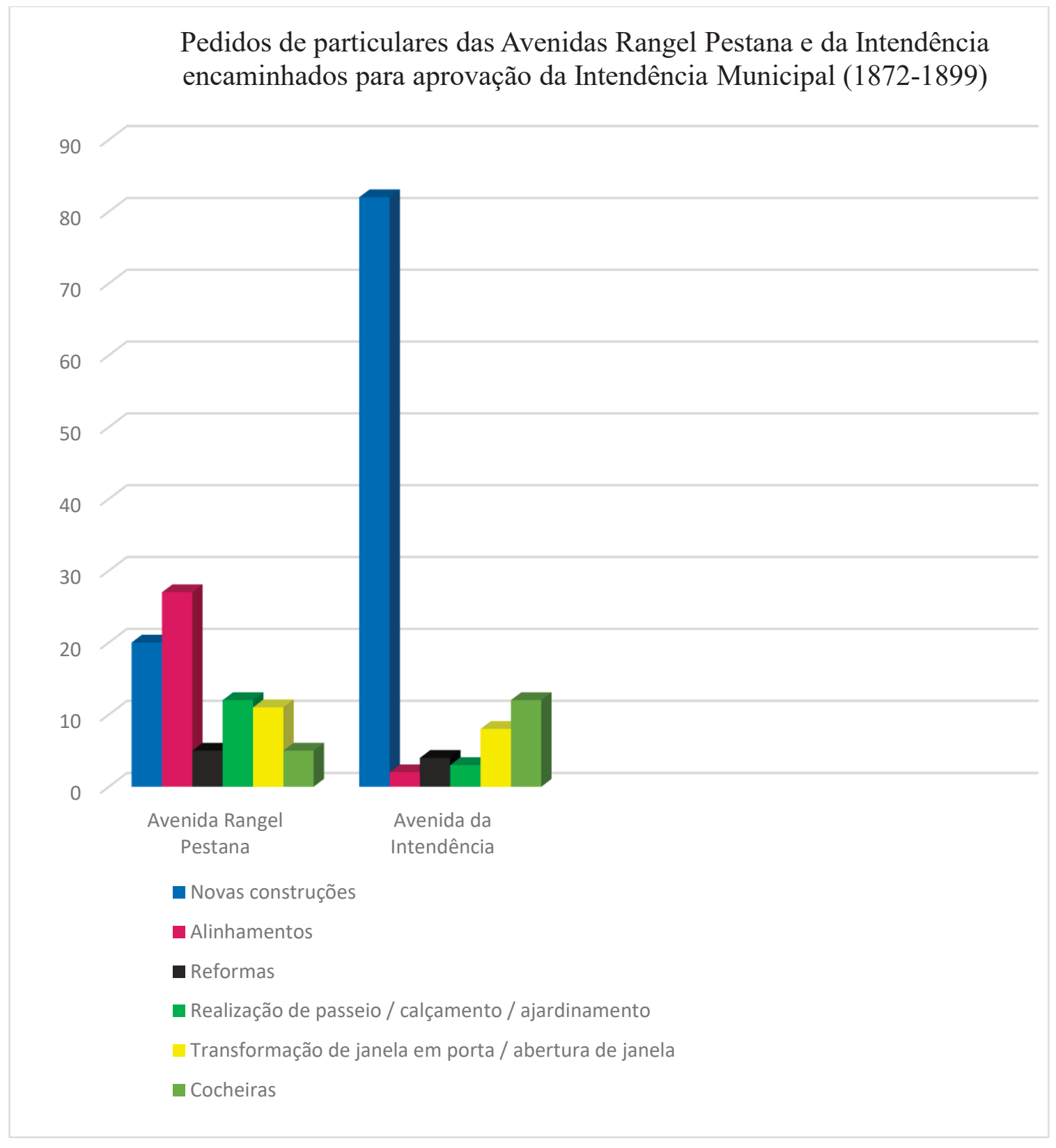

Gráfico 3: Elaborado pelo autor com base na Série Obras Particulares do Arquivo Histórico Municipal.

Exemplo da ação fiscalizadora da municipalidade é o embate entre o proprietário de um imóvel, o empreiteiro contratado e o funcionário da Intendência. Joaquim Carneiro, proprietário do imóvel número 145 da Avenida Intendência, representado por seu empreiteiro José Joaquim Lopes Braga em 14 de fevereiro de 1895, e segundo a planta apresentada pretendia construir "seis cômodos a dividir para casa de operários". Caio Lemos, certamente um fiscal da municipalidade, enviou-lhe a seguinte resposta: "referente às modificações indicadas, tenho a informação que se trata de uma casa velha baixa e situada 
em lugar húmido por natureza; sou pois, de parecer, que seja negada a licença, certa de que tais obras nem prejudicam as condições hyginenicas de casa" ${ }^{\text {"141. }}$.

Joaquim Carneiro não se deu por satisfeito e, em 06 de março do mesmo ano, representado novamente por seu empreiteiro, alegou que o pedido da separação dos cômodos na realidade tratava de "transformal-as de modo a servir para receber cagas e tropeiros que venham do interior", apresentando "as (...) plantas afim de obter approvação para as referidas obras, notando-se de antemão que as diversas casas que servirão para cargas e para o pernoite de tropeiros por uma só noite". O avaliador municipal, Caio Lemos, desta vez demonstrou-se satisfeito, sendo favorável às reformas propostas, que a seus olhos “trata-se de uma reforma para uma hospedaria de tropeiros ${ }^{142}$. Mas afinal, quem garantiria que tais quartos não seriam destinados a trabalhadores fixos da cidade e não à tropeiros, configurando-se em cortiços? Interessante notarmos que Joaquim Carneiro nos relata um episódio que entra em conflito com a imagem oficial da cidade que se deseja construir e evidenciar à luz dos melhoramentos urbanos, ao citar que nela ainda passam tropeiros, os mesmos homens que realizavam o abastecimento interno de diferentes porções do território brasileiro com seus animais de carga desde o período colonial, atividade que persistiu ao longo do tempo, e pôde ser observada sua continuidade até 1895, ano do relato por nós encontrado. Mesmo com o aumento da rede ferroviária o transporte com animais parecia continuar ativo, e a cidade de São Paulo recebia estes personagens, os quais podiam instalarse muitas vezes nos bairros que permitiam a entrada ou saída da capital, como o Brás, por estar localizado numa região privilegiada e contar com uma ampla rede de vias que possibilitava o contato com outras partes da cidade e do interior.

Os casos de atenção do poder público em torno da cidade almejada reforçam-se sobremaneira nas vias mais importantes por se conectarem a outros centros, seja por serem habitadas por determinados setores sociais, seja por contarem com uma rede de aparatos urbanos. A Avenida Intendência, um prolongamento da Avenida Rangel Pestana, destacavase nesse quesito, justamente por ser uma importante via de acesso ao Rio de Janeiro, estar próxima ao Gasômetro, à Estação do Norte e à Estação do Brás, bem como contar com serviços de bonde movidos à tração animal. Os números demonstrados no gráfico 3 reafirma a tese do elevado número de construções capitaneadas na avenida e do interesse de particulares em transformá-la segundo os padrões construtivos da época.

\footnotetext{
${ }^{141}$ Acervo do Arquivo Histórico Municipal, Fundo "Diretoria de Obras", Série “Obras Particulares”, vol. 85, fls. $79-80$.

${ }^{142}$ Idem.
} 
Em 14 de dezembro de 1899, o inspetor de obras Eugênio Castro escreve para o Diretor da Seção de Obras, Amaral Gama, sobre um mandato de conferência de uma construção de uma cocheira de Adolfo Rodrigues, que estaria localizada na rua José de Alencar, respondendo que nesta rua não havia nenhum lugar para inspecionar. No mesmo dia o diretor remete um desabafo ao conselho da Intendência Municipal com as seguintes palavras:

\footnotetext{
“À Intendencia Municipal

À vista do alvará contando de indivíduos que se encarregam de encaminhar requerimentos de partes, que forem a Eng[enheir]os e empregados desta repartição a um trabalho inútil fornecendo-lhes esclarecimentos deficientes ou falas, como na presente casa; abuso esse que se torna nesessario corrigir, para que seja dada a este requerimento o seguinte despacho:

Archive-se, à vista dos esclarecimentos falsos fornecidos pelo requerente." ${ }^{\prime 43}$
}

Ao lermos com atenção os adjetivos presentes na fala de Amaral Gama, nota-se sua frustração diante dos trabalhos efetuados, no qual não valorizam os esforços do poder público, e acolhem com boa fé as exigências de envio de informações imprescindíveis para o cumprimento dos trabalhos de fiscalização das obras que estão sendo capitaneados na cidade. Três dias depois, outra resposta é acrescentada ao relatório, desta vez do engenheiro Álvaro Campos: “Acho que se deve exigir o comparecimento do requerente á repartição, para prestar esclarecimentos, desde que não é encontrado, como parece, na Avenida Intendencia $\mathrm{n}^{\circ} 8$. O guarda do distrito pode verificar o seu (...), para a procedência que se torna precisa."

Um dia antes da véspera de Natal daquele ano, F. Salles, outro funcionário do quadro da Diretoria de Obras, escreve ao diretor da Seção de Obras, alegando que

\footnotetext{
“nesta data foi passada guia para esta construção que é rua José de Alencar e não Av. da Intendência N. 08, como está neste requerimento. É facto muito comum com o autor deste requerimento e ja tem provocado reclamação verbaes dos três Engenheiros que perdem muito tempo com as indicações falsas.”144
}

O excerto do documento revela uma rede de pessoas trabalhando em conjunto para averiguar questões de ordem social e edilícias em nome do cumprimento da legislação, com vistas a colocar em prática todo o aparato de ideais embelezadores da cidade. Amaral Gama,

\footnotetext{
${ }^{143}$ Acervo do Arquivo Histórico Municipal, Fundo "Diretoria de Obras", Série "Obras Particulares", vol. 238, fls.5-6.

${ }^{144}$ Idem.
} 
ainda em 23 de dezembro, escreve ao Chefe da Seção de Polícia e Higiene, chamando "a sua attenção para este requerimento acima do qual já tive ocasião de lhe falar", ou seja, ao fato de existir um homem que remetia documentos para análise dos funcionários da Intendência Municipal com informações divergentes, processo corrente e conhecido por muitos.

O engenheiro Álvaro Campos volta a se pronunciar, colocando um fim à discussão que envolveu o proprietário do imóvel, Adolfo Rodrigues, dizendo que se

\begin{abstract}
"Deve voltar á secção de obras este requerimento, muito já ter sido espedido guia para o pagamento de emolumentos e expedição de alvará de licença, segundo informa aquela secção. Si o requerente continuar a prestar propositalmente informações inexatas, como o tem feito simplesmente, entendo que não devem ser processados os seus requerimentos sem que ele compareça à repartição, para sempre acompanhar o engenheiro." ${ }^{\prime 45}$
\end{abstract}

Apesar de a discussão maior se entreter em torno do proprietário que remete documentações com um endereço diferente do proposto, podemos verificar que essa discussão é muito mais profunda e se estende para o eixo da Avenida Intendência, a qual mereceu intensa fiscalização dos órgãos competentes, envolvendo fiscais, delegados, engenheiros e arquitetos em finais do século XIX. Adolfo Rodrigues, que inscreve seu imóvel como pertencente à rua José de Alencar, talvez não se desse conta que, para a municipalidade, a avenida era mais que um simples logradouro, mas um dos acessos à cidade, merecedor, portanto, de atenção redobrada. Estamos tratando de um período no qual a própria população é pega de surpresa em como agir diante das questões legais. Aos poucos podemos perceber que a população foi se adequando, e procurando se enquadrar diante dos ditames legais que o governo impõe para serem seguidos em nome da cidade "oficial".

Tanto a avenida Rangel Pestana como a da Intendência, estavam inseridas no rol das preocupações da municipalidade que, como se vê, não centravam-se apenas nas transformações ocorridas no Triângulo. A cidade como um todo era fiscalizada e objeto de atenção, sobremaneira as áreas que dariam acesso à cidade exposição ${ }^{146}$, principalmente por parte dos agentes que atuavam como olheiros, sabendo quem estava e quem não estava se adequando às questões prescritas pela burocracia da época. Vide quando o secretário geral Henrique Castro remeteu uma informação ao Diretor da Seção de Obras em 28 de outubro de 1899, dizendo que no número 61 da Avenida Intendência, de propriedade de Alfredo

\footnotetext{
145 Idem.

${ }^{146}$ Refiro-me à região do Triângulo da cidade de São Paulo, expressão utilizada por Heloísa Barbuy para se referir à esta porção da cidade. BARBUY, Op. Cit.
} 
Gomes Branco, o "telheiro já foi feito, faltando apenas ladrilhar e revestir as paredes" e dois dias depois a resposta de que "o Engenheiro Ernesto Dias de Castro foi a Avenida da Intendência, N 61 á requerimento de Alfredo Gomes Branco e encontrou a construção concluída, faltando apenas ladrilhar e revestir as paredes, sem a licença necessária"147. Se o Código de Obras de 1894 prescrevia que toda construção que se fizesse na cidade deveria apresentar um memorial descritivo das obras acompanhado de uma planta, nota-se que a própria burocracia municipal deixava passar algumas questões por mais que tivesse conhecimento de sua inadequação aos ditames legais, não embargando ou impedindo a obra, desde que o engenheiro pudesse acompanhar o andamento da mesma e desse o aval para sua continuidade. Um caso não pode passar despercebido: o fato de Ernesto Dias de Castro participar do processo de discussão urbanística da cidade de São Paulo, na figura de engenheiro, além de ser genro de Francisco de Paula Ramos de Azevedo, foi conhecido como o "maior importador de materiais de construção da cidade"148, e proprietário da atual Casa das Rosas, na Avenida Paulista.

Caso parecido com este foi o de Sebastião Facho que em 14 de março de 1899, pedia que houvesse continuidade das obras de sua casa, na Avenida Intendência número 329, "que já se acha em construção sem planta approvada." A fiscalização responde que "póde ser concedida a licença porque a construção esta sendo feita de accordo com o projecto e este está em conformidade com o padrão municipal.”149

Este processo de fiscalização também estava atento às reformas dos imóveis e mesmo pedidos de construção de cocheiras. O construtor Joaquim Cavalheiro, representando o proprietário Nicolas Angelo, solicitou em 12 de abril de 1899 a "abertura de uma porta em uma janela da frente e edificar uma cocheira e um barracão no terreno da casa número 8 da Avenida da Intendência, onde pretende abrir a sua refinação”. No dia 29 do mesmo mês também solicitou a licença para "edificar uma cocheira nos fundos do terreno, ficando $38 \mathrm{~m}$. retirado do alinhamento da rua, conforme mostra nas plantas juntas e na lei 234" ${ }^{150}$, desta vez em nome de Francisco Rossi, proprietário do imóvel número 19 da mesma avenida.

\footnotetext{
${ }^{147}$ Acervo do Arquivo Histórico Municipal, Fundo “Diretoria de Obras”, Série “Obras Particulares”, vol. 238, fl.11.

${ }^{148}$ FISCHER, Sylvia. Os arquitetos da Poli: ensino e profissão em São Paulo. São Paulo: Edusp, 2005, pág. 228.

${ }^{149}$ Acervo do Arquivo Histórico Municipal, Fundo “Diretoria de Obras”, Série “Obras Particulares”, vol. 238, fls. $108-110$

${ }^{150}$ Acervo do Arquivo Histórico Municipal, Fundo "Diretoria de Obras”, Série “Obras Particulares”, vol. 238, fl.14.
} 
A sistematização das obras realizadas na Avenida Intendência e na Avenida Rangel Pestana nos indicou que uma mesma área do Brás tivesse diferentes formas de urbanização, principalmente no que toca às construções efetuadas em ruas paralelas ao eixo citado. A partir da separação das ruas entre aquelas que se situavam "acima " e "abaixo" das avenidas Rangel Pestana e da Intendência, analisamos cada um dos pedidos de particulares encaminhos para avaliação dos técnicos, engenheiros e arquitetos que compunham a burocracia na última década do século XIX. Com os dados em mãos, realizamos dois gráficos que permitem conhecer a natureza dos pedidos de novas construções, alinhamentos, demolições e reformas, realização de passeios, abertura ou transformação de janelas em portas, e mesmo a construção de cocheiras e imaginar as suas áreas de incidência, quantitativa e qualitativamente.

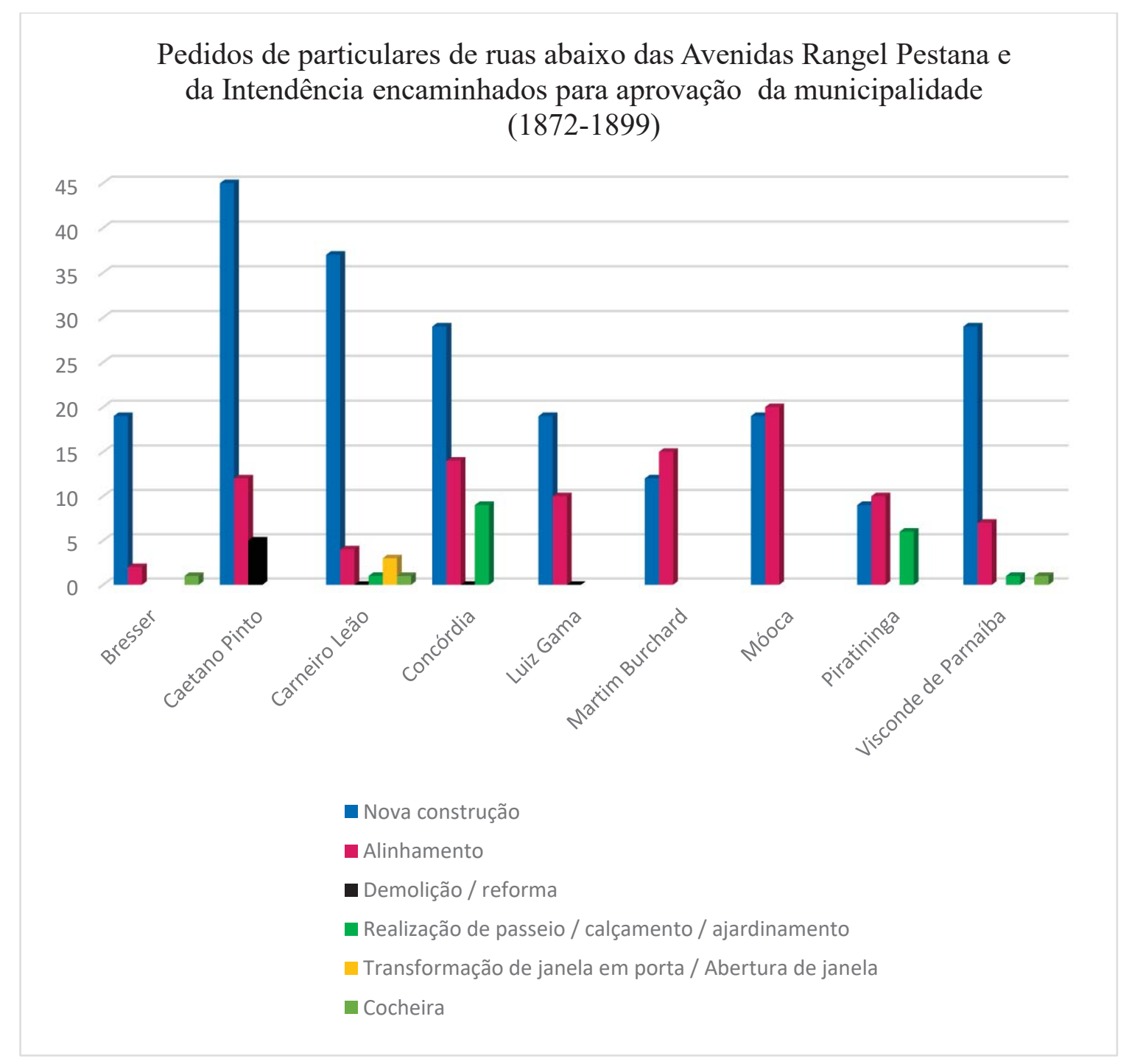

Gráfico 4 - Elaborado pelo autor com base na Série Obras Particulares do Arquivo Histórico Municipal. 
Pedidos de particulares de ruas acima das Avenidas Rangel Pestana e da Intendência encaminhados para aprovação da municipalidade (1872-1899)

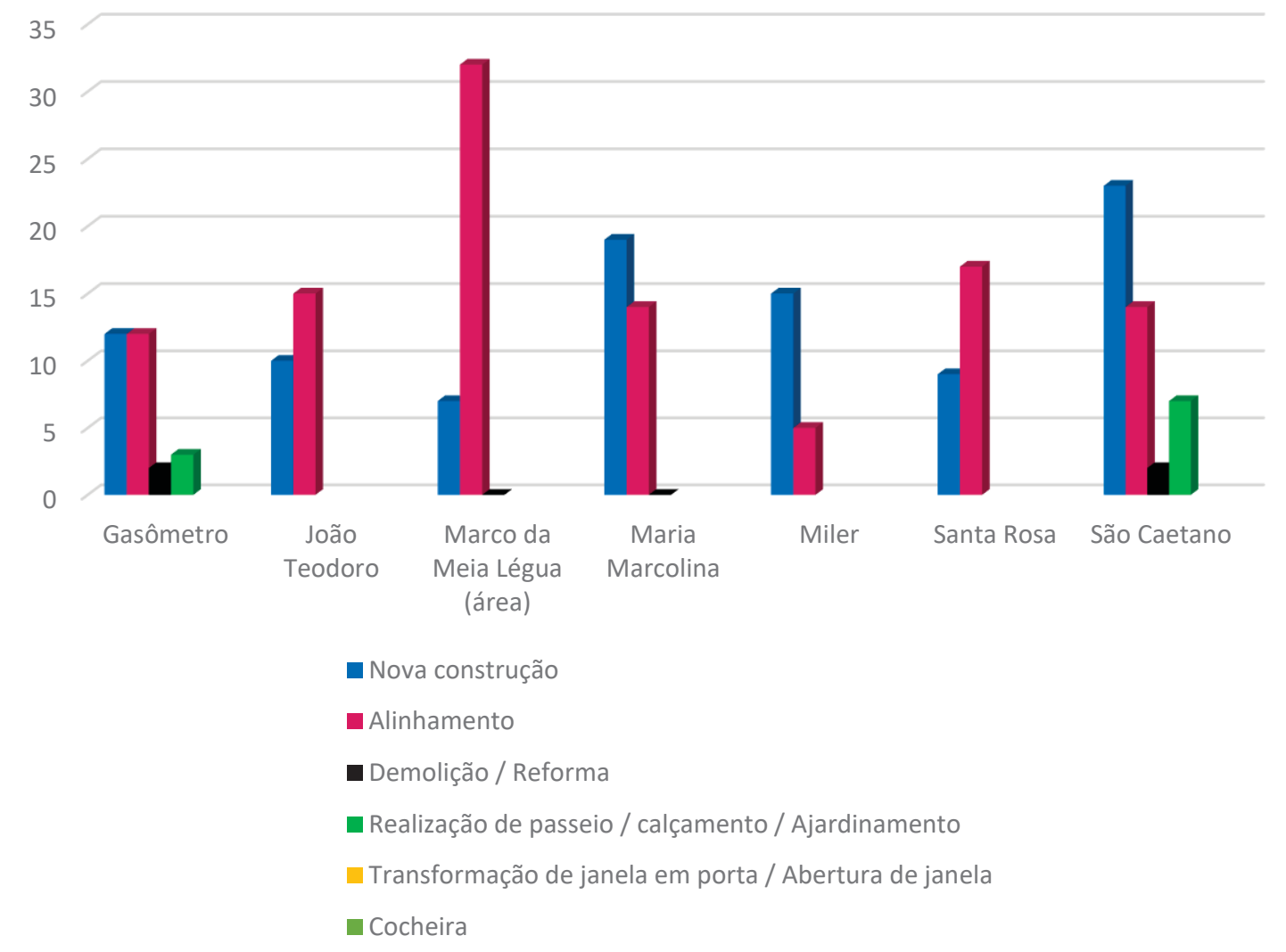

Gráfico 5 - Elaborado pelo autor com base na Série Obras Particulares do Arquivo Histórico Municipal.

O primeiro gráfico demonstra que o número de novas construções excedia os demais, seguido pelos pedidos de alinhamento e, em menor escala, pelos pedidos de calçamento, demolição e/ou reforma, cocheiras e de aberturas de janelas ou de transformações destas em portas (este último dado que pode ser observado apenas na rua Carneiro Leão). Embora pouco expressivas quantitativamente, as solicitações de reforma indicam alguns anseios de particulares em transformar seus imóveis e adequá-los a novos usos 


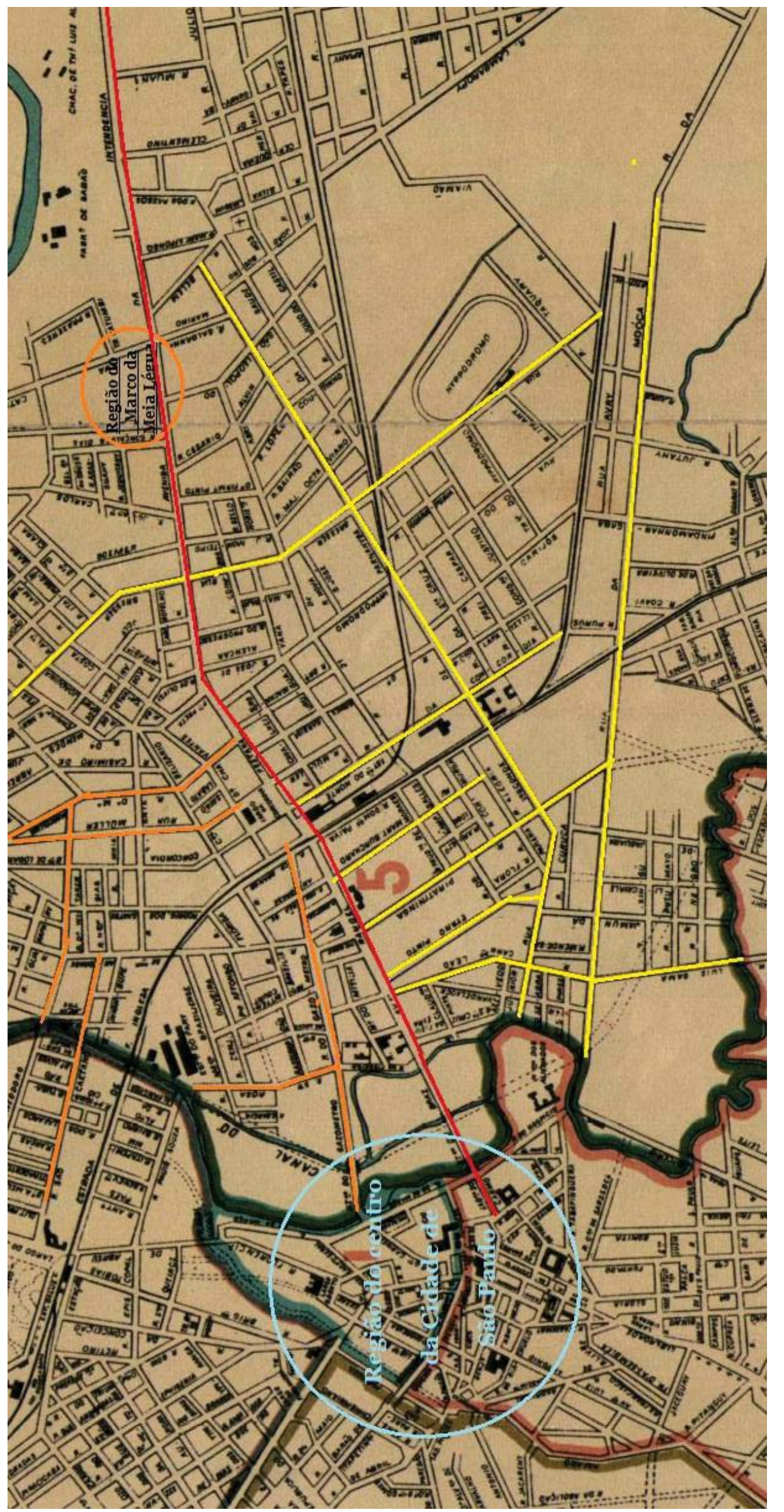

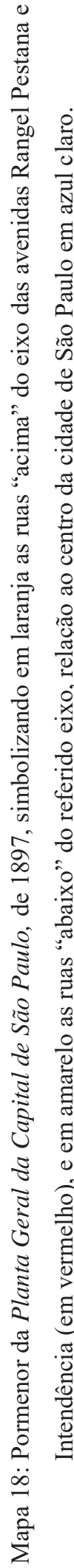


A rua Carneiro Leão, aberta no último quartel do século XIX contava com uma posição privilegiada, por estar próxima da Estação do Norte, e por ter fácil acesso ao centro da cidade, bastando seguir até a rua do Carmo e subir a ladeira. Apesar de estar próxima à várzea, a rua Carneiro Leão polarizava um crescente número de pessoas que transitava na região, o que explica o desejo de muitos dos seus antigos moradores de transformarem um dos seus cômodos (convencionalmente o que ficava de frente à rua) em botequins e armazéns. Ângelo Trevisiani é um destes personagens atentos às transformações em curso no bairro e na cidade que solicitou no ano de 1894 a abertura de uma porta em um de seus imóveis (no caso no número 32 da rua Carneiro Leão), seguido de outros tantos interessados em estender o alinhamento para construção de uma casa, como por Otavio Marangoni, proprietário de um terreno que desejava "fazer de uma janela, porta"151, possivelmente transformando o cômodo ali existente num comércio.

Na rua Carneiro Leião avolumou-se um considerável número de pedidos de novas construções entre os anos de 1890 e 1899, mas seria sua vizinha, a Caetano Pinto que se sobressaiu das demais apresentadas no gráfico. Também com fácil acesso à rua do Carmo e à avenida Rangel Pestana, estava a poucos metros da estrada de ferro, o que facilitava o interesse de outras pessoas por alugarem cômodos, ou casa inteira, ou mesmo comprarem gêneros de primeira necessidade. No período em questão, a rua parece ter se configurado como residencial, dado o elevado número de pedidos acompanhados com "planta de casa de operário", as quais eram em sua maioria de três a quatro cômodos com um corredor lateral que proporcionasse a entrada de luz e de ventilação. Não apenas casas, observamos também ali muitos pedidos de armazéns, casas de negócios, oficina de carpintaria, cocheiras e também aberturas de portas onde anteriormente haviam janelas.

A quantidade de pedidos de alinhamentos presentes no gráfico também é considerável, e demonstram o interesse dos particulares de integrarem seus lotes à malha da cidade para no futuro se iniciarem os trabalhos de construção de novos imóveis. A rua Luiz Gama, por exemplo, contava com um número de quase 20 pedidos de construções e outros 10 pedidos solicitando alinhamento.

As ruas apresentadas no gráfico supracitado possuem uma particularidade: nem todas polarizavam os bondes puxados por burros. Bondes passavam apenas pelas ruas da Móoca, Piratininga, Bresser e Visconde de Parnaíba e destas, apenas na última pôde ser

${ }^{151}$ Acervo do Arquivo Histórico Municipal, Fundo "Diretoria de Obras", Série "Obras Particulares", vol. 60, fls.s/n. 
observado um número de pedidos de construção e alinhamento acima de 20. As ruas Carneiro Leão, Caetano Pinto e Martim Burchard não contavam com o serviço de bondes, mas, por estarem muito próximas da linha férrea, em uma área loteada anos antes das demais, mereceram em fins do século XIX muito mais pedidos de construção que as do segundo grupo.

Esta leitura combinada dos pedidos de alinhamento e construção feitos por particulares com o traçado das linhas de bonde, (auxiliada pelo contexto de loteamento desta área) permite entrever outro quadro quando analisamos a porção "acima" do eixo das avenidas Rangel Pestana e Celso Garcia, área que teve um processo de loteamento mais tardio, e na qual a maioria de suas ruas pôde contar com linhas de bondes: como a Santa Rosa, Gasômetro, Maria Marcolina, São Caetano, e a área próxima ao Marco da Meia Légua que era assistida pelos bondes da rua Bresser e da Avenida da Intendência.

Os números de solicitações de particulares para alinhar e edificar novos prédios revela-se menor quando comparado à região de "baixo", vide o número de alinhamentos para novas construções nas ruas João Teodoro (próxima da Estação da Luz) ou da rua São Caetano, onde além de ter novos pedidos de construção e obras em curso, as demolições e/ou reformas foram surgindo, acompanhadas do calçamento de muitos dos lotes.

A rua do Gasômetro além dos seus pedidos de alinhamentos e construções também apresentou pedidos de ajardinamentos no ano de 1881, como o proposto por Augusto Unioste e por José Vilhocão Pinheiro, proprietários dos imóveis número 29 e 33, e 31. Já a rua Maria Marcolina parece evidenciar construções iminentes devido ao crescente número de pedidos de alinhamentos, todos efetuados entre os anos de 1890 e 1892 .

O gráfico 5, ao demonstrar as ruas que ficavam na parte de "cima" do Brás, indica que o número de solitações de alinhamento eram superiores aos demais número de novas construções a serem edificadas. Interessante notar que na região do Marco da Meia Légua, porção mais afastada do perímetro central nos limites do Brás, o número de solicitações de alinhamento foi relativamente alto, passando da casa dos 30 pedidos, enquanto na rua São Caetano, foi o número de construções que se destacou, talvez por se tratar de área mais próxima à Estação da Luz, portanto mais consolidada e assim apresentando mais pedidos de reforma e/ou demolição e de calçamento.

O fato de as ruas Carneiro Leão, Luiz Gama, Caetano Pinto, Piratininga, Martin Burchard, Concórdia e Visconde de Parnaíba serem ruas paralelas e retilíneas à linha férrea 
e terem fácil acesso à avenida Rangel Pestana, pode ser um dos fatores de participarem mais ativamente do primeiro surto de expansão urbana do Brás. O segundo fator talvez seja a chegada da linha dos bondes, que induziriam a população a construir ali, concentrando-se na parte "alta", comparativamente à "baixa" menos provida dos serviços de transporte público. Não por acaso concentramos nossas pesquisas na parte de cima do Brás.

O crescimento da cidade além do centro foi registrado pela lente de diversos fotógrafos, interessados em documentar as mudanças urbanísticas em curso na São Paulo do começo do século XX. A cartografia também auxilia a compreender tal dinâmica de urbanização no Brás, como a Planta geral da cidade de São Paulo, de 1905, que indica os limites das zonas da cidade, as delegacias, bombeiros, edifícios, e instituições notáveis, mostrando que o Brás enquadrava-se numa área suburbana.

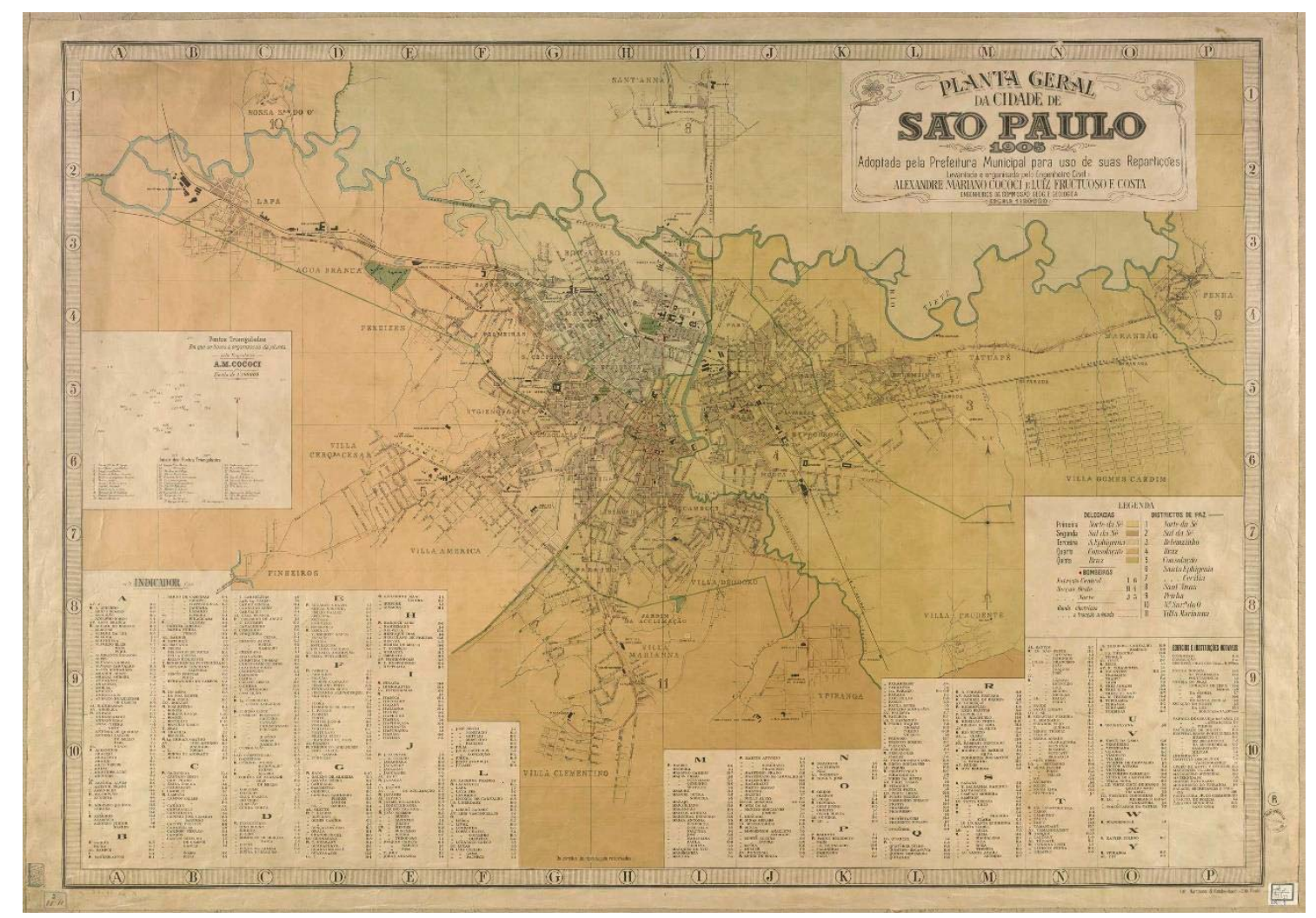

Mapa 19: Planta Geral da cidade de São Paulo, 1905. Acervo da Biblioteca Nacional.

A mesma planta nos permite vislumbrar as linhas de bondes existentes na presente época, nos indicando que os veículos saem da porção central, em direção ao Brás, seguindo as Avenidas Rangel Pestana e Celso Garcia, e nas imediações, passam pelas ruas Visconde de Parnaíba, Miller, Maria Joaquina, Oriente, Monsenhor Andrade, Américo Brasiliense. Ao nosso ver, os trilhos dos bondes servem para transformar o morador em consumidor da 
cidade, além de proporcionar seu deslocamento à rede de trabalhos e serviços disponíveis pelo bairro, no centro e em outras porções da cidade ${ }^{152}$. Ele se desloca não apenas para seu destino final (emprego, escola), mas também na direção dos comércios que estão à sua volta. Isso explica o fato de grande parte do comércio do Brás estar localizado nas vias onde passavam os bondes. Ademais, a planta também coloca em perspectiva a centralidade que o Brás ocupava em relação á bairros adjacentes como a Móoca, Pari, Marco da Meia Légua e Belenzinho, o que pode ser vislumbrado no mapa 20.

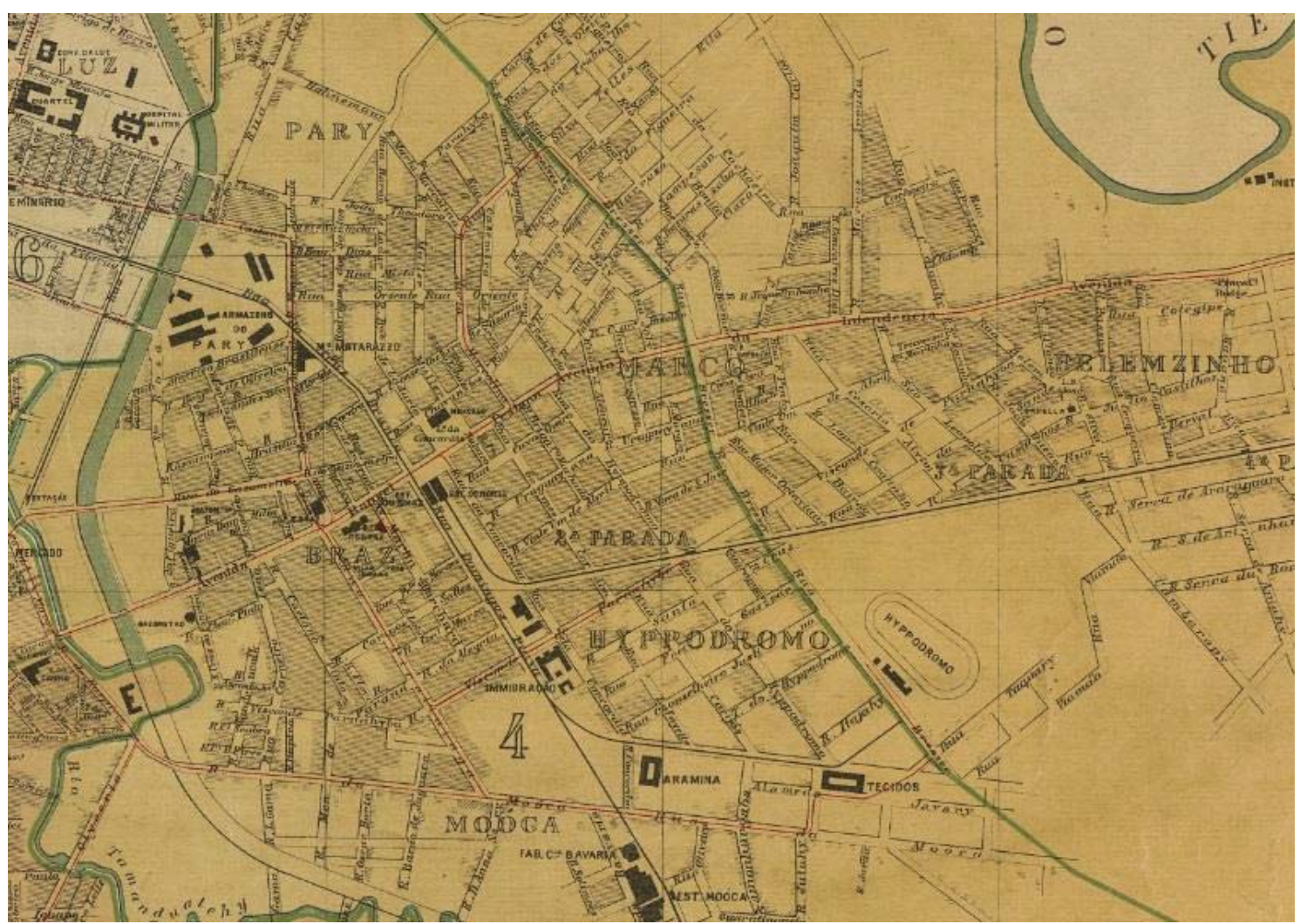

Mapa 20: Pormenor da Planta Geral da Cidade de São Paulo, 1905. Acervo da Biblioteca Digital Luso Brasileira.

A Planta da cidade de S. Paulo com as redes dos esgotos organizada pela Secção de esgotos 1901, além de fornecer indicações sobre as zonas contempladas pelos serviços, indica os encanamentos, coletores principais, canos de ferro e altitude dos bairros. A área do Brás era a maior da cidade, e o bairro era servido pelo encanamento geral da cidade. As ruas parcialmente encanadas eram: João Boemer, Sampson, Almirante Barroso, Xavantes, do Trabalho, dos Oleiros, Gonçalves Dias, o que indica que grande parte do bairro não contava com os serviços mínimos de salubridade.

${ }^{152}$ Assunto que será melhor trabalhado no capítulo 3. 


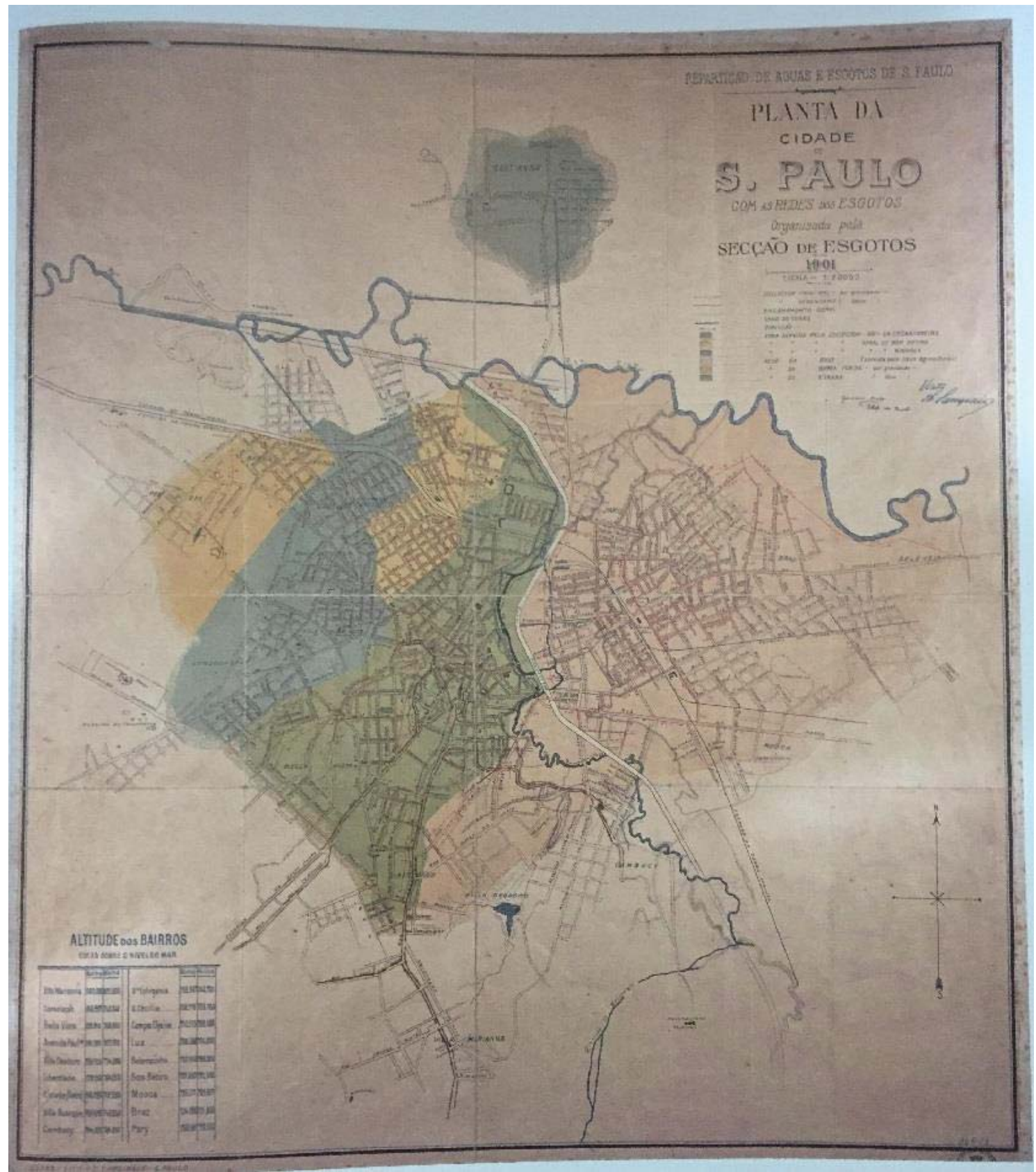

Mapa 21: Planta da cidade de São Paulo com as redes de esgotos, 1901. Acervo da Biblioteca Mário de Andrade. Apud: PASSOS, Maria Lucia Perrone. Desenhando São Paulo: mapas e literatura: 1877-1954.

São Paulo: Editora Senac São Paulo: Imprensa Oficial, 2009, pág. 47. 


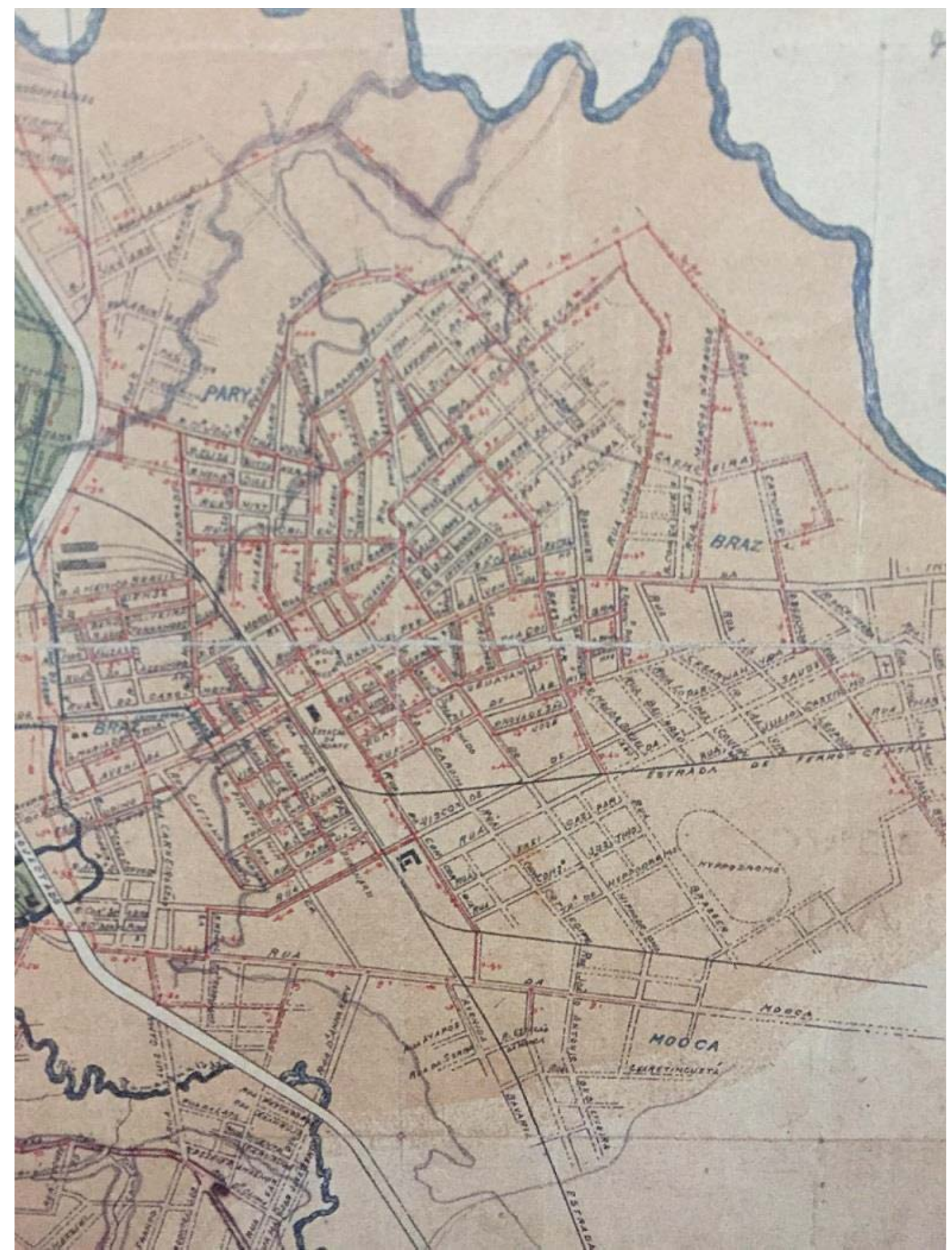

Mapa 22: Pormenor da Planta da cidade de São Paulo com as redes de esgotos, 1901. Acervo da Biblioteca Mário de Andrade. Apud: PASSOS, Maria Lucia Perrone. Desenhando São Paulo: mapas e literatura: 1877-1954. São Paulo: Editora Senac São Paulo: Imprensa Oficial, 2009, pág. 47.

Apesar de a cartografia nos auxiliar a compreender como a cidade, e em especial o bairro do Brás, foi se configurando até os anos de 1910, podemos perceber que este processo advém sobretudo da segunda metade do século XIX, envolvendo interesses diversos em 
jogo. Obviamente as linhas de bondes e os serviços básicos de abastecimento de água e coleta de esgotos condicionam maiores interesses e investimentos nas ruas por onde passam. Segundo Fábio Alexandre dos Santos, a encampação dos serviços de água e esgoto era de uma oferta que "Não alcançava a totalidade da população, nem mesmo com a qualidade necessária, no que tange a água destinada ao consumo humano"153.

Fotografias que trazem em perspectiva a urbanização e o adensamento populacional que se configurava, especialmente no Brás, revelam o aparato de artefatos urbanos possíveis no bairro, que contava com um aparato de elementos urbanos que passam a compor a paisagem, indiretamente dando pistas sobre os possíveis novos usos e imóveis ali instalados sobrepondo-se à tessitura das chácaras e alterando a feição rural outrora predominante.

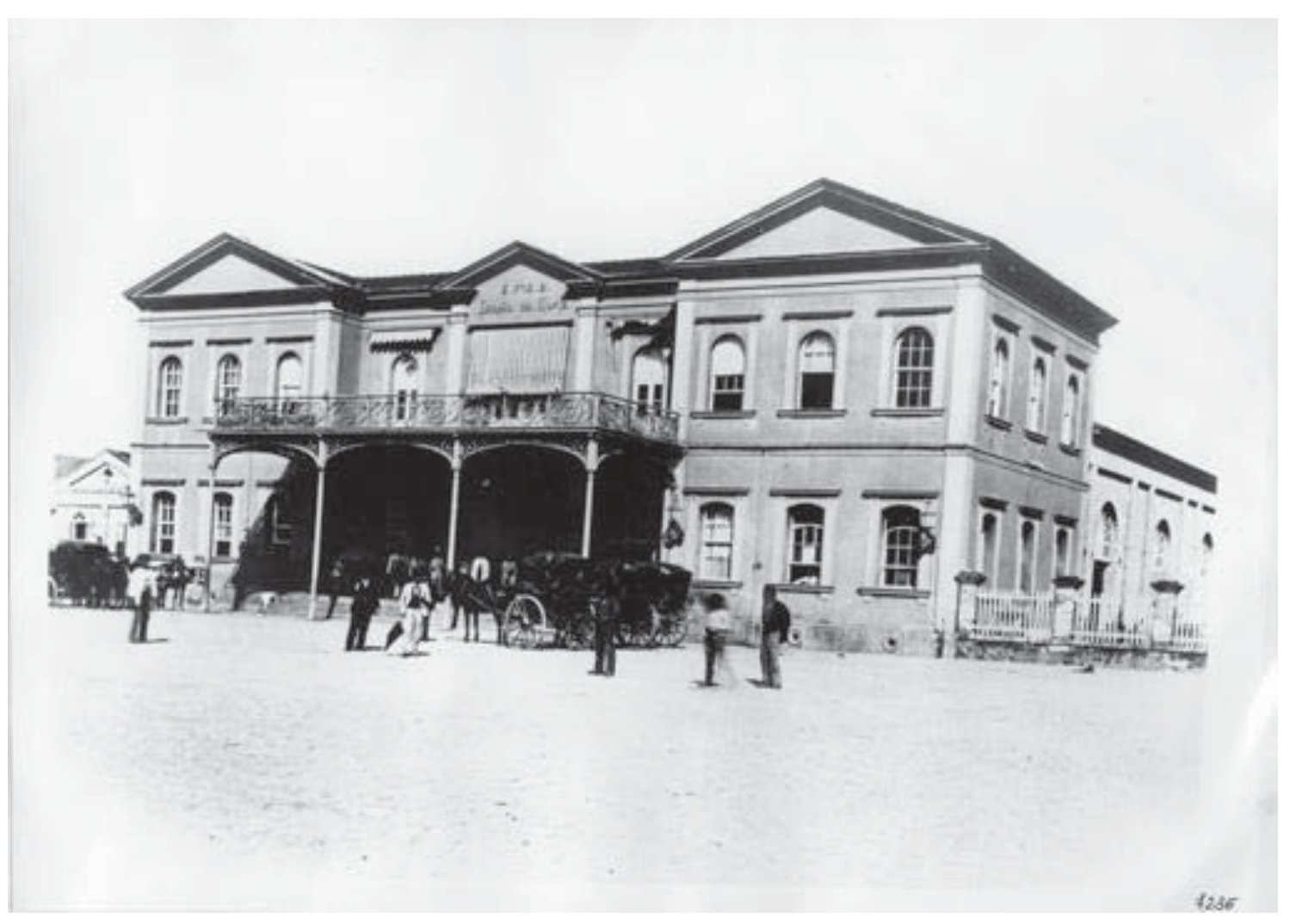

Figura 29: Estação do Norte, Fotógrafo não identificado, 1894 c., Acervo Fotográfico do Museu da Cidade de São Paulo

A Estação do Norte, instalada no Brás desde a década de 1870 tornou-se uma referência para aqueles provenientes do Vale do Paraíba e do Rio de Janeiro. As carroças

153 SANTOS, Fábio Alexandre dos. Domando águas: Salubridade e ocupação do espaço na cidade de São Paulo, 1875-1930. São Paulo: Alameda, 2011, pág. 93. 
puxadas por mulas e o andar das pessoas parece demonstrar o momento daqueles que iriam embarcar no próximo trem ou daqueles que chegavam e se dirigiam ao centro da cidade.

As fotos revelam o processo crescente de ocupação de certos eixos viários, com uma tipologia de casinhas que se torna predominante no bairro. As fotografias abaixo, nos conferem análises mais acuradas de como a Várzea do Carmo demarcava um processo de separação entre a cidade que se construía na colina, e o bairro que se formava para além do Tamanduateí. Não é de se desprezar o fato da ideia do Parque D. Pedro II ser alvo de intensos debates a fim de que proporcionasse um ambiente para a população que residisse nas proximidades, mas também servisse como marco separatório entre a cidade da colina, e o bairro que se formava na planície do rio, alvo de constantes inundações advindas do rio Tamanduateí. $^{154}$

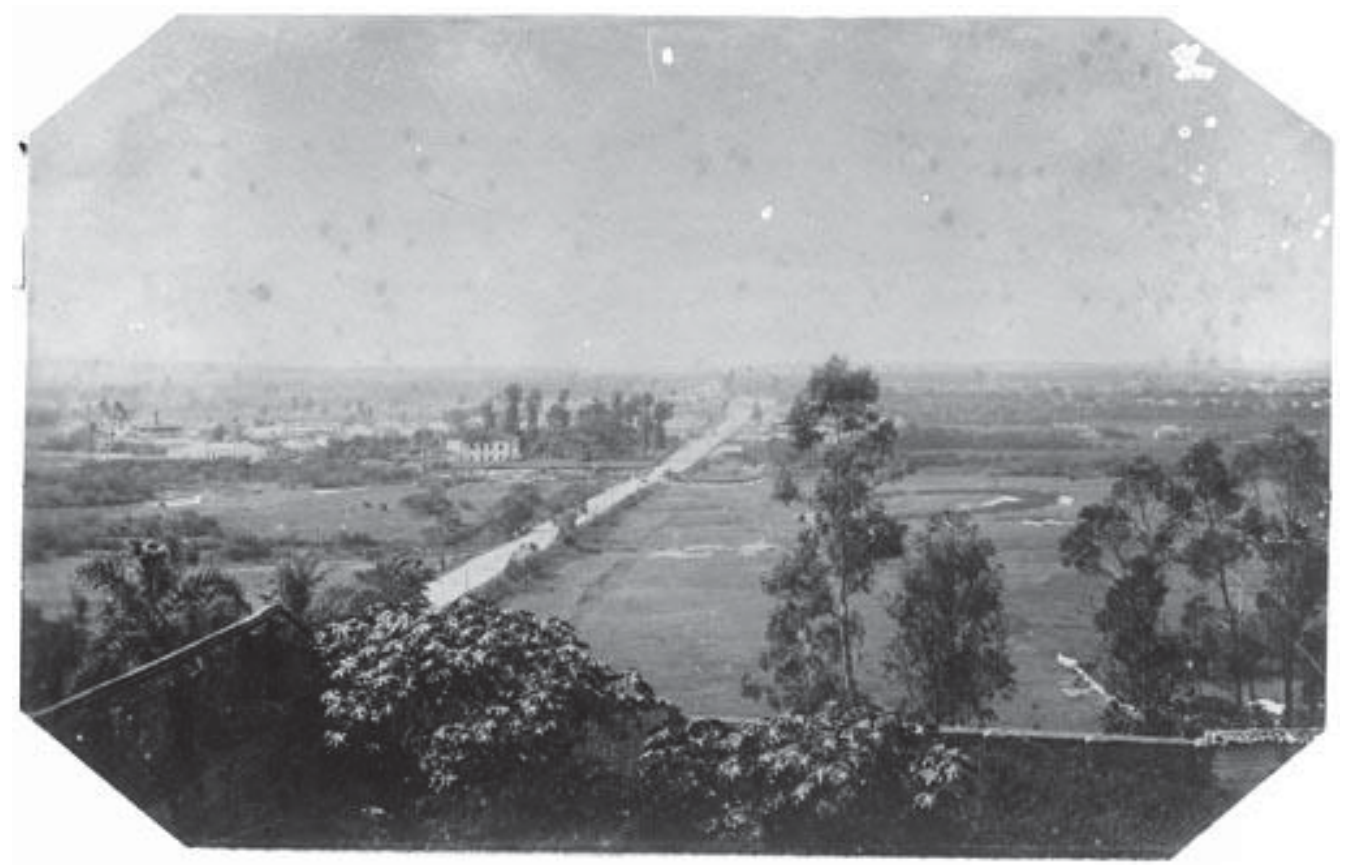

Foto 30: Várzea do Carmo, 1887, Militão Augusto de Azevedo. Acervo Fotográfico do Museu da Cidade de São Paulo.

\footnotetext{
${ }^{154}$ Em sua pesquisa de mestrado, Vanessa Costa Ribeiro analisou uma série de representações iconográficas da Várzea do Carmo entre as décadas de 1890 e 1950, com sua transformação em Parque Dom Pedro II. RIBEIRO, Vanessa Costa. Várzea do Carmo a Parque Dom Pedro II: de atributo natural a artefato. Décadas de 1890 a 1950. Dissertação de Mestrado (História). São Paulo: FFLCH, 2012.
} 


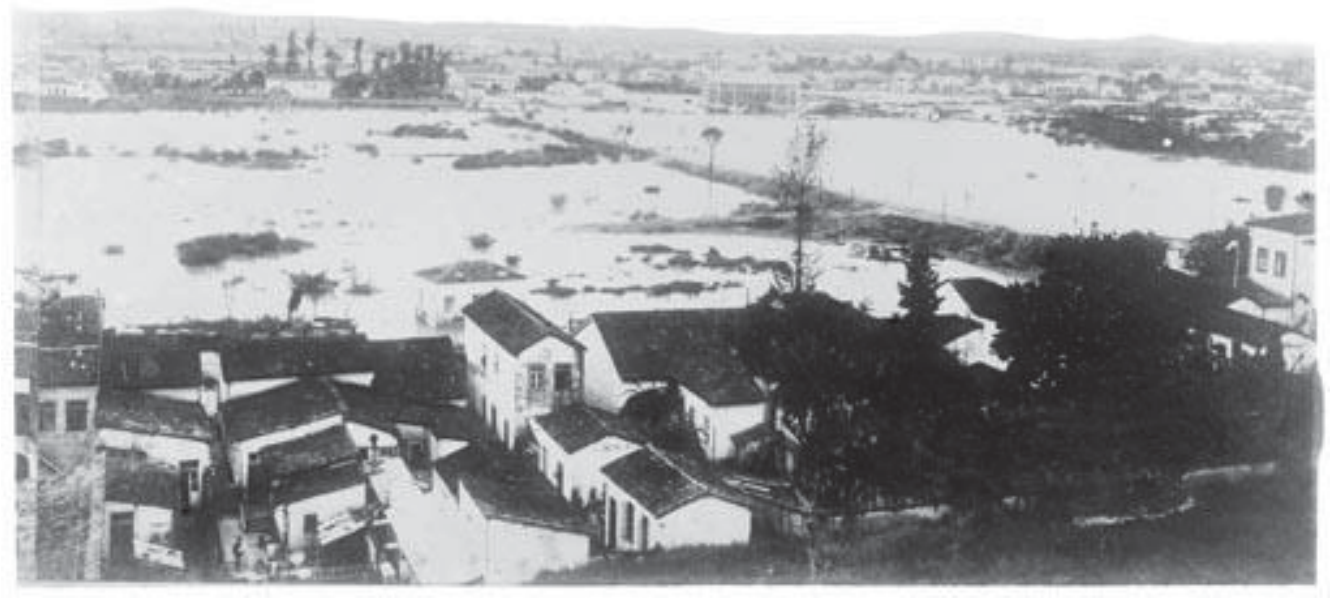

Foto 31: Várzea do Carmo, 1887, Militão Augusto de Azevedo. Acervo Fotográfico do Museu da Cidade de São Paulo.

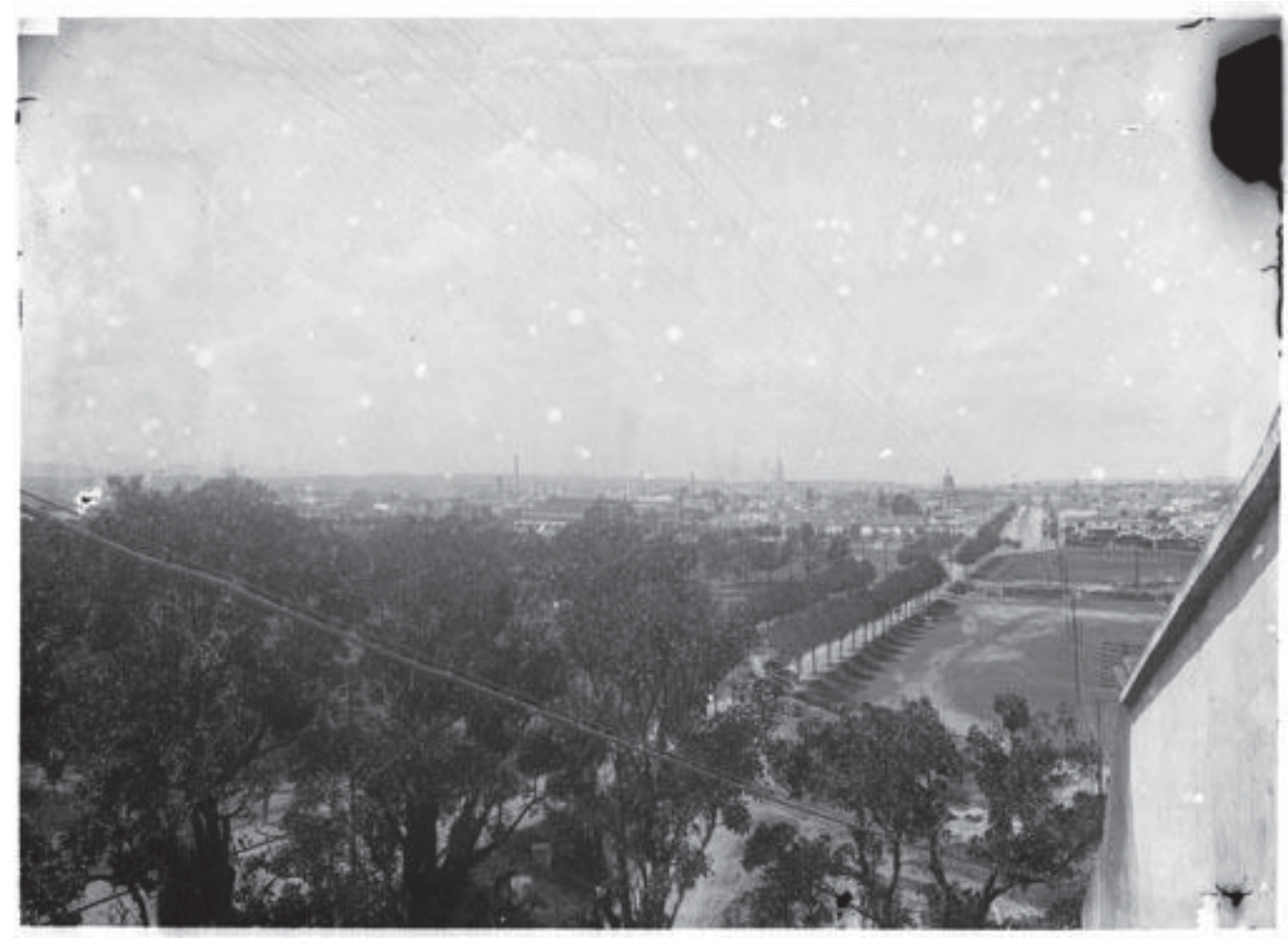

Figura 32: Várzea do Carmo, 1916 c., Fotógrafo não identificado. Acervo Fotográfico do Museu da Cidade de São Paulo. 


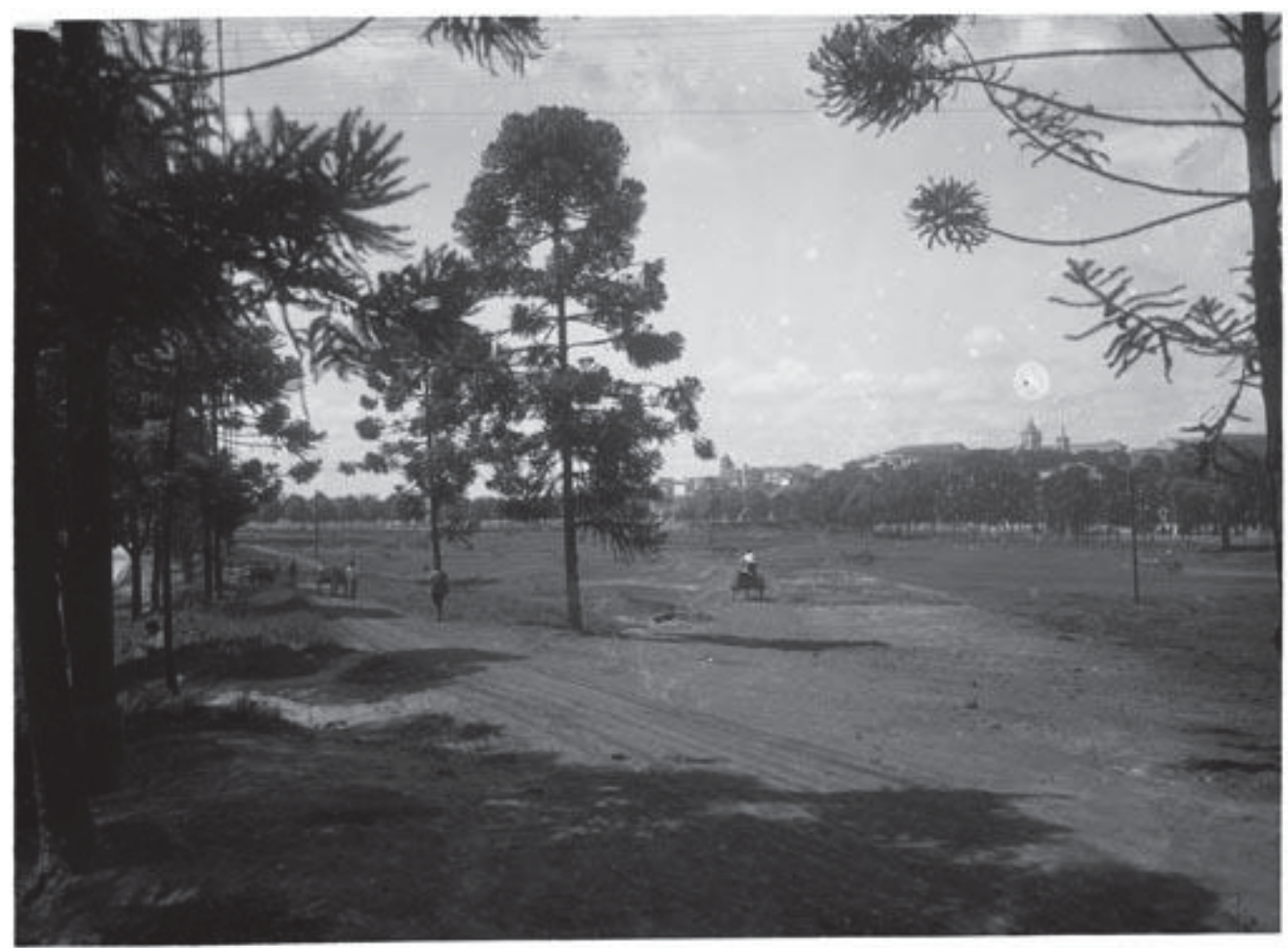

Figura 33: Várzea do Carmo, 1919, Aurélio Becherini. Acervo Fotográfico do Museu da Cidade de São Paulo.

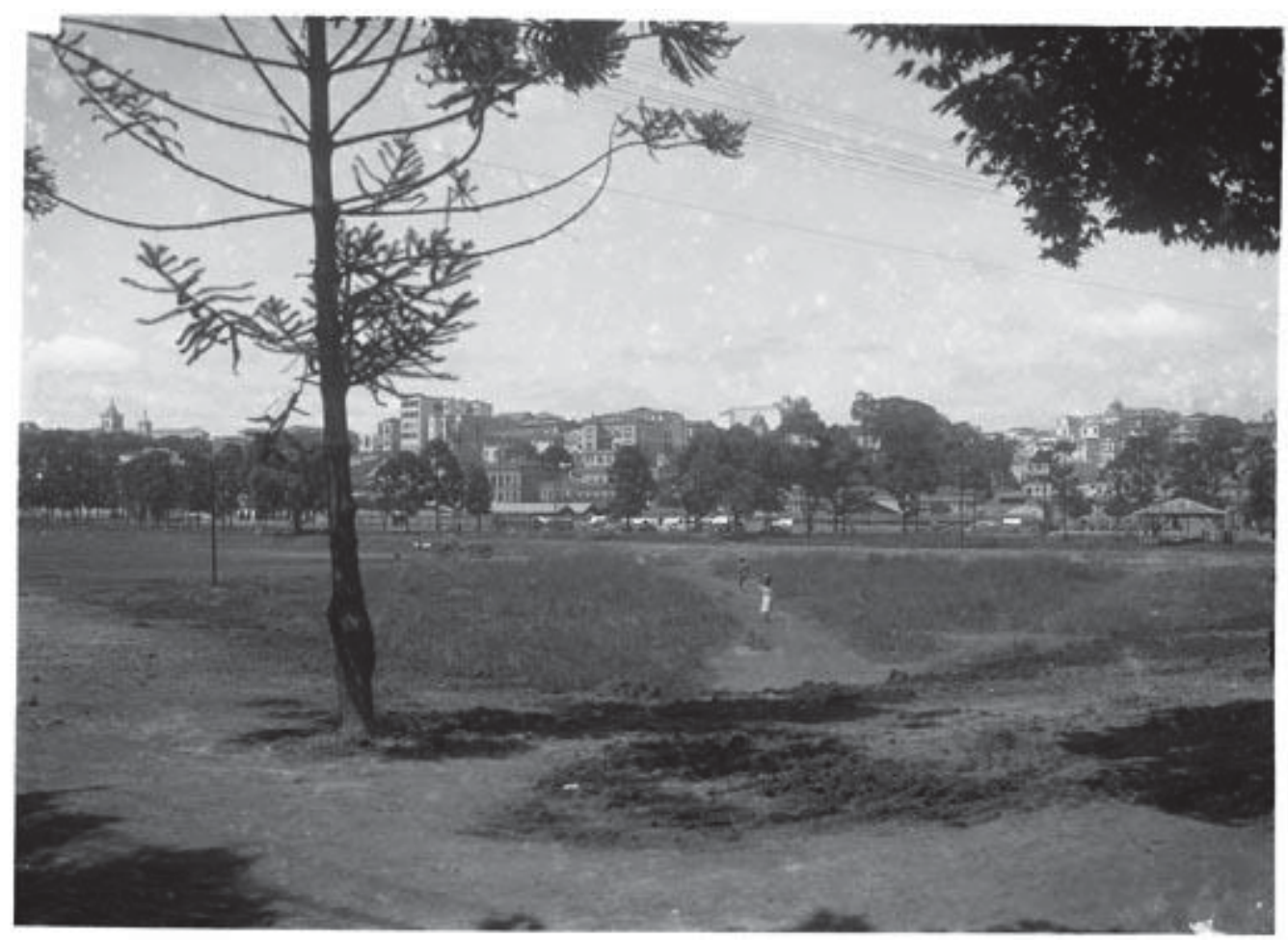

Figura 34: Várzea do Carmo, 1919, Aurélio Becherini. Acervo Fotográfico do Museu da Cidade de São Paulo. 


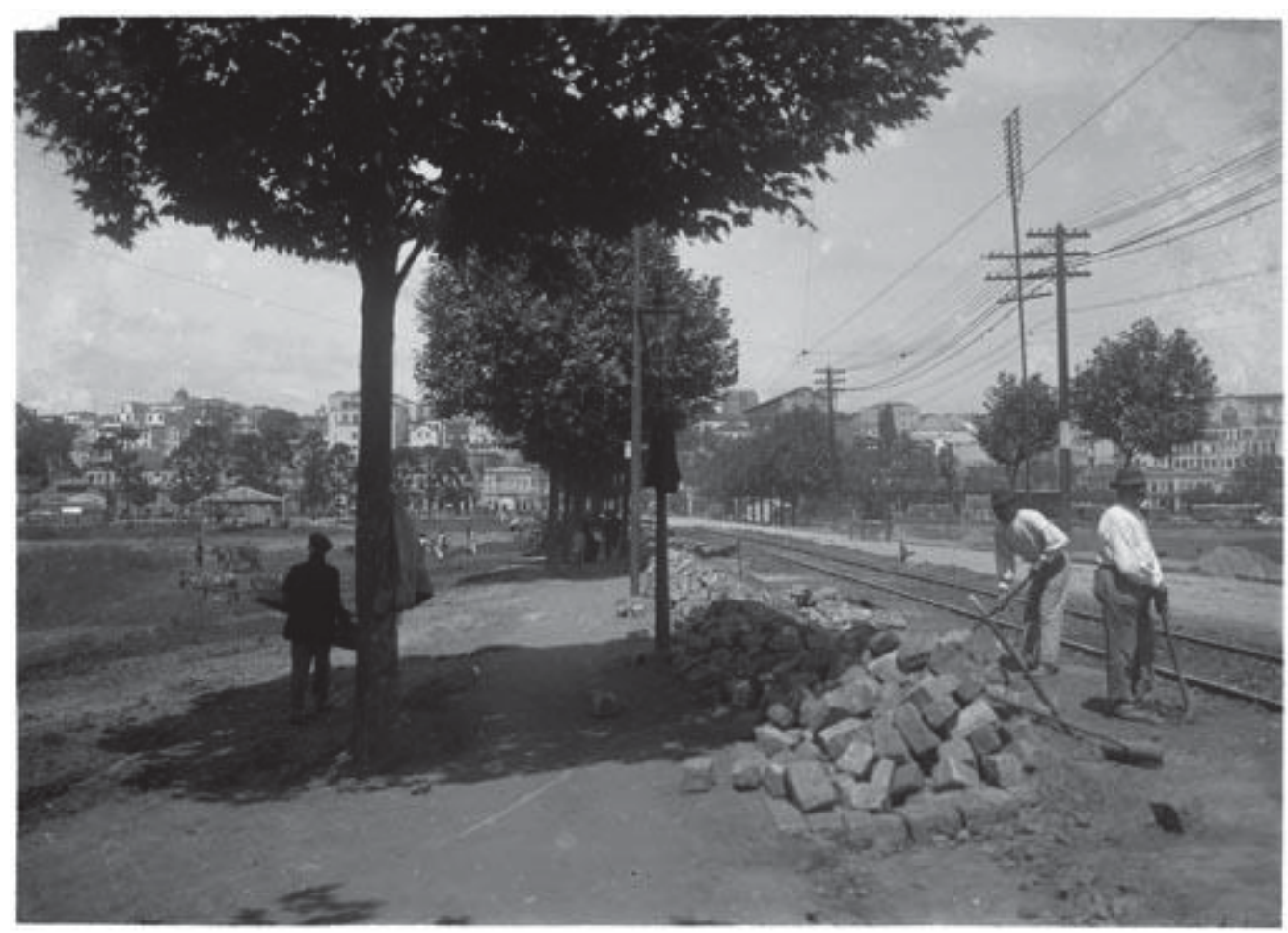

Figura 35: Várzea do Carmo, 1919, Aurélio Becherini. Acervo Fotográfico do Museu da Cidade de São Paulo.

Outras fotos revelam o contraste entre o que estava se transformando: a cidade propriamente dita, cada vez mais verticalizada. Ao contrário, nos subúrbios, irradia-se um casario térreo ao longo dos eixos viários. Os registros do fotógrafo italiano Aurélio Becherini (1879-1939), vão de encontro à visão de cidade que se desejava no momento, e não apenas circunscrito à região central, mas em suas adjacências, como a área por nós privilegiada, a Várzea do Carmo e sua porção além, presente nas figuras 31, 32 e 33.

Enquanto na primeira foto têm-se uma ampla vista da Várzea do Carmo, tomada das proximidades da rua do Gasômetro, no primeiro plano o Aterrado do Brás, e ao seu final, cortado por uma fileira de árvores a avenida Rangel Pestana. Ao fundo, sobre a colina, ao centro a torre da Igreja da Boa Morte, e à direita, as torres da Igreja do Carmo. Se juntarmos com a foto número 32 , teremos uma vista panorâmica da cidade vista a partir da várzea: à direita o antigo Mercado dos Caipiras; ao fundo, sobre as colinas mais uma vez as torres da Igreja do Carmo; ao centro, os fundos do Solar da Marquesa de Santos (na época, escritório da Companhia de Gás); e espraiando-se para a direita, um conjunto de edificações na região da rua Boa Vista e do Largo São Bento. 
As transformações deflagraram diversas melhorias urbanísticas que envolviam aterros, extensão de linhas de bondes e outros serviços como iluminação a gás, água e coleta de esgotos. Aurélio Becherini foi figura ímpar em torno dos registros feitos sobre a cidade de São Paulo do começo do século XX. Sob suas lentes, captava não apenas a cidade consolidada, mas o próprio fazer da cidade, o espaço que se configurava ao longo do tempo, tal qual a figura 35 que traz em perspectiva operários assentando blocos e trilhos para os bondes no que presumimos que seja a rua Santa Rosa (visto ser a rua mais próxima da Várzea do Carmo, e que passava a linha de bondes).

O destino de muitas dessas vias era o Largo do Brás, coração dessa área suburbana que se urbanizava, o qual foi recebendo melhorias urbanísticas - calçamento de paralelepípedos, iluminação a gás e depois elétrica, passeios laterais às ruas - e remodelouse integrando-se ao padrão vigente no centro da cidade. A Igreja do Bom Jesus (Matriz do Brás - inaugurada em 1903) foi totalmente reconstruída ao gosto eclético e muito maior que a modesta capela anterior, demolida em 1896 (ver figuras 38, 39 e 40). Ao seu redor, instalaram-se as principais lojas da área, cujos toldos expressam o desejo de sintonizar-se com os congêneres das ruas Direita e XV de Novembro. Interessante notar que em 1887, as calçadas já encontram-se arborizadas, parcialmente alinhadas e combustores de gás iluminam a Estrada do Brás.

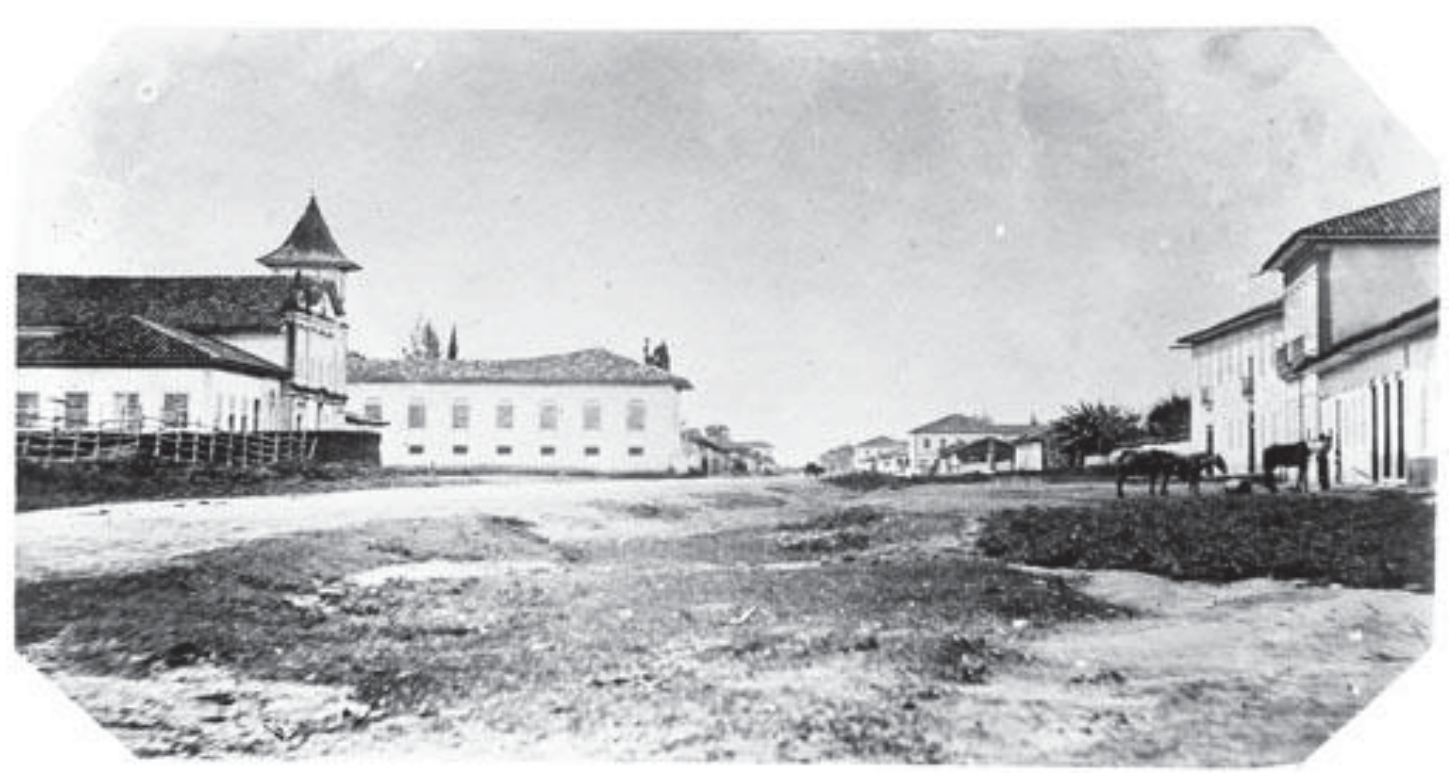

Figura 36: Largo do Brás, 1862, Militão Augusto de Azevedo. Acervo Fotográfico do Museu da Cidade de São Paulo. 


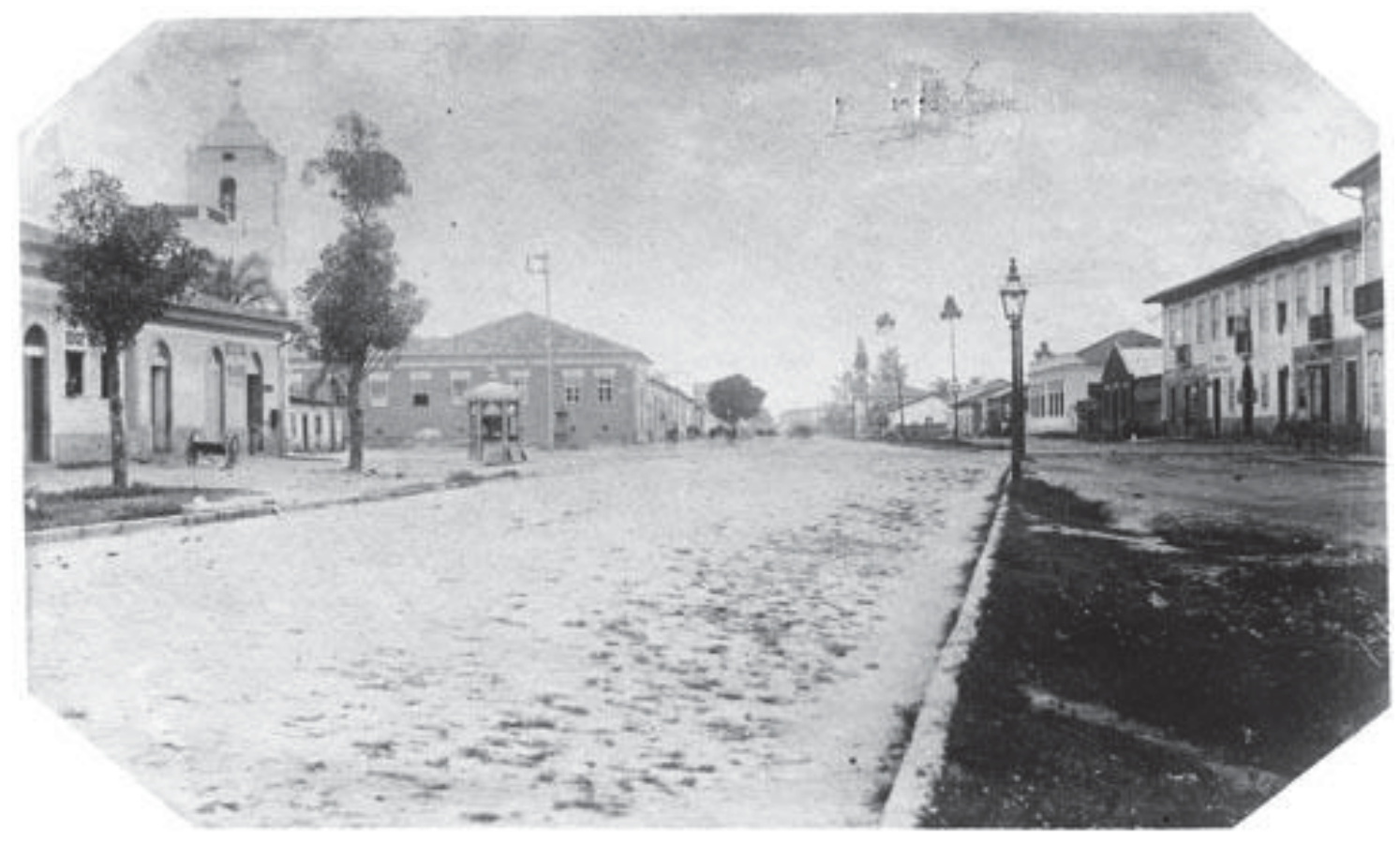

Figura 37: Largo do Brás,1887, Militão Augusto de Azevedo. Acervo Fotográfico do Museu da Cidade de São Paulo.

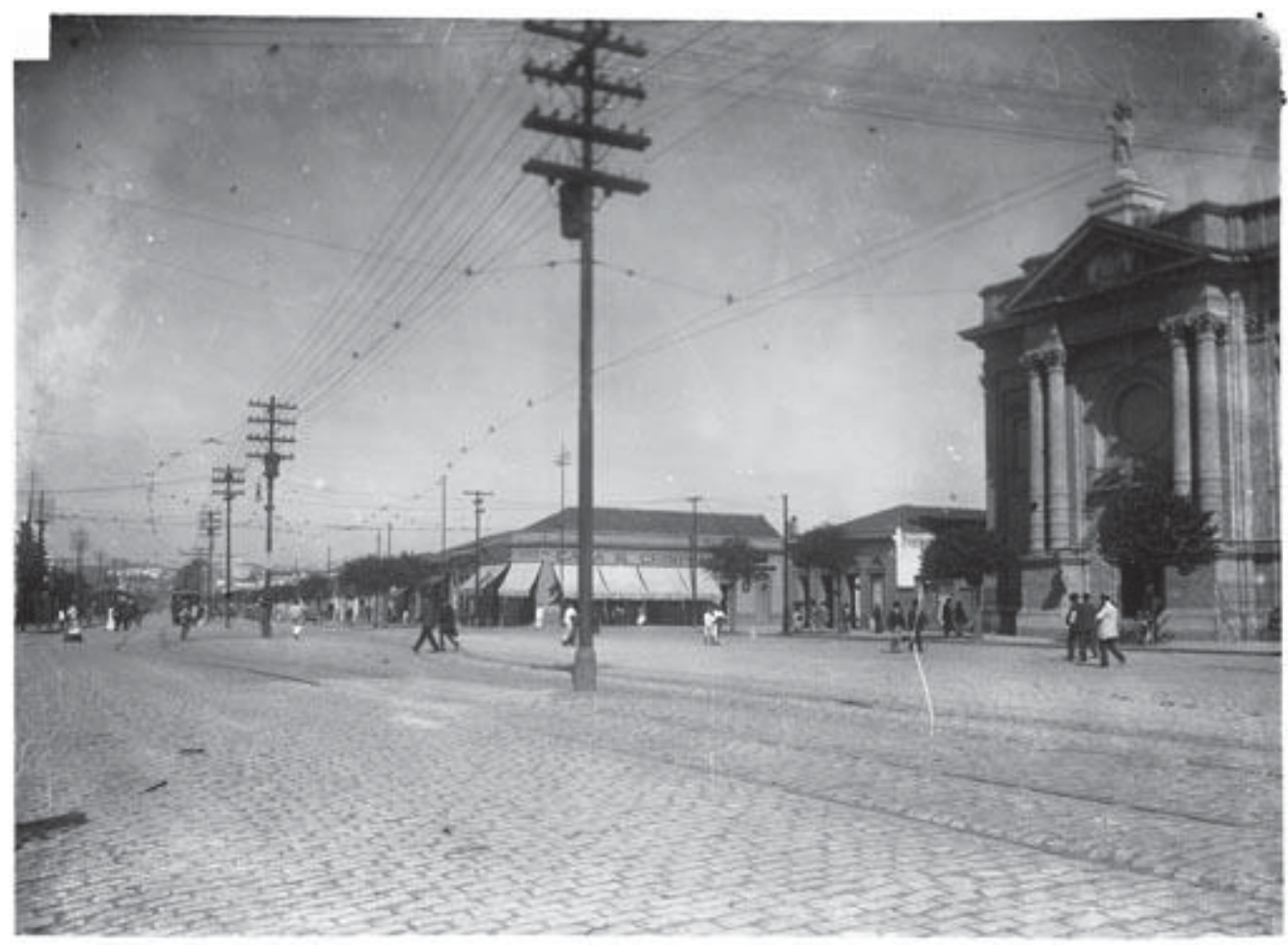

Figura 38: Largo do Brás, 1914, Aurélio Becherini.

Acervo Fotográfico do Museu da Cidade de São Paulo. 


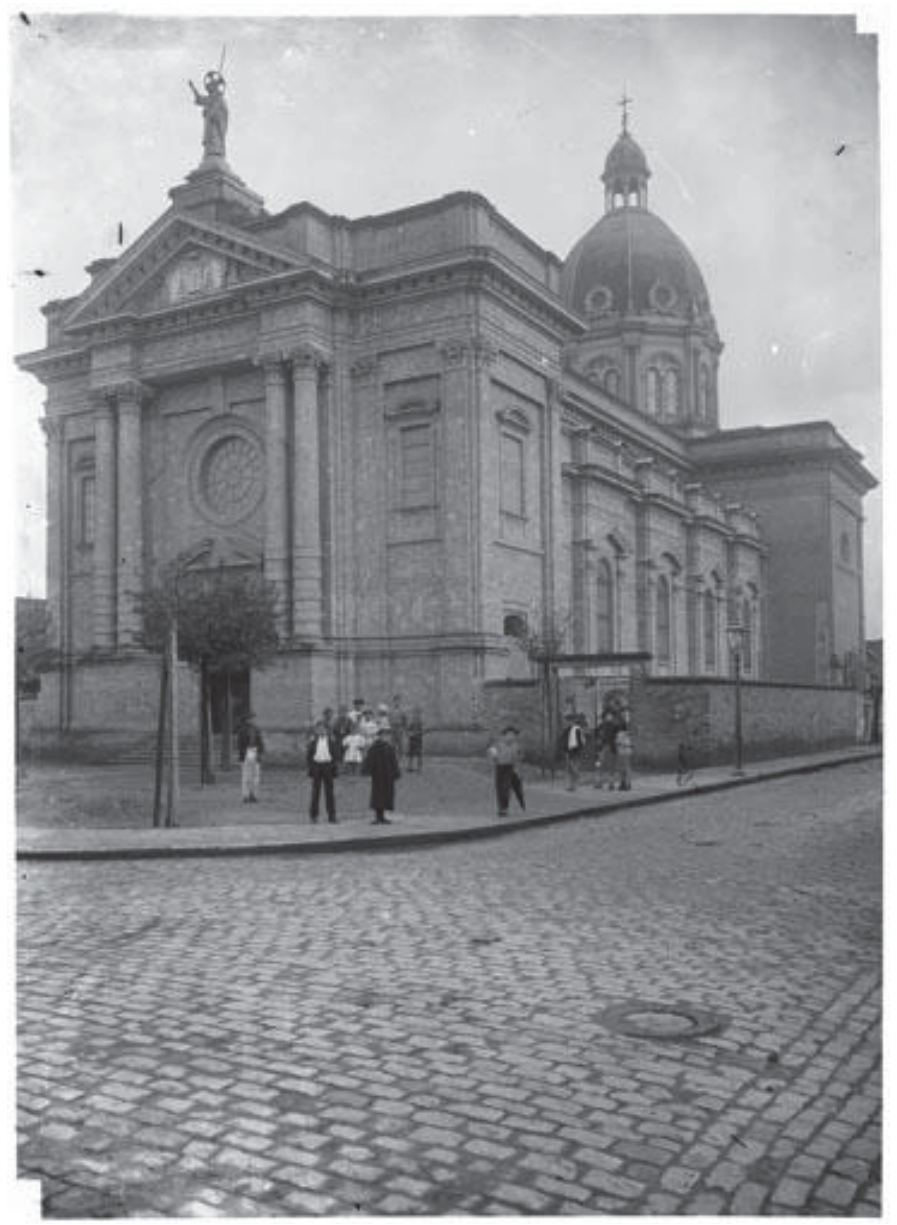

Figura 39: Igreja do Senhor Bom Jesus, 1920 c., Aurélio Becherini. Acervo Fotográfico do Museu da Cidade de São Paulo.

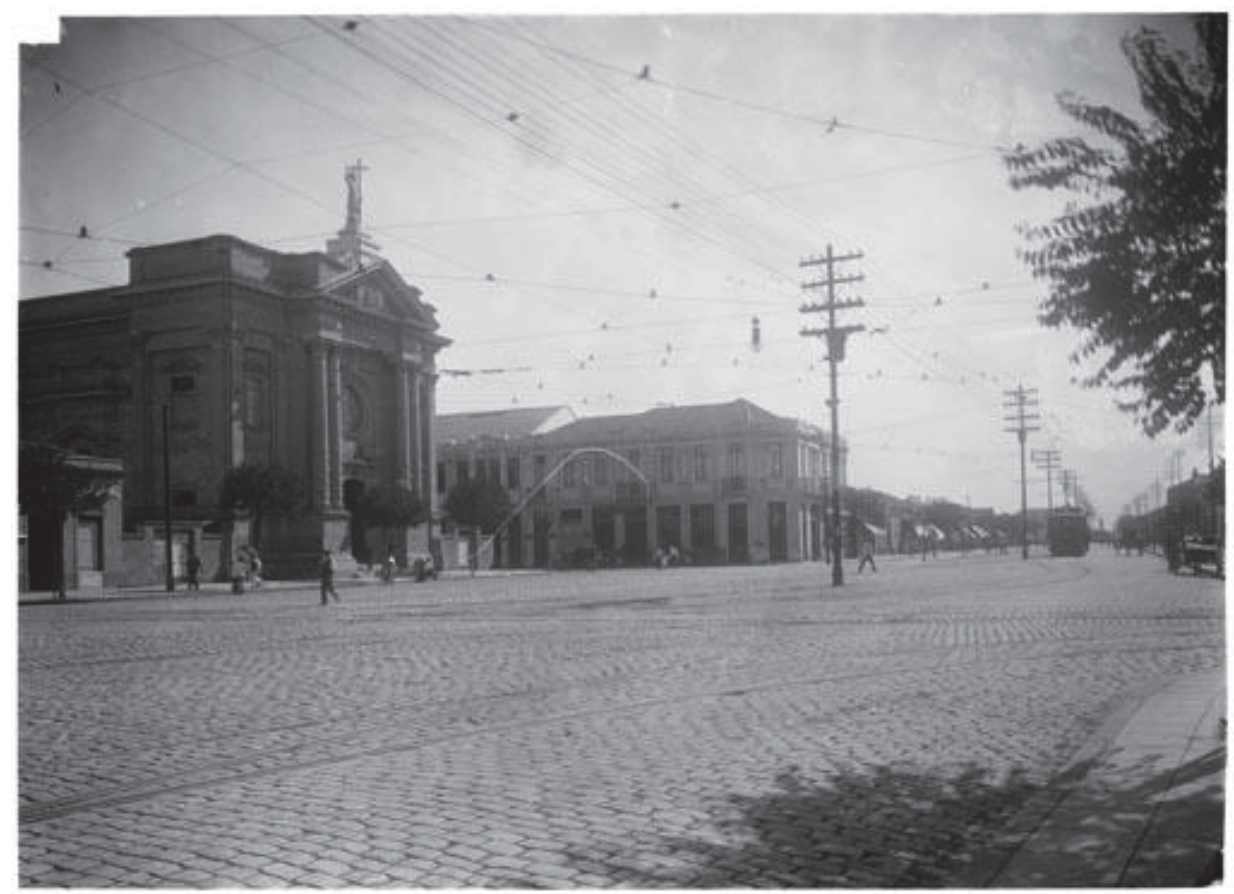

Figura 40: Largo do Brás, 1914, Aurélio Becherini.

Acervo Fotográfico do Museu da Cidade de São Paulo. 


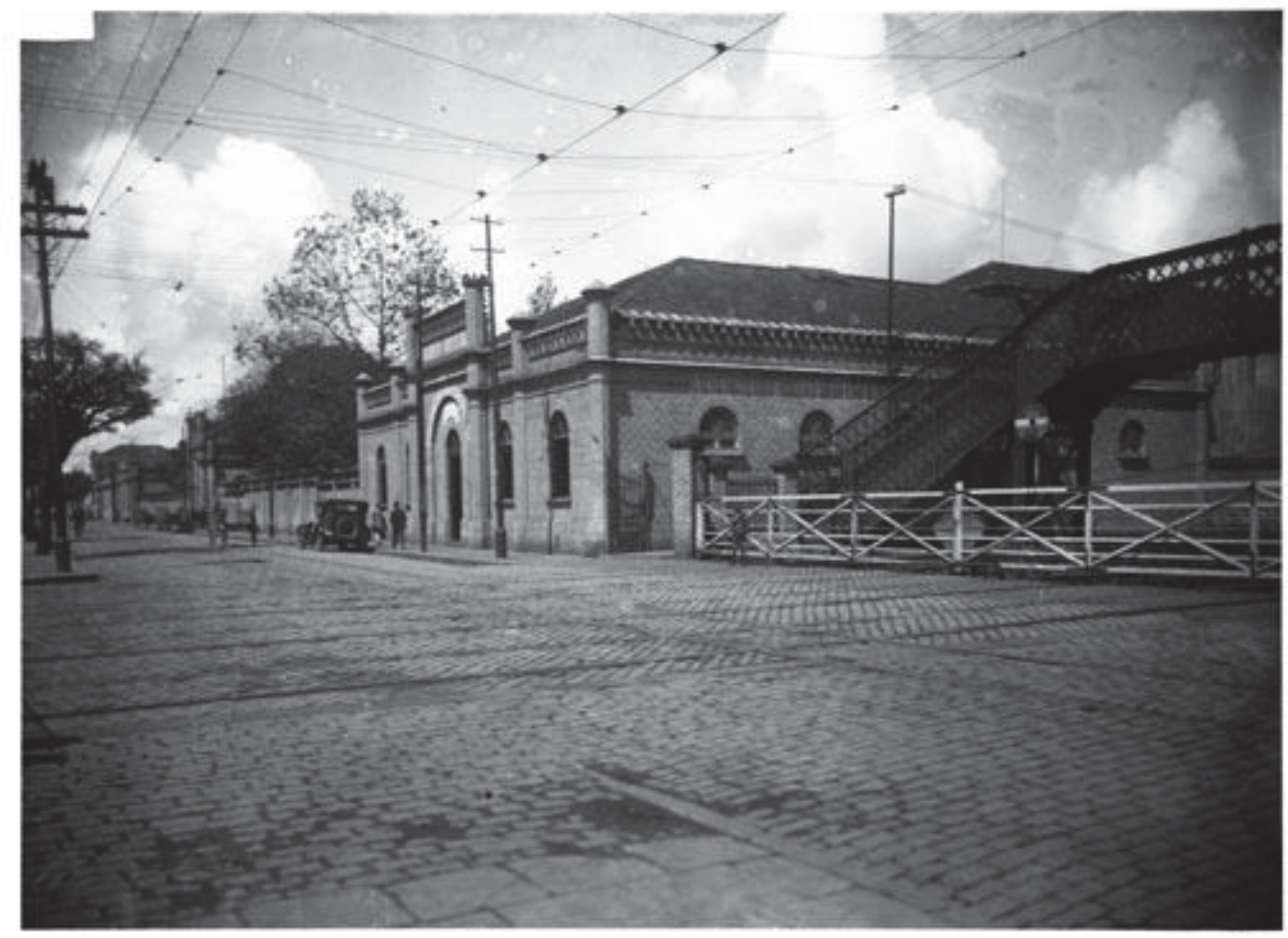

Figura 41: Rua Visconde de Parnaíba [e a entrada da Hospedaria dos Imigrantes], 1900-1930, Aurélio Becherini. Acervo Fotográfico do Museu da Cidade de São Paulo.

Interessante entender o que significa "alinhar" e, portanto, qual o papel dos "pedidos de alinhamento" então em curso. Alinhar significa garantir a contiguidade dos imóveis, impedindo que se tornassem salientes da rua e a seus pares. Ou seja, cabia às autoridades municipais definir as testadas dos terrenos onde seriam edificadas as novas construções. Se nos atentarmos ao projeto de desapropriação assinado pelo engenheiro Sá Rocha, em 1908, sobre um terreno situado na esquina do Beco do Lucas com a rua Assunção, verificaremos que muitas das vias ainda estavam para ser totalmente alinhadas. 


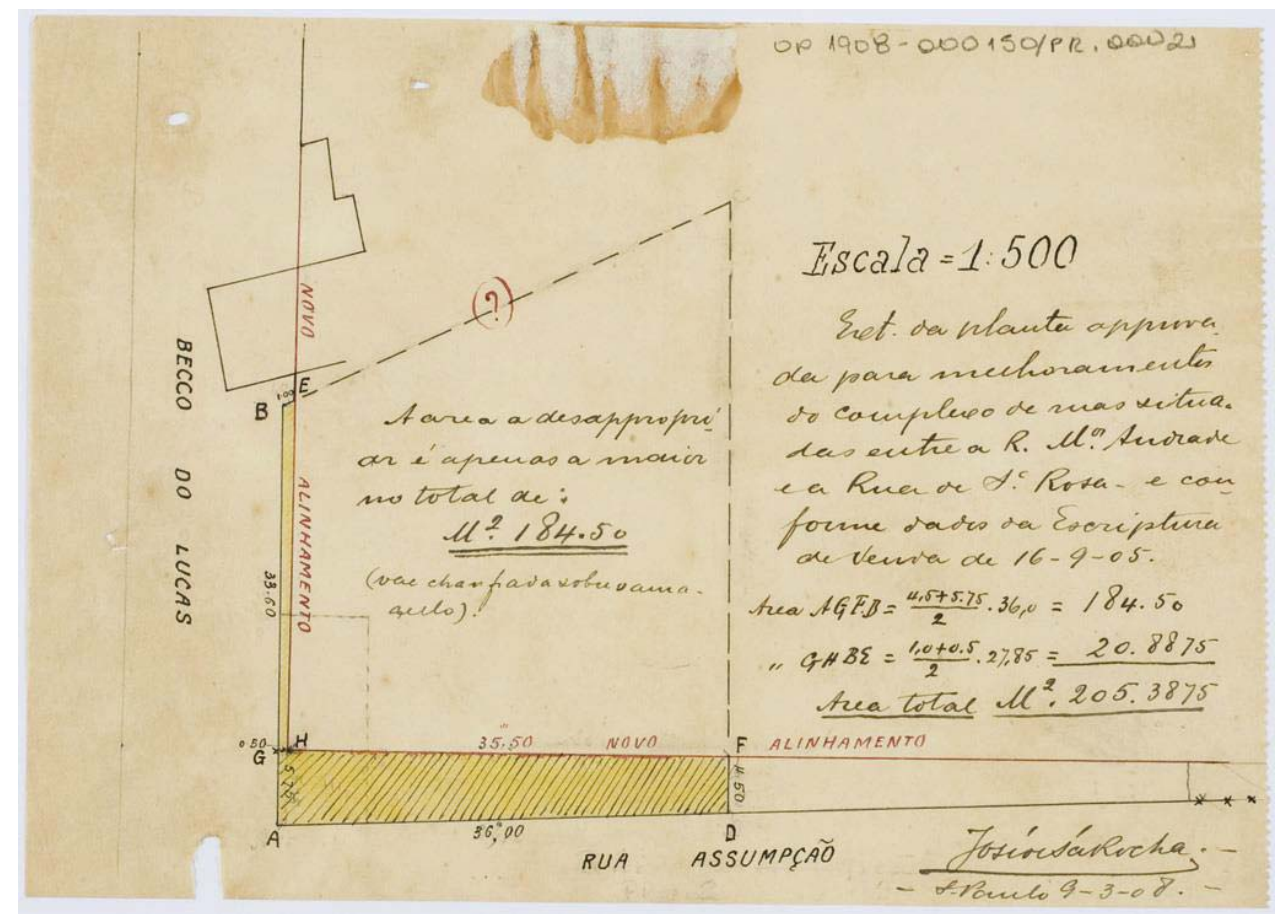

Figura 42: Área a ser desapropriada entre o beco do Lucas e a rua Assunção. Arquivo Histórico Municipal, Fundo "Diretoria de Obras", Série Obras Particulares, OP1908.000.150.

Não podemos nos esquecer que esta área se tratava de uma região suburbana, separada do perímetro central, definido em 1916, pelo rio e sua várzea, bem como pelas linhas férreas da São Paulo Railway e da Ferrovia D. Pedro II, tornando o locus adequado a polarizar certas atividades e edifícios indesejados na área central. Nesse âmbito das políticas de zoneamento então em curso, à periferia - e assim ao Brás - destinaram-se a implantação do Gasômetro, da Hospedaria dos Imigrantes (figura 41), de imensos complexos fabris. O Palácio das Indústrias, instalado no coração do Parque D. Pedro II, recém-construído, remodelando a Várzea do Carmo, não por acaso foi o ícone eleito para a área, referindo-se às indústrias ali predominantes, servindo como um espaço de mostra para os produtos produzidos ao redor da cidade. 


\section{Capítula 2 - Um canteira de abras a céu aberta: nava alhar sabre um bairra - entre cartiças, casas, wilas e sabradas}

A vinda de fazendeiros de café para São Paulo ao final do século XIX, além de garantir a presença nos debates políticos da capital, assumia uma outra feição: a de um capitalista que não podendo ficar preso à sua fazenda, tinha de acompanhar as várias frentes de atividades que estavam entrelaçadas à produção e venda do café: aquisição de terras, recrutamento de mão de obra, organização e direção da produção, transporte interno, comercialização nos portos, contatos oficiais, e as relações políticas e econômicas que poderia realizar na capital da província reunido com seus pares, fortalecendo assim cada vez mais o grupo econômico vigente do período. Mônica Brito ao estudar a organização do mercado imobiliário paulistano ao longo da segunda metade do século XIX, nos elucida que:

\footnotetext{
"tais empreendedores, embora mantivessem suas fazendas, transferiram residência para a capital, onde aplicavam o leque de seus investimentos, aplicando nos serviços públicos, comerciais, de crédito, industriais e, ainda, no mercado imobiliário. Esses investimentos se viabilizaram porque, mantendo uma unidade da gestão de diversos empreendimentos, foi possível organizar uma economia que não contemplava desvios significativos dos recursos acumulados"155.
}

Neste rol de acontecimentos em torno das transformações urbanísticas em curso na cidade, e da inserção de novos grupos sociais nesse processo, o bairro do Brás mostrou-se um cenário privilegiado para se demonstrar a dinâmica da urbanização entre finais do século XIX e o primeiro quartel do século XX, corroborada pelos elevados números de pedidos de particulares que solicitam autorização à prefeitura municipal para realizar a construção de novos edifícios, ou reformar os já existentes, derivando num conjunto arquitetônico não monumental com casas em série, edifícios de uso misto, fábricas (grandes e pequenas), tipologias edilícias dignas de serem trazidas à luz em conexão com o processo social que lhes conferia razão de ser.

\footnotetext{
155 BRITO, Mônica Silveira. Modernização e tradição: urbanização propriedade imobiliária e crédito hipotecário em São Paulo, na segunda metade do século XIX. São Paulo: FFLCH (Tese de Doutorado em Geografia Humana), 2006, pág. 39.
} 


\subsection{Habitação: um debate para além da edificação}

No auge das comemorações do IV Centenário de fundação de São Paulo em 1954, um dos grandes slogans propagandeados nas páginas de muitos jornais da época era o de que "São Paulo é a cidade que mais cresce no mundo"156, estabelecendo conexão entre a grande massa populacional que ainda se instalava na cidade (envolvendo muitos migrantes), e o crescente número de construções que se avolumavam nos seus quatro cantos. De certo modo os dizeres não estavam errados, mas claramente evidenciam a intenção de afirmar a cidade no cenário global, ideia forjada desde finais do século XIX, mas realizada principalmente ao longo das duas primeiras décadas do século XX. Os discursos de "embelezamento e melhoramentos urbanos" materializaram-se por meio de uma minuciosa legislação que pretendeu garantir uniformidade do conjunto, garantindo à iniciativa privada facilidades ao seu processo de feitura, concretizando uma ação de compreender a cidade como um excelente negócio, questão que se perdurou desde o período colonial ${ }^{157}$.

O crescimento da capital paulista ocorrido desde finais do século XIX foi marcado por um conjunto de edificações novas, cuja construção decorreu das novas demandas, dentre as quais habitações para atores que elegeram a cidade como morada e local de trabalho e consumo, com viajantes, imigrantes e migrantes nacionais, ex-escravos e diversos outros personagens. A Câmara e Intendência Municipal, posteriormente Prefeitura, não puderam esquivar-se diante da problemática social que era a questão da habitação, orquestrando o parcelamento das chácaras que se situavam ao redor da cidade, e orientando o modo de como um conjunto de capitais poderia enraizar-se no âmbito de um efervescente mercado imobiliário rentista que começava a investir maciçamente na produção de edifícios em resposta ao desequilíbrio da lei da oferta e da procura, ação que o Estado capitaneou para a iniciativa privada "com incentivos fiscais, segurança jurídica para os locadores e tolerância em relação ás normas edilícias e sanitárias" ${ }^{158}$.

Com a República ganharam fôlego as discussões higiênico-sanitárias, permitindo que houvesse um maior controle sobre as construções executadas na cidade, em especial da

\footnotetext{
${ }^{156} \mathrm{O}$ que pode ser vislumbrado a partir dos jornais editados nas comemorações do IV Centenário da Cidade de São Paulo, em 1954, e depositados na Biblioteca do Arquivo Histórico Municipal.

${ }^{157}$ BUENO, Beatriz Piccolotto Siqueira. "A cidade como negócio: mercado imobiliário em São Paulo no século XIX”. In: Cidades latino-americanas: um debate sobre a formação de núcleos urbanos. Fania Fridman e Maurício Abreu (organizadores). Rio de Janeiro: Casa da Palavra, 2010, pág. 145.

${ }_{158}$ BONDUKI, Nabil. Os pioneiros da habitação social no Brasil. V. 1. São Paulo: Editora Unesp: Edições SESC, 2014, pág. 19.
} 
habitação que se espraiava nos diferentes bairros. Seus representantes no âmbito municipal, aliados muitas vezes ao empresariado, estavam atentos às mudanças da cidade em curso e assim, a atuação dos vereadores, nos primeiros anos da República, não fora no sentido de encontrar soluções para viabilizar a construção de moradias destinadas à grande população que se instalava na cidade, mas ao contrário, aturam no âmbito de questões de ordem econômica, promovendo o loteamento e doação de terras municipais aos seus pares. Segundo Carlos Lemos, "a República deflagrou grande esforço modernizador e, pela primeira vez, introduziu nos códigos exigências ligadas à higiene, sobretudo à da habitação. A lei, entrou dentro de casa, não ficando só nas veleidades estéticas dos frontispícios"159.

Ao lermos os debates promovidos pelos vereadores da Câmara Municipal de São Paulo entre os anos de 1900 e 1910, no que concerne às questões habitacionais, percebemos a quase totalidade das leis e atos que relacionaram-se à distribuição de terras e indicação de soluções que não atingiam a grande massa populacional da cidade. Um destes vereadores, Celso Garcia, destacou-se dos demais justamente pelo seu posicionamento quase sempre contrário às propostas de outros vereadores no que tange ao problema habitacional da cidade de São Paulo.

Com pautas que denotam uma ligação com os interesses dos habitantes dos bairros não centrais, Afonso Celso Garcia da Luz teve como uma de suas principais bandeiras a questão da moradia, entendendo que caberia ao poder público a solução da falta de casas para a população de São Paulo, visto que muitas pessoas habitavam áreas consideradas sem higiene e propícias ao contágio de doenças, lugares que iam na contramão dos preceitos científicos e ideológicos então em voga.

Sua primeira fala sobre o assunto remete à sessão de 29 de julho de 1905, quando "pretende apresentar alguns projectos e indicações sobre habitações dos operários pobres." ${ }^{160}$, apresentando um minucioso estudo da situação habitacional em São Paulo e em outras cidades do mundo, colocando como tardia a nomeação de uma comissão para estudos sobre as chamadas "casas de operários e pobres", questão que na época "em toda a parte tem despertado a attenção dos povos civilizados, desde os mais radicados, os mais conservadores, até os mais progressistas"161.

${ }^{159}$ LEMOS, Op. Cit., 1999, pág. 17.

160 Anais da Câmara Municipal de São Paulo: Legislatura de 1905. Org. Aníbal Machado. São Paulo: Typographia H. Rossi, pág. 111.

${ }^{161}$ Idem, pág. 112. 
Seu relatório inicia-se com um balanço da situação da habitação na Inglaterra, considerada por ele como o primeiro país a iniciar um movimento para solucionar o déficit habitacional ali existente, destacando o fato de Londres ter demolido 23 quarteirões e, neste espaço, construído casas. No caso da Bélgica, nota que "chegaram a edificar-se 800 e tantas casas em que abrigaram pouco mais de 8 mil moradores, e em geral nas cidades grandes da Holanda "seus arrabaldes [estão] cheios de casas para os operários e para os pobres". Já na Dinamarca e Alemanha, desde o final do século XIX foram adotadas medidas para a construção de "casas operárias", assim como no Rio de Janeiro uma das medidas encontradas pelo governo foi oferecer "dinheiro sobre hypotheca, á juro modico, àquelles que quizessem edificar essas casas." ${ }^{162}$ O projeto carioca não foi por nós encontrado, mas é de se destacar que Sidney Chalhoub teve seus olhares voltados às condições habitacionais da capital nacional até finais do século XIX, destacando o "déficit crônico de moradias" e os impactos de retirada da população mais pobre de áreas da cidade que seriam convertidas em espaços da remodelação urbana. ${ }^{163}$

Celso Garcia enfatiza que São Paulo, na época a segunda maior cidade do Brasil e uma das maiores da América do Sul, com uma das populações que mais cresce no mundo, é de se "admirar que ainda não houvéssemos tratado com todo o afinco de resolver entre nós o problema das habitações operarias", cabendo então ao poder público solucionar esta questão, sobretudo porque muitas das construções da cidade não estavam de acordo com os padrões higiênicos e eram foco da transmissão de doenças, problema que já vinha sendo observado pelo poder público desde finais do século XIX. Citou também, como exemplo, o caso da Intendência Municipal de Buenos Aires que, em 1890, criou uma comissão para estudar as causas da mortalidade infantil, chegando à conclusão que a resposta podia ser encontrada nas "vastas habitações em commum para pobres e para operários", fato que fora notado na França, já "que essas habitações constituem um serio perigo, pois offerecem terreno fértil ao desenvolvimento das moléstias contagiosas e ao desenvolvimento e propagação, sobretudo, das epedimias", condenando, assim, as habitações que reúnem muitas pessoas sob o mesmo teto, exigindo, por questões morais, uma reposta imediata da Câmara de São Paulo. Cita o fato de que enquanto determinadas ruas da cidade,

\footnotetext{
162 Idem.

${ }^{163}$ CHALHOUB, Sidney. Cidade febril: cortiços e epidemias na Corte imperial. São Paulo: Companhia das Letras, 1996. A problemática do déficit habitacional carioca foi um problema que rondou a cidade por um longo período, existindo ações que procuravam equalizar esta questão, como o surgimento do Departamento de Habitação Popular, surgido em 1946 e funcionando até 1962, quando foi extinto e substituído por outras ações locais. Sobre o tema, consultar: NASCIMENTO, Flávia Brito do. Entre a estética e o hábito: o Departamento de Habitação Popular (Rio de Janeiro, 1946-1960). Rio de Janeiro: Secretaria Municipal das Culturas, Coordenadoria de Documentação e Informação Cultural, Gerência de Informação, 2008.
} 
"aparentemente hygienicas", como a Avenida Higienópolis e Avenida Paulista seriam chamadas de "muito formosas", em outras eram comumente vistos

\begin{abstract}
“estirados, caídos pelas calçadas, numerosos mendigos; estes aleijados, aquelles cegos, aquelles deitados pelo chão, muitos acompanhados de creanças; algumas dessas creanças são levadas pela mão, e algumas mal dão os primeiros passos. Eu pergunto, sr. presidente: que temos nós feito, que leis temos votado à vista desse triste espectaculo que vão apresentando as ruas de São Paulo?"164
\end{abstract}

A fala de Celso Garcia coloca em pauta o fato de muitos vereadores, em seus discursos, já terem atentado para a existência de inúmeras habitações comuns notadas em bairros como do Bom Retiro e Brás, sem nada fazer para solucionar o problema, denunciando que

\footnotetext{
“muitas famílias compostas de muitas pessoas e morando em uma só casa, num só quarto até, às vezes num corredor húmido e infecto. Nessas habitacoes qual não há de ser o ar viciado? Em cada habitação é um accumulo de pessoas, de moveis, de objetos, de utensílios de cozinha, um soalho que não se lava; nesses antros vive o velho, o moço a creança; ahi dão a luz as mulheres, cerram os olhos os moribundos; ahi talvez em mais deu um caso, quando muitas famílias morem em um só commodo, dorme o impudico ao lado da donzela, o ébrio ao lado do velho e da creança." 165
}

O discurso do vereador se exalta ao citar as opiniões de um médico do Serviço Sanitário sobre as habitações operárias, argumentando o fato de São Paulo ser uma das cidades mais expostas à invasão e à propagação de epidemias, problema este que deveria ser solucionado com apoio tanto do governo do Estado, como também da Municipalidade. Nesse sentido, apresentou um projeto sobre auxílios indiretos que a Câmara poderia oferecer para resolver o problema habitacional em São Paulo. ${ }^{166}$

Reconhecendo que seu projeto seria rejeitado, visto a oposição que se manifestou, solicitou que inicialmente se formasse uma comissão de médicos e engenheiros sanitários para estudar o estado das ditas habitações operárias, a partir do ponto de vista higiênico e não dos vários fenômenos que o governo federal mandou estudar na cidade do Rio de Janeiro. Ao final, Celso Garcia nota a inconsistência existente nos conceitos "operário" e "pobre", visto serem empregados de diferentes maneiras entre os legisladores, pois enquanto "uns querem que operários seja aquelle que se entrega aos trabalhos physicos, aos

164 Anais da Câmara Municipal de São Paulo, Idem.

${ }^{165}$ Idem, pág. 113.

${ }^{166}$ Idem, pág. 114. 
trabalhos manueaes; outros querem que seja também aquelles que se entrega a qualquer trabalho, embora intelectual"167. Desta forma, acreditava que a melhor forma era definir um conceito a partir da comissão formada, e iniciar um processo de inspeção das casas com base em seu "estudo nas habitações dos operários, porque, do contrário, certas informações que desejo que se colham, será impossível obtel-as se se recorrer à força coerciva"168, dando indicações de como eram obtidas as respostas de muitos dos relatórios da época. Criou-se, assim, o projeto número 19 de 29 de julho de 1905 :

Art. $1^{\circ}$ Fica a Prefeitura auctorizada a nomear uma comissão de um ou mais

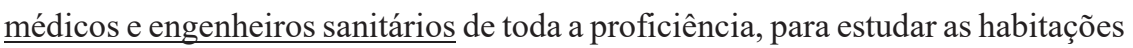
de operários e de pobres, sob o ponto de vista hygienico.

$\S$ único - Para se representarem nessa commissão, serão convidados o governo do Estado e a Sociedade de Medicina desta cidade.

Art. $2^{\circ}$ A commissão, em seu relatório, entre outras informações necessárias, dirá o numero de casas respectivas, especificando a sua forma, capacidade, valor locativo, numero de habitantes, sua nacionalidade, profissão, meios de subsistência, numero de menores segundo a edade, côr e sexo, numero de habitações, sua capacidade cubica, numero de pessoas que moram em cada uma dessas hbaitacoes, aluguel de cada uma.

Art. $3^{\circ}$ Fica a Prefeitura auctorizada a fazer as operações de credito que julgar necessárias para a execução desta lei.

Art. $4^{\circ}$ Revogam-se as disposições em contrario" (grifo nosso).

O projeto parece encontrar resistência na Câmara, pois Nicolau Baruel, personagem de destaque no campo farmacêutico e no ramo industrial, sugere que o parecer de aprovação exija inicialmente uma apreciação do prefeito, para que depois siga à comissão de Justiça e à comissão de Finanças, e, se possível, à comissão de Higiene, da qual Celso Garcia era membro.

Celso Garcia, ao contrário, considerava desnecessário que os papeis seguissem para a Prefeitura, já que todos tinham o conhecimento das leis da Câmara referentes à habitação, desejoso que o projeto tivesse andamento, e que, ainda no ano de 1905, fosse encaminhado ao Congresso do Estado. O prefeito Antônio Prado, que participava da sessão, se colocou

\footnotetext{
${ }^{167}$ Idem, pág. 115.

${ }^{168}$ Idem.
} 
favorável à ideia do projeto, entendendo também ser desnecessária a sua discussão na Prefeitura, haja vista a existência de comissões na Câmara que versavam sobre a questão da higiene, mas, deixa claro que sua administração não poderia arcar com os custos do projeto, colocando fim às propostas do vereador Celso Garcia.

Cremos que a comissão proposta por Celso Garcia para realizar um estudo aprofundado das condições de moradia dos habitantes de determinadas parcelas da sociedade paulistana não foi elaborada até o final da gestão de Antônio Prado (1911), mesmo após a morte do vereador em 1908. Porém, é de se destacar que o projeto foi o primeiro a colocar em pauta a necessidade de um estudo aprofundado sobre a moradia das classes mais pobres, com especial atenção aos inúmeros cortiços que vinham surgindo sobre a cidade. O projeto proposto por Celso Garcia trazia em pauta a importância do Estado entender a moradia como uma questão social, e não apenas como sujeita dos desejos do mercado imobiliário.

Celso Garcia e os demais vereadores enxergavam a cidade que vinha sendo construída e que se expandia velozmente para além dos seus limites tradicionais e percebiam um descompasso. Enquanto projetos eram debatidos na Câmara, tijolos, pedras e cimento eram encomendados por inúmeros proprietários do Brás e outras zonas para edificarem casas que serviriam de moradia para si mesmos ou para renda de aluguel para outras tantas famílias e grupos que ali se instalavam.

A cidade que se construía foi registrada pela burocracia municipal e hoje podemos contar com a série Obras Particulares do Arquivo Histórico Municipal, um material com rico potencial de análise, que traz consigo uma gama de desenhos e pareceres técnicos envolvendo engenheiros, arquitetos, proprietários, construtores e fiscais entre os anos de 1906 a 1915, período eleito para estudo por referir-se ao conjunto documental já informatizado e disponibilizado online no site www.projetosirca.com.br. Tratamos então da "cidade oficial", daquela que fora registrada e vista essencialmente pelos olhos e o crivo da municipalidade. 
Acreditamos que uma das formas de se compreender a materialidade da cidade construída nas duas primeiras décadas do século XX seja por meio da análise dos pedidos de construção e reformas endereçados pela iniciativa privada à Prefeitura que, atreladas ao conjunto de transformações urbanas em curso, conferem luz ao que se produziu em São Paulo. Desta produção, podemos verificar que a sua grande maioria era de casas e que estas foram destinadas predominantemente para renda de aluguel. Com a grande leva imigrante estabelecida na cidade desde finais do oitocentos, podemos afirmar que havia demandas e, sendo a oferta inferior que a demanda, proprietários envolvidos nesse efervescente mercado imobiliário rentista, com destacada atuação na área central e igualmente vigente em bairros que se formavam, como o Brás.

Do grande volume de construções realizadas no bairro entre os anos de 1906 e 1915, podemos verificar que mais de $75 \%$ foram residências, para moradia dos proprietários e renda para os investidores. Assim, as casas construídas além rio Tamanduateí evidenciam um processo de produção de uma cidade que se expandia e ao mesmo tempo conferia lucro àqueles que estavam inseridos no rol de proprietários de imóveis. Segundo Beatriz Bueno até a promulgação da Lei do Inquilinato em 1942, boa parte da população ainda morava de aluguel, tornando-se vantajoso investir na construção de casas, e imóveis de outras naturezas, em resposta às demandas então em curso ${ }^{169}$.

São Paulo congregava um montante de capitais prontos para serem investidos, oriundos essencialmente da expansão da lavoura cafeeira, o que permitiu uma diversificação de investimentos, pautado também no ramo imobiliário. Como Bueno demonstra, "loteamentos e novos bairros foram produzidos pela iniciativa privada, atrelando acessibilidade ao centro e infraestrutura - água, esgoto, iluminação a gás, elétrica e telefone" 170

Ao espacializarmos os pedidos de construção encaminhados à prefeitura municipal entre os anos de 1906 e 1915, pudemos perceber que, apesar do grande volume de documentos trabalhados (pelo menos 2 mil processos), as ruas analisadas não pareciam estar em sua totalidade ocupadas por construções, pois, mesmo após termos alinhado cada projeto

\footnotetext{
${ }^{169}$ BUENO, Op. Cit, 2015.

${ }^{170}$ Idem, pág. 144.
} 
segundo o número do lote informado, as quadras não se preencheram, evidenciando que o processo construtivo no Brás prosseguiu mesmo após a data limite da nossa investigação, ou que a cidade "não oficial" possa ali ter existido, não sendo registrado pelo crivo municipal.

$\mathrm{Na}$ documentação processada, procuramos analisar a arquitetura produzida em cada um dos lotes por meio dos desenhos encaminhados para análise dos técnicos da prefeitura, e assim, compreender as características da tessitura urbana formada no Brás, trazendo em perspectiva os atores envolvidos (proprietários e inquilinos / usuários), tipologias edilícias, programas e usos. Numa primeira amostra eleita, e confirmando os dados levantados anteriormente, percebemos no Brás a predominância da construção de casas, seja uma única residência, conjuntos de casas em série ou vilas.

Muitos desses projetos referiam-se a pedidos para reforma de edificações para introdução de armazéns e comércios de pequeno porte, como cabeleireiros, botequins ou galpões para armazenamento de lenha. O perímetro eleito para estudo foram os limites do bairro até 1915: ao norte a avenida Carlos de Campos; ao sul a rua Visconde de Parnaíba; a oeste a rua Santa Rosa; e a leste a rua Bresser. Da espacialização dos projetos de obras particulares, e com apoio da cartografia, obtivemos os seguintes números:

\begin{tabular}{|c|c|c|c|c|c|}
\hline \multicolumn{6}{|c|}{ Relação de projetos de obras particulares referentes a ruas do Brás entre 1906-1915 } \\
\hline RUA & $\begin{array}{l}\text { NÚMERO } \\
\text { DE } \\
\text { PROJETOS } \\
\text { ANALISA- } \\
\text { DOS }\end{array}$ & $\begin{array}{c}\text { NÚMERO DE } \\
\text { RESIDÊNCIAS } \\
\text { CONTABILI- } \\
\text { ZADAS A } \\
\text { PARTIR DA } \\
\text { ANÁLISE DOS } \\
\text { PROJETOS }\end{array}$ & $\begin{array}{l}\text { NÚMERO } \\
\text { DE } \\
\text { PROJETOS } \\
\text { DE CASAS } \\
\text { EM SÉRIE } \\
\text { OU VILAS }\end{array}$ & $\begin{array}{l}\text { NÚMERO DE } \\
\text { ARMAZÉNS, } \\
\text { DEPÓSITOS } \\
\text { E GALPÕES }\end{array}$ & $\begin{array}{l}\text { NÚMERO DE } \\
\text { COCHEIRAS }\end{array}$ \\
\hline Alfândega & 16 & 27 & 3 & 6 & 0 \\
\hline $\begin{array}{l}\text { Álvares de } \\
\text { Azevedo }\end{array}$ & 13 & 14 & 1 & 0 & 0 \\
\hline Assunção & 21 & 30 & 5 & 3 & 0 \\
\hline $\begin{array}{l}\text { Azevedo } \\
\text { Júnior }\end{array}$ & 13 & 10 & 3 & 3 & 3 \\
\hline $\begin{array}{l}\text { Barão de } \\
\text { Ladário }\end{array}$ & 36 & 42 & 12 & 0 & 0 \\
\hline $\begin{array}{l}\text { Benjamin de } \\
\text { Oliveira }\end{array}$ & 16 & 20 & 5 & 4 & 0 \\
\hline Bering & 3 & 3 & 0 & 0 & 0 \\
\hline Bresser & \begin{tabular}{|l|}
273 \\
\end{tabular} & 278 & 57 & 73 & 7 \\
\hline $\begin{array}{l}\text { Campos } \\
\text { Sales }\end{array}$ & 25 & 21 & 4 & 2 & 0 \\
\hline $\begin{array}{l}\text { Carlos } \\
\text { Botelho }\end{array}$ & 13 & 34 & 7 & 2 & 1 \\
\hline
\end{tabular}




\begin{tabular}{|c|c|c|c|c|c|}
\hline Cavalheiro & 5 & 23 & 5 & 1 & 0 \\
\hline $\begin{array}{l}\text { Celso Garcia } \\
\text { (e Avenida } \\
\text { Intendência). }\end{array}$ & 330 & 190 & 40 & 123 & 28 \\
\hline $\begin{array}{l}\text { Claudino } \\
\text { Pinto }\end{array}$ & 16 & 9 & 1 & 4 & 0 \\
\hline Coimbra & 23 & 52 & 10 & 1 & 0 \\
\hline Concórdia & 71 & 64 & 4 & 21 & 6 \\
\hline $\begin{array}{l}\text { Conselheiro } \\
\text { Belisário }\end{array}$ & 29 & 30 & 3 & 6 & \\
\hline Cruz Branca & 8 & 0 & 0 & 3 & 0 \\
\hline $\begin{array}{l}\text { Domingos } \\
\text { Paiva }\end{array}$ & 11 & 4 & 0 & 8 & 0 \\
\hline Dona Júlia & 6 & 4 & & & \\
\hline $\begin{array}{l}\text { Elisa } \\
\text { Whitaker }\end{array}$ & 15 & 16 & 4 & 6 & 0 \\
\hline $\begin{array}{l}\text { Euclides da } \\
\text { Cunha }\end{array}$ & 10 & 10 & 1 & & \\
\hline $\begin{array}{l}\text { Fernandes } \\
\text { Silva }\end{array}$ & 5 & 9 & 1 & 2 & 0 \\
\hline Flora & 10 & 15 & 3 & 0 & 0 \\
\hline Florida & 8 & 5 & 0 & 3 & 0 \\
\hline Gasômetro & 35 & 30 & 4 & 17 & 0 \\
\hline $\begin{array}{l}\text { Gomes } \\
\text { Cardim }\end{array}$ & 19 & 26 & 6 & 3 & 1 \\
\hline $\begin{array}{l}\text { Henrique } \\
\text { Dias }\end{array}$ & 29 & 28 & 4 & 7 & 0 \\
\hline $\begin{array}{l}\text { Inácio de } \\
\text { Araújo }\end{array}$ & 22 & 59 & 10 & 4 & 0 \\
\hline Joao Boemer & 108 & 148 & 17 & 18 & 1 \\
\hline $\begin{array}{l}\text { Joaquim } \\
\text { Nabuco }\end{array}$ & 9 & 19 & 4 & 2 & 0 \\
\hline Joli & 50 & 56 & 9 & 14 & 1 \\
\hline $\begin{array}{l}\text { José } \\
\text { Monteiro }\end{array}$ & 9 & 13 & 2 & 0 & 0 \\
\hline Lucas, do & 13 & 21 & 4 & 4 & 0 \\
\hline $\begin{array}{l}\text { Major } \\
\text { Otaviano }\end{array}$ & 16 & 47 & 6 & 0 & 0 \\
\hline $\begin{array}{l}\text { Maria } \\
\text { Domitila }\end{array}$ & 4 & 6 & 2 & 1 & \\
\hline $\begin{array}{l}\text { Maria } \\
\text { Joaquina }\end{array}$ & 36 & 72 & 12 & 4 & 1 \\
\hline $\begin{array}{l}\text { Maria } \\
\text { Marcolina }\end{array}$ & 59 & 97 & 6 & 14 & 3 \\
\hline $\begin{array}{l}\text { Mendes } \\
\text { Gonçalves }\end{array}$ & 30 & 36 & 7 & 5 & 0 \\
\hline $\begin{array}{l}\text { Mendes } \\
\text { Junior }\end{array}$ & 40 & 41 & 7 & 4 & 3 \\
\hline Miler & 85 & 101 & 11 & 5 & 1 \\
\hline $\begin{array}{l}\text { Mista / Julio } \\
\text { Ribeiro }\end{array}$ & 39 & 43 & 5 & 6 & 2 \\
\hline $\begin{array}{l}\text { Monsenhor } \\
\text { Andrade }\end{array}$ & 42 & 32 & 4 & 11 & 1 \\
\hline Oriente & 53 & 79 & 19 & 0 & 0 \\
\hline Paraíba & 3 & 4 & 1 & 0 & 0 \\
\hline
\end{tabular}




\begin{tabular}{|c|c|c|c|c|c|}
\hline $\begin{array}{l}\text { Paulo } \\
\text { Afonso }\end{array}$ & 5 & 14 & 3 & 0 & 0 \\
\hline Ponte Preta & 11 & 19 & 0 & 0 & 0 \\
\hline $\begin{array}{l}\text { Rangel } \\
\text { Pestana }\end{array}$ & 216 & 95 & 2 & 58 & \\
\hline $\begin{array}{l}\text { Rodrigues } \\
\text { dos Santos }\end{array}$ & 21 & 64 & 4 & 3 & 2 \\
\hline $\begin{array}{l}\text { Sampaio } \\
\text { Moreira }\end{array}$ & 4 & 2 & 2 & 1 & \\
\hline Santa Clara & 31 & 26 & 6 & 1 & 4 \\
\hline Santa Rita & 29 & 48 & 9 & 2 & 0 \\
\hline Santa Rosa & 20 & 17 & 0 & 13 & \\
\hline Uruguaiana & 43 & 76 & 8 & 10 & 2 \\
\hline $\begin{array}{l}\text { Vinte e Um } \\
\text { de Abril }\end{array}$ & 62 & 109 & 21 & 2 & 5 \\
\hline $\begin{array}{l}\text { Visconde de } \\
\text { Abaeté }\end{array}$ & 3 & 11 & 2 & 1 & \\
\hline $\begin{array}{l}\text { Visconde de } \\
\text { Parnaíba }\end{array}$ & 50 & 97 & 14 & 9 & 1 \\
\hline Xavantes & 59 & 80 & 12 & 14 & 1 \\
\hline TOTAL & 2.231 & 2.526 & 408 & 504 & 74 \\
\hline
\end{tabular}

Tabela 5: "Relação de obras particulares referentes a ruas do Brás entre 1906-1915”, segundo suas tipologias construtivas, elaborada pelo autor com base na Série "Obras Particulares".

Cada um dos projetos foi ordenado de acordo com sua localização, rua a rua segundo suas numerações, possibilitando que tivéssemos um olhar sobre os perfis das ruas e dos proprietários e construtores envolvidos no processo de produção do bairro. Um primeiro ponto deve ser colocado em discussão: a ocupação das ruas trabalhadas por nós. A partir do momento em que obtivemos os desenhos da série obras particulares e os ordenamos segundo seus números, pudemos perceber que cada rua teve um processo distinto de ocupação, sendo que, enquanto algumas alcançaram o ano de 1915 com muitas construções ocupando a maioria de seus lotes, outras tinham poucas ou quase nenhuma em andamento.

Os lotes também não seguiam um padrão uniforme, dada a particularidade do processo de loteamento, em geral, por extensão do arruamento e menos por loteamentos formais. Os pedidos de alinhamentos efetuados por diferentes agentes não obedeceram à um programa de divisão exata de lotes, o que acabou por configurar uma colcha de retalhos, na qual as diferentes quadras, com variados tamanhos, interligavam-se umas às outras por meio de ruas que se formaram, ao longo do último quartel do século XIX, entremeando as artérias principais irradiadas a partir do centro da cidade. Afinal, a quem pertenciam estes lotes do Brás? Houve um processo de compra igualitário entre aqueles que residiam no bairro?

Partindo da análise do banco de dados por nós construído, percebemos que a grande maioria dos lotes tinham apenas um proprietário (contabilizamos um total de 869), 
totalizando assim, a marca de 73,8\% de proprietários no Brás, os quais, oficialmente, solicitaram entre os anos de 1906 a 1915 a construção ou reforma de apenas um edifício. Destaca-se a presença de um proprietário com 27 imóveis, João Ferreira, com a grande maioria de seus lotes distribuídos pela rua Inácio de Araújo (figuras 84 e 85), o qual possivelmente comprou uma extensa área da antiga chácara do proprietário que batiza o nome da rua citada, diferenciando-se drasticamente daqueles que possuíam o segundo maior número de imóveis na região: Manoel Alves de Faria, com 14 lotes distribuídos pelas ruas Casemiro de Abreu, Maria Marcolina, Mendes Gonçalves, Oriente, Sampson e Silva Teles; e Manoel da Corte, também com 14 lotes, distribuídos na rua Carlos Botelho.

Quantidade de lotes por proprietários do Brás

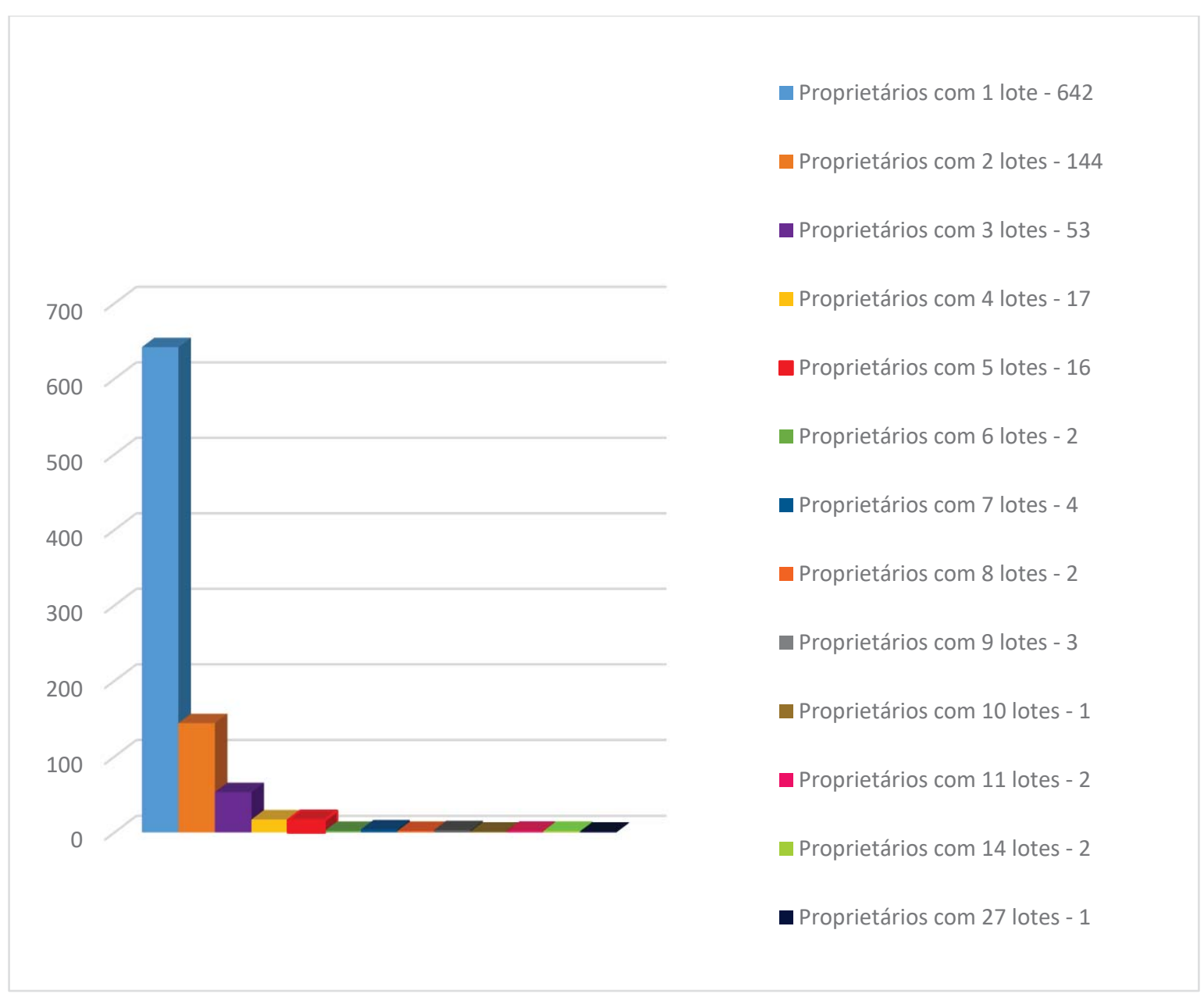

Gráfico 6: Número de proprietários com suas respectivas quantidades de lotes distribuídos no bairro do Brás, elaborado pelo autor com base na Série Obras Particulares do Arquivo Histórico Municipal. 
Nossa principal fonte documental, a Série Obras Particulares, permitiu que tivéssemos um olhar centrado na produção dos desenhos arquitetônicos, produzidos por construtores muitas vezes não diplomados, que atuavam não apenas no Brás, mas em toda a cidade, formando uma rede de produção sente inclusive no centro de São Paulo. Foram os desenhos das obras particulares, cotejados com outras fontes documentais que permitiram que novos dados e informações a respeito do processo de produção do Brás viesse à tona. Apesar de não nos determos especificamente na ação e espacialização dos construtores que assinaram os projetos de construção e reforma de edificações do Brás, elaboramos um gráfico que permite dar luz à quantidade de obras assinadas por tais. O gráfico 7 vai de encontro às pesquisas realizadas por Lindener Pareto Júnior, que traz em perspectiva a atuação destes profissionais desde o final do século XIX e os embates que estiveram em jogo com engenheiros e arquitetos até a década de $1930^{171}$.

171 PARETO JÚNIOR, Lindener. Pândegos, rábulas, gamelas: Os construtores não-diplomados entre a engenharia e a arquitetura, 1890-1960. Tese (Doutorado em Arquitetura e Urbanismo). São Paulo: Faculdade de Arquitetura e Urbanismo da USP, 2016. 
Projetos assinados por construtores, práticos-licenciados e arquitetos no Brás

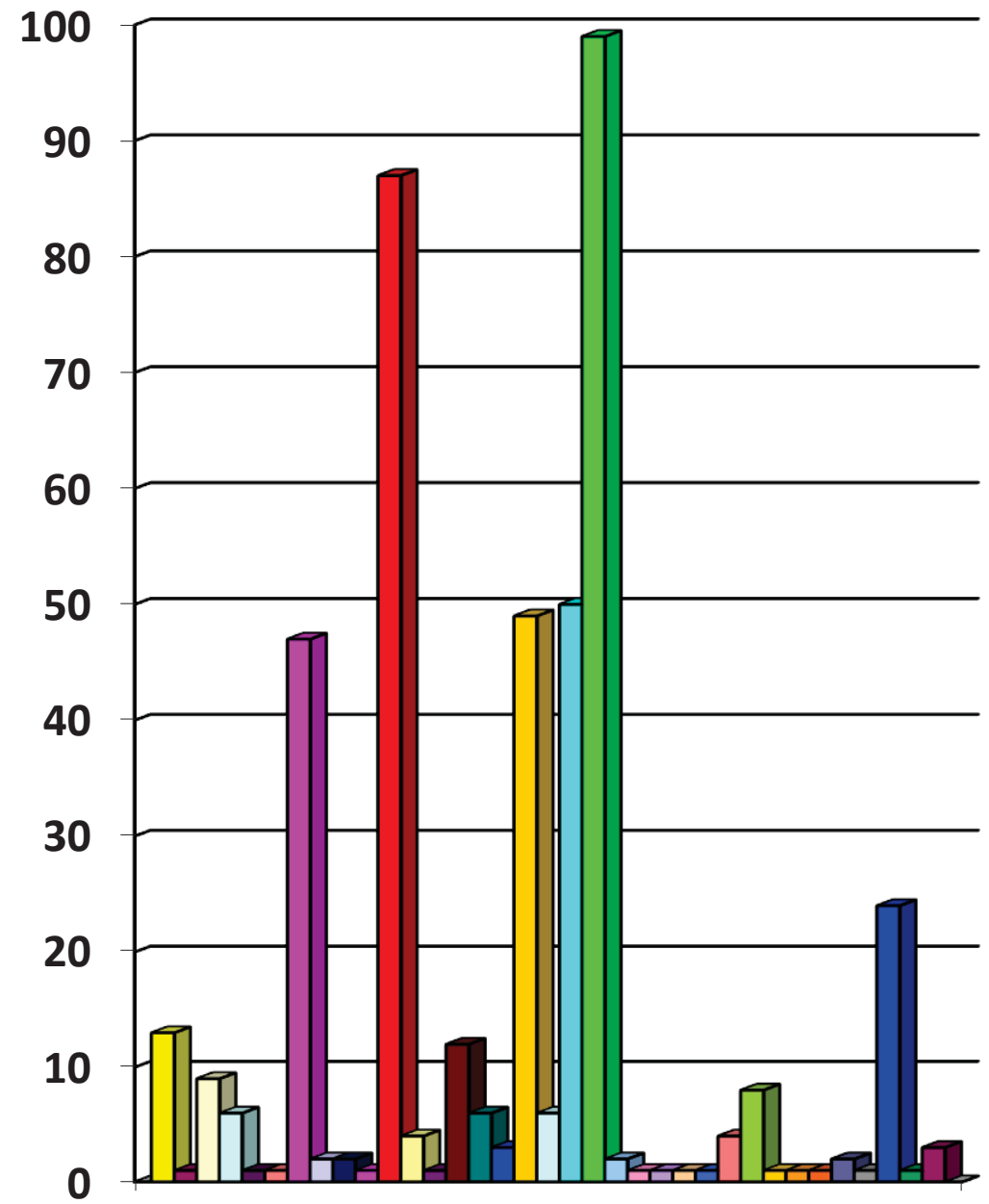

口Adalberto Bueno - 13

$\square$ Aeidel Bettoy - 1

AAlfredo Santos - 09

口Antonio Azevedo - 6

- Alessandro di Battisti - 1

B. Gauchery - 1

$\square$ Benedicto Bettoy - 47

David Ferreira / Pereira - 2

E. Maurer - 2

$\square$ Erhart e Ortroman - 1

口Fernando Simões - 87

口Ferreira e Cia - 4

- Francisco di Pace - 1

- Francisco Pompeo - 12

口 Hermilo Santos - 6

口 Horácio Nogueira - 3

口João Eusébio Peixoto - 49

口João Grass - 6

口Joaquim Cavalheiro - 50

口José Kanz - 99

口Julio Micheli - 2

ㄴ. Capobianchi - 1

- Luiz Asson - 1

- Luiz Bahia - 1

M. Andrade - 1

口M. Steidel e Bettoy - 4

口Manoel Francisco Dias - 8

口Pio Paste - 1

口S.P. da Costa - 1

口Sebastião Lang - 1

Silvino da Silva - 2

$\square$ Ramos de Azevedo - 1

- Raul dos Santos - 24

口Sante Bertolazzi - 1

Vicente Bianco - 3

Gráfico 7: Projetos assinados por construtores, práticos-licenciados e arquitetos no Brás, elaborado pelo autor com base na Série Obras Particulares do Arquivo Histórico Municipal.

Podemos observar que a grande maioria dos lotes que receberam obras destes construtores variavam em tamanho, o que permitia que a determinadas construções de habitação fossem mais profundas e seus espaços reaproveitados para outros fins, como uma segunda cocheira, galpão, etc. De maneira geral, pode-se perceber que havia um tamanho médio de terrenos que variava entre 8 e 15 metros de largura por 25 a 40 metros de 
profundidade. Aliás, muitos desses lotes não chegaram a configurar quadras retas, demonstrando um processo de loteamento que obedeceu aos desígnios do mercado imobiliário. Exemplo é o terreno de Abel Augusto Salles, localizado na rua Almirante Barroso, que sem definir a metragem exata do mesmo, demonstra que nele havia a possibilidade da construção de outra residência para além da existente ou de um quarto para ferragens nos fundos. Esta rua, quando analisada em seu conjunto, denota que até o ano de 1915 mereceu muitos projetos e novas construções disformes em lotes mais regulares e outro, como o apresentado por Abel Augusto Salles.

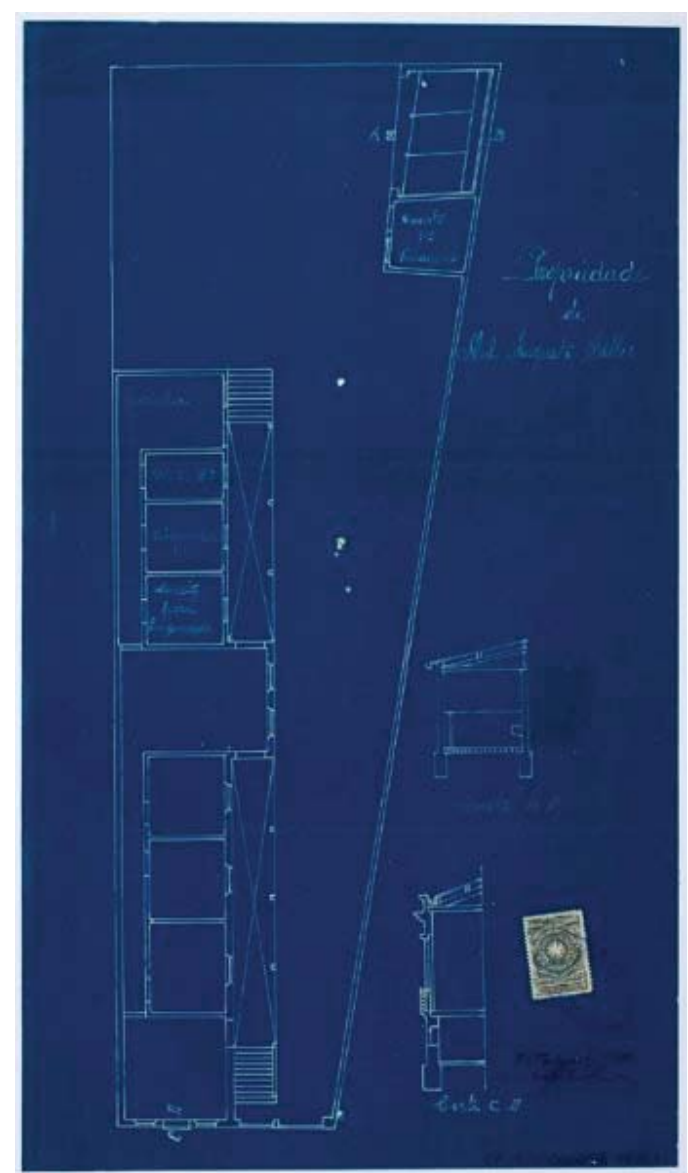

Figura 43: "Propriedade de Abel Augusto Salles", rua Almirante Barroso, s/n. Arquivo Histórico Municipal, Fundo "Diretoria de Obras", Série "Obras Particulares", OP1911.000.088.

A Série Obras Particulares nos permite compreender o processo de formação do bairro, seu ritmo e tipologias predominantes, relacionadas em geral à habitação e ao trabalho. Procuramos trazer ao debate o tipo de residência que se construiu no Brás entre os anos de 1906 e 1915, em meio aos demais edifícios ali construídos, com foco nos atores que os produziram e usaram a série Obras Particulares permite formular questões no que tange à história da habitação da porção leste da cidade de São Paulo nestas quase duas décadas. Analisando o conjunto de obras executadas no Brás e regiões próximas, podemos dizer que 
esta era uma região exclusivamente de cortiços e vilas operárias, como muito se convencionou falar na historiografia?

No tocante às construções destinadas à habitação, algumas considerações devem ser tecidas antes de iniciarmos nossas análises daquilo que se produziu no espaço e na época em questão. Uma primeira é que este material contém as intenções dos seus autores, proprietários de lotes que desejavam capitanear a construção (e às vezes reforma) de imóveis que eram cotejadas à legislação urbanística em curso desde finais do século XIX pelo quadro do funcionalismo público (envolvendo físcais e engenheiros) e aprovadas ou não para realização. Como visto anteriormente, muitas vezes o pedido constante no desenho arquitetônico não correspondia à realidade exata do lugar e das intenções do proprietário, estendendo-se o processo por alongarem-se as discussões por escrito entre a Diretoria de Obras e Viação da Prefeitura Municipal e o comitente / interessado / requerente.

O desenho, apesar de demonstrar visualmente aquilo que se pretendia realizar no lote, podia também ser apenas a formalização daquilo que já estava em curso na obra. Logo, sua leitura enquanto "documento fiel" deve ser atenta e minuciosa, o que não o exclui ou o torna menor diante de outras séries documentais. Para a história das cidades é imprescindível que haja uma conexão entre documentos, para que diferentes vozes, atores e ações se manifestem e confiram luz às dinâmicas de transformação e mudança efetuadas ao longo do tempo.

Ao analisarmos em conjunto os projetos referentes à construção de habitações produzidas no Brás entre os anos de 1906 e 1915, nos perguntamos qual o tipo de residências que estavam sendo construídas neste espaço. Percebemos que em muitos destes projetos haviam similaridades e diferenças, formando um espaço aparentemente homogêneo no conjunto, mas heterogêneo se atentarmos para cada uma das ruas, lote a lote.

Seguindo parte da metodologia empregada por Carlos Lemos ${ }^{172}$ em sua pesquisa sobre a questão habitacional de São Paulo entre os anos de 1893 e 1907, o qual teve por base as plantas das obras particulares contidas no acervo do Arquivo Histórico Municipal,

“evidentemente esse número não corresponde à totalidade das casas levantadas na cidade nesses catorze anos porque acreditamos ter sido enorme tanto o número

172 LEMOS, Carlos Alberto Cerqueira. Cozinhas, etc. São Paulo: Perspectiva, 1978. Alvenaria burguesa. Breve história da arquitetura residencial de tijolos em São Paulo a partir do ciclo econômico liderado pelo café. 2. ed. ver. Ampl. São Paulo, Nobel, 1989. . A República ensina a morar (melhor). São Paulo: Hucitec, 1999. 
de construções clandestinas (mais tarde regularizadas administrativamente) como outras situadas fora do perímetro urbano"173

Carlos Lemos reconhece que esta infinidade de construções apresentava uma gama de variadas soluções, com projetos de arquitetos, engenheiros e essencialmente construtores práticos e empreiteiros que atuavam sob pedido da população com menos recursos, o que não significaria que esta fosse a totalidade, haja vista que os setores médios vinham ganhando força ao longo do período em questão. Carlos Lemos identifica assim "casas de todos os tamanhos, desde as de três cômodos, ditas operárias, até as enormes, com dependências descomunais" $" 174$ espalhadas pela cidade, inclusive no Brás. Numa amostragem de 317 exemplares, classifica-as nas seguintes categorias:

- Cortiços: Englobariam toda sorte de habitação promíscua ${ }^{175}$, em que necessariamente os tanques de lavagem de roupa e as latrinas fossem de uso comunitário, sendo que aí também estão incluídas as moradias de até três cômodos, isolados entre si, mas com privadas compartilhadas por todos.

- Casas operárias: Moradias pequenas de até três acomodações, fora o WC de uso exclusivo da família.

- Casas de classe média baixa: Moradias com quatro cômodos e instalações sanitárias.

- Casas de classe média: Casas com qualquer número de dormitórios, mas portadoras de duas salas, a de receber (o "gabinete"), a sala de jantar (também chamada de "varanda"), fora a cozinha e as instalações sanitárias.

- Casas de classe média alta: Casas com qualquer número de dormitórios, mais salas de visitas, "gabinete" (agora com feições de escritório, sala de jantar, copa-cozinha e quarto de empregada), eventualmente constando uma despensa e um quarto de engomar, sendo construções realizadas quase sempre no alinhamento e com um jardim lateral, raramente assobradada.

173

$174 \overline{\text { Idem. }}$

Op. Cit., 1999, pág. 32.

175 O conceito de "promiscuidade" leva em consideração a mistura desordenada, alijada ao relacionamento sexual entre vários parceiros. Em contato com o historiador e teólogo Gregory Gallo, ele nos informa que seu significado na Idade Antiga (e particularmente em latim - promiscuu), estaria próximo ao sentido de "aquele para quem tudo é válido", sendo muito provável que a palavra foi ressignificada com a palavra porneia do grego, que traduziria as práticas sexuais gregas. Tradição que se prolongou pela Idade Média e chegou aos nossos dias, a promiscuidade estaria relacionada às práticas sexuais que fogem ao "padrão" de comportamento. Na passagem do século XIX para o XX, com as legislações sanitárias, o conceito fora absorvido e traduzido essencialmente para as habitações que continham diversos moradores, especialmente nas dependências dormitório. 
- Palacete: Raramente térrea, esta habitação seria o exemplo do chamado "morar à francesa", com elevada quantidade de acomodações individualizadas, como a "sala da senhora", o "fumoir", a sala de música, a biblioteca conjugada ao gabinete, quarto de hóspedes, sala de bilhar, sala de almoço, quarto da governanta, cocheira ou garagem.

- Mistas: As habitações que reuniram todas as soluções unidas a locais de comércio.

A categorização proposta por Carlos Lemos permitiu enquadrar soluções arquitetônicas encontradas nos cinco distritos da cidade: o Centro, a Liberdade, a Consolação, Santa Ifigênia e o Brás, sendo que para o último contabilizou um total de 70 construções, dentre as 317 sorteadas, apresentando destacado número de casas de classe média baixa (19 exemplares), casas de classe média (21 exemplares) e edificações com funções mistas (17 exemplares). Do levantamento das casas do Brás, o autor não identificou aquelas destinadas ao aluguel, questão recentemente levantada por Luciana Alem Gennari que trouxe importantes contribuições sobre o mercado imobiliário rentista nos bairros da Mooca e do Brás no final do século XIX até os anos de 1930, envolvendo a ação de investidores dos setores médios da população.

A partir da documentação processada por nós, estabelecemos um critério de ordenação das tipologias edilícias das diferentes formas de morar no Brás, essencialmente entre os anos de 1890 à 1915, cruzando diferentes fontes que permitiam tratar da formação do bairro com foco nas ações dos seus produtores (fiscais, proprietários, moradores e políticos). Com apoio da bibliografia, estabelecemos critérios para melhor compreender as formas de se construir e morar no Brás até o ano de 1915, data eleita como baliza final da pesquisa por encerrar-se a documentação disponível online. Assim, ordenamos os projetos segundo suas tipologias edilícias (cortiços, casas comuns, casas em série, sobrados e palacetes), procurando compreender onde, quando, por que, por quem e para quem foram realizados, bem como as formas de implantação no lote, buscando mostrar a heterogeneidade dos atores e soluções no Brás. 
2.3 Os cortiços da cidade de São Paulo: os embates entre a cidade oficial e a cidade clandestina

Como outras cidades da passagem do século XIX para o XX, São Paulo não fugiu à regra quanto à presença de cortiços, tipologia que esteve presente no centro e em novos bairros que surgiam nas franjas da cidade. Carlos Lemos nos indica que a maioria estava localizada fora dos distritos estudados em A República ensina a morar (melhor), dado este que pode ser relativizado, haja vista a quantidade numérica de cortiços existentes na região da Santa Ifigênia e que foi alvo de intensos estudos, a partir da análise do seu famoso relatório de comissão de exame e inspeção das habitações operárias e cortiços no distrito de Santa Ifigênia, de $1893^{176}$. Segundo Jaime Rodrigues, o relatório vai de encontro às discussões sanitárias da época de sua produção, e sua explicação deva ser "focada no higienismo e no saneamento urbano do que no combate a uma epidemia específica", no caso, a febre amarela ${ }^{177}$. Carlos Lemos também coloca que este tipo de residência da cidade de São Paulo não eram propriamente casas, mas "habitáculos singelos, onde havia superposição total de todas as funções da habitação"178, sem que houvesse uma divisão espacial dos cômodos da casa, contrapondo-se ao ideal de cidade desejada (da cidade oficial) pelos agentes públicos, traduzido em perspectivas sanitárias e de higiene próprio dos registros da época. A partir do levantamento realizado na base de dados SIRCA, de um total de 2.231 projetos pesquisados, apenas 17 registros trazem a palavra "cortiço" distribuídos por toda a cidade ${ }^{179}$, presentes na rua dos Oleiros, Monsenhor Andrade, Major Diogo, Almirante Barroso, São Domingos, dos Imigrantes, Aguiar de Barros, Rui Barbosa, 13 de Maio, Ladeira Porto Geral, Bresser, Caetano Pinto, Barão de Ladário, Alfândega e Gusmões, o que vai de encontro ao debate de produção construtiva oficial da cidade, não passando assim pelo crivo da Diretoria de Obras Municipal. Destacamos assim os projetos localizados em ruas do Brás e, a partir deles, cruzamos os endereços e nomes dos interessados no banco de dados elaborado por nós, analisando os pedidos de construção encaminhados à Prefeitura entre os anos de 1906 a 1915 e as respostas da municipalidade.

\footnotetext{
${ }^{176}$ LEMOS, Carlos. "Os primeiros cortiços paulistanos”. In: SAMPAIO, Maria Ruth Amaral de. Habitação e cidade. São Paulo: Laboratório de Programação Gráfica da FAUUSP, 1998; CORDEIRO, Simone Lucena (org.). Os cortiços de Santa Ifigênia: sanitarismo e urbanização. São Paulo: Imprensa Oficial, 2010.

${ }^{177}$ RODRIGUES, Jaime. "Da "chaga oculta” aos dormitórios urbanos: notas sobre higiene e habitação operária na São Paulo de fins do século XIX”. In: CORDEIRO, Op. Cit, pág. 79-80.

${ }^{178}$ LEMOS, Op. Cit., 1998, pág. 9.

${ }^{179}$ Lembrando que o total de projetos referentes à toda a cidade oficial, constantes no banco de dados SIRCA do Arquivo Histórico Municipal ultrapassa a casa dos 35 mil.
} 
Com base na documentação por nós processada no banco de dados, dos poucos cortiços que conseguimos mapear, pudemos aferir que muitos destes espaços de habitação coletiva já existiam nestas primeiras décadas do século $\mathrm{XX}$, e eram propriedades de pessoas ligadas ao mercado imobiliário, como por exemplo Ambrosina Amalia Franco de Macedo, que solicitou licença para reforma em seu imóvel na rua Monsenhor Andrade $n^{\circ} 98$ (casas 1,3 e 5), visto que recebera uma intimação do Serviço Sanitário para que suspendesse o telhado de um cortiço ${ }^{180}$, além de possuir um sobrado na rua da Concórdia sem número que tinha como construtor Otavio Macedo ${ }^{181}$. Interessante notar que este mesmo endereço, três anos antes, era de propriedade de Miguel d'Elias, que solicitara a construção de uma casa nos fundos de uma edificação já existente ${ }^{182}$. O projeto apresentado por Miguel d'Elias parece indicar tratar-se de uma residência com dois cômodos grandes e entradas laterais diretas e independentes e ligeiramente afastado. Presumimos que o pedido de reforma se refira não à casa, mas a uma ampliação da própria construção, introduzindo uma cozinha após os cômodos e um banheiro, reforma destacada em vermelho.

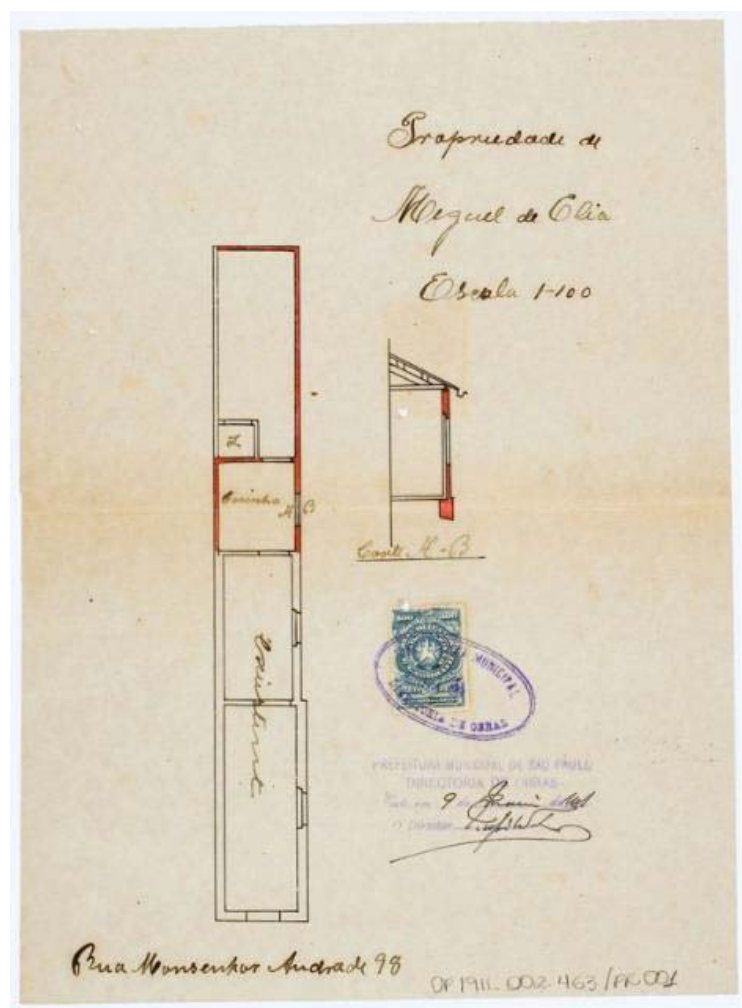

Figura 44: "Propriedade de Miguel d'Elia", Arquivo Histórico Municipal, Fundo "Diretoria de Obras", Série "Obras Particulares, OP1911.002.463.

${ }^{180}$ Arquivo Histórico Municipal, Fundo "Diretoria de Obras", Série “Obras Particulares”, OP1914.003.172
${ }_{181}$ Arquivo Histórico Municipal, Fundo "Diretoria de Obras", Série “Obras Particulares", OP1914.001.305
${ }^{182}$ Arquivo Histórico Municipal, Fundo "Diretoria de Obras”, Série “Obras Particulares", OP1911.002.463 
Os pedidos de construção de telheiros que indicam na realidade tratar-se de serem destinados às dependências de cortiços parece ter sido uma questão frequente entre os proprietários de imóveis no Brás, pois, assim como Ambrosina Amalia Franco de Macedo, Manoel Joaquim também pediu autorização para construção de mesma natureza, alegando ser para cobertura de um tanque para guardar lenha, em sua propriedade na rua Almirante Barroso, número 156, solicitando inclusive a guia de pagamento do imposto municipal sobre construções. Em nota, o fiscal negou veementemente a licença solicitada, afirmando "que o telheiro não era para tanque e sim para uma casinha coletiva, banheiro, tratando-se de um cortiço" $" 183$.

Os cortiços abrigavam outras funções além da moradia, servindo de espaços da diversificação de renda dos seus proprietários, como o de Antonio Pagano que, em 1907, solicitou licença para transformação do cortiço existente na rua Caetano Pinto (sem número), em local de moradia e comércio ${ }^{184}$, o que não significava que realmente tivesse a intenção de acabar com as moradias ali existentes, mas apenas adequá-las aos preceitos da legislação da época. Não tão distante, Victorino da Ressurreição (nome que aparece diversas vezes em nosso banco de dados, seguido de distintos sobrenomes) era proprietário de um imóvel na rua Barão de Ladário, número 12, e solicitou autorização para a reforma de um cortiço e a construção de outras casas ${ }^{185}$.

Raquel Rolnik nos lembra que tanto o Código de Posturas de 1886, como o Padrão Municipal do mesmo ano, tinham dois tratamentos distintos sobre os cortiços na cidade. $\mathrm{O}$ primeiro procurava em seu $20^{\circ}$ artigo proibir

\footnotetext{
“a construção na capital, a não ser que ocupasse um terreno com mais de 15 metros de largura, tivesse uma separação de pelos menos 5 metros entre cada linha de cortiços; no caso de constar de uma só peça deveria ter pelo menos 5 metros quadrados de área, janelas de no mínimo 90 centímetros, pé-direito de 4 metros, e 20 centímetros de elevação em relação ao solo. Já no Padrão Municipal os cortiços inauguraram um capítulo à parte intitulado "Cortiços, casas de operários e cubículos"”. 186
}

\footnotetext{
${ }^{183}$ Arquivo Histórico Municipal, Fundo “Diretoria de Obras”, Série “Obras Particulares”, OP1914.000.097

${ }^{184}$ Arquivo Histórico Municipal, Fundo "Diretoria de Obras”, Série "Obras Particulares”, OP1907.000.313.

185 Arquivo Histórico Municipal, Fundo "Diretoria de Obras”, Série “Obras Particulares”, OP1906.000.150

${ }^{186}$ ROLNIK, Raquel. A cidade e a lei: legislação, política urbana e territórios na cidade de São Paulo. São Paulo: Studio Nobel: Fapesp, 1997, pág. 35-36.
} 
Analisando o Código de Obras de 1894, verificamos que o mesmo opõe-se à legislação pré-existente, proibindo terminantemente os cortiços:

Artigo 138. - Deve ser terminantemente prohibida a construcção de cortiços, convindo que as municipalidades providenciem para que desappareçam os existentes.

Artigo 139 - Não devem ser toleradas as grandes casas subdivididas, que servem de domicilio a grande número de individuos.

Artigo 140. - Todas as exigencias estabelecidas para as habitações em geral devem ser applicadas ás habitações das classes pobres

Esta ambiguidade da legislação que permitia e ao mesmo tempo restringia determinadas condições e em determinadas áreas da cidade a construção de cortiços, além de ir ao encontro de promover a habitação individual (como prezava o Artigo 139), era o que garantia a pequenos proprietários, como Antônio Regas (proprietário de um imóvel na rua Bresser número 42), encaminharem pedidos à Intendência (e mesmo à Prefeitura) disfarçados de casas ou vilas que, na realidade, eram habitações coletivas. Ao entrar com um pedido de licença para aumentar a área ocupada pelas suas casas e realizar diversos outros consertos, o fiscal municipal entende (no seu parecer de 06 de fevereiro de 1907) que a área tratava-se de um cortiço "fora de todas as regras", e assim solicitou a apresentação de planta "obedecendo as determinações legais" ${ }^{187}$. O posicionamento do fiscal ia ao encontro ao que preconizava a lei número 38 de 24 de maio de 1893, que tornava obrigatória a apresentação de plantas para as novas edificações da cidade ${ }^{188}$, e como parte do Código de Posturas do mesmo ano, proibia os cortiços. Antonio Regas destacava-se por sua atuação no mercado imobiliário do Brás, sendo proprietário de uma vila de 9 casas com padrão mínimo (de três cômodos), na rua Cajuru número 189 no bairro do Belenzinho, contratando inclusive os serviços do construtor Fernando Simões para assinar o requerimento e o projeto em 1912. ${ }^{189}$ Além destas, ainda contava com uma casa na rua Onze de Agosto ${ }^{190}$ e outras duas geminadas na rua Baronesa de Itu $^{191}$, no Centro da cidade e em Santa Cecília respectivamente.

\footnotetext{
${ }^{187}$ Arquivo Histórico Municipal, Fundo "Diretoria de Obras”, Série “Obras Particulares”, OP1907.002.272

${ }^{188}$ Leis e resoluções da Câmara Municipal da capital do Estado de S. Paulo de 29 de setembro de 1892 a 30 de dezembro de 1893. São Paulo: Typ. Official, s/d, p.104-5

${ }^{189}$ Arquivo Histórico Municipal, Fundo "Diretoria de Obras”, Série “Obras Particulares", OP.1912.000.945

${ }^{190}$ Arquivo Histórico Municipal, Fundo "Diretoria de Obras”, Série “Obras Particulares”, OP1913.003.896

${ }^{191}$ Arquivo Histórico Municipal, Fundo "Diretoria de Obras”, Série “Obras Particulares”, OP1908.000.246
} 


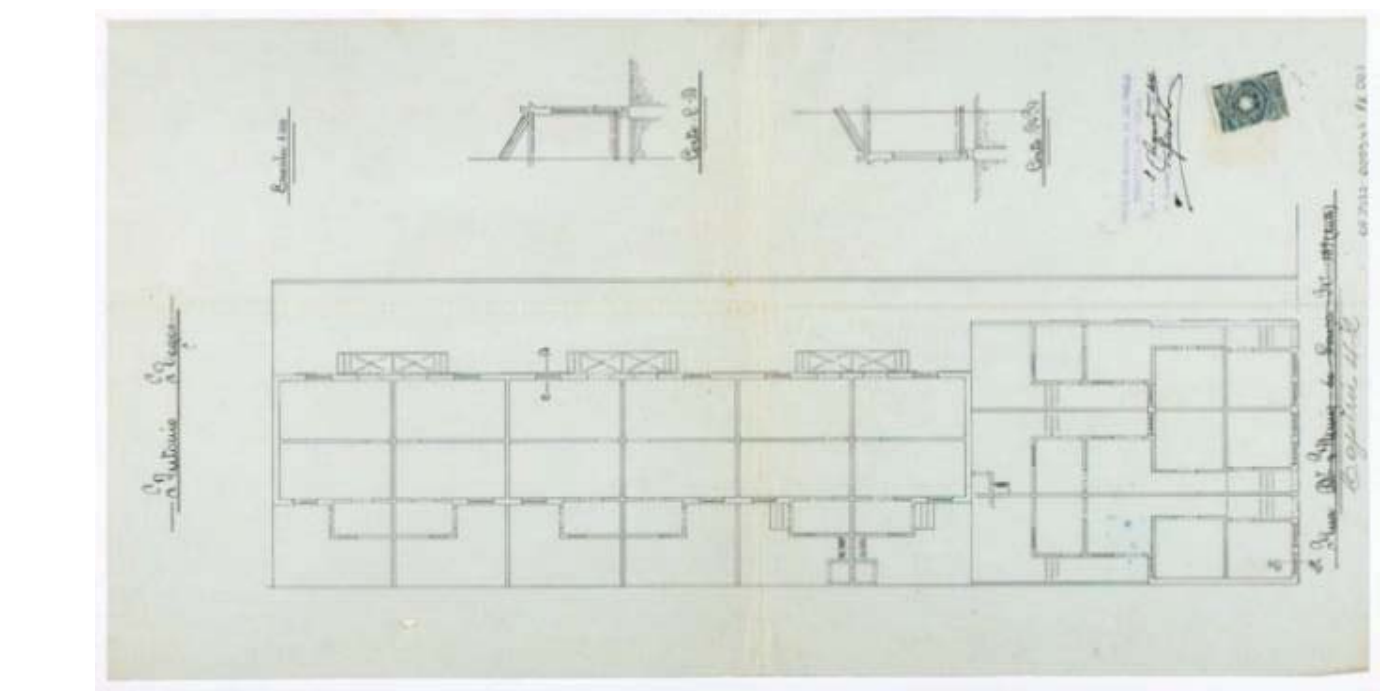

Figura 45: “Antonio Regas" - Arquivo Histórico Municipal, Fundo "Diretoria de Obras", Série "Obras Particulares”, OP.1912.000.945

Os cortiços do Brás apesar de não terem sido alvo constante da Diretoria de Obras e Viação da Prefeitura Municipal, constantemente passaram pelo crivo dos fiscais que atuavam na região. Pouco antes da promulgação das leis que orientavam as construções na cidade, a fiscalização já vinha dando sinais de sua atuação.

Curiosamente, ao contrário do que pensávamos inicialmente, na série Obras Particulares do Arquivo Histórico Municipal não encontramos uma quantidade significativa de referências a cortiços. Nesse sentido, procuramos nos basear em outros conjuntos documentais que trouxessem à tona a presença desse tipo de habitação no Brás. Considerando que a construção dos mesmos tornou-se ilegal, mas que ao mesmo tempo podiam existir desde que seguissem determinadas normas, procuramos seguir os fios e os rastros do perfil técnico administrativo da Intendência e posterior Prefeitura de São Paulo. Sobre o período da Intendência, é de se destacar que ele vinha acompanhado da nova ideologia republicana, de conferir um novo perfil às administrações de Estado, e com relação às cidades, suas Câmaras seriam dissolvidas e um dos vereadores seria eleito entre seus pares a fim de ocupar a Presidência da mesma, denotando, assim, um primeiro esboço do Executivo municipal. Em São Paulo, a Intendência passou a vigorar desde 1892, sendo que sua administração fora dividida em quatro Intendências que zelavam pela administração pública local: Justiça e Polícia, Higiene e Saúde Pública, Obras Municipais e Finanças, sendo que cada uma delas ficava sob a direção de um Intendente escolhido pelos vereadores, documentação que posteriormente fora organizada em oito caixas sob o Fundo Intendência Municipal. 
Todo este aparato de mudanças técnico-administrativas ia ao encontro das transformações urbanas que a cidade vinha passando, logo, os registros do cotidiano dessa cidade que cada vez mais e mais se avolumavam, e paralelamente as Intendências administrativas aperfeiçoaram suas práticas de fiscalização e controle. Em 1899 ocorreu a criação do cargo de prefeito, sendo Antônio da Silva Prado o primeiro da cidade de São Paulo. Diante dos poucos registros alusivos a cortiços encontrados no volumoso conjunto documental oriundo da Intendência de Obras e Viação, do Grupo Diretoria de Obras e Viação, do qual fazia parte a Série Obras Particulares, optamos por perseguir, a partir de outro conjunto documental: o Grupo Polícia e Higiene, que abarca o período de 1892 a 1898.

O Grupo nos trouxe muitas surpresas. A partir da leitura dos diversos relatórios dos fiscais encaminhados aos membros da Intendência foi possível traçar o perfil de certos personagens antes não identificados na pesquisa, atores que também participaram do processo de urbanização que a cidade vinha enfrentando e procuravam se inserir na mesma.

José Ignacio de Oliveira Arruda fora um destes fiscais que atuaram pela cidade no começo de 1890. Sua área, o Brás, era seu espaço de físcalização, e como físcal descreveu o que via, e ao mesmo tempo posicionando-se diante daquilo que estava fora dos padrões pré-estabelecidos pela legislação em vigor. Em 29 de janeiro de 1892, escreveu ao Presidente da Intendência Francisco Ignacio de Toledo Barboza e aos demais membros da Intendência, registrando as "péssimas condições de higiene, no barracão da rua Piratininga, onde moram várias famílias de italianos". Apesar de anteriormente já ter intimado o proprietário do imóvel, Francisco Cacelli, para que não continuasse a fazer do espaço um cortiço, percebeu que "continua o mesmo a dar moradia no referido barracão a uma multidão de italianos que não tendo a limpesa necessaria e sem as comodidades proprias como sejão esgotos e latrinas" os mesmos "fasem ordinariamente os dispejos na rua, empestando assim a salubridade publica", intimou assim o proprietário do cortiço a comparecer na Subdelegacia Policial "a fim de lhe ser ordenado o dispejo da referida gente no praso de 48 horas"192.

Os cortiços eram alvo corrente da Intendência de Polícia e Higiene, que cumpria um papel de fiscalizar a ordem pública, denunciando as más condições de vida da população de menos condições financeiras. José Arruda, em outro relatório sobre o cortiço da rua

\footnotetext{
${ }^{192}$ Fundo: Intendência; Grupo: Polícia e Higiene; Série: Relatórios fiscais; Caixa: 5; Acervo Arquivo Histórico mUnicipal; Relatórios fiscais de Data: 29 de janeiro de 1892
} 
Piratininga ainda relatou que a falta de limpeza e higiene era o que provava "o facto de haverem morrido alguns ali de febre palustre e estarem outras atacadas do mesmo mal", e acrescentando que "a propria multa perde a sua eficácia em virtude de serem os mesmos miseráveis e não podem paga-la". Nesse sentido, pediu que o proprietário do barracão fosse intimado e responsabilizado pelas chamadas "infracções de limpesa ocorridas ali, ou que seja o mesmo considerado cortiço a fim de pagar o imposto e como tal sujeito as leis como é de pracee", lembrando inclusive que "o referido barracão deveria ser feiceado, a bem da salubridade publica, vistas as rasões que vem de [...], muito embora a aparência de sua frente illuda a quem não penetrar no referido barracão."193

Considerados focos de proliferação de doenças, os cortiços seriam identificados como espaços da não higiene e causadores de inúmeras enfermidades que vinham ganhando força não apenas em São Paulo, mas em diversas outras cidades do país ${ }^{194}$. José Arruda possuía um olhar sobre sua área que ia além da simples intimação das pessoas, descrevendo o ambiente e a situação em que muitas viviam no Brás na última década do século XIX. Em relatório de 25 de maio de 1892, escreveu à Clementino de Souza e Castro, presidente da Intendência Municipal, sobre a existência de cortiços na rua Carneiro Leão, de propriedade de Maria Berine, indo "respeitosamente representar contra a existência dos mesmos cortiços não só pela falta de hygiene nos curtiços como pela maneira immunda por que são conservados, sem limpesa alguma, apesar de constantes intimações feitas por si na qualidade de fiscal", e que mesmo tendo autorização verbal para que se fechem tais cortiços, os mesmos não são cumpridos, mesmo sendo considerados "foco de miasmas e febres de todas as qualidades", pedindo que se encontre "uma medida útil a salubridade publica". ${ }^{195}$

A atuação de José Arruda parece ter ido além da simples verificação dos cortiços e aplicação de multas aos proprietários dos existentes no Brás, pois, chegou inclusive a ser denunciado por Giuseppe Boschini, negociante e proprietário na rua Carlos Garcia sem número, alegando que seu prédio nunca teve forma ou adaptação de cortiço em 1896:

\footnotetext{
“appareceu em sua casa o Capitão José Ignacio d’Oliveira Arruda, Inspetor de Fiscalisação, que sob o pretexto de que sua casa era um cortiço exigio do suplicante a quantia de $160 \$ 000$, para pagamento de impostos, quantia esta que o supplicante prontamente satisfez, na persuasão de que fasia um pagamento de
}

\footnotetext{
${ }^{193}$ Idem.

${ }^{194}$ Ver CHALHOUB, Sydney. Cidade febril: cortiços e epidemias na corte imperial. São Paulo: Companhia das Letras, 1996.

${ }^{195}$ Arquivo Histórico Municipal, Fundo "Intendência"; Grupo: "Polícia e Higiene"; Série "Relatórios fiscais"; Caixa: 5; Data: 25 de maio de 1892.
} 
imposto a que estivesse sujeito. Mais tarde, porém, indagando o supplicante soube que esta quantia lhe fora extorquidas por abuso do Capitão Arruda por isso que não entrou para os cofres do Thesouro Municipal"

A insatisfação de Giuseppe Boschini vai além, quando relata que poucos meses antes “appareceu em sua casa um funcionário da Municipalidade que avisou ao supplicante que estava collectado para o pagamento do imposto sobre cortiços, e isto com supresa para o suplicante", e logo depois

\begin{abstract}
"appareceu em sua casa o mesmo Capm. Arruda que disse ao supplicante que para eximir-se da responsabilidade de pagar o imposto sobre cortiços devia faser approvar uma planta na Repartição respectiva e exigio-lhe adiantadamente a quantia de quarenta mil reis (40\$000), que o supplicante promptamente satisfez com o intuito de evitar questões e para sua tranquilidade, com o receio de ser victima de perseguições do Fiscal Arruda, geralmente conhecido como perseguidor dos munícipes que não satisfazem ás suas exigencias pecuniárias."
\end{abstract}

Infelizmente, não sabemos se o fiscal Arruda realmente mereceu alguma punição ou mesmo se o caso foi resolvido, mas importante é documentar as relações entre aqueles que cumpriam os desígnios do poder público com os agentes privados. Não sabemos se a tal planta foi encaminhada à Intendência de Obras, mas o proprietário clama ao final de sua petição que possa ficar "tranquilo e livre das perseguições do Fiscal Arruda, que ameaça perseguir o supplicante." $" 196$

Segundo as anotações do fiscal José de Arruda, os cortiços eram instalações em habitações improvisadas, instalando-se quartos nos fundos ou anexo à edificação já existente, a partir dos chamados "barracões", tipo de construção que apareceu com frequência na documentação das Obras Particulares entre os anos de 1906 a 1915, em meio a outros destinados a cocheiras ou materiais de construção e carpintaria. Fato é que eventualmente tal construção também poderia ser destinada à habitação, e o nome indicado ser apenas uma forma de afastar os fiscais. Em 1892, o Presidente da Intendência, Cesário Ramalho da Silva, apresentou uma determinação, dirigida a todos os fiscais dos distritos do Brás, Santa Ifigênia, Consolação e Sé para que apresentassem "uma relação de todos os cortiços existentes, bem como, que fossem observadas rigorosamente as posturas

${ }^{196}$ Arquivo Histórico Municipal, Fundo "Intendência”; Grupo: "Polícia e Higiene”; Série "Relatórios fiscais”; Caixa: 5 ; sem data. 
municipais, quanto à limpeza pública e terrenos de particulares que encontram-se com águas estagnadas"197, condenando terminantemente como uma das medidas finais que condenassem de vez a existência dos cortiços na cidade. Sobre a região de Santa Ifigênia, a historiografia caminhou a largos passos, mas falta um olhar mais acurado sobre os cortiços existentes em outras regiões da cidade, como o Brás, reduto de grande parte dos novos habitantes da cidade.

Neste universo estudado, o cortiço de Maria Barine voltou à discussão, e em 04 de julho de 1892 lhe foi determinado o prazo de quinze dias para demolir sua propriedade na rua Carneiro Leão. O engenheiro do distrito do Brás, ao analisar este cortiço anteriormente, escreveu que

\footnotetext{
"há completa falta de asseio em toda a entrada (única) para os mesmos cortiços havendo grande quantidade de águas estagnadas eshalando mao cheiro constantemente em prejuízo da saúde pública. Além disso está completamente fora do padrão municipal, não tendo seu proprietário seguido o regulamento para construção idênticas adoptado pela Intendência." 198
}

Pouco mais de duas semanas, um minucioso relatório foi apresentado pelo fiscal do Brás, José Ignacio de Oliveira Arruda, listando todos os cortiços do distrito, com seus proprietários, endereços, quantidade e, eventualmente, observações: "em cumprimento a deliberação do Illustre Conselho de Intendência”. Com base nesse relatório, elaboramos a tabela a seguir:

\begin{tabular}{|c|c|c|}
\hline \multicolumn{3}{|c|}{ Relação dos cortiços do Brás em 1892} \\
\hline PROPRIETÁRIO & ENDEREÇO & $\begin{array}{l}\text { QUANTIDADE } \\
\text { DE CORTIÇOS }\end{array}$ \\
\hline Guilherme Antonio de Godoy & Rua Carneiro Leão, 17 & 3 \\
\hline Caetano Luçéro & Rua Carneiro Leão, 17 A & 3 \\
\hline José Martins Real & Rua Carneiro Leão, portão número 39 & 28 \\
\hline José Raprial & Rua Carneiro Leão, $13 \mathrm{~A}$ & 2 \\
\hline Fuam Arlindo (corneta mor) & Rua Carneiro Leão, 9 & 3 \\
\hline Manoel de Aguiar & Rua Carneiro Leão, 11 & 3 \\
\hline Giuseppe Pico & Rua Carneiro Leão, sem número & 3 \\
\hline Maria Berini & Rua Carneiro Leão, sem número & 18 \\
\hline Benedicto Alves de Fonseca & Rua Carneiro Leão, sem número & 5 \\
\hline Pascoal Caporino & Rua Visconde de Parnaíba, sem número & 1 \\
\hline José Brandieri & Rua Visconde de Parnaíba, sem número & 4 \\
\hline Francisco Carmellio & Rua Visconde de Parnaíba, sem número & 1 \\
\hline Paulo Manja Carvalho & Rua Visconde de Parnaíba, sem número & 1 \\
\hline José Brandini & Rua Visconde de Parnaíba, 58 & 5 \\
\hline Manoel Carneiro Reis & Rua Visconde de Parnaíba, sem número & 13 \\
\hline
\end{tabular}

197 Arquivo Histórico Municipal, Fundo "Intendência"; Grupo: "Polícia e Higiene"; Série "Relatórios do Presidente da Intendência”; Data: 1892.

${ }_{198}$ Arquivo Histórico Municipal, Fundo "Intendência"; Grupo: "Polícia e Higiene"; Série "Relatórios fiscais"; Caixa: 5; Relatório de 02 de julho de 1892. 


\begin{tabular}{|c|c|c|}
\hline Antonio Purtuguez & Rua Visconde de Parnaíba, sem número & 6 \\
\hline José do Rego & Rua Visconde de Parnaíba, 90 & 2 \\
\hline José de Souza M. B. & Rua Visconde de Parnaíba, 93 & 10 \\
\hline Luiz Angelo e Campos & Rua Concórdia, sem número & 4 \\
\hline Companhia Industrial do Brasil & Rua Concórdia, sem número & 3 \\
\hline Januario Marco & Rua Santa Rosa, número 15 & 5 \\
\hline Francisco Guedes & Rua Santa Rosa, número 23 & 4 \\
\hline Barão de Jaguará & Rua Santa Rosa, número 31-53 & 5 \\
\hline Campim (?) Primo & Rua Santa Rosa, número 1 & 3 \\
\hline $\mathrm{D}^{\mathrm{a}}$ Roza Ozorio & Rua da Mooca, sem número & 12 \\
\hline Antonio Augusto Corrêa & Rua da Mooca, número 49 & 2 \\
\hline Affonso Cammara & Rua do Gasômetro, número 56 & 6 \\
\hline J. Sampaio Moreira & Rua do Gasômetro, número 97 & 4 \\
\hline Dr. João Baptista de Alvarenga & Rua do Gasômetro, número 99 & 7 \\
\hline Luiza Antonieta Jury (?) & Rua do Gasômetro, número 75 & 38 \\
\hline $\begin{array}{l}\text { Comendador José Rangio (?) } \\
\text { Nobrega }\end{array}$ & Avenida Rangel Pestana, número 2 & 16 \\
\hline Manoel Joaquim de Oliveira & Avenida Rangel Pestana, número 43 & 5 \\
\hline Salvador Marotto & Avenida Rangel Pestana, número 45 & 3 \\
\hline Emilia Francisca Braga & Avenida Rangel Pestana, número 66 & 3 \\
\hline José Mathias Oleiro (?) & Avenida Rangel Pestana, sem número & 3 \\
\hline José Bento Rodrigues & Rua Maria Domitila, número 2 & 5 \\
\hline Felicio Canolli & Rua Maria Domitila, número $2 \mathrm{~A}$ & 4 \\
\hline José Carreira & Rua Maria Domitila, número 31 & 7 \\
\hline José Caetano Motta & Rua Maria Domitila, número 43 & 8 \\
\hline Dr. Carlos Villa Nova & Rua Benjamin de Oliveira & 3 \\
\hline José Santa Anna e Silva & Rua Caetano Pinto, número 26 & 1 \\
\hline Joaquim Rugi & Rua Caetano Pinto, sem número & 9 \\
\hline Francisco Julião & Rua Caetano Pinto, sem número & 3 \\
\hline Paulo Pascoal & Rua Caetano Pinto, número 16 & 5 \\
\hline Angela Maria & Rua Caetano Pinto, 16 & 5 \\
\hline Galbigio Pilijanta (?) & Rua Caetano Pinto, sem número & 5 \\
\hline Antônio Fazendelli & Rua Caetano Pinto, sem número & 5 \\
\hline Paulo Bianti & Rua Caetano Pinto, sem número & 5 \\
\hline Francisco Talisani & Rua Caetano Pinto, número 6 & 2 \\
\hline Francisco Belanni & Rua Caetano Pinto, número 4 & 8 \\
\hline Julio Juliano & Rua Caetano Pinto, número 49 & 4 \\
\hline Caetano Vialho & Rua Caetano Pinto, número 47 & 4 \\
\hline Angelo Constanci & Rua Caetano Pinto, número 45 & 5 \\
\hline Nome não identificado & Largo da Concórdia & 5 \\
\hline João Gomes de Castro & Rua Domingos Paiva, sem número & 4 \\
\hline T. Patisco (?) de Barros & Rua Domingos Paiva, número 11 & 1 \\
\hline Pascoal Martins & Rua Domingos Paiva, sem número & 1 \\
\hline Cesare Puctinelli & Rua Monsenhor Andrade, número 24 & 1 \\
\hline Miguel de Oliveira Prigoto & Rua Carlos Garcia, 10 A & 10 \\
\hline Alves Penteado \& Filho & Rua Cruz Branca, número 7 & 16 \\
\hline José Lampião & Rua Cruz Branca, sem número & 5 \\
\hline Constantino Maia & Rua São Caetano, número 113 & 2 \\
\hline Dr. Pereira Barreto & Rua São Caetano, 113 B & 10 \\
\hline D ${ }^{a}$ Emilia B. Puscato & Rua São Caetano, número 111 & 10 \\
\hline Francisco Rodriguez Bettancurt & Rua São Caetano, 116 & 6 \\
\hline Capitão Messias E. dos Santos & Avenida Intendência, sem número & 4 \\
\hline João Punchetti & Avenida Intendência, sem número & 11 \\
\hline \multicolumn{2}{|c|}{ TOTAL DE CORTIÇOS MAPEADOS NO BRÁS PARA O ANO DE 1892} & 408 \\
\hline
\end{tabular}

Tabela 6: "Relação de cortiços do Brás em 1892". Quadro elaborado pelo autor com base no relatório do

Fiscal de Polícia e Higiene do Brás, José Ignacio de Oliveira Arruda, de 20 de junho de 1892, encaminhado ao Presidente da Intendência Municipal, Cesário Ramalho da Silva. 
O quadro dá ideia das ruas onde se concentravam os cortiços: Caetano Pinto, Carneiro Leão e Visconde de Parnaíba, em meio a outras onde também apareciam, embora mais pulverizadamente. As três supracitadas apresentaram um destacado número de solicitações para novas construções e reformas encaminhados à aprovação da Intendência Municipal entre 1872 e 1899, conforme apresentado no gráfico 4.

Se para o ano de 1892 conseguimos uma relação de pelo menos 408 cortiços apenas para a região do Brás, entendemos que os números para a cidade tenham sido muito maiores, algo que merece cotejamento já que o relatório estendia-se aos demais distritos. Concentrando-nos no Brás, procuramos comparar os endereços dos cortiços de 1892 com os números dos lotes da Série Obras Particulares, mas nenhum pôde ser relacionado com as plantas que dispomos. Procuramos então pelo nome dos proprietários e os resultados foram mais promissores. Acreditamos que os proprietários listados nos cortiços sejam os mesmos proprietários das construções, cuja autorização foi solicitada à Prefeitura entre os anos de 1906 e 1915: Manoel Reis, por exemplo, solicitava a construção de uma casa em $1910^{199}$ na rua Maria Marcolina; Francisco Guedes aparece com 4 cortiços na rua Santa Rosa número 23. Este mesmo personagem pode ter adquirido um terreno entre as ruas Martim Afonso e a avenida Celso Garcia, continuando a continuar a atuar no mercado imobiliário, com a construção de duas casas mínimas, em que a entrada se fazia da rua diretamente para o quarto, e ao lado havia dois escritórios e um armazém.

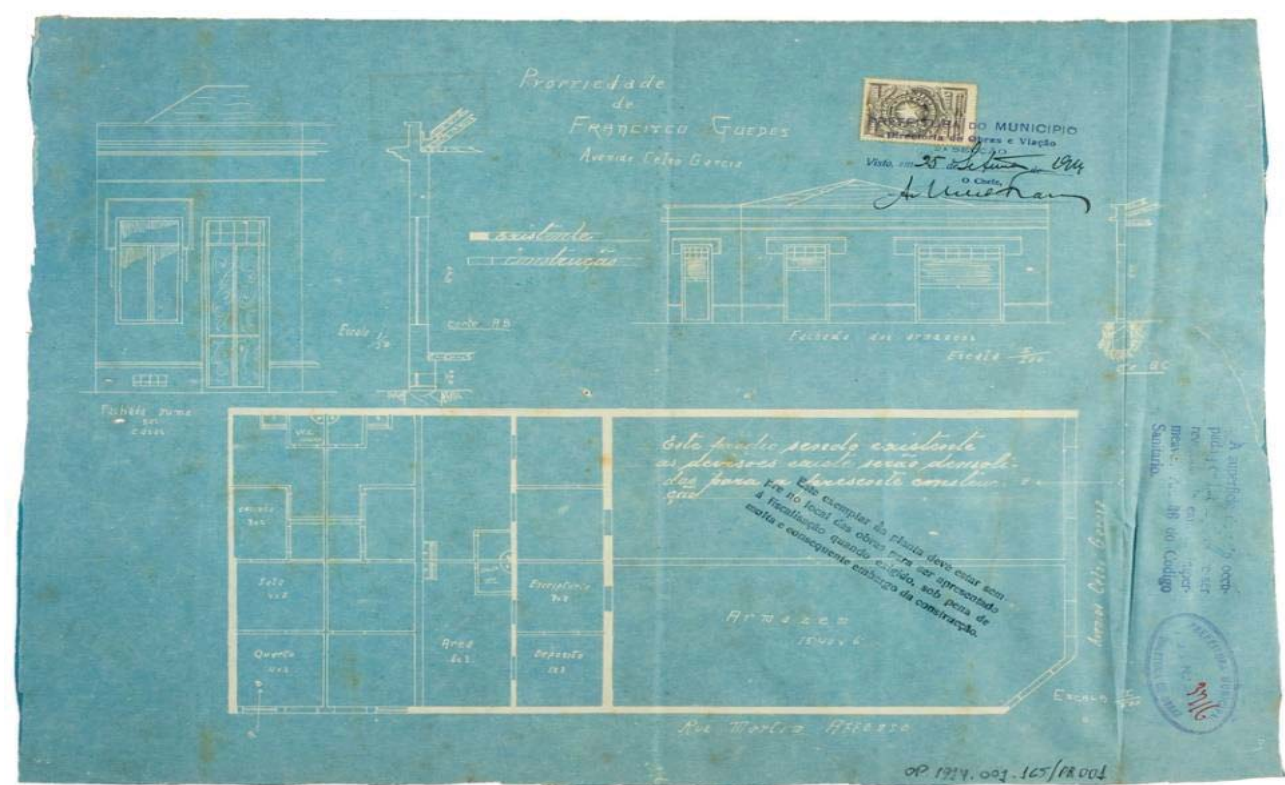

Figura 46: "Propriedade de Francisco Guedes" - Arquivo Histórico Municipal, Fundo "Diretoria de Obras", Série "Obras Particulares", OP1914.001.165

${ }^{199}$ Arquivo Histórico Municipal, Fundo “Diretoria de Obras”, Série “Obras Particulares”, OP.1910.001.708 
Chama a atenção a presença de certos personagens como proprietários de cortiços: José Sampaio Moreira (oriundo de propriedade rural da cidade de Cajuru, antigo proprietário de terras do Brás, comerciante e banqueiro paulistano, proprietário daquele que foi considerado o mais alto edifício da cidade entre os anos de 1924 e 1929 na rua Líbero Badaró, e que possuía 4 cortiços na rua do Gasômetro número 97); D ${ }^{\mathrm{a}}$ Roza Osório (proprietária da chácara que se situava nas proximidades do rio Tamanduateí e da antiga Chácara da Figueira, que deu origem ao Parque D. Pedro II e à rua da Mooca, era proprietária de 12 cortiços); o Barão de Jaguará, Antônio Pinheiro de Ulhôa Cintra, possuía 5 cortiços na rua Santa Rosa número 31B, embora fosse médico, ex-deputado e exPresidente da Província de São Paulo; o Dr. Luís Pereira Barreto (outro médico) tinha 10 cortiços na rua São Caetano número 113 B; e por fim Alves Penteado \& Filho, que pode se tratar do conde Armando Álvares Penteado, embora não tenha deixado descendentes.

2.4 Um ponto temporal fora da curva: uma análise das fotografias de cortiços do Brás a partir dos anos 1930

Após análise da série Obras Particulares, percebemos que a mesma não é a principal fonte para chegarmos aos cortiços que existiram em São Paulo, por tratarem de questões da burocracia municipal, visto que sua produção estava atrelada à construção da cidade oficial, ou seja, dos projetos construtivos que deviam passar pelo crivo da aprovação municipal, e estavam atrelados à legislação urbanística e sanitária da época.

A iconografia sobre São Paulo foi profusa, desde os registros de Militão Augusto de Azevedo que remontam à década de 1860, fora inúmeros outros fotógrafos que captaram a cidade, seus edifícios, suas transformações urbanísticas, os modos de vida da população, tornando-se uma importante fonte para se observar as mudanças e permanências que a cidade teve ao longo desses mais de 150 anos. As lentes de Aurélio Becherini, Vincenzo Pastore, Hildegard Rosenthal, Guilherme Gaensly, dentre outros legaram um rico material 
que, quando analisado, pode oferecer respostas aos questionamentos de como a cidade se apresentava em várias temporalidades e especialidades ${ }^{200}$.

O registro fotográfico, quando colocado para análise juntamente com outras fontes, torna-se uma documentação valiosa, na medida em que traz à tona personagens, vivências e espaços não contemplados anteriormente. Nesse sentido, na linha do primeiro capítulo, elegemos algumas fotografias que juntamente com a cartografia e a toponímia do Brás foram espacializadas para dar a ver onde e como eram esses cortiços.

O bairro foi alvo de muitos registros fotográficos, que não se restringiram às construções realizadas na primeira fase de sua produção na passagem do século XIX para o $\mathrm{XX}$, ou aos trabalhadores em seus espaços de trabalho ou ao transporte na região, mas incluíram o interior de habitações coletivas, proporcionando uma visão de determinadas construções e possíveis usos ao longo do tempo. Explorando a coleção de fotografias da Biblioteca Mário de Andrade, encontramos uma série de registros que retratam os diversos cortiços da cidade de São Paulo, especialmente entre as décadas de 1930 e 1960, feitas pelos fotógrafos Benedito Junqueira Duarte e Sebastião Assis Ferreira, ambos do quadro da burocracia municipal. Do álbum Vistas da Cidade de São Paulo entre as décadas de 1930 e 1960, procuramos separar as fotografias de duas das ruas do Brás nas quais nossa pesquisa inicial mapeou a existência de cortiços: as ruas Carneiro Leão e a Visconde de Parnaíba. A ideia era aferir se, ao menos até a primeira metade do século XX, eles continuaram existindo e como perduraram desde seus anos de construção, possivelmente datando do final do século XIX.

Não podemos concluir que os números dos lotes apresentados pelos fotógrafos sejam os mesmos apresentados na lista que elaboramos com base no relatório do fiscal José Ignacio do ano de 1892, haja vista as mudanças na numeração da cidade nestes mais de 30 anos que separam as duas séries documentais ${ }^{201}$. Nem por isso descartamos as fotografias, pois além de registrarem espaços anteriormente mapeados por nós, permitem também um

\footnotetext{
${ }^{200}$ Além da fotografia, a pintura a óleo revela as tensões do processo de urbanização da cidade de São Paulo, especialmente porque a Várzea do Carmo foi um dos temas recorrentes, juntamente com seus atores ali expressos, dado este observado por Maria Luiza Ferreira de Oliveira (2005).

${ }^{201}$ Segundo Heloisa Barbuy, os números de imóveis encontrados em almanaques são o indicar mais completo que se dispõe, mas, numerosas foram as mudanças no sistema de numeração, além das mudanças pontuais acarretadas por desapropriações de áreas inteiras na região central, o que parece-nos também ter ocorrido no Brás. A autora ainda nos coloca que "o sistema de numeração definido em 1886 permaneceu até os anos de 1930, quando foi adotado o sistema métrico por determinação do Ato n. 1.013 de 13 de fevereiro de 1936." BARBUY, Op. Cit, pág. 254, Apud Ayres Netto \& Ramos, Código de Obras, 1968, apud José Eduardo de Assis Lefèvre, Entre o Discurso e a Realidade: A Quem Interessa o Centro de São Paulo? A Avenida São luiz e sua Evolução, 1999, pág. 26.
} 
olhar distinto da produção oficial da cidade registrada nas permissões de construção encaminhadas por particulares.

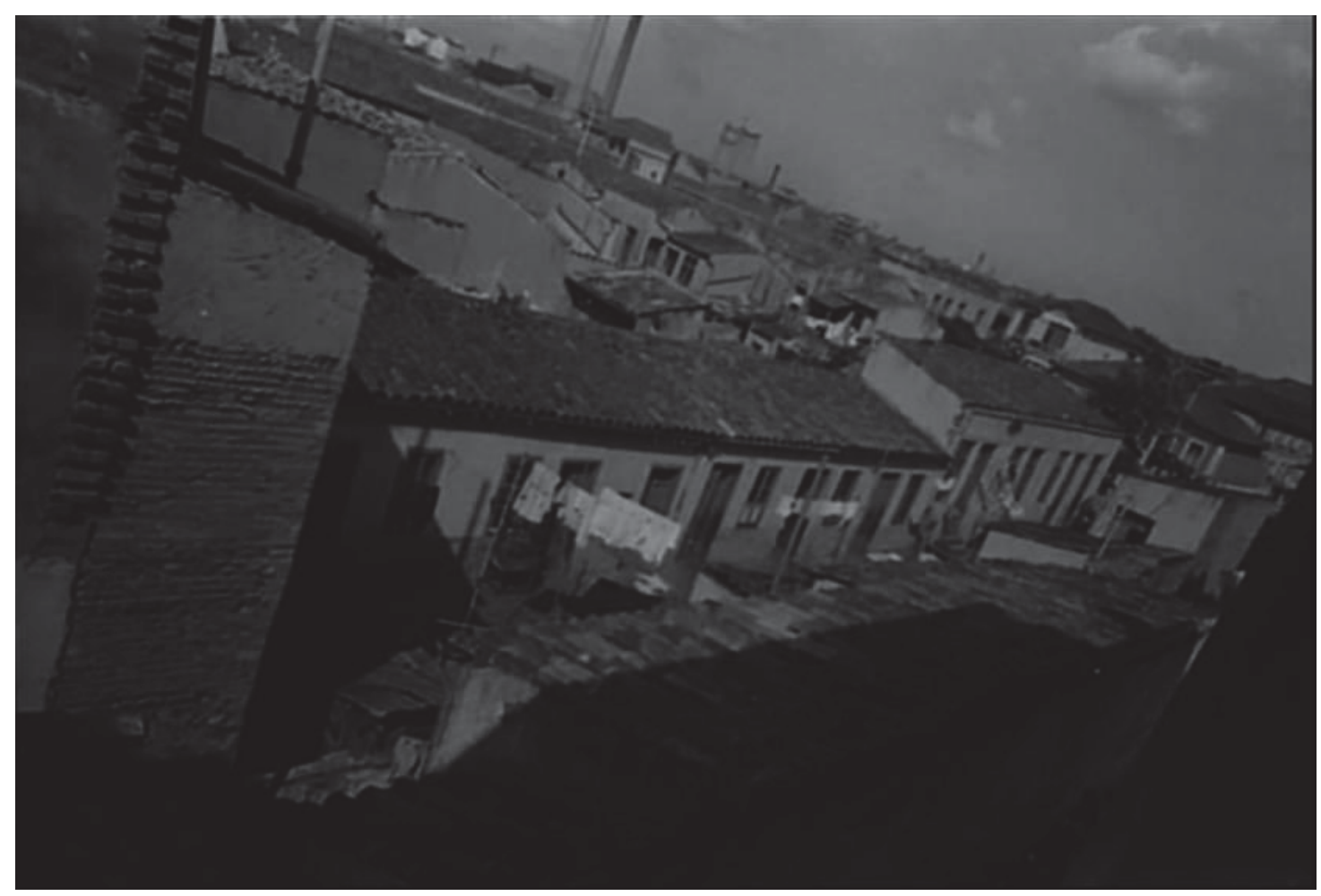

Figura 47: "Rua Visconde de Parnaíba no 592”, Benedito J. Duarte, 1939, Acervo da Biblioteca Mário de Andrade, Registro número 2234A.

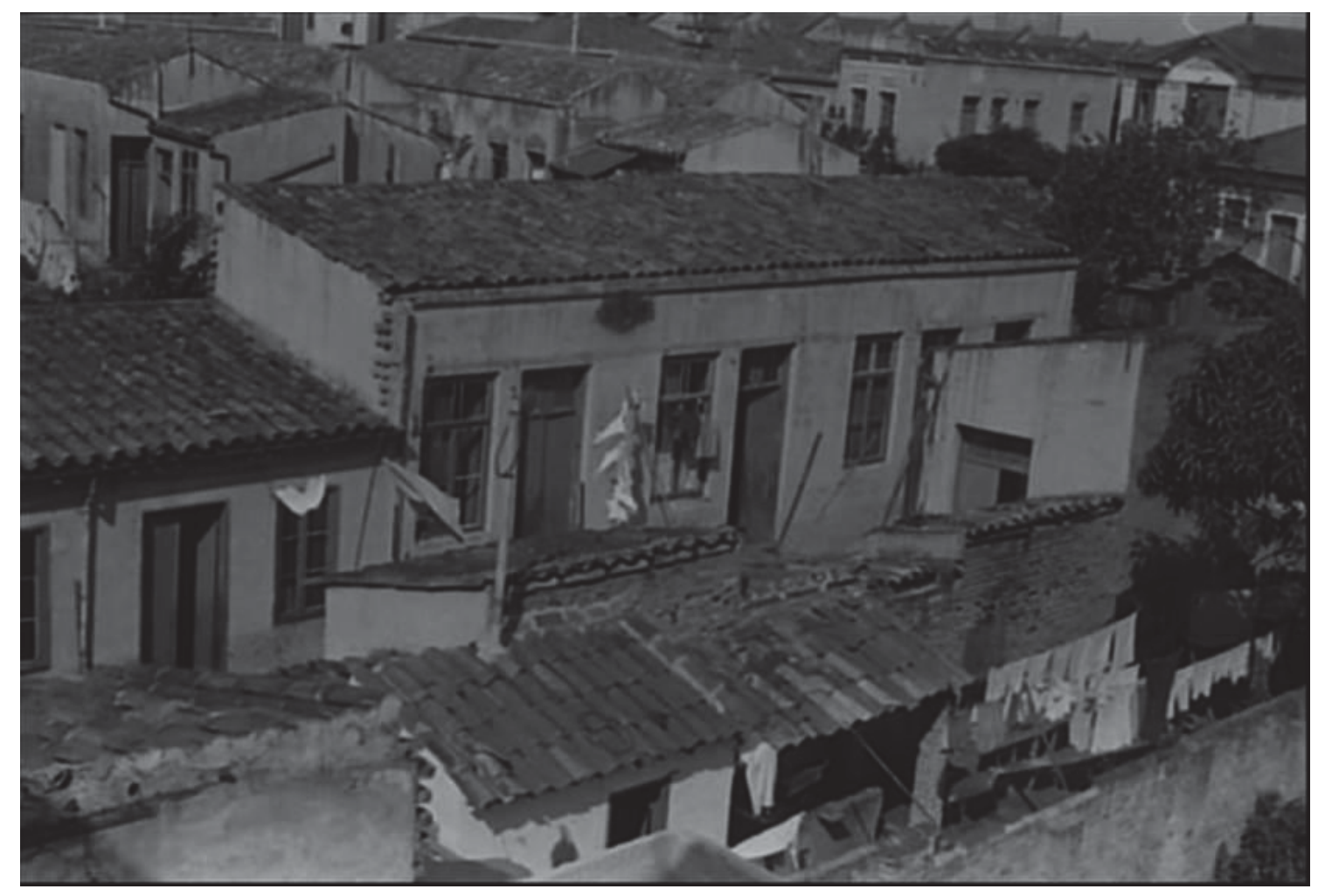

Figura 48: "Rua Visconde de Parnaíba n 592", Benedito J. Duarte, 1939, Acervo da Biblioteca Mário de Andrade, Registro número 2235A. 


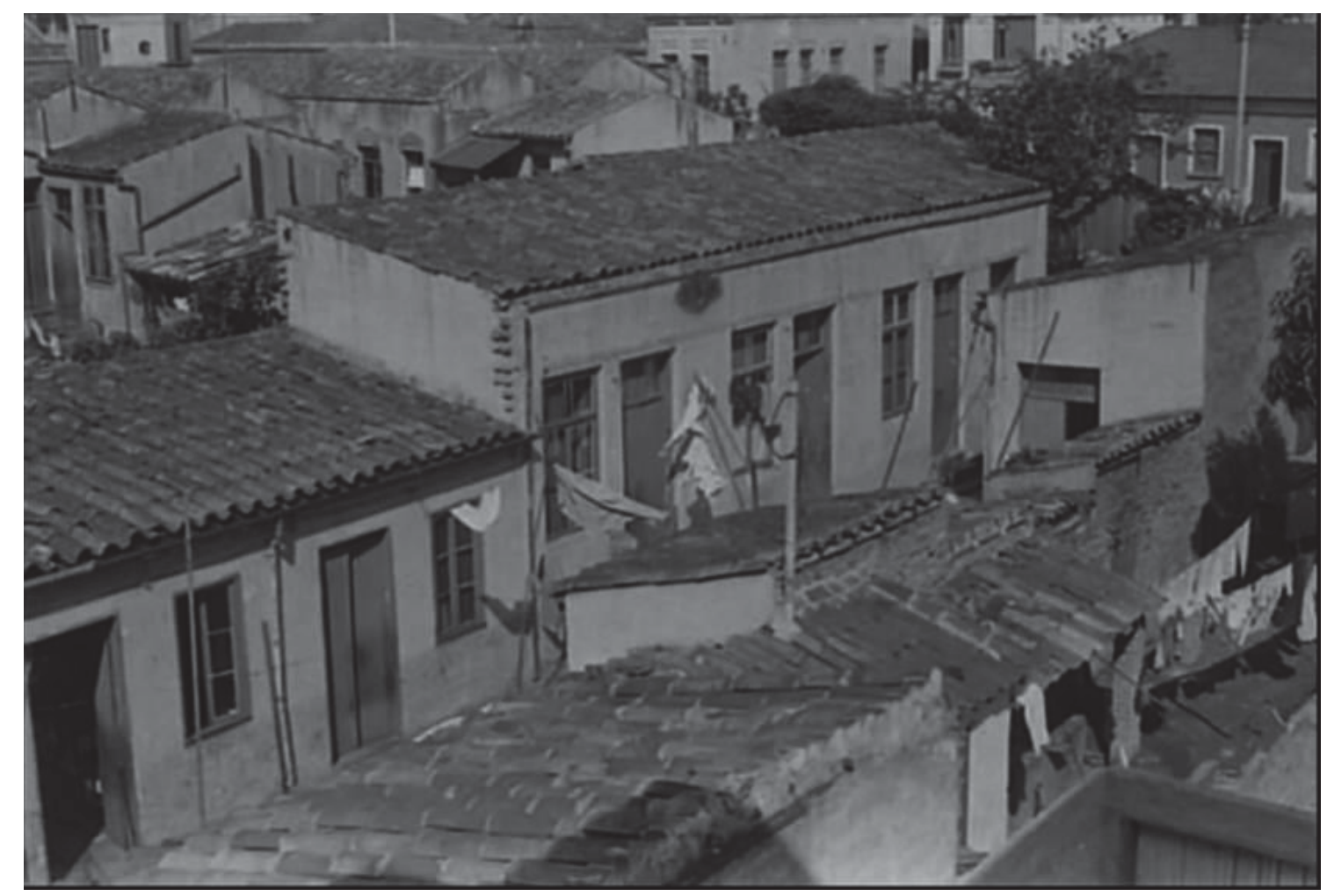

Figura 49: "Rua Visconde de Parnaíba n ${ }^{\circ}$ 592", Benedito J. Duarte, 1939, Acervo da Biblioteca Mário de Andrade, Registro número 2236A.

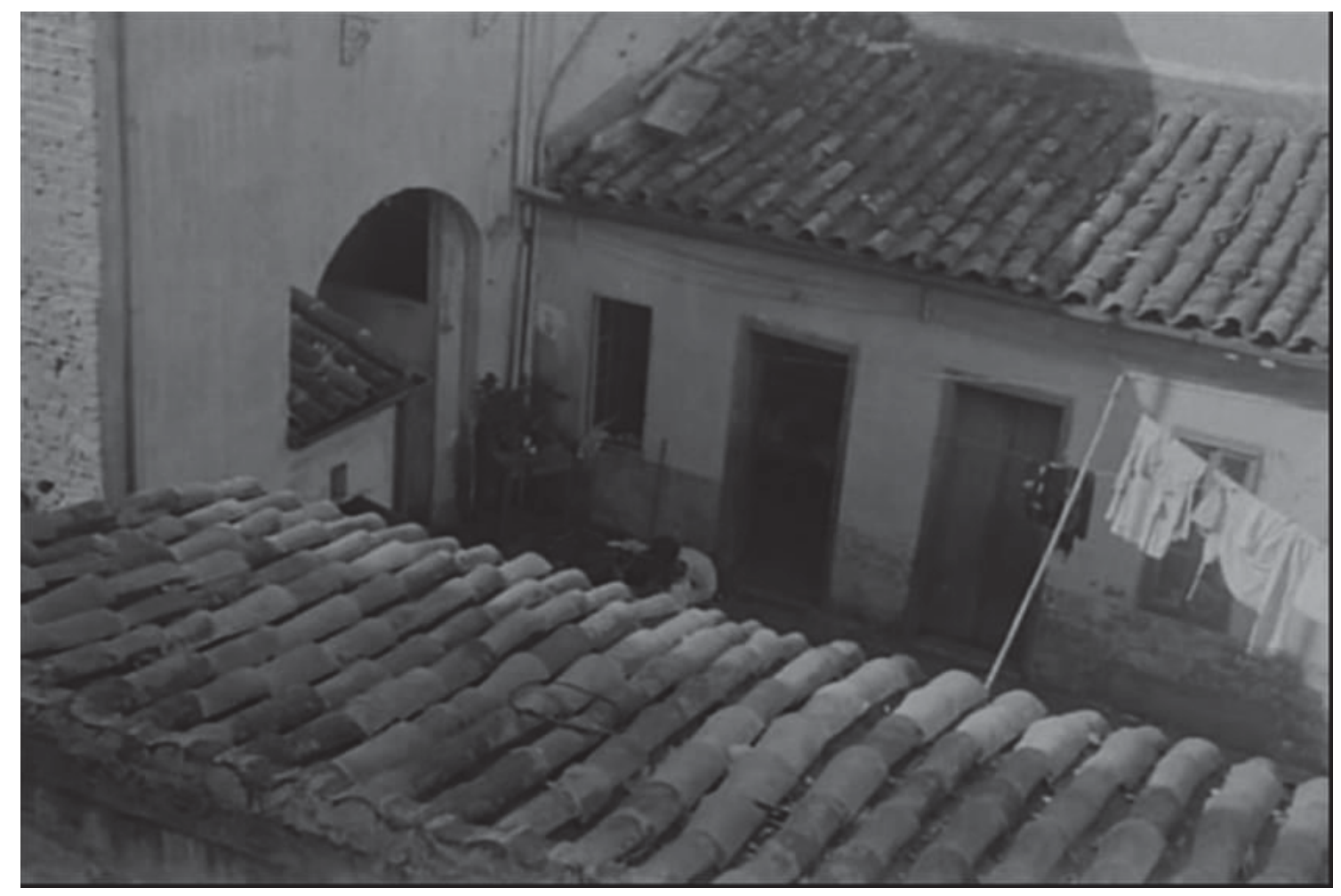

Figura 50: "Rua Visconde de Parnaíba no 592”, Benedito J. Duarte, 1939, Acervo da Biblioteca Mário de Andrade, Registro número 2237A. 


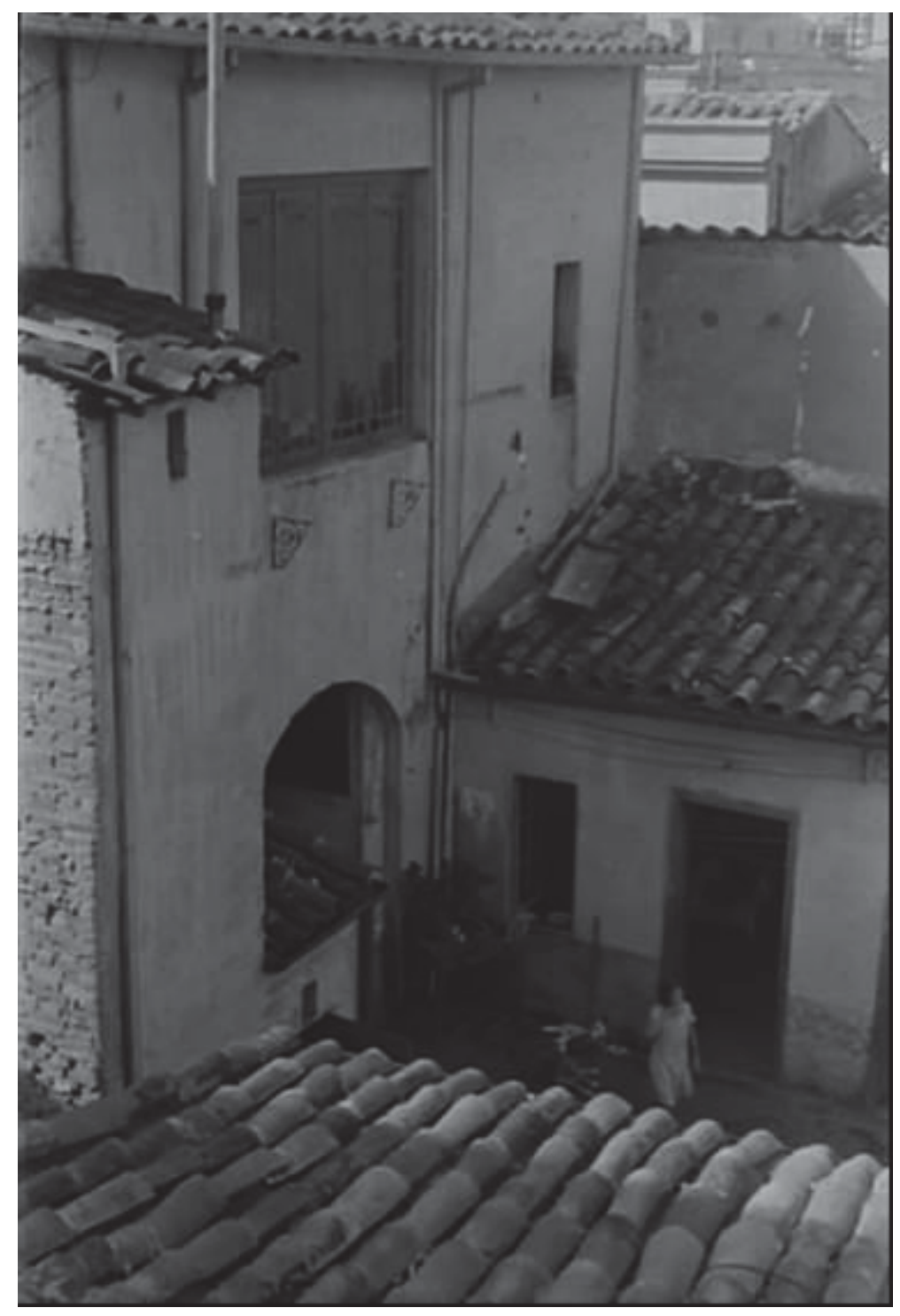

Figura 51: "Rua Visconde de Parnaíba no 592”, Benedito J. Duarte, 1939, Acervo da Biblioteca Mário de Andrade, Registro número 2238A.

Os registros feitos por Benedito Junqueira Duarte sobre a rua Visconde de Parnaíba, em 1939, concentraram-se em torno de um cortiço desta rua, sito no número 592, evidenciando tratar-se de um espaço amplo, que ocupava toda a área disponível do lote com casas, áreas correspondentes ao banheiro ou tanque e quintal, no qual aparecem as roupas estendidas em varais sustentados por taquaras de bambus.

B. J. Duarte para conseguir captar o cortiço, parece subir no telhado ou sacada de uma construção vizinha, iniciando o registro pelos fundos do lote, retratando, assim, as construções que serviriam de moradia coletiva, pois à frente desses imóveis nem sempre se via tratar-se de cortiços. Na fachada frontal da casa havia uma passagem em sua lateral, no canto inferior esquerdo da foto (figuras 50 e 51), que permitia o acesso aos quartos e fundos. 
Ao que parece, tratam-se de quatro casas coletivas, cujas portas dão acesso a um pátio comum que permite a iluminação dos quartos. Das duas construções que estão de frente para o fotógrafo, podemos observar oito portas, cada uma seguida por uma janela. É de se destacar que a casa maior goza de um pé direito alto, sendo então a casa mais alta do grupo. No fundo do pátio observa-se um sobrado, e uma mulher que parece ter acabado de sair dele.

Os registros feitos por Sebastião de Assis Ferreira na rua Carneiro Leão, em 1942, nos propõem que também se trata de um único espaço e não de diversos cortiços espalhados sobre diversos lotes, visto existirem elementos que permitem a aproximação entre eles. $\mathrm{O}$ chão de paralelepípedos e a disposição de alguns personagens reforçam tal hipótese.

A figura 52, de autoria de Benedito Junqueira Duarte, trata-se de um cortiço da rua Carneiro Leão em finais da década de 1920, mas não podemos aferir se corresponde ao fotografado por Sebastião de Assis Ferreira. A foto, com uma imensa quantidade de crianças e duas senhoras que as alinham para o fotógrafo, seu cenário de fundo está repleto de roupas estendidas nos varais balançando contra o vento, além das edificações que servem de habitação, certamente para estas crianças e seus familiares. Logo atrás das crianças, um pequeno barracão, que podia servir de latrina ou lavandeira ou mesmo depósito.

As demais fotos parecem tratar de um cortiço grande, com amplo corredor e pátio comum, permitindo que muito mais roupas estejam secando nos varais. A luz do sol reflete sobre as construções, que aparentam ser sobrados, mas na realidade são casas com pésdireitos altos, com aproximadamente 4 metros de altura, visto que a mulher que segura um bebê na figura 53 ser quase da mesma altura do teto do primeiro andar. Presumimos então que a construção fora adaptada para assim tornar-se um espaço de moradia (figuras 54, 55 , 56 e 57). Esta mesma morada, conta com gradis de ferro, nos quais uma mulher e três crianças se apoiam (figura 54), e uma delas no canto inferior direito, pareceu desejar participar e não apenas assistir as brincadeiras que outras crianças fazem no chão calçado com de paralelepípedos (figuras 55 e 56), estando algumas de pé e outra deitada sobre o chão, podendo ser moradoras de um dos inúmeros quartos contidos nessas fotos. Aos menos cinco construções se fazem presentes nessas fotos, sendo uma delas esta casa com pé-direito mais elevado, e que conta com escadas em suas duas laterais (figuras 53 e 55).

Os vários objetos contidos no quintal como vassouras, cestos, banquinhos, bacias, baldes, flores, cadeiras, devem servir para o que as mulheres e outras da figura número 57 
acabaram de fazer: um almoço para as crianças que agora se servem e provavelmente moram na casa em primeiro plano, com dois degraus acima do nível do pátio.

Não podemos afirmar com precisão que a organização dos cortiços de São Paulo no começo do século se dava da forma como estão representados nessas fotos dos anos $1930 \mathrm{e}$ 1940, mas este material é um rico subsídio para análise da questão da moradia em bairros como o Brás que acolheram grande leva de imigrantes e nacionais na passagem do século XIX para o XX.

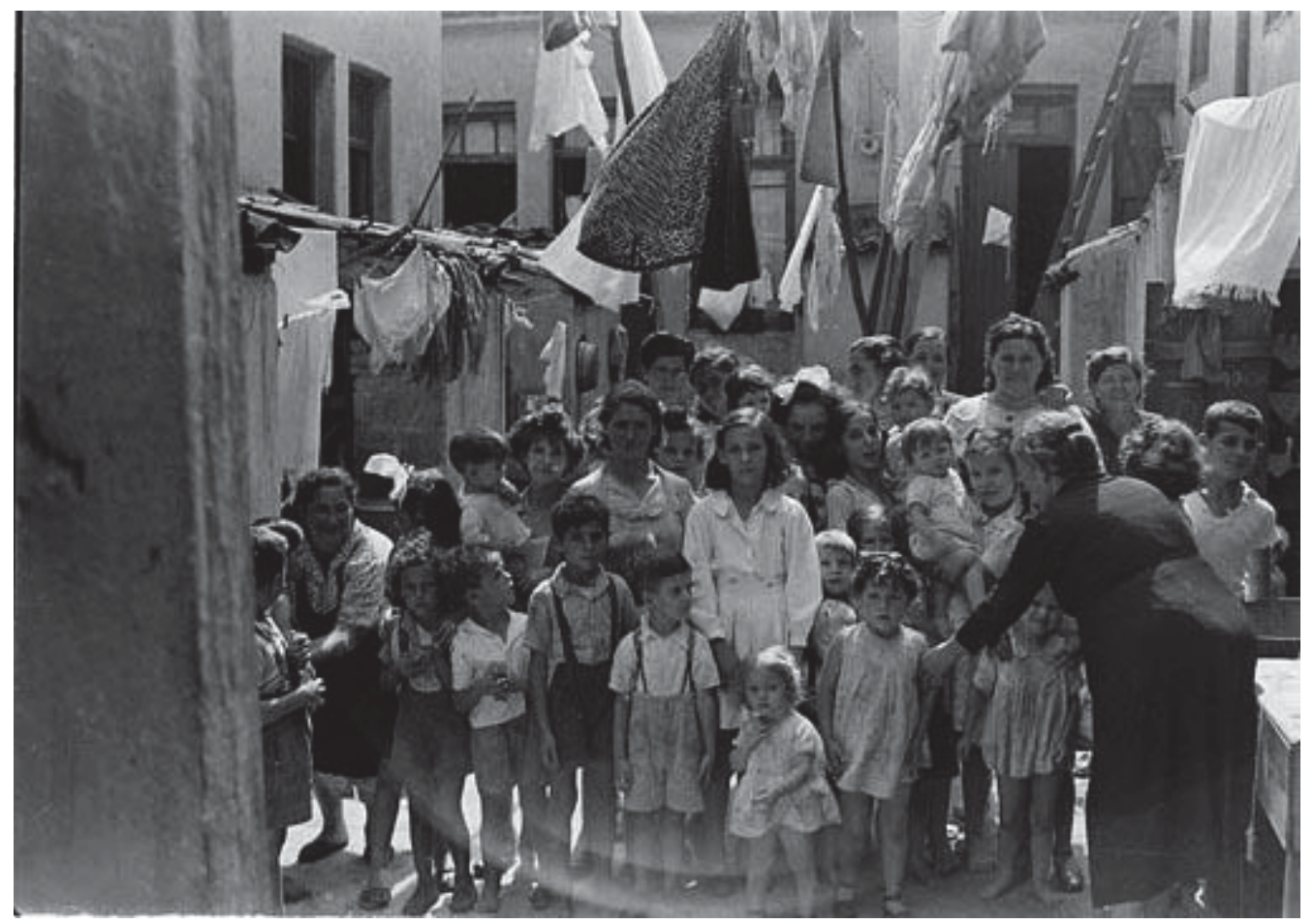

Figura 52: “Rua Carneiro Leão”, Benedito Junqueira Duarte, 1929, Acervo Fotográfico do Museu da Cidade de São Paulo. 


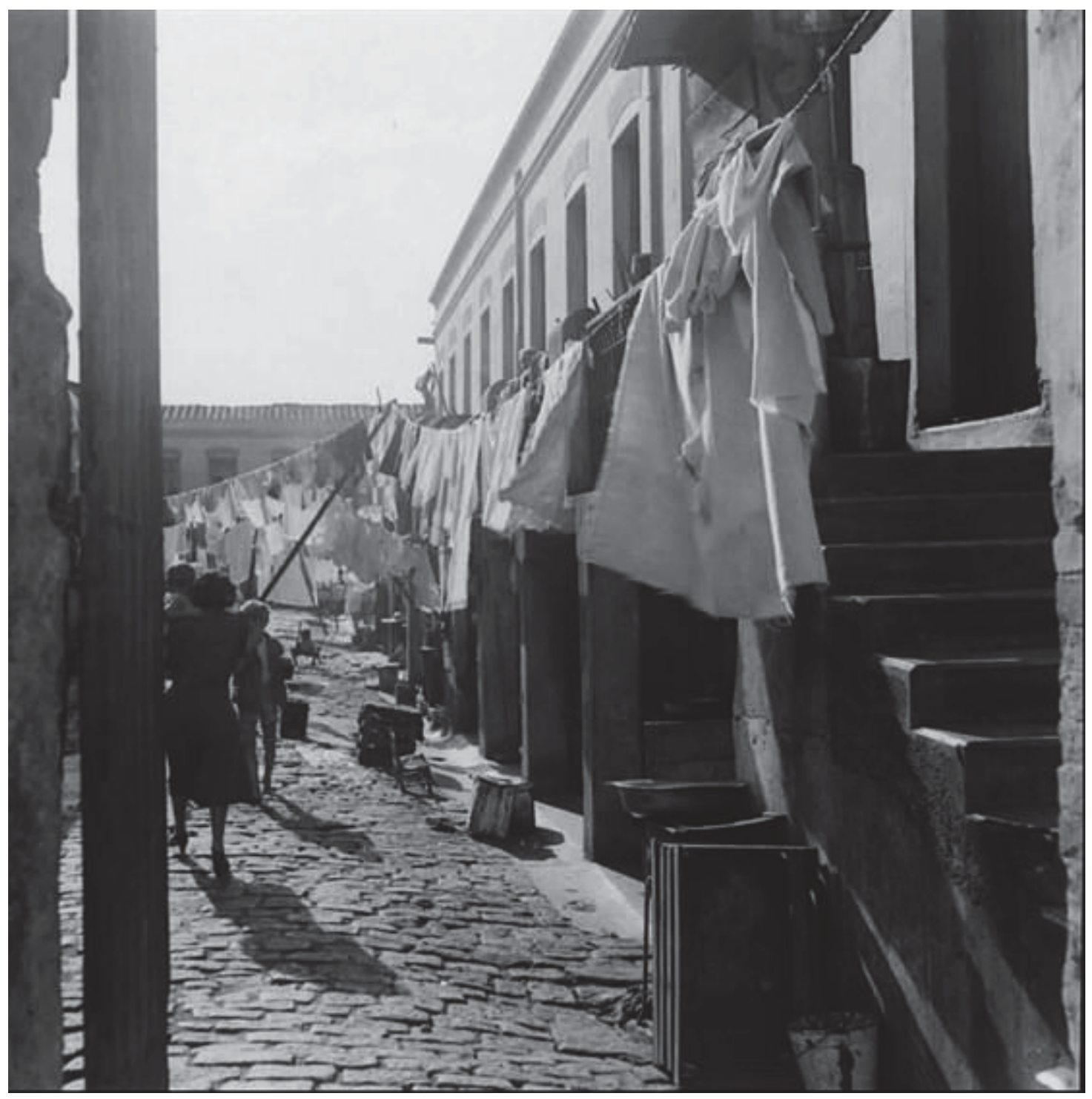

Figura 53: "Rua Carneiro Leão", Sebastião de Assis Ferreira, 1942,

Acervo Fotográfico da Biblioteca Mário de Andrade, Registro número 176B. 


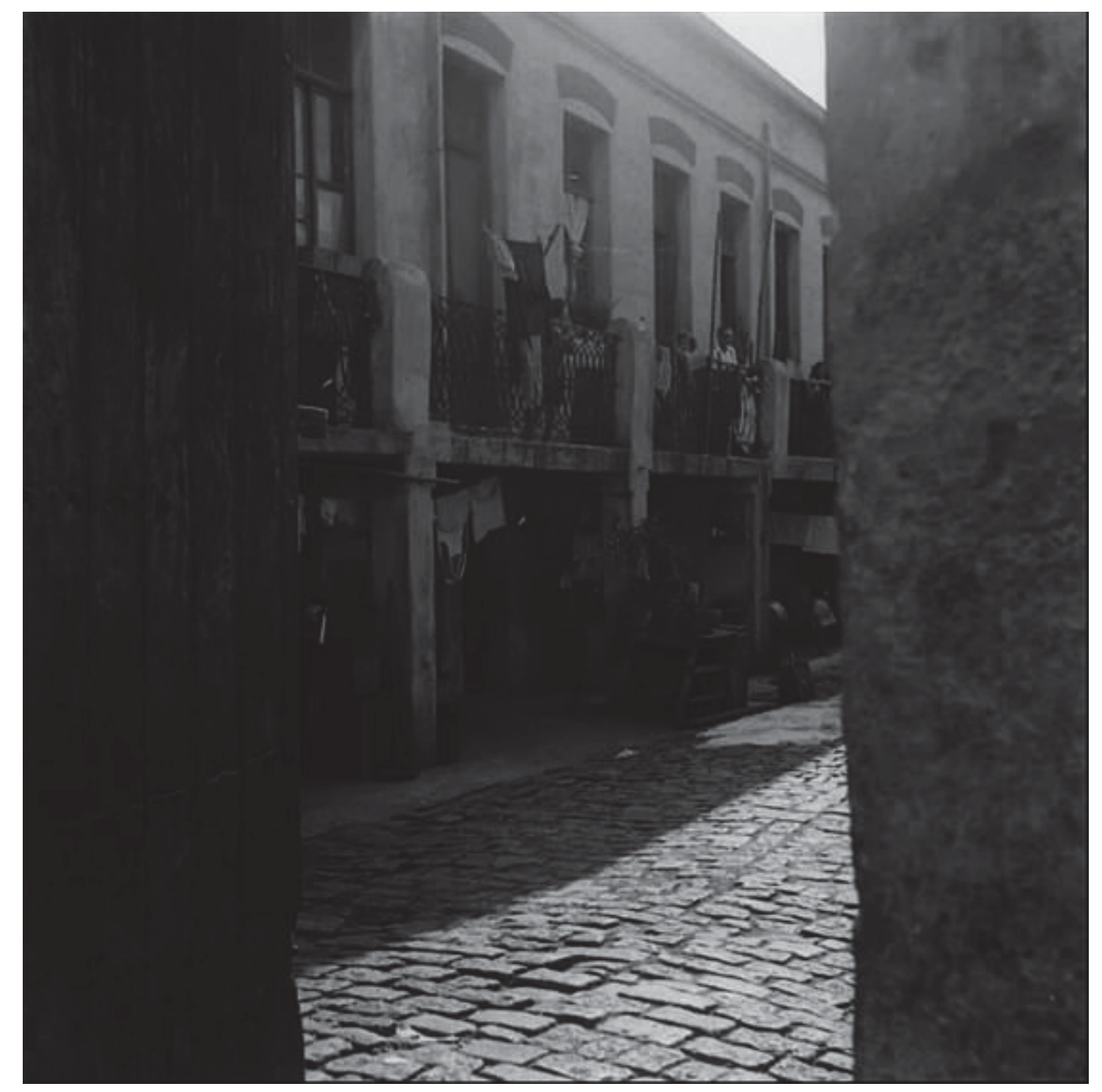

Figura 54: "Rua Carneiro Leão", Sebastião de Assis Ferreira, 1942, Acervo Fotográfico da Biblioteca Mário de Andrade, Registro número 177B. 


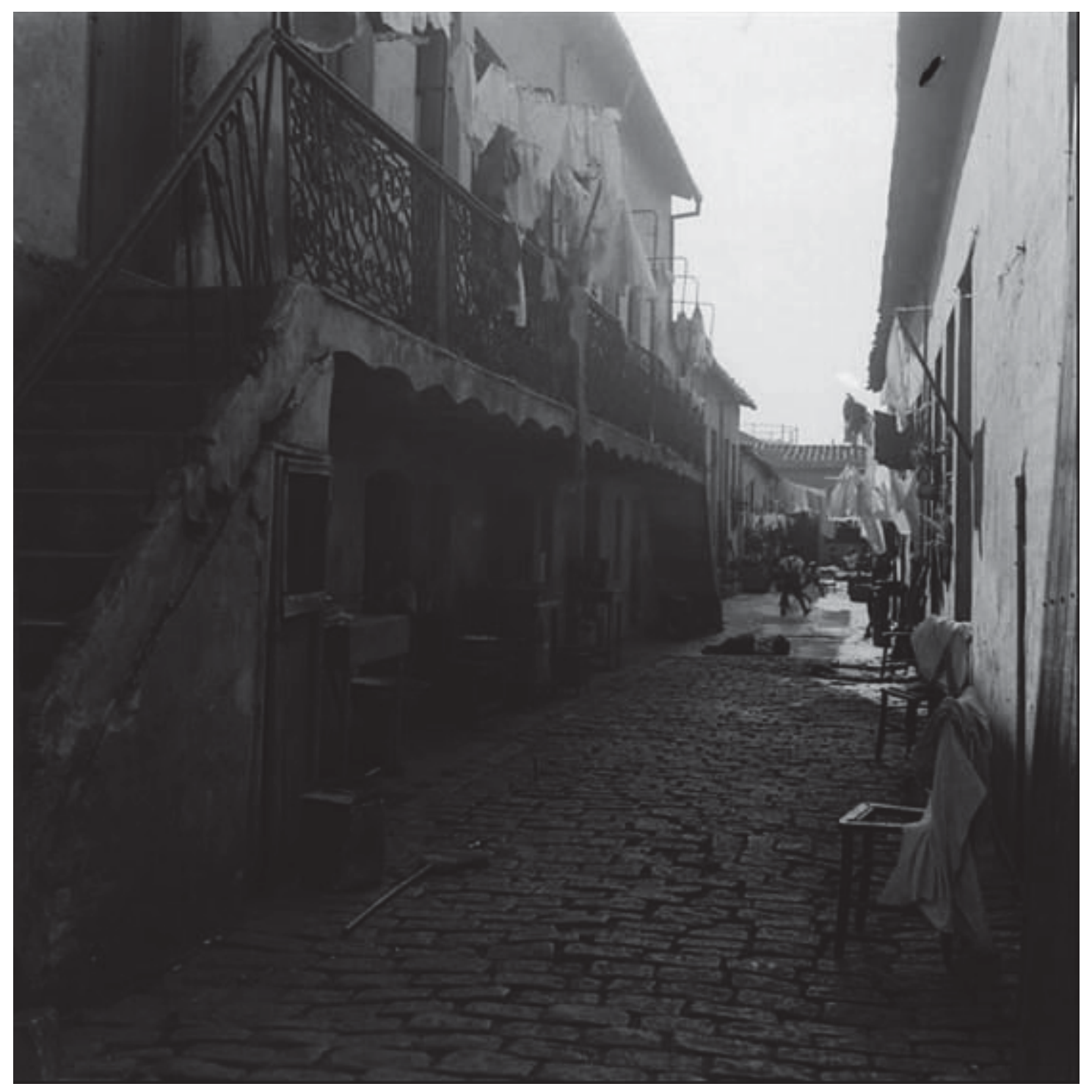

Foto 55: "Rua Carneiro Leão", Sebastião de Assis Ferreira, 1942, Acervo Fotográfico da Biblioteca Mário de Andrade, Registro número 178B. 


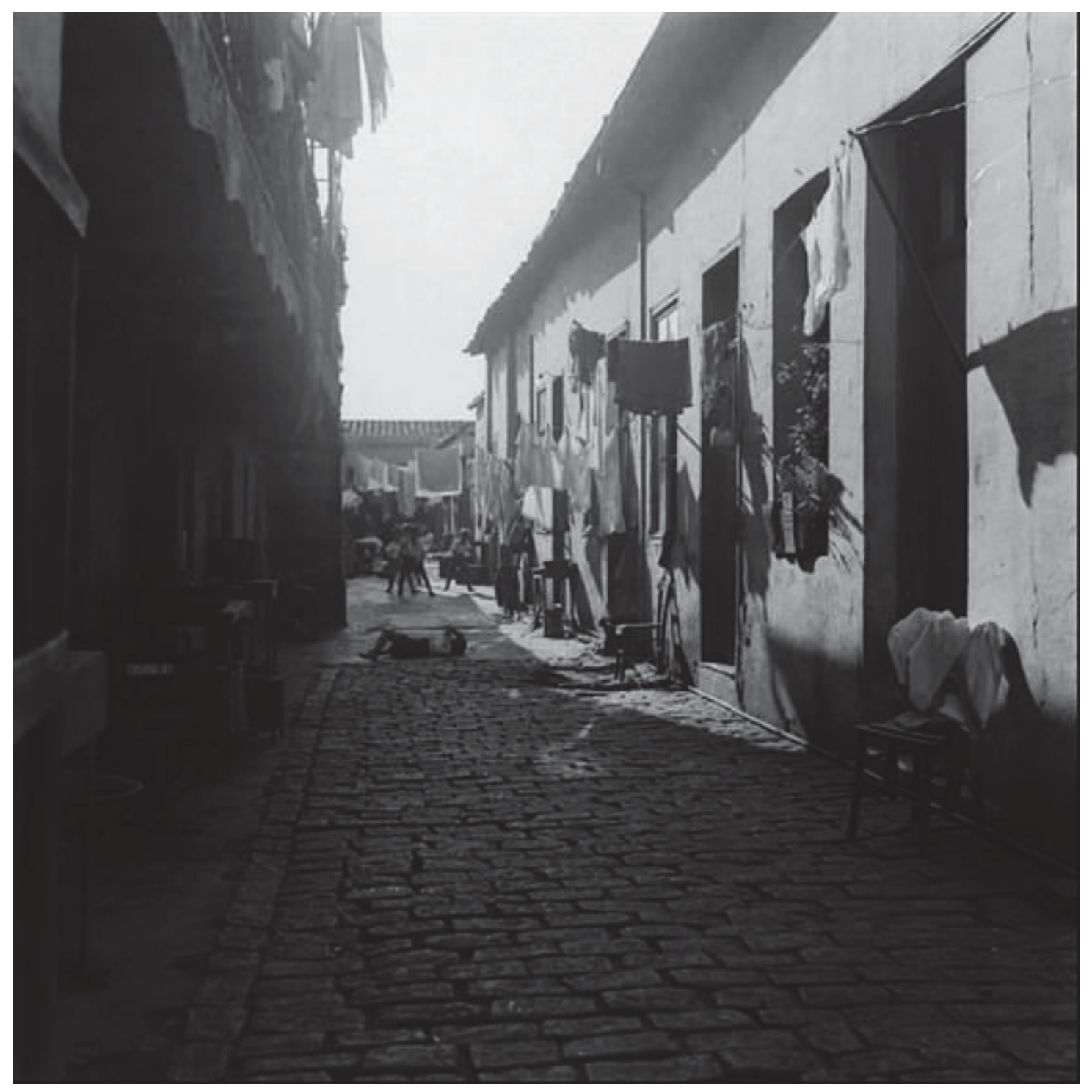

Foto 56: "Rua Carneiro Leão”, Sebastião de Assis Ferreira, 1942,

Acervo Fotográfico da Biblioteca Mário de Andrade, Registro número 179B. 


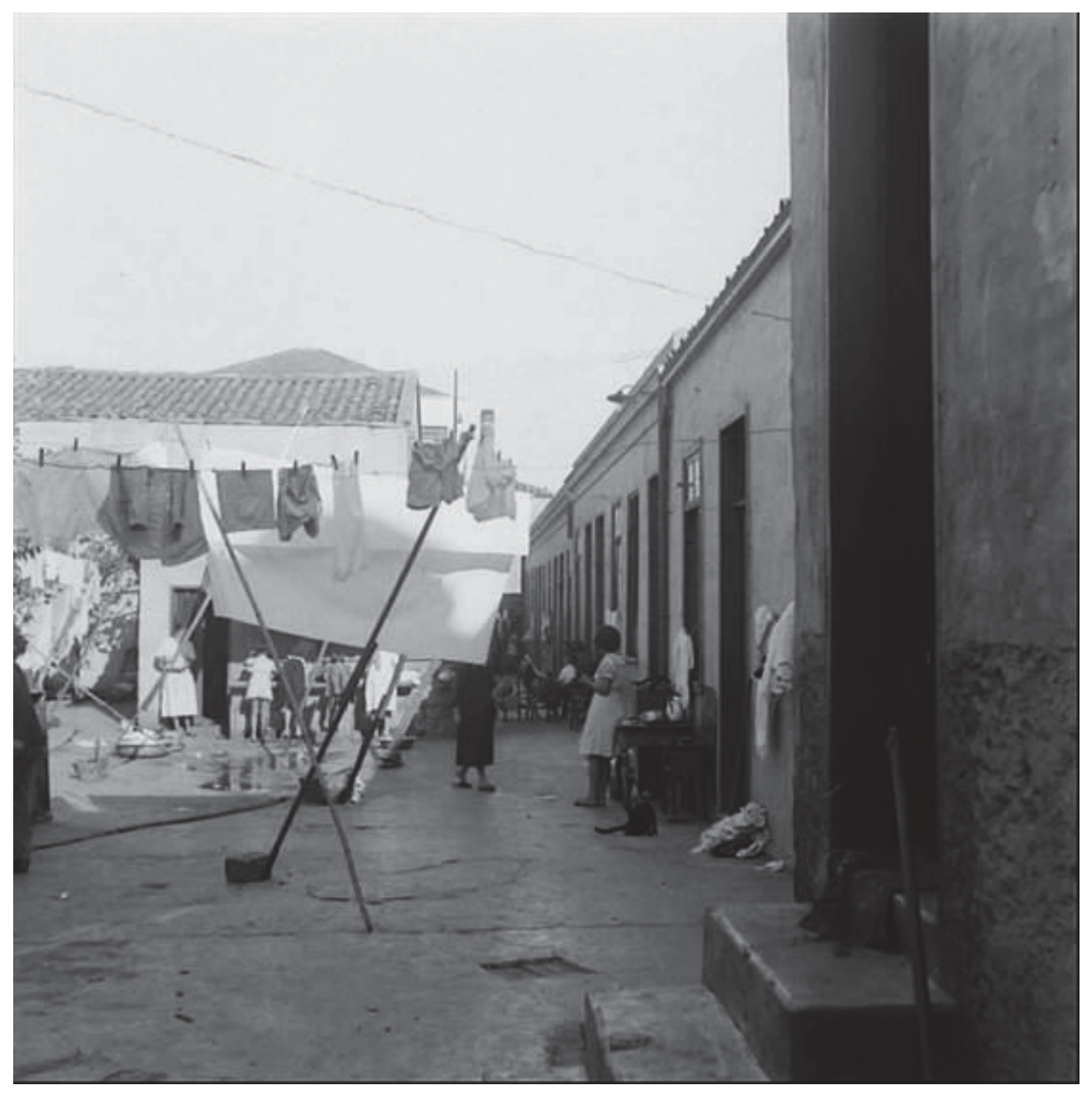

Foto 57: "Rua Carneiro Leão", Sebastião de Assis Ferreira, 1942, Acervo Fotográfico da Biblioteca Mário de Andrade, Registro número 180. 
Ao analisarmos os desenhos da Série Obras Particulares, por vezes encontramos referências à construção de "moradias para operários", o que não significaria necessariamente que eram moradias voltadas apenas para esta camada profissional, mas atendia a um padrão mínimo orientado pelas diretrizes da legislação em vigor na época para as camadas mais pobres. Talvez esta nomenclatura seja um dos pontos que auxiliou a forjar a imagem do Brás como um bairro exclusivamente "operário", apesar de contar com um expressivo número de pessoas ligadas aos setores médios, e os setores remediados não serem apenas os trabalhadores de fábricas, mas incluir vendedores, açougueiros, cabeleireiros, dentre outros que estavam inseridos na dinâmica de apropriação e produção desses bairros, alugando espaços para o estabelecimento de seus comércios e serviços. O próprio Padrão Municipal de 1886 contava com uma parte dedicada aos "cortiços, casas de operários e cubículos", sintetizando que "a construção destas casas, quer ao longo das ruas, praças, etc., quer dentro de terrenos particulares, era inteiramente proibida no perímetro do comércio"202, ou seja, no Triângulo central formado pelas ruas XV de Novembro, Direita e São Bento e imediações na colina histórica. Isso dava ensejo para que em outras regiões da cidade, os cortiços fossem permitidos, tal como no Brás, na Mooca e no Belenzinho.

À medida que a população paulistana aumentava, a demanda por habitação tornavase uma das grandes questões a serem enfrentadas, papel que a iniciativa privada abraçou no primeiro instante das transformações ocorridas na cidade ainda no último quartel do século XIX. Mas, foi ao longo da primeira década do século seguinte que entrou com toda a força produzindo casas para todos os estratos sociais, essencialmente para os setores mais remediados da população. Dispondo de portentoso capital em busca da diversificação de lucros, a elite de empresários e capital investiu no mercado imobiliário, construindo, entre outros imóveis, residências de padrões mínimos, chamando muitas das vezes estas de casas como casas de "operários", também chamada por Carlos Lemos de "casa popular"203.

No ano de 1908, Michele Lavieri remeteu à Prefeitura Municipal uma planta e memorial descritivo de obras a serem realizadas na rua Azevedo Júnior entre os números 9 e 11, solicitando a construção de uma "casa para trabalhadores", projeto que quase não se distingue do apresentado por Pedro Gomes da Silva, em 1913, ao solicitar a construção de

202 Padrão Municipal, 06 de outubro de 1886, seção VI.

${ }^{203}$ LEMOS, Op. Cit., 1978, pág. 163-164, 167. 
duas casas operárias no lugar de uma antiga cocheira no número $18 \mathrm{C}$ da rua Barão de Ladário. Enquanto no primeiro há a indicação que de o terreno media 5 metros de comprimento, no outro, dormitório e sala de jantar mediam $4 \times 4$ metros quadrados, e a cozinha 2,5 x 2,5 metros, perfazendo a média de 42 metros quadrados de área construída, sem contar os banheiros. A metragem destas casas seguia os preceitos e ideais higienistas em voga, além de apresentar o recuo lateral exigido de um dos lados, permitindo a entrada de luz e ventilação, tal como preconizava o artigo $15^{\circ}$ do Código de Posturas Municipal de 1886, que deixava claro que "todos os comodos deverão ter aberturas para o exterior de modo que disponham amplamente de ar e luz.”204

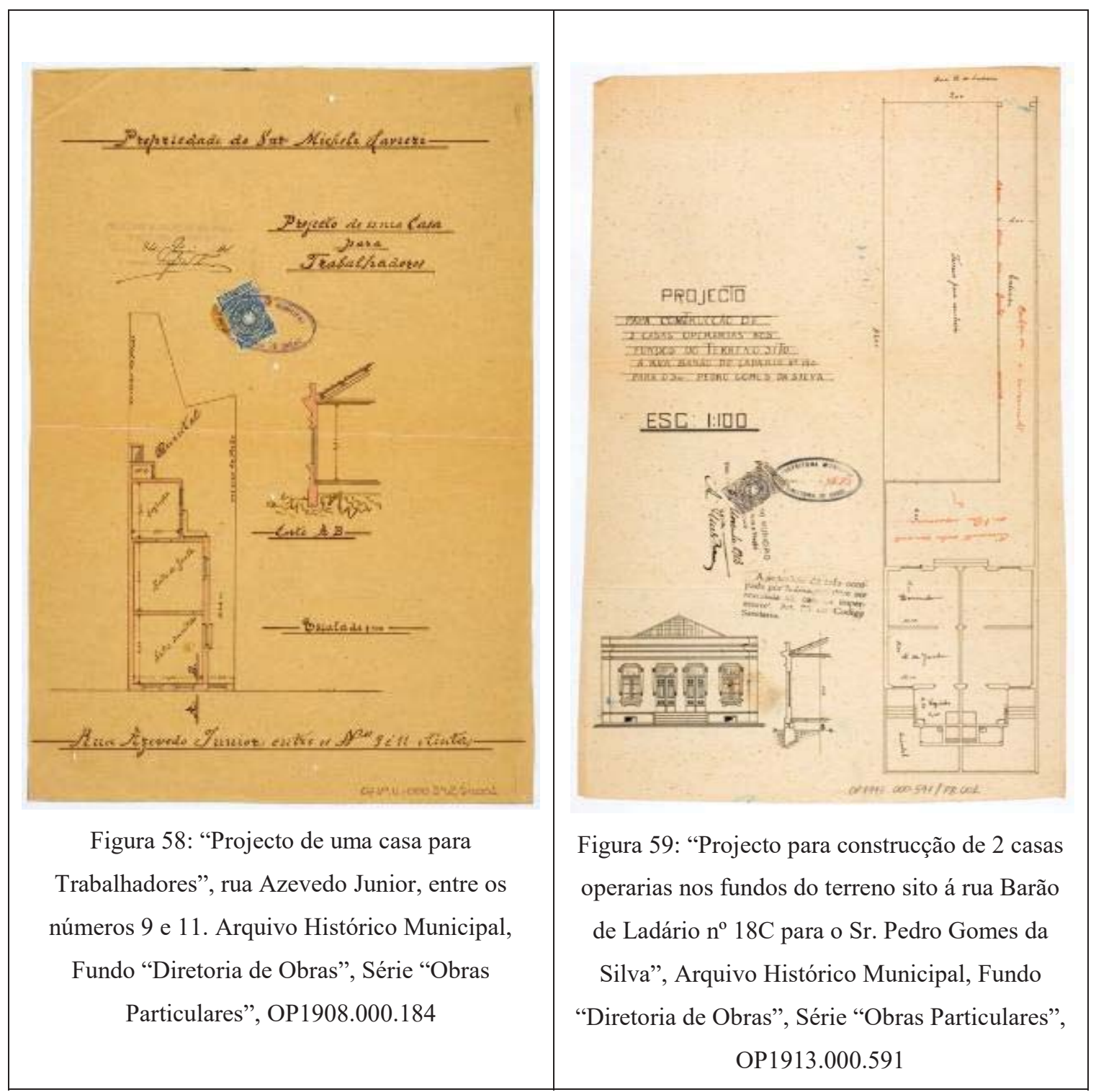

${ }^{204}$ Padrão Municipal, 06 de outubro de 1886, seção VI. 
Se analisarmos o cabeçalho dos projetos das residências que eram destinadas à “operários", "trabalhadores" ou "empregados", podemos verificar que na realidade trata-se de construções seguindo os padrões mínimos exigidos pela legislação, tal como preconizava o $45^{\circ}$ artigo do Código Sanitário de 1894, o qual dispunha que cada operário devia dispor de ao menos 14 metros cúbicos livres em cômodos de habitações em geral da cidade ${ }^{205}$. Portanto, não os conceitos adotados nos títulos das plantas respaldam a própria legislação em vigor da época, e não necessariamente destinam tais casas à um único público alvo.

Luiz Golfieri, proprietário com diversos imóveis espalhados pelo Brás também entende que suas construções pudessem ser destinadas às classes sociais menos favorecidas, ao solicitar a construção de duas casas para operários na travessa Joli, chamada posteriormente de rua Euclides da Cunha. Seu lote sinuoso, apesar de não especificar o tamanho, parece poder comportar duas pequenas casas, contendo dormitório, sala de jantar, cozinha e um banheiro separado do corpo do imóvel pelo quintal. A mesma ideia de aproveitamento do lote para construção de várias moradias aparece em outras ruas do Brás, como na Visconde de Parnaíba número 377, na qual seu proprietário Francisco Antonio de Camacho solicita a construção de "11 casas operárias", sendo que as que ficavam de fronte à rua contavam com quatro cômodos (dormitório, varanda, cozinha e despensa), e as outras sete nos fundos com três cômodos, suprimindo a despensa anexa à cozinha.

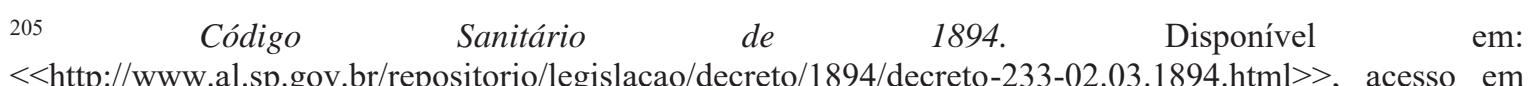
$10 / 02 / 2017$.
} 


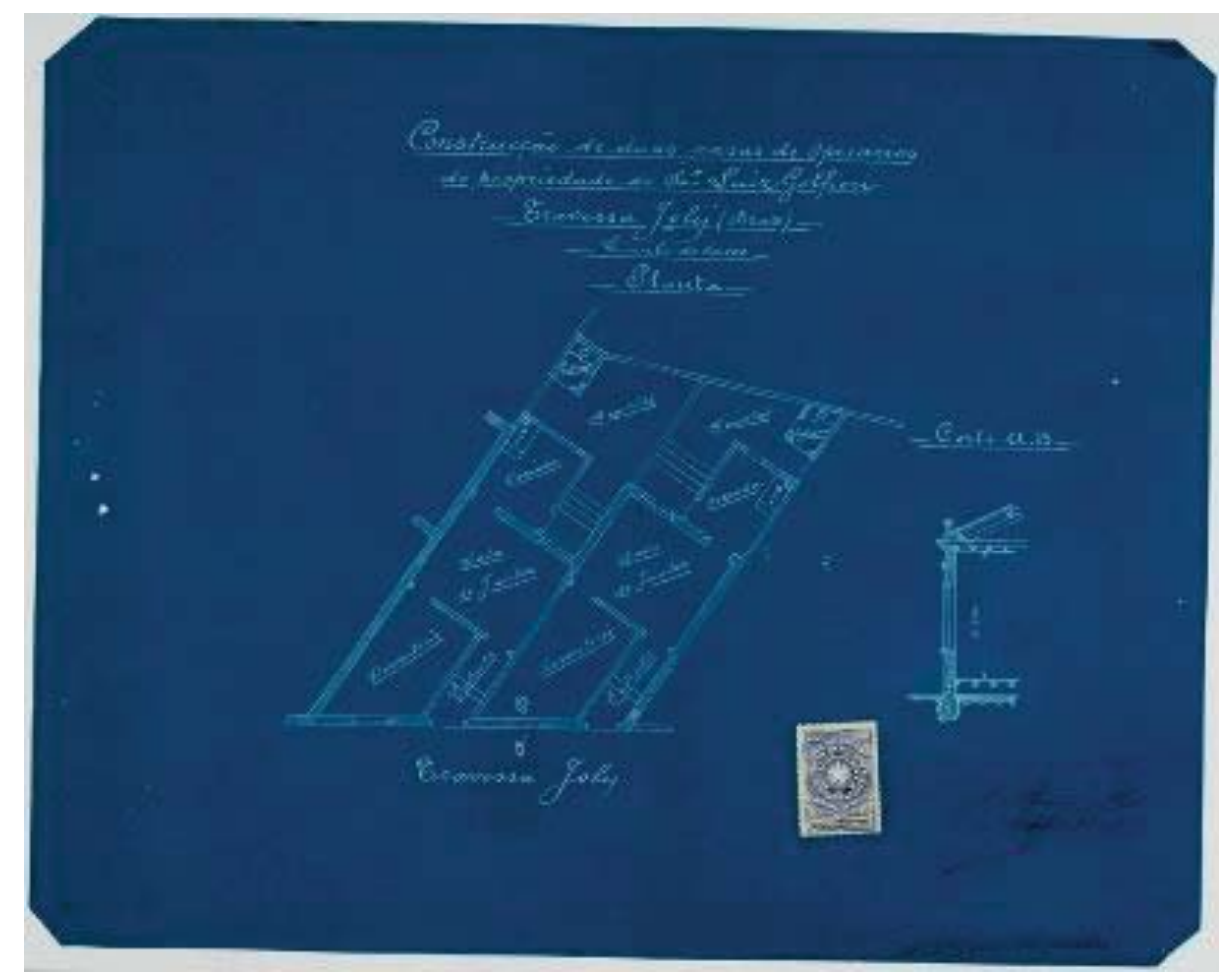

Figura 60: "Construcção de duas casas de Operarios de propriedade do Sr. Luiz Golfieri. Travessa Joly (Braz)". Arquivo Histórico Municipal, Fundo "Diretoria de Obras”, Série "Obras Particulares”, OP1909.001.380.

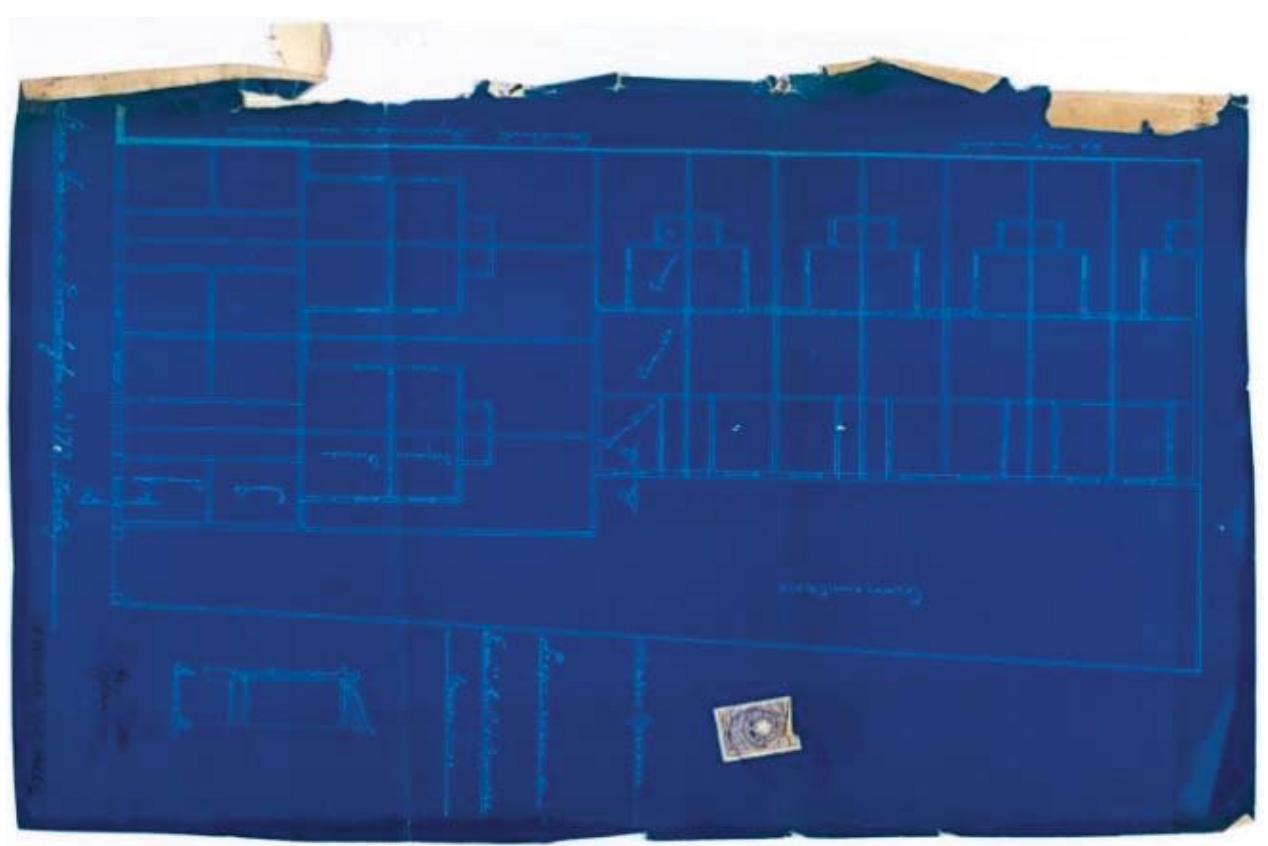

Figura 61: Conjunto de "11 casas operarias" a serem construídas na rua Visconde de Parnaíba número 377. Arquivo Histórico Municipal, Fundo “Diretoria de Obras”, Série “Obras Particulares”, OP1912004.602 


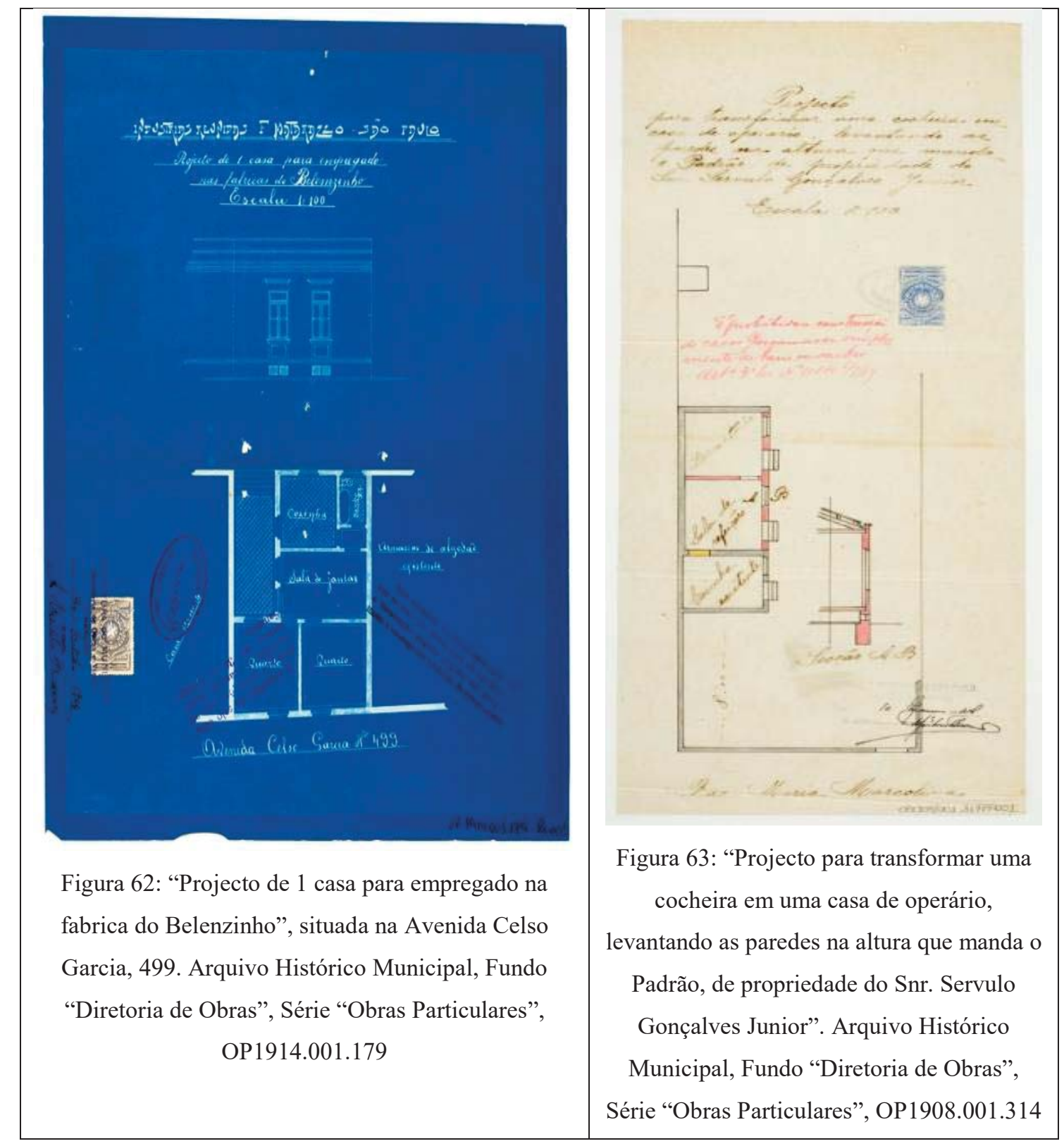

As casas, segundo o exigido por lei, envolviam o aproveitamento máximo do terreno e não se restringiam aos setores médios, mas a toda e qualquer construção destinada à habitação na cidade de São Paulo. No ano de 1914, as Indústrias Reunidas Francisco Matarazzo solicitaram a construção de uma "casa para empregado" na avenida Celso Garcia número 499, entre uma casa já existente e o armazém de algodão, com dois quartos, sala de jantar, cozinha e área descoberta nos fundos, seguindo os preceitos higienistas evocados no Código de Posturas. Esta atenção pode ser observada em outro projeto, na rua Maria Marcolina, no qual o proprietário Servulo Gonçalves tem intenção de transformar uma cocheira numa "casa de operário, levantando as paredes na altura que manda o Padrão", ou seja, de pelo menos quatro metros de altura conforme atestava o $8^{\circ}$ artigo do referido código. 
É de se destacar que a Série Obras Particulares traduz um ideal de cidade e que, não necessariamente coincide com a realidade que se construiu, mesmo com toda a fiscalização e vigilância por parte dos agentes públicos. Analisar um conjunto documental requer certos questionamentos quanto às intenções daqueles que produziram tal material frente ao espaço e tempo no qual estão inseridos. A disponibilização online dos desenhos remetidos à Prefeitura entre os anos de 1906 e 1915 nos auxiliou a caminhar a passos largo na pesquisa, pois permitiu acesso a um material praticamente inexplorado (sobretudo com relação à região na qual nos debruçamos), trazendo à tona diversos agentes que antes não tinham visibilidade, como construtores e proprietários ${ }^{206}$.

Podemos perceber que as solicitações de construção das residências vislumbradas por nós, espalharam-se por diversas das ruas, formando uma geografia espacial do morar, onde ruas podiam ser exclusivas de uma das tipologias apresentadas, ou ser totalmente mista, conferindo ao Brás a particularidade de ser um bairro em que a habitação teve um papel singular na sua formação.

Com lotes que apresentavam uma média de 10 metros de largura com até 40 metros de profundidade, grande parte das casas construídas no Brás procuravam ocupar o máximo disponível, com um número de cômodos que podia variar de três a seis, e até mesmo oito. José Sehiafoni possuía um terreno com 36,5 metros de profundidade na rua Miler, solicita em 1913 a autorização para construção de uma casa, um pouco maior que as com perfil “operário", apresentando sala, dois dormitórios, sala de jantar, banheiro, cozinha e despensa, além de um provável tanque para lavagem de roupas e quintal nos fundos. $\mathrm{Na}$ mesma rua, Frederico Fortunato fez o mesmo tipo de autorização para construção, mas desta vez para com uma casa muito menor, muito parecida com as de "perfil operário", com um dormitório, sala de jantar, cozinha e banheiro, implantada no lado esquerdo do terreno em forma de um trapézio, mostrando uma exceção à grande maioria das casas construídas no Brás por aproveitar só parcialmente o terreno e não a sua capacidade máxima exigida pela lei.

\footnotetext{
${ }^{206}$ Sob esta ótica, os trabalhos de Lindener Pareto Júnior (2011) e o mestrado de Luciana Além Gennari (2005) configuram uma nova forma de se compreender as dinâmicas do processo de produção da cidade de São Paulo, em especial na transição do século XIX para o XX. Enquanto Lindener traz à luz a ação dos construtores, práticos e licenciados que estiveram ofuscados pela historiografia, Luciana Gennari tem seus olhos voltados aos agentes que solicitavam a construção de casas em série na região da Móoca e no bairro estudado por nós.
} 


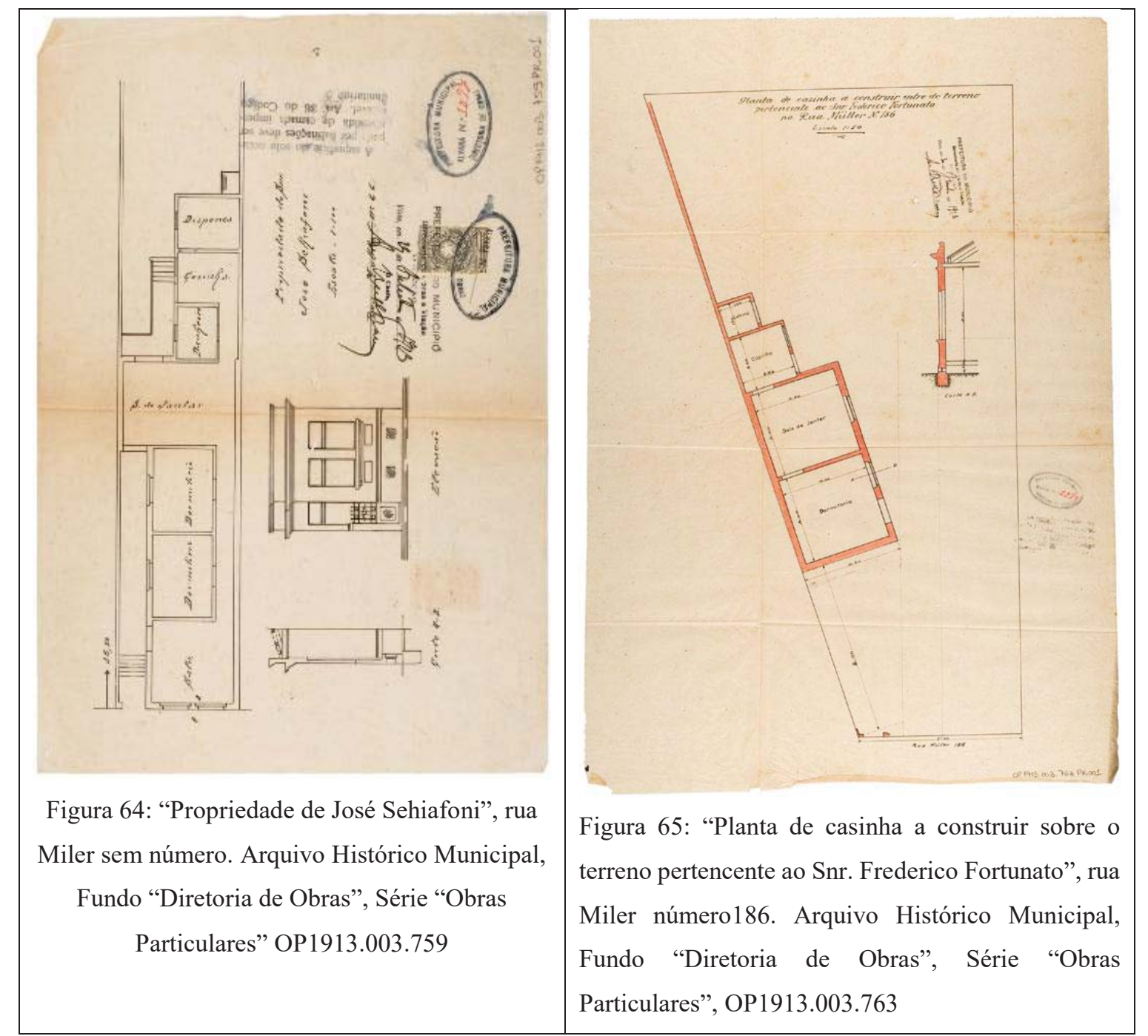




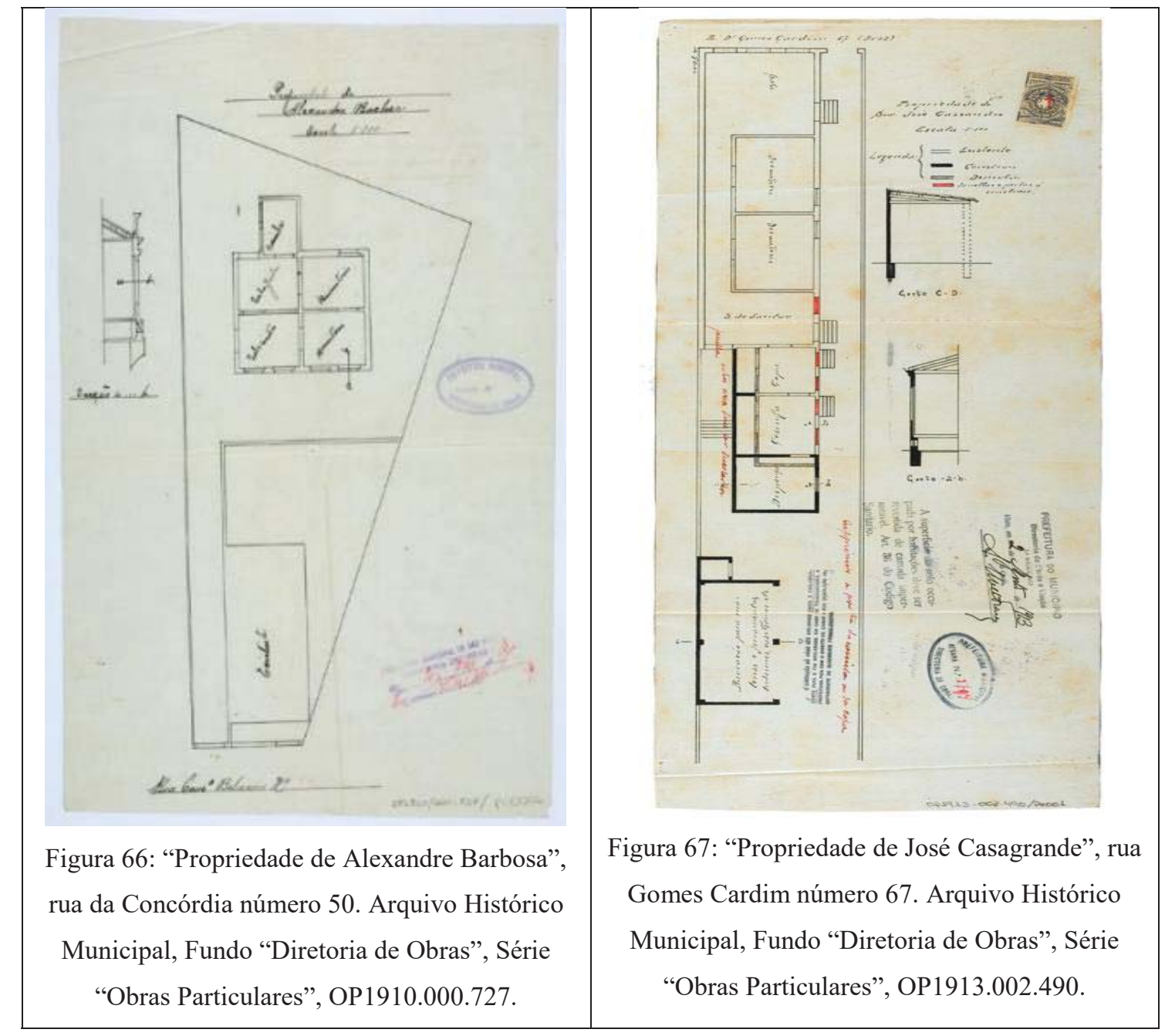

O mesmo pode ser observado no lote número 50 da rua da Concórdia (figura 66) em que Alexandre Barbosa possuía um terreno que aumentava proporcionalmente nos fundos e apresentava um recuo frontal menor com uma construção já existente. Ao solicitar a construção de uma casa nos fundos, ao invés de colocá-la junto à uma das paredes, preferiu que ocupasse o meio do lote, diferindo-se da grande maioria das casas implantadas no Brás, que optavam por um dos lados, deixando o recuo lateral exigido pela lei.

Sobre o aproveitamento do espaço dos lotes, podemos ver que esta prática fora algo muito comum em ocorrências nas ruas do Brás. Com falta de moradia na cidade e o mercado imobiliário ávido por lucros, aproveitar o terreno para a construção de casas era uma das questões que se colocava como primordial, seja com uma nova construção máxima de casas era a tônica em bairros destinados às camadas mais baixas. Na rua Elisa Whitaker, no ano de 1912, Luiz Fraga (figura 68) aproveitou ao máximo o espaço ocioso em seu terreno já ocupado (na parte da frente) por dois imóveis. A casa dos fundos, aparentemente grande, 
continha três quartos, duas cozinhas, uma área, varanda, forno, banheiro e water closet $(W C)$.

O construtor Joaquim Cavalheiro ao projetar o aumento de três cômodos nos fundos de uma construção já existente de Caetano Cardamano, solicitou a abertura de abriram janelas e portas a fim de que o novo edifício pudesse se comunicar com a garagem ao lado, transformando os dois primeiros cômodos do imóvel existente num "negócio". A nova casa seria totalmente nos fundos do terreno, privilegiando a fachada para o comércio que ali seria instalado.

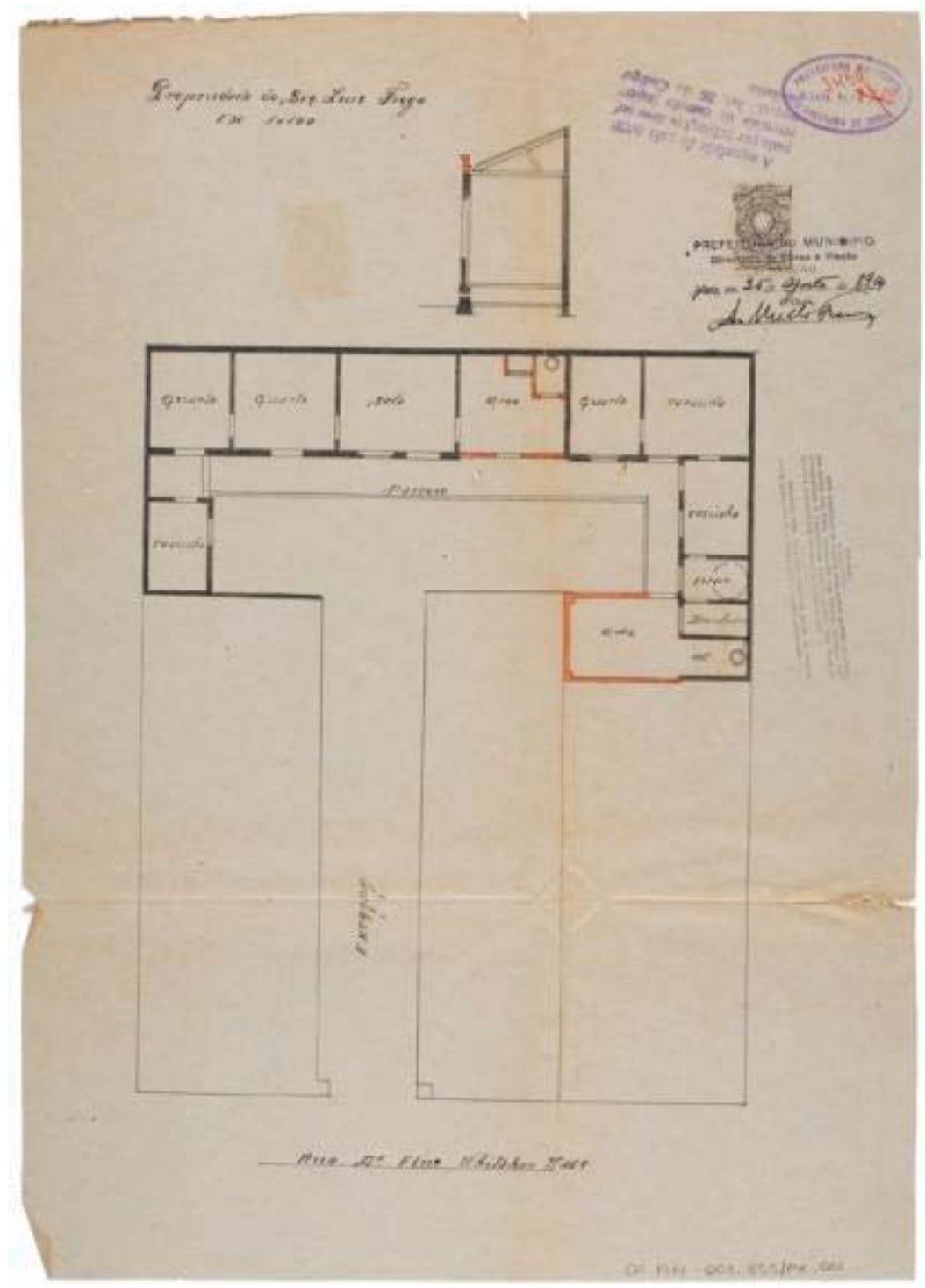

Figura 68: "Propriedade de Luiz Fraga", rua Elisa Whitaker número 458. Arquivo Histórico Municipal, Fundo "Diretoria de Obras", Série “Obras Particulares", OP1912.001.793. 


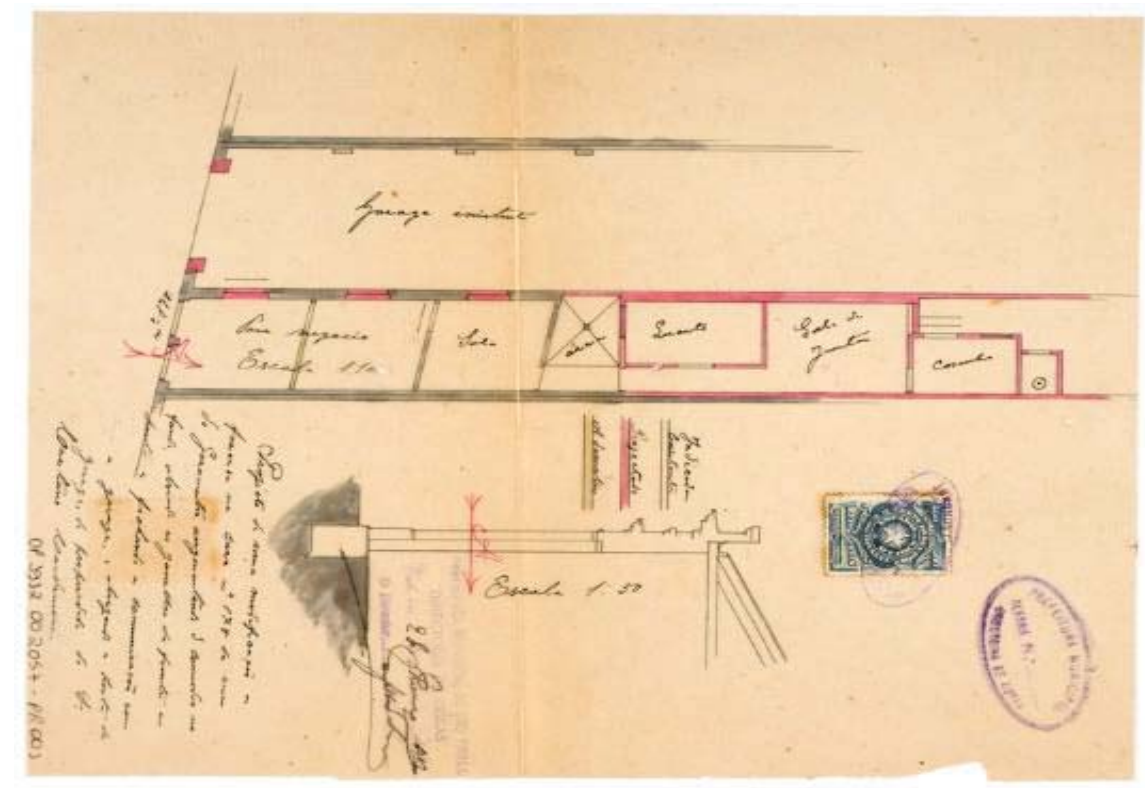

Figura 69: "Projecto de uma modificação a faserse na casa nº178 da rua do Gasometro (...)".Arquivo Histórico Municipal, Fundo “Diretoria de Obras”, Série “Obras Particulares”, OP1912.002.057

Ao analisarmos mais detidamente os cômodos das casas unifamiliares, começamos a nos indagar sobre seus usos, pois, enquanto a maioria apresenta uma média de dois dormitórios, sala (varanda ou sala de jantar), cozinha e banheiro, em outros aparece um número maior de quartos, oferecendo indícios que eventualmente não fosse projetado para apenas uma família, mas para várias, formando um cortiço futuramente, como o de propriedade de Luiz Fraga analisado anteriormente.

Na rua Claudino Pinto número 8, Cesario Magri solicita autorização para a construção de uma cocheira e uma casa contendo sala, sala de jantar, cozinha e quatro alcovas. A alcova, como bem salientou Maria Luiza Ferreira de Oliveira, era um dos aposentos para dormir, sendo passível de confusão quanto ao emprego dos nomes, servindo como espaço da privacidade e descanso, seja de casais ou de prostitutas que ali recebiam seus clientes. No caso em questão, inúmeras são as possibilidades de leitura sobre quais os destinos que Cesario Magri gostaria de dar ao seu imóvel tivesse, apesar de constar uma sala e cozinha nos fundos, o que inicialmente nos induz a pensar que seja uma casa para simples habitação, mas dada a presença dos nomes tais espaços de descanso, podia tratar-se de um cortiço, de um prostíbulo, de uma pensão, ou da persistência de um tipo de cômodo que sobreviveu ao longo do tempo e alcançou o construtor do período em questão. 


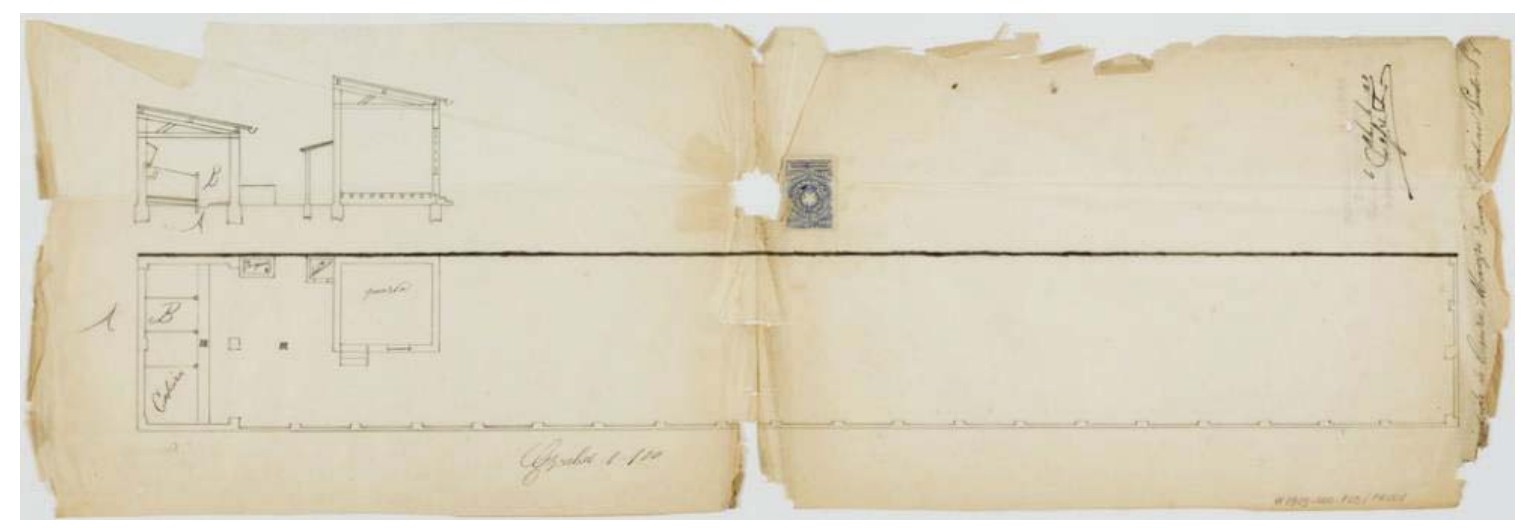

Figura 70: Projeto de construção de uma cocheira de Cesario Magri, na rua Claudino Pinto número 8 Arquivo Histórico Municipal, Fundo “Diretoria de Obras”, Série “Obras Particulares”, OP1909.000723.

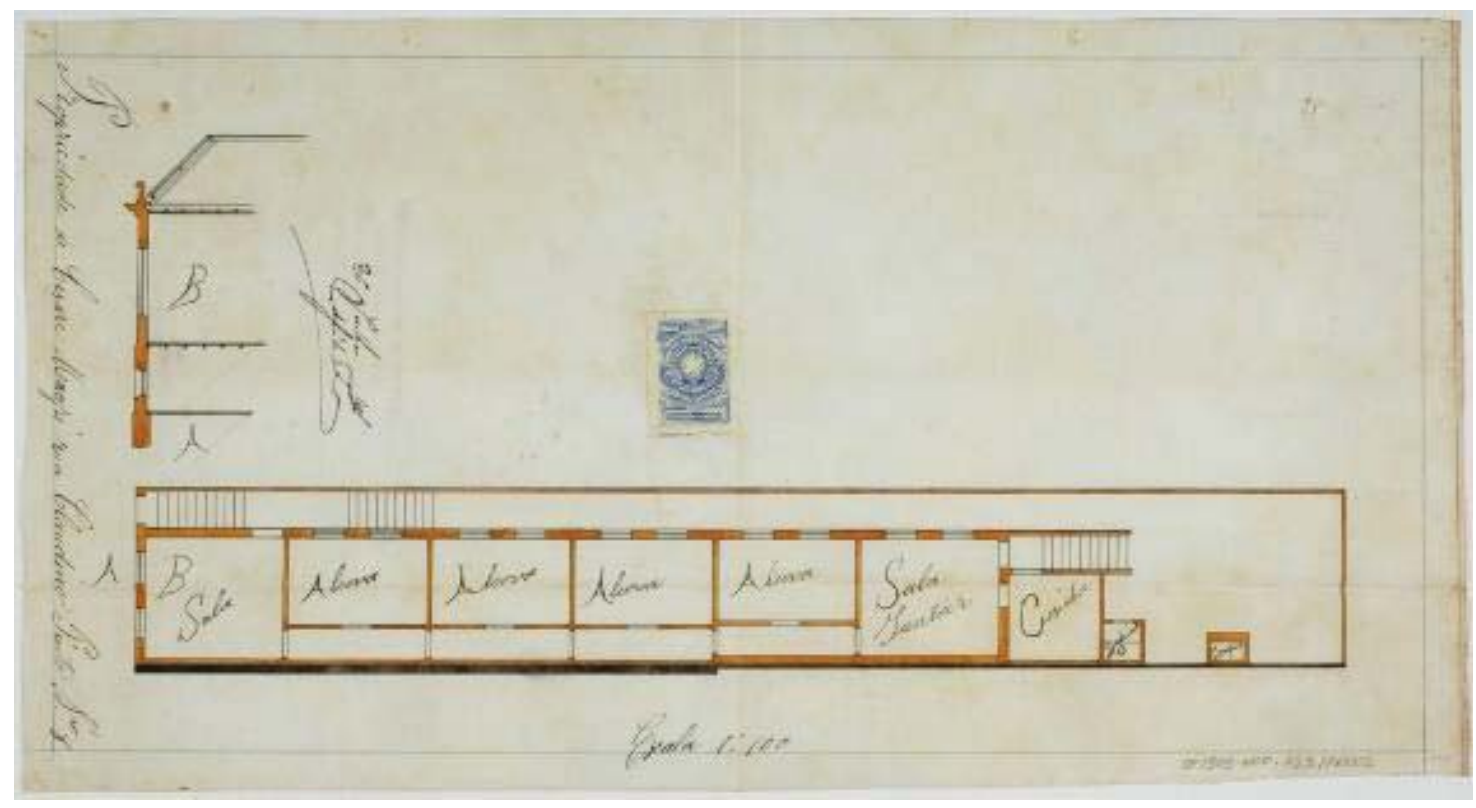

Figura 71: "Propriedade de Cesari Magri", rua Claudino Pinto número 8, Arquivo Histórico Municipal, Fundo “Diretoria de Obras”, Série “Obras Particulares”, OP1909.000.723.

Outro projeto faz alusão à alcova, desta vez, na rua Uruguaiana número 36, de propriedade da Dona Geltrude de Andrade Alves, em 1915 (figura 72). Trata-se de uma ampla reforma num prédio já existente, no qual portas seriam fechadas, outras transformadas em janelas; paredes seriam demolidas e outras construídas, permitindo um aumento da varanda e da despensa. A alcova permaneceria onde já estava, entre a sala e o dormitório, fechando sua janela que dava para a área descoberta, abrindo uma porta para acesso ao dormitório e continuando com seu acesso à sala. Certamente este cômodo seria considerado como um espaço de repouso intermediário, feito para o dia, pois não havia 
entrada de luz, e não necessitava de uma intimidade garantida, haja vista que tinha fácil acesso a outros cômodos da casa.

A alcova chegou a aparecer em outros três projetos no Brás, dois deles provavelmente do mesmo construtor, visto ser a caligrafia muito parecida à apresentada no projeto de Cesario Magri, na rua Claudino Pinto (figura 71). Estes projetos referem-se às ruas Maria Marcolina número 120, de propriedade de Ernesto Venturini; e os outros dois da rua Américo Brasiliense (um de propriedade de Julio Bernardi, no número 66, e o outro de Luigi Baldi, número 68, ambos do ano de 1909). Quanto ao primeiro, trata-se de uma construção na testada do lote, com exceção de uma sala e a alcova que se encontram colados do lado esquerdo do lote, novamente seguidas de um telheiro e outro cômodo recuados. Ao fundo, nota-se a presença da latrina. Já o imóvel vizinho (figura 73) encontra-se alinhado a outra parede, e o telheiro conectado à casa, mesmo que para seu acesso haja a necessidade de acessar uma escada. Não nos deteremos sobre os possíveis usos que as alcovas deste imóvel podem ter tido, mas no fato da casa não apresentar banheiros em seu projeto, o que nos leva a deduzir que estes telheiros pudessem servir de latrinas. Se nos atentarmos ao projeto de dona Geltrudes de Andrade (figura 72) notaremos que, em sua casa, o banheiro situa-se fora do corpo da casa também, não constando na proposta de reforma que ele fosse integrado à residência. A chegada da água encanada e dos esgotos no Brás parecia ter-se consolidado em grande parte do bairro, segundo o mapa de $1905^{207}$, mas não se efetivou em banheiros (WC), em todas as casas prontamente, o que pode ser explicado pelo possível alto preço na época.

${ }^{207}$ Sobre o assunto, consultar: SANTOS, Op. Cit., 2011. 


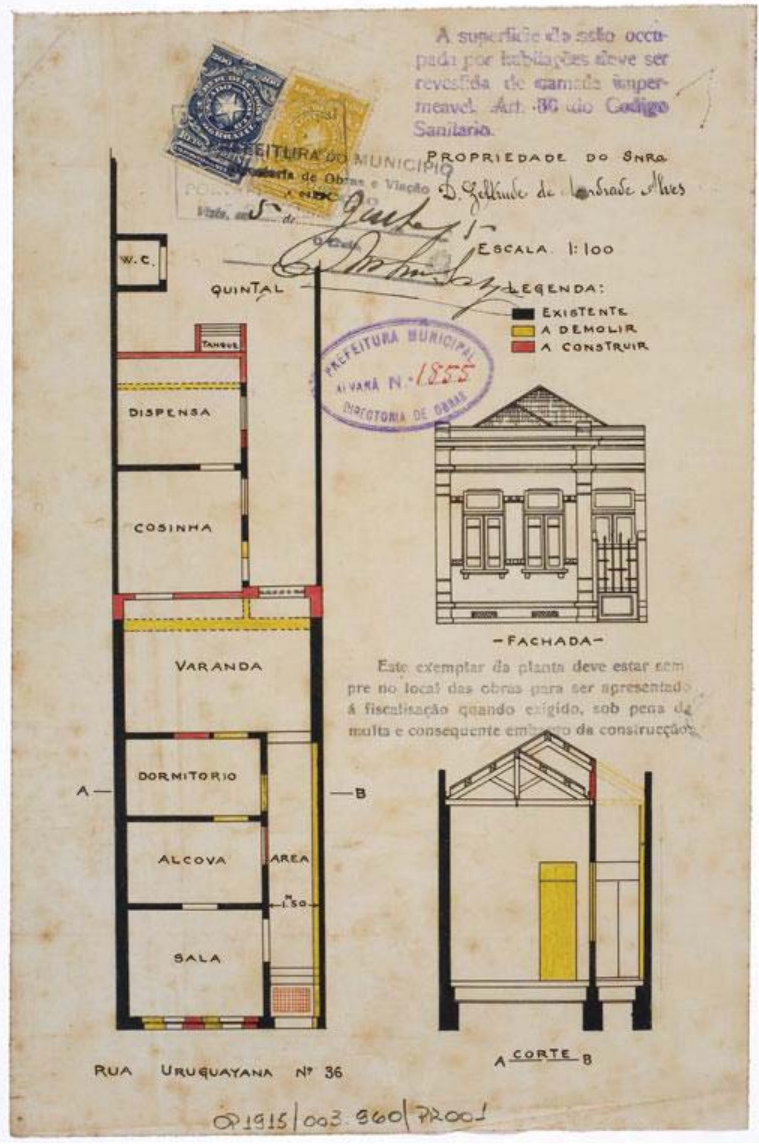

Figura 72: "Propriedade da Snra. D. Geltrudes de Andrade Alves", rua Uruguaiana número 36. Arquivo Histórico Municipal, Fundo “Diretoria de Obras”, Série “Obras Particulares”OP1915.003.960.

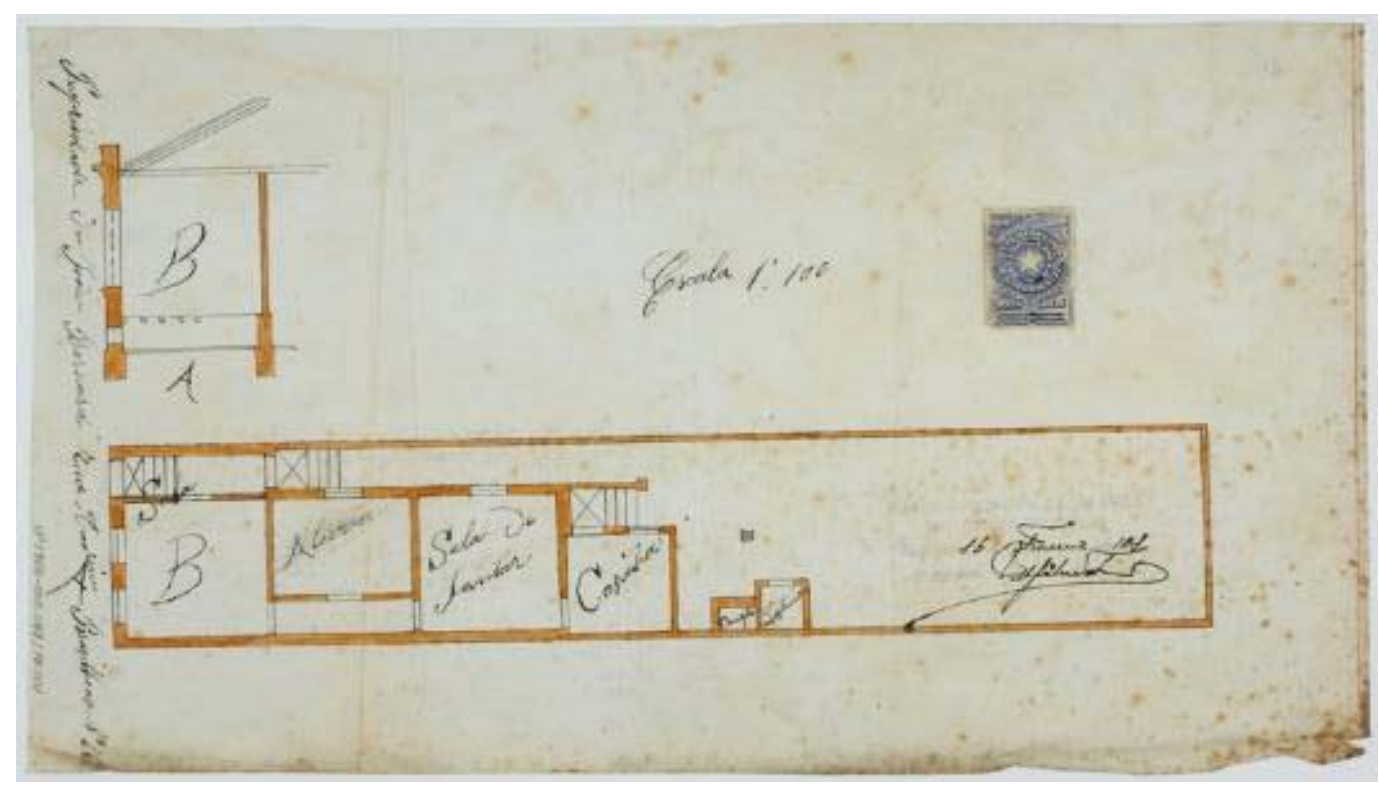

Figura 73: "Propriedade de João Bernardi”, rua Américo Brasiliense número 66. Arquivo Histórico Municipal, Fundo “Diretoria de Obras”, Série “Obras Particulares”OP1909.000.098. 


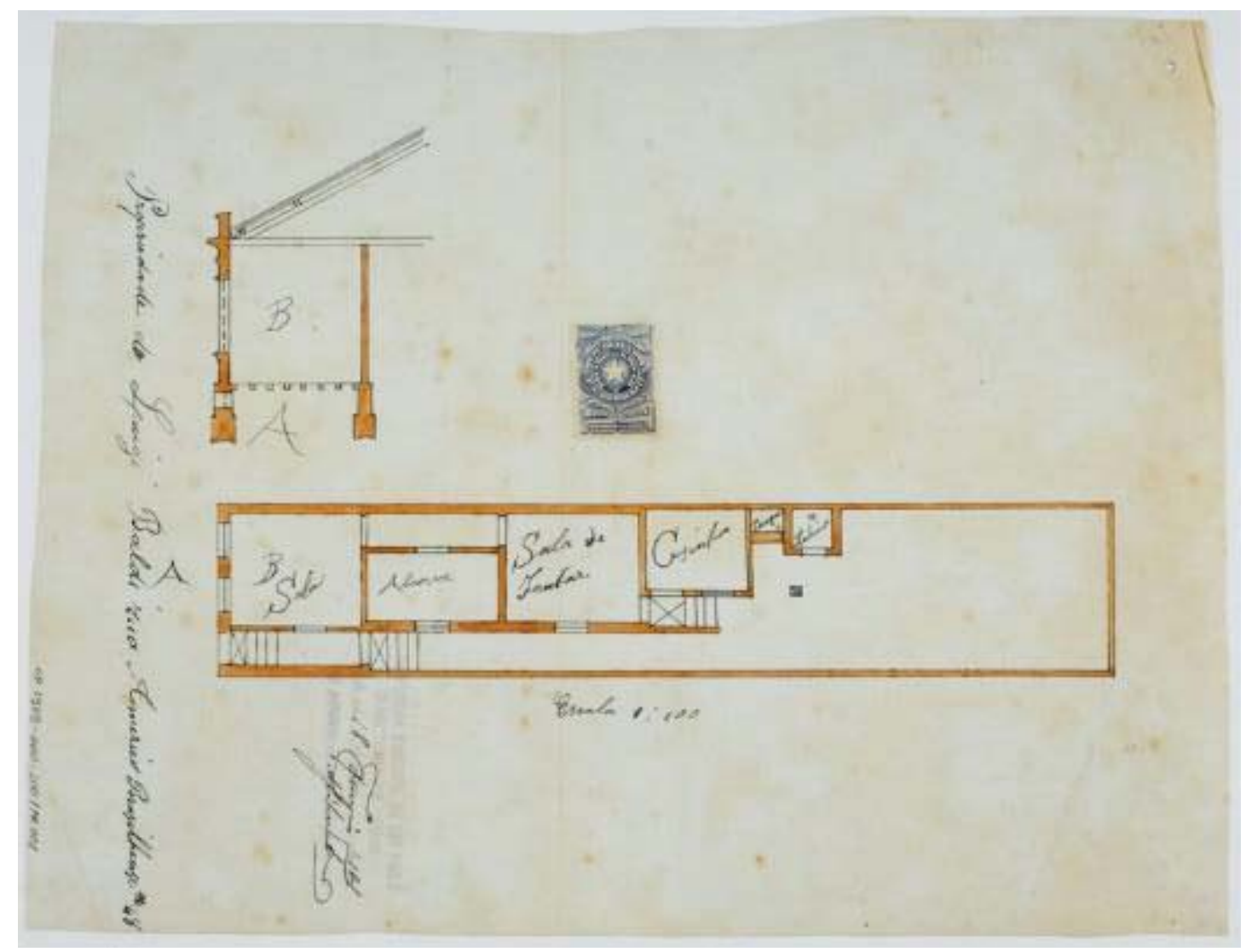

Figura 74: "Propriedade de Luigi Baldi", rua Américo Brasiliense número 69. Arquivo Histórico Municipal, Fundo "Diretoria de Obras", Série “Obras Particulares”OP1909.000.100.

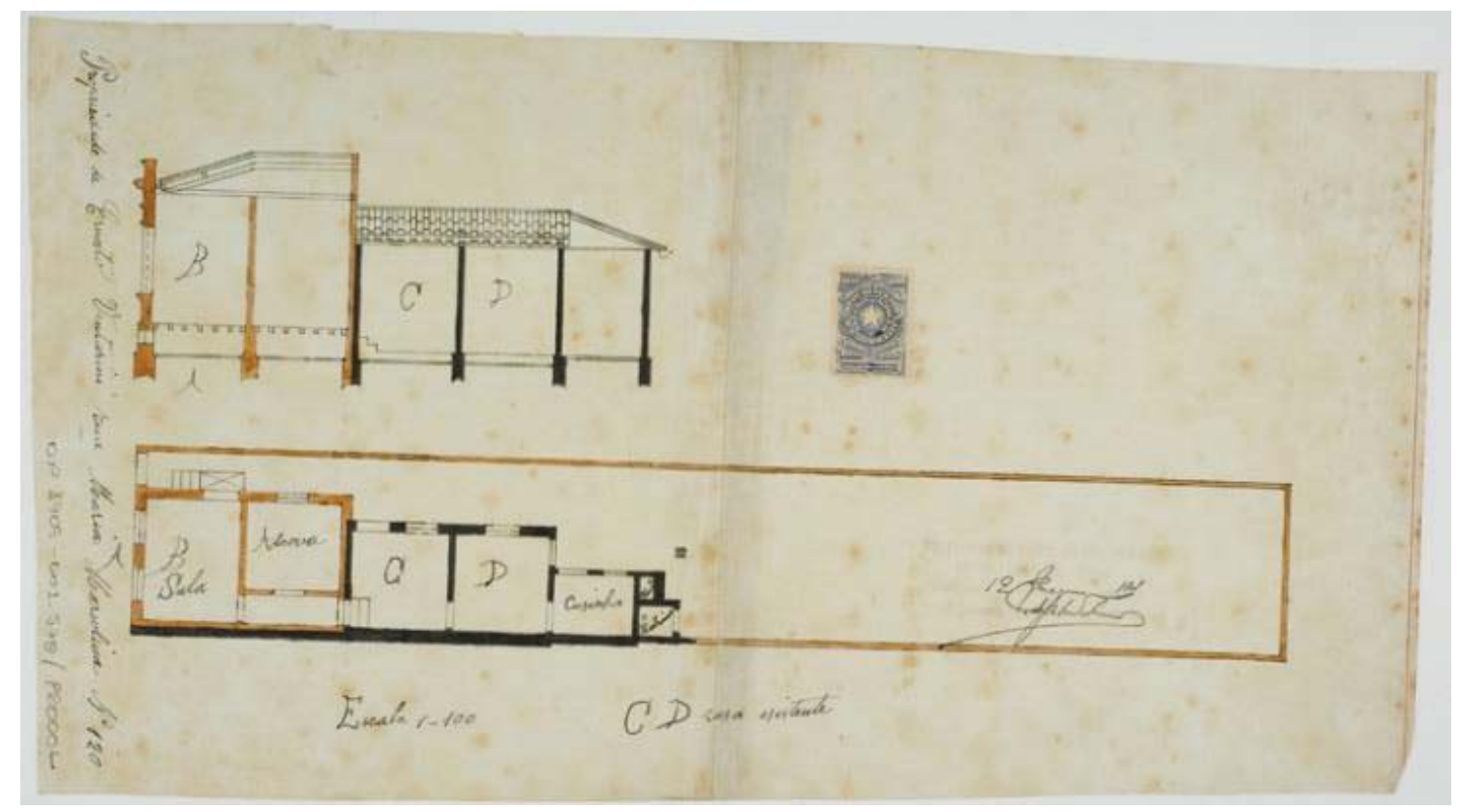

Figura 75: "Propriedade de Ernesto Venturini”, rua Maria Marcolina número 120. Arquivo Histórico Municipal, Fundo “Diretoria de Obras”, Série “Obras Particulares”OP1909.001.578.

Em grande parte dos projetos apresentados à Prefeitura constam lugares específicos para a higiene, mas considerável é o número de projetos em que não constam estes espaços, 
como os da rua Américo Brasiliense. Quais as razões para que o banheiro ou latrina se mantivesse fora do corpo da casa? Uma das respostas pode ser encontrada dentro do próprio processo de urbanização que o bairro passava, como a distribuição de água e a coleta de esgotos que estava sendo implantada paulatinamente. Ao analisarmos o mapa da distribuição de águas e esgotos da capital em 1905, veremos que nem todas as ruas eram servidas pelo serviço, o que dificultava a ligação dos encanamentos com a rede em certas zonas.

No Capítulo II do Código Sanitário de 1894, a construção de latrinas seguia um rigoroso processo de instalação:

Artigo 56. - Não deverá ser permitida latrina, destinada ao uso commum dos moradores, unida aos aposentos de dormir. O espaço a ella destinado deve ser ventilado e bem iluminado.

Artigo 57. - De permeio ao gabinete da latrina e aos aposentos interiores deverá haver um compartimento claro e bem arejado, que nunca deverá servir para dormitorio.

Artigo 58. - O chão do gabinete da latrina deverá ter revestimento impermeavel, prolongando-se a impermeabilidade até á altura de $1 \mathrm{~m}, 50$.

Artigo 59. - Deverão ser prohibidas as caixas de madeiras para revestimento dos apparelhos hygienicos.

Artigo 60. - A bacia ou receptaculo das latrinas deverá ser de materia impermeavel, solido, polido interiormente, sem relevos nem ornatos. Os apparelhos munidos de fundos moveis e valvulas deverão ser condemnados nas habitações a construir de ora avante.

Artigo 61. - A installação dos apparelhos deverá ser tal, que a bacia e o syphão possam ser constante e rigorosamente limpos e desinfectados, interna e externamente.

Artigo 62. - Todas as latrinas deverão ter syphão simples em - S - com Interceptor hydraulico.

Artigo 63. - Far-se-á a ventilação dos encanamentos pela corôa do syphão.

Artigo 64. - O tubo de ventilação deverá elevar-se a dous metros pelo menos acima dos telhados das casas proximas e bem afastado sempre dos reservatorios ou depositos de agua potavel.

Artigo 65. - Os tubos de descida das latrinas deverão ser impermeaveis e resistentes á acção das materias que por elles circulam.

Artigo 66. - A superficie interna destes tubos deverá ser perfeitamente polida e o seu diametro calculado de modo que a velocidade das aguas de lavagem augmente progressivamente.

Artigo 67. - Servindo a differentes andares de uma mesma casa, os tubos secundarios abrir-se-ão no tubo de descida, em sentido obliquo. 
Artigo 68. - Não deverá ser permittido um tubo unico de descida para duas casas diferentes.

Artigo 69. - As caixas de agua para lavagem das latrinas deverão ser exclusivamente destinadas a este mister e não poderão ter communicações com o reservatorio de agua potavel.

Artigo 70. - As caixas deverão dar descargas provocadas ou automaticas intermittentes, convenientemente calculadas.

Artigo 71. - O jorro de agua descarregado deverá ser calculado para produzir a lavagem completa da bacia e do tubo de descida.

Artigo 72. - Na construcção dos mictorios deverão ser observados os mesmos preceitos indicados para as latrinas.

Artigo 73. - Todos as aguas servidas deverão ser conduzidas para os exgottos.

Artigo 74. - Os encanamentos das aguas servidas de cozinha, banheiros e lavatorios deverão ser separados dos exgottos por meio de interceptor hydraulico.

Artigo 75. - Os encanamentos de exgottos não poderão em caso algum communicar directamente com os drenos das habitações.

Artigo 76. - Os drenos deverão entroncar nos collectores dos exgottos, mas sempre separados destes por interceptor hydraulico.

Artigo 77. - Na falta de galeria de exgottos, deverão ser toleradas as fossas fixas.

Artigo 78. - Estas fossas deverão ser construidas sempre fóra das habitações e não deverão ter mais de um metro cubico de capacidade.

Artigo 79. - Deverão ser rigorosamente impermeaveis sem arestas ou reentrancia, protegidas contra a invasão das aguas das chuvas, e outras, perfeitamente fechadas e munidas de tubos de ventilação.

Artigo 80. - As materias das fossas fixas deverão ser diariamente cobertas com terra secca ou desifectadas.

Artigo 81. - As fossas serão esvasiadas e limpas duas vezes por mez, pelo menos, e os residuos nellas contidos levados em caixas fechadas para fóra do limite urbano.

Artigo 82. - Deve ser prohibido o despejo das materias residuaes nos cursos de agua potavel dentro ou fóra das povoações, salvo a hypothese dos arts. $173 \mathrm{e}$ 174 do capitulo $7^{\circ}$.

Artigo 83. - Não deverão ser admittidas fossas fixas onde houver cisternas, poços ou nascentes de agua potavel ou para este fim utilizadas.

Artigo 84. - Na hypothese anterior, ou quando em presença de cursos de agua potavel, as fossas deverão ser substituidas por celhas moveis de material impermeavel.

Artigo 85. - Para facilitar a remoção dos residuos, esvasiamento e desinfecção das celhas, deverá haver pelo menos duas em cada habitação. 
Artigo 86. - As celhas deverão ser transportaveis e removidas, fechadas, para fóra do limite urbano, antes que haja decomposição dos residuos.

Artigo 87. - E' recommendavel o esvasiamento das fossas fixas pelo processo pneumatico aperfeiçoado.

Artigo 88. - Em caso algum as fossas fixas deverão communicar com galerias de aguas fluviaes ou quaesquer conductos permanentement" 208

Apesar de o Código Sanitário ser bem rigoroso quanto à instalação das latrinas, existia uma flexibilização que servia de alternativa aos projetos que não pudessem contar com todos os novos ditames impostos pelos órgãos públicos. Do artigo $77 \mathrm{em}$ diante podemos perceber uma alternativa para aqueles que não podiam contar com os esgotos, perpetuando as latrinas, prática que perdurou até pelo menos os anos de 1915. Nesse sentido, encontramos muitas referências às mesmas nos desenhos da Série Obras Particulares.

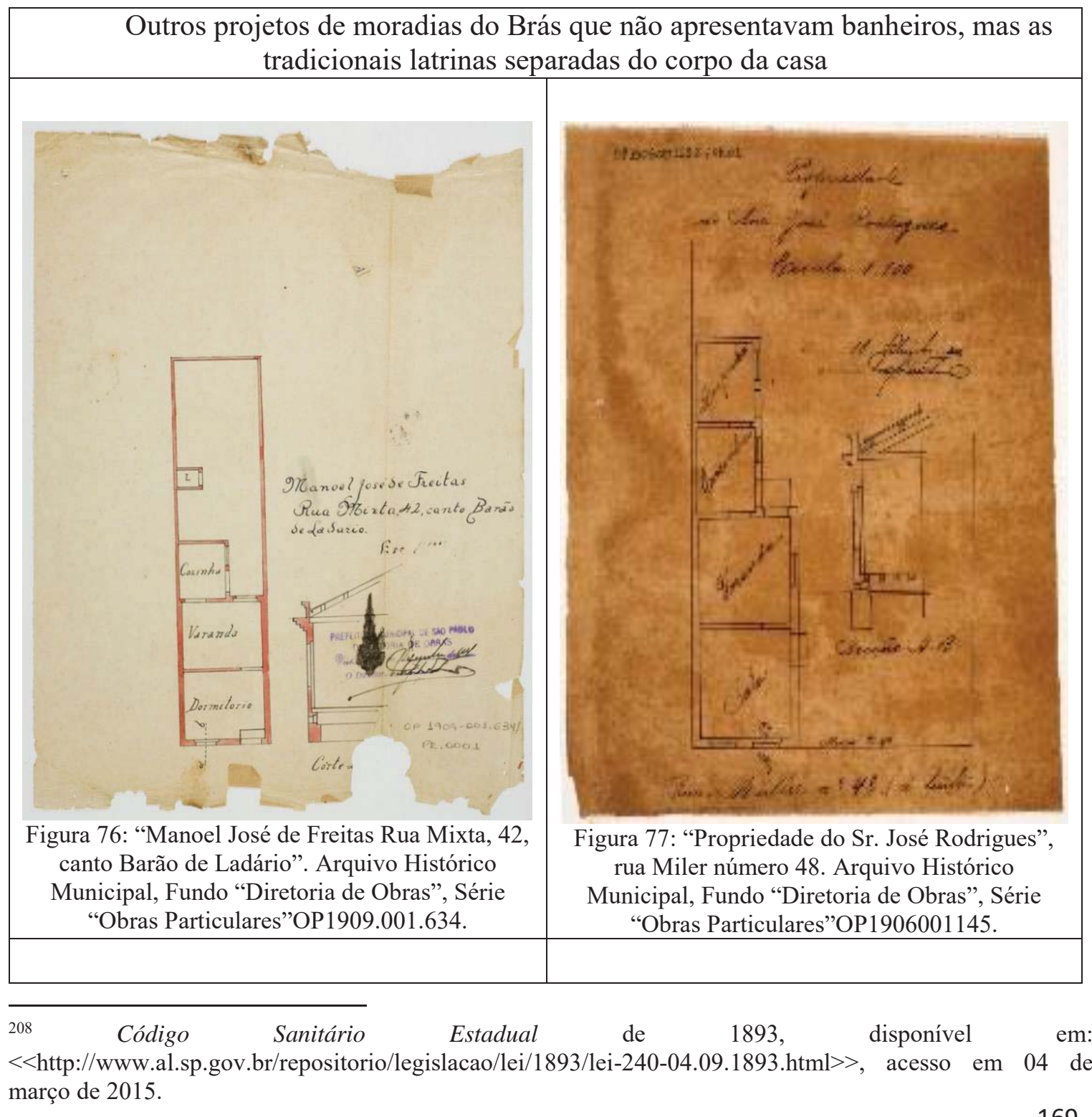




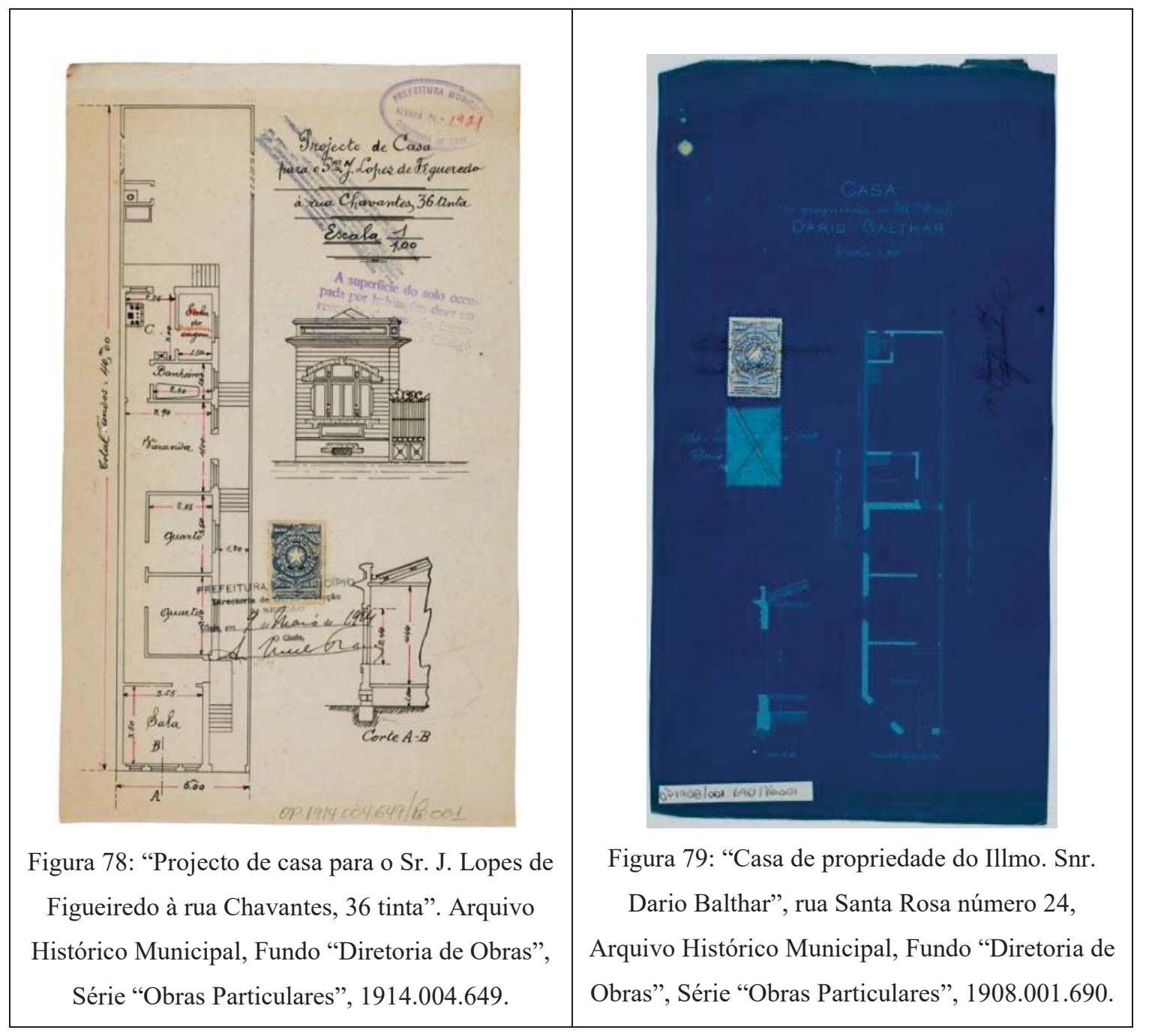

\subsection{As casas em série e vilas como alternativa ao mercado imobiliário}

Com uma população cada vez maior concentrada, em especial, nos bairros além rio Tamanduateí, o mercado imobiliário enxergou uma oportunidade para gerar mais lucros e satisfazer em parte as necessidades da população no quesito moradia. São Paulo se constituiu então, nas primeiras décadas do século XX, numa cidade construída por diferentes grupos de empreendedores. No Brás, nota-se a presença predominante de proprietários médios, com pequenos lotes de terra, que ali construíram pequenas edificações para uso próprio ou renda de aluguel, que versaram principalmente em torno de proprietários médios, com pequenos lotes de terra. 
O Código Sanitário de 1894 já trazia em seu artigo 141 que "as vilas operárias deverão ser estabelecidas fora da aglomeração urbana", como forma de transformar o centro num espaço dedicado ao comércio e às camadas altas, bem como num espaço de prestação de serviços, enquanto áreas adjacentes seriam destinadas à população mais pobre e dos setores médios. Além da legislação em vigor desde o final do século XIX, figuras do meio político municipal como Celso Garcia, levaram à discussão a necessidade de se estudarem formas de conter o grande déficit habitacional que pairava em São Paulo.

$\mathrm{Na}$ documentação processada por nós, pudemos perceber a construção de duas tipologias numericamente predominantes em termos de habitação: as casas em série e as vilas operárias. Ambas apresentam aspectos que as aproximam enquanto opções do mercado imobiliário residencial, mas também as distanciam quanto às suas formas.

As vilas operárias foram entendidas ao longo do tempo como uma alternativa do empresariado para manter seus operários vinculados ao trabalho das fábricas, ideia que fora enriquecida com o trabalho de Eva Blay, Eu não tenho onde morar, no qual a autora entende que esta forma de habitação servia essencialmente "para tornar possível armazenar a força de trabalho livre necessária à produção", cristalizando-se no imaginário coletivo o estereótipo de certos bairros como operários e fabris, nos quais aparecem com certa ênfase essas tais “vilas operárias”, dentre os quais a Móoca, o Brás, o Bom Retiro e a Luz ${ }^{209}$.

Outro ponto tocante às vilas operárias concerne do entendimento corrente de que eram construídas pela bondade do empresariado, ao conceder moradia aos seus diversos empregados. Como já demonstrou a historiografia ${ }^{210}$, essa prática na realidade não alcançava a totalidade de empregados, e aqueles que usufruíram de tal benefício, tinham desconto na sua folha de pagamento, o que demonstra que tais habitações eram pagas mensalmente, como um aluguel.

\footnotetext{
209 BLAY, Op. Cit., pág. 40.

210 Paulo Fontes realizou um intenso levantamento de pensões de São Miguel Paulista a partir da década de 1950, o que dava por muitos dos moradores locais serem trabalhadores da Companhia Nitro Química Brasileira, e não residirem na vila construída pela fábrica. Já Luciana Tonaki trouxe à tona a construção dos equipamentos da fábrica em questão, e demonstrou que a vila era um espaço voltado para determinados setores que ali trabalhavam. FONTES, Paulo. Um Nordeste em São Paulo: Trabalhadores migrantes em São Miguel Paulista (1945-66). Rio de Janeiro: Editora FGV, 2008. TONAKI, Luciana Lepe. A Companhia Nitro Química: indústria e vila operária em São Miguel Paulista. Dissertação (Mestrado), Instituto de Arquitetura e Urbanismo de São Carlos, Universidade de São Paulo, São Carlos, 2013.
} 
Telma de Barros Correia nos coloca que a partir da segunda metade do século XIX, no Brasil, a construção de vilas para empregados foi uma prática recorrente por empresas que inicialmente tendiam a abranger os operários de um mesmo empreendimento fabril, e

\footnotetext{
"logo seria estendido para designar grupos de casas modestas semelhantes produzidas por outros agentes. Sob a denominação "vila operária”, eram reunidas no país, até os anos trinta, as experiências mais diversas: conjuntos construídos por empresas imobiliárias para aluguel ou venda a proletários urbanos, por empresas ferroviárias para seus funcionários, por indústrias, minas, frigoríficos e usinas para seus operários, técnicos e administradores, e pelo Estado.”211
}

A partir de um levantamento no Almanaque Laemmert mapeamos as seguintes vilas, com seus respectivos endereços, situadas especialmente entre ruas do Brás, mas em localidades próximas. Ademais, com a análise pormenorizada dos projetos de obras particulares, descobriu-se que número de vilas construídas por particulares foi muito intensa.

\begin{tabular}{|c|c|c|}
\hline \multicolumn{3}{|c|}{ Relação de vilas do Brás anunciadas no Almanack Laemmert } \\
\hline VILA & ENDEREÇO & REFERÊNCIA \\
\hline Vila Nayr & $\begin{array}{c}\text { Perto do número } 42 \text { da rua } \\
\text { da Alfândega }\end{array}$ & 1911 \\
\hline Vila Queiroga & $\begin{array}{l}\text { Perto do número } 6 \text { da rua } \\
\text { Maria Domitila }\end{array}$ & 1911 \\
\hline Vila Três Irmãos & $\begin{array}{c}\text { Perto do número } 25 \text { da rua } \\
\text { Piratininga }\end{array}$ & 1911 \\
\hline Vila Vautier & Fim da rua João Teodoro & 1911 \\
\hline Vila Zilda & $\begin{array}{l}\text { Perto do } 5^{\circ} \text { desvio do } \\
\text { bonde da Penha }\end{array}$ & 1911 \\
\hline Vila Operária & $\begin{array}{l}\text { Rua Coronel Cintra, perto } \\
\text { da rua da Mooca }\end{array}$ & 1915 \\
\hline Vila Operária da CNTJ & $\begin{array}{c}\text { Rua Conselheiro Belisário, } \\
100 \text { e na rua Oriente, } 26\end{array}$ & 1915 \\
\hline Vila Polydoro & $\begin{array}{l}\text { Ao lado do número } 143 \mathrm{da} \\
\text { rua Concordia }\end{array}$ & 1915 \\
\hline Vila Abreu Junior & $\begin{array}{l}\text { Em frente ao número } 86 \text { da } \\
\text { rua Miler }\end{array}$ & 1915 \\
\hline
\end{tabular}

Tabela 7: "Relação de vilas operárias do Brás anunciadas no Almanak Laemmert”, elaborada pelo autor.

${ }^{211}$ CORREIA, Telma de Barros. "De Vila operária a cidade-companhia: as aglomerações criadas por empresas no vocabulário especializado e vernacular". Revista Brasileira de Estudos Urbanos e Regionais. N $N^{\circ}$ / maio, 2011, pág. 83-84. 


\begin{tabular}{|c|c|c|c|c|c|}
\hline \multicolumn{6}{|c|}{ Relação de vilas operárias construídas por particulares encontradas na série Obras Particulares } \\
\hline VILA & ENDEREÇO & $\begin{array}{l}\text { NÚMERO } \\
\text { DE } \\
\text { CASAS } \\
\end{array}$ & $\begin{array}{l}\text { PROPRIETÁ- } \\
\text { RIO }\end{array}$ & $\begin{array}{l}\text { CONSTRU- } \\
\text { TOR }\end{array}$ & $\begin{array}{l}\text { NÚMERO DE } \\
\text { REFERÊNCIA }\end{array}$ \\
\hline $\begin{array}{l}\text { Companhia } \\
\text { Nacional } \\
\text { de Tecidos } \\
\text { de Juta }\end{array}$ & $\begin{array}{l}\text { Entre as ruas } \\
\text { Conselheiro } \\
\text { Belisário e Barão } \\
\text { de Ladário }\end{array}$ & 60 & $\begin{array}{l}\text { A.Siciliano / } \\
\text { Alexandre } \\
\text { Leslie } \\
\text { (diretor) }\end{array}$ & & $\begin{array}{l}\text { OP1911.002.628_PR006 } \\
\text { OP1911.002.628_PR002 } \\
\text { OP190.000.646_PR001 } \\
\text { OP1908.000.646_PR002 }\end{array}$ \\
\hline $\begin{array}{l}\text { Costabile } \\
\text { Matarazzo }\end{array}$ & $\begin{array}{l}\text { Rua Rodrigues } \\
\text { dos Santos, } 23 \text { e } \\
25\end{array}$ & 38 & $\begin{array}{l}\text { Andrea } \\
\text { Matarazzo }\end{array}$ & & OP1912.003.701_PR001 \\
\hline $\begin{array}{l}\text { João } \\
\text { Ferreira }\end{array}$ & $\begin{array}{l}\text { Entre as esquinas } \\
\text { da rua Bresser e } \\
\text { rua Inácio de } \\
\text { Araújo }\end{array}$ & 65 & João Ferreira & & OP1912.000.779_PR001 \\
\hline $\begin{array}{l}\text { Vila } \\
\text { Barros }\end{array}$ & $\begin{array}{l}\text { Rua Gomes } \\
\text { Cardim } 167 / 187 ?\end{array}$ & 40 & \begin{tabular}{|l|} 
Joaquim \\
Mendes de \\
Oliveira
\end{tabular} & \begin{tabular}{|l|} 
Joaquim \\
Carlos \\
Augusto \\
Cavalheiro \\
\end{tabular} & OP1911.001.647_PR001 \\
\hline $\begin{array}{l}\text { Villa } \\
\text { operária da } \\
\text { rua Miller }\end{array}$ & Rua Miler & 6 & \begin{tabular}{|l|} 
Pedro \\
Lavieri
\end{tabular} & & OP1915.002.784_PR001 \\
\hline \multirow{9}{*}{$\begin{array}{l}\text { Do Dr. } \\
\text { Arlindo } \\
\text { Ernesto } \\
\text { Miranda } \\
\end{array}$} & $\begin{array}{l}\text { Rua Visconde de } \\
\text { Parnaíba }\end{array}$ & 10 & $\begin{array}{l}\text { Arlindo } \\
\text { Ernesto } \\
\text { Miranda }\end{array}$ & & OP1911.003.773_PR001 \\
\hline & $\begin{array}{l}\text { Rua Visconde de } \\
\text { Parnaíba, } 377\end{array}$ & 11 & \begin{tabular}{|l} 
Francisco \\
Antonio de \\
Carvalho
\end{tabular} & & OP1912.004.602_PR001 \\
\hline & $\begin{array}{l}\text { Avenida Rangel } \\
\text { pestana, } 127 ?\end{array}$ & 10 & $\begin{array}{l}\text { Lydia } \\
\text { Augusta } \\
\text { Saraiva } \\
\end{array}$ & & OP1910.002.134_PR001 \\
\hline & $\begin{array}{l}\text { Rua Almirante } \\
\text { Barroso, } 65\end{array}$ & 24 & $\begin{array}{l}\text { Abel A. } \\
\text { Salles }\end{array}$ & $\begin{array}{l}\text { Francisco } \\
\text { Pompeo }\end{array}$ & OP1912.000.090_PR001 \\
\hline & $\begin{array}{l}\text { Rua Almirante } \\
\text { Barroso, junto ao } \\
\text { número } 84\end{array}$ & 8 & $\begin{array}{l}\text { José Antonio } \\
\text { Nogueira }\end{array}$ & & OP1914.000.100_PR001 \\
\hline & Rua Bresser, 153 & 9 & \begin{tabular}{|l|} 
Arthur \\
Ferreira \\
Lima \\
\end{tabular} & & OP1913.000.841_PR001 \\
\hline & Rua Bresser, s/n & 22 & & & OP1914.000.730_PR001 \\
\hline & $\begin{array}{l}\text { Rua Visconde de } \\
\text { Parnaíba, s/n }\end{array}$ & 24 & \begin{tabular}{|l|} 
Clementino \\
de Souza e \\
Castro \\
\end{tabular} & & OP1911.003.765_PR001 \\
\hline & $\begin{array}{l}\text { Rua Vinte e Um } \\
\text { de Abril, } 107\end{array}$ & 6 & \begin{tabular}{|l} 
Manuel \\
$\mathrm{Ch}[?]$
\end{tabular} & & OP1911.003.712_PR001 \\
\hline \multirow[t]{3}{*}{$\begin{array}{l}\text { Vila } \\
\text { Godinho }\end{array}$} & $\begin{array}{l}\text { Rua Uruguaiana, } \\
130 \text { e } 132\end{array}$ & 28 & $\begin{array}{l}\text { Antonio } \\
\text { Godinho } \\
\text { Filho } \\
\end{array}$ & \begin{tabular}{|l|} 
João \\
Eusébio \\
Peixoto
\end{tabular} & OP1909.002.431_PR001 \\
\hline & $\begin{array}{l}\text { Rua Vinte e Um } \\
\text { de Abril, 43-45 }\end{array}$ & 7 & & & OP1912.004.547_PR001 \\
\hline & $\begin{array}{l}\text { Rua Vinte e Um } \\
\text { de Abril, s/n }\end{array}$ & 11 & & & OP1911.003.729_PR001 \\
\hline
\end{tabular}




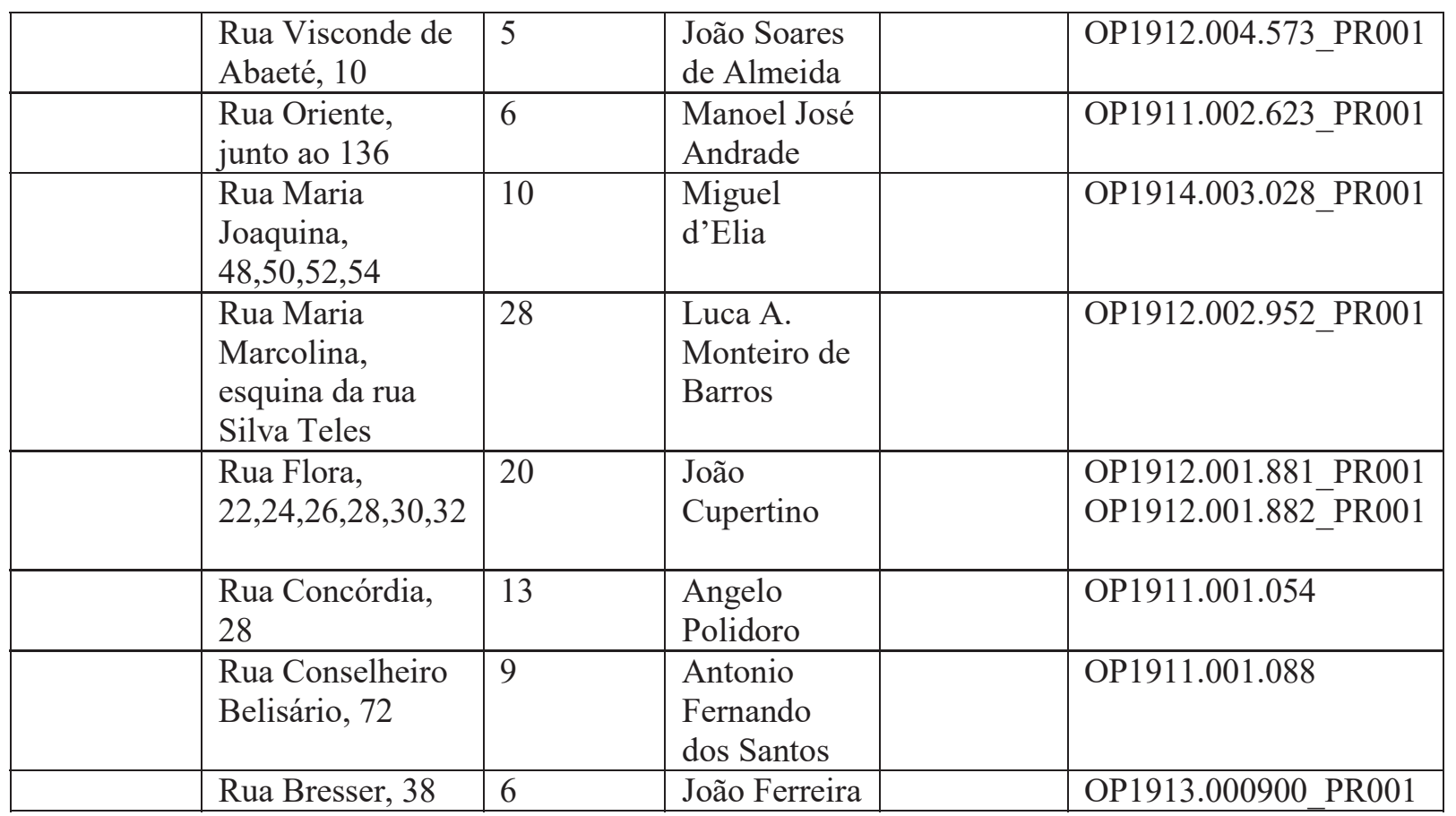

Tabela 8: "Relação de vilas operárias do Brás levantadas pelo autor na Série Obras Particulares”, elaborada

pelo autor.

A análise comparativa das duas tabelas acima dão um panorama inicial da distribuição espacial no Brás, situando-se quase que exclusivamente em vias de fácil acesso ao eixo das avenidas Rangel Pestana e Celso Garcia, bem como muitas delas contavam com a disponibilidade de bondes. Ou seja, o transporte torna-se um diferencial para aqueles que pudessem comprar ou alugar uma das casas destas vilas operárias.

Atentando ao número de residências contidas em cada vila, a partir da análise dos desenhos da Série Obras Particulares, pode-se perceber que o número era variável, podendo ir de 5 a 65 unidades habitacionais num mesmo lote. A Vila operária da Companhia Nacional de Tecidos de Juta, com 60 casas assobradadas, ocupava praticamente todo um quarteirão, estando muito próxima da fábrica (figuras 80, 81 e 82). 


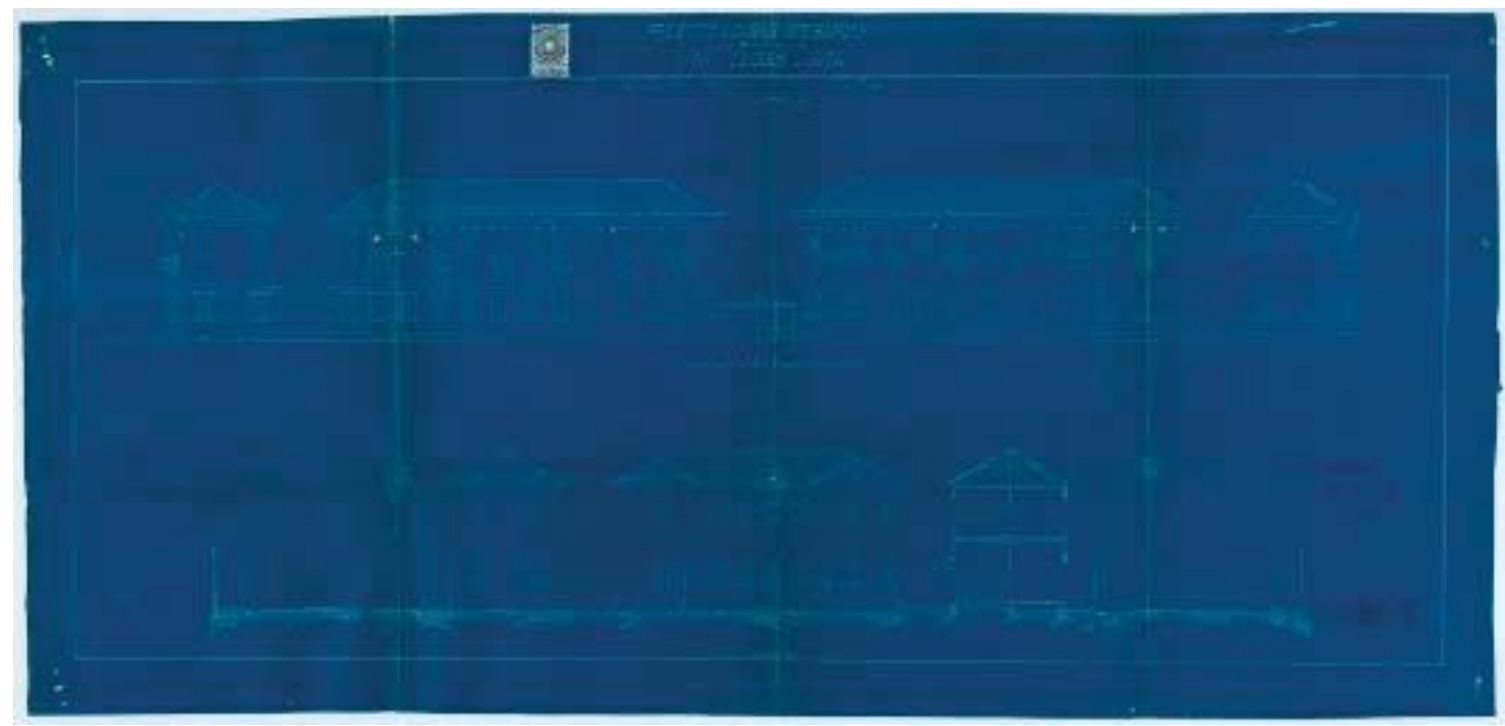

Figura 80: "Projecto de casas operárias para a C. N. de Tecidos de Juta". Arquivo Histórico Municipal, Fundo "Diretoria de Obras", Série "Obras Particulares", OP1911.002.628_PR002

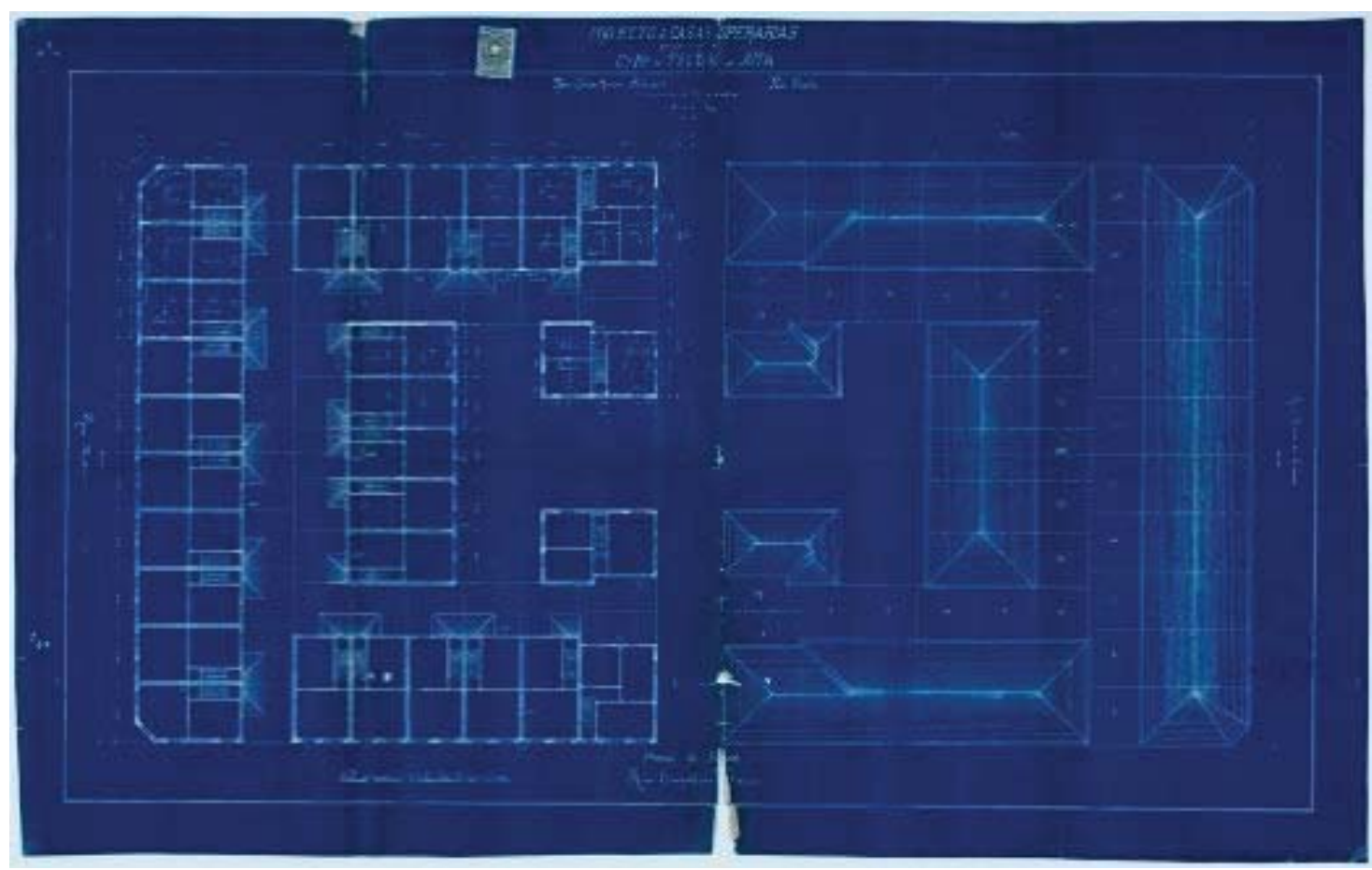

Figura 81: "Projecto de casas operárias para a C. N. de Tecidos de Juta”. Arquivo Histórico Municipal, Fundo "Diretoria de Obras", Série "Obras Particulares”, OP1911.026.28_PR006 


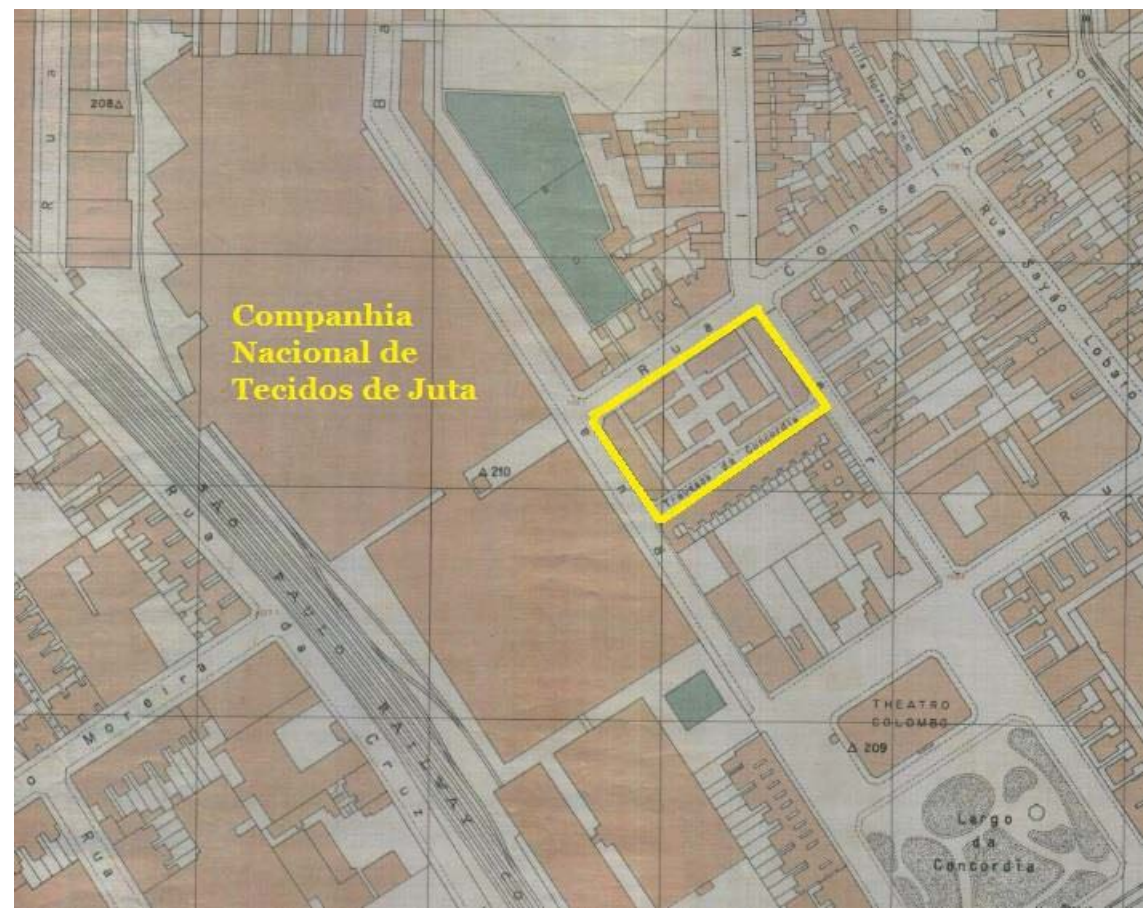

Figura 82: Localização da Vila Operária da Companhia Nacional de Tecidos de Juta entre as ruas Conselheiro Belisário e Barão de Ladário, defronte ao conjunto fabril. Fonte: Sara Brasil. - Acervo Cartográfico do Arquivo Histórico Municipal.

Outra vila financiada a partir do empresariado fabril do Brás, foi a Vila Costabile Matarazzo, muito próxima dos conjuntos fabris do grupo Indústrias Reunidas Francisco Matarazzo, e que seus funcionários poderiam alugar uma das 38 casas disponíveis. Interessante notar que as casas de frente do complexo, com vista para a rua Rodrigues dos Santos são maiores que as demais, nos fundos do lote, e com vista para a o pátio comum. Enquanto as primeiras possuem cinco cômodos mais banheiro, as demais possuem três cômodos e o banheiro, além de um amplo espaço nos fundos que formava um quintal (figura $83)$. 


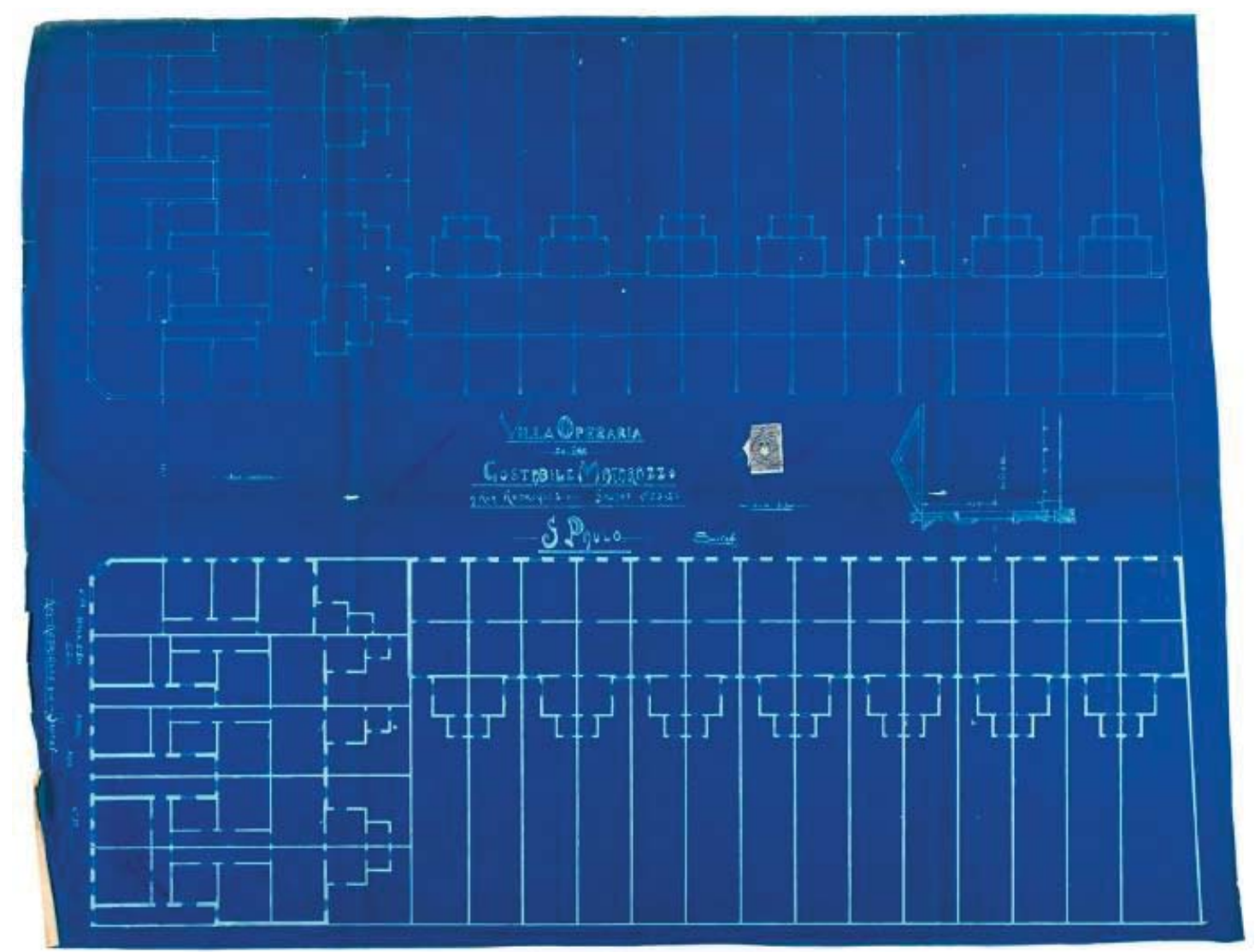

Figura 83: "Villa Operaria do Snr. Costabile Matarazzo" - Arquivo Histórico Municipal, Fundo "Diretoria de Obras”, Série “Obras Particulares”, OP1912.003.701

As vilas operárias também seguiam o padrão de casa mínima, traduzindo-se muitas vezes como vilas operárias dada a dimensão e número de seus cômodos, ainda que muitas dessas casas fossem destinadas a outros setores profissionais que não empregados das fábricas, e mesmo não tivessem sido financiadas pelo empresariado fabril. Exemplo que pode ser trazido à luz é o "Projecto de Villa Operaria de Propriedade do Snr. João Ferreira", personagem que possuía um dos maiores conjuntos de residências no Brás (ao menos 31), espalhados entre as ruas Bresser, Conselheiro Belisário, Hipódromo e principalmente na rua Inácio de Araújo (números 2, 4, 6, 8, 10, 12, 14, 16, 18, 20, 22, 24 e 25, 43, 45, 47, 49, 51, $53,55,61,63,65,67,69,71,73$ ). Sua vila (figura 84), com casas de três cômodos (quarto, sala, cozinha) e banheiro, contava com duas casas maiores na entrada (com sala, dois quartos, cozinha, despensa), além do banheiro e quintal. O conjunto de residências, ainda existente nos dias atuais, apesar de ter sofrido inúmeras mudanças em suas fachadas, e mesmo a transformação em sobrados, permanece com os tamanhos do projeto inicial. Das duas casas maiores, apenas a do lado esquerdo resistiu ao tempo, com sua fachada transformada num comércio 


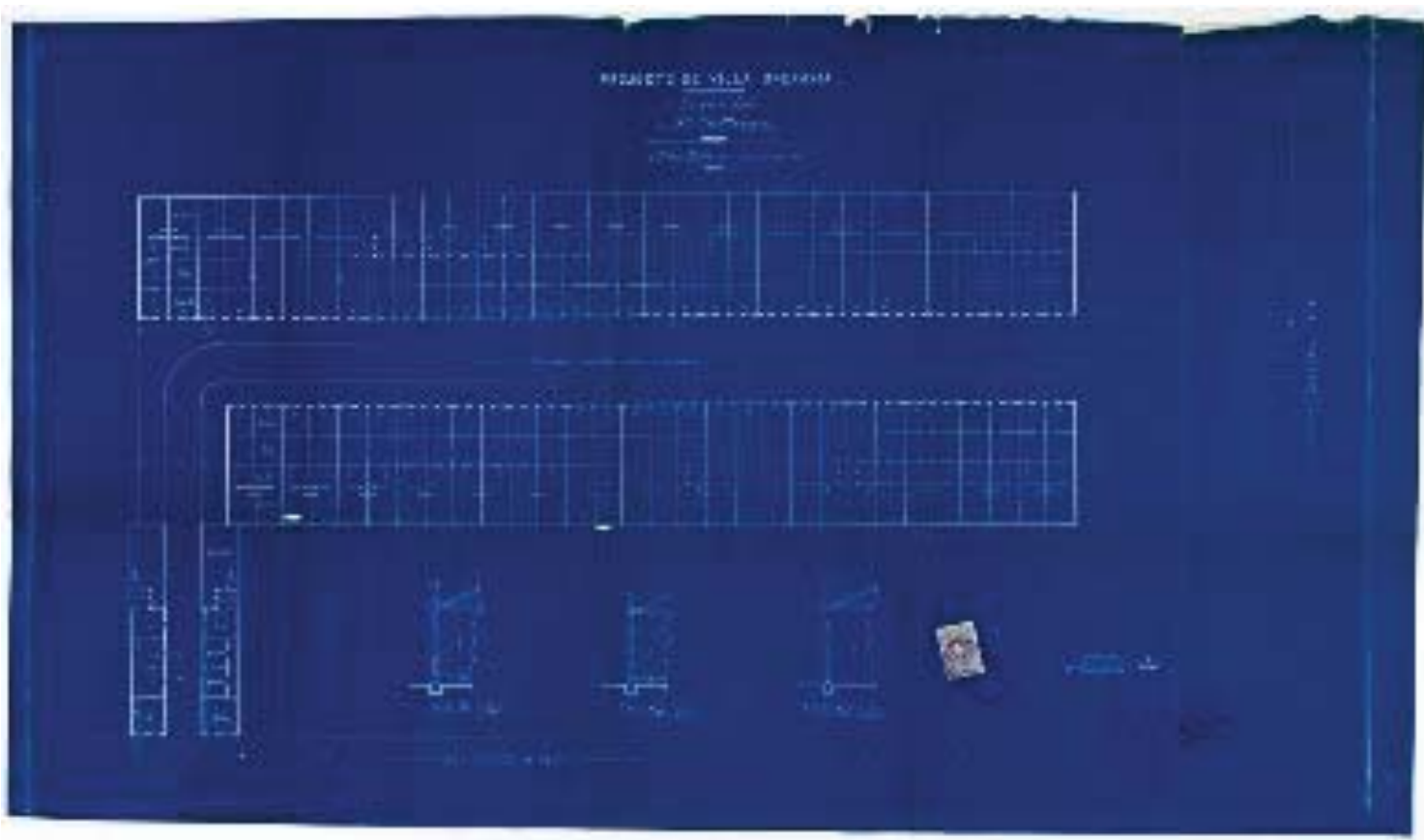

Figura 84: "Projecto de Villa Operaria de Propriedade do Snr. João Ferreira" - Arquivo Histórico Municipal, Fundo "Diretoria de Obras", Série "Obras Particulares”, OP1912000.779

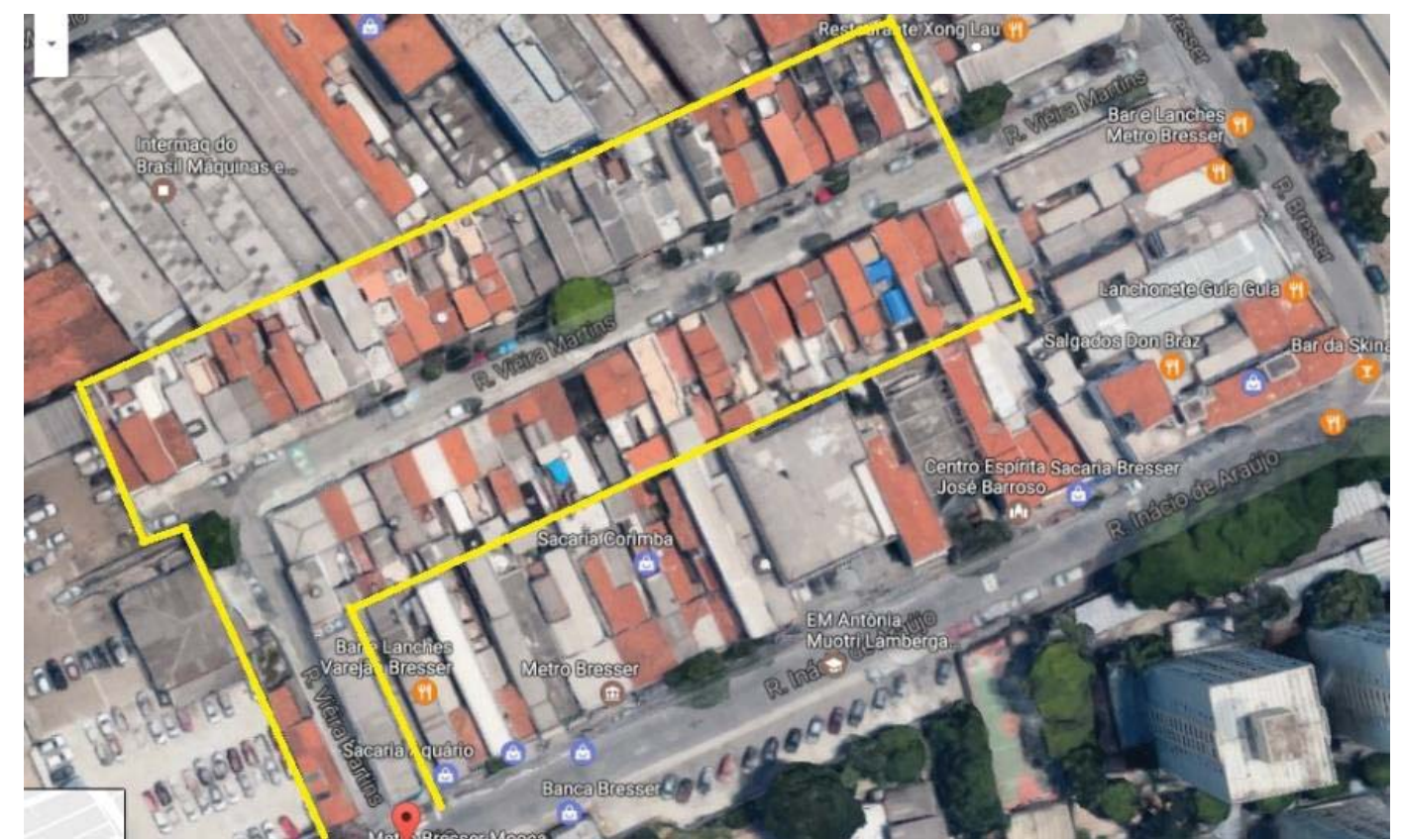

Figura 85: Conjunto de residências da antiga Vila Operária de João Ferreira, na atual rua Vieira Martins, entre a rua Bresser e Inácio de Araújo. Fonte: Google Street View.

As duas maiores casas da Vila Operária de João Ferreira, não foram um único caso de construções que ficavam na testada das ruas e ainda eram maiores que as demais casas dos fundos da vila. A partir da análise dos desenhos da Série Obras Particulares, percebemos que, das vilas encontradas, as casas defronte à rua quase sempre eram maiores que as do interior, com dois cômodos a mais e maiores em sua dimensão, garantindo a visibilidade da rua e um maior conforto, as quais poderiam ser compradas ou alugadas por 
aqueles que pudessem arcar com maiores quantias de dinheiro. As casas da vila propriamente dita, nos fundos do terreno, podiam atender a um público mais amplo, seja aos ditos operários fabris ou profissionais com menores rendimentos.

Na rua Almirante Barroso número 65, o construtor Francisco Pompêo, assinou um projeto para a construção de 24 casas para Abel Salles, sendo que 8 delas estavam na testada do lote, e as outras 16 nos fundos (figura 86). Enquanto as do fundo da vila seguiam o padrão mínimo exigido pela legislação, com três cômodos e, neste caso, com possivelmente latrinas, nas casas de frente à rua Almirante Barroso, quatro cômodos serviriam aos habitantes da mesma. Na mesma rua, José Antônio Nogueira parece ter se espelhado na proposta de Abel Salles, construindo uma vila de 8 casas, com 5 delas nos fundos e outras 3 na testada do lote. Enquanto estas podiam contar com dois quartos, uma sala de jantar e cozinha, nas casas do fundo do terreno a área reservada às refeições era eliminada (figura 87).

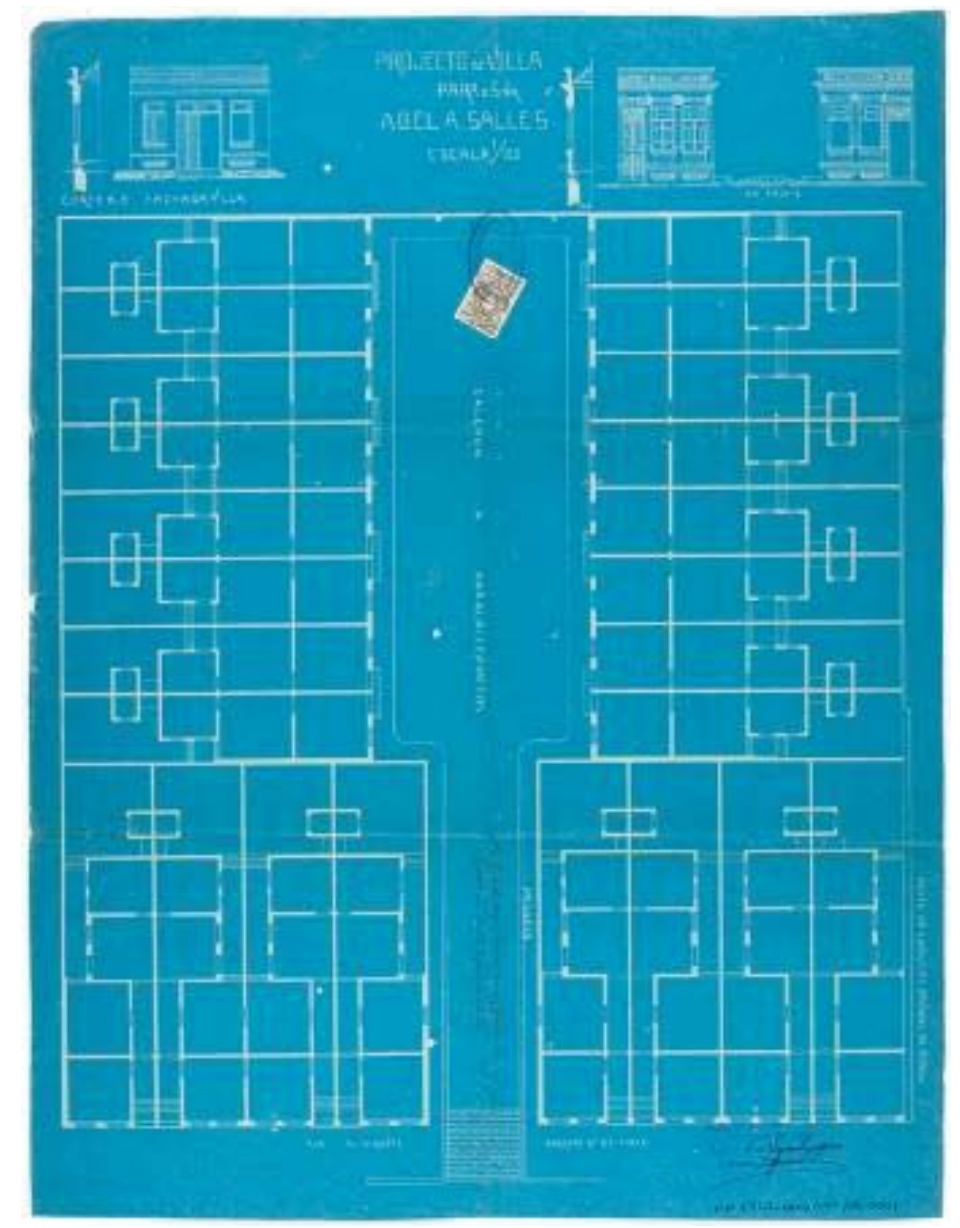

Figura 86: "Projecto de Villa para o Snr. Abel A. Salles", Arquivo Histórico Municipal, Fundo "Diretoria de Obras", Série "Obras Particulares"OP1912.000.090. 


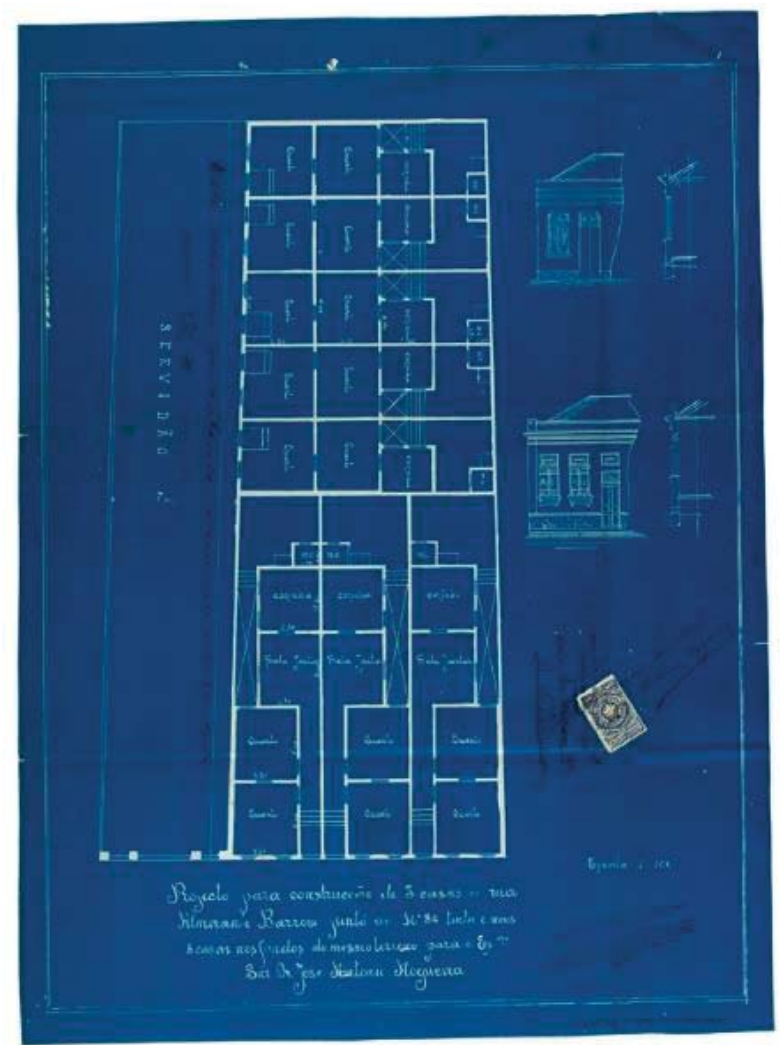

Figura 87: "Projecto para construcção de 3 casas á rua Almirante barroso junto ao $\mathrm{N}^{\circ} 84$ tinta e mais 5 casas nos fundos do mesmo terreno para o Exmo. Snr. Dr. José Antonio Nogueira”, Arquivo Histórico Municipal, Fundo "Diretoria de Obras”, Série “Obras Particulares”OP1914.000.100

Acompanhado a este processo de atender dois perfis sociais do bairro do Brás, as vilas operárias significavam a expressão máxima do potencial de aproveitamento de um lote, com a construção de casas que estivessem contíguas e que atendessem às disposições da legislação em vigor. A atenção aos desenhos da Série Obras Particulares demonstra que muitas destas vilas surgiram em decorrência do vazio dos fundos de muitos dos terrenos já edificados no Brás.

Na rua Almirante Barroso, dois exemplos de projetos de construção de vilas se referem à construção de novas casas nos fundos de construções existentes nas testadas da rua, como da propriedade de José Giaffoni, que possuía três casas na frente do lote (e que aparentemente, pelo tamanho, deduz-se que sejam voltadas para um perfil com maiores condições financeiras) e uma pequena casa nos fundos, solicita a construção de mais três casas mínimas, com um quarto, varanda, cozinha, latrina e um pequeno quintal. Na frente das casas, uma passagem de cimento e um canteiro enfeitando o espaço (figura 88). Outro personagem com destaque em propriedades imobiliárias do Brás é Miguel d’Elia, que juntamente com Paschoal Pitoche solicitou a construção de uma vila com 8 casas nos fundos 
do terreno da rua Almirante Barroso, junto ao número 84, além de duas grandes garagens que estariam na testada da rua (figura 89).

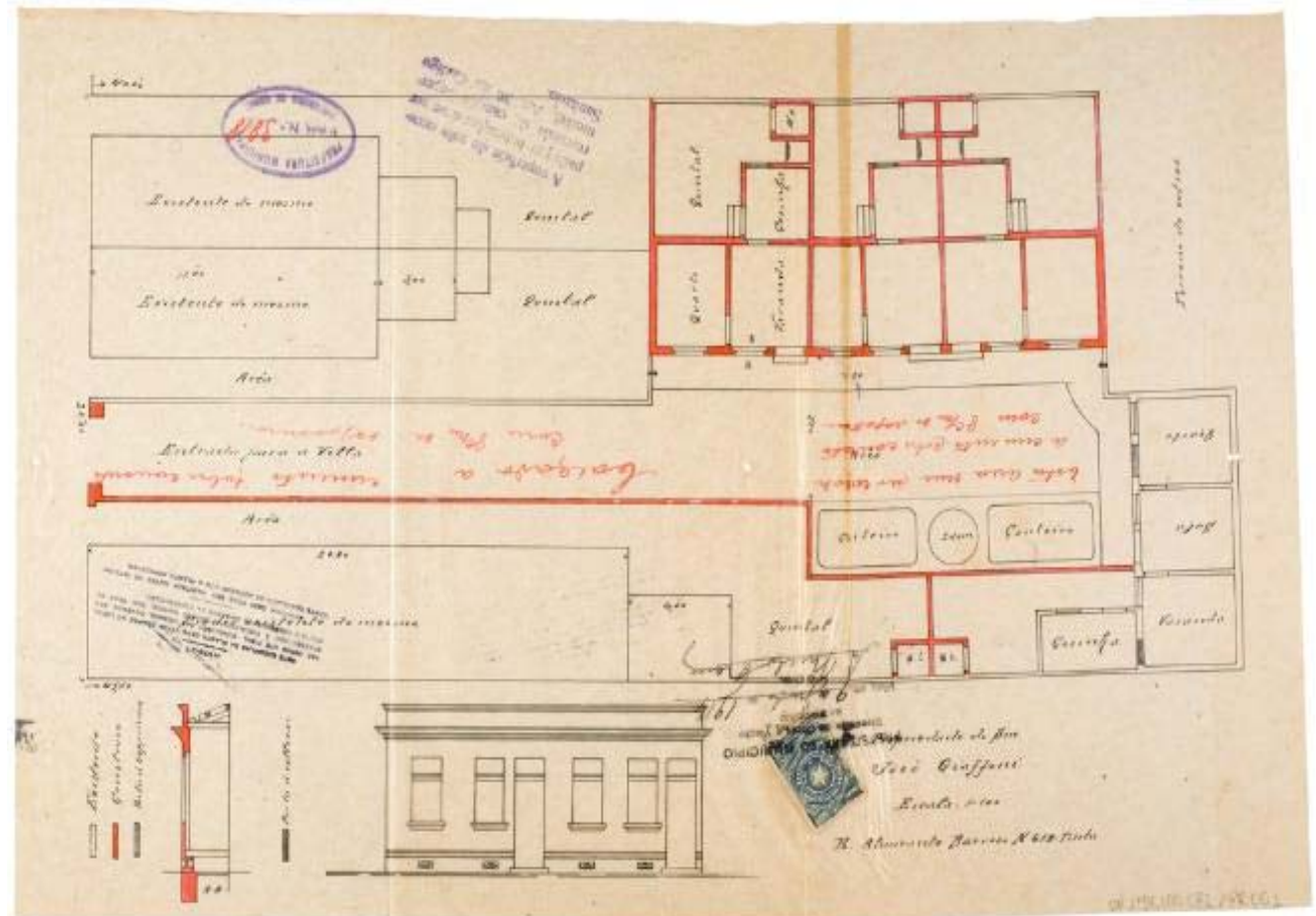

Figura 88: "Propriedade do Snr. José Giaffoni”, Arquivo Histórico Municipal, Fundo "Diretoria de Obras", Série "Obras Particulares" OP1914.000.082

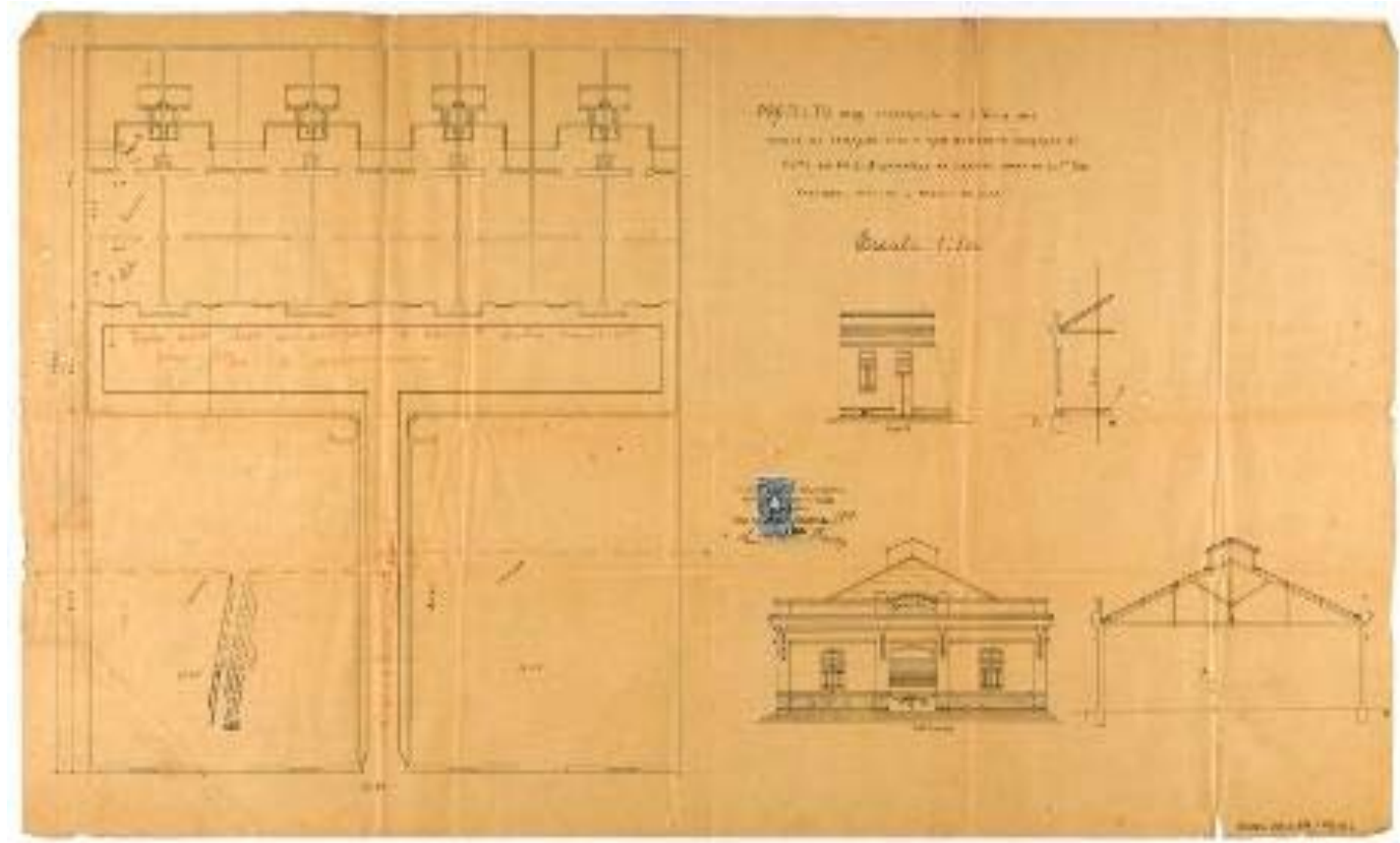

Figura 89: "Projecto para construcção de uma vila nos fundos do terreno sito à rua Almirante Barozo $\mathrm{n}^{\circ}$ junto ao 84 e 2 garages na frente (...)Arquivo Histórico Municipal, Fundo "Diretoria de Obras", Série "Obras Particulares"OP1914.000.084. 
Na rua Bresser, outro desenho chama atenção: Trata-se da propriedade de Paschoal Diorio, que solicita a construção de três casas nos fundos de outras duas "a pouco edificadas", visivelmente maiores que as que serão edificadas, com quarto, varanda, cozinha e uma latrina nos fundos (figura 90). Já na rua Maria Joaquina número 73, Manoel de Souza Costa, proprietário de um terreno com tamanhos irregulares, solicitou a construção de quatro casas nos fundos do terreno, além de outras duas no caminho de entrada da vila (figura 91).

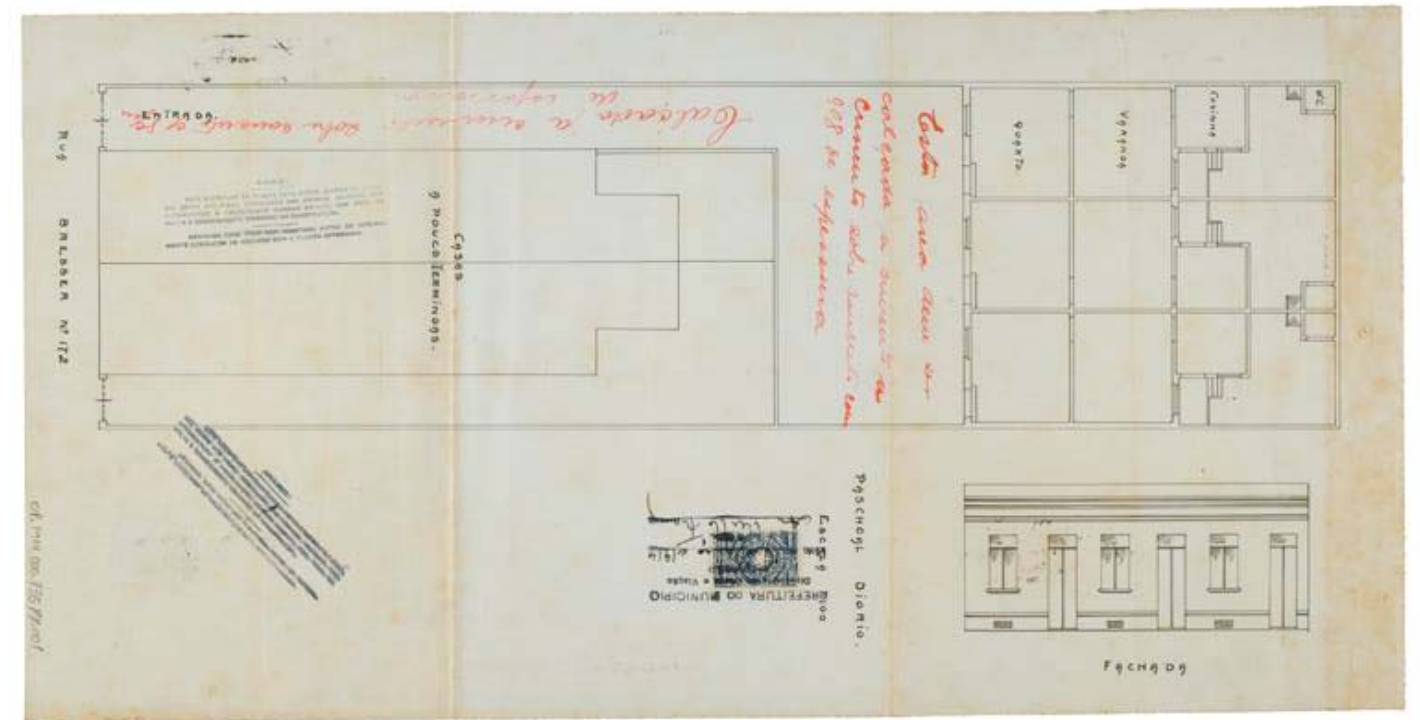

Figura 90: "Propriedade de Paschoal Diorio", Arquivo Histórico Municipal, Fundo "Diretoria de Obras", Série “Obras Particulares"OP1914.000.735.

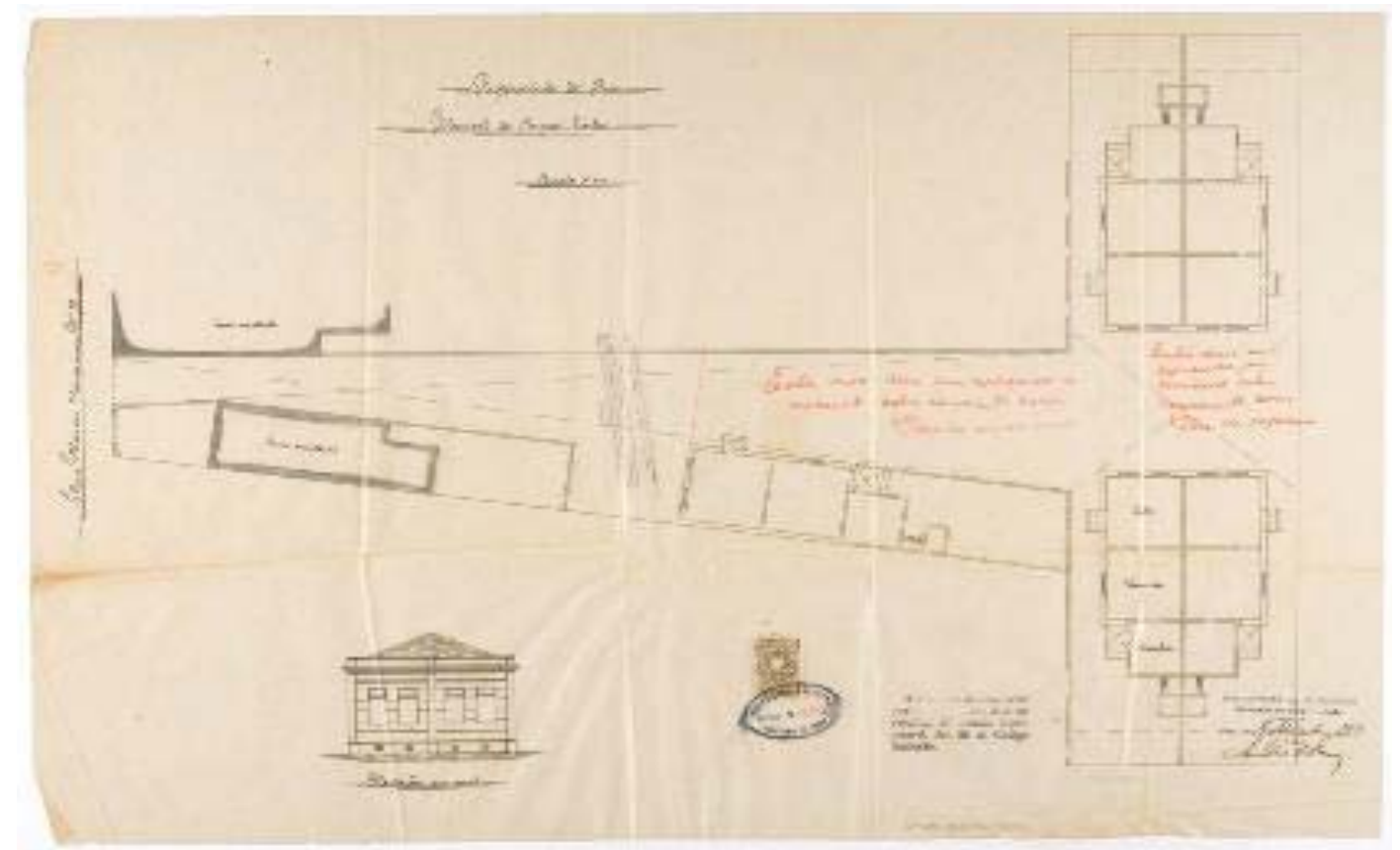

Figura 91: "Propriedade de Manoel de Souza Costa", Arquivo Histórico Municipal, Fundo "Diretoria de Obras”, Série “Obras Particulares”OP1913.003.536. 
Quando o aproveitamento não permitia a construção de novas residências, mesmo que nos padrões mínimos, os proprietários eram perspicazes para mostrar soluções aos lucros dos seus móveis. Muitos transformavam um dos cômodos existentes (quase sempre a sala de jantar ou um dos quartos) em salões, nos quais poderiam ser montados comércios, explorando a possibilidade de obter uma lucratividade mais rentosa, seja com os moradores da própria vila, seja com os visinhos, seja com moradores e demais pessoas que estivessem de passagem por ali. Estes salões, podiam então ser alugados para outros terceiros, ou sua utilização ficava a cargo do proprietário, que poderia montar um armazém de secos e molhados, um bar, um armarinho, uma padaria, um cabeleireiro, etc.

A vila de Lydia Augusta Saraiva, além das dez casas nos fundos do terreno, contava com dois armazéns de frente à avenida Rangel Pestana, explorando as possibilidades de venda que ali podiam ser angariadas (figura 92). Já na rua Maria Marcolina (número 74 e 76), Álvaro Ramos (major que daria nome à uma avenida do Belenzinho), solicitou a construção de seis casas, sendo quatro geminadas nos fundos do lote, formando uma pequena vila, e duas defronte à rua. Ao lado destas duas, montaria um açougue (figura 93).

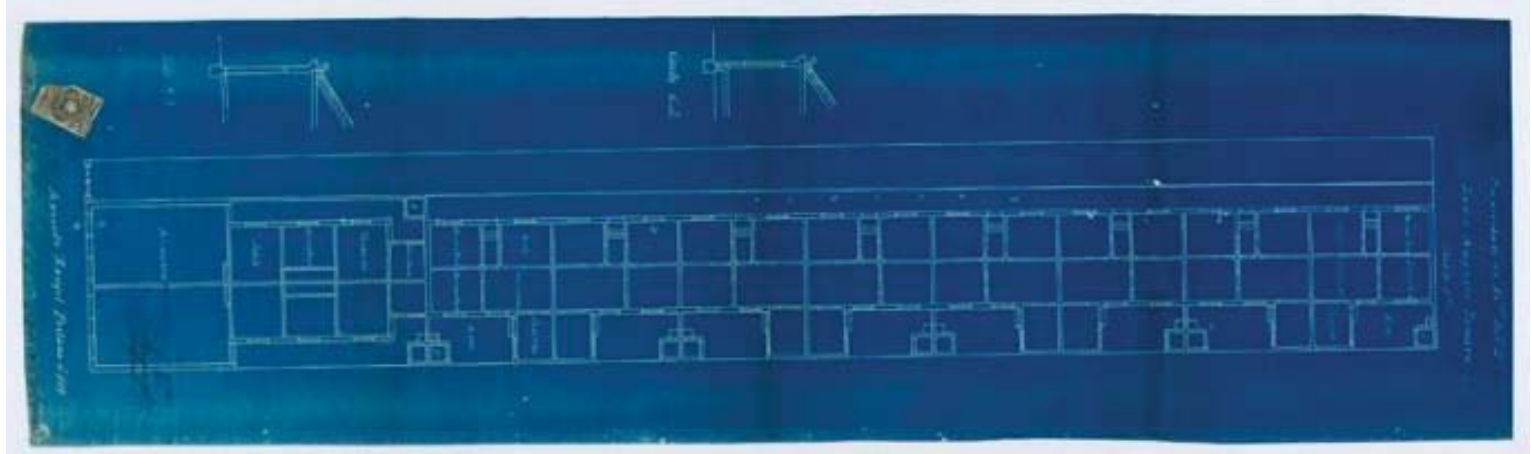

Figura 92: "Propriedade da Illma Sra. Lydia Augusta Saraiva", Arquivo Histórico Municipal, Fundo "Diretoria de Obras", Série “Obras Particulares”OP1910.002.134.

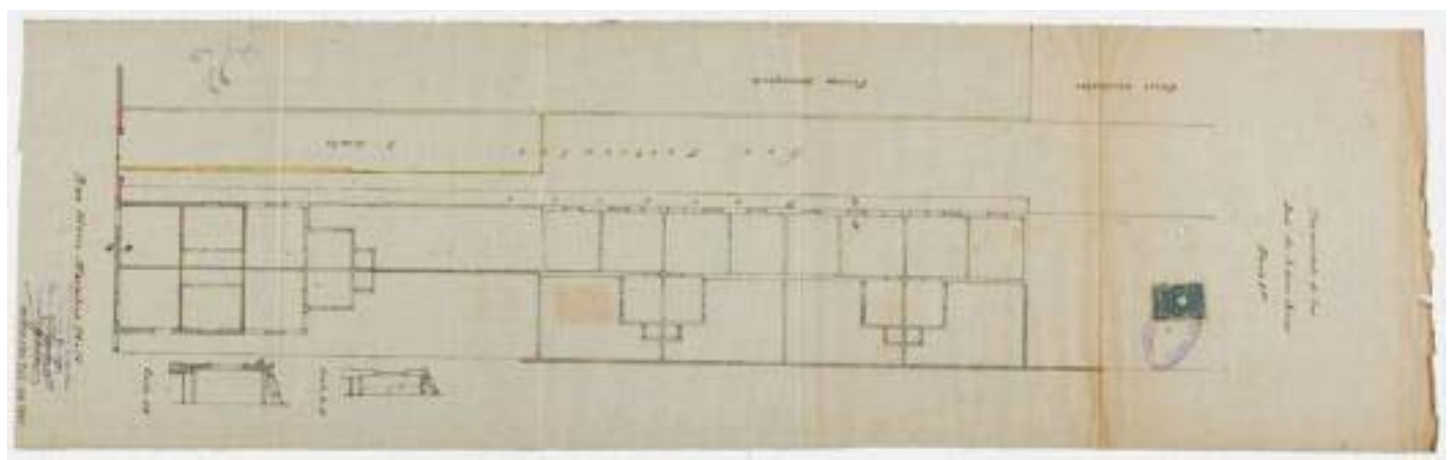

Figura 93: "Propriedade do Snr. Álvaro Ramos", Arquivo Histórico Municipal, Fundo "Diretoria de Obras", Série "Obras Particulares", OP1910.001.702. 
Grande parte das vilas operárias representadas na Série Obras Particulares não apresentam equipamentos como igreja, escola, creche, teatro, como vê em alguns outros exemplos, como pode-se observar alguns outros exemplos desta tipologia edilícia, como a Vila Maria Zélia. Além do mais, muitas das construções de casas, na realidade tratavam-se de serem casas em série, tema sobre a qual se debruçou a arquiteta Luciana Além Gennari, que teve como foco os bairros da Móoca e do Brás na primeira metade do século XX. A autora mapeou no corpus documental da Série Obras Particulares, e as reconstituiu espacialmente na Planta da Cidade de São Paulo de 1930 (Sara Brasil), trazendo ao debate os seus proprietários e construtores, ou seja, aqueles que investiram nessa forma de morar para obter lucro com sua venda ou aluguel, aproveitando a carestia de moradias que pairava sobre a cidade de São Paulo no começo do século XX. Gennari observa o potencial de lucro e rendimento que envolvia a construção dessa tipologia de imóveis geminados, espelhados e sequenciados num mesmo lote.

Para Gennari, as casas em série constituíram um dos grandes acertos do mercado imobiliário rentista, pois, sendo construídas em número maior que um, e implantadas em vilas, ruas particulares ou vielas, podiam ou não estar voltadas para a rua principal, formando assim unidades residenciais autônomas e completas, contando com ao menos um compartimento (que podia ser um quarto, sala de visita, sala de jantar, entre outros), cozinha e WC ou banheiro, individualizando os usos destes últimos aos moradores da casa, em contraposição aos cortiços no qual boa parte dos cômodos, e essencialmente o banheiro e a cozinha quase sempre eram divididos pelos diferentes habitantes que ali residiam.

\footnotetext{
Essas casas em série devem ter sido construídas por um mesmo proprietário, o que pode se traduzir em pessoas físicas ou jurídicas, associações, fábricas ou indústrias, famílias, entre outros. Elas não possuem necessariamente todas as plantas idênticas, quando projetadas em número maior que dois, com indicação nos projetos de pertencer a um mesmo lote ou seu desmembramento. Mas devem necessariamente ter plantas idênticas quando projetadas em número de dois e em lotes separados. ${ }^{212}$
}

A produção de casas em série atendia à lógica da produção imobiliária rentista em curso na cidade de São Paulo, a partir de um aproveitamento maciço dos lotes, garantido um lucro imediato ao investidor capitalista, também conhecido como "pequeno investidor". 
Conjuntos como o de Henrique Affonso e Souza, proprietário de um lote de esquina entre as ruas Alfândega e Álvares de Azevedo, envolveu um projeto para a construção de 9 casas em série (figura 94) ${ }^{213}$, sendo uma de costas para as demais e frente para a rua Álvares de Azevedo. Analisando a segunda planta proposta, o projeto anterior parece não ter logrado, desistindo desta última casa e suprimindo duas outras que constavam na proposta inicial. Porém, no novo pedido de construção de $6 \operatorname{casas}^{214}$, cada uma delas ampliada, cada qual passou a contar com cômodos, deixando uma área menor nos fundos de cada terreno. Além das casas, um armazém foi projetado na esquina das ruas, fazendo com que a casa de trás fosse ligeiramente aumentada nos fundos, perdendo-se assim o mais uma parte do terreno.

O aproveitamento do terreno por parte de casas em série, em geral, envolvia a destinação de um dos cômodos de uma das casas para comércio, característica recorrente no Brás. Na rua Elisa Whitaker, esquina com a rua Rodrigues dos Santos, Albino de Moraes solicitou a construção de quatro casas geminadas, suprimindo a sala ou quarto da casa situada na esquina para ali inserir um armazém.

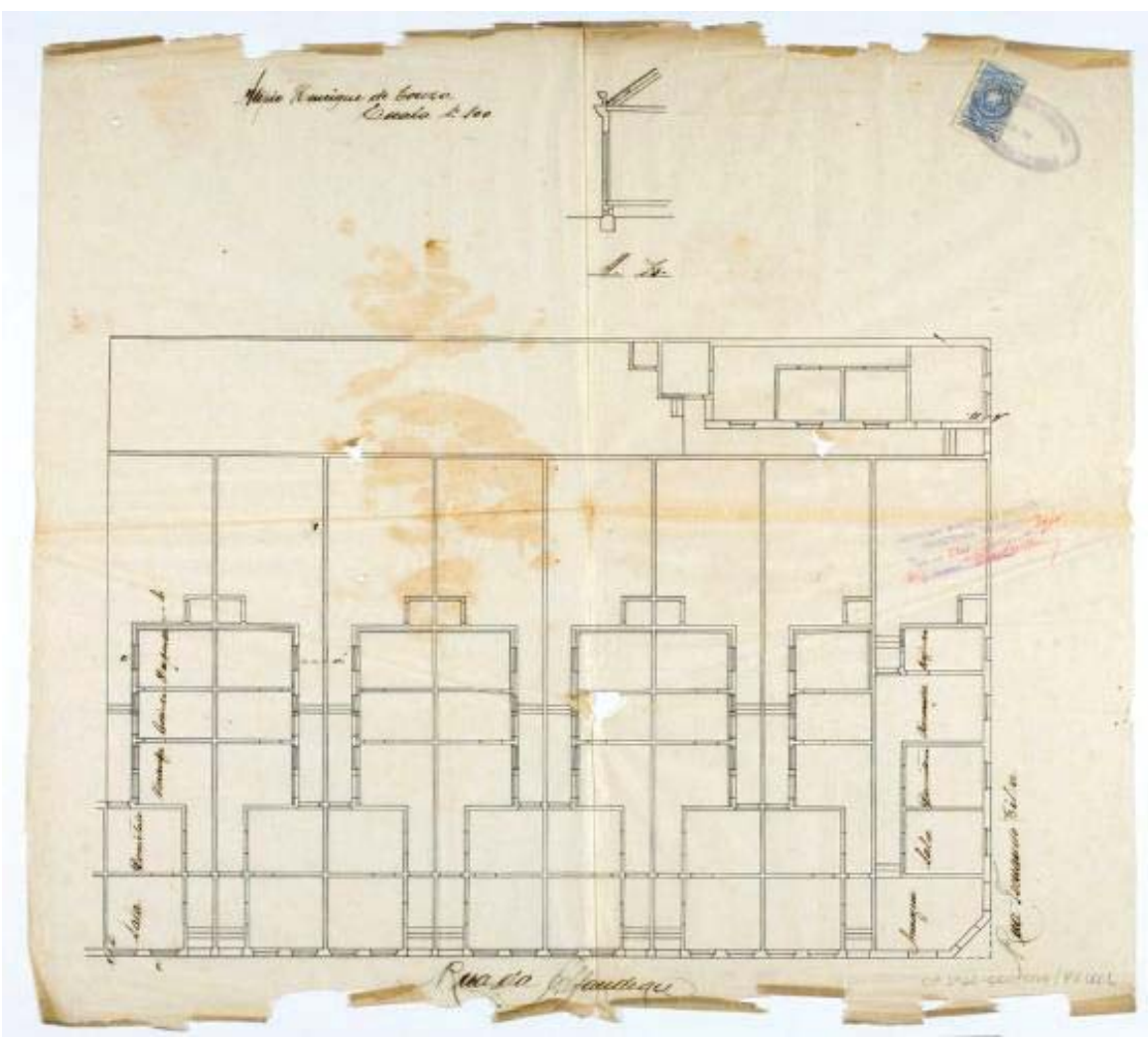

Figura 94: “Alipio Henrique de Souza”, Arquivo Histórico Municipal, Fundo "Diretoria de Obras”, Série "Obras Particulares", OP1910.000.048.

\footnotetext{
213 Arquivo Histórico Municipal, Fundo "Diretoria de Obras", Série "Obras Particulares", OP1910.000.048 PR001

214 Arquivo Histórico Municipal, Fundo "Diretoria de Obras", Série "Obras Particulares", OP1910.000.047_PR002
} 


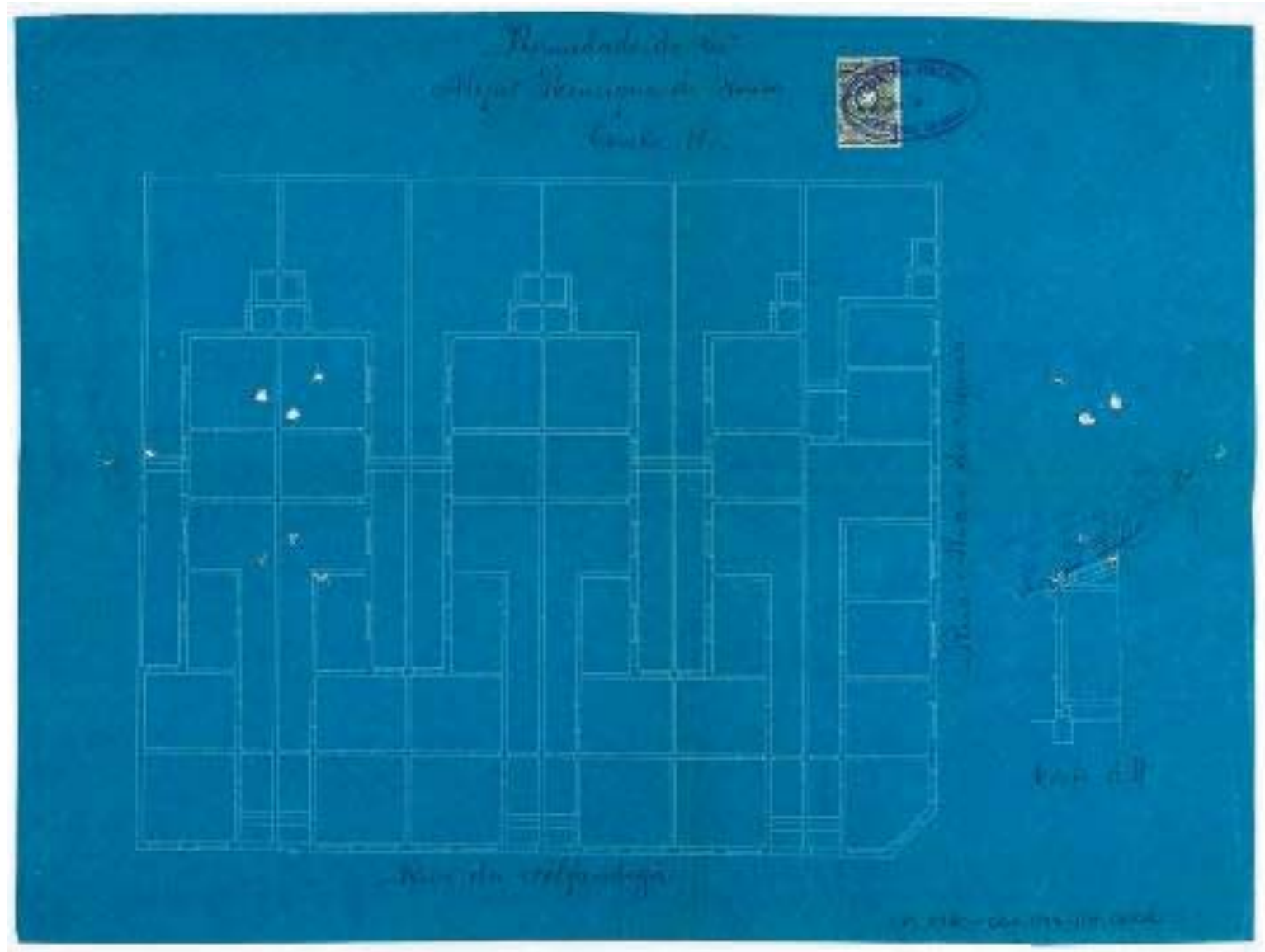

Figura 95: Propriedade do Snr. Alipio Henrique de Souza, Arquivo Histórico Municipal, Fundo "Diretoria de Obras”, Série “Obras Particulares”, OP1910.000.047.

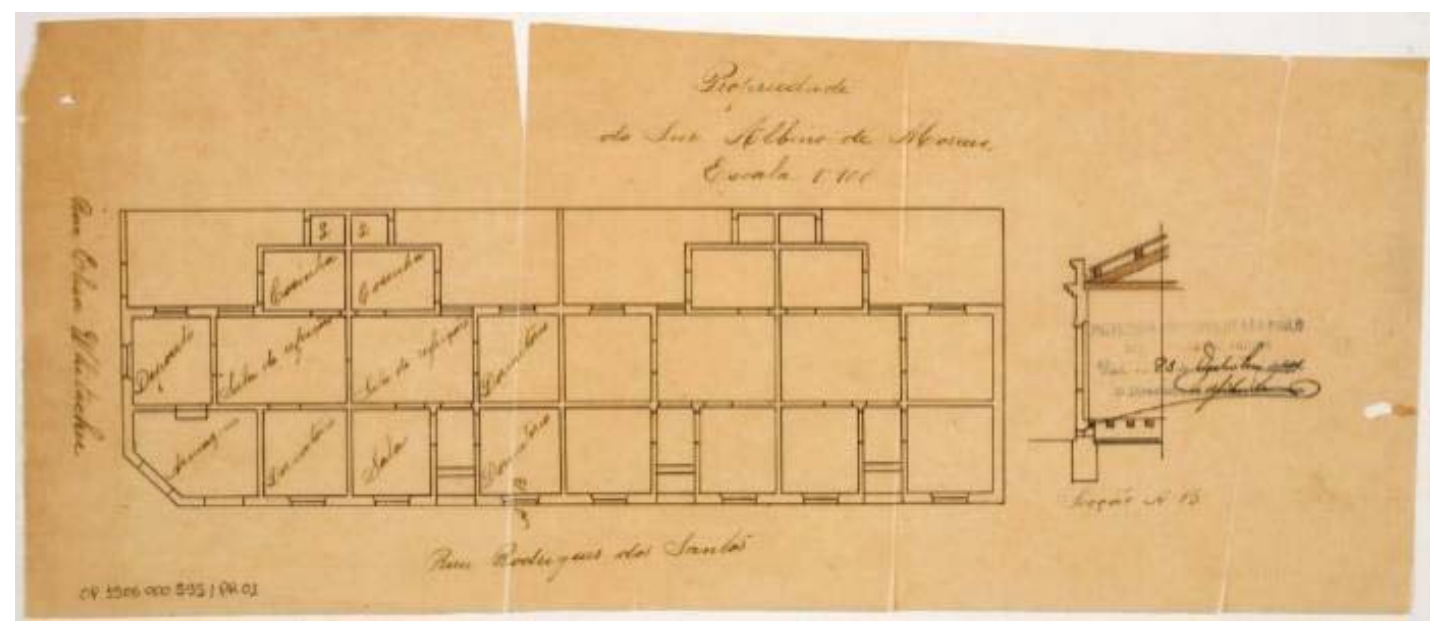

Figura 96: "Propriedade do Snr. Albino de Moraes", Arquivo Histórico Municipal, Fundo "Diretoria de Obras”, Série “Obras Particulares”, OP1906.000.595.

Como pontuado por Luciana Gennari, as solicitações de construção de casas em série não se restringiam a conjuntos em que as fachadas ficavam alinhadas à rua, ocupando a testada dos lotes. Podiam ocorrer também no interior dos lotes, aproveitando o espaço disponível nos fundos com a criação de uma pequena viela ou rua interna que servisse de 
caminho até o pátio comum às casas. João Cupertino possuía um terreno na rua Flora, e em 1912, resolveu ali edificar 10 casas, 6 no alinhamento da rua e mais 4 nos fundos, todas acessadas por um calçamento cimentado (figura 97). João Ferreira, um dos grandes proprietários de imóveis no Brás (pelo menos 27 contabilizados), não fugiu à regra de aproveitamento máximo do lote, construindo na rua Inácio de Araújo número 527, 5 casas, sendo duas delas no alinhamento da rua e mais três nos fundos, chamando-as de "vila" (figura 98). Ou também o caso de Antônio Sobrinho, que possuindo um terreno largo em sua parte direita e exíguo em sua ponta esquerda, ainda assim solicitou a construção de cinco casas entre as esquinas da rua Maria Marcolina com a rua Miler (figura 99). Esse caso é muito parecido com o do lote de João Bento Collaço na rua Xavantes, que mesmo irregular, solicitou a construção de seis casas em série, todas com suas fachadas voltadas para a rua (figura 100).

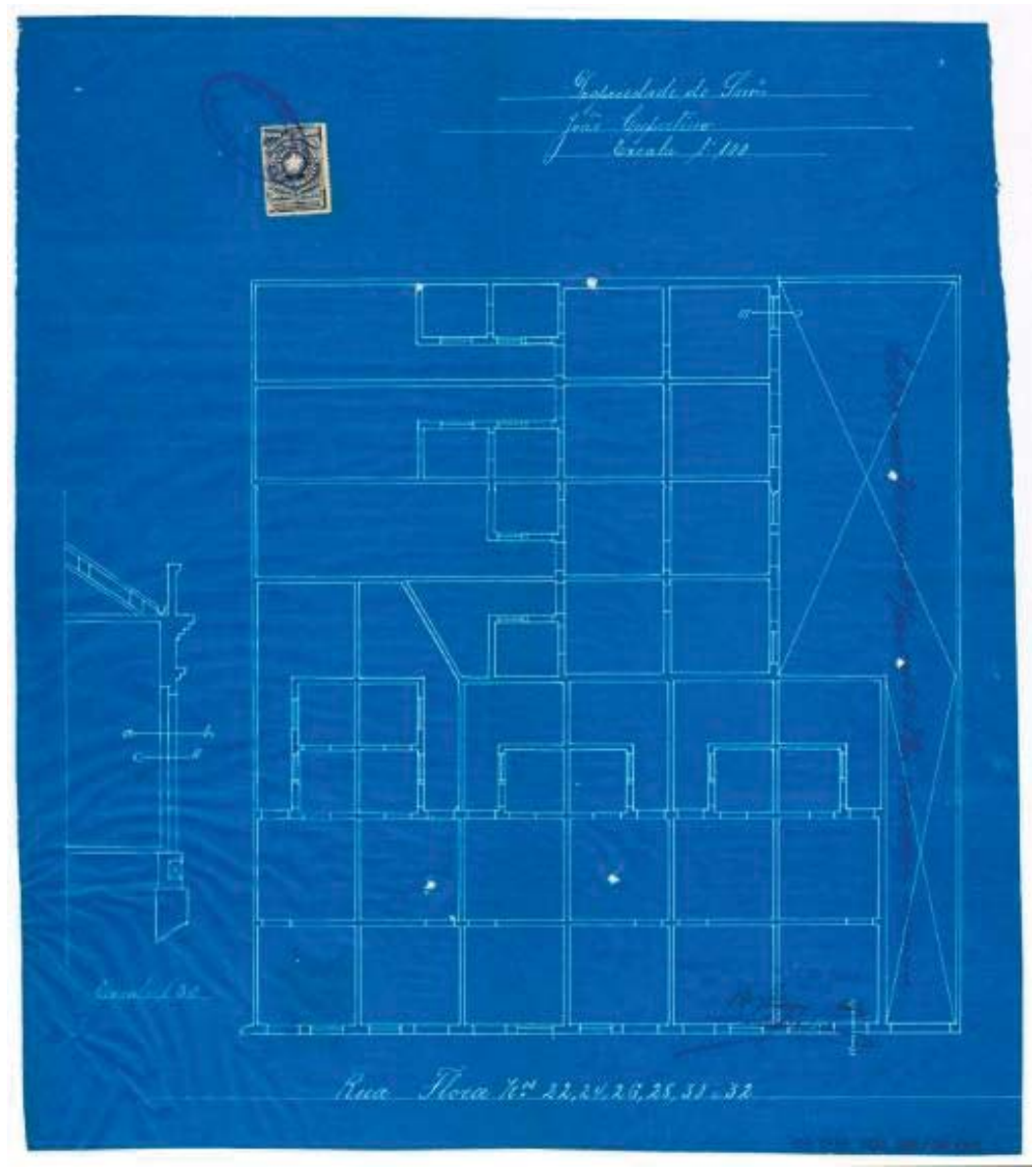

Figura 97: "Propriedade do Snr. João Cupertino", Arquivo Histórico Municipal, Fundo "Diretoria de Obras", Série "Obras Particulares", OP1912.001.881. 


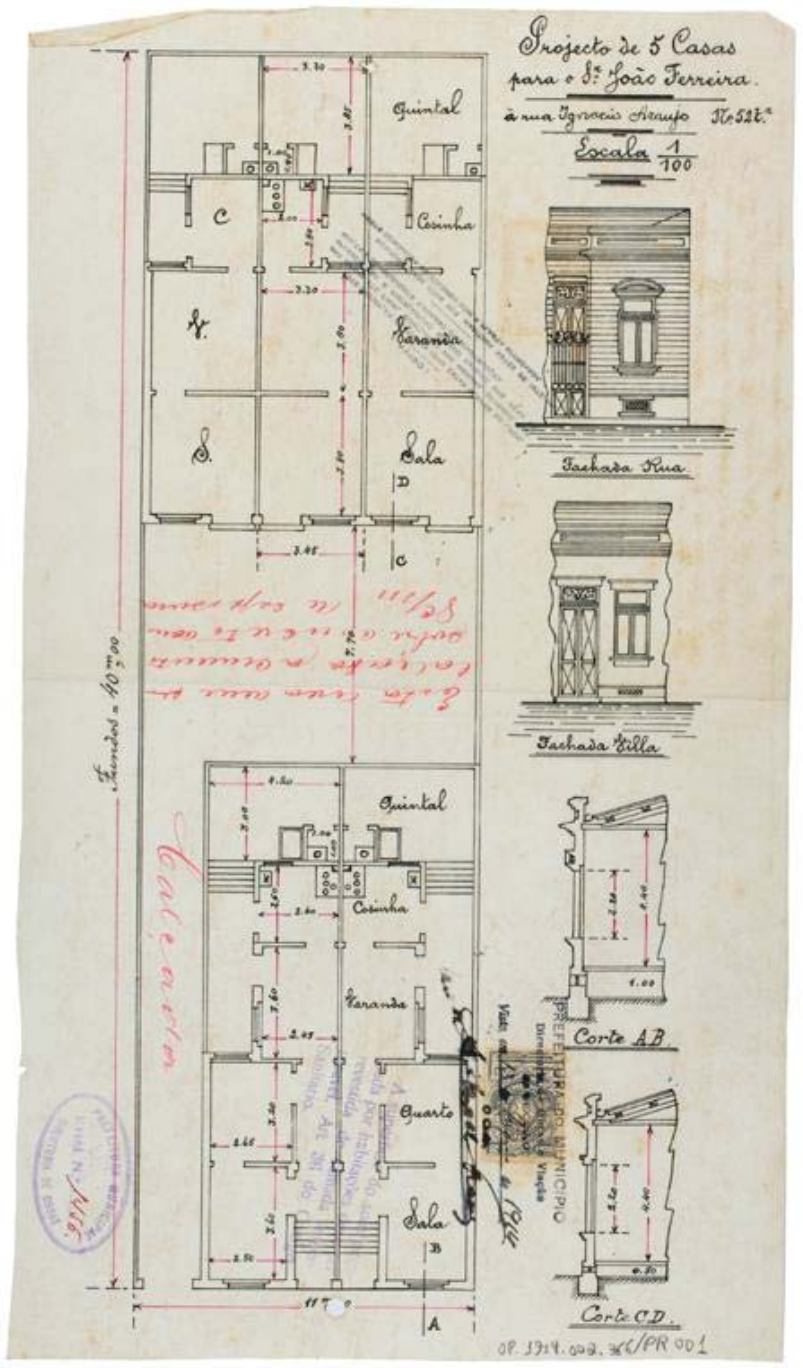

Figura 98: "Projecto de 5 casas para o Snr. João Ferreira", Arquivo Histórico Municipal, Fundo "Diretoria de Obras", Série "Obras Particulares”, OP1914.002.366.

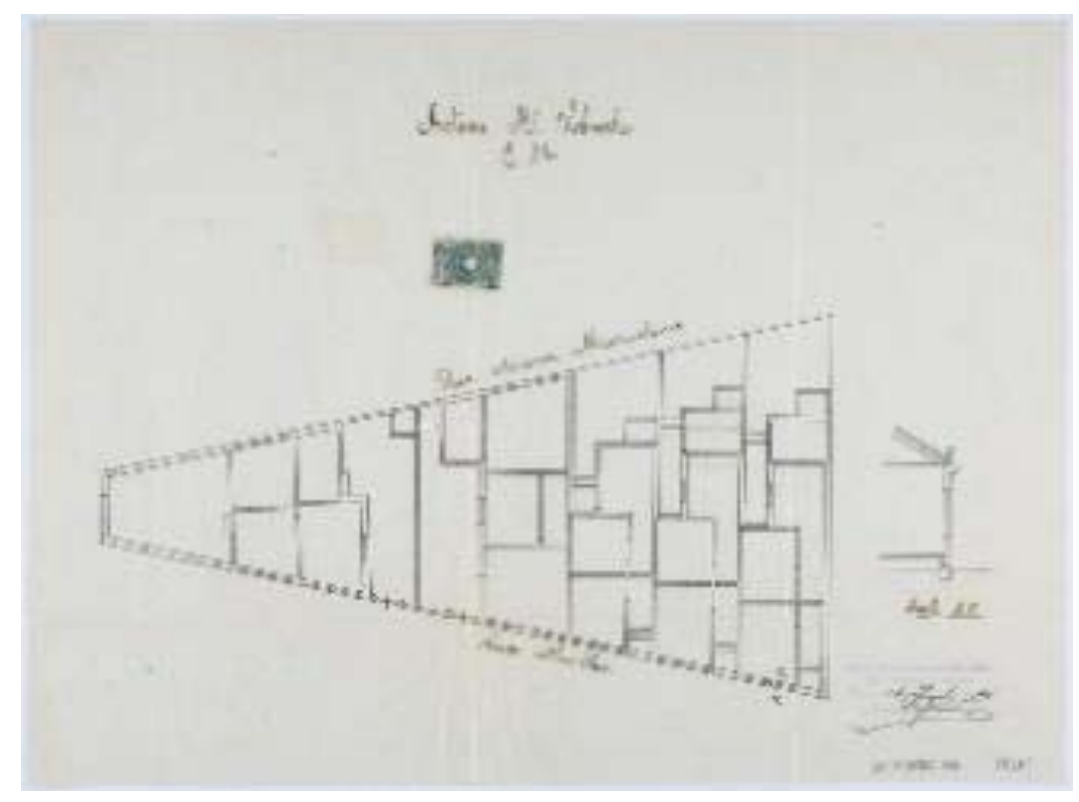

Figura 99: “Antonio M. Sobrinho", Arquivo Histórico Municipal, Fundo "Diretoria de Obras", Série "Obras Particulares", OP1911.002.344. 


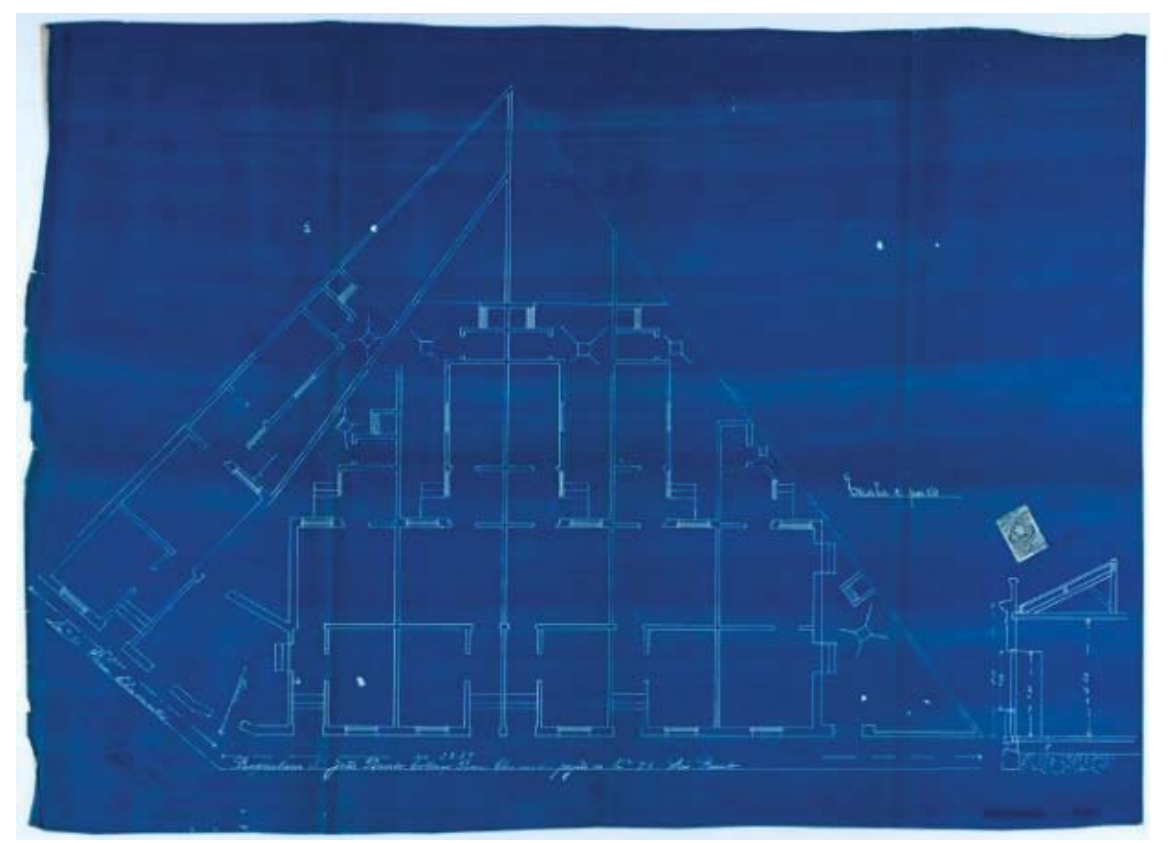

Figura 100: "Proprietario Snr. João Bento Collaço", Arquivo Histórico Municipal, Fundo "Diretoria de Obras”, Série “Obras Particulares”, OP1911.003.863.

As casas em série do Brás não destinavam-se a um único perfil social, haja vista a diversidade populacional que ali estava se concentrando entre os muitos operários. No Brás moravam também funcionários públicos, comerciantes, advogados e outros personagens que compunham os setores médios e remediados da população. Assim, podemos encontrar uma diversidade de tipologias nas próprias casas em série: casas que seguiam o padrão mínimo regido pela legislação (com um quarto, cozinha e banheiro), e outras maiores (com dois aposentos, sala de jantar, cozinha, despensa e banheiro acoplados). Procuramos atentar ao número de cômodos construídos, bem como à presença ou ausência de espaços dedicados à higiene, como o banheiro (WC).

Um projeto de construção de dez casas entre as ruas Bresser e a Carlos Botelho foi remetido para aprovação da Diretoria de Obras e Viação no ano de 1908. Cada casa, com três cômodos, contava com uma construção anexa que pode indicar tratar-se de um banheiro, e, além, de um pequeno quintal que dava acesso a um grande pátio interno, com um forno que servia a todas as casas (figura 101). Este pedido de construção vai ao encontro das categorias definidas por Carlos Lemos de que este tipo de casa se destinava aos setores da classe média baixa. Tendo em vista o volume de pedidos de construção que não se resumem a este exemplo, mas apresentam uma gama de possibilidades de moradias para os setores médios, procuraremos colocar em pauta as construções destinadas a este extrato social, 
tendo em vista essencialmente o número de cômodos e outros equipamentos que eventualmente podiam integrar a casa, como jardim e garagem.

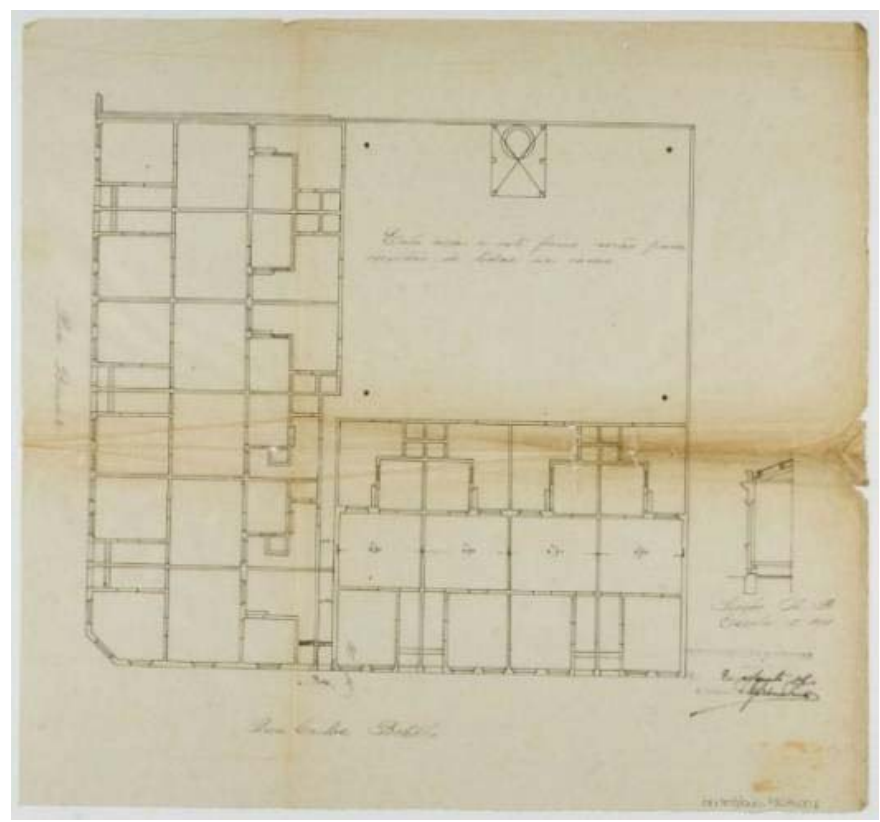

Figura 101: Projeto de 10 casas com um forno, Arquivo Histórico Municipal, Fundo "Diretoria de Obras", Série "Obras Particulares”, OP1908.000.736.

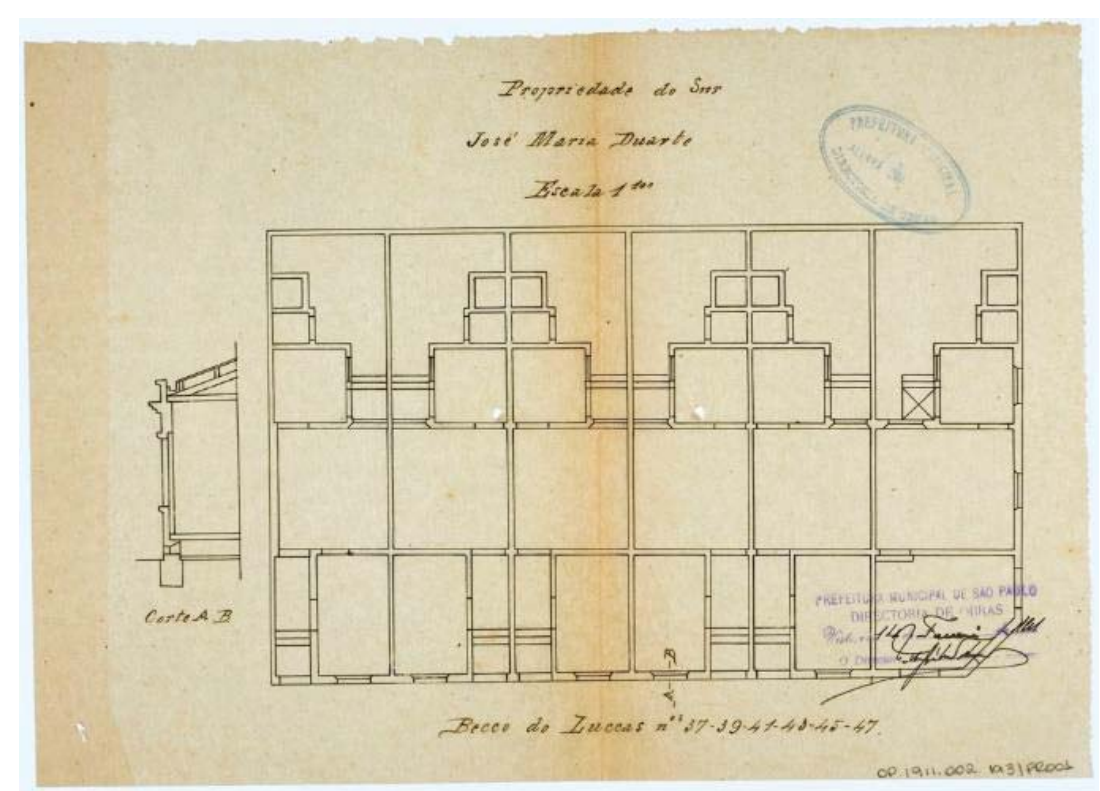

Figura 102: "Propriedade do Snr. José Maria Duarte", Arquivo Histórico Municipal, Fundo "Diretoria de Obras”, Série “Obras Particulares”, OP1911.002.193.

As casas destinadas aos setores médios não fugiam à regra quanto ao aumento dos seus rendimentos, sendo que muitos dos projetos de casas em série apresentados, eram 
acompanhados de um comércio no cômodo da frente, conferindo ao proprietário maiores rendimentos, além dos auferidos com a venda ou aluguel das residências. José Maria Duarte, proprietário de um lote no beco do Lucas solicitou um pedido de construção de seis casas, suprimindo o cômodo que voltado para rua Assunção, e transformando-o num comércio futuramente (figura 102) Leonor Monteiro da Silva foi outra proprietária que se destacou no ramo imobiliário, e solicitou a construção de quatro casas em seu terreno na rua da Concórdia número 213, esquina com a rua Ipanema (figuras 103 e 104) As três primeiras casas contavam com sala, quarto, sala de jantar, cozinha, banheiro e um quintal nos fundos. Isso não prejudicou aquela situada na testada do lote entre esquinas, visto que fora ampliada para os fundos, suprimindo parte do quintal. Hoje nome de uma rua do bairro de Vila Prudente, Leonor Monteiro da Silva enquadra-se no perfil de investidora do começo do século XX, por alugar ou vender essa tipologia de imóvel para a classe média residente no Brás.

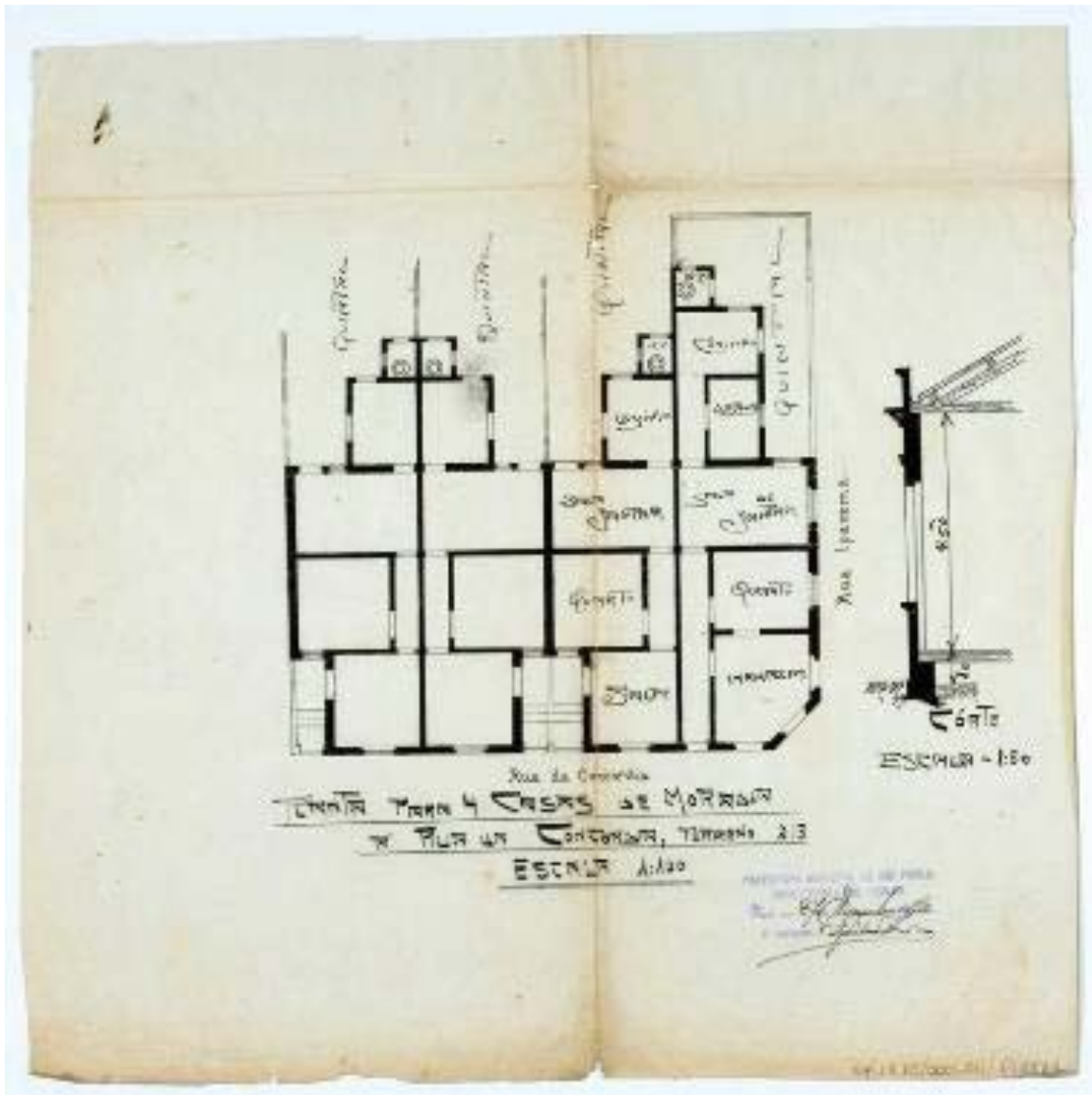

Figura 103: "Planta para 4 casas de moradia", Arquivo Histórico Municipal, Fundo "Diretoria de Obras", Série “Obras Particulares”, OP1910.000.711 


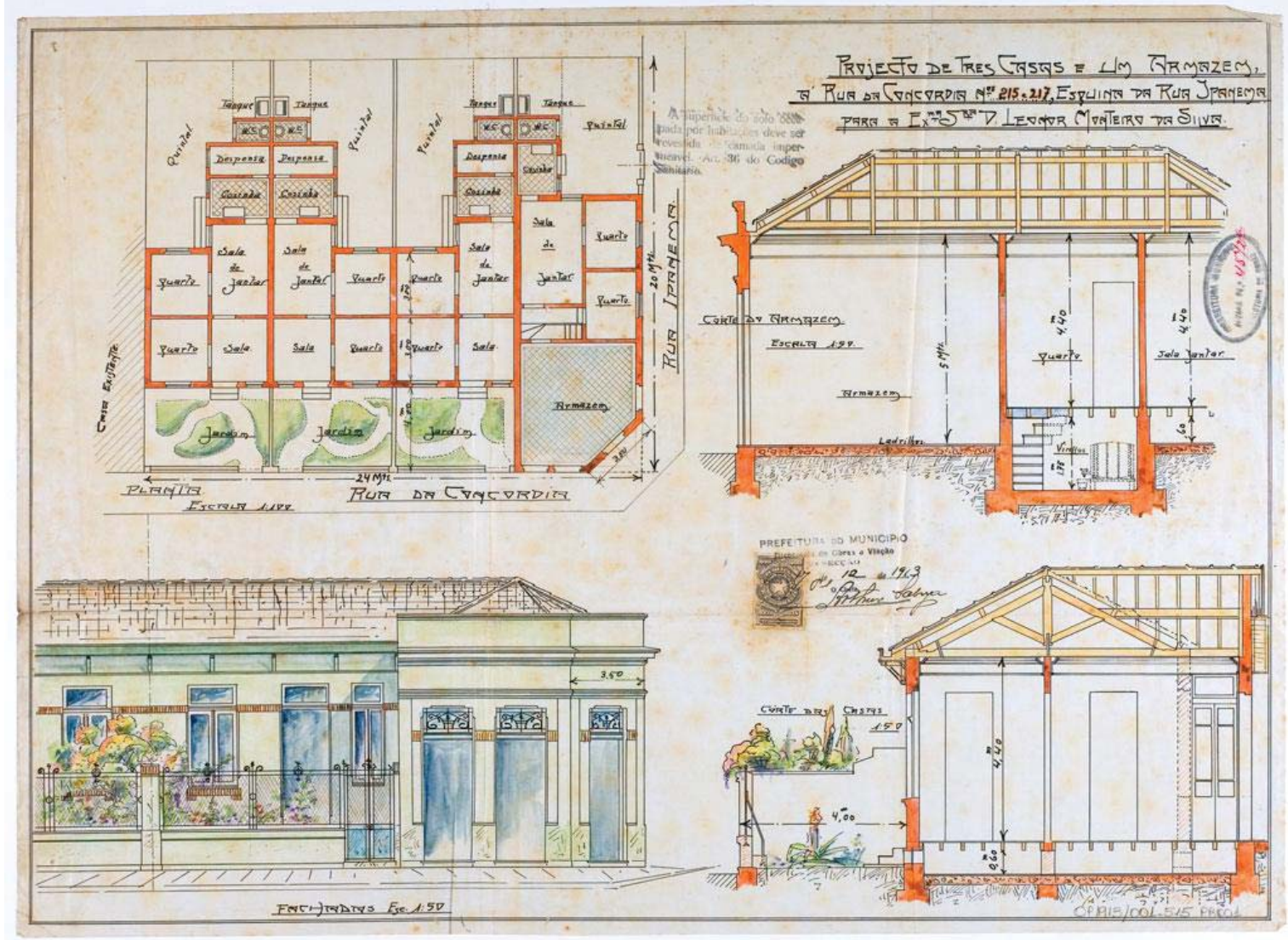

Figura 104: "Projecto de Três Casas e um Armazém”, Arquivo Histórico Municipal, Fundo "Diretoria de

Obras”, Série “Obras Particulares”, OP1913.001.515

A metodologia empregada por Carlos Lemos em A República ensina a morar melhor, para mapear o perfil dos possíveis habitantes das residências construídas em São Paulo até o ano de 1906, serve de subsídio para imaginarmos os possíveis moradores das casas em série. Sendo o número de cômodos um dos componentes do perfil dos possíveis moradores das residências, pode-se verificar que, no Brás, grande parte das casas construídas em série atenderam a um público médio, e não necessariamente apenas ao operariado empregado nas fábricas da região. Casas como a projetada para Arthur Wrigg na rua Benjamin de Oliveira (figura 105), nos ajudam a compreender seu possível habitante. Com sala, dormitório, sala de jantar, cozinha e banheiro nos fundos, a casa foge do padrão mínimo, atendendo a uma classe média baixa. Francisco Marengo ${ }^{215}$ e suas duas casas

215 “Francisco Marengo, viticultor, nasceu em Piemonte, Itália, em 1875. Veio para o Brasil aos dez anos de idade, em companhia de seus pais. Desde menino auxiliava o pai, Benedito Marengo, nas lidas da Chácara Marengo, então localizada na Sexta Parada, hoje Tatuapé. Ali se especializou na cultura de frutas, notadamente uvas, introduzindo em São Paulo, com excelentes resultados, a Nágara Branca, dos Estados Unidos. Essa espécie de uva veio a espalhar-se, depois, por todo o País, tornando-se conhecida por Uva Marengo. Foi um dos pioneiros da viticultura prática do Brasil. Entre os muitos títulos conquistados por Francisco Marengo (...) 
geminadas já parece atender um público com um pouco mais de recursos, ao disponibilizar em ambas as casas uma sala, dois quartos, sala de jantar, cozinha e banheiro nos fundos do lote, na Avenida Celso Garcia número 452 (figura 106).

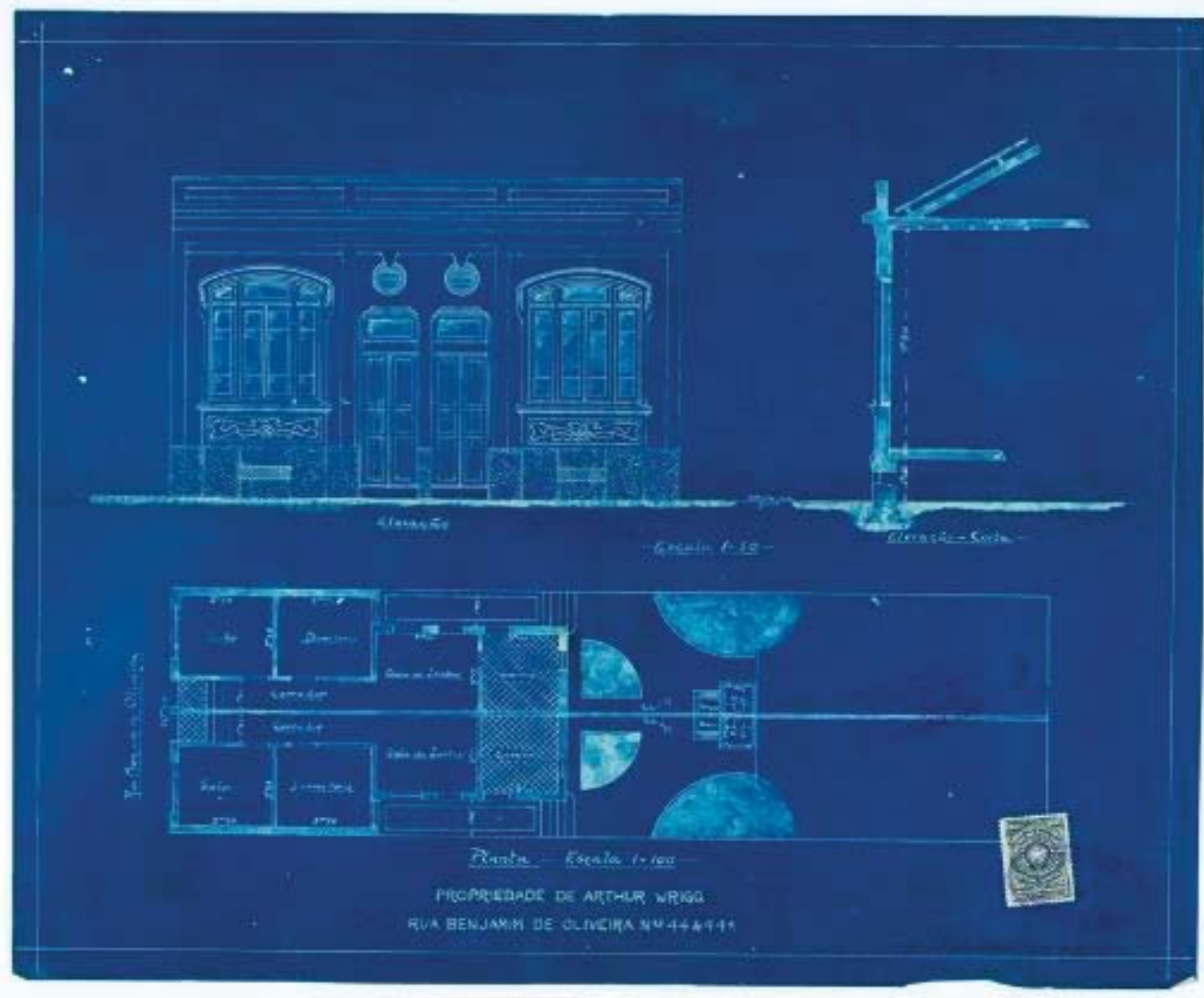

Figura 105: "Propriedade de Arthur Wrigg", Arquivo Histórico Municipal, Fundo "Diretoria de Obras”, Série “Obras Particulares”,OP1910.000.392.

está a medalha de ouro da Exposição de frutas em 1906, da Secretaria da Agricultura de São Paulo; conquistou, ainda o grande prêmio na Exposição Nacional em 1908 e os grandes prêmios e medalhas de ouro e prata na Exposição de Frutas em 1909; na Exposição Internacional de Indústria, Alimentação e Higiene de Gênova, em 1914, na Exposição de Frutas do Rio de Janeiro, em 1916, e na Exposição-Feira do Rio de Janeiro em 1917. Em 1915 foi nomeado membro de honra do Júri e agraciado com a grande Cruz, na Exposição Internacional de Milão. Em 1922 foi contemplado com a Grande Cruz de Prata oferecida pelo Governo do Estado de São Paulo, ao melhor cultivador de uvas do Brasil. Em 1924, o Instituto Agrícola Brasileiro conferiu-lhe Diploma Honorífico e medalha de ouro. O maior prêmio recebido por Francisco Marengo, foi o título de Cavalheiro da Coroa Italiana, que lhe foi conferido em 1930 pelo rei Vitório Emanuele III, em reconhecimento ao muito que fez pelo bom nome de sua pátria de origem, no exterior. Faleceu em São Paulo em 02 de maio de 1959." Junto com Emília Marengo, tiveram três filhos: Adelina Marengo, Amália Marengo e César Marengo, sendo que o nome do pai e da mãe batizam duas ruas do Tatuapé, e o nome do filho uma rua do bairro de Santo Amaro. Disponível em: http://www.dicionarioderuas.prefeitura.sp.gov.br/, acesso em 15 de abril de 2017. 


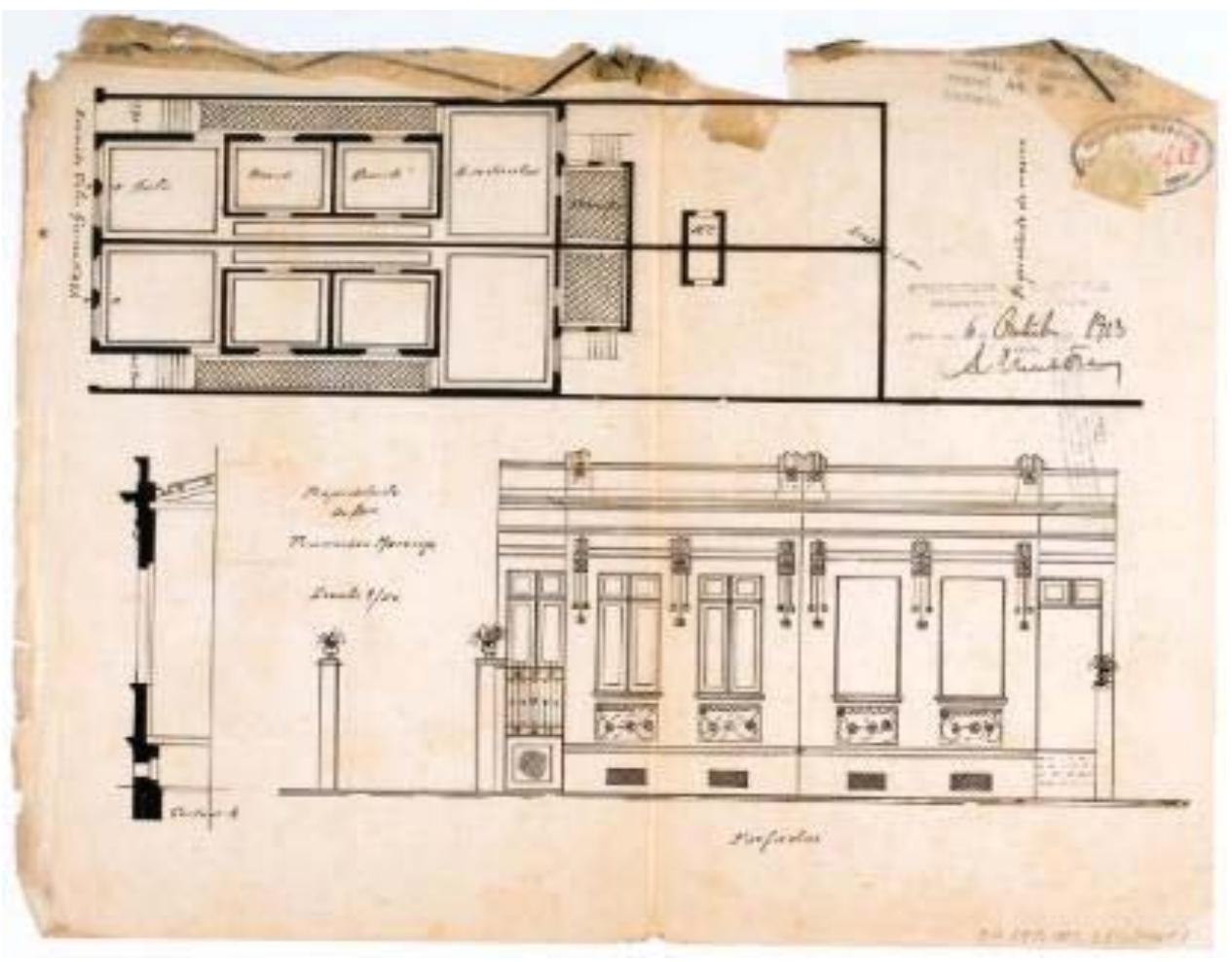

Figura 106: "Propriedade do Snr. Francisco Marengo", Arquivo Histórico Municipal, Fundo "Diretoria de Obras", Série "Obras Particulares”, OP1913.001.384.

João Bolognani ao solicitar a aprovação da construção de sete casas na rua João Boemer em 1913, foi ao encontro do que os setores médios buscavam no Brás: um afastamento cada vez maior da porção central do bairro, situando-se longe de alguns dos principais equipamentos notáveis do Brás, como a estação de trem, a Igreja do Brás e o Gasômetro, nos limites do bairro com a região do Belenzinho. As casas de João Bolognani traziam consigo toda a ideia de bem estar, de acordo com os padrões de higiene da época, bem como ofereciam uma sala, dois quartos (sendo um deles maior que o outro), uma sala de jantar, cozinha, despensa e banheiro, além do fato de estarem localizadas próximas de duas linhas de bondes: uma na rua Bresser e outra na avenida Rangel Pestana (figura 107). 


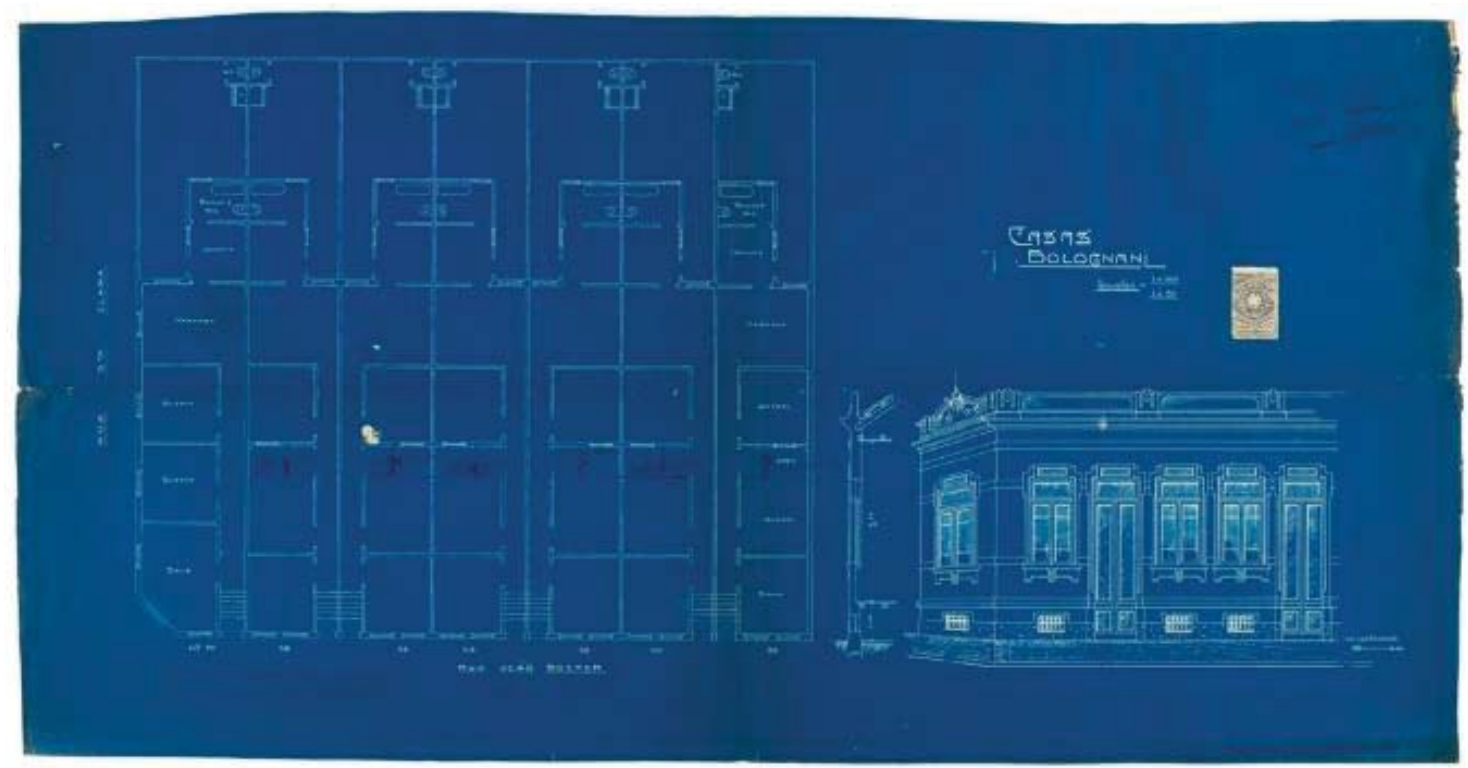

Figura 107: “Casas Bolognani”, Arquivo Histórico Municipal, Fundo “Diretoria de Obras”, Série “Obras Particulares”, OP1913.003.018.

2.7 Entre jardins, garagens e quartos para empregados: exceções das casas dos setores médios

Ao identificarmos casas destinadas a um público mais abastado que podiam usufruir de pelo menos dois quartos, uma sala, cozinha e banheiro, procuramos inseíi-las no rol de residências para uma parte da classe média do Brás, casas que estiveram distribuídas especialmente nas bordas do bairro, o que não exclui o fato de existirem em outras áreas, só que em menor número. Observamos uma maior incidência das mesmas entre as ruas João Boemer, Bresser, Almirante Barroso e Joli, já no limite do bairro do Brás com o Belenzinho, e longe dos grandes complexos industriais.

Mapeamos um total de mais de 400 pedidos que versavam sobre a construção de casas em série e vilas distribuídas entre as ruas do Brás entre os anos de 1906 a 1915. O trabalho de espacialização desta série fora desenvolvido por Luciana Além Genari, mas, pudemos ampliar o debate no tocante às vilas operárias e casas em série que localizamos entre as obras particulares. Os setores médios podiam estabelecer-se então, tanto nas casas de vilas operárias que se encontravam na testada dos lotes, ou seja, de frente para as ruas, como em casas individuais, as quais em sua forma, possuíam dimensões aproximadas às encontradas nas vilas ou em casas geminadas, com ao menos dois quartos, uma sala de jantar 
ou varanda, a cozinha e um banheiro, podendo variar para mais cômodos dependendo do projeto.

Casas como a de Filomena Gozza, na rua Bresser número 145, traduzem o perfil de habitação para determinadas parcelas dos setores médios do Brás. Chamada de "casa dupla", ambas as casas possuem dois quartos, sala de jantar, cozinha e a menção a um "quarto da criada" nos fundos, com acesso direto ao quintal. Este cômodo foi identificado por Carlos Lemos, como uma "solução nacional", que seguia a tradição do passado das construções para senzalas. Segundo Lemos:

\footnotetext{
"Nas casas de classe média para cima, por exemplo, começamos a encontrar, mais ou menos a partir da última década do século XIX, o quarto da "criada" dentro de casa ao lado da cozinha, o que não ocorria nas antigas moradas de alcovas centrais onde os fâmulos escravos dormiam nos quintais, nos porões, ou nos desvãos dos telhados, em cima dos forros das cozinhas ou das áreas de serviço. (...) Nesse ponto, o programa da casa paulista assemelha-se ao programa anterior ao período das providências abolicionistas: acomodações para os serviçais. Antes, a senzala, ou os quartos nos quintais ou águas-furtadas. Agora, a edícula com quarto e banheiro" $" 216$.
}

Outros exemplos de espaços destinados a empregados domésticos em casas dos setores médios do Brás foram encontrados, como o pedido de construção de uma casa de empregados nos fundos de um terreno (provavelmente já edificado) na rua Almirante Barroso, número 64. A casa mínima com quarto, varanda, cozinha e banheiro encontra-se nos limites do lote, na fronteira com a edificação vizinha (figura 108). Pena não dispormos do nome do proprietário ou construtor que assinou este projeto. Em contraposição, em outro projeto, da rua João Boemer número 120, podemos verificar que o construtor Benedicto Bettoy projetou uma casa para Nicola Gambini com um armazém na parte da frente, seguida de um dormitório, sala de jantar, cozinha, despensa e um quarto para empregados, muito próximo das áreas de serviço e contíguo ao espaço de guarda dos arreios e ferragem destinados aos animais da cocheira situada logo em seguida (figura 109).

${ }^{216}$ LEMOS, Op. Cit, 1989, pág. 80 e 149. 


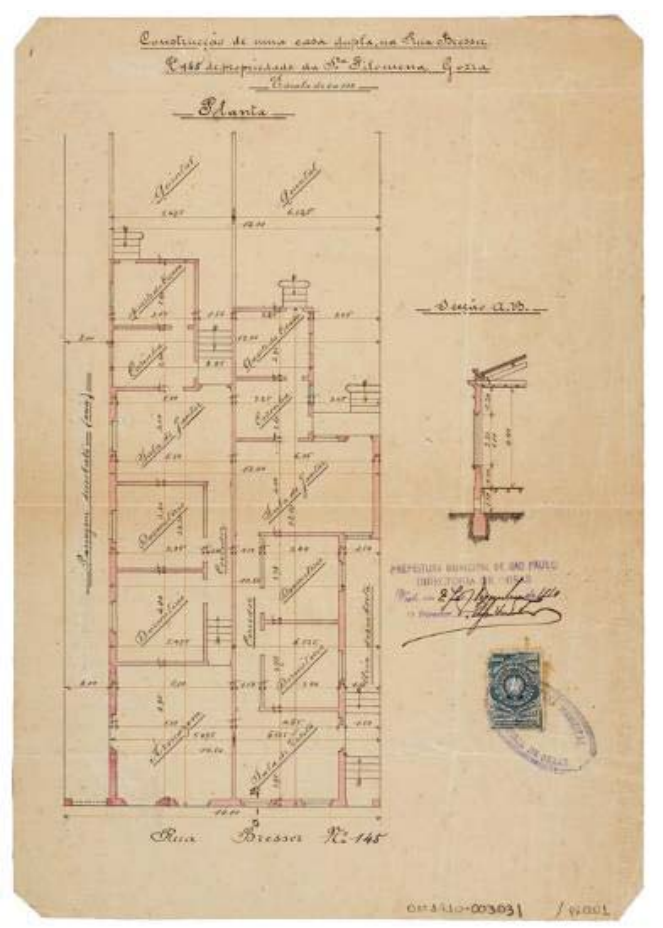

Figura 108: "Construcção de uma casa dupla na rua Bresser n ${ }^{\circ}$ 145, de propriedade da Sra. Filomena Gozza", Arquivo Histórico Municipal, Fundo "Diretoria de Obras", Série "Obras Particulares", OP1910.003.031.

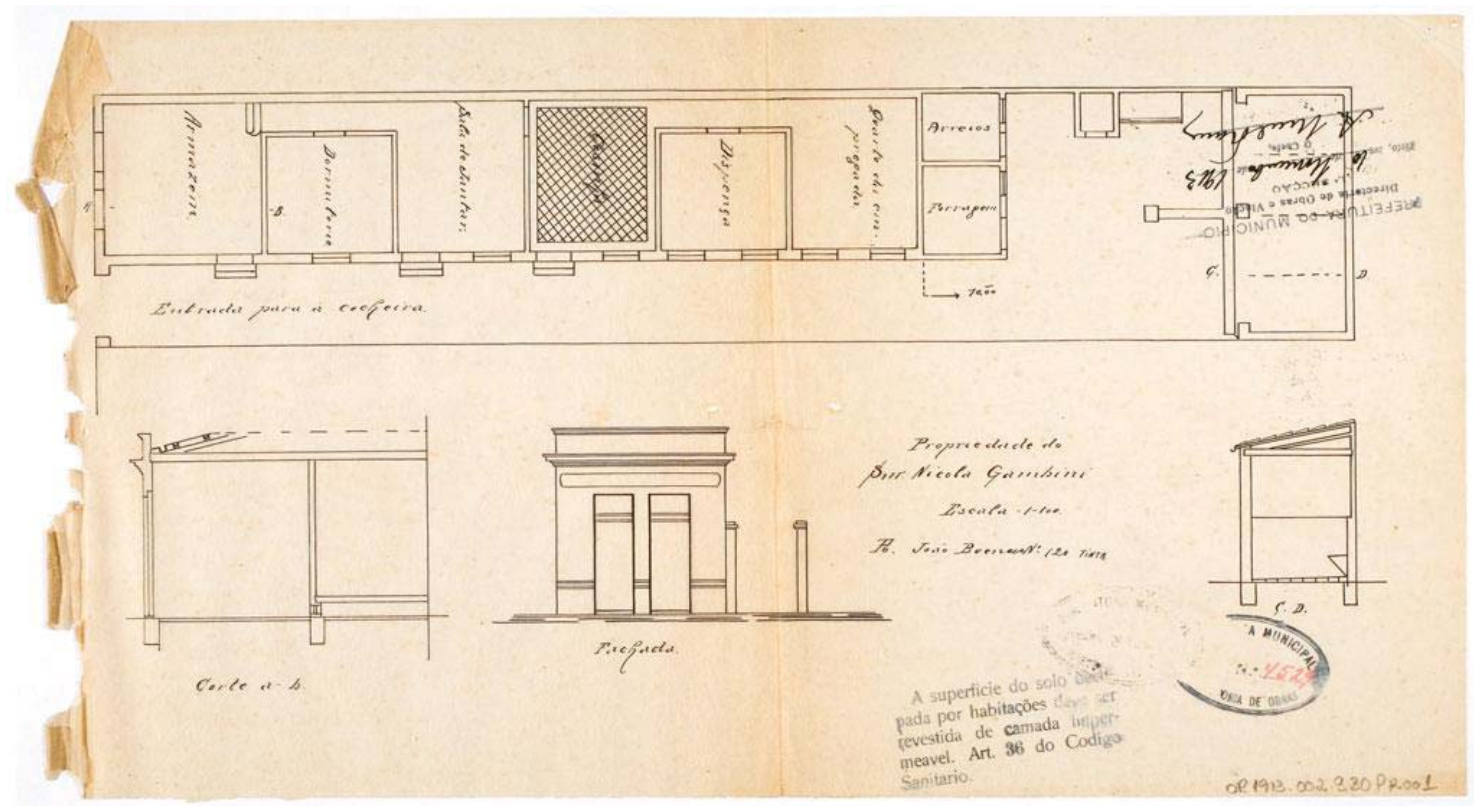

Figura 109: "Propriedade do Snr. Nicola Gambini”, Arquivo Histórico Municipal, Fundo "Diretoria de Obras", Série "Obras Particulares”, OP1913.002.980.

As casas dos setores médios do Brás que apresentavam uma série de equipamentos que as casas de perfil mínimo muitas vezes não tinham, como os jardins e garagens, eram exceções. Enquanto os jardins podiam ser montados a partir do espaço não construído na frente da casa (e aí outra diferença, o fato de muitas das casas dos setores médios não serem 
exclusivamente construídas na testada do lote, mas com um recuo), as garagens demandavam um espaço mais amplo para abrigar automóveis, e não as tão conhecidas cocheiras que faziam parte da paisagem do Brás até então. Os jardins foram observados em outros projetos de casas destinadas aos setores médios, como das residências construídas para Leonor Monteiro da Silva na rua da Concórdia (figura 104), e em dois projetos da rua Bresser: um situado nos fundos de um terreno que fora aproveitado para a construção de uma nova casa (figura 110), e outro um projeto do arquiteto João Grass, para Ismael Bresser, o qual transforma parte do grande jardim em uma garagem de frente à rua Bresser junto ao número 253 (figura 111). Em 1915, Ismael Bresser iria propor uma nova reforma à sua garagem, construindo uma parede lateral, sem eliminar o jardim ali existente (figura 112).

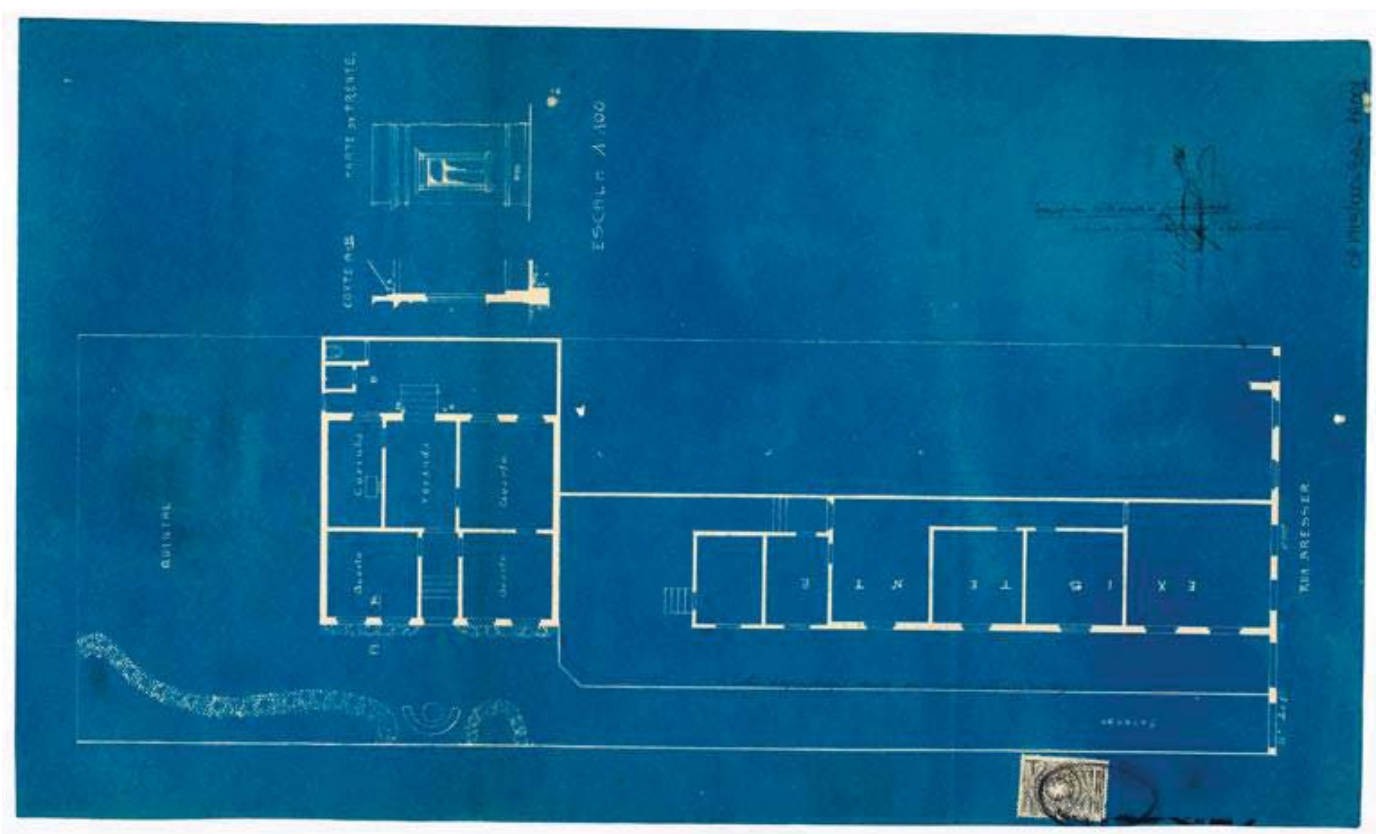

Figura 110: Casa com jardim, Arquivo Histórico Municipal, Fundo "Diretoria de Obras", Série "Obras Particulares", OP1913.000.832. 


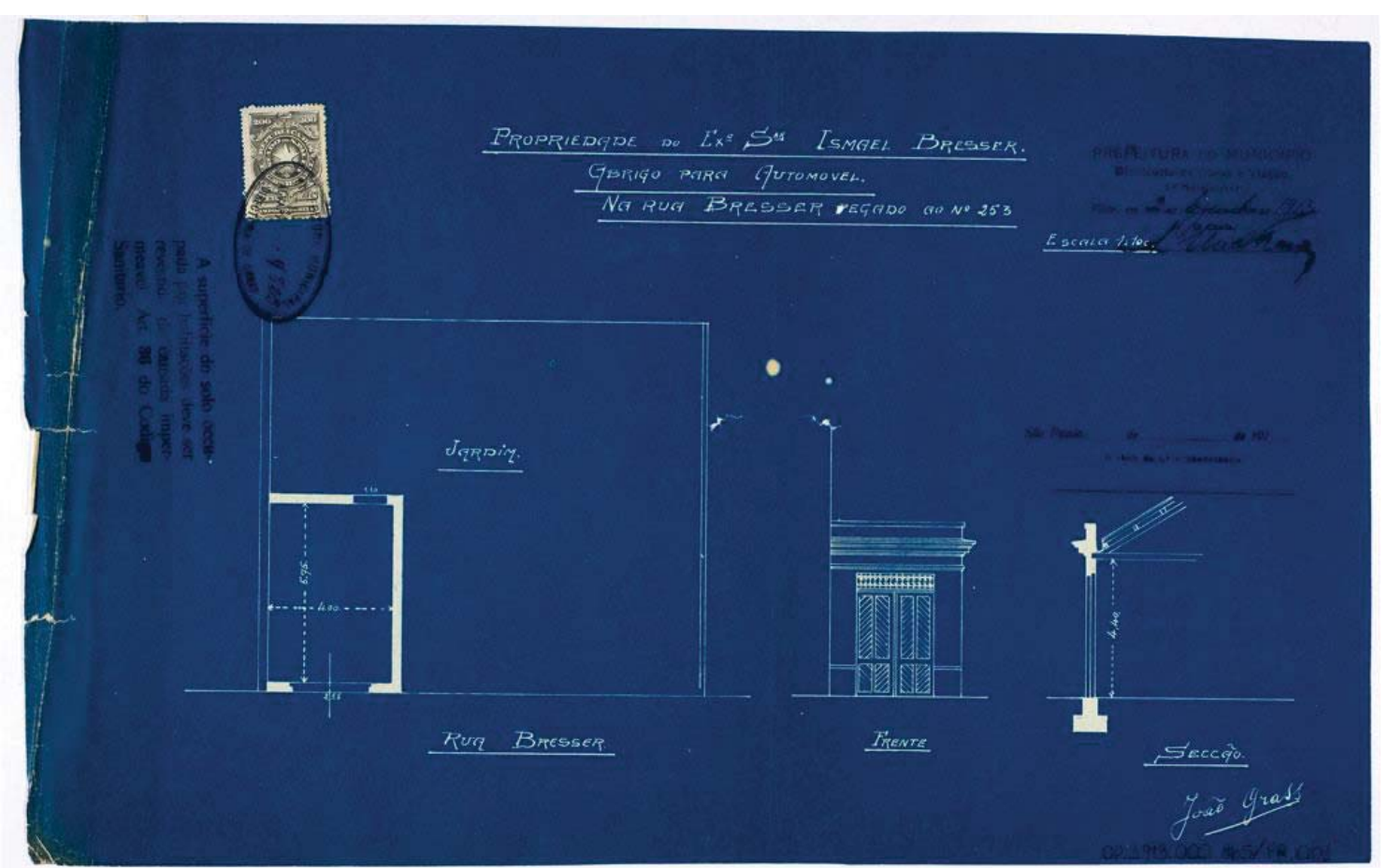

Figura 111: "Propriedade do Exm. Snr. Ismael Bresser", Arquivo Histórico Municipal, Fundo "Diretoria de Obras”, Série “Obras Particulares”, OP1913.000.865.

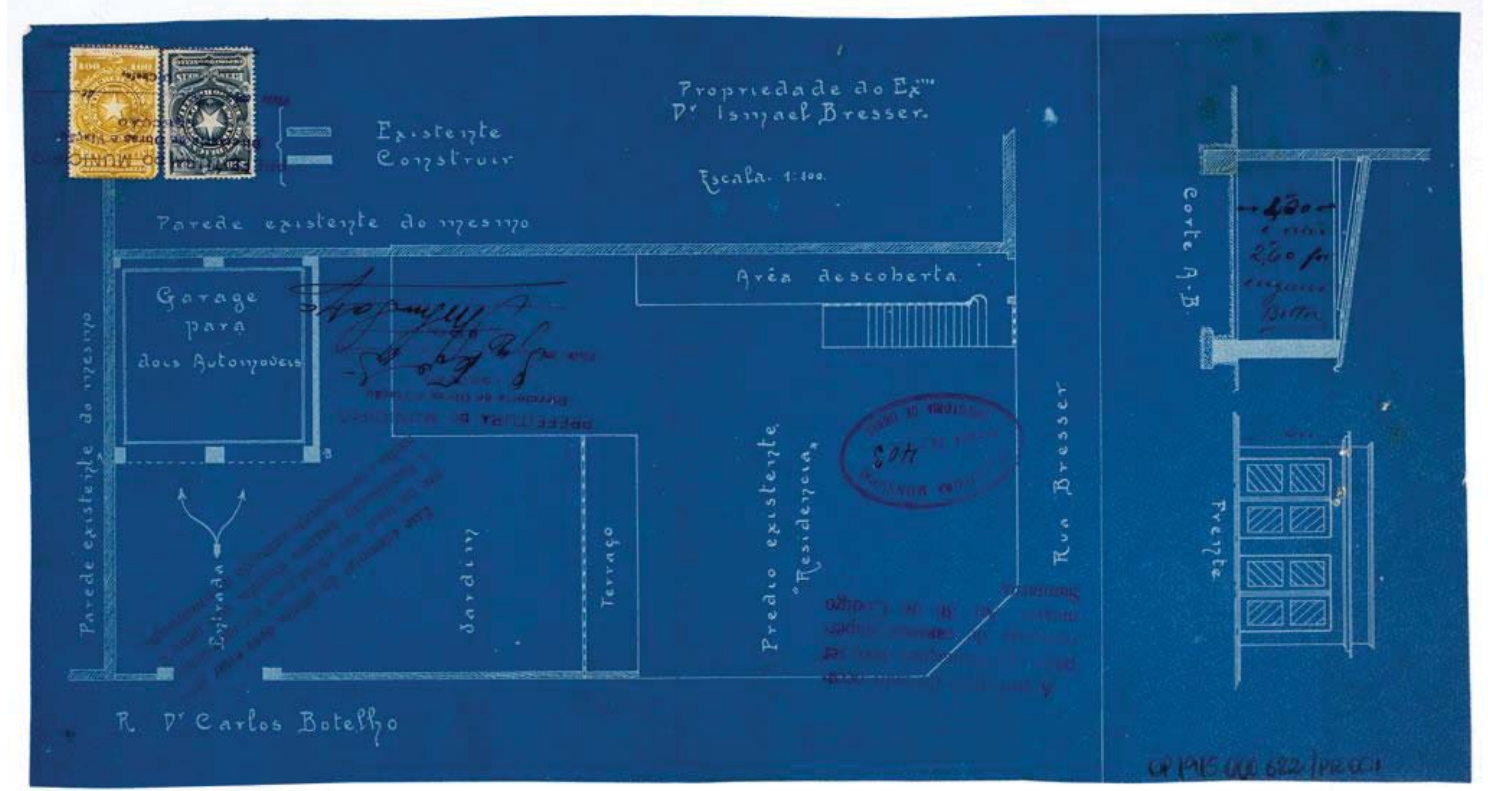

Figura 112: "Propriedade do Exmo. Dr. Ismael Bresser", Arquivo Histórico Municipal, Fundo "Diretoria de Obras”, Série “Obras Particulares”, OP1915.000.682.

Podemos perceber que muitas das casas dos setores médios do Brás ostentavam uma ampla área ocupada no lote, o que permitia a construção de cômodos maiores, bem como obter maiores áreas de ventilação. Uma das casas de José Pinheiro Monteiro, na avenida Celso Garcia número 93 traduz em parte o ideal de vida dos setores médios do Brás, que ao ascenderem de vida ostentam em suas residências o novo padrão de vida adquirido. Projetada pelo arquiteto Julio Micheli, a residência ocupou o espaço antes ocupado por duas 
casas existentes (figura 113), ostentando inúmeros cômodos não apresentados anteriormente em outras residências, como um hall de entrada, um gabinete, um quarto para vestir, copa, além dos já mencionados quartos, área, uma ampla sala de jantar, cozinha e o quarto de criada nos fundos da casa, junto ao banheiro (figuras 114 e 115).

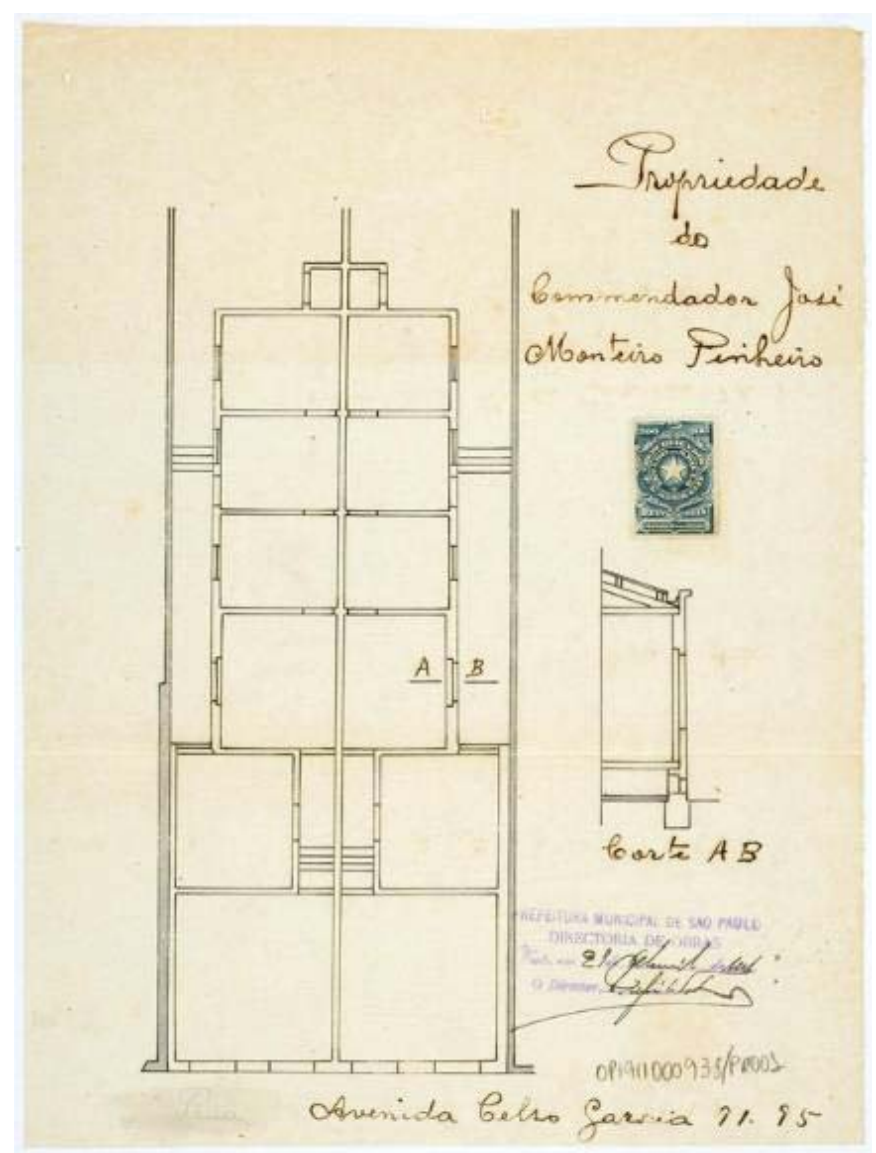

Figura 113: "Propriedade do Comendador José Monteiro Pinheiro", Arquivo Histórico Municipal, Fundo "Diretoria de Obras", Série "Obras Particulares", OP1911.000.938. 


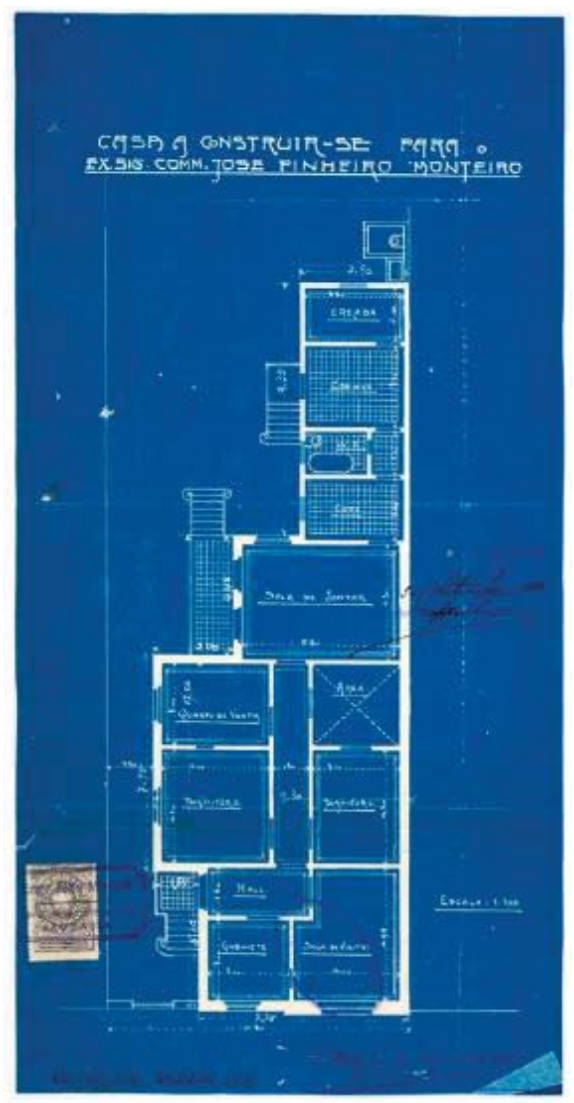

Figura 114: "Casa a construir-se para o Exmo. Sig. Comm. José Monteiro Pinheiro", Arquivo Histórico Municipal, Fundo "Diretoria de Obras”, Série “Obras Particulares”, OP1912.000.757_002.

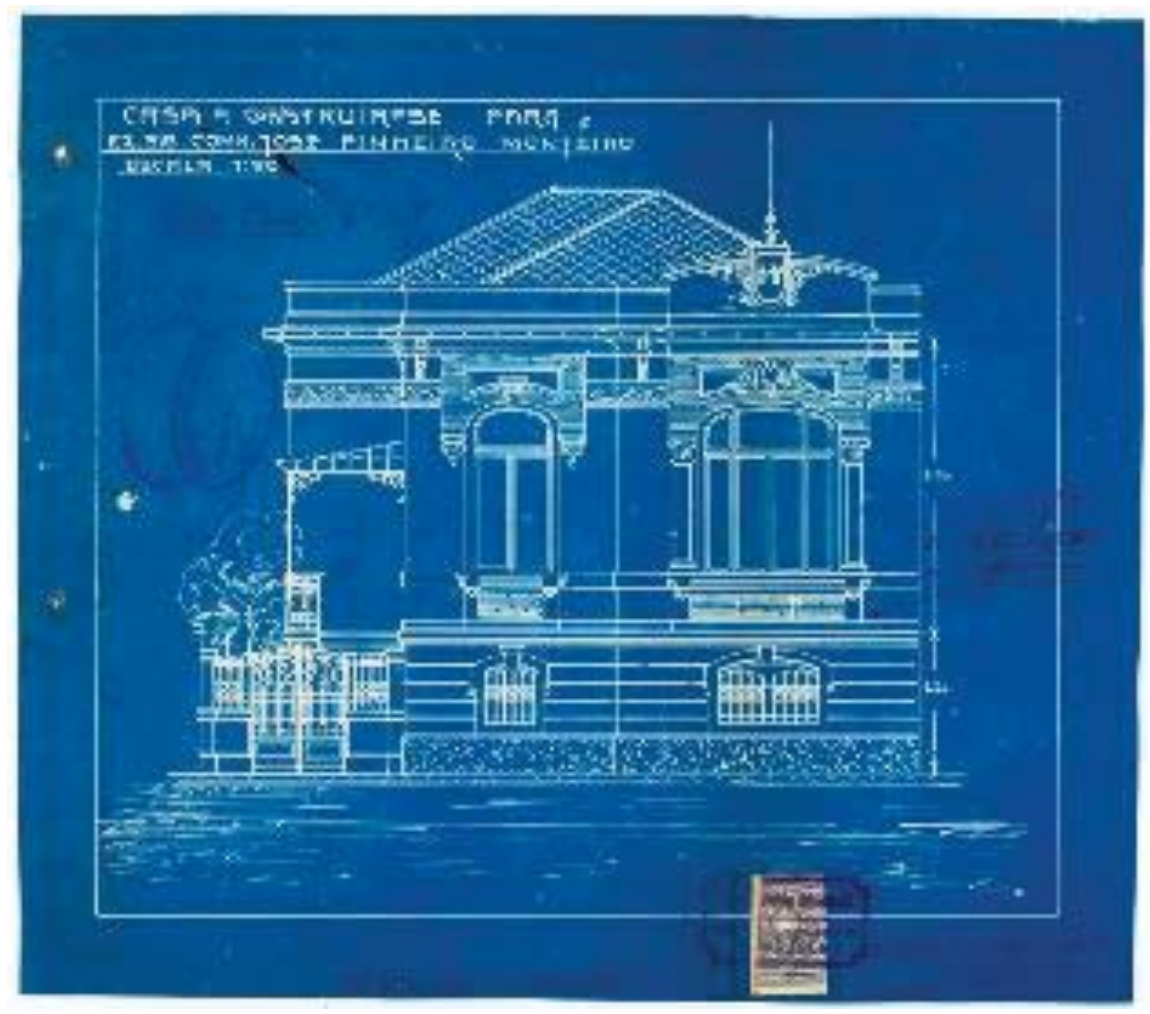

Figura 115: Casa a construir-se para o Exmo. Sig. Comm. José Monteiro Pinheiro", Arquivo Histórico Municipal, Fundo "Diretoria de Obras”, Série “Obras Particulares”, OP1912.000.757. 
A casa de João Senna, na rua Bresser número 48 parece seguir a mesma tipologia da residência de José Pinheiro Monteiro, com cômodos que diferem da maioria das casas construídas no Brás, como o gabinete, uma copa, existir três quartos, duas salas (uma dedicada para o jantar), cozinha, dispensa, além do fato do banheiro estar localizado no interior da residência, dado que se configura como uma grande diferença das tipologias residenciais do bairro (figura 116).

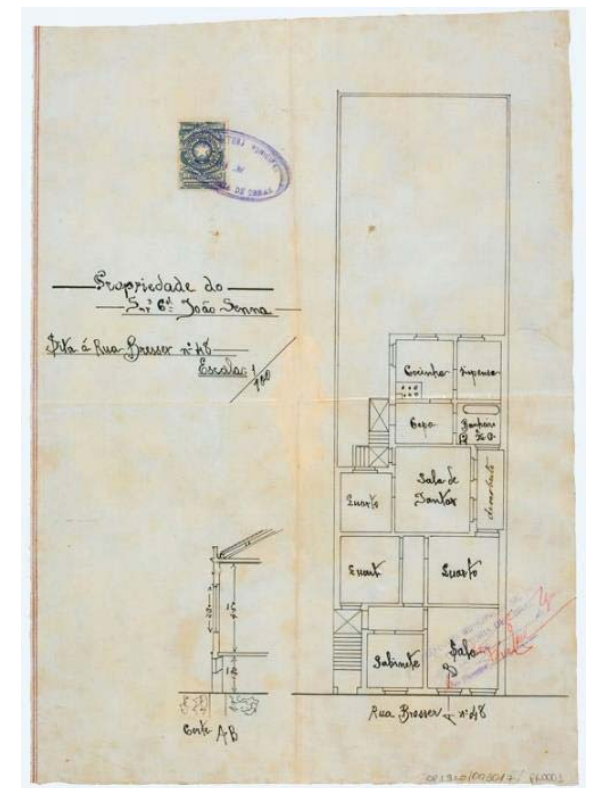

Figura 116: "Propriedade do Snr. José Senna", Arquivo Histórico Municipal, Fundo "Diretoria de Obras", Série "Obras Particulares", OP1910.003.017.

Podemos perceber que a região das ruas João Boemer, Bresser e Joli, anteriormente uma área da chácara Bresser, foram as ruas que mais concentraram pedidos de particulares solicitando a construção de casas voltadas para os setores médios do Brás. Nem todas as casas destas ruas ostentavam ter os cômodos do morar à francesa ${ }^{217}$, haviam também residências mais simples, mas que ainda assim configuram-se como voltadas para os setores médios, como a de Jácomo Coletti, na rua Bresser número 419, que em sua casa resgata num dos cômodos a alcova e o banheiro (figura 117). Natal Boni, proprietário da casa número 423 da mesma rua, apresentava para construção de sua casa os cômodos padrões para os setores médios da época, com dois quartos, sala de visitas, uma sala de jantar aqui denominada "sala de mesa", além da cozinha, despensa e banheiro (figura 118).

\footnotetext{
217 Segundo Carlos Lemos os "palacetes eram a novidade rica, raramente térrea, propiciando quase sempre o "morar à francesa" e procurando, sobretudo, uma quantidade muito grande de acomodações de modo que fossem evitadas, sempre que possível, superposições das atividades e daí, o surgimento da "sala da senhora", de "fumoir", da sala de música, da biblioteca conjugada ao gabinete, do quarto de hóspedes no térreo, da sala de bilhar, da sala de almoço, do quarto da governanta e da cocheira ou da garagem". LEMOS, Op. Cit, 1999, pág. 32-34.
} 


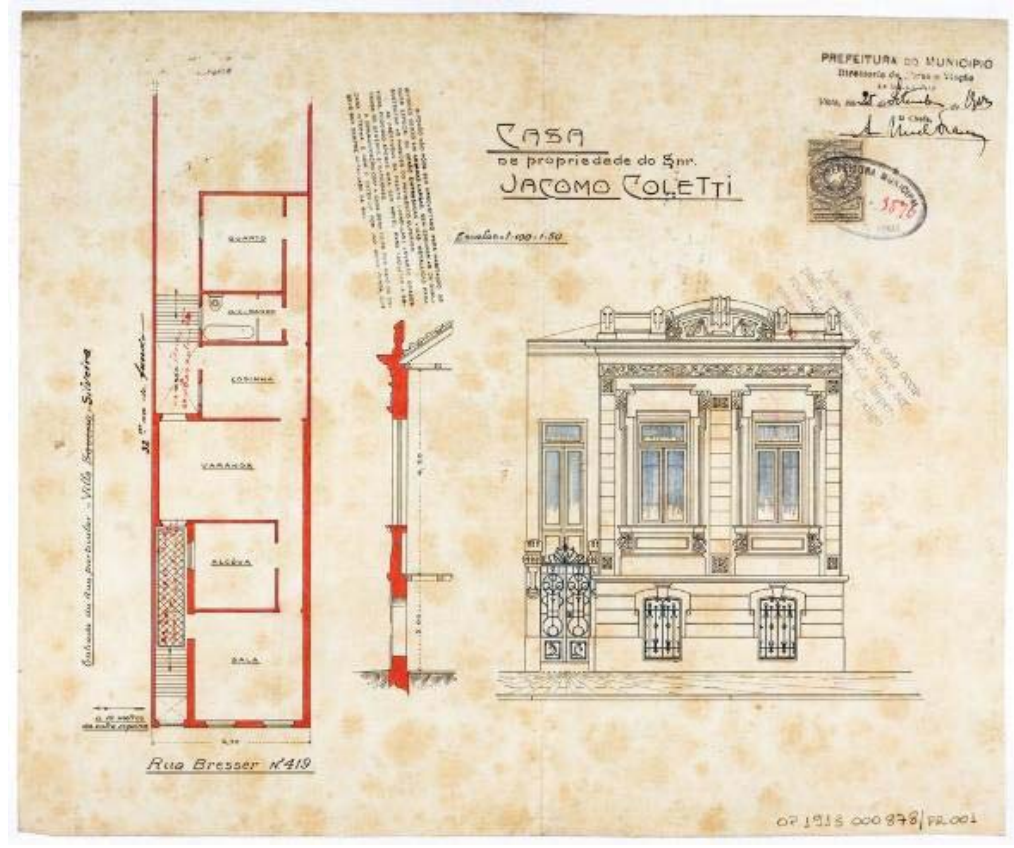

Figura 117: "Casa de propriedade do Snr. Jacomo Coletti”, Arquivo Histórico Municipal, Fundo "Diretoria de Obras”, Série “Obras Particulares”, OP1913.000.878.

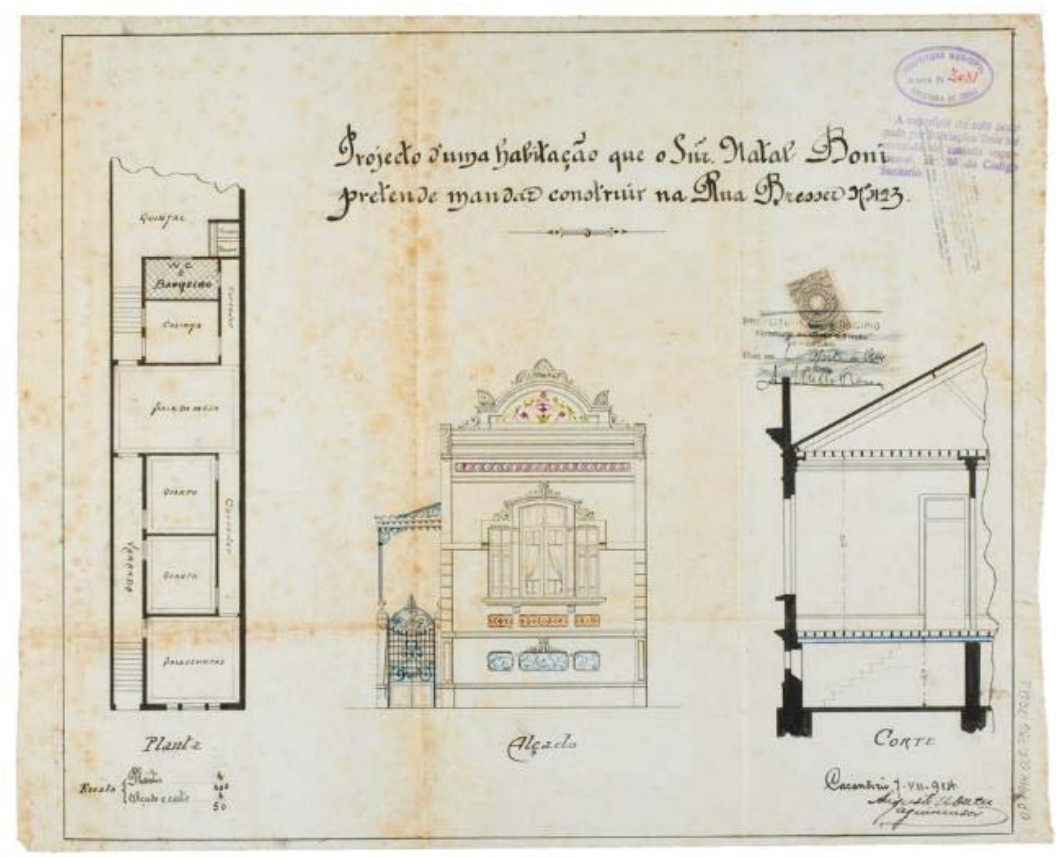

Figura 118:"Projecto d'uma habitação que o Snr. Natal Boni pretende mandar construir na rua Bresser 423", Arquivo Histórico Municipal, Fundo “Diretoria de Obras”, Série “Obras Particulares”, OP1914.000.756. 


\subsection{Sobrado: um espaço para a morada e o trabalho dos setores médios}

O grande conjunto de construções mapeadas por nós na Série Obras Particulares fora em torno de residências do perfil mínimo, as quais estavam presentes sozinhas em lotes, ou em séries e mesmo em vilas operárias. Destacamos que elas não perfizeram a totalidade construída nas ruas trabalhadas por nós, e assim, outras tipologias arquitetônicas fizeram-se presentes, como as residências voltadas às camadas médias, apresentando um número de cômodos maior que as casas mínimas, e em outras vezes compartimentos específicos deste perfil social, como quartos para empregados, jardins, garagens, gabinetes, etc.

Este processo de constituição residencial voltado às camadas médias do Brás, correspondia a um amplo processo de transformações vislumbradas no centro de São Paulo e em outras cidades que passavam por processos similares de urbanização. Com a ascensão de algumas parcelas dos setores médios, uma das formas de destaque na sociedade fora o crescente investimento em sobrados. Carlos Lemos nos coloca que esta tipologia indicava o "espaço sobrado", ou do espaço que se adquiria devido o "soalho suspenso", como em decorrência de um melhor aproveitamento de terrenos inclinados, os quais possibilitaram a criação de um pavimento inferior, posteriormente chamado de "porão", formando assim dois lances num só imóvel ${ }^{218}$.

Na São Paulo de finais do século XIX e princípios do século XX, uma das formas dos setores altos e médios se afirmarem, fora por meio do financiamento de novas edificações, construções estas que iriam além do andar térreo, simbolizando os princípios de uma verticalização. Maria Luiza de Oliveira, ao inventariar os bens de raiz de proprietários da São Paulo oitocentista, entre os anos de 1874 até 1900 registra que um dos grandes investimentos dos seus moradores fora em torno dos bens imóveis, contabilizando um total de 1112 os imóveis classificados, chamando atenção para o fato de apenas 82 serem sobrados. Ou seja, até o começo do século XX este era um programa pouco usual na arquitetura paulistana, e com o despertar dos anos seria incorporado na paisagem urbana da cidade. Segundo a historiadora

\footnotetext{
“podemos imaginar que passear na cidade de São Paulo, nos 25 anos finais do século, era ainda andar cercado de casas térreas, e vez por outra ter o horizonte modificado por um sobrado. Em apenas algumas ruas centrais terse-ia a sensação da mudança de perspectiva, com uma maior concentração de casas de dois
}

${ }^{218}$ LEMOS, Carlos. História da casa brasileira. São Paulo: Contexto, 1996, pág. 32-33. 
andares, e até algumas de três. São Paulo era uma cidade muito horizontal, basicamente de casas de um só pavimento ${ }^{219}$.

Sobre a região do Brás os perfis não se diferenciaram muito da visão conferida pela historiadora Maria Luiza de Oliveira no que toca à região central da cidade, pois no bairro além Tamanduateí grande parte dos imóveis mapeados por nós, após análise dos desenhos arquitetônicos, eram térreos, com a testada na beirada do lote. Entre os anos de 1906 e 1915, 69 sobrados foram erguidos em diferentes ruas do Brás, sendo a maioria deles concentrados no eixo das avenidas Rangel Pestana e Celso Garcia.

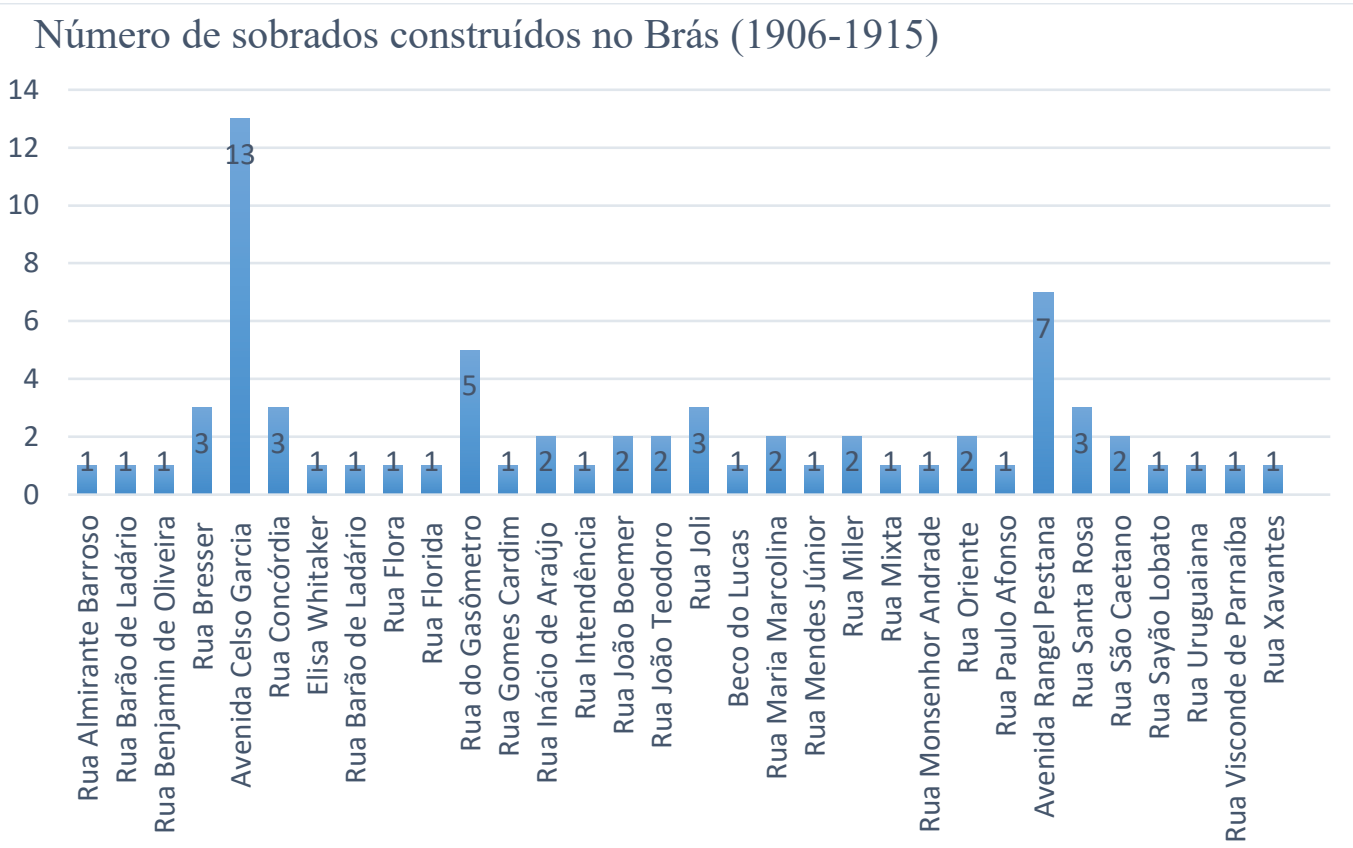

Gráfico 8: "Número de sobrados construídos no Brás (1906-1915)", elaborado pelo autor com base nas análises dos desenhos da Série Obras Particulares.

Percebemos que os sobrados cumpriam duas funções no que toca aos seus usos, pois, enquanto alguns seriam estritamente habitacionais, outros seriam de caráter misto,

219 OLIVEIRA, Maria Luiza Ferreira de. "Em casas térreas com alcovas. Formas de morar entre os setores médios em São Paulo, 1875 e 1900”. Anais do Museu Paulista, São Paulo. N. Sér. v. 8/9. p. 55-76 (20002001). Editado em 2003, pág. 58. 
congregando a função habitacional juntamente com atividades comerciais ou fabris. Ao contrário dos edifícios térreos que muitas vezes adaptaram o cômodo da frente (quarto ou sala) para virar um comércio, os sobrados, em sua concepção, informavam qual parte seria dedicada às funções que não habitacionais. No ano de 1912, Roberto Mei projetou um sobrado para Umberto Guidoni na rua Barão de Ladário número 86 A, com duas casas separadas entre si: uma no térreo e outra no primeiro andar, sendo que num dos cômodos daquela funcionaria um armazém, e no andar acima haveria um quarto. Pode-se perceber que são duas casas distintas pela presença de duas cozinhas, dois banheiros, e duas salas de jantar, diferenciando-se apenas o número de quartos (figura 119).

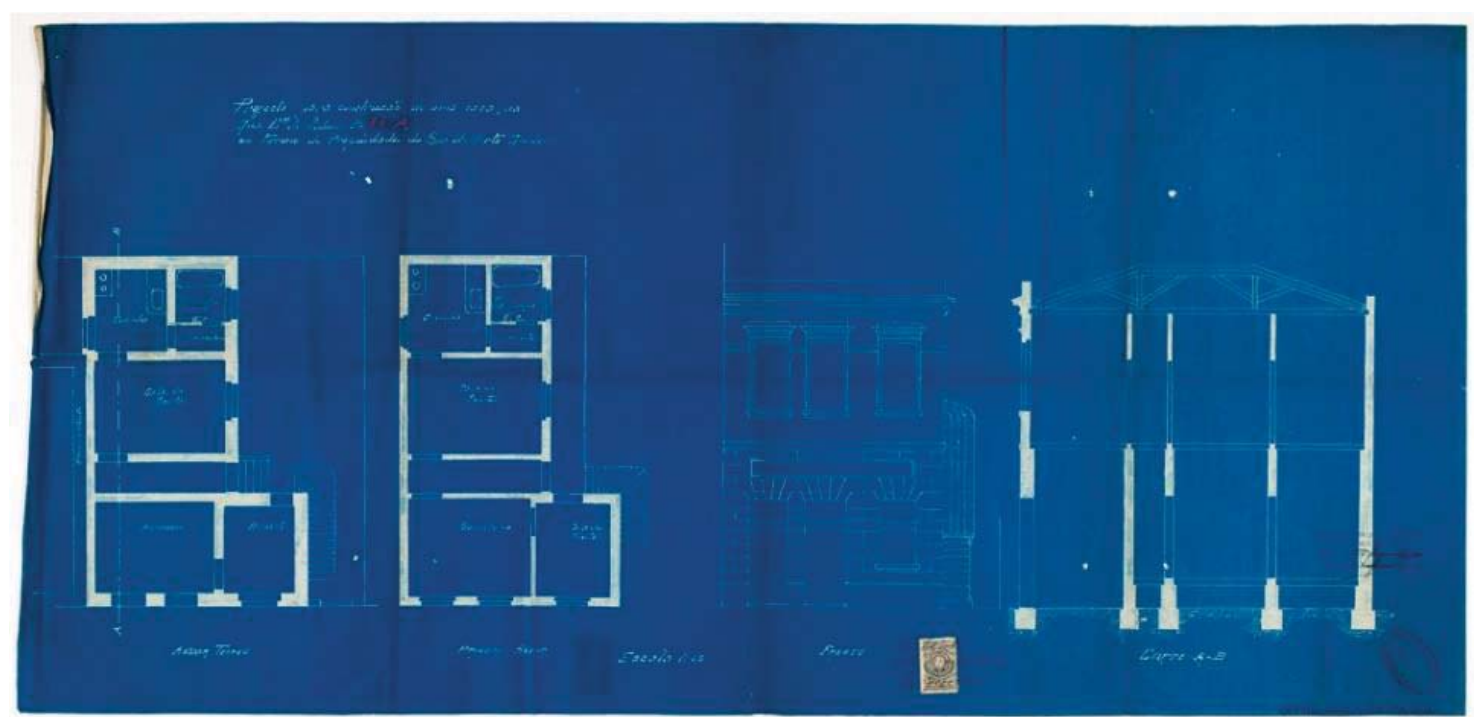

Figura119: Projecto para construcção de uma casa. - Arquivo Histórico Municipal, Fundo "Diretoria de Obras”, Série “Obras Particulares”, OP1912.000.522.

Felice Mollica, talvez por dispor de maiores quantias de capital, ao solicitar a construção de um sobrado na esquina da rua Bresser com a rua Nova de São José 220 , formou uma única casa, com 4 quartos, sala de visitas, sala de jantar, cozinha, banheiro e despensa, dedicando a testada do imóvel entre esquinas um armazém (figura 120). Já Da Ambrosina Analia Franco de Macedo, em 1914 solicitaria um pedido para edificar um sobrado na rua da Concórdia número 72, com duas salas de jantar, uma de visita, dois quartos, cozinha e banheiro, também dedicando boa parte do térreo do edifício para um armazém (figura 121).

${ }^{220}$ Atual rua Coronel Antônio Marcelo. 


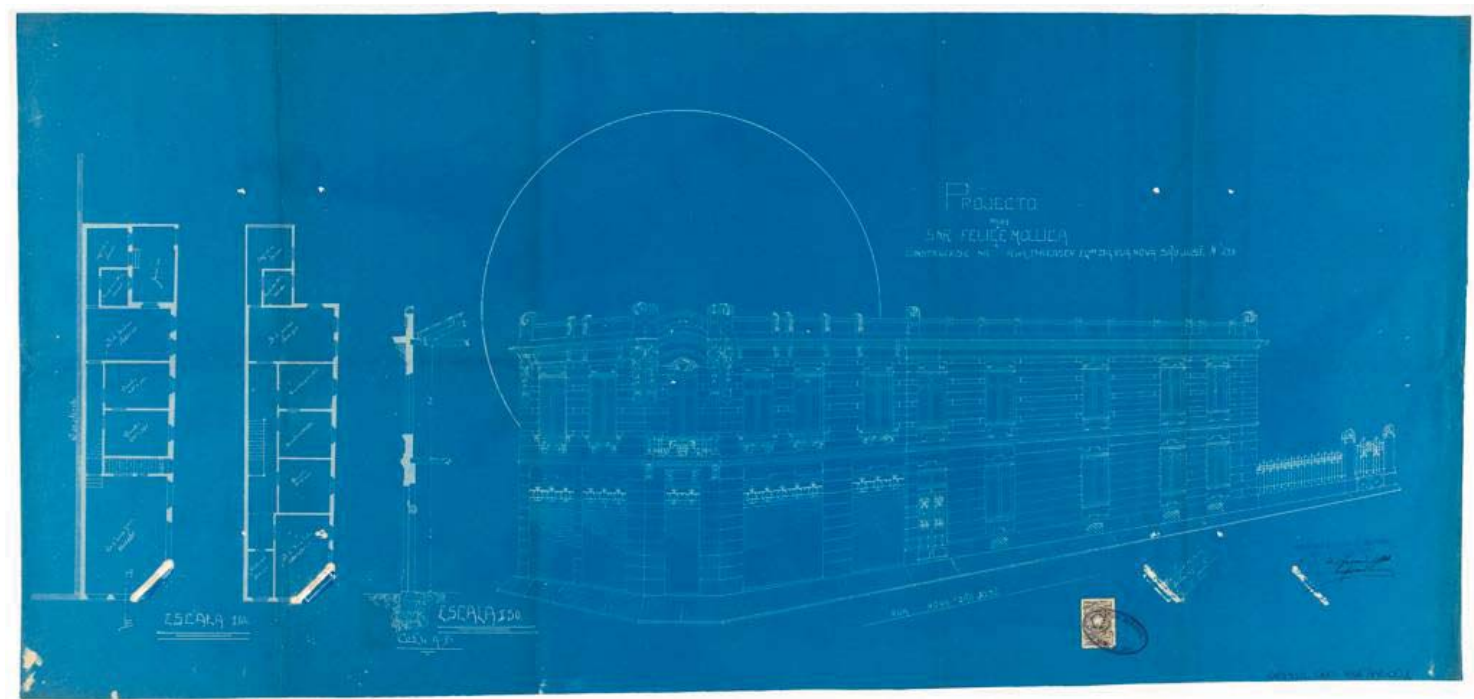

Figura 120: Projecto para Snr. Felice Mollica. - Arquivo Histórico Municipal, Fundo "Diretoria de Obras", Série "Obras Particulares", OP1912.000.786.

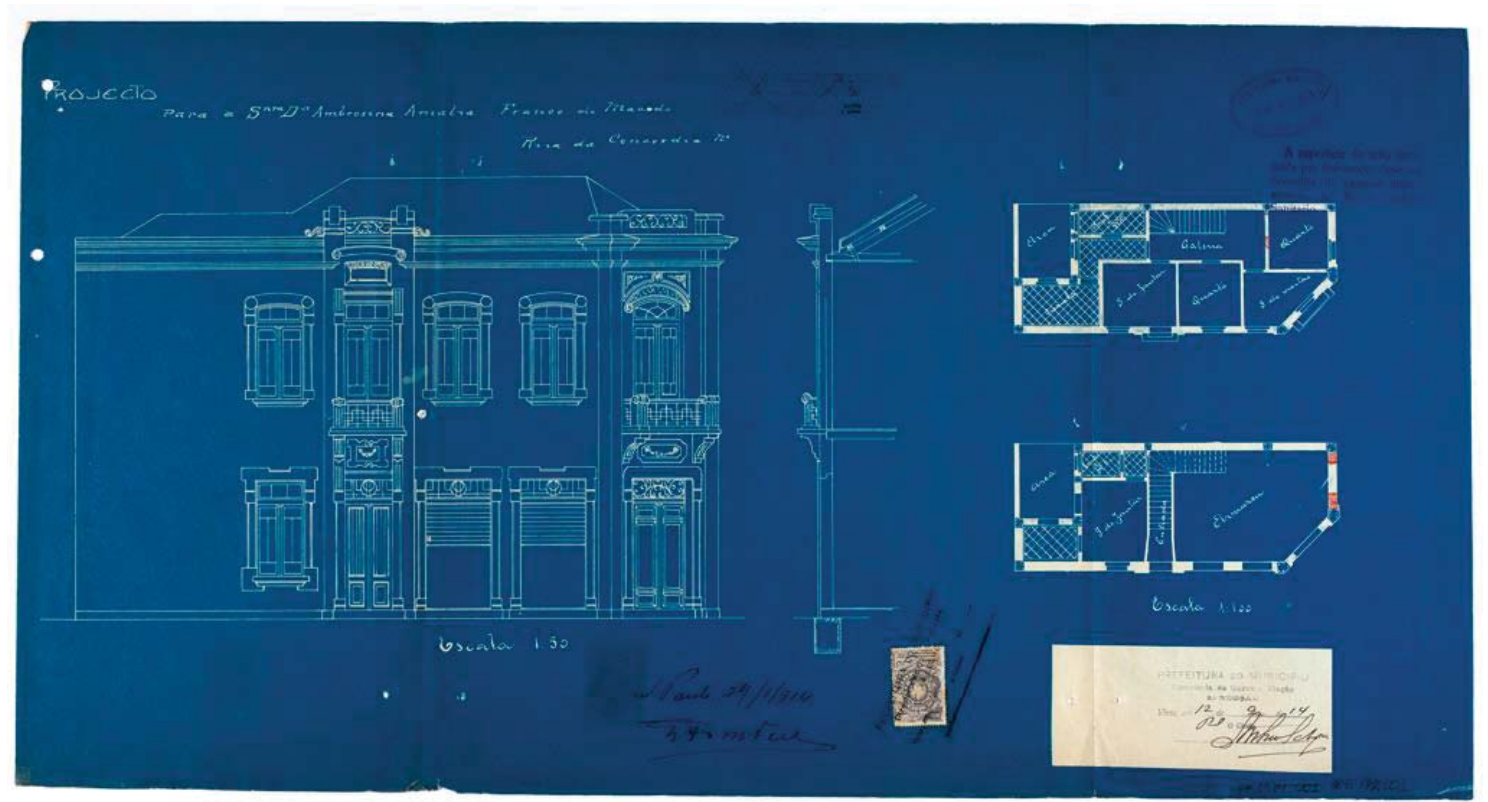

Figura 121: Projecto para a Snra. Ambrosina Amalia Franco de Macedo - Arquivo Histórico Municipal, Fundo "Diretoria de Obras", Série "Obras Particulares", OP1914.001.305.

Dos sobrados analisados, constaram também aqueles que eram unicamente residenciais, como o de José Glete na rua Mendes Júnior, em frente ao número 27, projetado por Antônio José das Chagas (figura 122), o de Mário Graco, na rua Bresser número 260 (figuras 123 e 124), ou o sobrado com feições de palacete do arquiteto João Grass, situado na avenida Celso Garcia, número 336 (figuras 125, 126 e 127). 


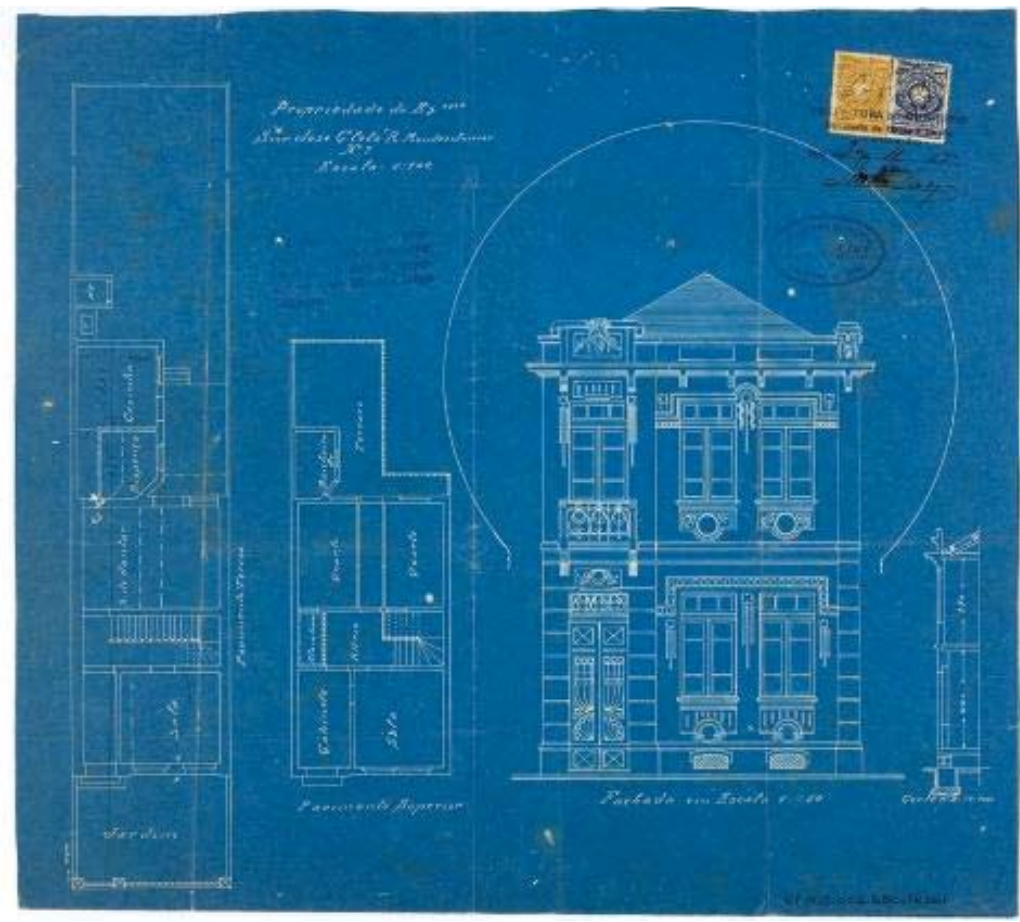

Figura 122: "Propriedade de José Glete", Arquivo Histórico Municipal, Fundo "Diretoria de Obras", Série "Obras Particulares", OP1915.002.680.

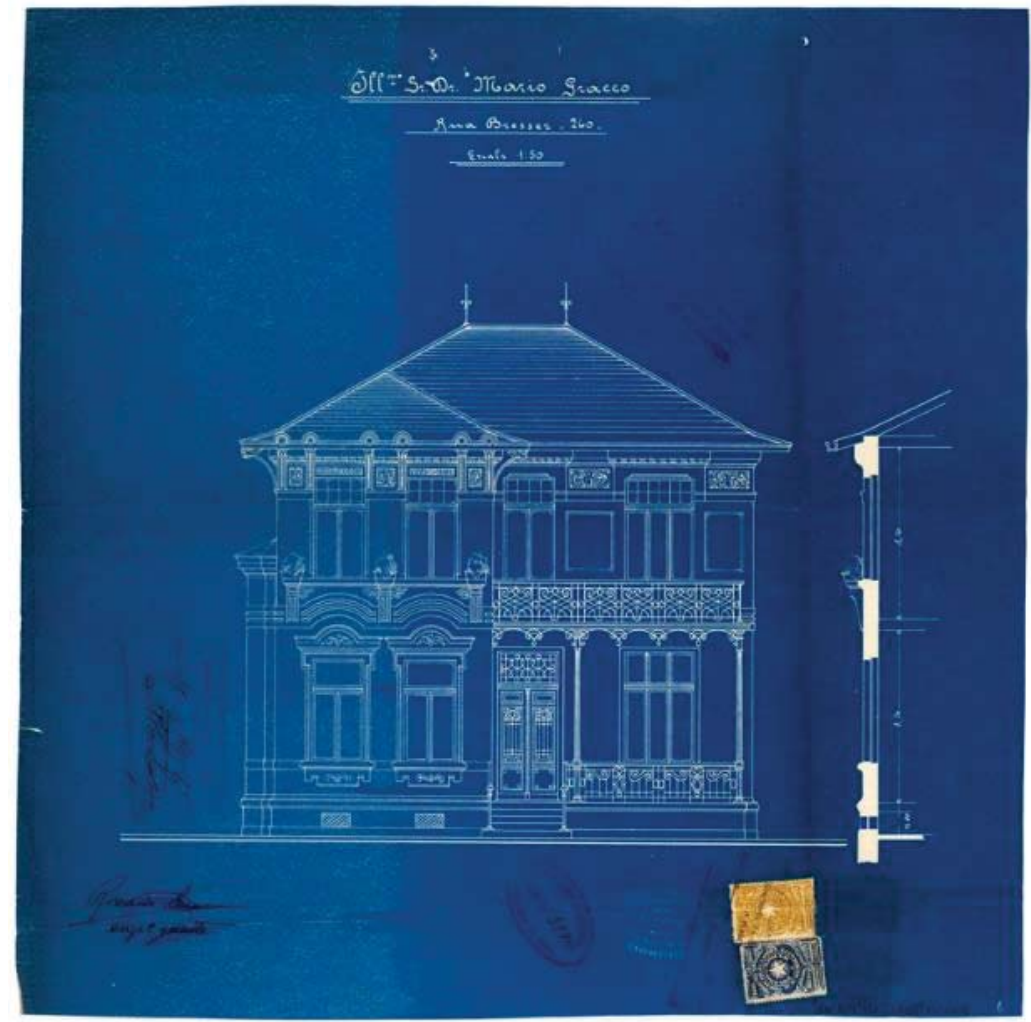

Figura 123: "Illmo. Sr. Dr. Mario Gracco", Arquivo Histórico Municipal, Fundo "Diretoria de Obras", Série "Obras Particulares", OP1915.000.668_PR001. 


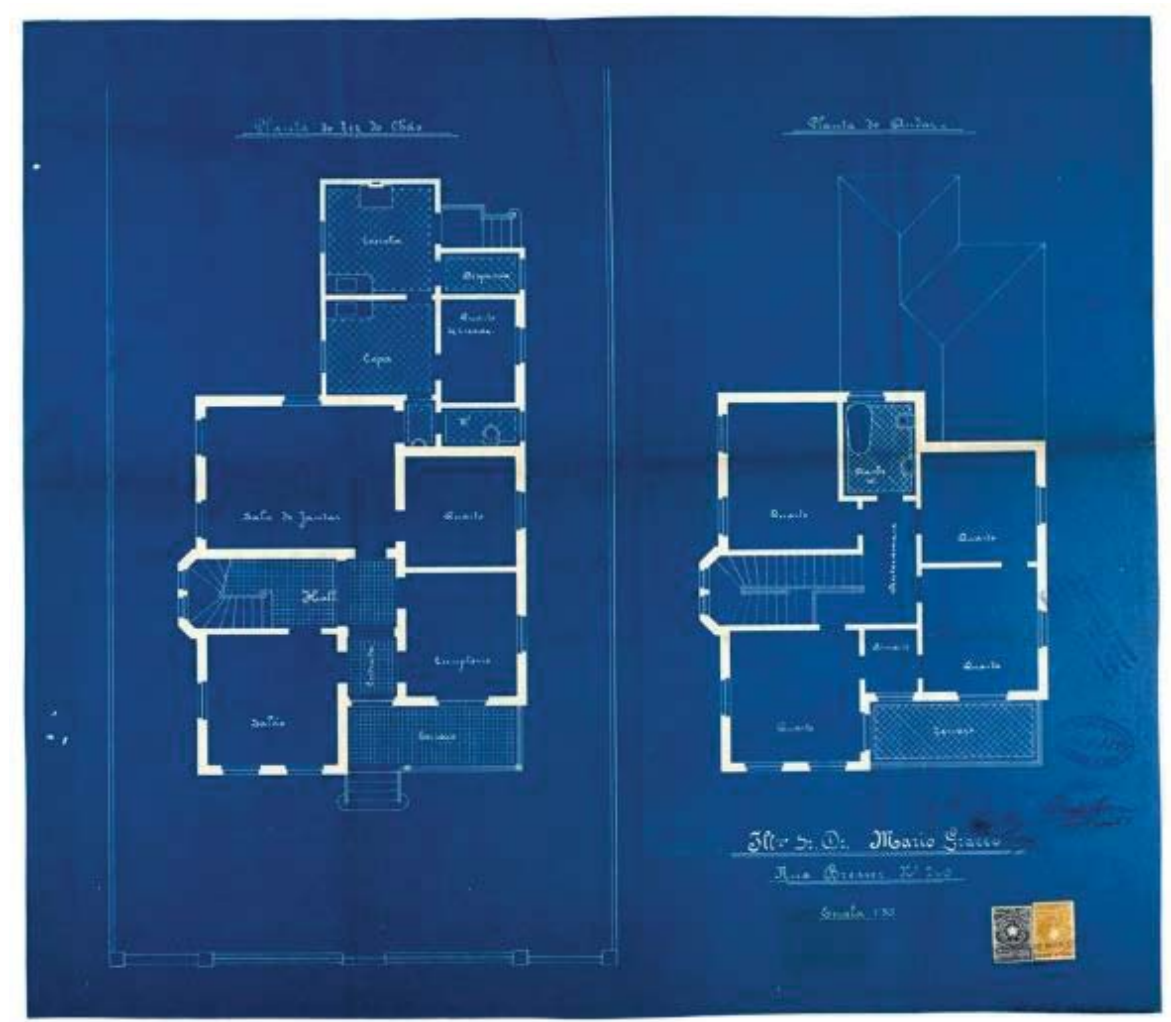

Figura 124: "Ilmmo. Sr. Dr. Mario Gracco", Arquivo Histórico Municipal, Fundo "Diretoria de Obras", Série "Obras Particulares", OP1915.000.668_PR002.

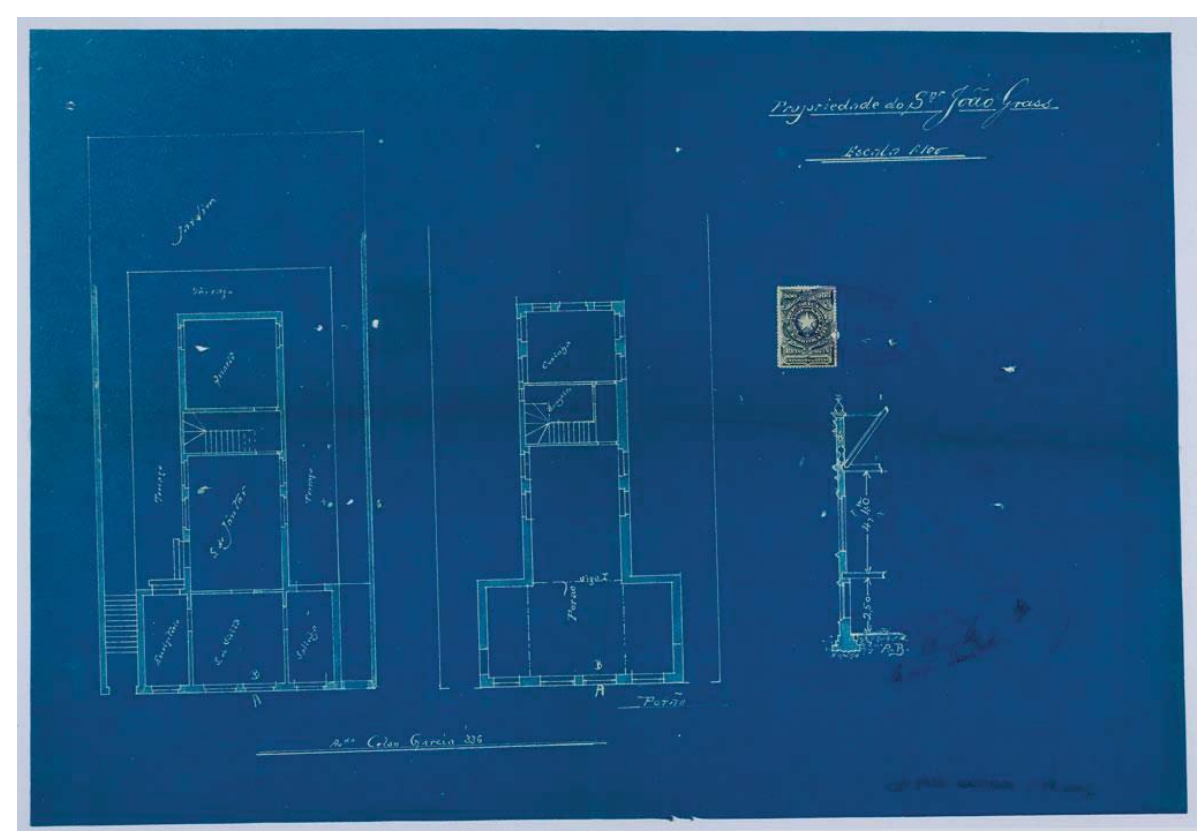

Figura 125: "Propriedade do Snr. João Grass", Arquivo Histórico Municipal, Fundo "Diretoria de Obras", Série “Obras Particulares”, OP1910.000.629_PR001. 


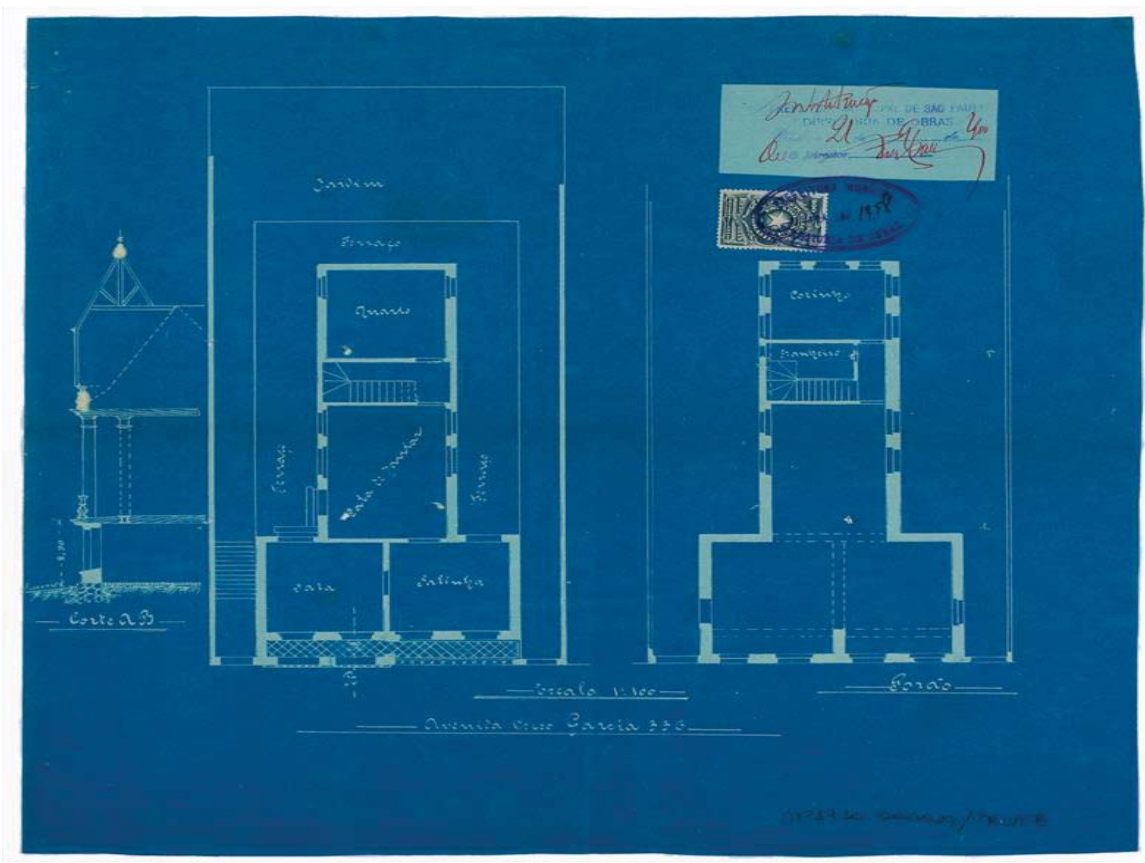

Figura 126: Propriedade do Snr. João Grass, Arquivo Histórico Municipal, Fundo "Diretoria de Obras”, Série “Obras Particulares", OP1910.000.629_PR003

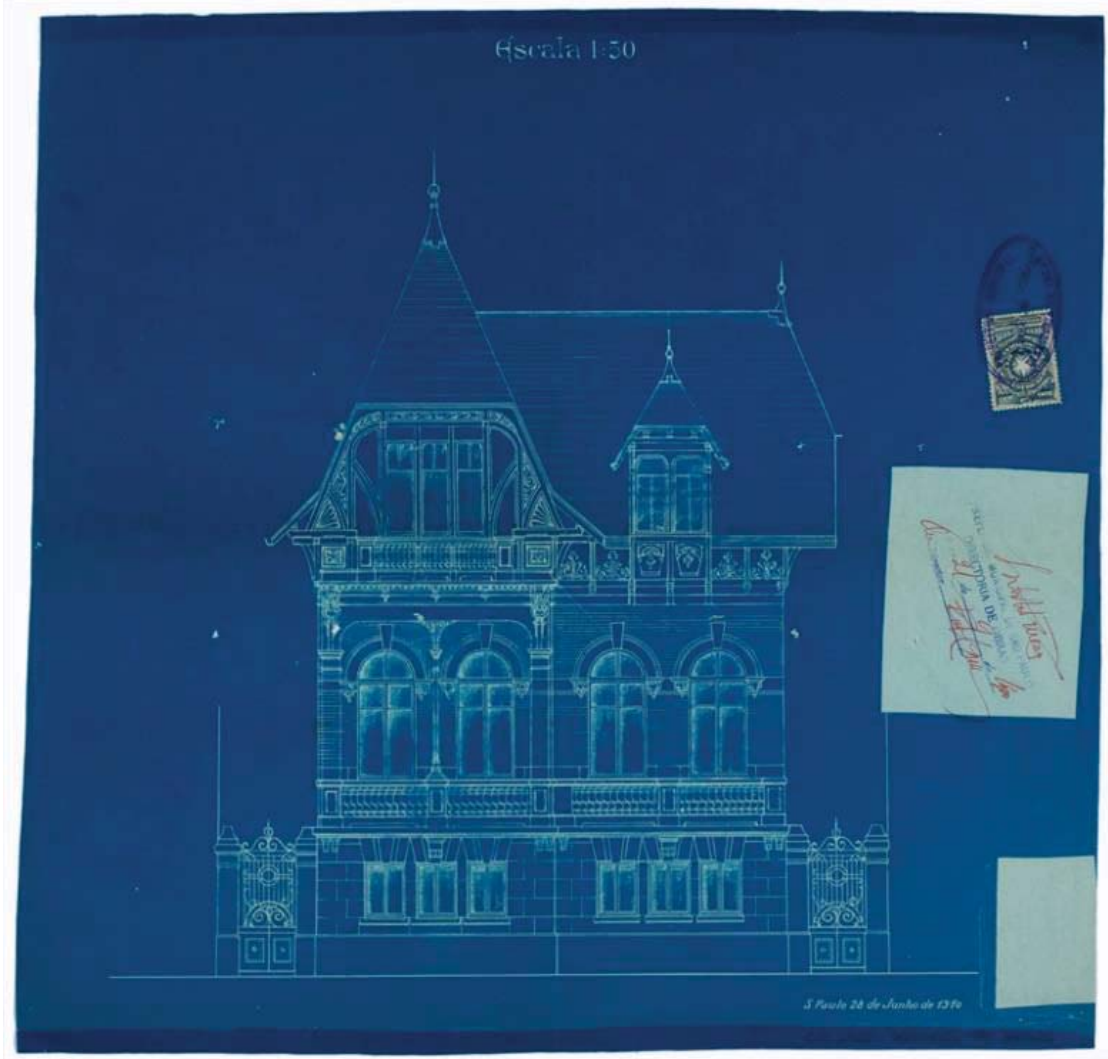

Figura 127: Propriedade do Snr. João Grass, Arquivo Histórico Municipal, Fundo "Diretoria de Obras", Série "Obras Particulares", OP1910.000.629_PR002.

A análise dos desenhos de sobrados do Brás revela uma nova página para a história da habitação do bairro, que não fora concentrada única e exclusivamente em torno das casas 
em série e vilas operárias, tampouco em cortiços. Apesar de numericamente serem poucos, quando comparados ao grande volume de casas mínimas, percebe-se que os setores médios compunham uma parcela importante no processo de formação da tessitura urbana do Brás, financiando uma série de edificações que marcariam a paisagem, com sobrados que se destacavam diante das demais casas, e podiam servir inclusive como edifícios mistos, servindo de comércios ou galpões em seus andares térreos.

Percebemos que determinados personagens, na ânsia de também serem identificados como pessoas ligadas aos setores médios, investiram em uma série de imóveis que não eram necessariamente sobrados, eram casas comuns, mas que aproveitavam das brechas da legislação para aumentar a elevação dos seus imóveis, de modo que parecessem mais altos. Este dado, reforça a tese de que os setores médios vinham ganhando força em princípios do século XX, e mesmo aqueles que não fossem de tal estrato, mas possuíssem rendas que permitissem a edificação de uma casa, simbolizassem o status a partir de suas casas.

Miguel d'Elia, proprietário de vilas e outros imóveis no Brás não deixou passar desapercebida esta questão, ao propor em 1915 a construção de uma casa com pelo menos 7,80 metros de altura na rua Uruguaiana. Só o porão apresentava 3,0 metros, e a casa na testada do lote, oficialmente continha uma sala, um quarto, uma varanda e uma cozinha, num terreno que se desdobrava para os fundos. No portão, uma inscrição faz referência ao nome do proprietário: "V. Delia" (figura 128), demarcando sua propriedade de quase 8,0 metros de altura, fazendo da casa um índice de reafirmação social, ainda mais para um homem que possuía ao menos outros 4 imóveis, espalhados entre as ruas do Carmo, Almirante Barroso e Monsenhor Andrade.

A rua Uruguaiana recebeu outro projeto parecido com o de Miguel d'Elia. No mesmo ano de 1915, João de Miranda (proprietário do lote número 151, e de uma casa com armazém na rua Maria Marcolina), solicitou a construção de uma casa com sala, dois quartos, sala de jantar, cozinha, despensa e banheiro, sob um "amplo porão edificado em areadas e vigas", com 2,20 metros de altura, proporcionando a casa nada menos do que 6,50 metros de altura (figura 129). João Alves Carneiro não foge à regra de agora, quando solicitou a construção de uma casa com um amplo porão iluminado, e que segue as mesmas divisões dos cômodos construídos acima. Se ele serviu de habitação a posteriori não sabemos (apesar de um carimbo fazer referência ao artigo 38 do Código de Posturas Municipal, ao demarcar que "a superfície do solo ocupada por habitações deve ser revestida 
de camada impermeável), mas o desenho indica que esta pode ter sido uma construção que se destacava na paisagem da rua Mendes Gonçalves (figura 130).

Entendemos que estes porões podem ter sido construídos com uma das finalidades de serem ocupados posteriormente, mesmo que a preços baixos, diante da carestia de habitações que se fazia em São Paulo. Porém, visto serem de propriedade de uma certa parcela populacional, que disputava o prestígio local, tais edifícios podem ser compreendidos dentro de um nível simbólico, de como representam as (pequenas) fortunas daqueles que exploravam o mercado imobiliário rentista do Brás em princípios do século XX.

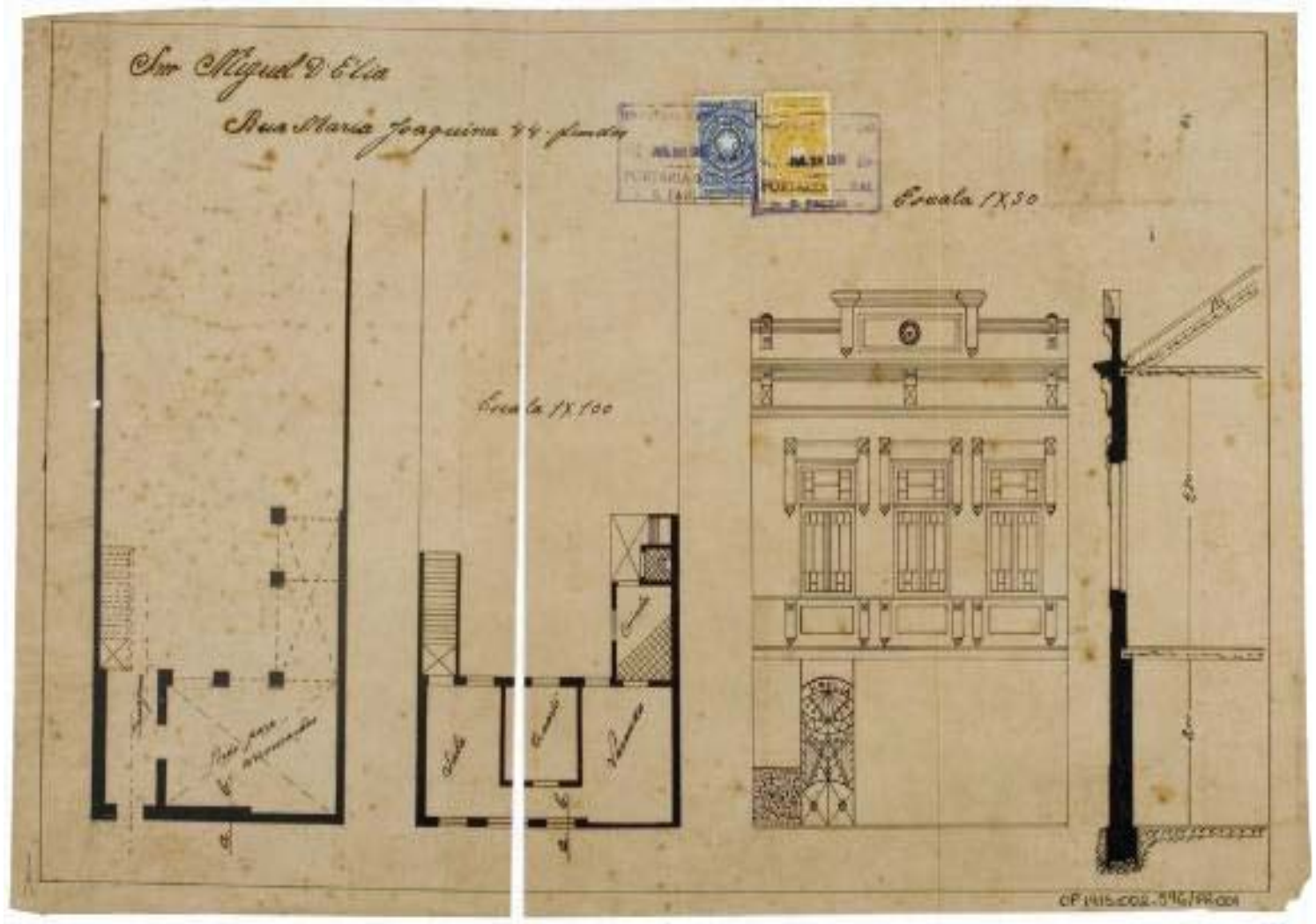

Figura 128: "Snr. Miguel D’Elia”, Arquivo Histórico Municipal, Fundo “Diretoria de Obras”, Série "Obras Particulares", OP1915.002.596. 


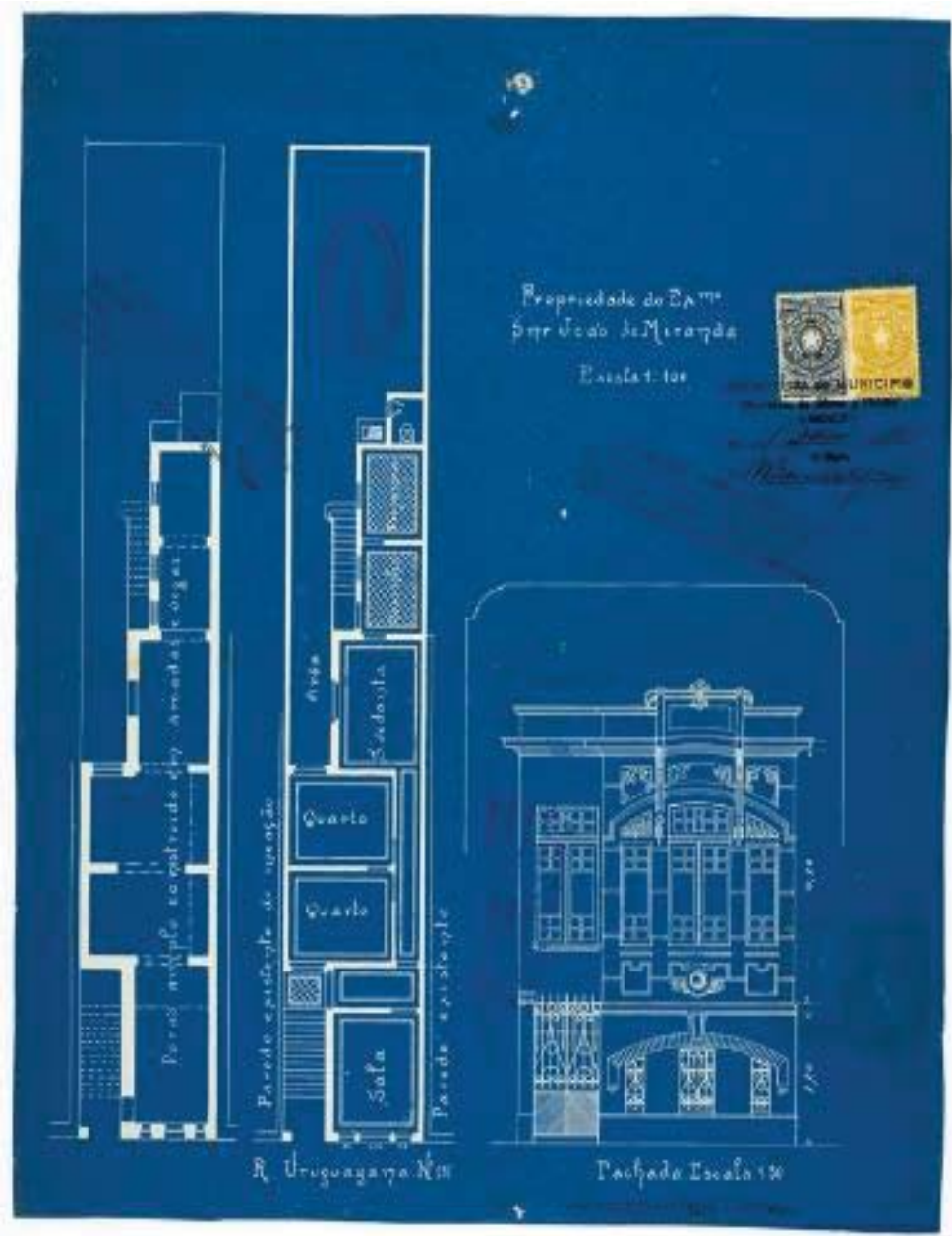

"Figura 129 : "Propriedade do Exmo. Snr. João de Miranda", Arquivo Histórico Municipal, Fundo "Diretoria de Obras", Série "Obras Particulares”, OP1915.003.966.

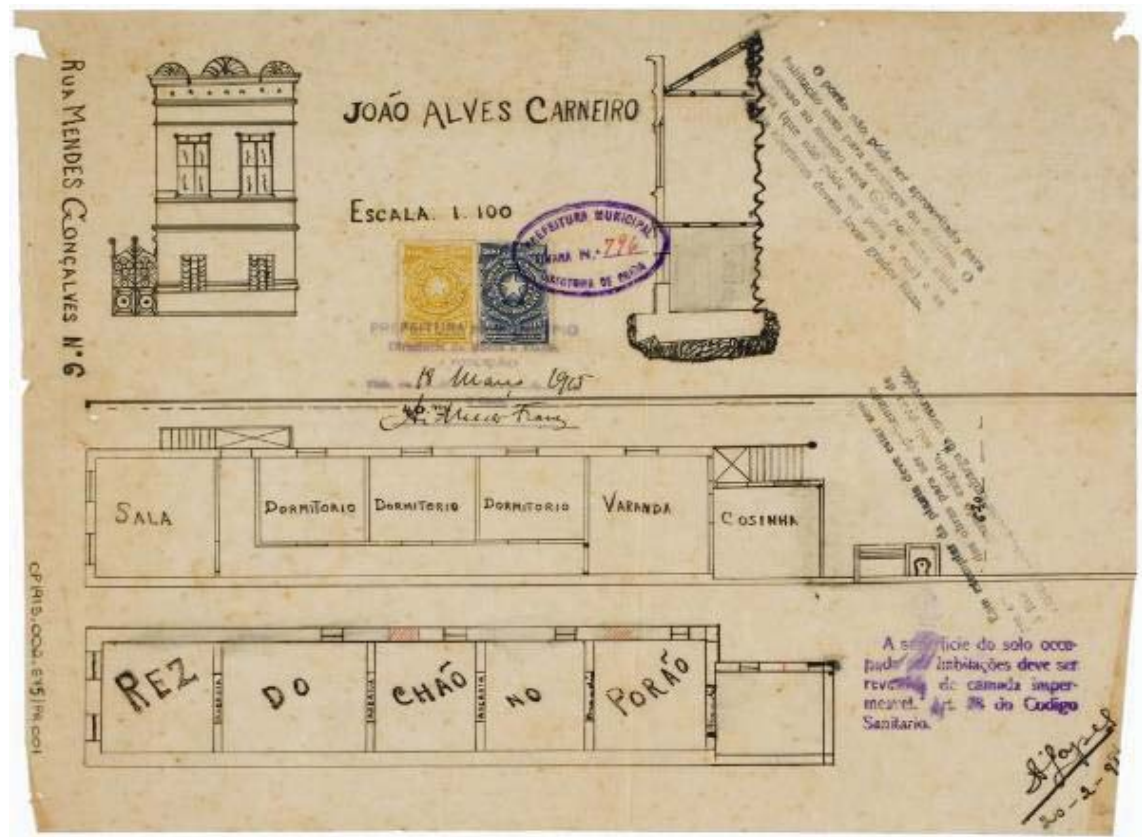

Figura 130: "João Alves Carneiro", Arquivo Histórico Municipal, Fundo "Diretoria de Obras”, Série "Obras Particulares", OP1915.002.675. 


\section{Capítula 3-Se nan è vera, è lèm travata ${ }^{221}$ : nãa sá italiana e fabril-Espaças de saciabilidade num bairra nãa exclusiuamente imigrante e aperária}

\subsection{Nem tudo era italiano e operário}

A historiografia recente sobre a cidade de São Paulo colonial têm demonstrado que, ao contrário da ideia de uma cidade pacata e isolada ${ }^{222}$, São Paulo tivera intenso dinamismo comercial mantendo desde o século XVII grandes trocas comerciais e mesmo interlocuções com outras cidades não apenas da América Portuguesa mas também da América Espanhola e mesmo do Velho Mundo ${ }^{223}$. Porém, a efetiva explosão urbana que a cidade enfrentou ocorreu somente em finais do século XIX, quando passou a receber um contingente populacional vindo de outras partes do Brasil e do mundo para servir de mão de obra para as fazendas de café localizadas no interior paulista, mas também permanecer na capital para as inúmeras atividades que se desenvolviam nas fábricas, comércios e construções então em curso. O contexto da imigração estava também atrelado a uma política de embranquecimento da população brasileira, capitaneada pela elite intelectual do país ${ }^{224}$. Outro fator que proporcionou em grande medida o desenvolvimento e a instalação destes grupos na cidade, foi o fato de nela concentrar-se o entroncamento de uma ampla rede ferroviária que a ligava ao interior do estado de São Paulo e do Rio de Janeiro, sobretudo alocada nos bairros da Luz e do Brás, onde foram instaladas suas estações e terminais de cargas, em meio a fábricas, residências e comércios.

À medida que São Paulo se expandia em número de habitantes, novos espaços tornaram-se alvo da especulação imobiliária, dado este que estimulou o aumento das demandas, e a carência de ofertas estimulou os proprietários das chácaras que circundavam as porções centrais da cidade a loteá-las, bem como construírem novas edificações no centro e nas áreas novas em expansão, atendendo às demandas que a nova cidade exigia com a

\footnotetext{
${ }^{221}$ Provérbio italiano "se não é verdade, é uma boa mentira" (tradução minha).

222 SILVA, Op. Cit,2013.

${ }^{223}$ Sobre o assunto, ver: VILlARDAGA, José Carlos. São Paulo no império dos Felipes: conexões na América meridional (1580.1640). São Paulo: Intermeios, 2014; BORREGO, Maria Aparecida de Menezes. A teia mercantil: negócios e poderes em São Paulo Colonial, 1711-1765. São Paulo: Alameda, 2010. BLAJ, Ilana. A trama das tensões: o processo de mercantilização de São Paulo Colonial (1681-1721). São Paulo: Humanitas / FAPESP, 2002.

224 SCHWARCZ, Lilia Moritz. O espetáculo das raças: cientistas, instituições e questão racial no Brasil 1870-1930. São Paulo: Companhia das Letras, 1993.
} 
intensa explosão populacional e mudanças na sua inserção econômica no cenário internacional e nacional.

\begin{tabular}{|l|c|c|c|c|}
\hline \multicolumn{5}{|c|}{ Aumento populacional dos distritos de São Paulo entre 1872-1893 } \\
\hline \multicolumn{1}{|c|}{ DISTRITOS } & 1872 & 1886 & 1890 & 1893 \\
\hline Sé & 9.213 & 12.821 & 16.395 & 29.518 \\
\hline Santa Ifigênia & 4.459 & 11.909 & 14.025 & 42.715 \\
\hline Consolação & 3.357 & 8.269 & 13.337 & 21.311 \\
\hline Brás & 2.308 & 5.998 & 16.807 & 32.387 \\
\hline Penha & 1.883 & 2.283 & 2.209 & 1.128 \\
\hline N. Senhora do Ó & 2.023 & 2.750 & 2.161 & 2.350 \\
\hline São Paulo & 23.243 & 44.030 & 64.934 & 129.409 \\
\hline
\end{tabular}

Tabela 9: “Aumento populacional dos distritos de São Paulo entre 1872-1893”, elaborada por Maria Celestina Torres, Op. Cit, pág. 112.

Torres avalia que os quatro distritos centrais cresceram em ritmo acelerado, dada a proximidade com a ferrovia e as paradas que existiam nessas áreas: "ao contrário da Penha e de Nossa Senhora do Ó, bairros periféricos, antigos pontos de pouso de tropas e tropeiros, prejudicados pelas ferrovias que neles não fazem paradas"225, dados coligidos com o Relatório da Comissão Central de Estatística de 1888 já estudados por Richard Morse ${ }^{\mathbf{2 2 6}}$. Passados mais de quinze anos, percebemos que a população da cidade explodiu sobremaneira, e quando coligidos os dados informados na obra O Estado de São Paulo ${ }^{227}$, é de se destacar que os bairros da Mooca, Brás e Belenzinho tinham pelo menos 192.767 habitantes, sendo a população respectiva de cada um 69.794, 66.086 e 56.887 habitantes, ou seja, formavam uma grande área populosa além do Tamanduateí e que concentrava $1 / 3$ da população da cidade.

Este aumento populacional da cidade não passou despercebido por Torres, que elegeu o do imigrante como grande povoador da cidade e do bairro do Brás, responsável pela introdução e formação das primeiras fábricas. Para Torres, "a imigração, trazendo o espírito de iniciativa e a necessária mão de obra à indústria, particularmente a têxtil que

225 TORRES, Op. Cit, pág. 112-113.

226 MORSE, Richard. De comunidade a metrópole: a biografia de São Paulo. São Paulo: Comissão dos Festejos do IV Centenário da Cidade de São Paulo, 1954, pág. 187.

227 Jornal O Estado de São Paulo, Op. Cit., pág. 96. 
encontra mercado certo na produção nacional"228, conferiu assim ao bairro seu caráter industrial e propício à implantação futura de indústrias, forjando-se como um bairro fabril e de típica residência operária. Tendo como fontes as Atas da Câmara Municipal de 1891, a autora da principal história do bairro do Brás, põe luz no seguinte episódio:

\footnotetext{
"Misturam-se fábricas e residências. Em 1878 os italianos Ludovico Dal Porto e Francisco Casini fundam a primeira fábrica de massas alimentícias na rua Monsenhor Andrade, em meio a modestas casas construídas nas antigas datas de terras. Nem sempre, porém, são as fábricas instaladas sem protestos de antigos moradores. Em 1891 os moradores da rua do Brás pedem a Câmara Municipal que não permita a construção de 'fábricas naquela rua', da 'Companhia de Fumos Paulista, em centro tão populoso'. Ouvido o Dr. Inspetor de Higiene, este, em virtude do parecer do Dr. Adjunto daquela inspetoria, resolveu que o maquinismo para manipulação seja montado a 100 metros afastados do estabelecimento da administração e depósitos"229.
}

O braço imigrante para Torres foi assim o elemento consolidador da formação do bairro do Brás, a começar pela instalação das pequenas fabriquetas que se avolumaram com o crescimento populacional vertiginoso que o bairro teve nas últimas décadas do século XIX. Para reforçar sua tese, a autora listou o total de imigrantes que adentraram o Estado de São Paulo entre os anos de 1882 e 1891, baseando-se nos dados coligidos pela Sociedade Protetora de Imigração, e trazendo ao debate o total de imigrantes que teriam se estabelecido na cidade de São Paulo:

228 TORRES, Op. Cit., pág. 113.

${ }^{229}$ Idem, pág. 113-114. 


\begin{tabular}{|c|c|}
\hline \multicolumn{2}{|c|}{ Imigrantes na cidade de São Paulo entre 1882 e 1891} \\
\hline GRUPO IMIGRANTE & TOTAL \\
\hline Italianos & 202.503 \\
\hline Portugueses & 25.925 \\
\hline Espanhóis & 14.954 \\
\hline Alemães & 6.196 \\
\hline Austríacos & 4.118 \\
\hline Russos & 33.315 \\
\hline Franceses & 1.922 \\
\hline Dinamarqueses & 1.042 \\
\hline Belgas & 851 \\
\hline Ingleses & 782 \\
\hline Suecos & 685 \\
\hline Suíços & 201 \\
\hline Outros & 483 \\
\hline TOTAL & 263.196 \\
\hline
\end{tabular}

Tabela 10: “Imigrantes na cidade de São Paulo entre 1882 e 1891”, apud TORRES, Op. Cit., pág. 119.

Apesar de a autora dar uma ideia do número de imigrantes que eventualmente podiam ter se estabelecido na cidade no final do século XIX, ela não indica uma relação aproximada dos que optaram pelo bairro do Brás, apenas enfocando que "evidentemente, boa porcentagem desses imigrantes irá alojar-se na Capital, e o Brás, como o Bom Retiro, há de se transformar em bairro onde a influência italiana se fará sentir de maneira decisiva e evidente" 230 . A obra de Torres dialoga com muitos memorialistas, que enfocaram o papel do braço imigrante na construção e da identidade paulistana, essencialmente em determinadas regiões da cidade, elegendo uma memória étnica para o Brás, como um bairro exclusivamente italiano, aspecto que pode ser observado em outros da cidade de São Paulo.

Procuramos trazer ao debate dados que possam discutir esta imagem do bairro do Brás ser essencialmente um bairro essencialmente italiano, a partir do cruzamento numérico das informações contidas nos Anuários Estatísticos publicados pelo governo estadual a 
partir do ano de $1894^{231}$, que sintetizam uma série de informações referentes à população, como origem, profissões, número de mortes e suas causas, tanto da capital como de cidades do interior. Para traçarmos os perfis daqueles que habitavam o Brás nos primeiros anos do século XX recorremos aos números de óbitos no bairro, que indicam o perfil dos falecidos.

Inicialmente, organizamos uma tabela referente aos anos de 1901 até 1915, na qual identificamos cada grupo de imigrantes, o que proporcionou quantificar cada grupo que morreu no Brás. Nem todos os dados pesquisados renderam resultados, visto que a partir do ano de 1909 em diante não constam mais a origem das pessoas que faleceram, apenas o número de mortos ocorridos no bairro. Ainda assim, os números levantados indicam possibilidades de melhor compreensão dos povos que se estabeleceram no Brás em sua primeira década do século XX.

Os Anuários não possuem uma padronização na forma em que estão organizados, existindo quase sempre a intenção de primeiro estabelecer um panorama de questões voltadas à cidade de São Paulo, e posteriormente tratar das demais cidades do estado. Em alguns casos é possível encontrarmos referências aos números de mortes de acordo com o sexo, em referências ao fato de serem brasileiros, paulistas ou de outros estados. Procuramos, então, padronizar as informações, contabilizando homens e mulheres que morreram e, no caso de migrantes, sistematizar apenas os brasileiros, de modo que facilitasse a leitura e houvesse um melhor aproveitamento das informações:

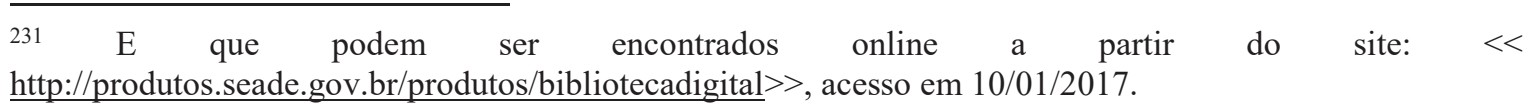




\begin{tabular}{|c|c|c|c|c|c|c|c|c|}
\hline \multicolumn{9}{|c|}{$\begin{array}{l}\text { Números de óbitos de prováveis moradores do Brás } \\
\text { nacionais (1901-1908) }\end{array}$} \\
\hline & 1901 & 1902 & 1903 & 1904 & 1905 & 1906 & 1907 & 1908 \\
\hline $\begin{array}{l}\text { Total de óbitos } \\
\text { do bairro / } \\
\text { Nacionalidades }\end{array}$ & 1.144 & 1.127 & 1.063 & 1.171 & 1.193 & 1.378 & 1.109 & 1.283 \\
\hline Brasileiros & 696 & 950 & 880 & & 2.114 & 1.105 & 1.109 & 980 \\
\hline Italianos & 281 & $175^{*}$ & 110 & & 106 & 126 & 139 & 153 \\
\hline Espanhóis & 44 & $21^{*}$ & 17 & & 73 & 97 & 36 & 41 \\
\hline Portugueses & 109 & $57 *$ & 56 & & 49 & 36 & 57 & 86 \\
\hline Alemães & 5 & 2 & 2 & & 1 & 5 & 1 & 6 \\
\hline Ingleses & 2 & & & & & & & \\
\hline Franceses & & 2 & & & & 1 & 1 & 1 \\
\hline Africanos & 1 & & & & & & & \\
\hline Austríacos & 1 & & 2 & & & 4 & 3 & 2 \\
\hline Belgas & & & & & & & & 1 \\
\hline Argentinos & & 1 & & & & & & \\
\hline Poloneses & 1 & & & & & & & \\
\hline Russos & 2 & & & & 2 & & 2 & 2 \\
\hline Suíços & 1 & & & & & & & \\
\hline Sírios & & 1 & & & & & & \\
\hline Turcos & & & 2 & & & & 2 & 1 \\
\hline Ignorada & & 1 & & & & 1 & 1 & 1 \\
\hline Diversos & & & & & 1 & & 4 & 5 \\
\hline
\end{tabular}

Tabela 11: "Números de óbitos de prováveis moradores do Brás segundo suas origens nacionais (1901-

1908)", elaborada pelo autor com base nos Anuários Estatísticos Estaduais. ${ }^{232}$

Ao atentarmos sobre o total de óbitos registrados para o bairro, pudemos verificar que os números, embora não exatos, visto que a contabilização do total de mortes entre as diferentes nacionalidades é quase sempre maior que o total, mostra que o pico de falecimentos (1.378 mortes), ocorreu em 1906. A tabela poderia tornar-se muito mais rica se dispuséssemos o total de falecidos até o ano de 1918, quando a gripe espanhola assolou sobremaneira a cidade de São Paulo, e que o Brás não passou desapercebido. Nicolau

\footnotetext{
${ }^{232}$ Os números que contém o símbolo “*” são imprecisos, visto que as páginas na qual o localizamos estavam muito danificadas, impedindo uma melhor leitura.
} 
Sevcenko coloca que a doença "caíra sobre a cidade com uma voracidade que evocava a peste negra medieval: em alguns meses prodigalizou São Paulo de valas coletivas lotadas de cadáveres, com não poucos moribundos atirados às fossas ainda vivos de permeio, nas correrias desencontradas do pânico". Junto dela, o historiador ainda cita outros quatro pontos que deixaram a cidade em pânico neste tempo: a geada, os gafanhotos, a Primeira Guerra e as greves. ${ }^{233}$

Se atentarmos para os grupos que faleceram no Brás, podemos verificar que entre os anos de 1901 e 1908, os italianos não eram a maioria do bairro, e sim, os próprios brasileiros que compunham pelo menos $70 \%$ da população ali residente nos anos iniciais do século XX. O número de italianos é grande quando comparado aos demais grupos imigrantes, mas ainda assim é reduzido quando ladeado aos nacionais. Com atenção aos espanhóis, é de se destacar que, entre 1905 e 1906, o número de mortos supera os dados coligidos anteriormente, bem como os anos posteriores e o número de portugueses, diminuem entre as duas balizas cronológicas.

Podemos perceber que o Brás não era um bairro essencialmente formado por italianos, pelo contrário, contava com uma diversidade cultural que abrangia pessoas oriundas da Rússia, Polônia, França, Polônia, Áustria, Bélgica, Inglaterra, Alemanha, Suíça, Síria, Turquia, do continente africano, e quem diria até argentinos. Apesar dos números destas nacionalidades serem pequenos, são uma amostra da diversidade presente não apenas no Brás, mas na cidade que se formava em princípios do século XX. Por sua vez, fica evidente que os italianos superaram qualquer outro grupo, com exceção, dos próprios brasileiros. Sobre os brasileiros mortos no Brás, é interessante notar que muitos não eram naturais de São Paulo, e assim, podemos entrever que o contexto migratório nacional tem suas raízes no começo do século XX.

Segundo George Andrews, “em 1902, 90\% da força de trabalho na indústria era composta por imigrantes - quadro este que seria alterado somente no decorrer dos anos $20^{\text {"234 }}$, dado que quando trazido em torno da força de trabalho empregada em São Paulo, se torna marcante pelos dados apresentados anteriormente. Contudo, quais os demais profissionais que atuaram na região do Brás no início do século XX? Desvendamos essas indagações por meio dos Almanaques comerciais, os quais anunciavam em suas páginas uma gama de profissionais atuantes na cidade. Obviamente que o Brás era um bairro

233 SEVCENKO, Nicolau. Orfeu extático na metrópole: São Paulo, sociedade e cultura nos frementes anos 20. São Paulo: Companhia das Letras, 1992, pág. 24.

${ }^{234}$ ANDREW, George Reid. Negros e brancos em São Paulo (1888-1988). São Paulo: Edusc, 1998, pág. 98. 
marcado pela presença de um contingente significativo de operários atuantes nas fábricas da região, mas o quadro a seguir dá a ver a diversidade de profissionais também atuantes / residentes no Brás.

\begin{tabular}{|c|c|c|c|}
\hline \multicolumn{4}{|c|}{ Residentes do Brás que atuavam no bairro em áreas centrais da cidade (1901-1915) } \\
\hline PROFISIONAL & NOME & ENDEREÇO & REFERENCIA \\
\hline $\begin{array}{c}\text { Guarda da Faculdade } \\
\text { de Direito }\end{array}$ & Gabriel Lenzi & $\begin{array}{c}\text { Rua da Concórdia, } \\
195\end{array}$ & 1910,1911 \\
\hline $\begin{array}{c}\text { Guarda da Faculdade } \\
\text { de Direito }\end{array}$ & $\begin{array}{l}\text { Luiz Antonio } \\
\text { Ramalho }\end{array}$ & $\begin{array}{l}\text { Rua da Concórdia, } \\
93\end{array}$ & 1910,1911 \\
\hline $\begin{array}{l}\text { Capitalista e } \\
\text { proprietário }\end{array}$ & Macedo \& Ferraz & $\begin{array}{c}\text { Largo da Concórdia, } \\
1\end{array}$ & 1901 \\
\hline $\begin{array}{c}\text { Ajudante de } \\
\text { contabilidade geral da } \\
\text { Secretaria da Fazenda } \\
\text { e Thesouro do Estado }\end{array}$ & $\begin{array}{c}\text { Theofilo de Moraes } \\
\text { Nóbrega }\end{array}$ & $\begin{array}{c}\text { Largo da Concórdia, } \\
10\end{array}$ & 1910,1911 \\
\hline $\begin{array}{l}\text { Comissões e } \\
\text { consignações }\end{array}$ & Arantes Sá \& C. & Rua Cruz Branca, 35 & 1908 \\
\hline $\begin{array}{l}\text { Comissões e } \\
\text { consignações }\end{array}$ & $\begin{array}{l}\text { Décio Ferreira \& } \\
\text { Irmão }\end{array}$ & Rua Cruz Branca, 37 & 1908 \\
\hline $\begin{array}{l}\text { Comissões e } \\
\text { consignações }\end{array}$ & João Silva \& C & $\begin{array}{c}\text { Rua do Gasômetro, } \\
116,118\end{array}$ & 1898 \\
\hline $\begin{array}{l}\text { Comissões e } \\
\text { consignações }\end{array}$ & Veríssimo Paiva & $\begin{array}{l}\text { Rua do Gasômetro, } \\
36\end{array}$ & 1908 \\
\hline $\begin{array}{c}\text { Thesouro, Funcionário } \\
\text { do }\end{array}$ & $\begin{array}{c}\text { Tiburcio Augusto de } \\
\text { Oliveira Macedo }\end{array}$ & $\begin{array}{c}\text { Rua do Gasômetro, } \\
147\end{array}$ & 1901 \\
\hline $\begin{array}{c}\text { Secretário da } \\
\text { Repartição de Águas e } \\
\text { Esgotos }\end{array}$ & $\begin{array}{c}\text { Major João Baptista } \\
\text { Rost }\end{array}$ & $\begin{array}{c}\text { Rua do Gasômetro, } \\
189\end{array}$ & 1909,1910 \\
\hline $\begin{array}{l}\text { Fiscal da } 3^{a} \text { Secção da } \\
\text { Procuradoria Fiscal do } \\
\text { Estado }\end{array}$ & João Camo Coutinho & Rua Luiz Gama, 128 & 1909 \\
\hline $\begin{array}{l}1^{\circ} \text { Escripturario de } \\
\text { Lançamentos do } \\
\text { Theatro Municipal }\end{array}$ & Eduardo Wolf & $\begin{array}{c}\text { Rua Brigadeiro } \\
\text { Machado, } 9\end{array}$ & 1910 \\
\hline $\begin{array}{l}2^{\circ} \text { Escritrário da } \\
\text { Hospedaria }\end{array}$ & $\begin{array}{l}\text { João Papaterra } \\
\text { Limongi }\end{array}$ & $\begin{array}{c}\text { Rua Brigadeiro } \\
\text { Machado, } 9\end{array}$ & 1915 \\
\hline Vigia da Hospedaria & João Dias Moreira & $\begin{array}{c}\text { Rua Brigadeiro } \\
\text { Machado, } 17\end{array}$ & 1915 \\
\hline $\begin{array}{c}\text { Datilógrafo da } \\
\text { Diretoria de Industria } \\
\text { e Comercio }\end{array}$ & Oscar Marcondes & $\begin{array}{c}\text { Rua Brigadeiro } \\
\text { Machado, } 14\end{array}$ & 1915 \\
\hline
\end{tabular}




\begin{tabular}{|c|c|c|c|}
\hline $\begin{array}{c}3^{\circ} \text { Escriturário da } \\
\text { e Tesouro }\end{array}$ & $\begin{array}{c}\text { Joaquim A. de Cruz } \\
\text { Rangel }\end{array}$ & $\begin{array}{c}\text { Rua Paulo Afonso, } \\
11\end{array}$ & 1910 \\
\hline $\begin{array}{c}\text { Tesoureiro da } \\
\text { Delegacia Fiscal }\end{array}$ & $\begin{array}{c}\text { Antonio Joaquim } \\
\text { Machado }\end{array}$ & Rua Piratininga, 61 & 1909 \\
\hline $\begin{array}{c}\text { Fiscal do Thesouro da } \\
\text { Delegacia Fiscal }\end{array}$ & João Deoclécio & Rua Piratininga, 69 & 1909 \\
\hline $\begin{array}{c}\text { Comissões e } \\
\text { consignações }\end{array}$ & Fernando Valente & Rua Santa Rosa, 84 & 1908 \\
\hline $\begin{array}{c}\text { Conferente da } \\
\text { Repartição de Águas e } \\
\text { Esgotos }\end{array}$ & $\begin{array}{c}\text { Gabriel M. Macedo } \\
\text { Conferente da } \\
\text { Repartição de Águas e } \\
\text { Esgotos }\end{array}$ & $\begin{array}{c}\text { Juvenal Fonseca Xavantes, 11 } \\
\text { Rua Bresser, 28 }\end{array}$ & 1909 \\
\hline $\begin{array}{c}2^{\circ} \text { Escripturário da } \\
\text { Recebedoria de } \\
\text { Rendas da Secretaria } \\
\text { da Fazenda }\end{array}$ & $\begin{array}{c}\text { Pedro Luiz de } \\
\text { Almeida }\end{array}$ & $\begin{array}{c}\text { Rua Nova de São } \\
\text { José, 72 }\end{array}$ & 1909 \\
\hline $\begin{array}{c}\text { Empregado do } \\
\text { Thesouro }\end{array}$ & Luiz Coelho & Avenida Rangel \\
Pestana, 273 & 1911 \\
\hline $\begin{array}{c}2^{\circ} \text { Escripturario da } \\
\text { Delegacia Fiscal }\end{array}$ & José B. Ramos & Avenida Rangel & \\
\hline
\end{tabular}

Tabela 12: "Residentes do Brás que atuavam no bairro e em áreas centrais da cidade (1901-1915)", elaborada pelo autor a partir do Almanak Laemmert.

Os profissionais listados acima, residentes em diversas ruas do Brás, apesar de numericamente diminutos quando comparados ao número de operários fabris e demais prestadores de serviços, nos fornecem algumas possibilidades de leitura quando cotejados seus locais de morada juntamente com as profissões que exercem. Como visto anteriormente, muitas das casas dos setores médios do Brás situavam-se no eixo das avenidas Rangel Pestana-Celso Garcia, e entre as ruas Bresser, João Boemer e Joli. Dos endereços que constaram na tabela acima, é de se destacar que a grande maioria dos profissionais listados eram ajudantes, secretários, conferentes, escriturários, vigias e secretários, e poucos ocupavam cargos de alta patente, como o major João Batista Rost, Secretário da Repartição de Águas e Esgotos, residente da rua do Gasômetro número 189.

Pode-se verificar que muitos profissionais, pertencentes aos setores médios atuavam no Brás, e não apenas residiam como atestam os desenhos da Série Obras Particulares. Quando lido atentamente, o Almanak Laemmert é uma rica fonte que indica aqueles 
profissionais solicitados pela população da época, com seus respectivos endereços de atuação, e para o Brás, há uma quantidade expressiva destes personagens que ampliam o debate sobre o bairro ser um território mais denso do que simplesmente operário e fabril. Da leitura do almanaque, organizamos uma tabela que organiza suas diversas categorias profissionais, com seus endereços, nomes e o ano na qual o anúncio fora publicado no Almanak Laemmert:

\begin{tabular}{|c|c|c|c|}
\hline \multicolumn{4}{|c|}{ Distribuição de profissionais liberais que atuavam no Brás (1897-1915) } \\
\hline \multirow[t]{14}{*}{ Advogados } & ENDEREÇO & NOME & REFERÊNCIA \\
\hline & Celso Garcia, 23 & & 1914 \\
\hline & Largo da Concórdia, 6 A & Luiz Mara & 1914 \\
\hline & \begin{tabular}{|l|l} 
Largo da Concórdia, 8 \\
\end{tabular} & Eneas Ferraz & 1909 \\
\hline & Gasômetro, 195 & $\begin{array}{l}\text { M. Octavio Pereira de } \\
\text { Souza (também } \\
\text { agente comercial) }\end{array}$ & 1913 \\
\hline & Maria Marcolina, 2 & Lucas de Arruda & 1911 \\
\hline & $\begin{array}{c}\text { Rua Xavantes, s/n e na } \\
\text { rua Rubino de Oliveira } \\
\text { número } 14\end{array}$ & $\begin{array}{c}\text { Theofilo Nobrega, } \\
\text { Torquatto Piccheti \& } \\
\text { Filho }\end{array}$ & 1913,1914 \\
\hline & Monsenhor Andrade, 90 & $\begin{array}{l}\text { Augusto Alves de } \\
\text { Oliveira }\end{array}$ & 1911 \\
\hline & Rangel Pestana, 24 A & Gomes Cardim & 1906 \\
\hline & Rangel Pestana, 59 & $\begin{array}{l}\text { Desembargador } \\
\text { Capina \& Bapt. }\end{array}$ & 1901 \\
\hline & Rangel Pestana, 121 & $\begin{array}{c}\text { Antonio Luiz Pereira } \\
\text { da Cunha }\end{array}$ & 1906 \\
\hline & Rangel Pestana, 153 & Jacintho Molina & $1897,1898,1899$ \\
\hline & Rangel Pestana, $217 \mathrm{~A}$ & $\begin{array}{l}\text { Augusto Alves de } \\
\text { Oliveira }\end{array}$ & 1906 \\
\hline & Rangel Pestana, 221 A & & 1906 \\
\hline \multirow[t]{12}{*}{ Caixoteiros } & ENDEREÇO & NOME & REFERÊNCIA \\
\hline & Américo Brasiliense, 30C & Onofre Lela & 1909 \\
\hline & Benjamin de Oliveira, 112 & Laporta Nita & 1908,1909 \\
\hline & Celso Garcia, 24 & Felippe Cecchio & \\
\hline & Celso Garcia, 91 & D'Ascanio Manicola & 1909 \\
\hline & Celso Garcia, 281 & Mauricio Serrado & 1909 \\
\hline & Gasômetro, 9 e 11 & Antenor Gimenez & 1909 \\
\hline & Gasômetro, 17 & Antonio Soares & 1908,1909 \\
\hline & Gasômetro, 61 & Gonçaves Guidet & 1908 \\
\hline & Gasômetro, 72 & Severino Theophilo & 1908,1909 \\
\hline & Gasômetro, 93 & João Navago & 1909 \\
\hline & Monsenhor Anacleto & Leonardo Crascia & 1910 \\
\hline
\end{tabular}




\begin{tabular}{|c|c|c|c|}
\hline \multirow[t]{13}{*}{ Dentistas } & ENDEREÇO & NOME & REFERÊNCIA \\
\hline & Celso Garcia, 125 & Juvenal Cruz & 1914 \\
\hline & Celso Garcia, 135 & João Alves da Silva & 1914 \\
\hline & Celso Garcia, 253 & Jonas Rosê & 1914 \\
\hline & $\begin{array}{l}\text { Largo da Concórdia, } \\
17\end{array}$ & J. A. Ferraz & 1913,1914 \\
\hline & Gasômetro, 27 & Victorino Antonio Ubá & 1909 \\
\hline & Maria Marcolina, 25 & $\begin{array}{c}\text { Guilherme Silveira } \\
\text { Martins }\end{array}$ & $1908,1909,1910$ \\
\hline & Monsenhor Andrade, 21 & Jayme Teixeira & 1909 \\
\hline & Rangel Pestana, 117 & Anizio Ortiz Monteiro & 1907 \\
\hline & Rangel Pestana, 131 & $\begin{array}{c}\text { João Laves da Silva / } \\
\text { Alfredo Brandão }\end{array}$ & $1914 / 1904$ \\
\hline & Rangel Pestana, 148 & Santo Granelli & 1914 \\
\hline & Rangel Pestana, 235 & Nicolao Pepe & 1914 \\
\hline & Rangel Pestana, 236 & Deodato de Moraes & 1914 \\
\hline \multirow[t]{2}{*}{ Engenheiro } & ENDEREÇO & NOME & REFERÊNCIA \\
\hline & Piratininga, 19 & Ataliba B. de O. Valle & 1906 \\
\hline \multirow[t]{2}{*}{ Escultor } & ENDEREÇO & NOME & REFERÊNCIA \\
\hline & Uruguaiana, 22 & Piaciullo \& Bonoldi & 1910 \\
\hline \multirow[t]{21}{*}{ Ferradores } & ENDEREÇO & NOME & REFERÊNCIA \\
\hline & Américo Brasiliense, 32 & Dante Guindini & 1909,1910 \\
\hline & Celso Garcia, 29 A & Sylvio Causaglio & 1909 \\
\hline & Celso Garcia, 37 & $\begin{array}{c}\text { Luiz Andraine / } \\
\text { Domingos Carvalho }\end{array}$ & $1901 / 1910$ \\
\hline & Celso Garcia, 148 & Domingos Guaimpo & 1909 \\
\hline & Celso Garcia, 170 & Daniel Kruss & 1901 \\
\hline & Celso Garcia, 206 & João Previdello & 1909 \\
\hline & Celso Garcia, 507 & Noseli Agostinho & 1910 \\
\hline & Celso Garcia, 537 & $\begin{array}{c}\text { Antonio Maria do } \\
\text { Amaral }\end{array}$ & 1910 \\
\hline & Celso Garcia, 538 & Antonio Genotte & 1909 \\
\hline & Concórdia, 33 & Salvador hímenes & 1909,1910 \\
\hline & Concórdia, $47 \mathrm{~A}$ & Ernesto Celso & 1909,1910 \\
\hline & Correia de Andrade, 3 & Reis \& Dias & 1909 \\
\hline & Monsenhor Anacleto, 11 & Fernando Magliano & 1909 \\
\hline & Monsenhor Andrade, 94B & & 1910 \\
\hline & Monsenhor Andrade, 98 & Francisco Beviláqua & 1909 \\
\hline & Piratininga, 3 & Anilo Dellamonica & 1909,1910 \\
\hline & Piratininga, 7 & Antonio Ferreira & 1909,1910 \\
\hline & Piratininga, 9 & Francisco Infante & 1909,1910 \\
\hline & Piratininga, 49 & Affonso Pinto & 1909 \\
\hline & Piratininga, 257 & Antonio Ferreira & $\mathrm{s} / \mathrm{d}$ \\
\hline \multirow[t]{3}{*}{ Ferreiros } & ENDEREÇO & NOME & REFERÊNCIA \\
\hline & Celso Garcia, 131 & Domenico Quarenho & \\
\hline & Piratininga, $41 \mathrm{C}$ & Bartholomeu Pinto & 1908 \\
\hline \multirow[t]{3}{*}{ Marmoristas } & ENDEREÇO & NOME & REFERÊNCIA \\
\hline & Correia de Andrade, 3 & Salvador Brevetera & 1909 \\
\hline & Maria Marcolina, 204 & Aurelia Maffei & 1908,1909 \\
\hline
\end{tabular}




\begin{tabular}{|c|c|c|c|}
\hline \multirow[t]{5}{*}{ Médicos } & ENDEREÇO & NOME & REFERÊNCIA \\
\hline & Largo da Concórdia, s/n & $\begin{array}{c}\text { Antonio Francisco de } \\
\text { Vasconcelos }\end{array}$ & 1905,1907 \\
\hline & Gasômetro, 118 & $\begin{array}{c}\text { Alfredo Zuquim de F. } \\
\text { Neves }\end{array}$ & 1910 \\
\hline & Rangel Pestana, 96 & $\begin{array}{c}\text { Mello Barreto (médico } \\
\text { de moléstias de } \\
\text { senhoras) }\end{array}$ & 1898,1899 \\
\hline & Rangel Pestana, 113 & $\begin{array}{l}\text { Anthur Cândido de } \\
\text { Almeida (médico e } \\
\text { operador) }\end{array}$ & 1899 \\
\hline \multirow[t]{3}{*}{ Serralheiros } & ENDEREÇO & NOME & REFERÊNCIA \\
\hline & Celso Garcia, 110 & J. Monteiro \& Cia & 1914 \\
\hline & Celso Garcia, 537 & $\begin{array}{c}\text { Antonio Maria do } \\
\text { Amaral }\end{array}$ & 1914 \\
\hline
\end{tabular}

Tabela 13: "Profissionais liberais que atuavam no Brás (1897-1914)", elaborada pelo autor com base no Almanak Laemmert.

A variedade de profissionais liberais atuantes no Brás é nítida quando analisamos a tabela acima, pois, verifica-se que havia uma demanda por serviços que apenas determinados agentes poderiam executar. Tais agentes, que variavam de advogados, engenheiros, médicos e dentistas, a serralheiros, ferreiros, marmoristas, ferradores, caixoteiros e até um escultor, possuíam uma clientela que era residente no Brás e que não precisava se deslocar até a região do Triângulo em busca destes profissionais. O centro, que polarizava em grande medida a oferta de muitos dos profissionais listados por nós, não era um local exclusivo para o atendimento aos setores médios, que podiam encontrar em seus bairros muitos dos serviços que necessitavam. No caso do Brás, pode-se verificar que grande parte destes profissionais atuavam em vias específicas, essencialmente no eixo das avenidas Rangel Pestana - Celso Garcia, e nas ruas do Gasômetro, Maria Marcolina, Monsenhor Andrade, Piratininga e no Largo da Concórdia, não por acaso vias que passavam bandes e tiveram um processo de apropriação muito rápido.

Interessante notar que os profissionais graduados (advogados e médicos) atuavam conjuntamente a outro grupo de não diplomados, os dentistas ${ }^{235}$. Os três grupos profissionais atuavam quase que exclusivamente nas avenidas Rangel Pestana, Celso Garcia e no Largo da Concórdia, vias que se destacaram como espaços da atenção do poder público e de

${ }^{235}$ As disputas, interesses e entraves em torno da regulamentação e profissionalização de dentista foi tema explorado por Cristina Leite Carvalho, em sua tese de doutorado "Dentistas práticos no Brasil: História de exclusão e resistência na profissionalização da odontologia brasileira", defendida na Escola Nacional de Saúde Pública Oswaldo Cruz, Rio de Janeiro, 2003. 
investimentos privados que capitanearam a construção de muitos edifícios ali localizados, dada a proximidade com a estação de trens do Brás e do Norte, da Igreja Matriz, bem como ser rota de passagem para outras importantes ruas como Maria Marcolina, Piratininga e Monsenhor Andrade.

Profissionais como caixoteiros e ferradores também podiam ser encontrados na avenida Celso Garcia, mas seus grandes setores de atuação se concentravam em outras vias como a rua do Gasômetro e Piratininga, não por acaso ruas com grande movimentação comercial, e que desembocariam em pontos de interesse: enquanto a primeira dava acesso à rua Santa Rosa, ao Palácio das Indústrias, rio Tamanduateí e ao Mercado Municipal, a rua Piratininga acompanhava os trilhos da linha férrea e certamente concentrava um elevado número de cocheiras, transporte que não fora substituído por completo com a chegada dos trilhos dos bondes.

3.2 Fábricas e comércios em perspectiva: um bairro se construindo na São Paulo dos anos 1910

Como vimos, um dos fatores que colocou em xeque a continuidade da existência das inúmeras chácaras além rio Tamanduateí, foi a instalação da Estrada de Ferro do Norte, que desde 1873 assentou seus trilhos para que então suas locomotivas pudessem ligar a cidade de São Paulo com a capital do Império. O jornal Correio Paulistano, declarava o entusiasmo que pairava na cidade de São Paulo com a inauguração da estrada de ferro

\author{
"O dia oito de julho \\ Parabéns à Província de São Paulo!
}

Após algum tempo de louvável perseverança e trabalho enérgico, ficou concluída a estrada de ferro SP e Rio de Janeiro, ligando a capital do império à esta adiantada província. Os athletas do progresso, os "yankees brasileiros" que tiveram a grandiosa ideia de construir esta estrada e que, vencendo milhares de dificuldades converteram-na em realidade, fizeram jus certamente à profunda gratidão dos seus patrícios. Conforme estava planejado, ante-hontem pelas três horas da tarde, o trem inaugural da estrada de ferro do norte chegou à estação desta cidade, entre as mais enthusiasticas demonstrações de júbilo da multidão de 
pessoas que se achavam não só no interior da estação, como nas adjacências. Este dia, o de oito de julho de 1877 , há de ser de terna recordação para o povo paulista." 236

Não foi só a inauguração da estrada de ferro que impulsionou um maior retalhamento das chácaras e sítios da região do Brás. Conforme Reale relata, "poucos dias antes da inauguração da Estrada de Ferro, no dia $1^{\circ}$ de julho de 1877, a Companhia Carris de Ferro de São Paulo iniciou o funcionamento das linhas de bondes para o Brás, com ponto final junto à Estação"237, dado que impulsionou o trânsito entre aqueles que saíam do centro e dirigiam-se para a nova estação, e daqueles que desembarcavam nela e seguiam para o centro.

O discurso, ancorado num ideal americanista por comparar os paulistas aos estadunidenses $^{238}$, envolvia uma série de melhoramentos urbanos em voga desde finais do oitocentos que correspondeu aos desejos de progresso, modernidade e civilidade presentes no imaginário das elites da cidade. São nos mapas turísticos, nos almanaques comerciais, nas fotos e mesmo nos livros escritos no período, que forjou-se a associação da nova cidade que estava sendo construída com determinados melhoramentos urbanos, com destaque para a indústria nascente.

As indústrias foram assim identificadas como responsáveis pela dinamização da cidade, do crescimento econômico, e mesmo da virada da cidade colonial para a cidade moderna, imagem incorporada pela historiografia subsequente. Assim, uma determinada área da cidade parece destinada a concentrar este elevado número de fábricas por dispor de uma rede ferroviária, ser próxima ao centro, mas suficientemente separada pelo rio Tamanduateí que, já retificado, permitia que as inundações fossem minimizadas.

As fábricas moldaram a paisagem de uma área, e ao mesmo tempo auxiliaram no processo de construção de uma certa história da urbanização ligada ao pioneirismo de determinados atores, essencialmente o empresariado industrial. As fábricas que surgiram no Brás e em outras porções da cidade de São Paulo, teriam sido o reflexo de uma ação maior, do governo federal da época, que atendeu às "reivindicações da indústria nacional, entre

236 REALE, Ebe. Brás, Pinheiros, Jardins: três bairros, três mundos. São Paulo: Pioneira; Ed. da Universidade de São Paulo, 1982, p. 15.

${ }^{237}$ Idem, p. 17

238 As relações intrínsecas entre o Brasil e os Estados Unidos foi tema abordado por Fernando Atique em sua tese de doutorado, abordando a arquitetura, o urbanismo e as relações sociais entre os dois países desde o último quartel do século XIX aos anos finais da Segunda Guerra Mundial. ATIQUE, Fernando. Arquitetando a "Boa-Vizinhança": a sociedade urbana do Brasil e a recepção do mundo norte-americano, 1876-1945. Doutorado em Arquitetura e Urbanismo. São Paulo: FAUUSP, 2007. 
eles a concessão de favores a empresas (isenção de impostos, empréstimos, prêmios, isenção de direitos de importação para aparelhamento industrial) ${ }^{239}$.

Realizamos um levantamento preliminar das fábricas do Brás, a partir da análise de três livros que trazem em perspectiva a instalação dos primeiros estabelecimentos em solo paulistano, com minuciosas descrições dos seus edifícios, localização, fundadores, quase sempre o número de operários e nacionalidade, servindo de fonte para uma análise mais acurada de como esses empreendimentos estiveram ligados ao processo de industrialização paulistano, e se foram predominantes para tornarem o Brás e adjacências em áreas exclusivamente "fabris" nos anos iniciais da Primeira República.

Uma das obras traz um minucioso panorama da indústria paulistana a partir do final do penúltimo quartel do século XIX. Escrita em 1901 por Antônio Francisco Bandeira Junior, A indústria no Estado de São Paulo, é tida como uma das primeiras e mais completas listagens de indústrias existentes em solo paulista, tanto da capital como do interior, mapeando um total de 145 estabelecimentos industriais, e procurando abranger "todas as faces da indústria [que] atestam o elevado grau de desenvolvimento a que ella tem atingido neste Estado"240. O autor traz para cada um dos estabelecimentos fabris diferentes informações (como data de fundação, número de máquinas e funcionários, e se estes seriam nacionais ou estrangeiros e até a produção anual da empresa).

Inicialmente, a obra parece ser uma forma de divulgar a crescente indústria paulista no despertar do século XX, sobretudo se atentarmos para os seus industriais. Ao mesmo tempo a obra tece uma crítica às ações de

\footnotetext{
“indifferença de alguns industriaes e com a má vontade de outros, que, acreditando tractar-se de mais um recurso para aumentar impostos, negaram-se em absoluto a fornecer apontamentos ou recusaram-se a ministral-os completos, principalmente em relação ao pessoal, alegando ser este variável em nacionalidade e numero" 241 .
}

A fala além de demonstrar a preocupação da rede de industriais preocupados com a fiscalização que se intensificava na cidade, louva os grandes proprietários fabris de terem sido os responsáveis pela mudança da paisagem paulista com a instalação de seus complexos

\footnotetext{
239 ANDRADE, Margarida Maria de. Bairros além Tamanduateí: o imigrante e a fábrica no Brás, Móoca e Belenzinho. Tese (Doutorado em Geografia). Faculdade de Filosofia, Letras e Ciências Humanas. São Paulo: Universidade de São Paulo, 1991, p. 91, Apud: LUZ, Nicia Vilela. A luta pela industrialização do Brasil (1808-1930). São Paulo: DIFEL, 1960.

240 BANDEIRA JUNIOR, Antonio Francisco. A indústria no Estado de São Paulo em 1901. São Paulo: Typ. do Diario Official, 1901, p. IX.

241 Idem.
} 
industriais, trouxeram o "engrandecimento de S. Paulo", pois com o final "de velhos pardieiros, surgiram soberbos palácios; de bairros sem habitantes, villas fabris: o trabalho, a belleza, a arte, a hygiene". Do mesmo modo que, questionam sobre "qual o brazileiro que não se curvará ante a memoria de José Clemente, Mauá e Marianno Procopio?”, aludindo assim ao papel de certos pioneiros na modernização de elementos urbanos, cabendo à posteridade reverenciar seus atos, e "ao lado desses grandes beneméritos, (...) colocar o busto de Antonio Alvares Penteado"242, um dos industriais mais reverenciados no livro, quiçá seu patrono.

Junto da obra de Bandeira Junior, os relatos de Alfredo Moreira Pinto são outra valiosa fonte para encontrarmos algumas impressões de quando esteve na cidade de São Paulo no ano de 1900. Professor da Escola Militar, fora um dos que assinaram o Manifesto Republicano de 1870, firmando, assim, seus contatos com a burguesia paulistana, objeto de sua análise no retorno à cidade em 1900. Nascido no Rio de Janeiro em 1847 ,

\footnotetext{
“era filho de um comerciante português. Em 1865 bacharelou-se em belas letras, e em 1866 ingressou na Faculdade de Direito de São Paulo. Embora não tenha concluído o curso de direito, foi nesse período que conheceu a cidade de São Paulo, sobre a qual viria a escrever mais de trinta anos depois, quando a visitou novamente". 243
}

Livro dedicado "ao seu bom amigo e correligionário político Dr. Manoel Ferraz de Campos Salles, e aos seus amigos Coronel Fernando Prestes de Albuquerque e Dr. Peixoto Gomide"244, Moreira Pinto inicia seus relatos descrevendo a cidade após mais de 30 anos tê-la deixado, conferindo um minucioso olhar sobre as transformações que podiam ser observadas nos 15 dias que passou na Pauliceia tais como "as ruas sem calçamento, iluminadas pela luz baça e amortecida de uns lampeões de azeite, suspensos a postes de madeira." 245 Um dos seus relatos chama a atenção ao se referir ao Brás, à Mooca e ao Pari, dizendo que

eram então insignificantes povoados com algumas casas de sapê, que a medo erguiam-se no meio de espessos mattagaes; a Varzea do Carmo, o logar escolhido para calçadas de cabritos; o Cambucy, o ponto de reunião dos rapazes,

\footnotetext{
${ }^{242}$ Idem, p. IV.

${ }^{243}$ BARBUY, Op. Cit. p. 215.

244 BANDEIRA JUNIOR, Op. Cit., s/n.

245 PINTO, Alfredo Moreira Pinto, A cidade de S. Paulo em 1900: Impressões de viajem. Rio de Janeiro: Imprensa Nacional, 1900, p. 08
} 
verdadeiros bohemios, que ahi jogavam o democrático marimbo, os aristocráticos voltarete e lansquenet e davam soberbos bailes fosforescentes; as ruas repletas de republicas de estudantes, que davam vais infernaes nos futricas, formigões, cascabulhos, caloiros e bichos que por ellas transitavam"246

o que denota não apenas uma memória dos tempos em que era estudante da Academia de Direito, mas faz enxergar que tais espaços firmaram laços com outras regiões da cidade, haja vista que não são mais "insignificantes povoados com algumas casas de sapê”, e a vida social agora envolver outras questões que aquelas que partilhava quando estudante.

Por fim, outra obra completa o quadro referente às indústrias existentes no Brás: o álbum O Estado de São Paulo, organizado pela Société de Publicité Sud-américaine, Monte Domecq \& Cia (Barcelona, 1918) ${ }^{247}$. O livro dá uma ideia dos grupos dirigentes da indústria paulista, mostrando-os nos ambientes privados (com fotos das fachadas e interiores de suas residências e com seus familiares), seja no seu ambiente de trabalho (com destaque aos escritórios, armazéns, fábricas, máquinas e os produtos fabricados). Ao contrário das duas obras anteriormente citadas, esta, além de descrever a formação das indústrias em São Paulo, apresenta um corpus visual extremamente rico sobre a cidade. Em paralelo, mostra também aspectos do urbanismo moderno que se instalara (postes e bondes elétricos que passavam pelas ruas, imponentes edifícios erguidos no centro da cidade, e o lazer que estes personagens realizavam, como frequentar cafés, ir ao cinema ou participar de questões solenes como inaugurações de obras públicas e missas).

O livro confere, assim, um panorama de como aquelas indústrias, vislumbradas por Antônio Francisco Bandeira Junior e Alfredo Moreira Pinto, transformaram-se, e mesmo se foram acrescidas de outras nestes quase 20 anos de diferença entre as publicações. Ao analisarmos as fábricas do Brás entre os anos finais do século XIX até meados dos anos 1920, procuramos reconstituir historicamente quem seriam seus proprietários, o que produziam, suas relações e mesmo seu papel no processo de formação do bairro. A partir do cruzamento destas obras, produzimos o mapa Grandes estabelecimentos industriais do Brás, o que nos permite uma melhor compreensão da localização, distribuição e da conexão destes empreendimentos com outros estabelecimentos urbanos do bairro.

${ }^{246}$ Idem.

247 Societé de Publicité Sud-Américaine, Monte Domecq' \& Cie. O Estado de S. Paulo. Barcelona: Estabelecimento Graphico Thomaz, 1918. 
Apesar destas três obras nos fornecerem um amplo repertório das fábricas que se instalaram na cidade de São Paulo, não contemplam a totalidade de estabelecimentos fabris e comerciais então existentes. Ao nos debruçarmos sobre o conjunto de solicitações de permissões de construção encaminhadas à Intendência (e posteriormente Prefeitura Municipal), verificamos que o universo é bem maior e variado, incluindo uma nova parcela de produtores ligados aos setores médios que se estabeleceram na região do Brás com pequenas fabriquetas e oficinas que também devem ser incluídas e contabilizadas nos estudos sobre o tema. Ao juntarmos os pedidos de construção e reforma encaminhados à Diretoria de Obras, com outras fontes (como anúncios em jornais, almanaques e fotografias), um novo panorama social pode ser reconstituído em torno de uma região que fora entendida como essencialmente fabril, proporcionando novos olhares sobre seu processo de ocupação e sobre os atores sociais envolvidos.

Verificamos que esta região, apesar de circunscrita ao que chamamos de Brás, era uma área híbrida, de limites imprecisos, marcada por um elevado número de edificações parecidas incluindo fábricas adjacentes como aquelas localizadas na Móoca, no Pari e mesmo no Belénzinho. Como seriam então essas fábricas? Qual o seu tamanho no momento de sua instalação? A partir dos projetos de construção encaminhados para a Prefeitura e pelas fotografias, pudemos recuperar a feição desses edifícios e verificar como se integravam à malha urbana, junto ou não da ferrovia e dos bondes, com ou sem a energia elétrica e telefone.

Procuramos, então, analisar as ruas que haviam um elevado número de solicitações de construção, amostragem que proporcionou uma melhor opção de comparação entre a natureza das mesmas. Outro ponto que levamos em consideração, foi o trajeto dos bondes no Brás, para se aferir se determinados programas edilícios concentravam-se nas ruas atendidas pelos bondes, sobretudo se ali se concentrava o comércio de determinados produtos. Para esta análise mais acurada foi substancial a pesquisa nos almanaques comerciais que divulgavam o comércio existente na cidade. Privilegiamos o Almanak Laemmert por encontrar-se integralmente disponível online pela Biblioteca Nacional, e assim, facilitar o sistema de buscas do que existia em cada uma das ruas escolhidas para pesquisa.

Como metodologia de pesquisa, elaboramos um banco de dados que descreve minuciosamente todos os anúncios tidos nas ruas de nossa pesquisa, informando endereço, nome comercial, especialidade do estabelecimento, proprietário, e o ano que constava o 
anúncio, de modo que facilite a busca direta na fonte. Com o banco elaborado, procuramos separar os anúncios conforme o gênero de especialidade, formando grandes categorias. Assim, os anúncios de açougues, refinarias de açúcar, armazéns de secos e molhados, refinarias e beneficiamento de arroz, bares e bebidas, fábricas e lojas de bolachas, doces e chocolates, café moído, lojas de cereais, confeitarias, padarias, quitandas e fábricas de salames, foram agrupados no campo “ALIMENTAÇÃO”. Com os anúncios de alfaiates e roupas feitas, armarinhos e fazendas, lojas e fábricas de calçados, chapelarias, fábricas de tecidos e tinturarias, inserimos no grupo "INDUMENTÁRIA E ARMARINHOS". Carpintarias, marcenarias, fábricas e lojas de móveis e colchões, e serrarias estiveram agrupadas no campo "MADEIRAS E MÓVEIS", enquanto lojas e depósitos de materiais para construção, louças, porcelanas e cristais no grupo "MATERIAIS PARA CONSTRUÇÃO E INTERIORES". Distribuidoras de carvão e lenha, fábricas e lojas de sabão, sabonetes, velas, fósforos, aparelhos ortopédicos, fábrica de lamparinas, fábrica de peneiras, escovas e vassouras, gaiolas, placas, artigos funerários e uma fábrica de ósseo de rícino ficaram reunidas em "UTILIDADES GERAIS".

Pensando num campo que abarcasse produtos e serviços especiais que envolvessem o uso do ferro, criamos o campo "METALURGIA", com fundições e funilarias, lojas de maquinários e serralherias. No campo "LAZER E DIVERSÕES", abarcamos os cinemas, teatros, casas de fumo, charutarias, hotéis, joalherias, ouriversarias e objetos de arte. Já as barbearias, cabeleireiros, joalherias, perfumarias, farmácias, e a fábrica e loja de pentes de chifre foram englobados no campo "BELEZA E SAÚDE". Por fim, as carroças e oficinas de bicicletas estiveram agrupadas no campo "TRANSPORTES".

Portanto, com as três obras selecionadas, cotejadas junto aos projetos de obras particulares e os anúncios do Almanak Laemmert, reconstituímos espacialmente o perfil arquitetônico e comercial do Brás. Partindo da colocação de Bernard Lepetit, de que "a cidade é feita de cruzamentos. O difícil, para compreender a mudança urbana, é percorrer juntas as duas vias que conduzem a ela, em vez de privilegiar uma ou outra"248, entendemos que o entrecruzamento de diferentes fontes nos permitem uma melhor compreensão histórica e social da formação das cidades, e no caso de São Paulo (e mesmo de outras do mundo capitalista), isso é permitido com o cuidado de atenção aos pormenores contidos em cada uma delas.

${ }^{248}$ LEPETIT, Bernard. Por uma nova história urbana. São Paulo: Edusp, 2016, pág. 177. 


\subsection{Entre armazéns e fábricas de alimentos}

Para atender a grande concentração populacional residente e operária do Brás, desde o começo do século XX, o bairro passou a concentrar uma série de estabelecimentos destinados à comercialização de produtos alimentícios, que variavam da simples casa de frutas a armazéns e botequins que se espalhavam por diversas das ruas da região. Não eram simples comércios que vendiam a produção artesanal feita nos fundos do terreno ou nas fabriquetas anexas. Cada comércio trazia em suas vendas produtos do dia a dia (como a farinha de trigo e o café), e até mesmo produtos mais refinados, e que de certa maneira podiam também atender ao consumo diário de parte desta população (como o chocolate, licor e salame).

A partir do cruzamento das permissões de construção e reformas encaminhados por particulares à Prefeitura com os anúncios dos almanaques, pudemos entrever que o Brás e bairros circunvizinhos formavam uma ampla área dedicada ao comércio alimentício 249 (tanto no atacado para revenda ou fabricação de produtos, como no simples varejo para suprimento das necessidades diárias das residências). Esta área não se formaria apenas pelo expressivo consumo que se dava na região, mas fora auxiliada pela proximidade do Mercado Municipal (na rua Vinte e Cinco de Março), que atendia essencialmente a região central, e seus produtos abasteciam armazéns nos subúrbios e quitandas. Enquanto que o Mercado Central localizava-se na margem esquerda do rio Tamanduateí (polarizando uma série de outros edifícios dedicados à venda de produtos alimentícios), na margem oposta, a rua Santa Rosa concentrava em seus sobrados uma série de armazéns, empórios e outros edifícios de uso mistos que vendiam da farinha de trigo aos grãos de milho, arroz e amendoim.

Não era apenas o Mercado Central (também conhecido como Mercado dos Caipiras) que se colocava como um grande entreposto comercial na cidade. Juntamente com o mercado da rua São João e o mercado do Brás, formavam uma tríade de espaços da distribuição de alimentos na cidade de São Paulo em finais do século XIX e começo do XX. Localizado no Largo da Concórdia, o mercado do Brás fora inaugurado em 1897, tornandose uma referência para os moradores e para outros comércios do bairro, como atesta o

249 Área conhecida na atualidade como Zona Cerealista. 
anúncio da venda de um negócio de secos e molhados na rua do Brás número 192, “em frente ao novo mercado do largo da Concórdia" ${ }^{250}$.

Considerado por Alfredo Moreira Pinto como o mais elegante, porém menos concorrido da cidade, o mercado do Brás estava instalado num "edifício quadrangular, tendo no centro um pateo com chafariz e aos lados diferentes casas de negocio", sendo "todo rodeado por duas galerias interiores, com o madeiramento em fórma de xadrez”, além de quatro portas de entrada e quarenta e oito janelas ${ }^{251}$. O mercado ainda contava com o fato de situar-se num largo que continha uma estátua de bronze da Aurora empunhando um bico de gás ${ }^{252}$.

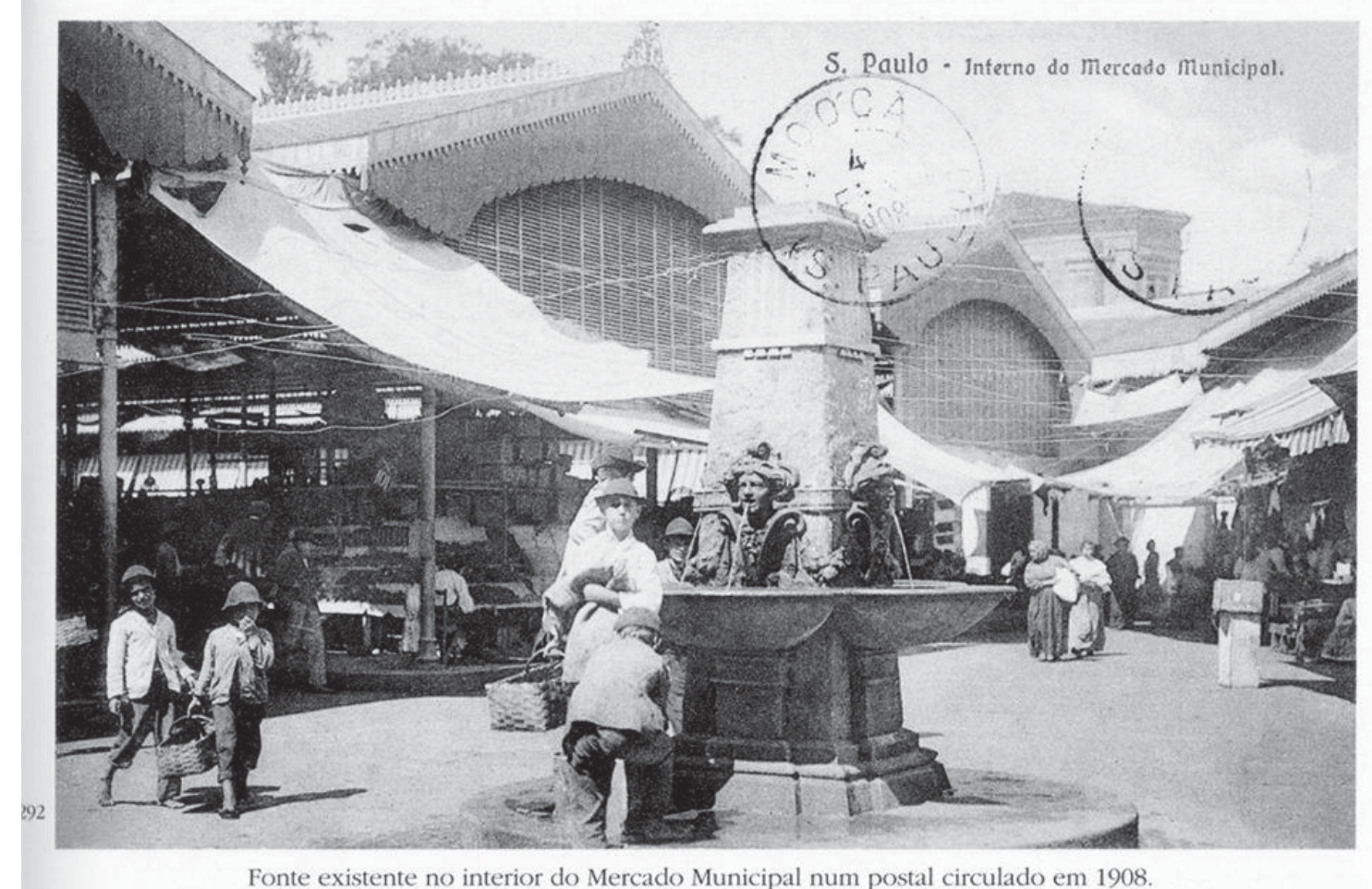

Figura 131: O Mercado do Brás no Largo da Concórdia, a partir de um postal do ano de 1908. Fonte: $<<$ https://www.facebook.com/100anos/photos/a.642031392604830.1073741827.642030575938245/7

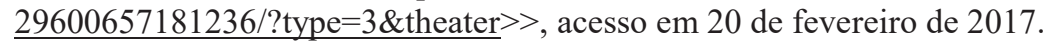

Talvez pelo aumento considerável de comércios espalhados pelo Brás, aos poucos o mercado não resistiu, e em 08 de abril de 1906, a Comissão Municipal de Justiça e Finanças aprova o ato do prefeito Antônio Prado em fechar o mercado "por não haver mais locatários" ${ }^{253}$. Três dias depois, uma comissão de moradores do Brás, pede que "o mercado

\footnotetext{
${ }^{250}$ Jornal O Estado de São Paulo, edição de 09 de janeiro de 1898.

${ }^{251}$ PINTO, Op. Cit, pág. 166.

${ }^{252}$ Idem, pág. 264.

253 Jornal O Estado de São Paulo, edição de 08 de abril de 1906.
} 
do Largo da Concordia seja transformado em circo ou Polytheama" com atenção para que não fosse dado como arrendamento "à certo politiqueiro de Villa Mariana”, para assim não privilegiar a abertura de uma concorrência apenas para beneficiar o dito, e lembram que com a concorrência "muito ganharão os cofres municipaes, pois a concorrência sera publica e não para privilegiados" ${ }^{254}$, demonstrando este ser um espaço de disputas e interesses entre a população paulistana do começo do século XX. O mercado fora desativado, e aproveitando seu espaço, um teatro fora levantado: o Colombo, permanecendo na paisagem do Brás até o ano de 1966, quando sofreu um incêndio que levou à sua posterior demolição.

Visto que a alimentação não se resumia aos cereais, convencionamos chamar a área como "zona alimentícia", dada a diversidade de alimentos ali encontrados para venda. Afim de que esta zona alimentícia fosse pormenorizada em seus detalhes, separamos seus espaços de venda de acordo com os produtos ali comercializados. Entretanto, verificamos que muitos destes comércios não apenas dedicam-se à venda exclusiva de produtos alimentícios, mas, expunham outros produtos igualmente importantes nos menus e cardápios dos restaurantes e botequins que se espalhavam pelas principais vias do Brás, bem como nos almoços e jantares da população ali residente.

A partir do cruzamento de fontes, elaboramos uma tabela que evidencia os estabelecimentos comerciais relacionados à produção ou venda de produtos alimentícios do Brás entre 1897 a 1915, e a quantidade encontrada em cada uma das ruas de nossa pesquisa. Evidentemente que não são todos os comércios, pois se trata de uma amostragem, porém os números aqui demonstrados servem de subsídio para uma melhor compreensão de como esta região da cidade se formou e afirmou, rompendo com o estereótipo de "bairro industrial" cristalizado na historiografia e no imaginário. A relação completa dos comércios e demais estabelecimentos industriais levantados a partir do Almanaque Laemmert, podem ser conferidos a seguir.

${ }^{254}$ Jornal O Estado de São Paulo, edição de 11 de abril de 1906. 


\begin{tabular}{|c|c|c|}
\hline \multicolumn{3}{|c|}{ Relação dos estabelecimentos comerciais do Brás especializados em alimentos (1897-1915) } \\
\hline $\begin{array}{c}\text { ESTABELECIMENTO } \\
\text { COMERCIAL }\end{array}$ & \multicolumn{2}{|c|}{$\begin{array}{l}\text { QUANTIDADE LEVANTADA EM CADA } \\
\text { UMA DAS RUAS }\end{array}$} \\
\hline \multirow[t]{18}{*}{ Açougue } & Rua & Quantidade \\
\hline & Barão de Ladário & 1 \\
\hline & Benjamin de Oliveira & 2 \\
\hline & Brigadeiro Machado & 3 \\
\hline & Bresser & 3 \\
\hline & Carneiro Leão & 2 \\
\hline & Celso Garcia & 22 \\
\hline & Concórdia & 3 \\
\hline & Gasômetro & 2 \\
\hline & Gomes Cardim & 1 \\
\hline & José Monteiro & 3 \\
\hline & Maria Marcolina & 3 \\
\hline & Monsenhor Andrade & 2 \\
\hline & Piratininga & 4 \\
\hline & Rangel Pestana & 10 \\
\hline & Rodrigues dos Santos & 1 \\
\hline & Visconde de Parnaíba & 8 \\
\hline & TOTAL & 70 \\
\hline \multirow{6}{*}{ Açúcar, refinaria de } & Rua & Quantidade \\
\hline & Maria Marcolina & 1 \\
\hline & Rangel Pestana & 2 \\
\hline & Piratininga & 1 \\
\hline & Santa Rosa & 1 \\
\hline & TOTAL & 4 \\
\hline \multirow[t]{20}{*}{ Armazéns de secos e molhados } & Rua & Quantidade \\
\hline & Bresser & 13 \\
\hline & Carlos Garcia & 1 \\
\hline & Carneiro Leão & 9 \\
\hline & Celso Garcia & 45 \\
\hline & Concórdia & 5 \\
\hline & Concórdia, Largo da & 3 \\
\hline & Conselheiro Belisário & 1 \\
\hline & Correia de Andrade & 1 \\
\hline & Gasômetro & 6 \\
\hline & Gomes Cardim & 3 \\
\hline & João Boemer & 2 \\
\hline & Maria Marcolina & 18 \\
\hline & Martim Burchard & 2 \\
\hline & Monsenhor Andrade & 5 \\
\hline & Oriente & 8 \\
\hline & Rangel Pestana & 17 \\
\hline & Santa Rosa & 14 \\
\hline & Visconde de Parnaíba & 9 \\
\hline & TOTAL & 168 \\
\hline \multirow[t]{2}{*}{ Arroz, Beneficiamento de } & Rua & \\
\hline & Monsenhor Andrade & 1 \\
\hline
\end{tabular}




\begin{tabular}{|c|c|c|}
\hline & TOTAL & 1 \\
\hline \multirow[t]{19}{*}{ Bares e bebidas } & Rua & Quantidade \\
\hline & Benjamim de Oliveira & 1 \\
\hline & Bresser & 3 \\
\hline & Celso Garcia & 26 \\
\hline & Concórdia & 2 \\
\hline & Domingos Paiva & 3 \\
\hline & Flora & 1 \\
\hline & Gasômetro & 12 \\
\hline & Maria Marcolina & 2 \\
\hline & Martim Burchard & 1 \\
\hline & Miler & 1 \\
\hline & Monsenhor Anacleto & 1 \\
\hline & Oriente & 1 \\
\hline & Piratininga & 4 \\
\hline & Rangel Pestana & 31 \\
\hline & Santa Rosa & 10 \\
\hline & Sayão Lobato & 1 \\
\hline & Visconde de Parnaíba & 8 \\
\hline & TOTAL & 108 \\
\hline \multirow[t]{9}{*}{ Bolachas, doces e chocolates } & Rua & Quantidade \\
\hline & Barão de Ladário & 1 \\
\hline & Celso Garcia & 1 \\
\hline & Concórdia, Largo da & 1 \\
\hline & José Monteiro & 1 \\
\hline & Maria Marcolina & 1 \\
\hline & Rangel Pestana & 1 \\
\hline & Sampaio Moreira & 1 \\
\hline & TOTAL & 7 \\
\hline \multirow[t]{8}{*}{ Botequins e bilhares } & Rua & Quantidade \\
\hline & Américo Brasiliense & 2 \\
\hline & Carneiro Leão & 7 \\
\hline & Concórdia & 8 \\
\hline & Concórdia, Largo da & 4 \\
\hline & Monsenhor Anacleto & 2 \\
\hline & Monsenhor Andrade & 11 \\
\hline & TOTAL & 34 \\
\hline \multirow[t]{7}{*}{ Café moído e torrado } & Rua & Quantidade \\
\hline & Celso Garcia & 3 \\
\hline & Gasômetro & 4 \\
\hline & Monsenhor Anacleto & 2 \\
\hline & Piratininga & 2 \\
\hline & Rangel Pestana & 31 \\
\hline & TOTAL & 41 \\
\hline \multirow[t]{4}{*}{ Cereais } & Rua & Quantidade \\
\hline & Gasômetro & 1 \\
\hline & Santa Rosa & 5 \\
\hline & TOTAL & 6 \\
\hline Confeitarias & Ruas & Quantidade \\
\hline
\end{tabular}




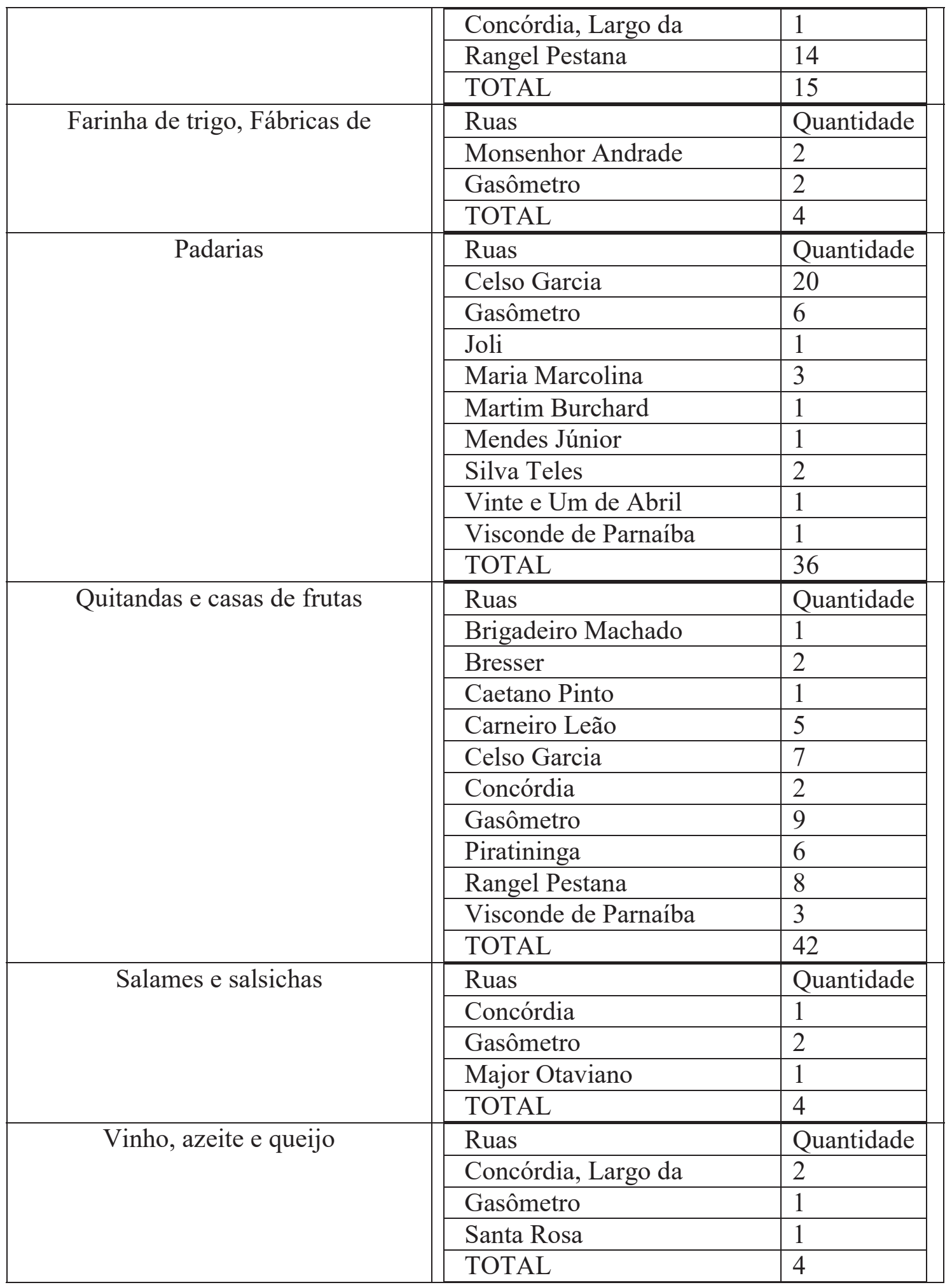

Tabela 14: "Relação dos estabelecimentos comerciais do Brás especializados em alimentos (1897-1915)", elaborada pelo autor com base no Almanak Laemmert.

A tabela revela a gama variada de gêneros comercializados no bairro do Brás, rua a rua, o que por si já é uma novidade. Em paralelo buscou-se as informações na planta da cidade de São Paulo organizada por Gomes Cardim em 1897, por conter as ruas 
contempladas nesta pesquisa e demonstrar o arrumamento da região em vias de consolidação desde finais do século XIX. Em seguida cotejamos os anúncios daquilo que podia ser encontrado para compra e venda na capital paulista, com destaque para a área do Brás.

Podemos perceber que a tabela especializa e permite vislumbrar a distribuição desses estabelecimentos, bem como imaginar a especialização de certas áreas na venda de determinados produtos em meio a outras de natureza mista ou ainda outras exclusivamente residenciais. O comércio de gêneros alimentícios estaria assim concentrado especialmente nas ruas Santa Rosa, Concórdia, Largo da Concórdia, Gasômetro, Piratininga, Carneiro Leão, Oriente, Maria Marcolina, Bresser e Visconde de Parnaíba (não à toa, vias em que circulavam os bondes, e assim proporcionavam uma maior dinâmica comercial e de fluxo de pessoas e produtos, inclusive de outras áreas da cidade). Claramente se vê que as avenidas Rangel Pestana e Celso Garcia concentravam um comércio misto e variado de alimentos, e mesmo de outros produtos como veremos mais adiante.

Em menor número, podemos verificar que as ruas Major Otaviano, José Monteiro, Barão de Ladário, Benjamin de Oliveira, Miler, Caetano Pinto, Flora, Brigadeiro Machado, Vinte e Um de Abril, Silva Teles, Brigadeiro Machado, Gomes Cardim, Martim Burchard, Mendes Júnior e Sayão Lobato também tinham armazéns dedicados à venda de gêneros alimentícios, mas em menor escala quando comparadas com as ruas anteriormente citadas, o que podia decorrer da ausência dos trilhos de bondes e mesmo pela distância em relação à pontos de destaque do bairro, como a estação de trens, o Gasômetro ou por se configurarem como áreas estritamente residenciais.

Em muitas ruas predominavam comércios de determinados gêneros: enquanto na Bresser, Maria Marcolina e Oriente, os armazéns de secos e molhados, a Monsenhor Andrade estaria repleta de bares e botequins. Interessante notar que as ruas em que havia um elevado número de armazéns de secos e molhados, eram também aquelas que concentravam um elevado número de pedidos de construção de residências, o que permite aferir que este comércio atendia os próprios moradores locais ou do entorno próximo. Agora, se nos determos na análise de vias próximas à estação de trens (e o Largo da Concórdia à sua frente), o Gasômetro e a Hospedaria dos Imigrantes, percebemos a concentração de um intenso comércio misto, com a presença de cafés, bares, confeitarias, padarias e casas de frutas. 
Os armazéns levantados na pesquisa parecem demonstrar que suas localizações não eram aleatórias, mas pensados estrategicamente, de modo a atender a população residente no Brás ou áreas adjacentes. Estavam em contato com uma série de outros comércios relacionados a outros gêneros alimentícios e de uso geral. Muitos desses armazéns de secos e molhados traziam em suas prateleiras produtos que podiam ser encontrados em outros comércios especializados em outros gêneros, como o armazém de Domenico Albano situado na Avenida Celso Garcia número $21^{255}$, que inicialmente fora uma loja especializada em armarinhos e fazendas e, em 1908, já de propriedade da Dona Maria, transformou-se em padaria e, no anúncio de 1914, em armazém de secos e molhados. Também, na mesma avenida, os números 192 e 194 conjugaram a padaria e armazém de Angelo Auricchio.

Outro dado que nos serve de subsídio é o fato destas mesmas ruas que concentraram um expressivo comércio alimentício, serem aqueles que eram atendidos pelo serviço de bondes que interligavam porções do bairro, dando acesso principalmente ao eixo Rangel Pestana - Celso Garcia, bem como ao Pari e Estação da Luz ao norte, e à Móoca ao sul, e à oeste ao centro da cidade. Este comércio miúdo de alimentos, encontrado nos armazéns de secos e molhados das ruas do Brás, podia atender ainda demandas de outras regiões da cidade, abastecendo as casas daqueles que viviam em áreas próximas, para que assim a população ali residente não precisasse se deslocar até as porções centrais, ou ao Mercado Central para se abastecer de gêneros necessários ao cotidiano.

O comércio de carne parece ter sido bem distribuído nas ruas do Brás, com açougues construídos quase sempre na frente de antigas residências, muitas com seus cômodos transformados para tal (neste caso, a sala ou um dos quartos convertidos em açougue). Boa parte dessas carnes provinham de frigoríficos situados nas proximidades, como o dos Irmãos Zimmermann, fundado em 1879 na rua Major Otaviano número 47, produzindo mortadelas, salames, presuntos, toucinho fumado, chouriços, gelatina, banha refinada, além de ser especializado em produzir salsichas e repolho em salmoura, vendidos no depósito no Mercado São João, número $44^{256}$.

\footnotetext{
${ }^{255}$ Almanaque Laemmert, edições de 1908, 1914.

${ }^{256}$ BANDEIRA JÚNIOR, Op. Cit, p. 207.
} 
Os açougues eram alvo constante da fiscalização municipal, que procurava manter os padrões de higiene e limpeza em diversos estabelecimentos da cidade, essencialmente aqueles que se dedicavam à venda de produtos alimentícios. Um caso envolvendo o proprietário de um açougue com a municipalidade é curioso para exemplificarmos tal embate: Em 11 de julho de 1914, José de Souza Oliveira requereu a aprovação de uma planta, "desejando por de accôrdo com o padrão o seu açougue sito à Avenida Celso Garcia $n^{\circ} 355$ ". O engenheiro José de Sá Rocha explicou que a Prefeitura não poderia aprovar a modificação projetada, tendo em vista as exigências pautadas na lei 63 sobre açougues, a qual dizia que tais espaços deviam ter uma área de $16 \mathrm{~m}^{2}$. Não se dando por satisfeito, José de Souza Oliveira explica que entende o fato da lei número 63 colocar como parâmetro uma área mínima, mas se sente inconformado com o fato de ser

\begin{abstract}
“proprietário do açougue em questão (...) há mais de 15 annos. Alli tem o mesmo exercido a sua honrada profissão donde tira para [manter] à sua família. Vem a Directoria do Serviço Sanitário e o intima para em certo praso fazer diversas reformas de accôrdo com o decreto sanitário, sob pena de multa de 200 [reis]. A [parte] fica como [bem] comprehende V. Excia. em sérias difficuldades. Recorre á Prefeitura apresentando planta; esta nega-se a approval-a porque o açougue não tem $4 \times 4$ - tendo porém a área legal, isto é, 16 m.2 É nessas [exigências] em que se acha a parte, e si não houver um acto de justiça por parte de V. Excia. tolerando essa pequena lacuna, vêr se á um chefe de família sem pão para dar aos seus filhos visto que a Camara tem um padrão e o Serviço Sanitário outro. Findo assim, espera o supplicante que V. Excia. Ihe faça justiça mandando approvar sua planta para salval-o desta [assaladossa] situação." ${ }^{257}$
\end{abstract}

Sá Rocha não pareceu comovido com a situação apresentada pelo proprietário do açougue, e responde que

"Por mais respeitáveis que possam parecer as allegações do interessado, a informação que dei não pode ser outra. A Prefeitura não deve acuar de seguir o cumprimento do acto de suas próprias leis, $[. .$.$] quanto tentativas como na casa$ em questão.

A exigência do cumprimento da lei tem [valor] legal, e não ficaria bem, pareceme fazer-se uma excepção que deve [...] em regra.

Leveo, pois, o caso á deliberação do Sr. Prefeito, que resolvera como ele pareça acertar. ${ }^{258}$

${ }^{257}$ Arquivo Histórico Municipal, Fundo "Diretoria de Obras", Série “Obras Particulares”, OP1914.001.163. ${ }^{258}$ Idem. 


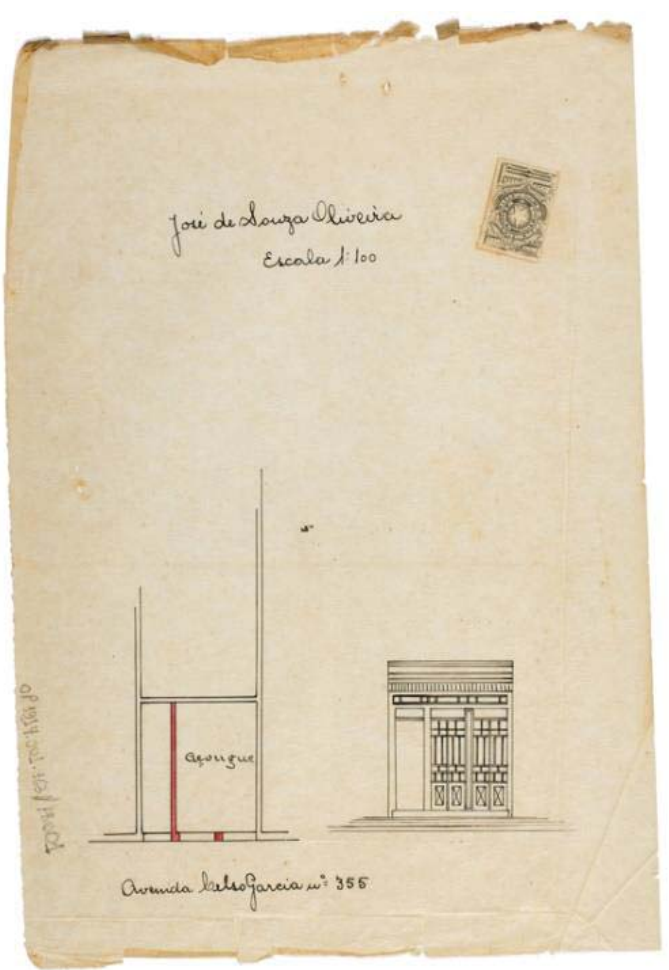

Figura 132: Açougue de "José de Souza Oliveira", Arquivo Histórico Municipal, Fundo "Diretoria de Obras”, Série “Obras Particulares”, OP1914.001.163.

Outro caso envolvendo a reforma de um açougue causou uma situação embaraçosa entre o proprietário e os agentes públicos. Benedicto José de Lima, proprietário de um imóvel na avenida Celso Garcia número 28, em julho de 1913 remeteu à Prefeitura uma planta assinada pelo "Architetcto-Constructor Leonardo Nardini”, solicitando a construção de um botequim que ficaria entre um açougue já existente na testada do lote, e a sua casa nos fundos. Enfático, o engenheiro municipal Arthur Rocha, escreve que

\footnotetext{
"Não é possível tolerar-se botequim comunicando diretamente com quarto destinado a habitação e entre (...) sala de jantar.

Aliás, acho esquisito o [amalgama] que se quer fazer de açougue com moradia e botequim. Acho que para os fins declarar a licença não deve ser concedida. Para que possa ser dada a licença e dado o augmento da casa existente é [energível] corredor interno que deve abranger os 3 [caminhos] entre o açougue e a varanda. É inadimissivel a introdução entre [...] de um botequim ou outro comércio." 259
}

Ou seja, uma das soluções para a continuidade do açougue seja a abertura de um corredor que levasse à varanda da casa, sem a construção do botequim. José de Sá Rocha entra no debate, sendo favorável à supressão do botequim, pois considera "inadmissível (...) 
um botequim entre os quartos e a sala de jantar", além de "um açougue na frente - negócio com o qual decerto o botequim nada tem de commum", concordando que ao menos o corredor interno seja feito a fim de facilitar a circulação interna do imóvel.

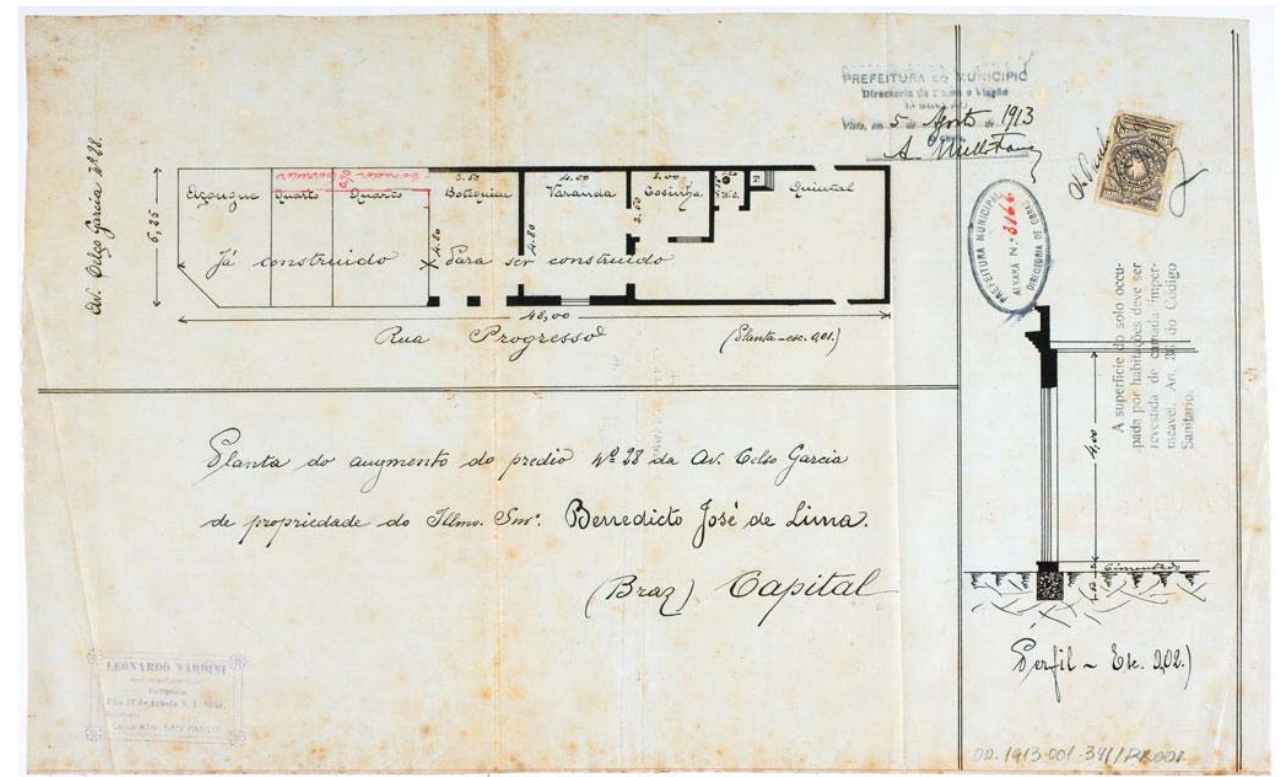

Figura 133: "Planta do augmento do predio n²8 da Av. Celso Garcia de propriedade do Illmo Snr. Benedicto José de Lima", Arquivo Histórico Municipal, Fundo "Diretoria de Obras", Série "Obras Particulares”, OP1913.001.341.

Podemos perceber que a implantação dos açougues eram alvo constante dos agentes fiscalizadores da Prefeitura, seja por não atenderem às disposições mínimas da legislação em vigor, ou por questões de ordem técnica, como conjugá-los a outros comércios, ainda que dedicados ao gênero alimentício. Os açougues, bem como diversos outros comércios implantados no Brás, eram uma adaptação do cômodo da frente de casas já construídas, como os exemplos anteriores (figuras 132 e 133) e as figuras 134, 135 e 136. 


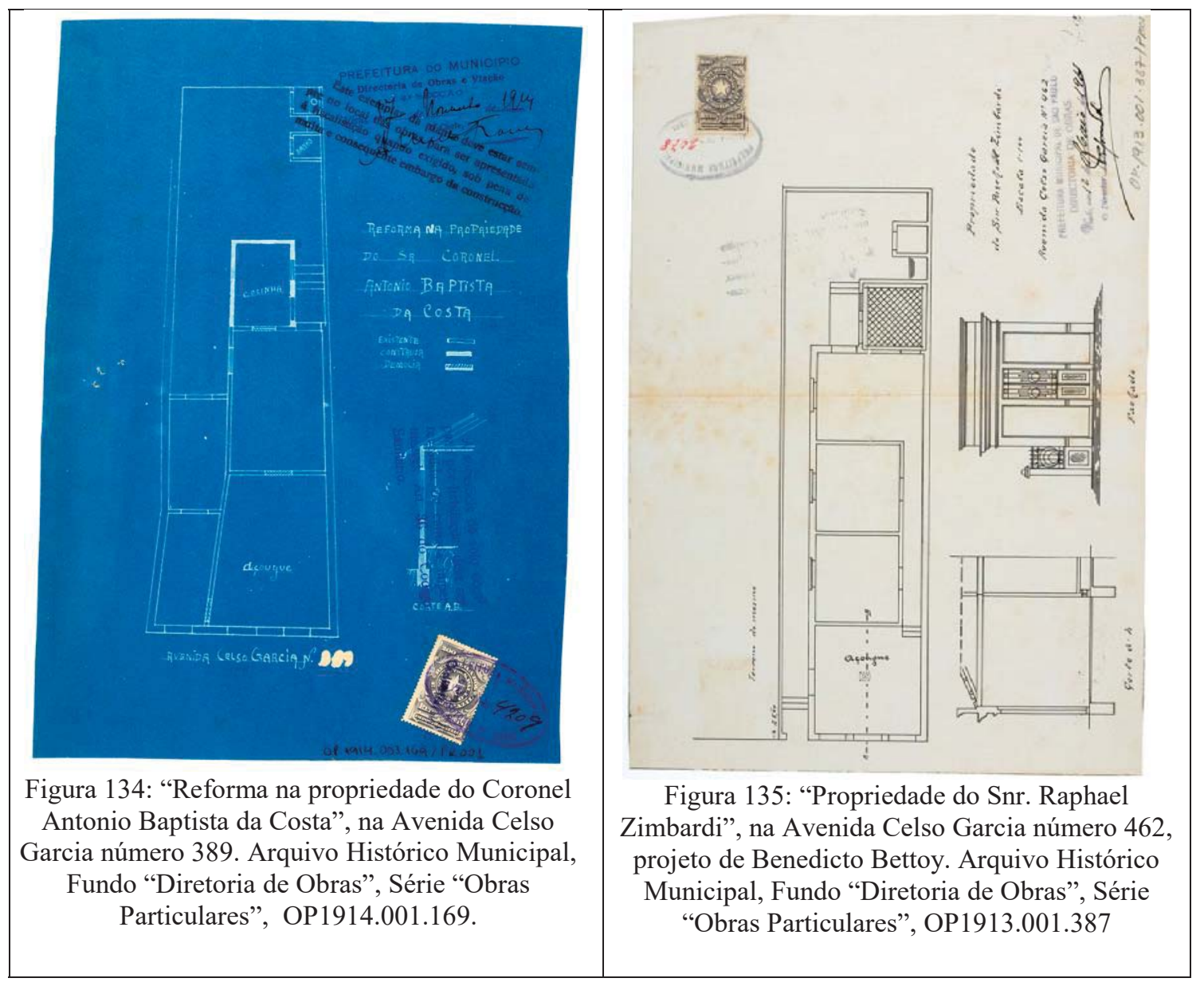

Presumimos que muito do que era comercializado nos armazéns de secos e molhados da região fosse produzido nas proximidades, seja em fabriquetas ou fábricas de grande porte, como a fábrica a vapor de massas alimentícias A Industrial, localizada na rua do Gasômetro, nos números 33 e 35, considerada por Bandeira Júnior uma das “melhores existentes". Tinha uma produção diária que chegava a 30 mil kilos de massas, o que só era possível com o apoio de um motor de 8 cavalos que alimentava a força de 5 máquinas industriais existentes no interior da fábrica, fundada em 1892 por Romali \& Companhia e desde junho de 1898, pertencente a José Pinto da Fonseca ${ }^{260}$.

Outra fábrica voltada à produção de massas registrada por Bandeira Junior é a dos Fratelli Secchi, localizada na rua Miler número 4. Fundada em 1896 por Henrique Secchi, Roberto Secchi e Atilio Secchi, num edifício de dois pavimentos, a fábrica contava com uma estufa para consolidar a massas, duas câmaras para resfriar, uma máquina com motor e caldeira e 10 máquinas para preparo da massa, podendo atingir mais de 70 mil kilos anuais, 
com base no trabalho de 50 a 90 operários, quase todos estrangeiros. Sua produção foi premiada com a medalha de primeira classe na exposição de Turin, em 1898, e com o "grande Diploma de Honra na exposição do $4^{\circ}$ Centenário da descoberta do Brazil, em Santos".

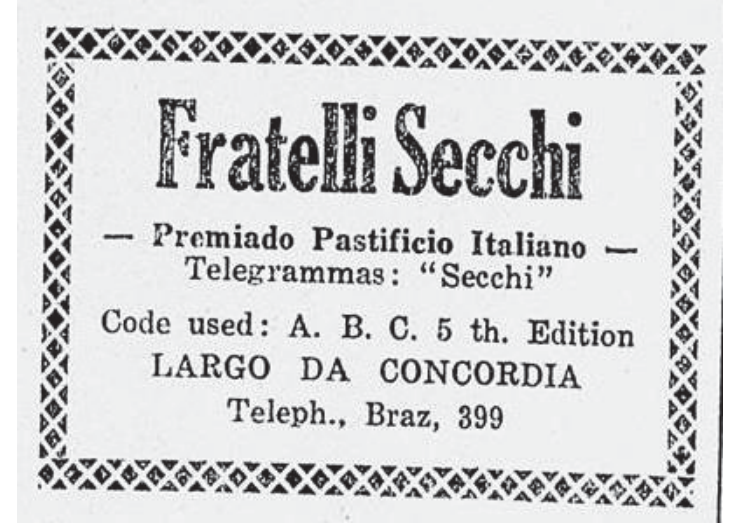

Figura 136: Anúncio da "Fratelli Secchi" no Almanaque Laemmert do ano de 1918. Acervo: Hemeroteca Digital Brasileira.

A produção de massas no Brás remontava a pelo menos o ano de 1878, quando foi instalada na rua Monsenhor Andrade número 82 a Christofani. Segundo Antônio Bandeira Junior tratava-se da mais antiga fábrica de massas do Estado, fundada por Ludovico Dal Portoz e Francisco Casini. No ano da publicação de sua obra, em 1901, a fábrica tinha outro proprietário, João Christofani, que possuía uma máquina a vapor e diversos outros aparatos para amassar farinha, uma estufa, vários depósitos para secagem, oficina de acondicionamento. Dez operários estrangeiros produziam 500 kilos diários de massas.

Um dos grandes empreendimentos alimentícios localizados no Brás, sem dúvida era o de Francisco Matarazzo, o detentor do maior complexo industrial, que se espraiava por diversas ruas não só do Brás mas de outros bairros ligados às estradas de ferro, como a Lapa, a Barra Funda, o Belenzinho e o Ermelino Matarazzo. Chamado por Bandeira Junior de "um dos mais opulentos attestados do adiantamento da indústria paulista”, o empreendimento de Francisco Matarazzo foi fundado em 15 de março de 1900 e seu edifício construído em dez meses. 


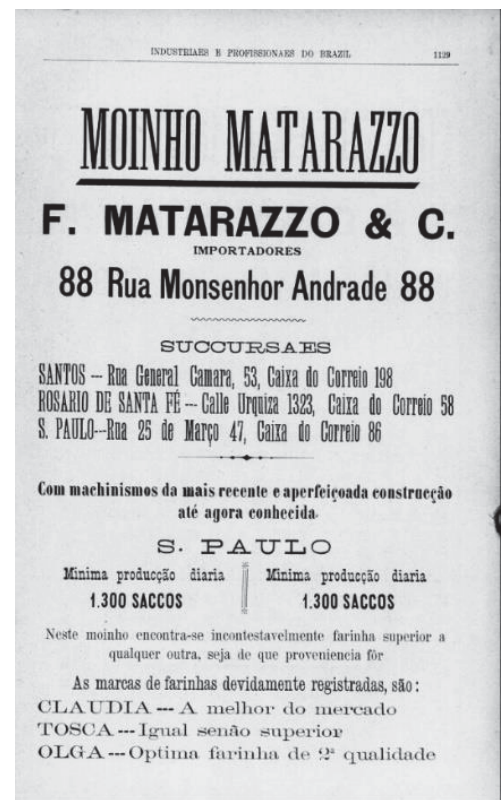

Figura 137: Anúncio do "Moinho Matarazzo" nas páginas do Almanaque Laemmert de 1901. Acervo: Hemeroteca Digital Brasileira.

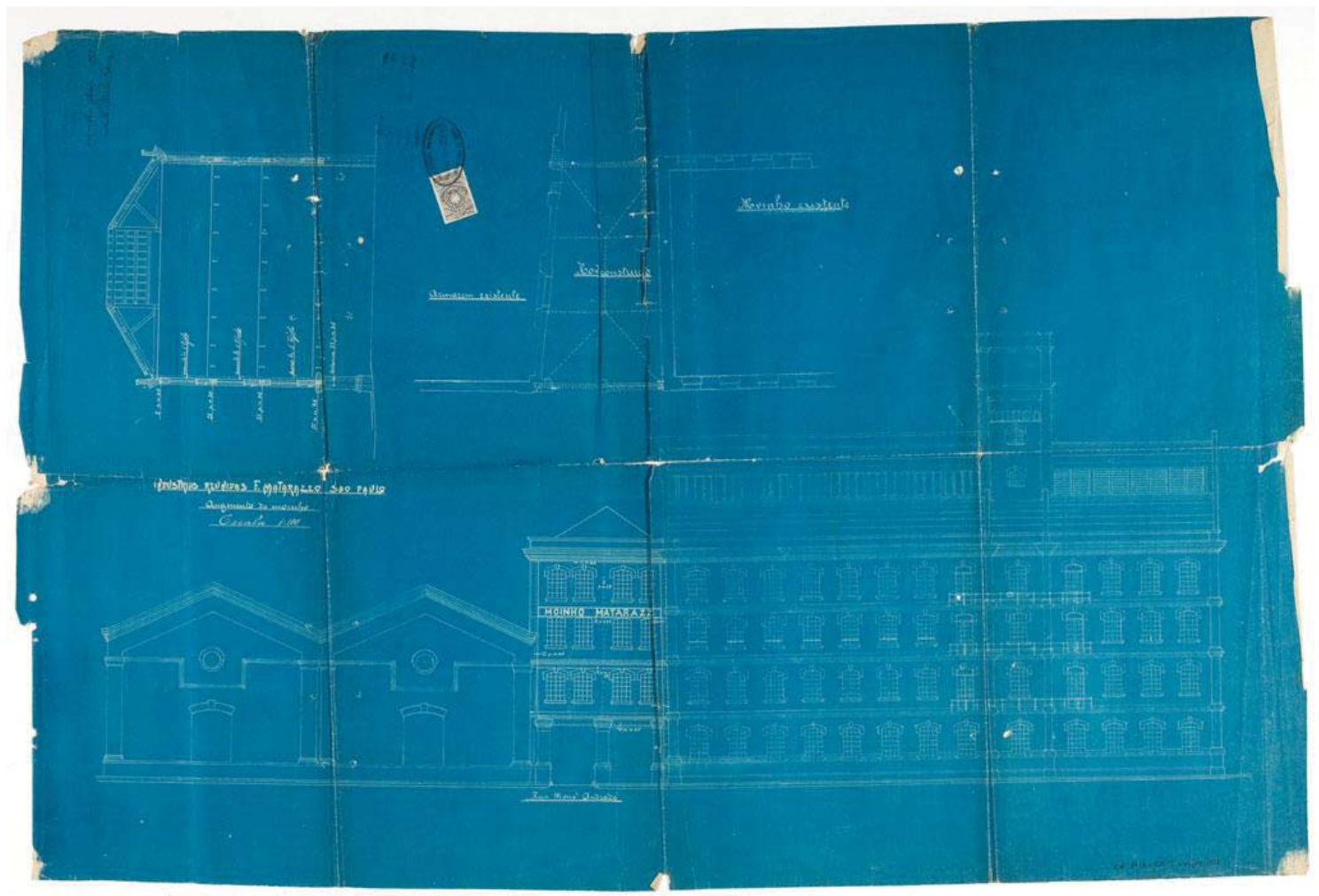

Figura 138: “Industrias Reunidas F. Matarazzo São Paulo - Aumento do moinho”. Arquivo Histórico Municipal, Fundo “Diretoria de Obras”, Série “Obras Particulares”, OP1913.003.699. 


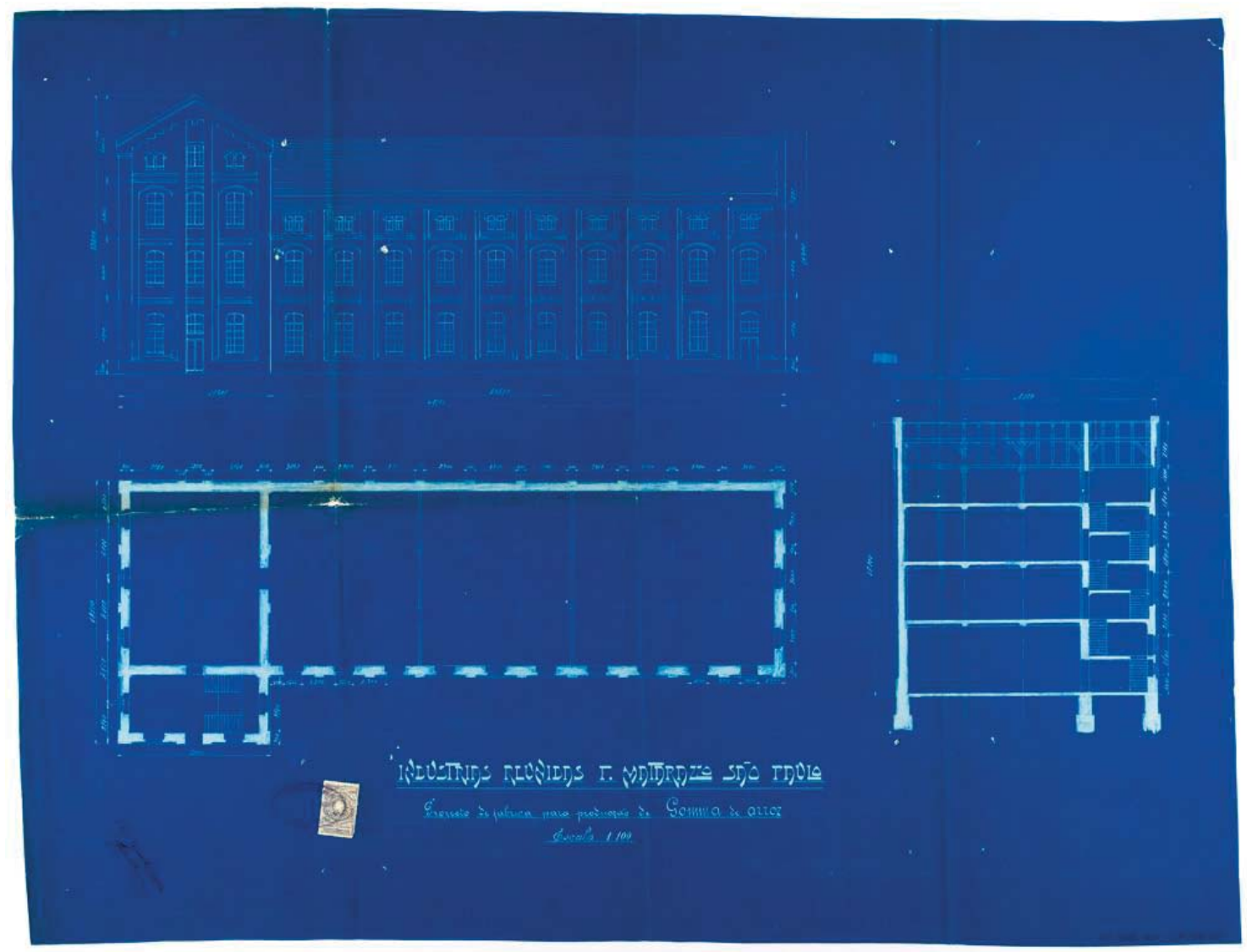

Figura 139: "Industrias Reunidas F. Matarazzo São Paulo - Fachada da fabrica para produção de goma de arroz", Arquivo Histórico Municipal, fundo "Diretoria de Obras", série "Obras Particulares", OP1912.001.208.

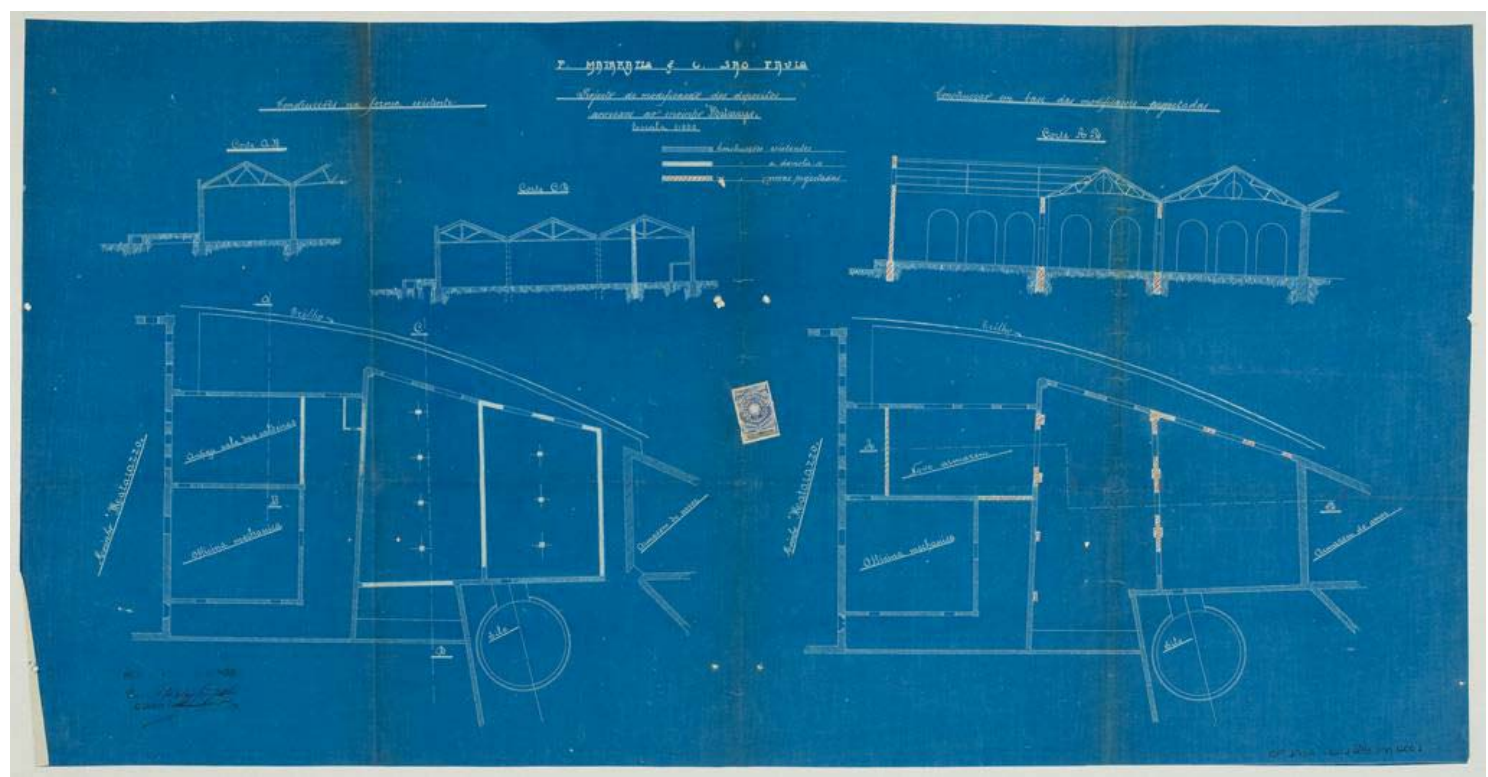

Figura 140: "F. Matarazzo \& C. São Paulo - Projeto de modificação dos depósitos anexos ao moinho Matarazzo". Arquivo Histórico Municipal, Fundo "Diretoria de Obras”, Série “Obras Particulares", OP1909.001.648. 


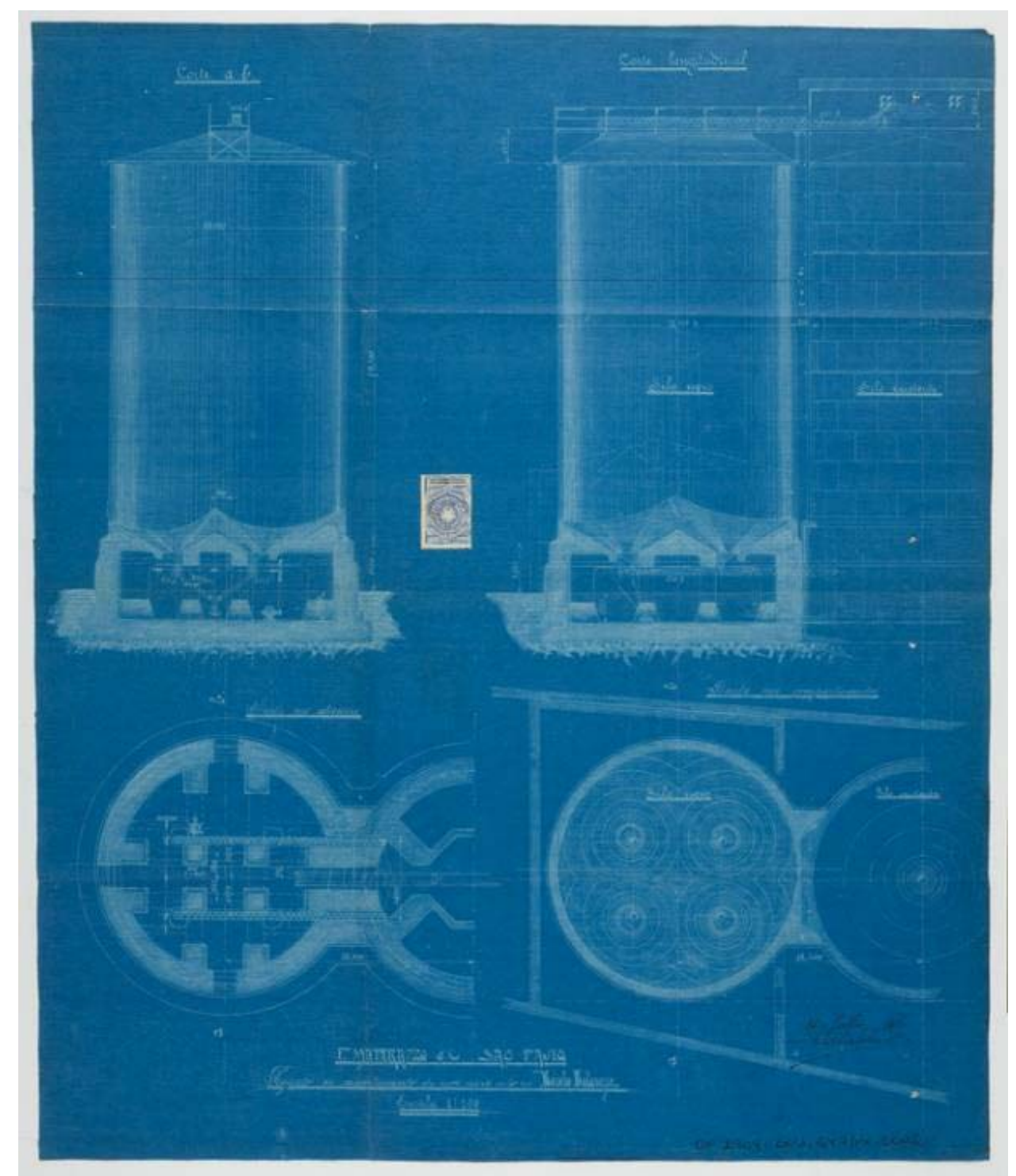

Figura 141: "F. Matarazzo \& C. São Paulo - Projeto de assentamento de um silo do Moinho Matarazzo" Arquivo Histórico Municipal, Fundo “Diretoria de Obras”, Série “Obras Particulares”, OP1909.001.647.

Dividido em quatro seções, a primeira era dedicada à limpeza do trigo por máquinas de peneirar, separar e escolher. Na segunda seção, as máquinas de lavagem e enxugo realizam o trabalho, que era repassado para uma balança automática para pesar 500 kilos de cada vez, onde o trigo seria armazenado num depósito que comportava pelo menos 360 toneladas. Já na terceira seção, o serviço de moagem se dividia em três partes: o esmagamento do grão de trigo por meio de cilindros; a limpeza da sêmola; e por fim os cilindros reduziam o trigo à farinha e farelo. Com a separação da farinha, do farelo e do farelinho, o acondicionamento era realizado por um processo mecânico em sacas que seriam depositadas com um elevador automático num espaço que permitia até 4500 toneladas de trigo, auxiliadas pelas máquinas do sistema Simon, vindas da cidade de Manchester. Em seu 
interior podia contar com os trilhos da Companhia Inglesa, empregando um total de 60 pessoas.

A partir da análise dos desenhos das edificações do Moinho Matarazzo (na rua Monsenhor Andrade) e da Fábrica de goma de arroz (na avenida Celso Garcia), percebe-se que um núcleo fabril pensado, de forma a racionalizar o sistema de produção, utilizando-se de novas formas de energia (como o carvão para a queima, e a posterior saída da fumaça pelas chaminés), pelo aproveitamento do espaço, com a construção dos silos em favor da moagem do trigo, e a posição estratégica de estarem próximas dos trilhos da estrada de ferro e do eixo da avenida Celso Garcia que facilitava a distribuição para o Brás e outras áreas da cidade.

\subsection{As padarias ocupando o cenário do Brás}

Em 27 de dezembro de 1912, 14 diferentes pedidos de construção chegaram às mãos do Diretor da Seção de Obras de São Paulo, Victor Freire, e um deles referia-se a um "Projecto de uma casa (sobrado) com armazém para padaria, sala de manipulação, forno e depósito"261, na rua Joli número 126. De propriedade de Odilon Lorenzo e Manoel Rodrigo, o projeto era assinado pelo construtor Horácio Nogueira, e, a partir do seu desenho, podemos estimar uma aproximação com o sistema de produção de pães que se realizava no Brás, e que eventualmente poderia servir de modelo para outras padarias da cidade de São Paulo, visto que muitos desses construtores não atuavam em apenas uma região, mas formavam uma rede que se espraiava pelas mais diversas ruas da pauliceia.

Enquanto no andar térreo da construção, o armazém destinado à padaria ocupava espaço privilegiado na esquina da rua Xavantes, o sistema de produção dos pães estava logo atrás, em um compartimento destinado à "manipulação" e outro para as "amassadeiras", muito próximas ao forno com sua chaminé que capturava e transferia toda a fumaça proveniente da queima do carvão. Aos fundos do terreno havia um depósito que certamente servia para armazenar a farinha de trigo. Já no primeiro andar, uma casa que não sabemos

${ }^{261}$ Arquivo Histórico Municipal, Fundo "Diretoria de Obras”, Série “Obras Particulares”, OP1912.002.605. 
se destinada a aluguel ou à moradia de um dos sócios, podia ser acessada por uma escada lateral da padaria (figura 142).

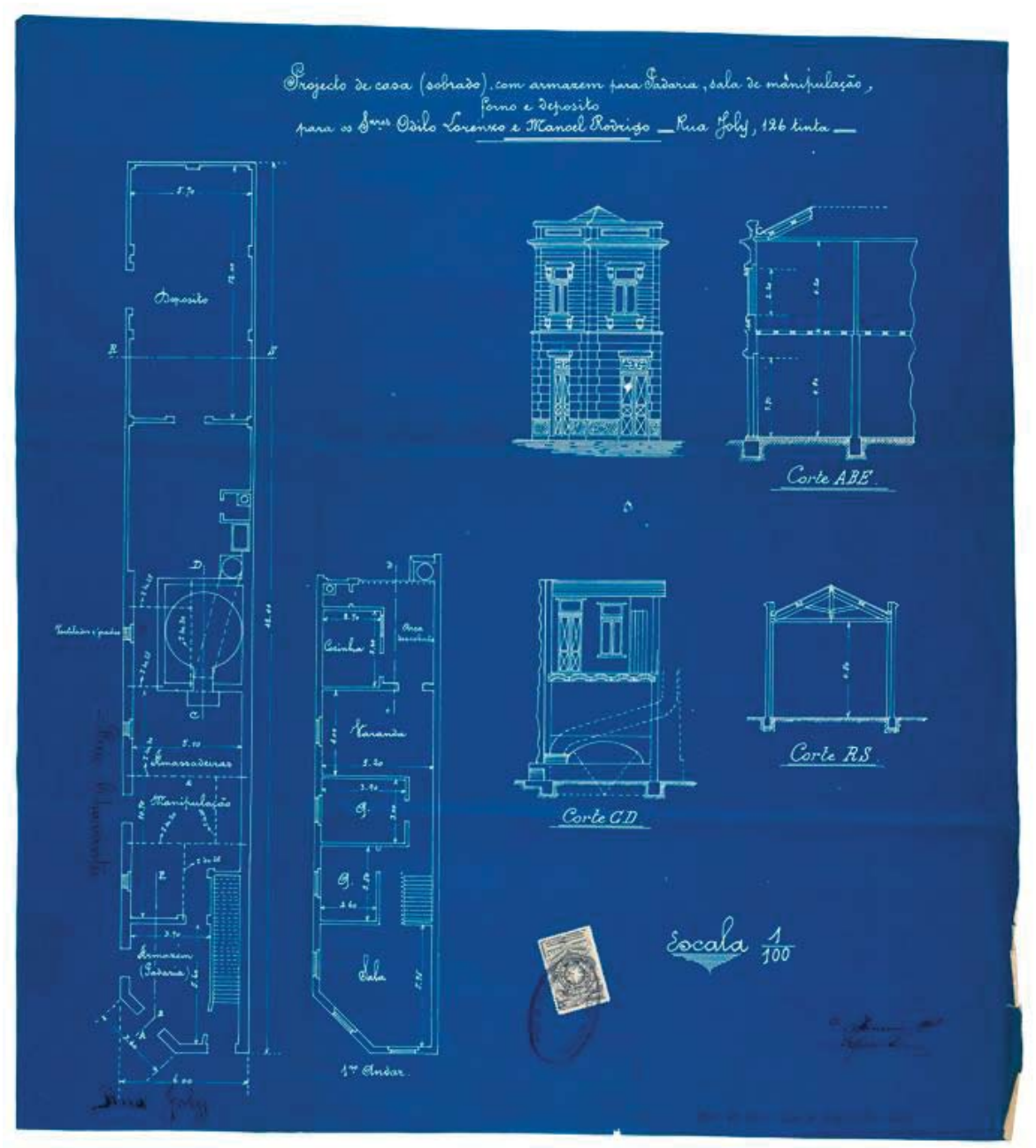

Figura 142: "Projecto de casa (sobrado) com armazém para padaria (...)”. Arquivo Histórico Municipal, Fundo "Diretoria de Obras", Série "Obras Particulares", OP1912.002.605.

Mesmo com o elevado número de armazéns de secos e molhados, trazendo em suas prateleiras os gêneros de primeira necessidade alimentar, as padarias vinham ganhando fôlego entre as ruas do Brás: 46 foram as padarias localizadas por nós a partir do mapeamento das solicitações de construção das obras particulares, bem como nos anúncios dos almanaques, estando presentes principalmente no eixo da Avenida Celso Garcia, que contava com pelo menos 23 estabelecimentos, seguida pela rua do Gasômetro com um total de 6, a Maria Marcolina com 3, Joli e Silva Teles com 2 cada, e as ruas Almirante Barroso, Azevedo Júnior, Barão de Ladário, Concórdia, Martim Burchard, Mendes Junior, Oriente, São Caetano, Vinte e Um de Abril e Visconde de Parnaíba que contavam com ao menos 1. Mas afinal, todas as padarias mapeadas seriam como as projetadas pelo construtor Horácio Nogueira, em sobrados, com divisões internas que favoreciam seu sistema de produção e de 
ventilação, situadas nas esquinas e com uma área destinada ao armazenamento da farinha de trigo?

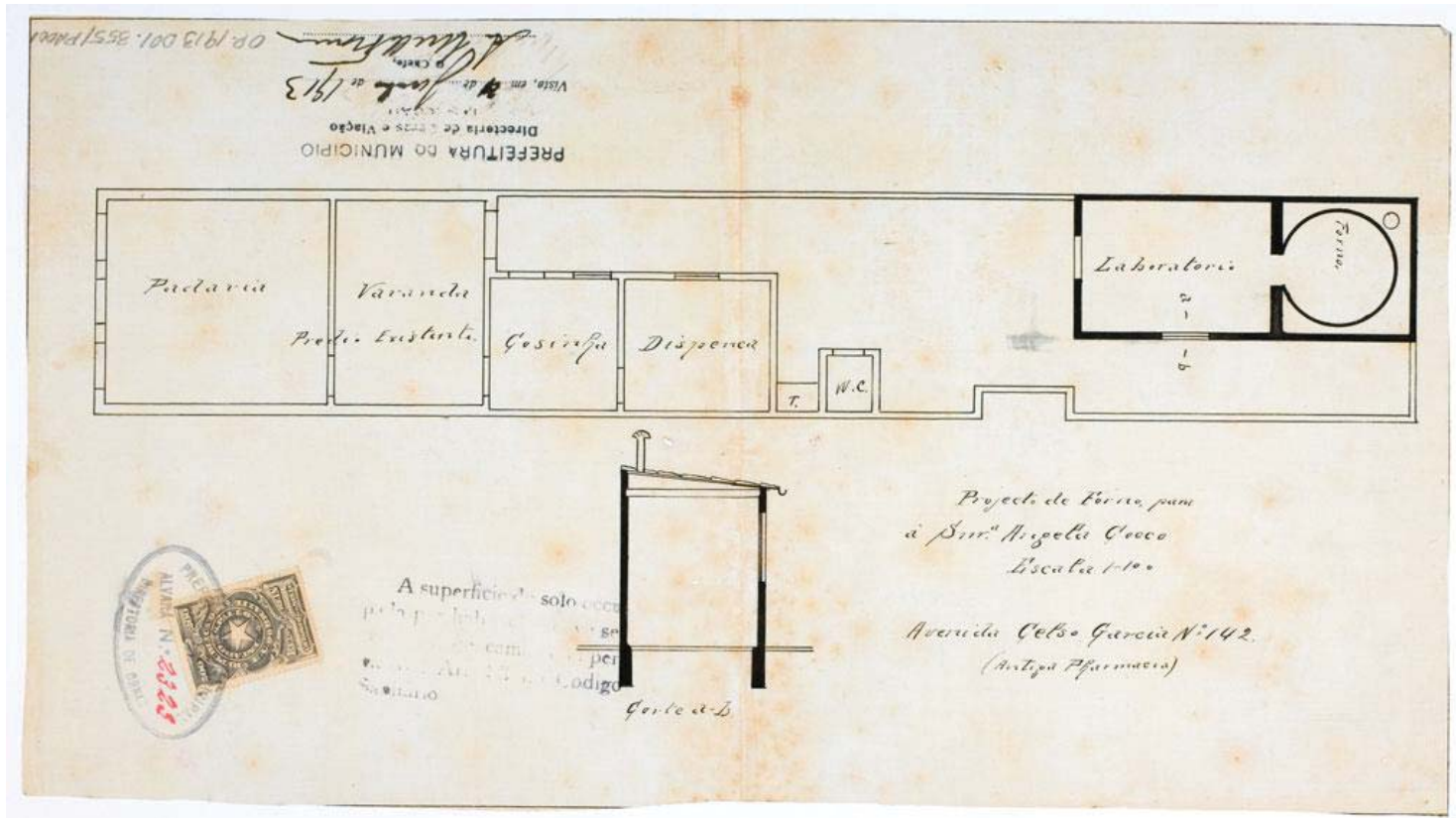

Figura 143: "Projecto de forno para a Snra. Angela Cocco", Arquivo Histórico Municipal, Fundo "Diretoria de Obras”, Série “Obras Particulares”, OP1913.001.355.

Por meio da análise dos pedidos de construção e reforma encontrados, verificamos que a grande maioria das padarias da região do Brás do começo do século XX foram implantadas a partir do aproveitamento do espaço de lotes já construídos, principalmente de casas, formando assim edifícios mistos. Enquanto o cômodo de frente à rua (uma sala ou quarto) era transformado no espaço de venda dos pães, nos fundos era projetado um depósito ou barracão para armazenamento da farinha de trigo, e um forno com o laboratório para que assim os pães pudessem ser produzidos sem que a fumaça ou sujeira adentrassem a casa à frente.

O construtor Benedicto Bettoy, em seu projeto assinado para a senhora Angela Cocco no ano de 1913, transformou o espaço anteriormente de uma farmácia em padaria, e nos fundos do lote localizado na Avenida Celso Garcia (número 142) pediu autorização da Prefeitura Municipal para edificar um forno e laboratório. Outro projeto que vai ao encontro do aproveitamento ocioso do lote, foi assinado pelo construtor Joaquim Carlos Augusto Cavalheiro e encaminhado com o título "Projecto de um forno com o respectivo galpão para uma pequena padaria”, atendendo ao pedido do Sr. Chiopedro no ano de 1913 (figura 144) . Com uma construção já existente na beirada do lote (e que presumimos ser uma casa, dada a divisão dos cômodos) na rua Oriente, número 188, o espaço que separaria a nova 
construção daquela existente era mínimo, transformando o lote de uso estritamente residencial, para uso misto.

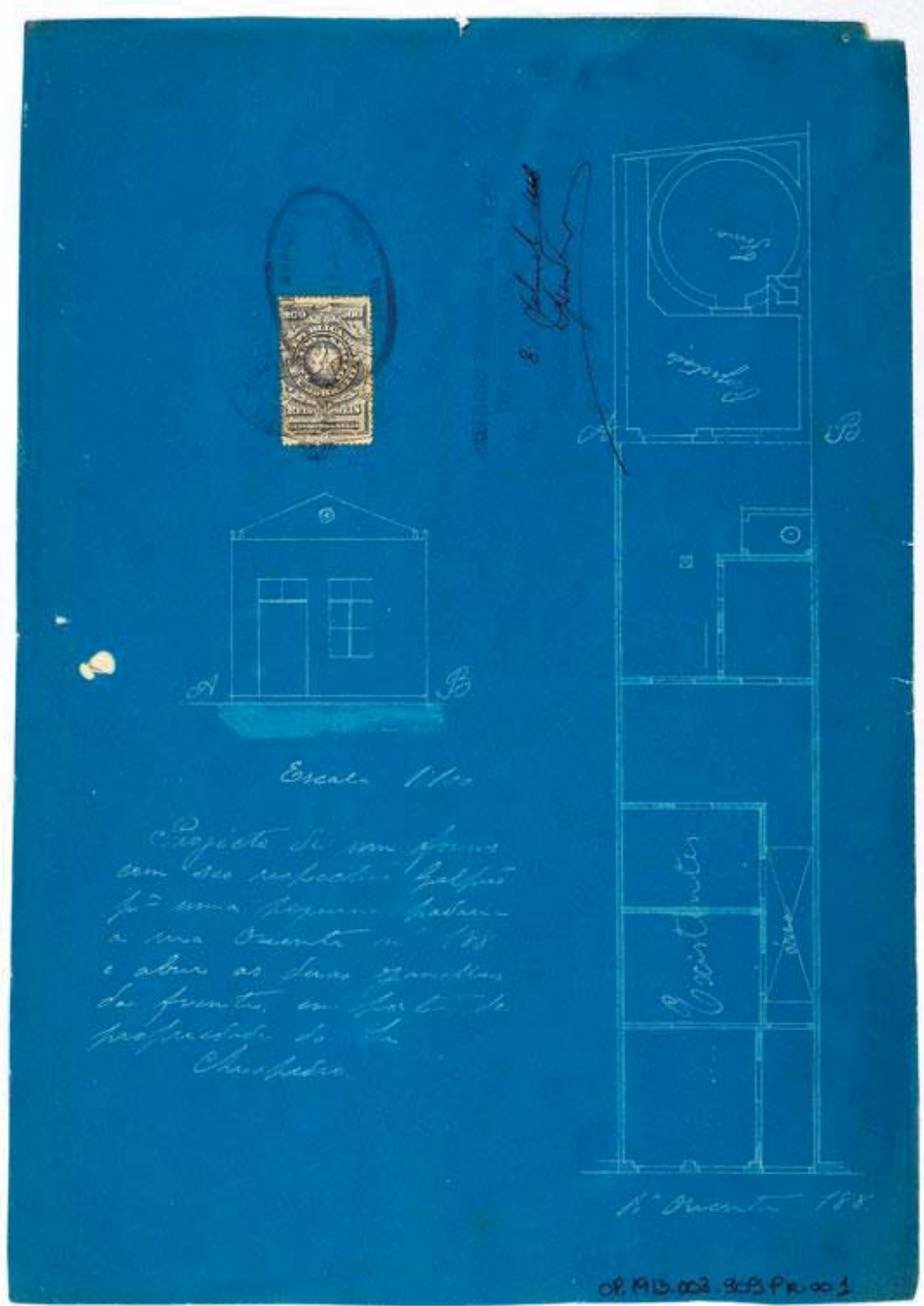

Figura 144: "Projecto de um forno com seu respectivo galpão [...]”. Arquivo Histórico Municipal, Fundo "Diretoria de Obras", Série "Obras Particulares", OP1913.003.909.

Esse processo de ocupação intensiva dos lotes pode ser entendido a partir de duas chaves: uma primeira em que a posse da terra se dava por poucas pessoas e o acesso a ela era estritamente dificultado; e a segunda que, aqueles que podiam adquirir tais lotes, aproveitavam-no ao máximo, dado este que Raquel Rolnik pontuou com muita perspicácia. Para a autora, mesmo o Brás tendo se tornado "um dos primeiros subúrbios populares, onde se constituiu um forte e emergente mercado de imóveis para armazéns, manufaturas, casas e cômodos de aluguel"262, a valorização foi tal, que bairros próximos como o Belenzinho,

${ }^{262}$ ROLNIK, Raquel. Op. Cit., pág. 115 
além de poderem "garantir um alto e imediato retorno do investimento, beneficiar-se-ia da valorização futura do bairro, quando a fronteira se deslocasse para mais adiante e o bairro contasse com as infraestruturas que os outros pontos da cidade já possuíam àquela data $[1916]^{263}$. O processo de implantação das padarias no Brás é um exemplo claro da não disponibilidade de terrenos para uma parcela da população que tinha rendas flutuantes e, não podendo dispor de outro imóvel para estabelecer seu negócio, preferindo associar moradia e trabalho no mesmo local, caracterizando indícios da formação de abairramento da cidade já no começo do século XX, e que pode ser observado em diferentes outras porções da capital paulista de além Tamanduateí, como o Belenzinho, Penha e Móoca. A configuração de bairros próprios para as camadas baixas e mesmo para os setores médios que ali também residiam, mostra-se como uma fronteira móvel no processo de formação e expansão da cidade moderna paulistana, que encontra em determinados espaços chances de se implantar e deixar demarcado o uso social daquele espaço, visto que poucos eram aqueles que conseguiam a utilização de um imóvel para seu uso como comércio que não fosse conjugado à sua própria moradia, como o caso das padarias em questão.

Dentre os 11 projetos de obras particulares referente a padarias no Brás, apenas dois são de construções em lotes anexos a construções já existentes, sendo os demais construídos nos fundos de outros lotes e quase sempre suprimindo o cômodo frontal. Um deles, localizado na rua Barão de Ladário número 65, na esquina da rua Mixta, ${ }^{264}$ de propriedade de Miguel Antonio Ferreira, solicitou em 15 de maio de 1913 a autorização para um "Projecto de padaria" (figura 145). Outro, também, intitulado "Projecto de uma padaria", localizava-se na rua Almirante Barroso número 76, sendo Domingos Alterio o proprietário do terreno de aproximadamente $647 \mathrm{~m}^{2}$, com uma área de pelo menos $437 \mathrm{~m}^{2}$ livre, visto que o restante era ocupado por um prédio já existente (figura 146). Comparando com o tamanho da grande maioria dos lotes da região do Brás, pode-se aferir que o tamanho deste terreno foge do padrão local, e mesmo assim, a construção da padaria se daria nos fundos, deixando uma grande área livre para futuras construções.

\footnotetext{
${ }^{263}$ Idem, pág. 121

${ }^{264}$ Atual rua Júlio Ribeiro.
} 


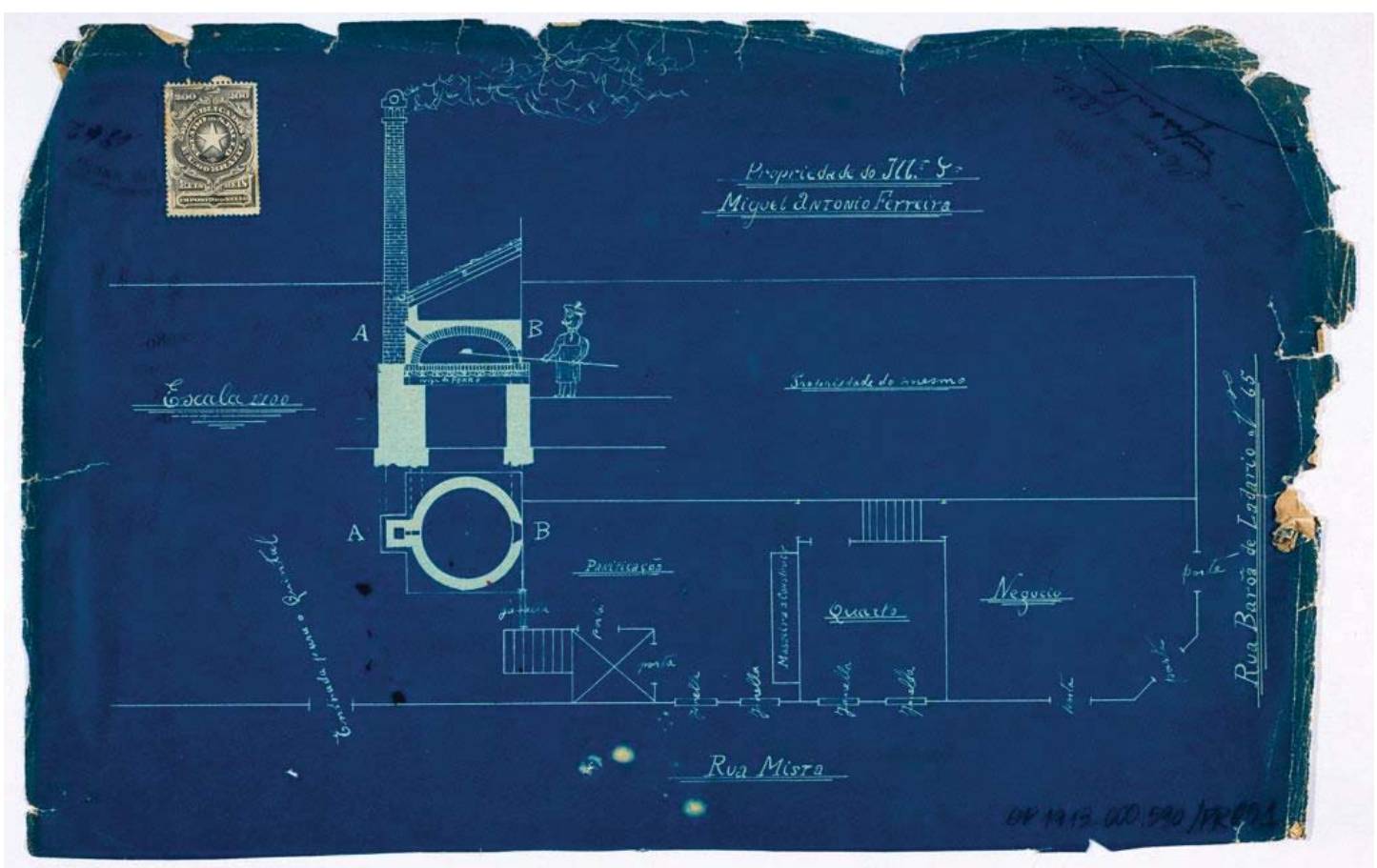

Figura 145: "Propriedade do Illm. Snr. Miguel Antonio Ferreira”, Arquivo Histórico Municipal, Fundo "Diretoria de Obras", Série “Obras Particulares", OP1913.000.590.

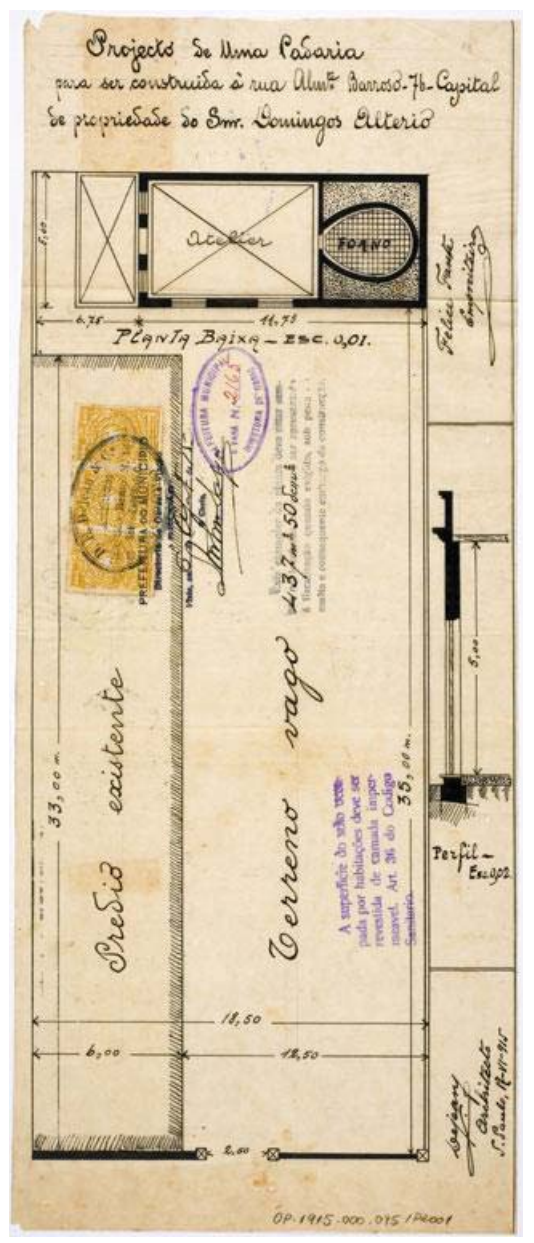

Figura 146: "Projecto de uma padaria para ser construída á rua Almt. Barroso - 76 - Capital de propriedade do Snr. Domingos Alterio", Arquivo Histórico Municipal, Fundo "Diretoria de Obras", Série "Obras Particulares, OP1915.000.075. 


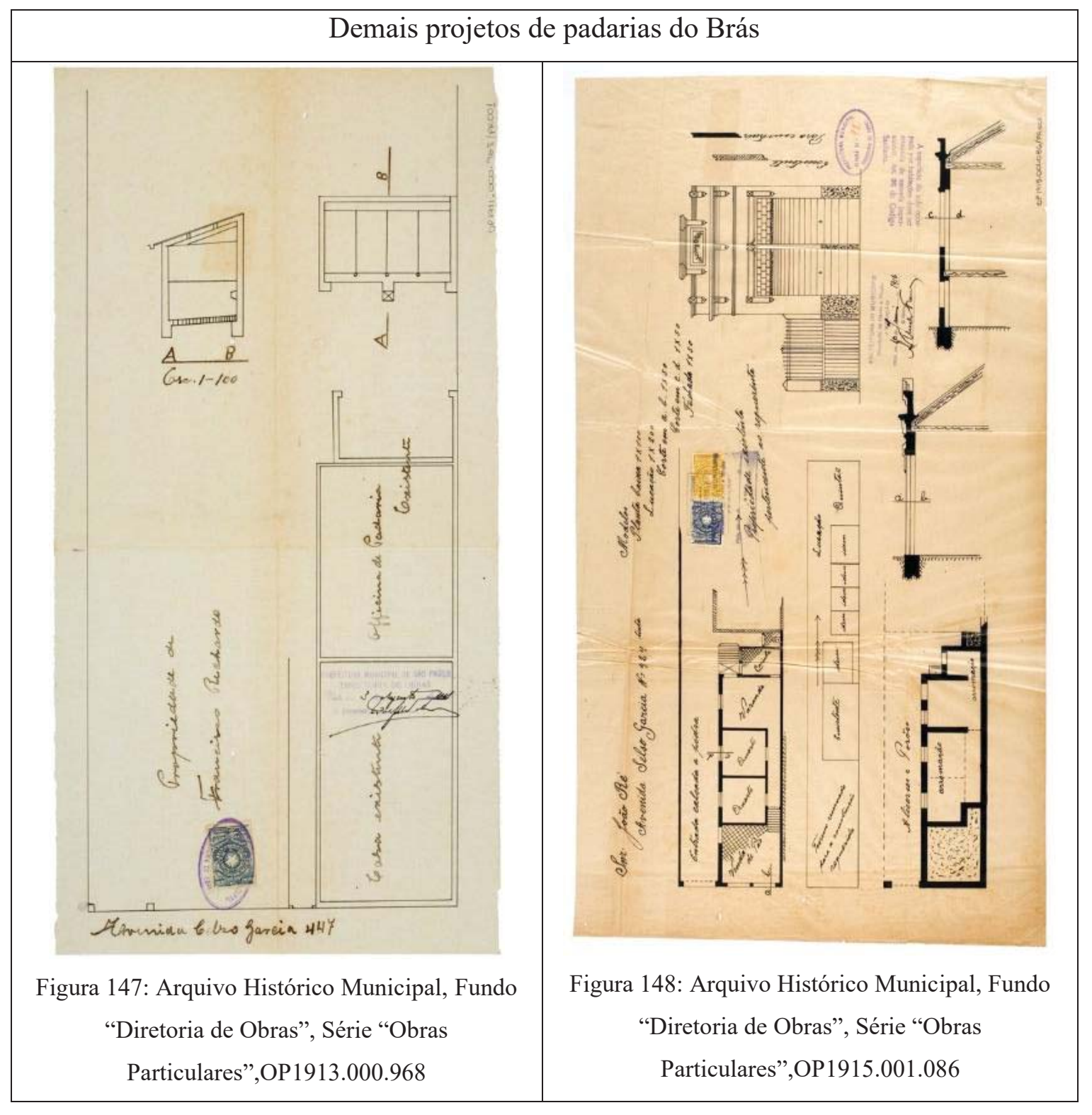




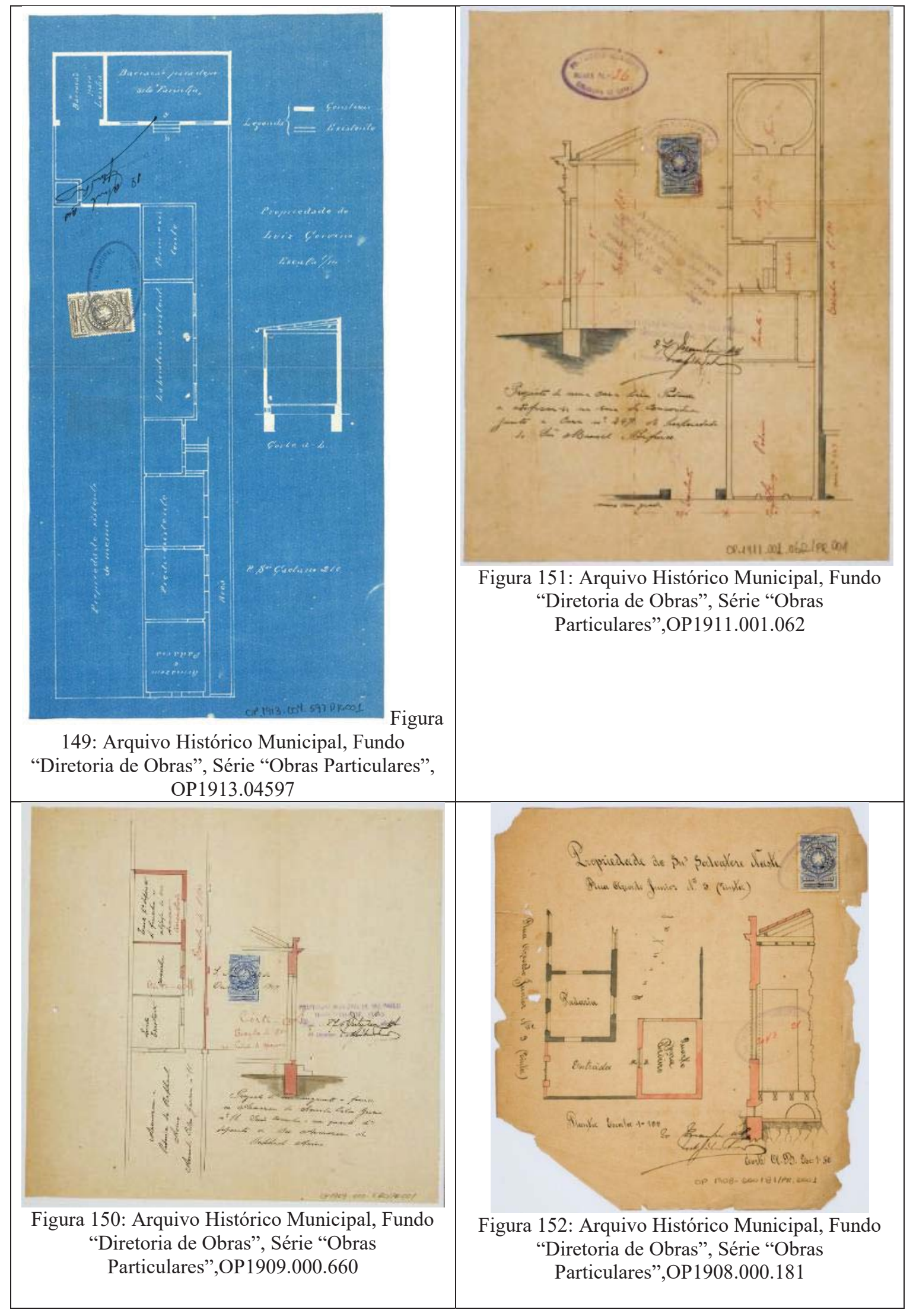




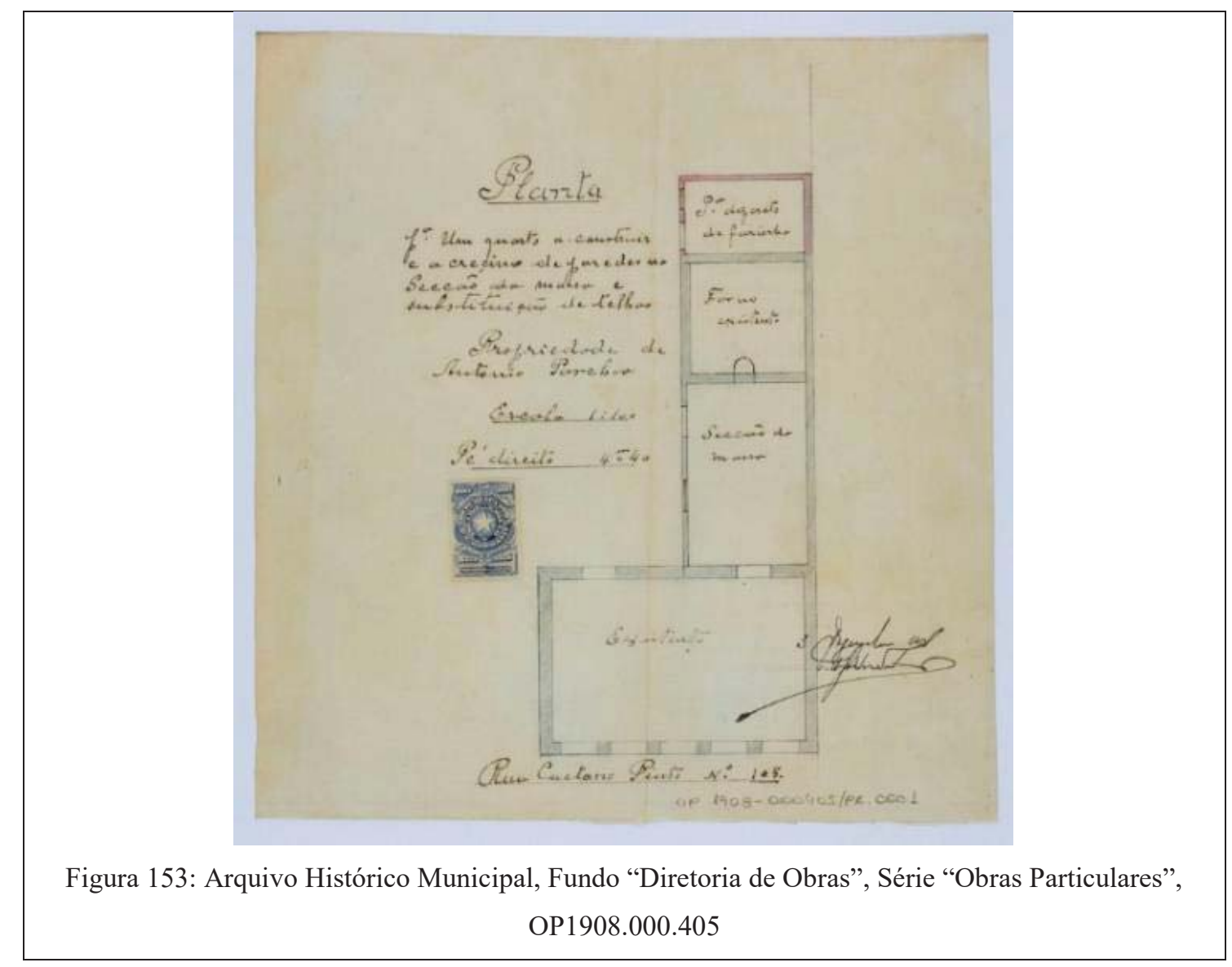

3.6 Entre as confeitarias, doces e os cafés: espaços de sociabilidade e lazer no Brás

Enquanto as padarias predominavam na Avenida Celso Garcia, na Avenida Rangel Pestana outro estabelecimento comercial ganhava vida: as confeitarias. Dedicadas à venda de doces, bebidas e guloseimas, em geral a quase totalidade das confeitarias mapeadas no Brás localizavam-se na via que dava entrada ao bairro, especialmente nas proximidades da Estação do Norte e do Largo da Concórdia.

Interessante notar que enquanto nos almanaques abundavam os anúncios da existência de confeitarias, nos pedidos de construção ou reforma, não se viu qualquer referência a esse tipo de estabelecimento comercial. Desta forma, procuramos relacionar essas duas séries documentais com outras que fornecessem subsídios para um melhor mapeamento e espacialização das confeitarias.

16 foram as confeitarias mapeadas, sendo que apenas uma situava-se fora da Avenida Rangel Pestana, no Largo da Concórdia número 24, de propriedade de Antonio 
Martins Salgado ${ }^{265}$, a única com telefone (número 3434). A partir do mapeamento da numeração dos edifícios, verificamos uma transformação nos usos deste espaço ao longo do tempo. Nosso banco de dados sobre os almanaques, ordenou lote a lote as construções e suas mudanças ao longo do tempo, registrando os novos usos que os imóveis receberam, bem como seus novos proprietários. Ao que tudo indica, apenas quatro das confeitarias listadas em nossa temporalidade (1897-1915) foram desde o início na mesma edificação inicial; as demais, serviram anterior ou posteriormente de armazéns de secos e molhados, bares, casas de café moído e torrado, casas de fumos e até mesmo chapelaria antes de se tornarem confeitarias, como no número 199 da avenida Rangel Pestana, que entre 1901 e 1908 passou a se dedicar a tal especialidade no lugar da venda das guloseimas, tendo à frente Carmine Pastore, mas parece não ter vingado, repassando o imóvel para que outro estabelecimento fosse montado (por Zeferino Baussoti, uma loja de móveis e colchões) ${ }^{266}$.

Um anuncio do jornal O Estado de São Paulo veiculado em 25 de março de 1915 oferece algumas pistas de como as confeitarias seriam espaços de sociabilidade de determinadas parcelas da população, e auxiliaram no processo de requinte e valorização da avenida Rangel Pestana. O anúncio da bebida Bohorques, do espanhol Jerez-Quina menciona que ela podia ser encontrada em diversos cafés, confeitarias e espaços dedicados ao desfrute de bebidas como bares e empórios, porém, a grande maioria dos endereços refere-se a espaços localizados na porção central da cidade e, apenas dois deles situam-se fora dali, ambos na avenida Rangel Pestana. O chamado "aperitivo tônico dos soberanos", o jerez ${ }^{267}$ ora comercializado, referia-se ao importado da firma de Eduardo Bohorques Carrasco, espanhol da cidade de Ubrique e que, desde 1885 exportava vinhos para todo o continente Americano, Oriente Médio, Índia, Austrália e Japão. ${ }^{268}$ Ao ser privilegiado em ser comercializado quase que em sua totalidade na região central de São Paulo, estar disponível em uma confeitaria e um empório da região do Brás demonstra que pessoas desta região poderiam consumi-lo. A Confeitaria e Café Portuense, na avenida Rangel Pestana número 239, bem como o Empório Concórdia, situado na mesma avenida no número 273, eram os dois espaços que vendiam a requintada bebida e faziam parte de um conjunto de outros estabelecimentos do Brás que atendia determinada parcela populacional mais

\footnotetext{
${ }^{265}$ Almanaque Laemmert, anos de 1913 e 1914.

${ }^{266}$ Idem, anos de 1901 e 1908.

${ }^{267}$ Em português xerex, refere-se à um tipo de vinho fortificado, licoroso, produzido entre as cidades de Cádis e Sevilha na Espanha, envelhecido no sistema de soleira, mas também a um tipo de uva branca da região da Andaluzia.

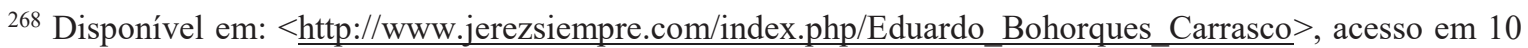
de janeiro de 2017.
} 
refinada e de maior poder aquisitivo, destacando-se dos demais espalhados pelas ruas do bairro.

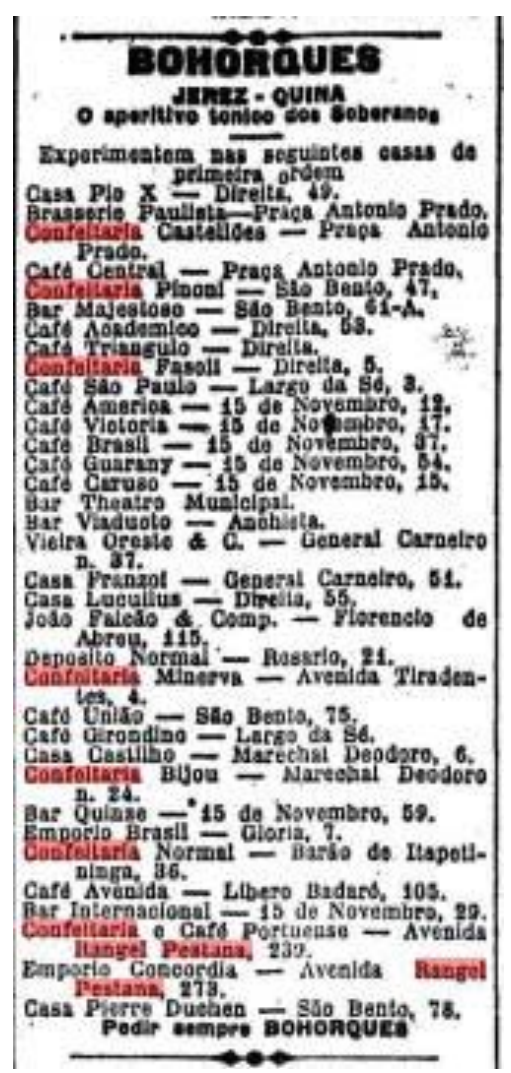

Figura 154: Anúncio da bebida "Bohorques" no jornal O Estado de São Paulo, edição de 25 de março de 1915.

As confeitarias ocupavam, assim, um espaço privilegiado na sociedade paulistana, e no Brás pode-se perceber que se situavam numa avenida que dava acesso imediato à estação de trens, bem como a lojas de outros artigos não tão facilmente encontrados no interior do bairro, como chocolaterias e cafés. Nas noites do bairro ocorriam os chamados

\footnotetext{
"footing, também conhecido no bairro como "tirar linha": os rapazes caminhando de um lado da rua e as moças de outro; nesse flanar, olhares discretos ou fulminantes eram dirigidos à pessoa interessada, mas raramente iniciavam uma conversa. O trajeto começava na avenida Celso Garcia, passando pela Caetano Pinto, indo até às porteiras, tendo como ponto central a Matriz e a Confeitaria Guarany. Esta confeitaria marcou época no Brás. Era o ponto elegante da época, sendo que nela funcionava gratuitamente um cinema"269.
}

269 RIBEIRO, Suzana Barretto. Italianos do Brás: Imagens \& Memórias (1920-1930). Dissertação (Mestrado em Multimeios). Instituto de Artes da Unicamp. Campinas: Universidade Estadual de Campinas, 1994, pág. 62 
A Confeitaria Guarany polarizava a vida do bairro, abrindo às oito horas da manhã e só fechava quando o último freguês saísse satisfeito, atendido pelo proprietário Emílio Siniscalchi, sua esposa, dona Vitória, ou um dos filhos, Dante ou Fiori. Lá, os fregueses podiam comer

\begin{abstract}
"panettone, pasticcera, cepolla di São Giuseppe, feita especialmente para o dia de São José, pasta reale, feita de amêndoa em formato arredondado ou de coração, cobertos com glacê branco, turron, torrone e torrentino; (...) sorvetes com sabores e consistências diferentes, com a cassata e o de torreone. As pessoas sentavam, comim um doce acompanhado de Ceci, gasosa ou cerveja." ${ }^{270}$
\end{abstract}

No processo de busca das confeitarias no Brás a partir do jornal O Estado de São Paulo, nos deparamos com a seguinte notícia:

Tentativa de suicídio

Julia Mancoso, de 19 annos, moradora á Avenida Rangel Pestana, onde é empregada na Confeitaria Guarany, por uma desintelligencia que teve na casa dos patrões, ás 11 horas e meia da manhan de hontem, ausentou-se dalli e tomou a direção da várzea do Carmo, onde, ai chegar numa das margens do Tamanduatehy, precipitou-se no rio, tentando suicidar-se.

A tresloucada moça foi salva e depois entregue a pessoas de sua família que foram chamadas para acompanhal-a..$^{271}$

Apesar da aura que parecia revestir as confeitarias, por serem espaços privilegiados de determinados setores da população, não parecia existir um convívio amistoso entre patrões e empregados ao menos neste caso envolvendo a Confeitaria Guarany. Aliás, as relações do proprietário da confeitaria, Emilio Siniscalchi, pareciam não ser das mais amistosas. Natural da cidade de Benevento, na Itália, Siniscalchi havia trabalhado na Confeitaria Caplice, e em São Paulo como confeiteiro da Castelões, filial da matriz fluminense instalada no Largo do Rosário ${ }^{272}$.

\footnotetext{
${ }^{270}$ Idem.

271 Jornal O Estado de São Paulo, edição de 31/05/1913.

272 BARBUY, Op. Cit., pág. 125; e RIBEIRO, Op. Cit., pág. 87-88.
} 
Completo sortimento de doces finos de todas as qualidades

fabrics dos diariamente. Recebe-se eqcommendas

para casamentos baptisados, etc. á prejos

reduzidos

N. B. -O proprietario d'este estabelcimento foi 4

annos contra mestre na bem

conhecida casa Paulicéa desta capital e 14 annos na

casa Danozze em Naroles.

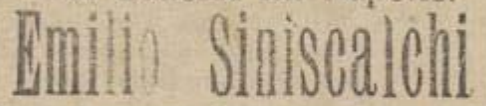

Aveatda Rivagel IPestana, 112 (Braz)

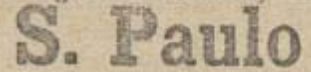

Figura 155: Anúncio da "Confeitaria Guarany”, Arquivo do Estado de São Paulo, Jornal O Braz, edição de 22 de outubro de 1902.

Em 1902, Emílio Siniscalchi fundou sua própria confeitaria, a Confeitaria Guarany, na Avenida Rangel Pestana número 112, produzida “com balcões, piso e mesas de mármore de Carrara" 273 , e como forma de trazer novos clientes e fidelizar aqueles já acostumados a frequentar seu espaço, oferecia espetáculos cinematográficos gratuitos. Ida Siniscalchi, filha do proprietário, "conta que frequentava pouco a confeitaria durante a semana, mas aos sábados não perdia uma sessão de cinema" ${ }^{\text {274 }}$, que ele ficava lotado, sendo seu irmão quem alugava as fitas envoltas em latas. Com a confeitaria lotada, eram exibidos filmes de caubói, filmes italianos, americanos, comédias e dramas, e por não conter som, um pianista do bairro (João Portaro) era contratado para fazer os sons dos filmes, tocando "composições próprias, valsas, maxixe e foxtrote, variando conforme o assunto da fita" ${ }^{275}$.

Para que o filme pudesse ser projetado, era improvisada uma grande tela com um pano, molhado a cada intervalo entre uma fita e outra, para que não pegasse fogo ${ }^{276}$.A ideia do cinema provinha desde pelo menos 1909, quando Emílio Siniscalchi encaminha um pedido de licença à Prefeitura para oferecer "espetáculos com cinematógrafo com o fim de divertir sua freguesia sem cobrar entrada". Segundo o historiador José Ignácio de Melo Souza,

\footnotetext{
${ }^{273}$ RIBEIRO, Idem.

${ }^{274}$ Idem.

${ }^{275}$ Idem.

${ }^{276}$ Idem.
} 
“o confeiteiro era morador do Brás pelo menos desde 1900 (...). Outro possível parente, Ernesto, tinha refinação de açúcar na avenida Tiradentes, 120, em fevereiro de 1901, e Pasquale Siniscalcho tinha uma padaria na rua da Consolação, 203, em 1909. Emílio foi um pequeno acionista do Banco Italiano del Brasile em 1905."277

Em abril de 1909, Emilio Siniscalchi entrou com um novo pedido de licença na Prefeitura, desta vez, com a intenção de cobrar os ingressos de sua clientela, "subentendendo-se que a experiência das exibições gratuitas fora atraente para o estabelecimento" 278 . O processo, que chegou ao chefe da Diretoria de Obras, José de Sá Rocha, fora impugnado em 30 de abril daquele ano, alegando que tratava-se "de um prédio que não reúne as necessárias condições para o fim que se tem em vista. Posso mesmo acrescentar que me consta ter havido há tempo já ali um princípio de incêndio ou cousa equivalente $[\ldots]$ ”. Contudo, o confeiteiro não se sentindo satisfeito, continuou com suas exibições, sendo multado cinco dias após a resposta dada por Sá Rocha. Procurando regularizar sua situação,

\footnotetext{
“apresentou-se à Diretoria de Obras e Viação disposto a empreender as reformas indicadas pela Prefeitura de forma a adequar a Confeitaria Guarani aos ditames da segurança do público. Sá Rocha, porém, mostrou-se irredutível já que as obras deveriam ser "radicais". Para ele, tendo em vista "[...] tratar-se de um prédio velho, em desacordo com o padrão e encaixado entre outros prédios igualmente velhos. Há pouco tempo pelos mesmos motivos foi indeferido idêntico pedido para a rua Barão de Itapetininga" ${ }^{279}$.
}

Sá Rocha solicitou assim uma planta que detalhasse as mudanças necessárias no prédio, e em quatro dias a mesma chegou em suas mãos. Siniscalchi depositou o memorial descritivo das obras que assim pudessem garantir a segurança dos espectadores do cinema e clientes da confeitaria: “1) colocação do projetor no fundo do espaço destinado ao público com a distância de 10 metros da primeira fila de cadeiras; 2) seguro do prédio e dos

\footnotetext{
277 Souza, José Ignacio de Melo. Inventário dos espaços de sociabilidade cinematográfica da cidade de São Paulo $\quad$ (1895-1929). $\quad$ Disponível em: $\quad<$ http://www.arquiamigos.org.br/bases/cine3p/historico/00144.pdf $>>$, acesso em 10 de janeiro de 2017. ${ }^{278}$ Idem.

${ }^{279}$ Idem.
} 
projetores em duas companhias; 3) o requerente estava disposto a empreender outras alterações pedidas pela Prefeitura." 280

Sá Rocha continuava irredutível, declarando em 18 de maio que

“Ainda uma vez mantenho as anteriores informações. As alegações atuais do requerente em minha opinião não procedem. O perigo para o público não consiste 'exclusivamente' como parece supor o requerente na maior ou menor distância a que esteja situado o aparelho cinematográfico, mas depende de muitas outras circunstâncias peculiares ao próprio prédio. As provas de seguro do prédio nada provam relativamente à segurança e comodidade do público". ${ }^{281}$

O debate entre Sá Rocha e Emilio Siniscalshi continuou. Uma nova planta fora apresentada ao engenheiro da prefeitura, alegando que a separação entre a sala de espera e a de sessões devia ser melhorada, assim com a circulação entre o público que saía e o que adentrava à sala. Segundo José Inácio, a lotação de 110 pessoas por sessão era conveniente, no entanto, Sá Rocha alertava que a vistoria antes da inauguração do cinema é que seria determinante para a confirmação da propriedade das medidas tomadas pelo proprietário durante a reforma, dando fim ao imbróglio entre ambos.

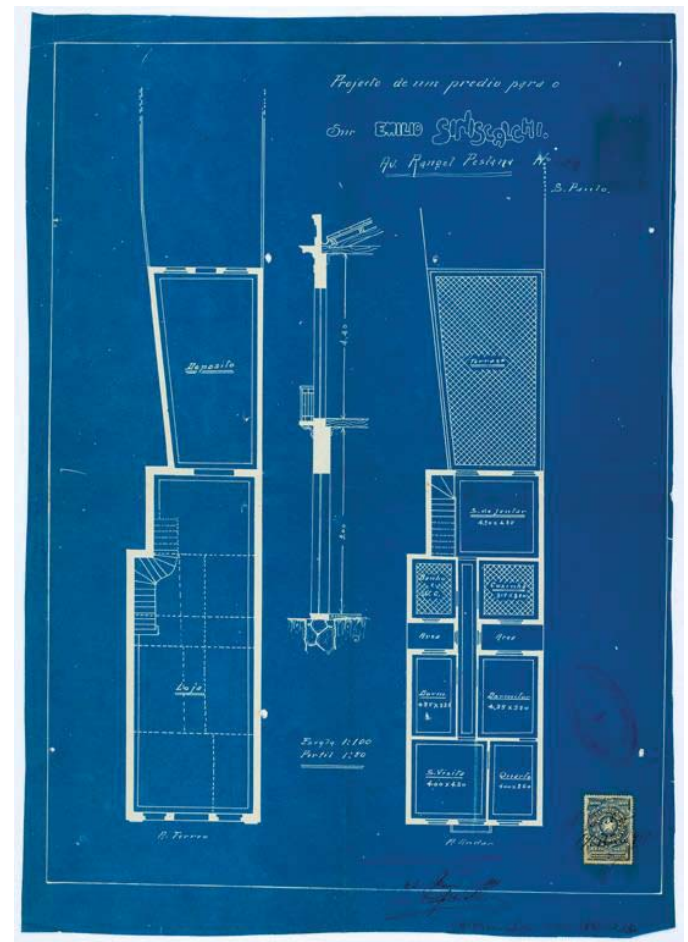

Figura 156: "Projecto de um prédio para o Snr. Emilio Siniscalchi”, Arquivo Histórico Municipal, Fundo “Diretoria de Obras”, Série “Obras Particulares”, OP1911.002.933.

${ }^{280}$ Idem.
${ }^{281}$ Idem. 


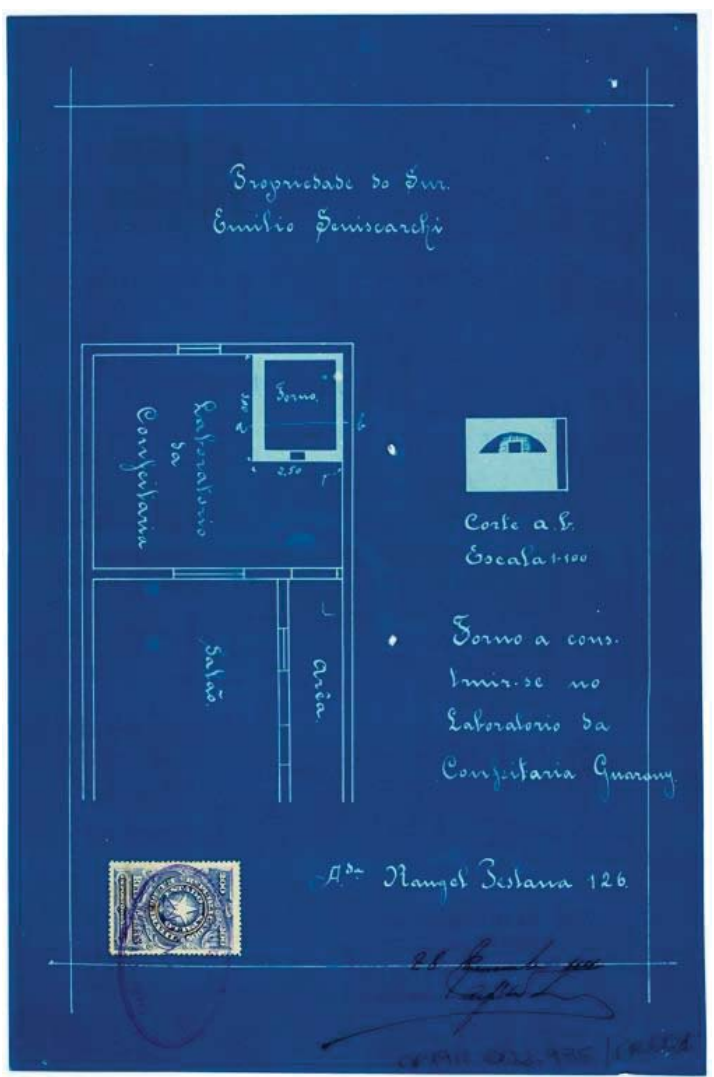

Figura 157: "Forno a construir-se no Laboratorio da Confeitaria Guarany", Arquivo Histórico Municipal, Fundo "Diretoria de Obras", Série "Obras Particulares, OP1911.002.935.

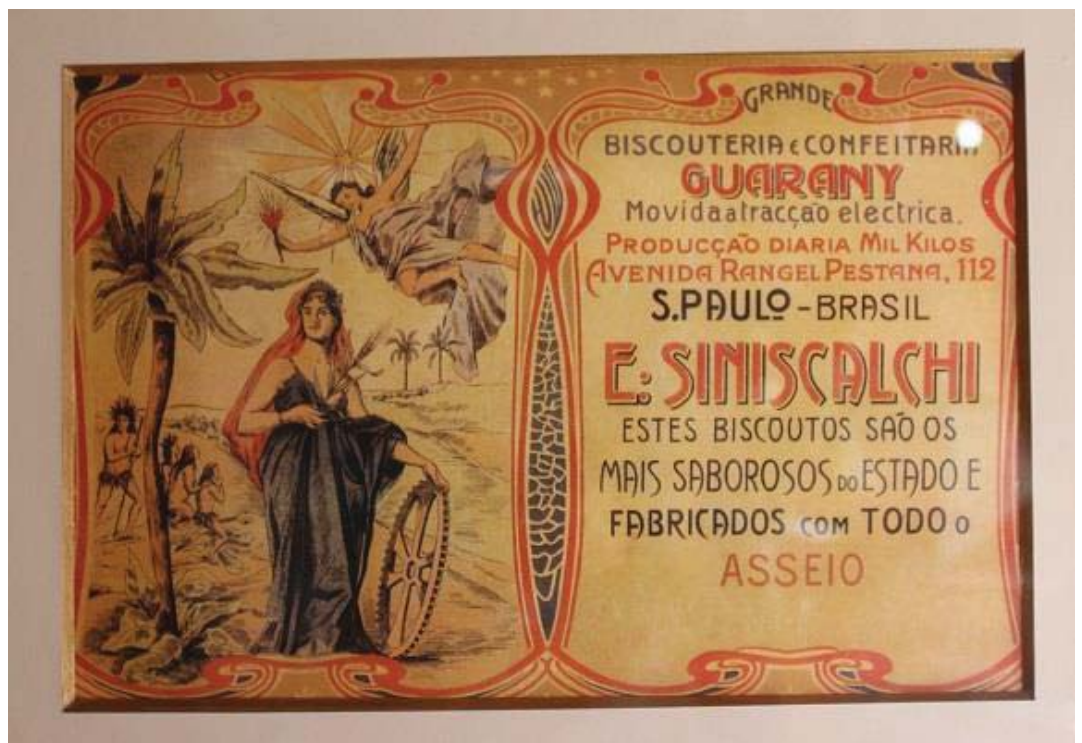

Figura 158: Cartaz da “Confeitaria Guarany”, começo do século XX, Acervo Fábio Donato. Foto do autor.

Em 1911, Emilio Siniscalshi e sua família mudariam do número 112 para o 126 da Avenida Rangel Pestana, e continuaram até pelos menos o ano de 1921 no ramo da gastronomia, com a Confeitaria Guarany permanecendo aberta até a década de 1960, quando o prédio seria transformado numa agência bancária. Ainda na década de 1920, seu genro 
abriu uma das primeiras pizzarias com forno à lenha na cidade, a Pizzaria Castelões, localizada na rua Jairo Góis, também no bairro do Brás, e que continua a funcionar até os dias de hoje, podendo ser a mais antiga em funcionamento da cidade. Segundo Fábio Donato, atual proprietário da Pizzaria Castelões, a história da pizzaria se confunde com a história da confeitaria, visto que seu bisavô, Giovanni Donato (italiano que chega no Brasil logo após a abolição da escravatura e vem trabalhar como oficial sapateiro da fábrica Spina) morava com seu irmão Ettore Donato (confeiteiro italiano) em cima da Confeitaria Guarany. Ettore, idealizador de um bolo inspirado na ópera O Guarani, de Carlos Gomes, garantiu o primeiro lugar num concurso mundial de confeiteiros e casou-se com uma das filhas de Emilio Siniscalchi. Da união, surge a atual Pizzaria Castelões, nome inspirado em um dos times de futebol que disputavam partidas num dos muitos campos da Várzea do Carmo.

O atual edifício da pizzaria remonta a princípios de 1900, construído com tijolos de 35 centímetros, uma adaptação de duas casas que virou o grande salão de atendimento ao público, sofrendo duas grandes intervenções: uma em 1935 e a outra na década de 1940.

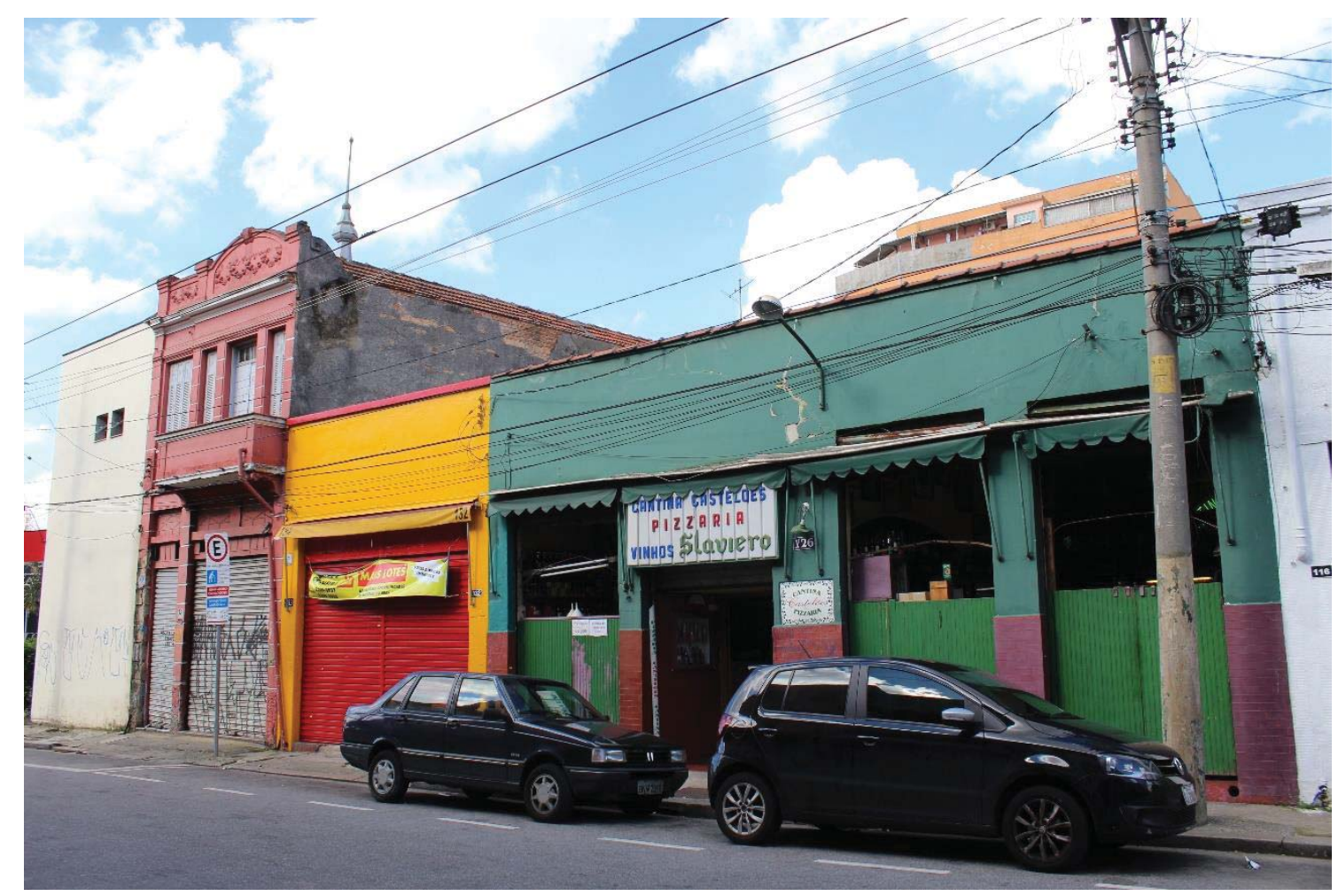

Figura 159: A Pizzaria Castelões, possivelmente a mais antiga da cidade em funcionamento até os dias atuais. Foto do autor, 25 de janeiro de 2017. 


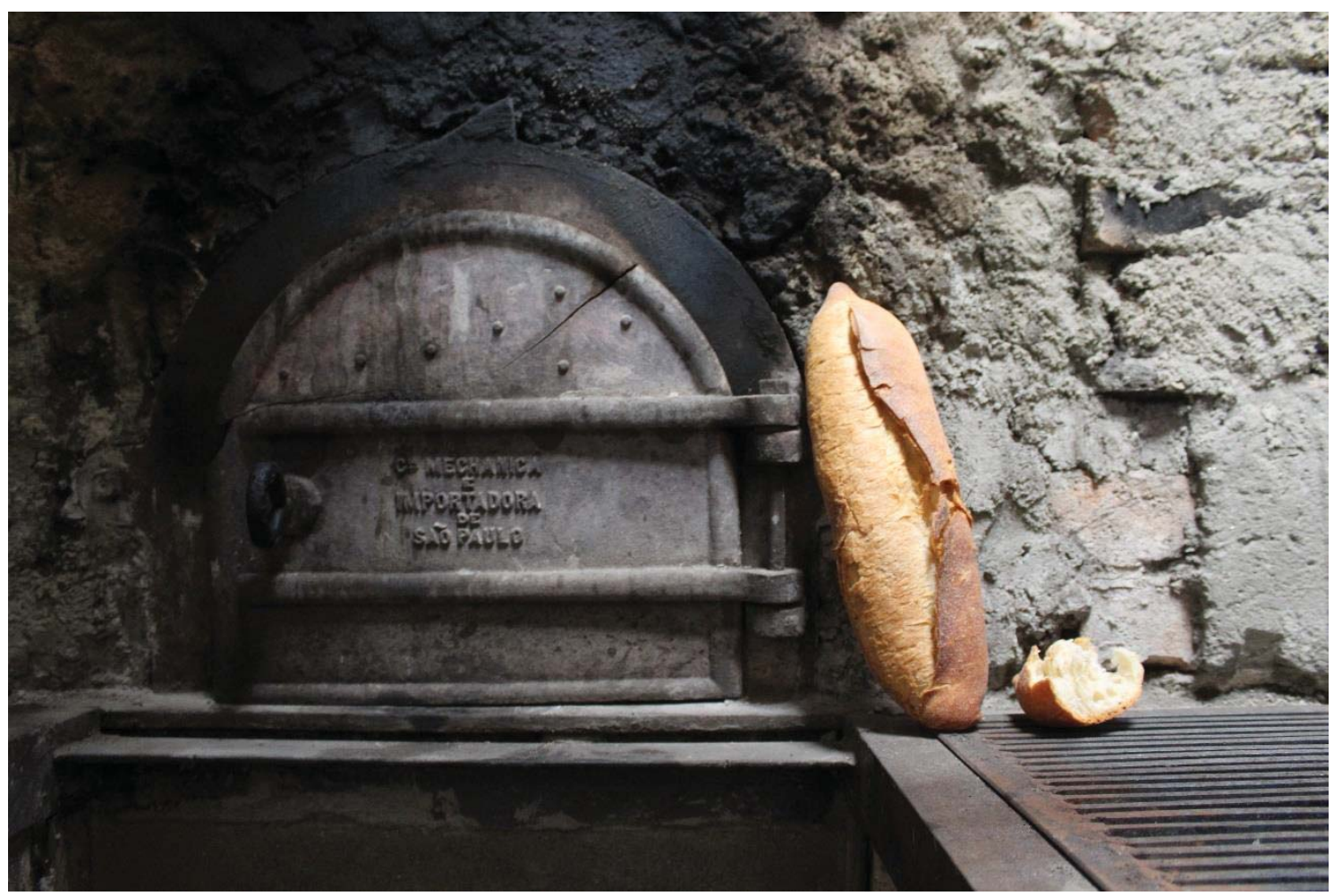

Figura 160: Forno a lenha da Pizzaria Castelões, com porta de ferro produzida pela Companhia Mechanica e Importadora de São Paulo. Foto do autor, 25 de janeiro de 2017.

Não apenas as confeitarias demonstravam o grande interesse nas vendas de doces e bolos para aqueles que habitavam, trabalhavam e estudavam no Brás. As fábricas de doces estavam espalhadas por várias ruas do bairro, especialmente em locais estratégicos, com fácil acesso às principais vias de comércio da região. Só no Largo da Concórdia encontramos duas fábricas de doces: no número 47 a fábrica de chocolates e confeitos de Salvador Flosi \& Filho, fazia propaganda no Almanaque Laemmert nos anos de 1913 e 1914, e tendo a particularidade de poder contar com uma caixa postal nos correios (número 274) e o telefone 646, facilitando o sistema de correspondência e de comunicação, especialmente com clientes. A outra loja de doces situava-se no número 20 do Largo da Concórdia, a Doces Pires Ramos, de propriedade de Reis Ramos, anunciando no mesmo almanaque nos anos de 1908, 1909, 1913 e 1914, que, além dos tradicionais doces, produzia bolachas, chocolates e até chinelas. Sua fábrica situava-se na rua Maria Marcolina número 77 , rua que se destaca pelo elevado número de outros comércios e pela presença do bonde.

As fábricas de doces não apenas produziam, mas nos próprios estabelecimentos mantinham uma venda anexa, de modo que seus clientes tinham sempre à mão produtos frescos. Dessa forma, situarem-se em locais estratégicos era crucial para que as vendas obtivessem sucesso. Vale destacar neste caso a fábrica de doces de Antonio Pasquale, na Avenida Rangel Pestana número 86, fundada em 1901, no mesmo ano da fábrica de doces 
de Angelo Rossi, no Beco do Lucas número 20. O processo de produção de doces no Brás fora tão intenso que pudemos contar pelo menos sete fábricas até o final da primeira década do século XX. Além das citadas, a fábrica de doces de Eduardo Lourenço, na rua Barão de Ladário, sem número; a de José Araeti, situada na Avenida Celso Garcia número 61; e Souto \& Cia, na rua Sampaio Moreira número 8, todas fundadas no ano de 1909.

Não apenas doces perfaziam parte da dieta de quem circulava pelas ruas do Brás; os biscoitos tiveram presença marcante. Exemplo disso é a fábrica de José M. Gaia, na Avenida Celso Garcia. Em 07 de outubro de 1912, Gaia encaminhou um pedido para a Prefeitura Municipal a fim de construir uma casa com $225 \mathrm{~m}^{2}$, um conjunto de 12 casas operárias, sendo que cada uma mediria $40 \mathrm{~m}^{2}$ e sua fábrica de biscoitos que seria movida com motor elétrico com $580 \mathrm{~m}^{2}$ (figura 161), possibilitando o aumento de sua produção. Passado menos de um ano, em 27 de setembro de 1913, solicitou o aumento de dois cômodos no interior da fábrica de biscoitos em construção, sendo eles necessários para depósito de matéria-prima (que presumimos ser farinha).

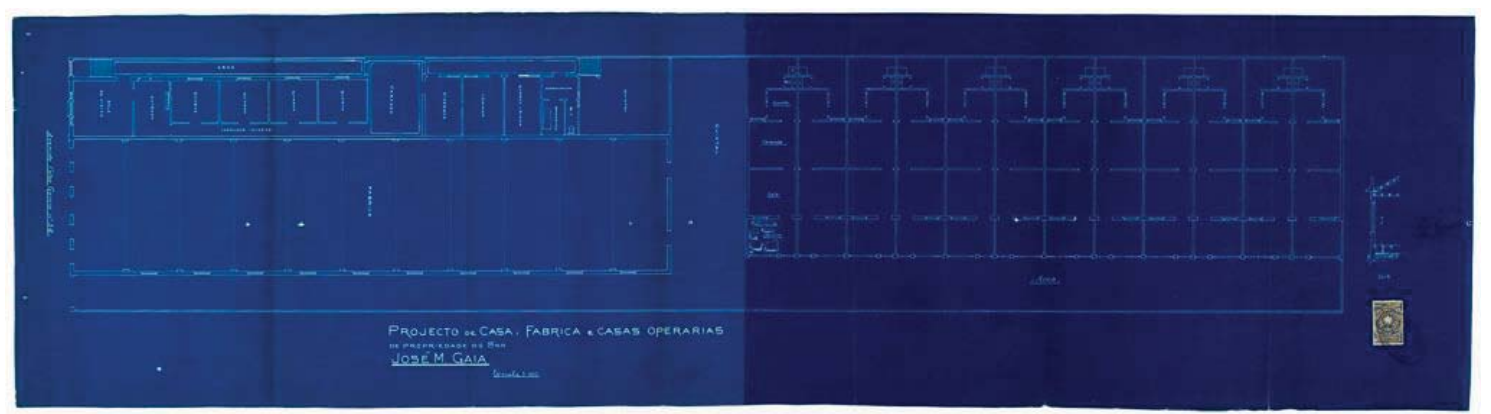

Figura 161: "Projecto de casa, fábrica e casas operárias", Arquivo Histórico Municipal, Fundo "Diretoria de Obras”, Série “Obras Particulares, OP1912.001.178.

Já com a fábrica construída, José Gaia, solicitou em 1913 (figura 162) o aumento de dois cômodos no interior da fábrica, necessários para armazenamento das matérias primas. No despacho entre os funcionários da Prefeitura, José de Sá Rocha relata que o pedido tratase de uma simples "modificação de planta anteriormente approvada [com] as divisões internas que o requerente pretende fazer". Contudo, o engenheiro, em sua análise detida sobre o desenho apresentado, escreve que considera

\footnotetext{
“esquisito que sendo a fabrica 'de biscoitos' haja depósitos declarados para fumo! e papel para cigarros - que nada tem de relação com biscoitos.

Isto porem nada tem de commum com a construção.
}

A licença pode ser dada pagando o requerente mais a taxa de substituição da planta já approvada. 
Alem d'isso há o augmento ao lado, que é novo e não fazia parte da antiga planta e que são $[. .$.$] duas pequenas [. .$.$] com área \mathrm{m}^{23} 3,000 . ”$

Como resposta, José Gaia afirma que já possuía a fábrica de cigarros há muito tempo, pagando os impostos devidos e "desejando continuar a mesma indústria junto a Fabrica de biscoitos em construção". Sá Rocha rebate, dizendo que sua “observação foi motivada pela heterogeneidade dos dois ramos de commercio", não fazendo "disso propriamente questão alguma", tanto que concedeu "as notas para approvação das plantas"282. José Gaia é um típico personagem dos setores médios, que procurava a diversificação de suas rendas, explorando a produção de produtos que tinham grande consumo na época, sem deixar de aproveitar as oportunidades que o mercado imobiliário lhe garantiam, com a instalação de casas nos fundos de sua fábrica de biscoitos e de fumos.

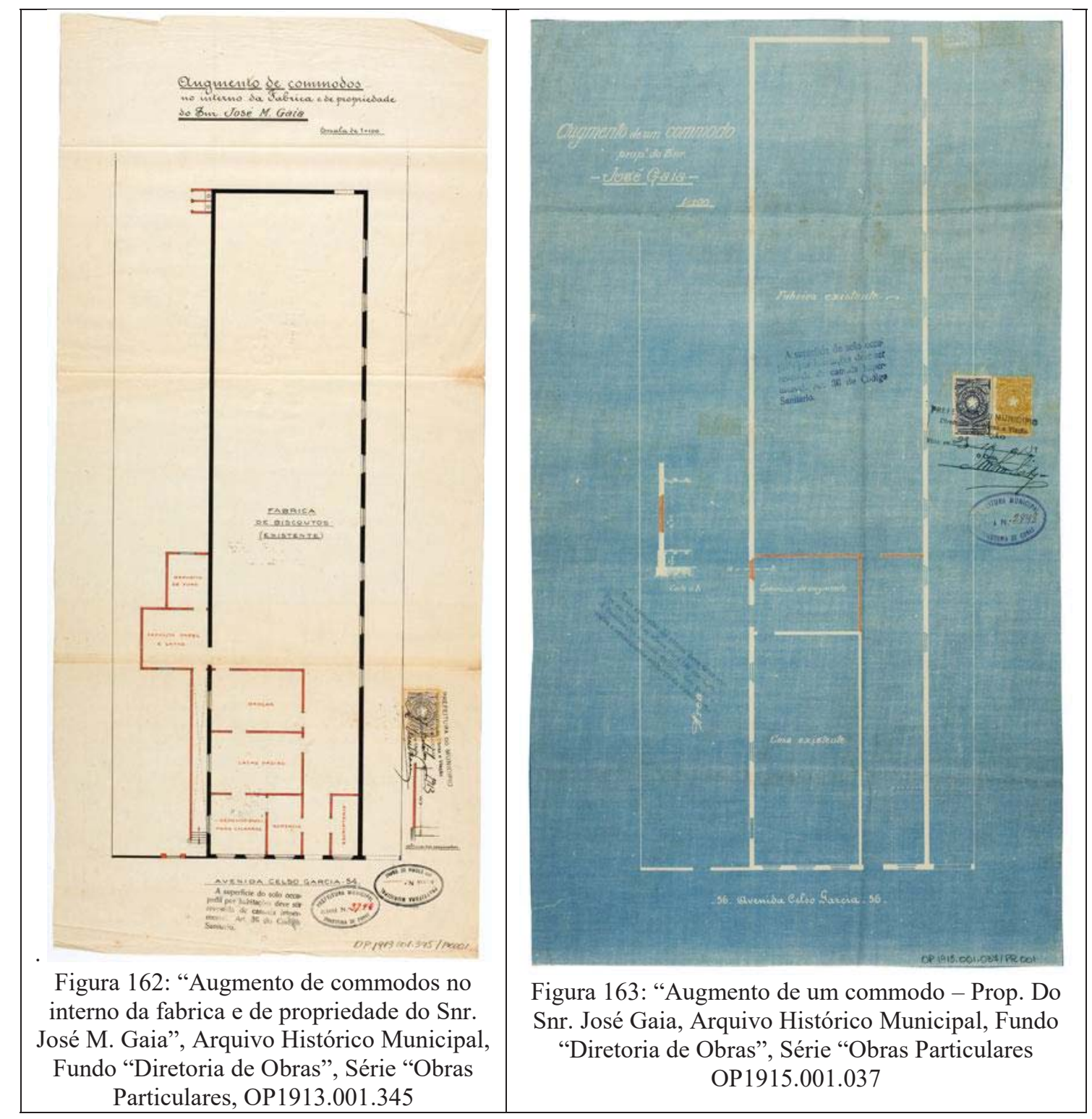

${ }^{282}$ Arquivo Histórico Municipal, Fundo "Diretoria de Obras”, Série “Obras Particulares, OP1913.001.345 


\subsection{Botequins e bilhares $x$ Bares e bebidas}

Ao analisarmos a tabela dos estabelecimentos comerciais, constatamos que os botequins eram distintos dos bares, possivelmente relacionando-se à públicos diferentes. Apesar de inicialmente seus nomes nos indicarem que vendiam bebidas em geral, na leitura dos almanaques podemos perceber que muitos dos botequins são acompanhados por bilhares, proporcionando assim uma diversão para aqueles que lá se encontram, enquanto os bares faziam associação apenas com "bebidas".

Enquanto os bares situavam-se essencialmente no eixo das avenidas Rangel Pestana e Celso Garcia, e nas ruas do Gasômetro, Santa Rosa e Visconde de Parnaíba, os botequins e bilhares se concentram quase que exclusivamente nas ruas Monsenhor Andrade, Concórdia e Carneiro Leão, com alguns poucos espalhados em ruas adjacentes e no Largo da Concórdia. Mas, quais os fatores para a existência desta distinção geográfica entre os bares e botequins no Brás?

Um primeiro ponto a ser analisado é o da função que o eixo formado pelas duas principais avenidas do bairro possui. A Rangel Pestana com a Celso Garcia influíram decisivamente sobre as demais ruas, exercendo um poder simbólico em torno das suas ocupações, essencialmente sob o discurso de cidade que se pretendia construir nas primeiras décadas do século XX. Como visto anteriormente, a fiscalização municipal se dava de uma maneira intensa sobre essas vias, ainda mais por serem importantes eixos viários que se ligavam ao centro da cidade. Outro fato se dava pelos estabelecimentos comerciais ali instalados, como os armazéns, padarias e confeitarias. Talvez não seja fortuito pensarmos que os bares ali instalados seguiriam a mesma lógica simbólica, de que estes estabelecimentos serviriam como espaços para o lazer da sociedade local, em que diferentes pessoas pudessem consumir bebidas distintas, como as cervejas e cafés, e até mesmo comer petiscos e pratos variados, quase como restaurantes locais. A mesma lógica pode ser observada nas ruas atendidas pelos bondes: Gasômetro (que se destacava pelo expressivo número de sobrados ali erguidos e que se distinguia como uma típica via do status dos setores médios), Santa Rosa (que cumpriu um papel de vitrine do bairro do Brás, visto que seria aquela primeira avistada de quem cruzasse a Várzea do Carmo, e posterior Parque D. Pedro II, em direção do Brás), e Visconde de Parnaíba (nos limites do bairro, e que proporcionava fácil acesso aos bairros da Móoca e Belenzinho). Tais ruas, atendidas pelos bondes e, que de certa forma, teriam melhor acesso ao centro e a outras localidades das 
proximidades, permitiam que camadas sociais de outras porções da cidade frequentassem seus estabelecimentos. Logo, os bares não seriam apenas espaços da venda de bebidas, mas de requinte para as camadas médias da cidade.

Exemplo deste estabelecimento pode ser denotado no projeto de Manoel Asson de 1914, o “Café e Bilhares”, situado na Avenida Rangel Pestana número 229, no lugar do antigo armazém de J. Ferraz \& Mendes ${ }^{283}$. A fachada do novo estabelecimento convidava os fregueses da rua para conferirem os atrativos que ali podiam ter, como os chops, uma alusão à venda de cerveja (figura 164). É de se destacar, que desde o final do século XIX a cerveja vinha ganhando cada vez mais espaço na cidade de São Paulo, tornando-se uma das principais bebidas dos círculos sociais em bares, restaurantes e em reuniões familiares. Segundo Edgar Kob, "como produto comercial, a cerveja teve mais sucesso que outras bebidas, perdendo em preferência somente para a cachaça"284.

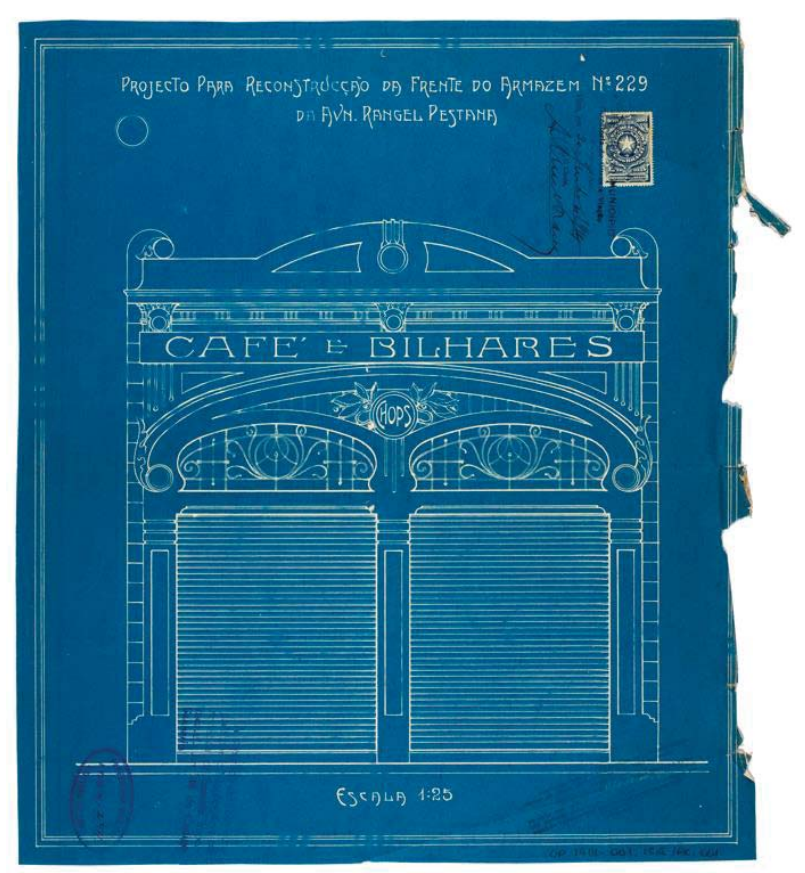

Figura 164: "Projecto para reconstrução da frente do armazém no 229 da Avn. Rangel Pestana". Arquivo Histórico Municipal, Fundo "Diretoria de Obras", Série "Obras Particulares, OP1914.001.152.

Tais estabelecimentos eram servidos por uma série de fábricas de bebidas da própria região do Brás, como a Premiada Destilação Italiana a Vapor de Luiz Trevisan e seu irmão, fundada em 1886. Segundo Bandeira Júnior, a destilaria localizada na Rua Visconde de

${ }^{283}$ Almanak Laemmert, edição de 1901. Acervo da Hemeroteca Digital Brasileira.

${ }^{284}$ KOB, Edgar. "Como a cerveja se tornou bebida brasileira". In: Revista do Instituto Histórico e Geográfico Brasileiro. Ano 161, n. 409, out./dez. 2000, pág. 43. Agradeço ao Diógenes Sousa pela valiosa indicação do artigo que rendeu uma boa dose de conhecimento sobre a temática. 
Parnaíba número 146, nas proximidades do Marco da Meia Légua, fabricava licores finos, licores comuns, doces e "espirituosos de todas as qualidades", bem como xaropes e vinagre, produzindo anualmente 100.000 litros por 21 operários, sendo que destes funcionários, apenas um era nacional no ano de 1901. ${ }^{285}$

A Destilaria Franceza, de V. Conlon \& C, localizada na rua do Gasômetro número 79 , também vai ao encontro do que estas ruas simbolizavam na paisagem urbana do Brás, sendo anunciada nos almanaques desde o ano de 1905. Outras fábricas procuravam ir além da produção de destilados, como a de Augusto Tolle \& Cia, na rua Piratininga, números 17 e 19 (figuras 165, 166, 167 e 168), que fazia parte do grupo Socièté Financiére et Commerciale Franco-Brésilienne, instalada no Brasil dede 1907, dedicando-se a outras atividades comerciais, como tecidos, ferragens e madeiras. Já a Grande fábrica a vapor de águas minerais e outras bebidas de Guilherme Christoffel Stupakoff, fundada em 1871, produzia as águas gasosas Seltz e syphons, Ginger-Ele; Champagne de frutas; Limonadas diversas, licores, conhaque, vinho de uva, abacaxi, laranja e outras frutas; vinagre; chocolate; confeitos, caramelos e bombons; perfumes, tônicos, sabonetes, pó de arroz, pasta para dentes, e até mesmo óleo de rícino, trabalhados por 100 operários em sua maioria estrangeiros, numa fábrica que ocupava uma área de 7.200 metros quadrados, com máquinas de 40 e de 4 cavalos, as quais eram auxiliadas por um alambique, um retificador, um gasômetro interno ${ }^{286}$. Além destas, é de se destacar o complexo da Companhia Antarctica, no vizinho bairro da Móoca, fábrica que exerceu destacado papel no processo de urbanização da cidade, criando uma série de equipamentos urbanos em São Paulo, como destacado pelo trabalho de Diógenes Sousa. ${ }^{287}$

${ }^{285}$ BANDEIRA JUNIOR, Op. Cit., pág. 110.

${ }^{286}$ BANDEIRA JÚNIOR, Op. Cit., pág. 196 e 197.

287 SOUSA, Diógenes. Cidade e cerveja: Companhia Antarctica Paulista e Urbanização em São Paulo. Dissertação (Mestrado em Urbanismo). Pontifícia Universidade Católica de Campinas. Campinas, 2017. 


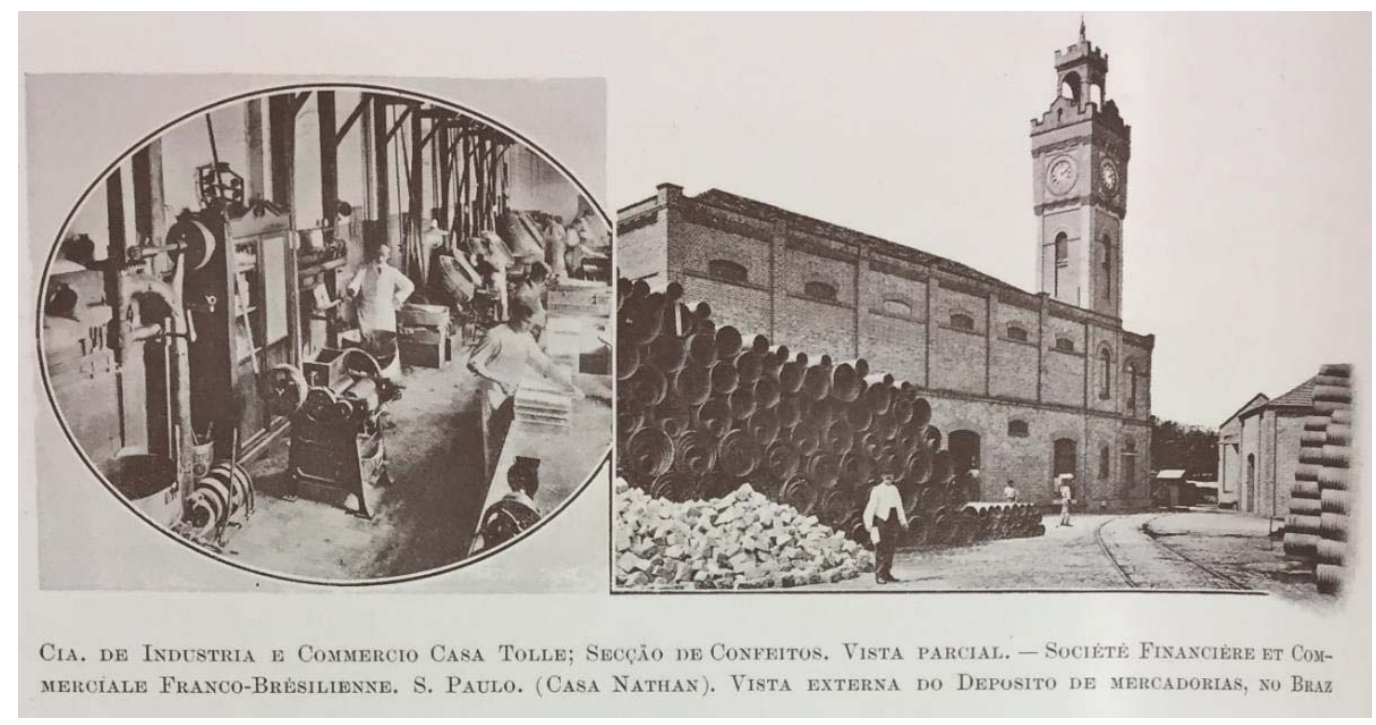

Figura 165: Depósitos da “Casa Tolle”. Societé de Publicité Sud-Américaine, Monte Domecq' \& Cie. O Estado de S. Paulo. Barcelona: Estabelecimento Graphico Thomaz, 1918, pág. 340.

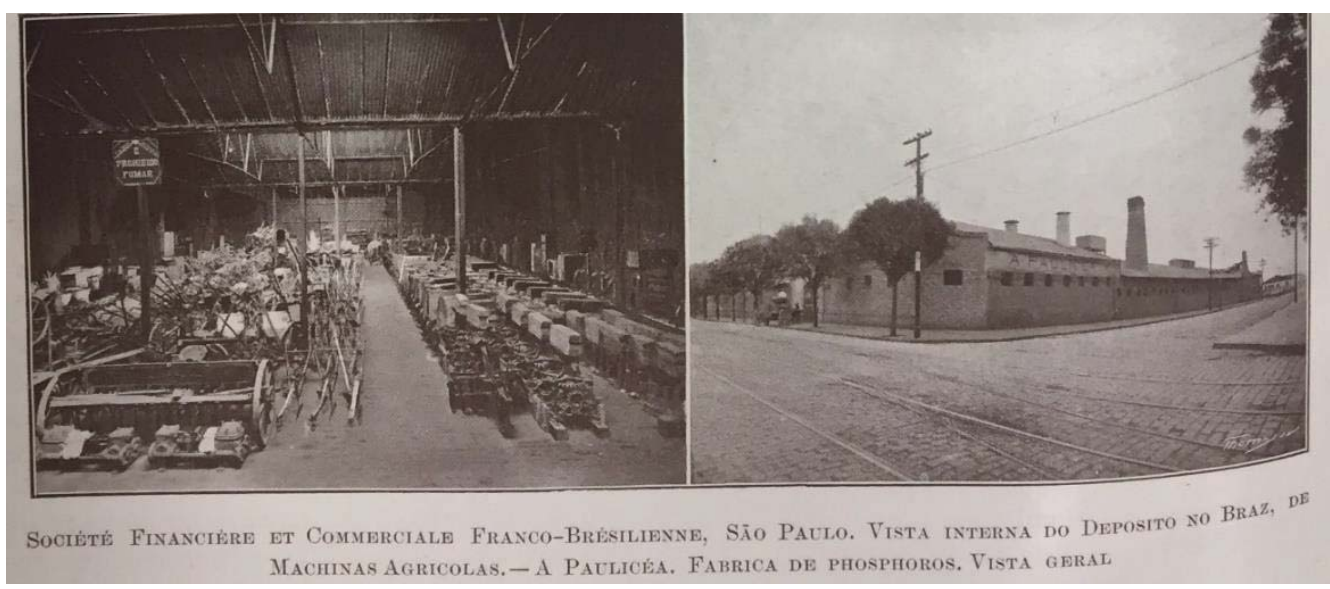

Figura 166: Depósitos da “Casa Tolle”. Societé de Publicité Sud-Américaine, Monte Domecq' \& Cie. O Estado de S. Paulo. Barcelona: Estabelecimento Graphico Thomaz, 1918, pág. 340.

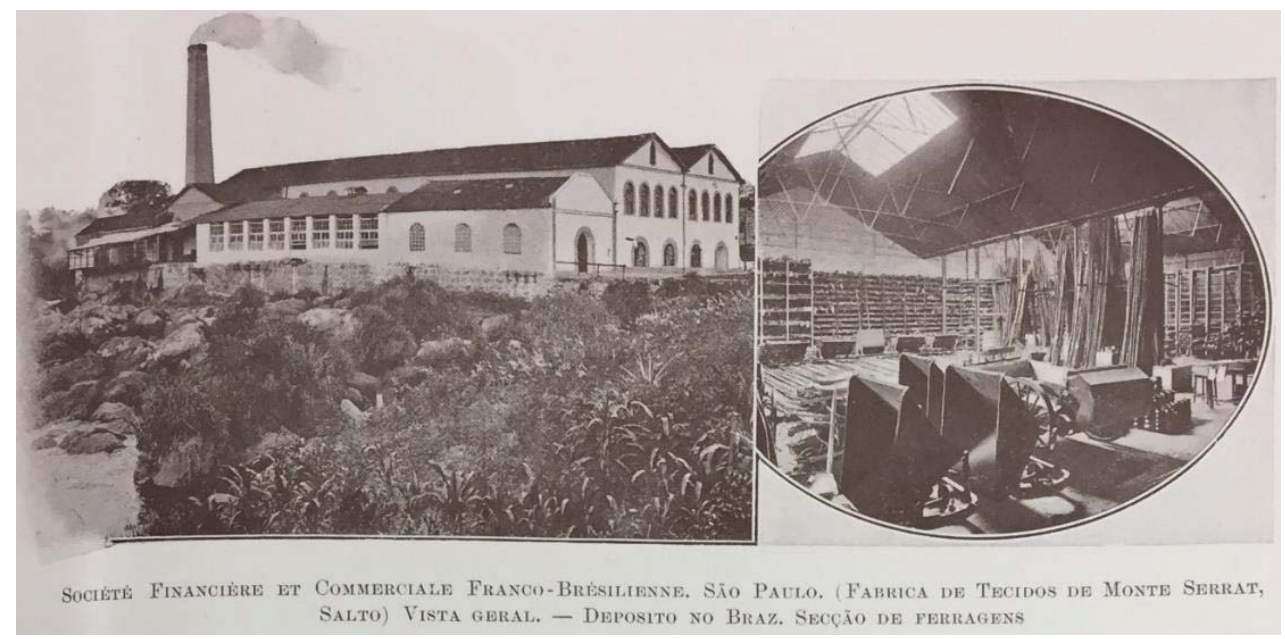

Figura 167: Depósitos da “Casa Tolle”. Societé de Publicité Sud-Américaine, Monte Domecq' \& Cie. O Estado de S. Paulo. Barcelona: Estabelecimento Graphico Thomaz, 1918, pág. 341. 


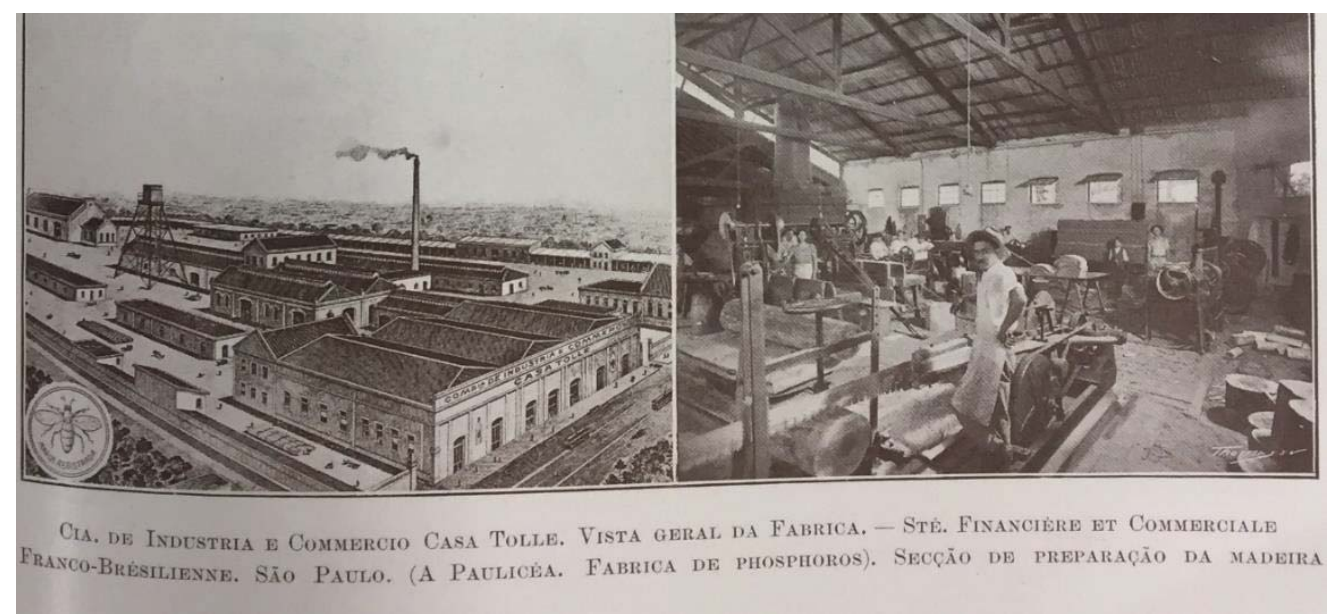

Figura 168: Depósitos da “Casa Tolle”. Societé de Publicité Sud-Américaine, Monte Domecq’ \& Cie. O Estado de S. Paulo. Barcelona: Estabelecimento Graphico Thomaz, 1918, pág. 341.

Além destas a Fábrica de Álcool de Milho e Cana da Societé Anonyme des Desilleries Brésiliennes (também conhecida como “Destillaria da Várzea), seria uma fábrica de destaque no Brás, localizada na rua Piratininga. ${ }^{288}$

E os botequins, quais questões estavam em jogo para que sua instalação estivesse concentrada principalmente nas ruas Monsenhor Andrade, Concórdia e Carneiro Leão, e em menor escala no Largo da Concórdia, Monsenhor Anacleto e Américo Brasiliense?

Ao analisarmos o levantamento aerofogramétrico SARA Brasil, produzido na década de 1930, pudemos perceber que entre as ruas acima descritas, grandes conjuntos industriais se faziam presentes, como as Indústrias Reunidas Francisco Matarazzo, a Importadora Rickmann, a Companhia Nacional de Tecidos de Juta e galpões que se alastravam ao longo da via férrea. Um dos motivos que estariam por trás da instalação dos botequins nestas ruas seria de justamente atender aos operários que trabalhavam nestas fábricas. Perceptível é o caso da rua da Concórdia, que ao cotejarmos com a Série Obras Particulares nos deparamos com um expressivo conjunto de desenhos de grandes empreendimentos ali instalados, como a importadora inglesa Wilsons Co (importadora de máquinas para indústrias e carvão de pedra e animal com atuação em diversos estados do Brasil, como Bahia, Pernambuco, Rio de Janeiro e em São Paulo com escritórios nas ruas Barão de Paranapiacaba número 10, rua Vinte e Quatro de Maio número 107, e rua Álvares Penteado número 19, este atendendo pelo telefone número 107 e os demais pelo número 123 - figuras 169 e 170) ${ }^{289}$; da fábrica de calçados Alpargatas (fundada pelo escocês Robert Fraser que chega ao Brasil em 1907,

\footnotetext{
${ }^{288}$ Almanak Laemmert, edição de 1910.

${ }^{289}$ Almanak Laemmert, edições de 1913 e 1918.
} 
e funda inicialmente a Sociedade Anonyma Fábrica Brazileira de Alpargatas e Calçados figuras 171 e 172)290; dos armazéns e cocheiras do italiano Palaride Mortari (que se estendiam à rua Sayão Lobato número 3 e na rua Xavantes número 7, onde se fabricavam sabão, sabonetes e velas, e à uma serraria na rua Monsenhor Andrade - figuras 173, 174, 175 e 176) ${ }^{291}$; de Martins Ferreira \& Cia. (figuras 177, 178, 179, 180, 181, 182 e 183) e os armazéns de Machado e Mello - Cia. do Rio de Janeiro (figura 184), todos margeados de um lado pela extensão da linha férrea, e do outro lado da rua diversos botequins que podiam atender aos operários destas empresas bem como de localidades próximas. Com os dados coligidos, elaboramos o mapa 24, Área de influência entre fábricas, bares e botequins, que dá a ver a relação entre os grandes estabelecimentos industriais mapeados anteriormente (ver mapa 23), com os estabelecimentos que eram demarcados na época como "Bar e bebidas", "Botequim e bilhar", e apenas "Salão de bilhar". Num raio de aproximadamente 500 metros, conseguimos perceber que as fábricas exerciam notável influência na implantação de comércios que vendiam bebidas, comidas e ofereciam diversões aos operários e demais trabalhadores da região. Nos anexos do trabalho podem ser vislumbradas algumas percepções de uma rua que contava com elevado número de armazéns e comércios: a rua Concórdia, que a partir dos seus desenhos remetidos para aprovação da Prefeitura Municipal, formavam uma ampla área voltada ao armazenamento de produtos das fábricas e comércios da região.

Das fotografias coletadas a partir do livro editado pela Societé de de Publicité SudAméricaine, verifica-se uma quantidade de maquinários no interior das fábricas que surpreende o leitor num primeiro momento, ocupando o papel de protagonistas desses registros, e em segundo lugar aqueles que as manipulavam: os operários. Tanto os maquinários como os edifícios e seus produtos armazenados ocupam uma posição privilegiada, como símbolos da riqueza industrial, propagandeados no livro.

${ }^{290}$ Com base no site $<<\underline{\text { http://ri.alpargatas.com.br/alpargatas/historico }}>>$, acesso em 20 de fevereiro de 2017 ${ }^{291}$ Almanak Laemmert, edições de 1901 e 1902. 


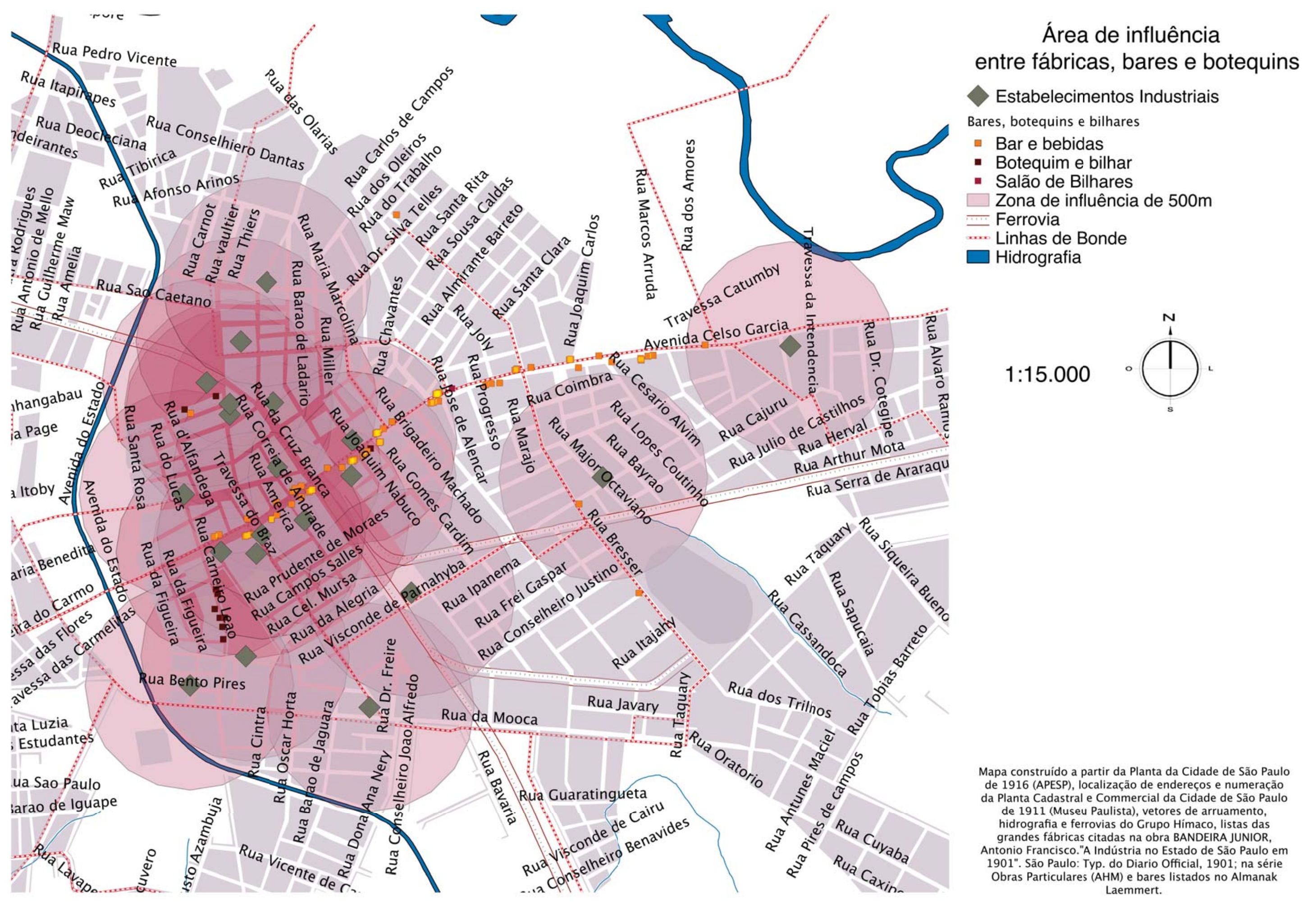




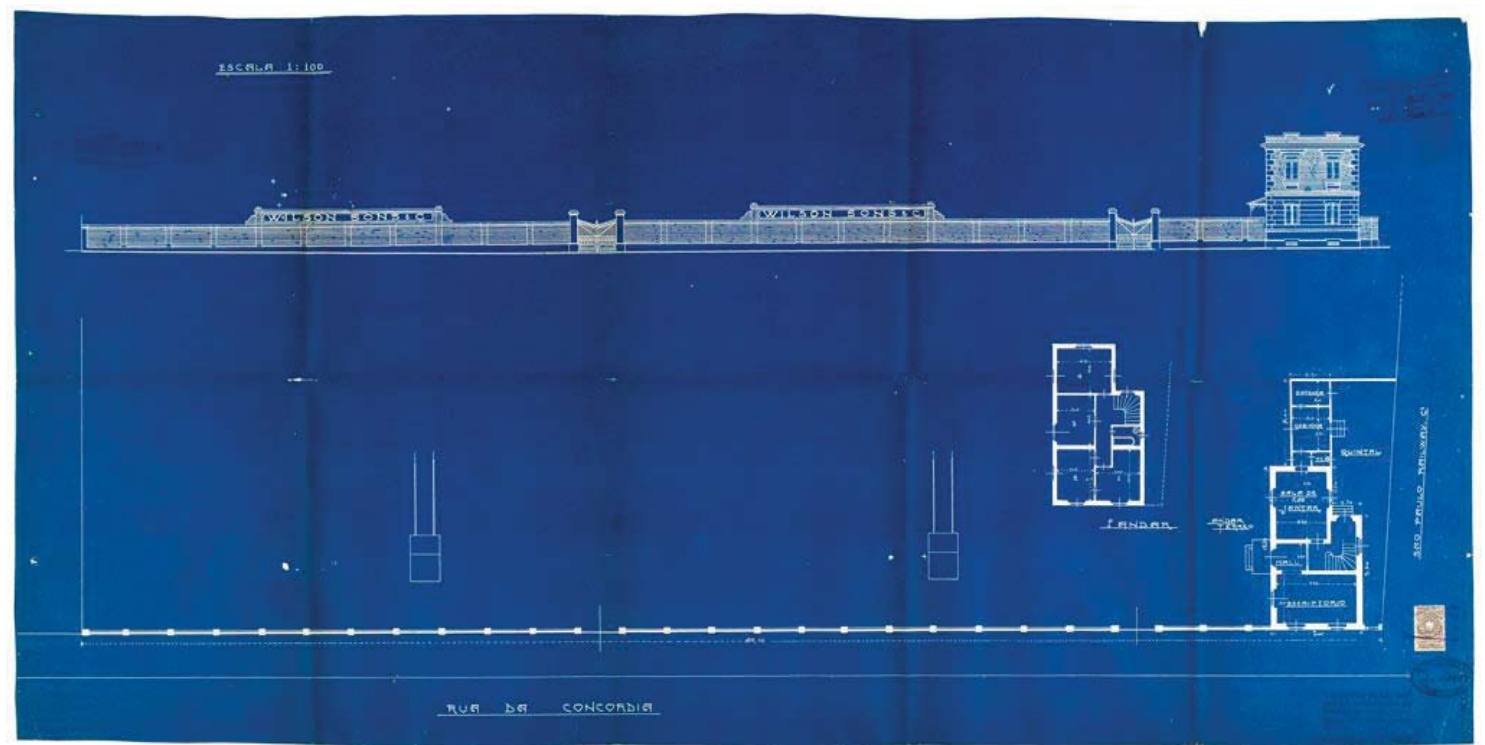

Figura 169: Fachada da Companhia Wilson Sons \& C. Arquivo Histórico Municipal, Fundo "Diretoria de Obras”, Série “Obras Particulares, OP1913.001.517.

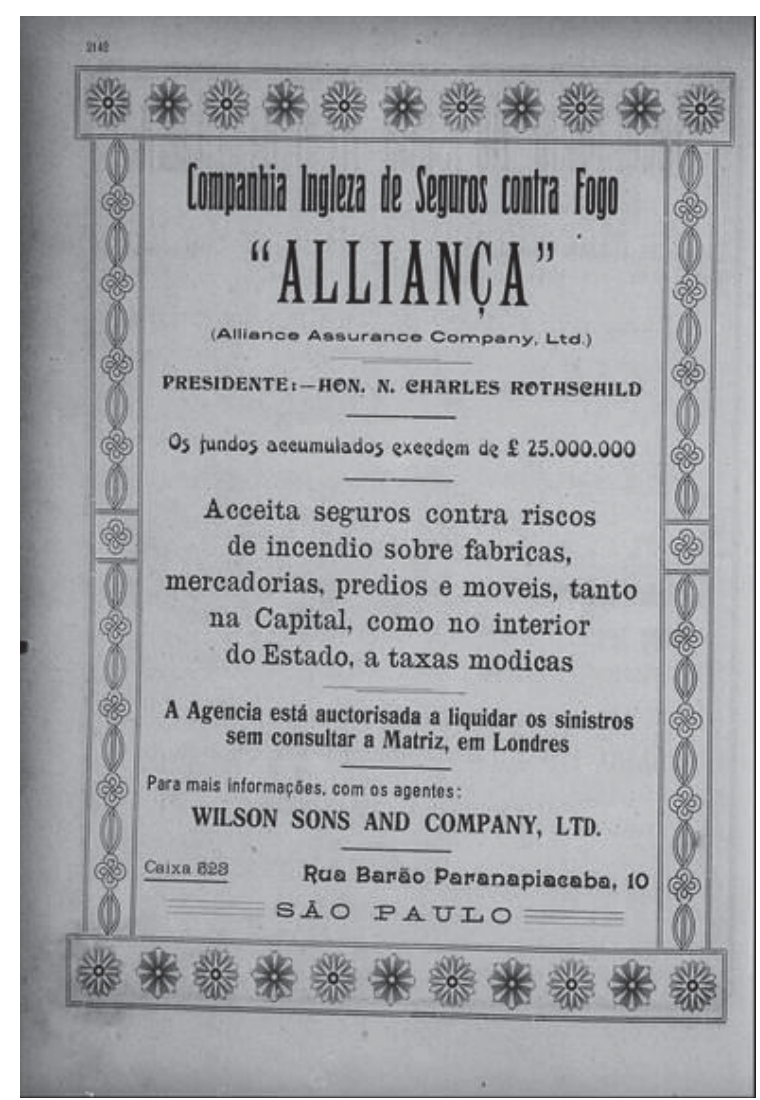

Figura 170: Anúncio da agência de seguros Alliança, que contava com a Wilson Sons and Company como representante. Almanak Laemmert, 1918. 


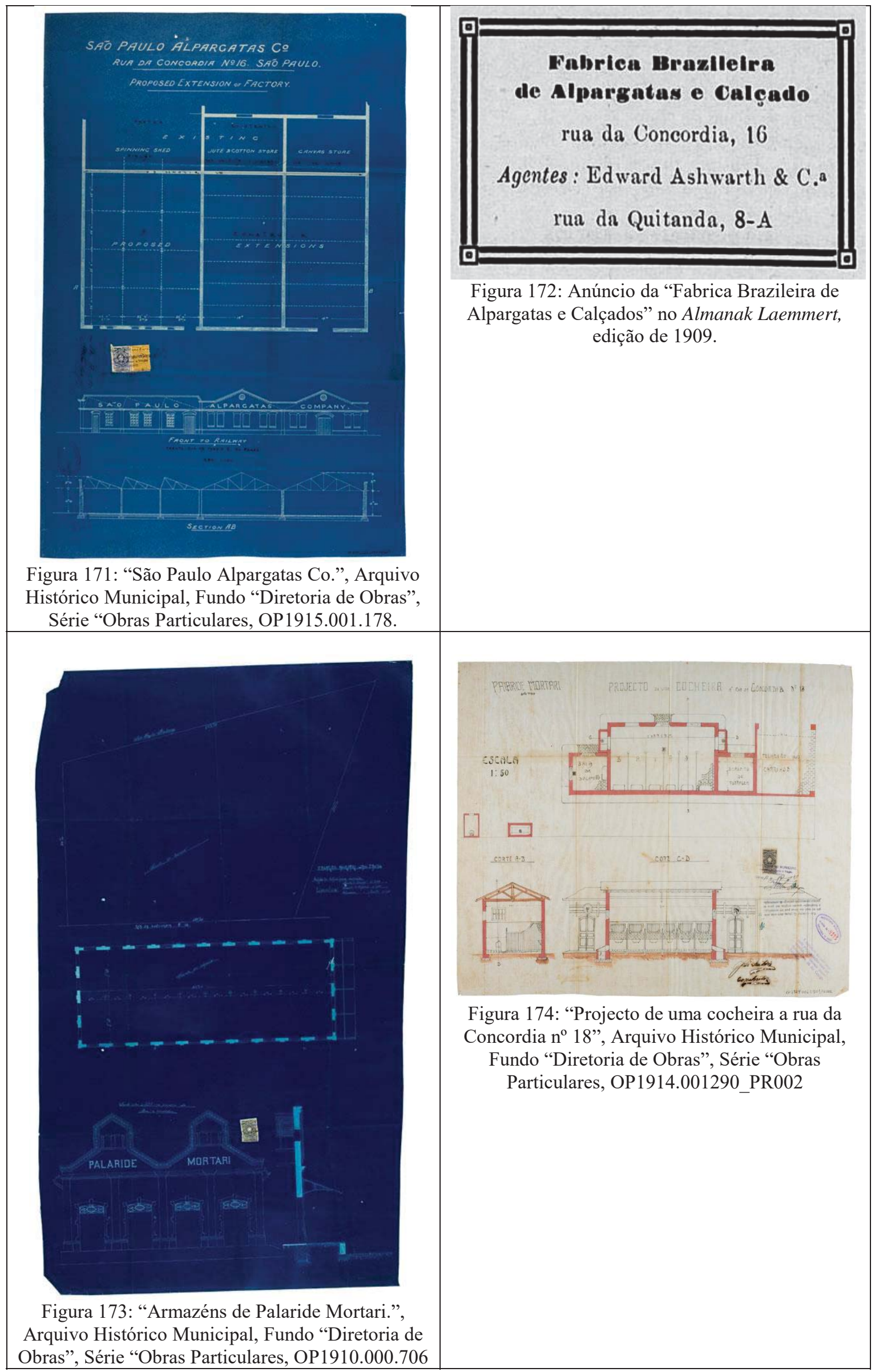



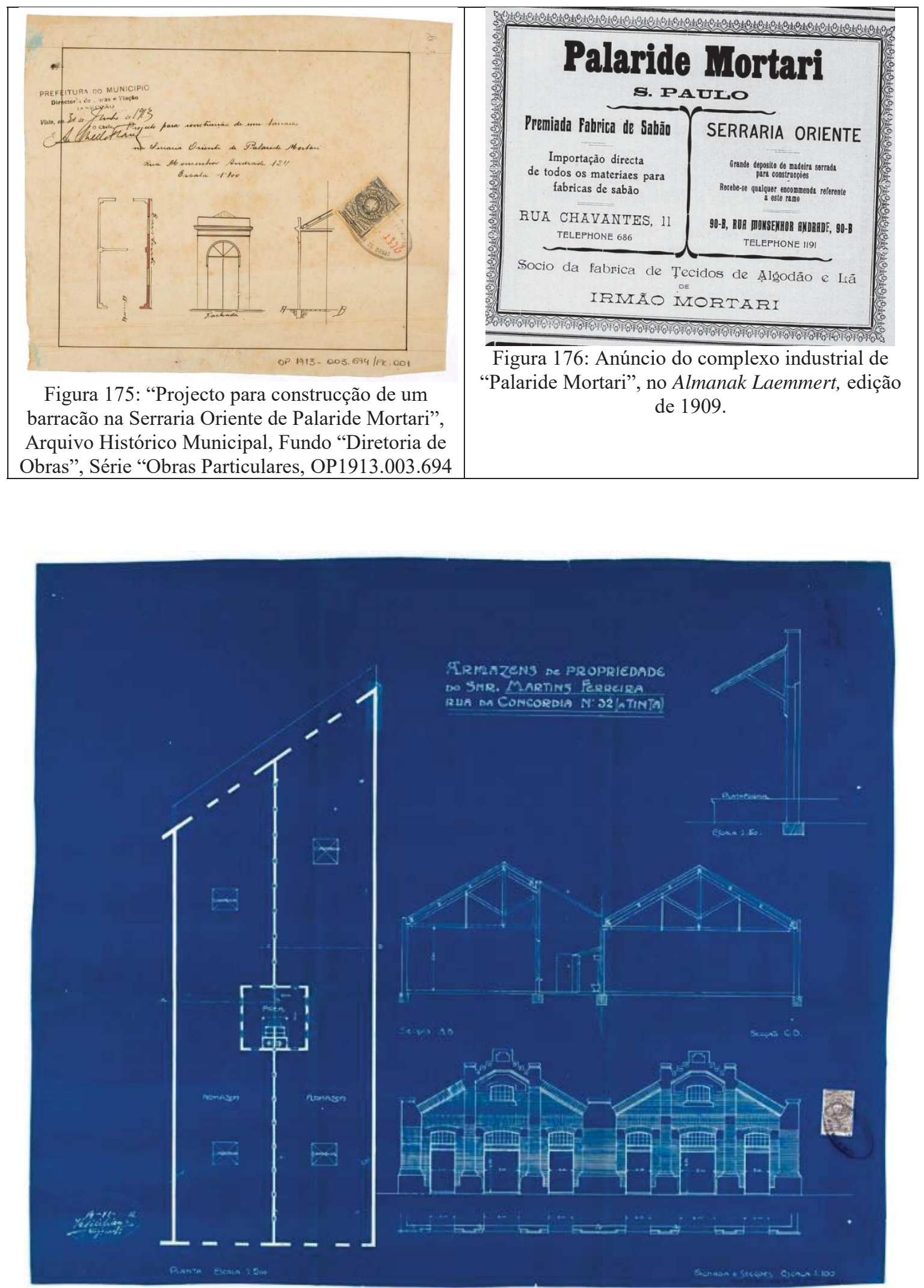

Figura 177: “Armazéns de propriedade do Snr. Martins Ferreira”. Arquivo Histórico Municipal, Fundo "Diretoria de Obras", Série "Obras Particulares, OP1912.001.285. 


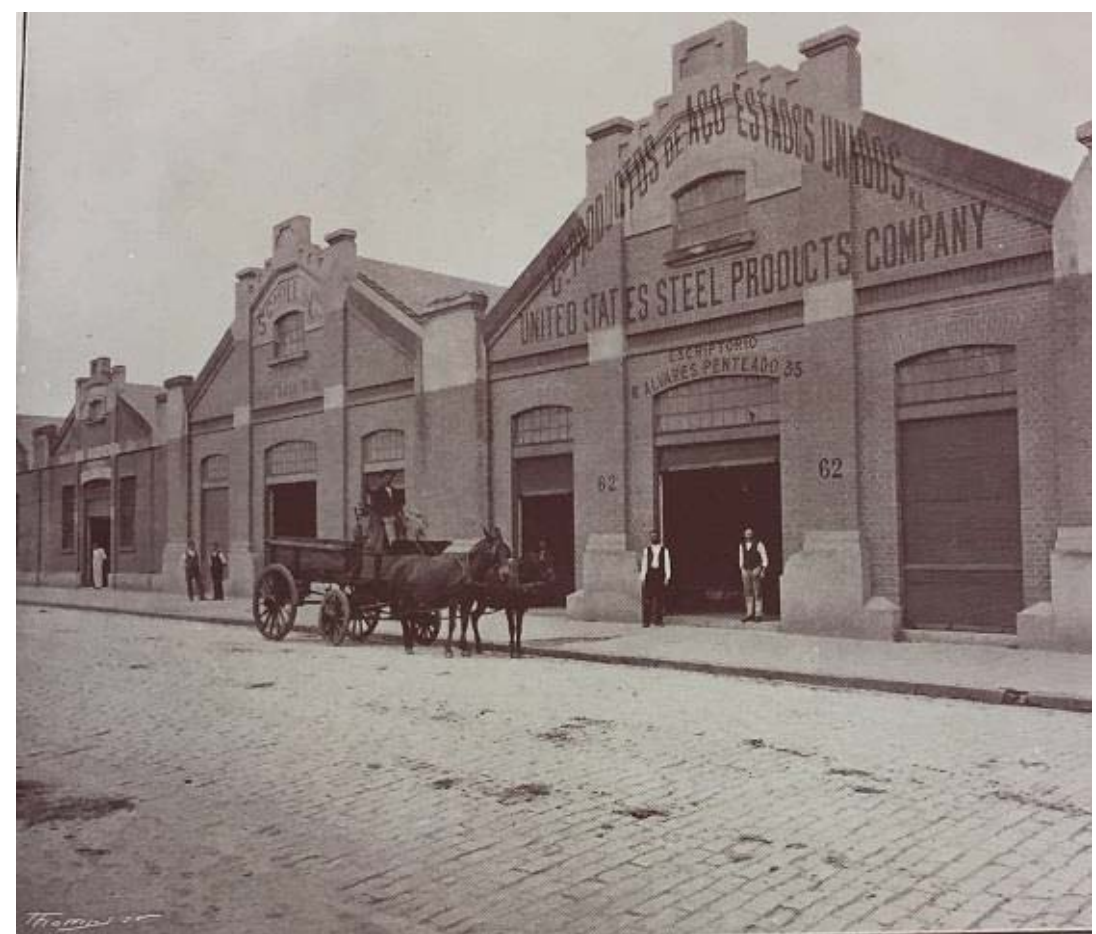

Figura 178: Depósitos da "Martins Ferreira \& Cia". O primeiro é ocupado pela U. S. Steel Products Co.; o segundo por Schill \& Co., servindo os demais de depósito de mercadorias da firma proprietária Societé de Publicité Sud-Américaine, Monte Domecq' \& Cie. O Estado de S. Paulo. Barcelona: Estabelecimento Graphico Thomaz, 1918 pág. 236.

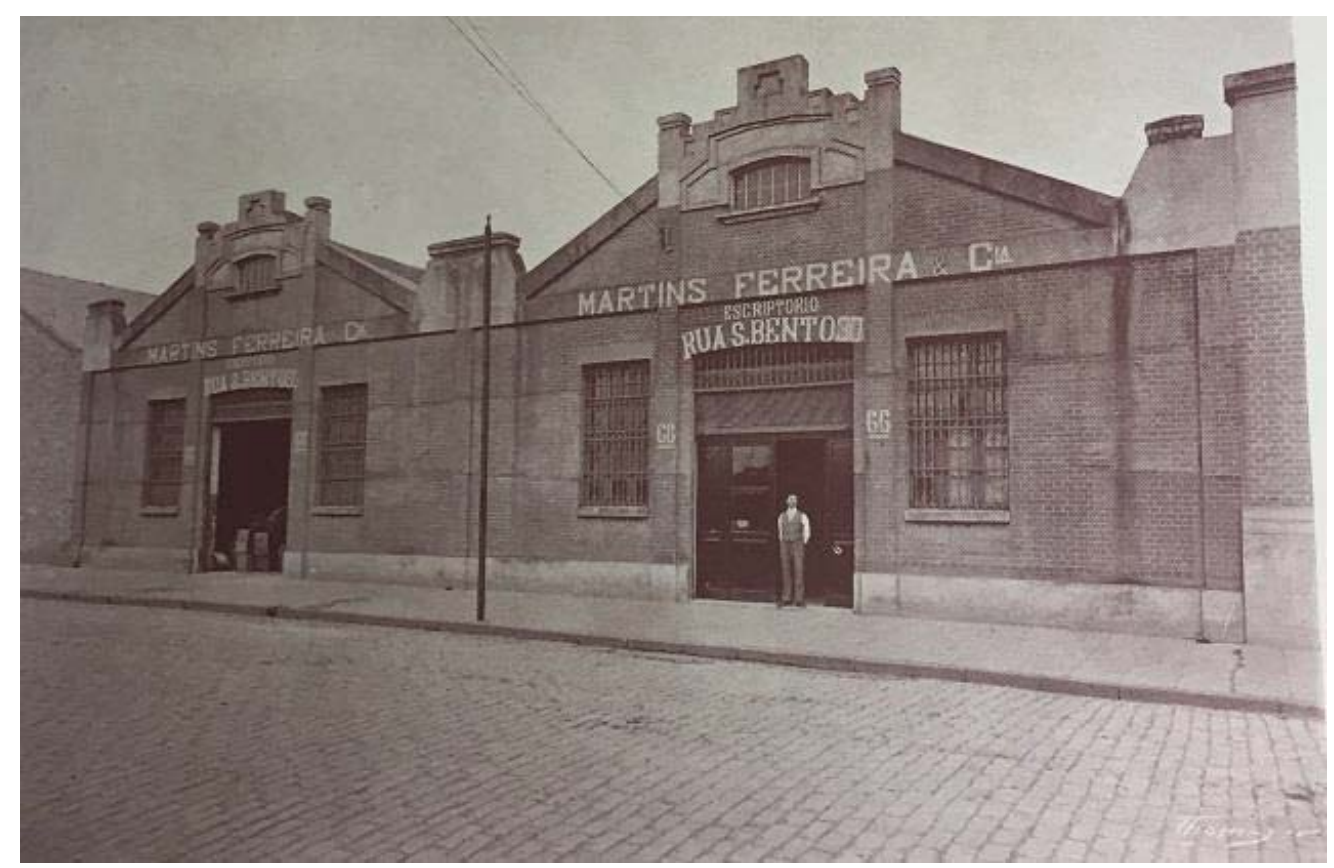

Figura 179: Fachada dos depósitos da "Martins Ferreira \& Cia", vizinha à S. Paulo Railway. Societé de Publicité Sud-Américaine, Monte Domecq' \& Cie. O Estado de S. Paulo. Barcelona: Estabelecimento Graphico Thomaz, 1918, pág. 237. 


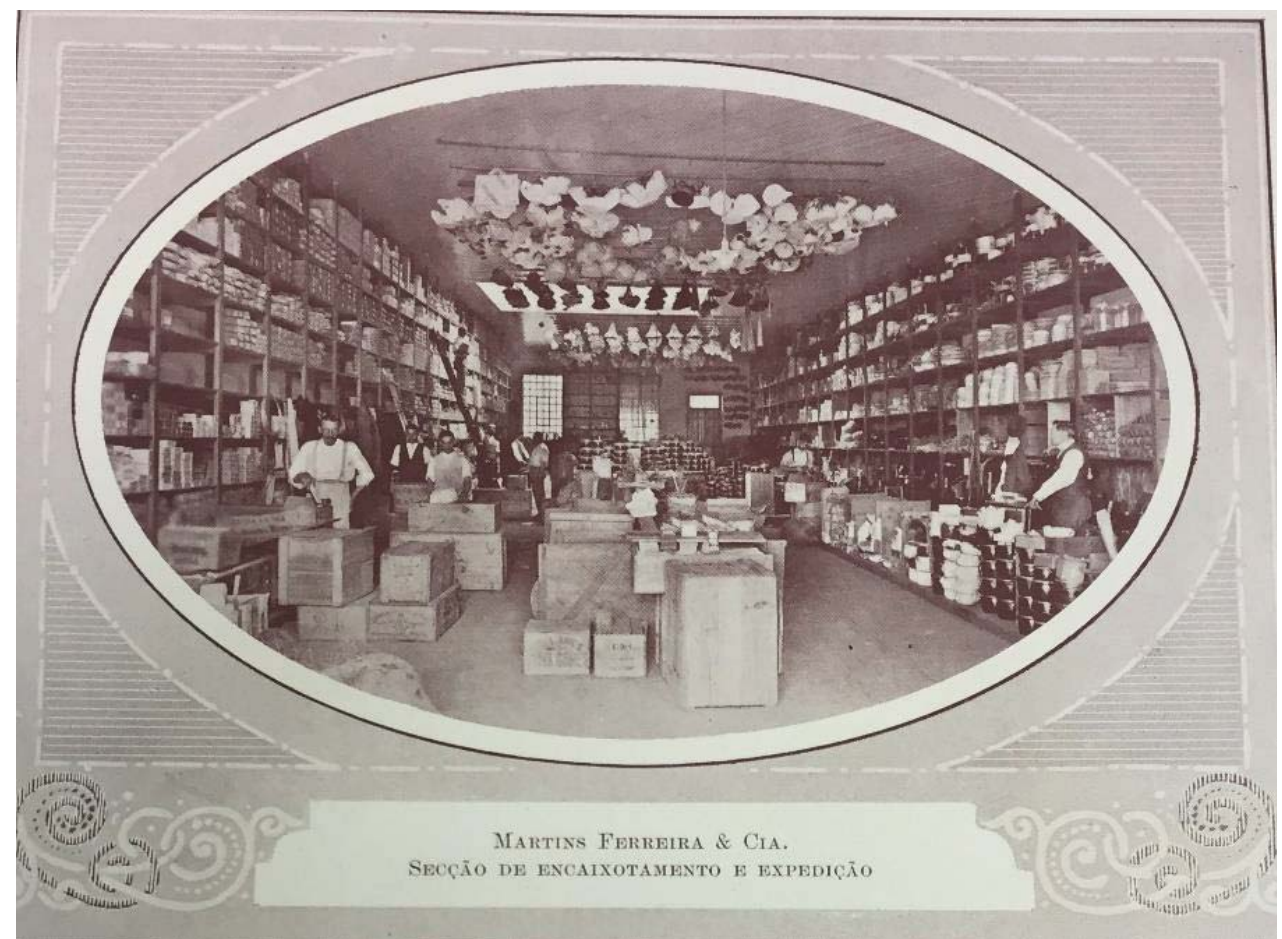

Figura 180: Depósitos e seção de encaixotamento e expedição da "Martins Ferreira \& Cia". Societé de Publicité Sud-Américaine, Monte Domecq’ \& Cie. O Estado de S. Paulo. Barcelona: Estabelecimento Graphico Thomaz, 1918, pág. 237.

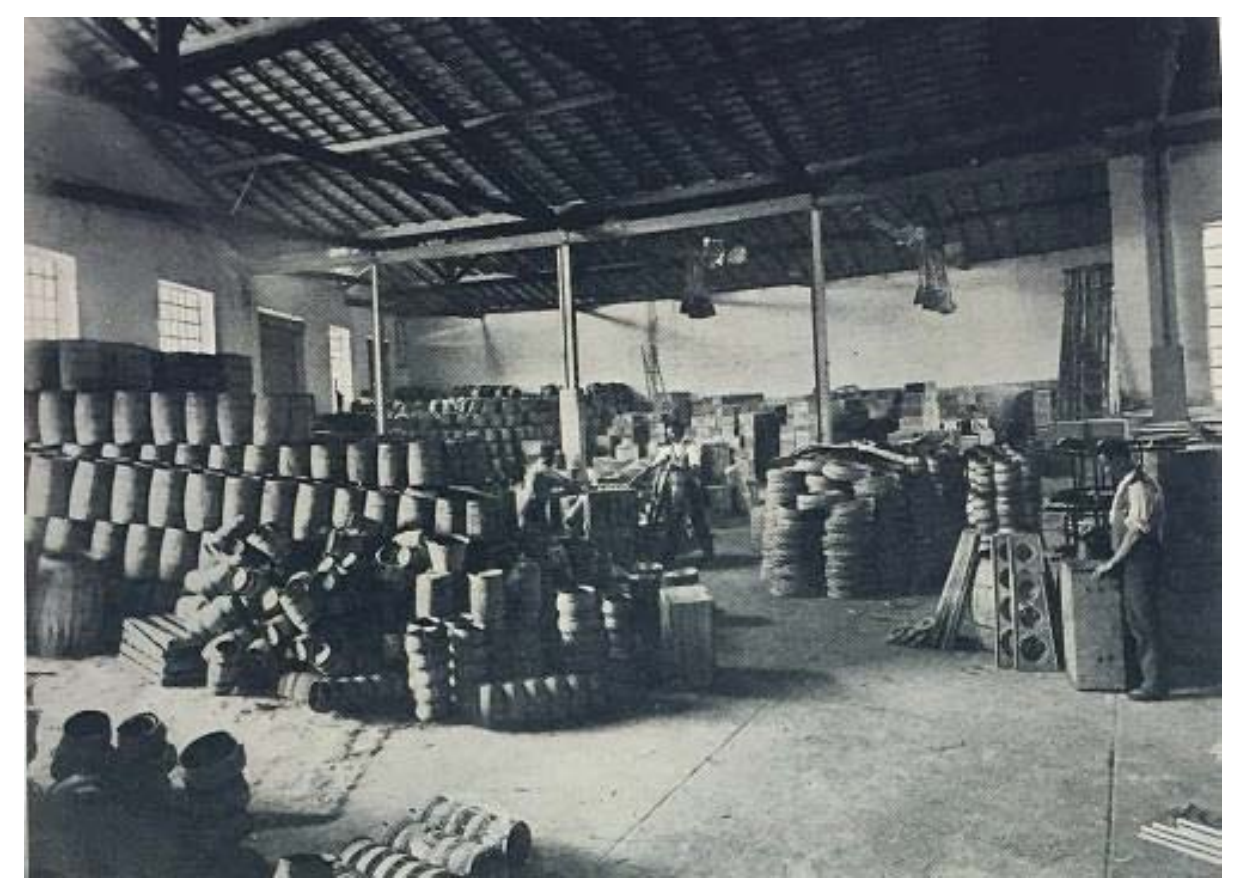

Figura 181: Depósitos da "Martins, Ferreira \& Cia". Societé de Publicité Sud-Américaine, Monte Domecq' \& Cie. O Estado de S. Paulo. Barcelona: Estabelecimento Graphico Thomaz, 1918, pág. 238. 


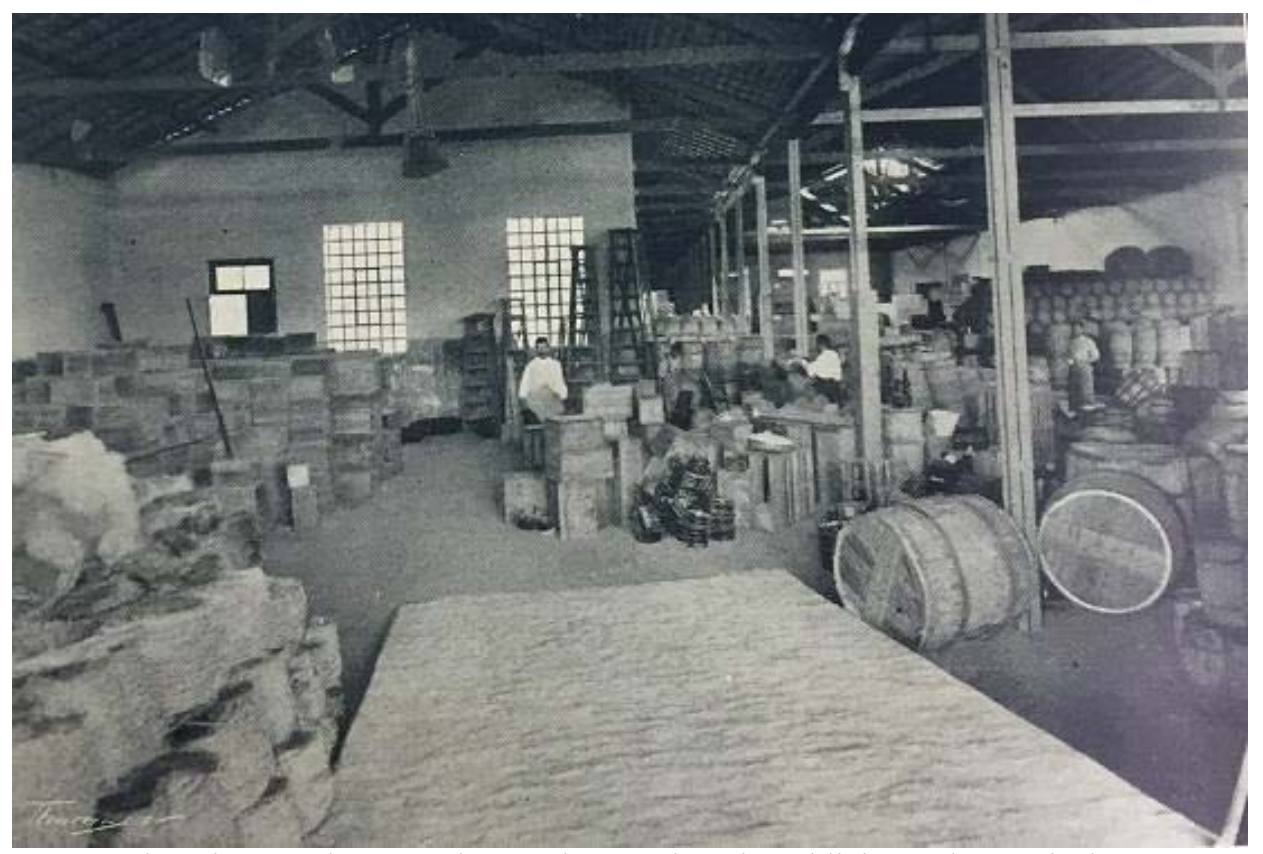

Figura 182: Depósitos da “Martins, Ferreira \& Cia”. Societé de Publicité Sud-Américaine, Monte Domecq' \& Cie. O Estado de S. Paulo. Barcelona: Estabelecimento Graphico Thomaz, 1918, pág. 238.

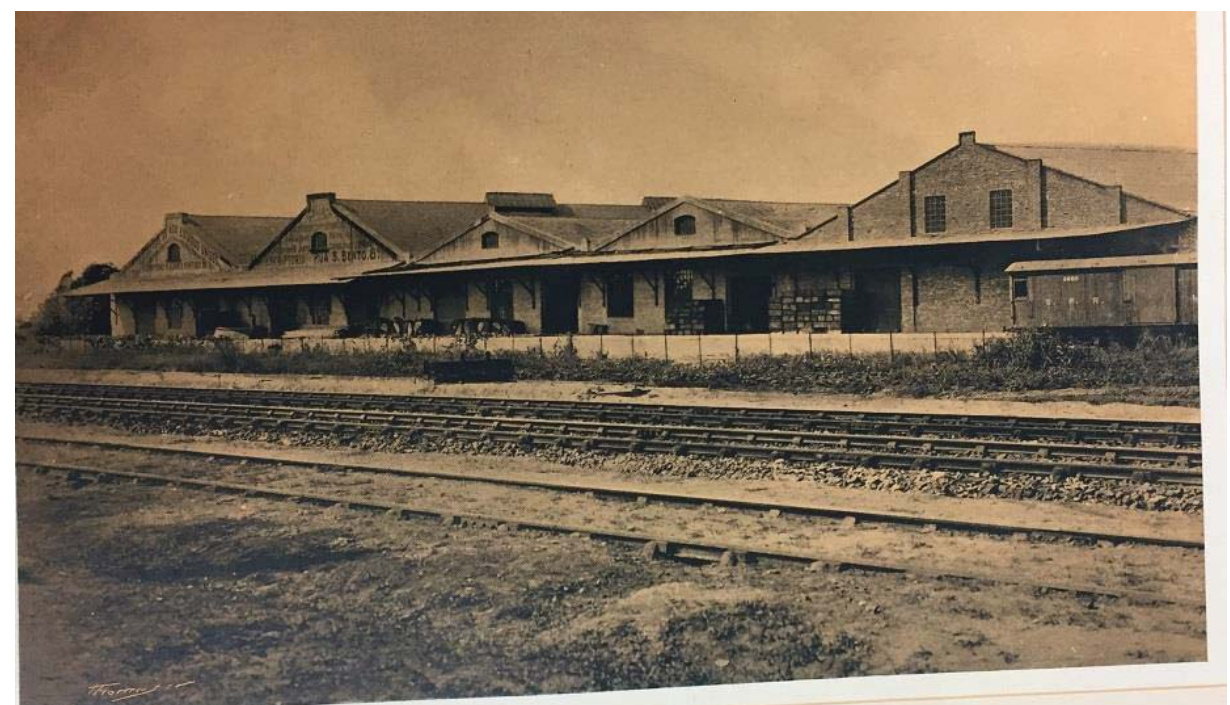

Figura 183: Vista geral dos armazéns e depósitos da "Martins, Ferreira \& Cia" com os desvios da S. Paulo Railway. Societé de Publicité Sud-Américaine, Monte Domecq' \& Cie. O Estado de S. Paulo. Barcelona: Estabelecimento Graphico Thomaz, 1918, pág. 239. 


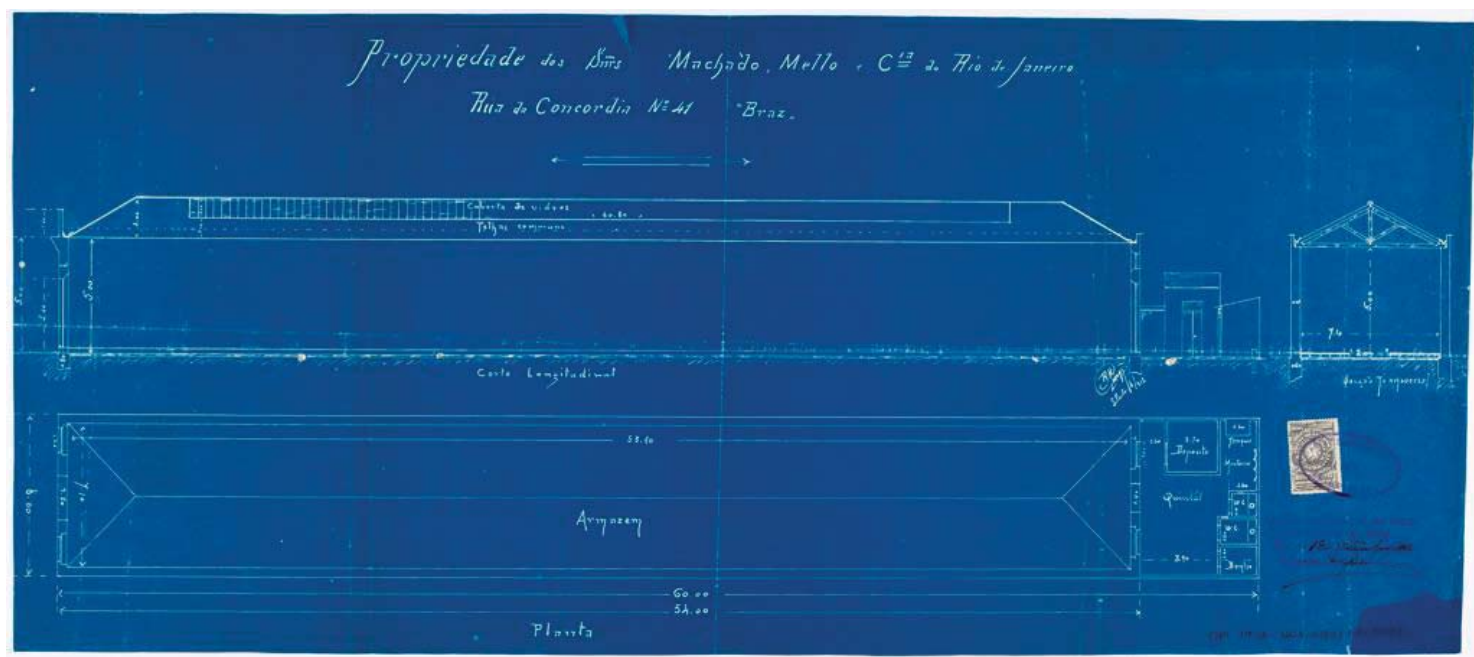

Figura 184: "Propriedade dos Srs. Machado, Mello e Cia. do Rio de Janeiro. Arquivo Histórico Municipal, Fundo “Diretoria de Obras”, Série “Obras Particulares OP1912.001.285.

O conjunto de depósitos e galpões da rua da Concórdia ${ }^{292}$ apresentado nas figuras, formava um complexo industrial privilegiado do Brás, por ser servido pelos trilhos das estradas de ferro, bem como estarem numa via que desembocava em frente ao Largo da Concórdia e consequentemente na avenida Rangel Pestana, proporcionando que os produtos ali estocados fossem distribuídos por toda a cidade, seja por meio dos bondes ou cocheiras. A questão que se coloca é: todo este complexo industrial congregava uma série de operários, muitos deles residentes (senão a maioria) no Brás. Porém, a maneira mais fácil destes se alimentarem ou usufruirem de algum possível momento de descanso seria nas próprias redondezas do trabalho. Logo, os 8 botequins e bilhares da rua da Concórdia mapeados a partir do Almanak Laemmert, cumpriam uma importante função de sociabilidade para os operários que trabalhavam nesta via e em suas redondezas. Não é à toa que esta via, juntamente com a rua Carneiro Leão (marcada pela presença de cortiços) e a rua Monsenhor Andrade (com um complexo fabril considerado, se formos levar em consideração apenas o Moinho Matarazzo), sejam as ruas que mais continham botequins e bilhares em toda a área do Brás, pois eram aquelas que estavam situados grande número de operários.

${ }^{292}$ Atual rua Dr. Almeida Lima. 
À medida que novos habitantes se estabeleciam na cidade, novos gostos se faziam e novas demandas se apresentavam. Desde finais do século XIX, a produção de tecidos em São Paulo seguiu num ritmo acelerado, processo que fora auxiliado pela importação de maquinários que aumentavam a sua produção. Se "nada se igualou, no Triângulo, à quantidade de oficinas e lojas voltadas para o ramo do vestuário"293, no Brás não fora diferente. Contava com uma imensa rede de armarinhos e lojas de fazendas, fábricas e lojas de calçados, chapelarias, alfaiatarias, fábricas e lojas de bordados, rendas, meias, tecidos de lã, tecidos de aniagem, tinturaria, colchoaria...

A historiografia demonstrou a produção de tecidos em larga escala, principalmente pondo luz nos grandes complexos industriais que se formaram nas bordas da cidade. A indústria têxtil avança sobremaneira na cidade, formando um dos principais braços produtivos da cidade, atendendo às necessidades da população que se estabelecia na cidade, bem como distribuindo para outras regiões do Estado e do país. Edgar Carone pontua que grande parte deste tecido era voltado para uso doméstico, ou necessários para o vestuário masculino e feminino, a um público com menores recursos e "que se pode avaliar é que a maioria das fábricas produzem tecidos crus e tintos, chitas, morins e brins, tecidos riscados, zefirs, cassinetas, colchas, atoalhados, xales, etc" ${ }^{\text {294 }}$. Esta indústria não estaria confinada à produção de tecidos para o vestuário, mas também voltada à produção de sacos de juta para o ensacamento de café no interior do estado, como a do conde Armando Álvares Penteado, a Companhia Nacional de Tecidos de Juta, "com mais de 2.000 teares e 80.000 fusos para a produção de tecidos de algodão" ${ }^{295}$, que anos depois passaria às mãos de Jorge Street, o qual financiaria a construção da Vila Maria Zélia.

Carone observou que esta indústria ainda não atendia a totalidade da população paulistana, pois “os tecidos para vestimentas da classe média e alta não são fabricados no Brasil" e o estado de São Paulo importava grande volume a fim de suprir as suas necessidades ${ }^{296}$. Além disto, o historiador confere um destacado papel à figura do imigrante, pois, como trabalhador e consumidor das cidades,

\footnotetext{
${ }^{293}$ BARBUY, Op. Cit, pág. 172

${ }^{294}$ CARONE, Edgar. A evolução industrial de São Paulo (1889-1930). São Paulo: Editora SENAC, 2001, pág. 97.

${ }^{295}$ Idem, pág. 98.

${ }^{296}$ Idem, pág. 99.
} 


\begin{abstract}
“possuíam, em geral, necessidades mais sofisticadas do que os nativos, alargando assim o mercado interno. Em suma, os imigrantes transplantavam novas atitudes, técnicas e atividades; tem maior ambição; seu consumo incluía artigos industriais em maior quantidade e qualidade; era outra sua atitude diante do trabalho; eram, em conjunto, melhor qualificados profissionalmente, sua mentalidade de poupança era mais desenvolvida; características essas mais condizentes com o crescimento econômico capitalista"297.
\end{abstract}

Heloisa Barbuy buscou trilhar o consumo de roupas na região do Triângulo, pois segundo a autora nada teria se igualado "à quantidade de oficinas e lojas voltadas para o ramo do vestuário" ${ }^{298}$. Alfaiates, costureiras, tecidos elegantes, chapéus, vestidos, a moda europeia dominava o cenário paulistano, essencialmente sob inspiração de lojas francesas. Casas como À la Belle Jardinière, Au Bon Marche, Au Paradis des Enfants, dentre muitas outras se consagrariam como espaços do requinte e da moda, voltados essencialmente para os setores altos da cidade.

Enquanto isso, nos novos bairros como o Brás, comércios se especializavam numa infinidade de artigos que atendiam aos setores médios e baixos da população, com produtos que provinham muitas vezes de fábricas das redondezas. Alfredo Moreira Pinto em seu livro de memórias de quando visitou a cidade de São Paulo, coloca que a Fábrica de Tecidos do Braz, de propriedade de Antônio Álvares Penteado, foi a primeira a ser instalada na capital paulista entre as ruas Rodrigues dos Santos e de frente às ruas Florida e Cruz Branca. Duas fábricas, uma destinada à produção de tecidos de lã e outra destinada à produção de aniagens para a confecção de sacos para exportação de café. Possuía 600 operários que produziam de 55 a 60 mil metros diários de tecido, produção que podia ser exportada para outras regiões do país, como os estados do sul e para o Rio de Janeiro ${ }^{299}$, alimentada por mais de 2.000 teares e 80.000 parafusos $^{300}$.

Já Bandeira Júnior relata de maneira mais suntuosa, assim referindo-se ao Brás, que “dentro de poucos anos, será o primeiro bairro comercial, por isso que reúne todas as condições necessárias a uma Village desse gênero. Bem cêdo o compreendeu o perspicaz Snr. Penteado, escolhendo-o para edificar os soberbos edifícios onde

\footnotetext{
${ }^{297}$ Idem, pág. 107.

298 BARBUY, Op. Cit., pág. 172.

${ }^{299}$ PINTO, Op. Cit., 1901, p. 207.

${ }^{300}$ CARONE, Op. Cit., pág. 98.
} 
funccionam as fabricas e mais outro em que habitam muitos dos seus numerosos operários. ${ }^{301}$

A primeira fábrica, fundada em 1889, destinava-se à produção de aniagem (em um edifício de um só pavimento, medindo cerca de 20 mil metros quadrados e 1.000 operários, a maioria italianos e $90 \%$ destes funcionários eram mulheres). Bandeira Júnior coloca que havia também 100 outras máquinas auxiliares movidas por dois vapores do sistema Compound com força de 800 cavalos. Além das máquinas, quatro caldeiras forneciam energia para a fábrica, alimentadas a carvão a pedra. Já a água, destinada ao vapor das caldeiras provinha de reservatórios, "ligados por meio de tubos, que atravessam diversas ruas do Braz, a um outro grande reservatório situado a quatro quilômetros da fabrica, em terrenos do mesmo proprietário, com capacidade de 50.000.000 de litros fornecidos por um manancial próprio" ${ }^{\circledR 02}$, num reservatório na região da Móoca que permitiam chegar a uma força motriz de 450 cavalos. ${ }^{303}$

O sistema de produção de tecelagem era privilegiado, pois as peças de tecido seguiam da "porta da officina para os vagões da "E. de Ferro Ingleza", que tinha desvios nos terrenos da fábrica, construídos com este propósito eram também privilegiadas por também estarem nas proximidades dos bondes elétricos, dados que demarcariam o crescimento do bairro do Brás ${ }^{304}$.

A fábrica de aniagem ocupava uma área de doze mil metros quadrados, esclarecendo que suas "oficinas e todas as dependencias são vastas, claras, arejadas e limpas, observandose logo á primeira vista, que a construcção obdeceu á todas as regras da arte e da hygiene, indispensáveis ás obras dessa natureza" 305 , em consonância com os preceitos higienistas que estavam em vigor na cidade de São Paulo desde finais do século XIX, e ditados segundo as normas do Código Sanitário de 1894.

Contando com um sistema de produção industrial altamente equipado, apresentava 800 operários que produziam tecidos ali com relativa rapidez, já alinhados ao modo de produção industrial, já que "a primeira officina é destinada ao preparo dos fios, que passam

\footnotetext{
${ }^{301}$ BANDEIRA JÚNIOR, Op. Cit., pág. 3.

${ }^{302}$ PINTO, Op. Cit., pág. 208

${ }^{303}$ BANDEIRA JÚNIOR, Op. Cit., pág. 4.

${ }^{304}$ Idem, pág. 4.

${ }^{305}$ Idem, pág. 3.
} 
aos carreteis, destes para os medideiros, destes para as machinas de engomar, indo finalmente para os teares, em número superior a seiscentos"306.

Já a fábrica destinada aos tecidos de lã, fundada em 1898, estava situada num edifício que ocupava uma área de dez mil metros quadrados, também servido pelos motores do sistema Compownd de força de oitenta cavalos, bem ao lado da fábrica de tecidos de aniagem, "gosando das mesmas vantagens de locomoção", empregando de 130 a 150 operários de ambos os sexos..$^{307}$

Com um sistema de produção dividido em sete etapas, pode-se verificar que esta fábrica também seguia os padrões de divisão do trabalho, sendo que na $1^{a}$ seção contavamse com duas máquinas para urdir e engomar; uma máquina para passar os rolos; uma máquina para fazer os estulos e uma máquina para fazer os carreteis. Já na $2^{\mathrm{a}}$ seção, diversas máquinas de lavagem, enquanto na $3^{\mathrm{a}}$ a seção de tinturaria, com maquinismos e tanques. $\mathrm{Na}$ $4^{\mathrm{a}}$, o processo de secagem e na $5^{\mathrm{a}}$ as máquinas de tesourar, isto é, de tirar os pelos que permaneciam em grande volume no tecido, trabalho este que era realizado com auxílio de tesouras cilíndricas (o que facilitava o trabalho da próxima seção, para alisar os tecidos, por meio das máquinas Calandras). Na última etapa do sistema de produção, com a máquina Decatril, dava-se no tecido um banho de vapor que tirava todo o "lustre desnecessário", para que então pudesse ser "medido, pesado, dobrado, enrolado e enfardado afinal, recebendo logo a marca e o número correspondente.”308

Uma outra fábrica de tecidos, a São Paulo, fundada em janeiro de 1897 por Alexandre Ranzini, ficava na região do Belenzinho, produzindo "artigos de primeira qualidade": anualmente 15.000 metros de casemira, 3.000 metros de chalés e 2.000 metros de palas. Tinha 32 funcionários empregados, sendo os nacionais: 1 homem, 6 mulheres e 1 criança; e os estrangeiros: 12 homens, 10 mulheres e dois menores ${ }^{309}$.

Procurando reconstituir o Brás como um espaço que teve desde os primeiros anos do século XX uma forte produção de tecidos, procuramos listar diferentes referências que teciam relações com o mundo da moda, da estética, da beleza com base nos almanaques comerciais, construímos a seguinte tabela com base nos anúncios do Almanak Laemmert.

\footnotetext{
${ }^{306}$ Idem.

${ }^{307}$ Idem, pág. 6.

${ }^{308}$ Idem, pág. 5 e 6.

${ }^{309}$ Idem, pág. 76.
} 


\begin{tabular}{|c|c|c|}
\hline \multicolumn{3}{|c|}{$\begin{array}{l}\text { Relação dos estabelecimentos comerciais do Brás especializados no ramo vestuário e } \\
\text { de armarinhos e fazendas (1897-1915) }\end{array}$} \\
\hline ESTABELECIMENTO COMERCIAL & \multicolumn{2}{|c|}{ QUANTIDADE } \\
\hline \multirow[t]{16}{*}{ Alfaiatarias e roupas feitas } & Ruas & Quantidade \\
\hline & Carneiro Leão & 1 \\
\hline & Celso Garcia & 10 \\
\hline & Concórdia & 1 \\
\hline & Concórdia, Largo da & 2 \\
\hline & Concórdia, Travessa da & 2 \\
\hline & Correia de Andrade & 1 \\
\hline & Gasômetro & 3 \\
\hline & Maria Marcolina & 4 \\
\hline & Monsenhor Anacleto & 1 \\
\hline & Monsenhor Andrade & 4 \\
\hline & Piratininga & 1 \\
\hline & Rangel Pestana & 20 \\
\hline & Santa Rosa & 2 \\
\hline & Visconde de Parnaíba & 1 \\
\hline & TOTAL & 53 \\
\hline \multirow[t]{16}{*}{ Armarinhos e fazendas } & Rua & Quantidade \\
\hline & Brigadeiro Machado & 1 \\
\hline & Carneiro Leão & 2 \\
\hline & Celso Garcia & 36 \\
\hline & Concórdia & 2 \\
\hline & Concórdia, Largo da & 2 \\
\hline & Gasômetro & 3 \\
\hline & Joli & 1 \\
\hline & Maria Marcolina & 2 \\
\hline & Monsenhor Andrade & 5 \\
\hline & Oriente & 2 \\
\hline & Piratininga & 6 \\
\hline & Rangel Pestana & 10 \\
\hline & Rodrigues dos Santos & 1 \\
\hline & Visconde de Parnaíba & 1 \\
\hline & TOTAL & 74 \\
\hline \multirow{10}{*}{ Calçados, Fábricas e lojas de } & Ruas & Quantidade \\
\hline & Celso Garcia & 34 \\
\hline & Concórdia & 5 \\
\hline & Concórdia, Largo da & 2 \\
\hline & Gasômetro & 12 \\
\hline & Maria Marcolina & 2 \\
\hline & Piratininga & 2 \\
\hline & Rangel Pestana & 16 \\
\hline & Santa Rosa & 1 \\
\hline & TOTAL & 74 \\
\hline \multirow[t]{7}{*}{ Chapelarias e camisarias } & Ruas & Quantidade \\
\hline & Celso Garcia & 10 \\
\hline & Gasômetro & 2 \\
\hline & Maria Marcolina & 2 \\
\hline & Rangel Pestana & 10 \\
\hline & Vinte e Um de Abril & 1 \\
\hline & TOTAL & 25 \\
\hline Fábricas diversas & Ruas & Quantidade \\
\hline
\end{tabular}




\begin{tabular}{|l|l|l|}
\hline \multirow{4}{*}{} & Flórida & 2 \\
\cline { 2 - 3 } & Gasômetro & 2 \\
\cline { 2 - 3 } & Joli & 1 \\
\cline { 2 - 3 } & Maria Marcolina & 3 \\
\cline { 2 - 3 } & Rodrigues dos Santos & 1 \\
\cline { 2 - 3 } & Saião Lobato & 1 \\
\cline { 2 - 3 } & TOTAL & 10 \\
\hline \multirow{2}{*}{ Tinturarias } & Ruas & Quantidade \\
\cline { 2 - 3 } & Monsenhor Andrade & 1 \\
\cline { 2 - 3 } & Rangel Pestana & 2 \\
\cline { 2 - 3 } & TOTAL & 3 \\
\hline
\end{tabular}

Tabela 15: "Relação dos estabelecimentos comerciais do Brás especializados no ramo vestuário e de armarinhos e fazendas (1897-1915)", elaborada pelo autor com base no Almanak Laemmert.

Já pelo levantamento que obtivemos com os almanaques, pudemos ver que o mundo da produção de tecidos era muito mais extenso que este mencionado por Alfredo Moreira Pinto e Antonio Bandeira Júnior, pois diversos outros personagens estavam atrelados a este ramo nas ruas do Brás. A tabela por nós elaborada a partir dos almanaques fornecem uma ideia da multiplicidade de agentes que atuavam para além do ramo da alimentação, envolvendo profissionais que se dedicavam á inúmeras atividades no ramo da indumentária (como alfaiates, costureiras, donos de armarinhos e fazendas que vendiam diversos artigos inclusive roupas, sem contar as chapelarias, tinturarias, fábricas e lojas de calçados que se espalhavam pelo Brás).

Ernani Silva Bruno, a partir de um livro que focalizava cenas da vida paulistana no começo do século $\mathrm{XX}$, coloca que muitos homens, quando estavam às portas do Café Guarani, "costumavam expor diariamente aos transeuntes pacatos o irrepreensível corte das calças vincadas e dos paletós cintados, a cromática mirabolância das gravatas e a extravagância morfológica dos chapéus". ${ }^{310}$ Os cafés eram assim vistos como espaços em que a sociabilidade paulistana se concentrava, dado este que pôde ser empiricamente verificável naqueles situados no Brás, especialmente no eixo das avenidas Rangel Pestana e Celso Garcia. Mas afinal, como a roupa auxiliava neste processo de socialização? As roupas daqueles que frequentavam a confeitaria homônima à citada por Ernani Silva Bruno, será que eram fabricadas no próprio Brás? Quem as fazia?

Quem consumia boa parte da indumentária produzida no Brás podia se valer das várias alfaiatarias localizadas no eixo das avenidas Rangel Pestana e Celso Garcia, ruas que juntas, detinham 30 das 53 mapeadas nas ruas do Brás. Talvez aqui estejam algumas das

${ }^{310}$ AGUDO, José. Gente rica, pág.119 apud, BRUNO, Op. Cit., pág. 1157. 
chaves para se compreender o fato do Brás ter-se firmado na contemporaneidade como polo distribuidor de roupas. Os armarinhos e fazendas não fogem à regra quanto à localização, privilegiando o eixo das avenidas supracitadas, com um total de 46 de todos os 74 localizados nas páginas dos almanaques comerciais. As ruas Monsenhor Andrade, Maria Marcolina, Gasômetro, dentre outras ruas, também tinham alguns destes estabelecimentos, servindo assim outras porções do bairro, e mais uma vez contando com o fato de serem atendidas pela passagem dos bondes em suas portas.

Por sua vez contabilizamos fábricas de calçados, formando um polo diversificador, de venda não apenas dos Calçados Clark, mas uma série de manufaturas que se desenvolviam produzindo os mais diversos sapatos, desde aqueles destinados ao público masculino como o feminino, e para crianças. Só a rua do Gasômetro detinha 12 destas fabriquetas com lojas.

O chapéu era um símbolo de status, de inserção nos círculos de relação da São Paulo da Belle Epoque, e comprar um numa das 10 lojas da Avenida Rangel Pestana ou nas outras 10 da Avenida Celso Garcia significava manter este status. Caso não estivesse nas proximidades das avenidas, ou fosse um cliente de outras lojas, poderia ainda encontrar duas lojas na rua do Gasômetro ou outras duas na Maria Marcolina e uma na rua Vinte e Um de Abril.

\subsection{Produzir a cidade, alimentar as fábricas e mobiliar as casas}

À medida que São Paulo crescia em número de habitantes, novas demandas surgiam e se tornavam mais frequentes no mercado consumidor interno da cidade. Não foi apenas o crescimento do consumo de alimentos e do vestuário, mas de uma série de objetos que começaram a fazer parte do cotidiano de fábricas, oficinas, casas e comércios. No Brás, pode-se vislumbrar que várias carpintarias e marcenarias, serrarias, fábricas de canos, tintas, parafusos, vidros, fundições, funilarias, dentre outros, foram produzidas até os princípios da Primeira Guerra Mundial.

Uma das fábricas que marcou a região do Brás e de muitas outras regiões de São Paulo, fora a dos irmãos Reffinette. Fundada em 1888 na rua Piratininga entre os números 
10, 12 e 14, tinha uma produção especializada em móveis escolares e uso doméstico. O estabelecimento podia contar com maquinários a vapor, com um motor da força de 8 cavalos, além de uma oficina de empalhar e lustrar os móveis. Bandeira Júnior relata que do operariado empregado, variava "entre 40 e 50 homens em sua maioria estrangeiros" 311. Já o Almanaque Laemmeet, em sua edição de 1914, relata que neste ano a especialidade da fábrica se estendia para o ramo do vestuário, com a produção de "armarinhos, fazendas, modas e roupas feitas", atendendo também na rua General Carneiro, número 19.

Pesquisando uma de suas propagandas, vemos o entusiasmo de serem revendedores de móveis ao Governo do Estado de São Paulo, para escolas e colégios da cidade, não deixando em segundo plano o fato de terem sido condecorados em 1908 com a Medalha de Ouro na Exposição Nacional do Rio de Janeiro, e até mesmo ter ganho dois prêmios internacionais na Itália: o Diploma de Honra e a Medalha de Prata na Exposição Internacional da cidade de Turim, e a Medalha de Ouro na Exposição Internacional de Roma, ambas no ano de 1911, destacando a qualidade dos produtos fabricados no Brás (figuras 185 e 186).

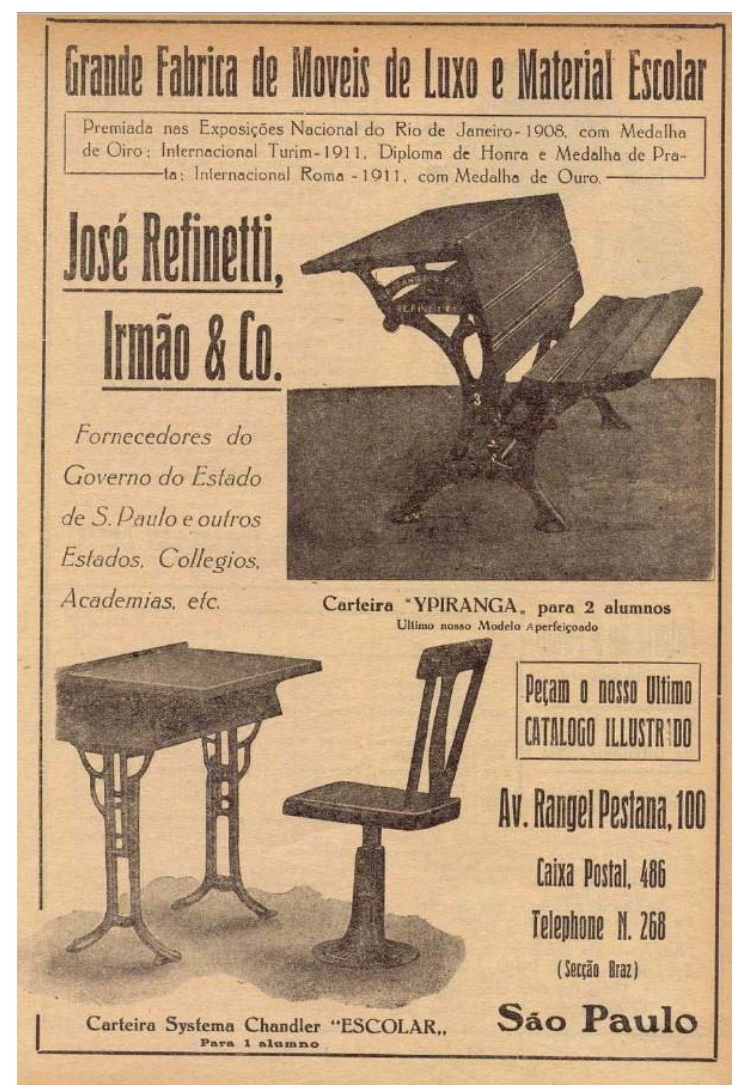

Figura 185: Anúncio da "José Refinetti, Irmão \& Co", Revista A Cigarra, edição de 09 de novembro de 1916. Acervo do Arquivo Público do Estado de São Paulo.

${ }^{311}$ BANDEIRA JUNIOR, Op. Cit., pág. 33. 


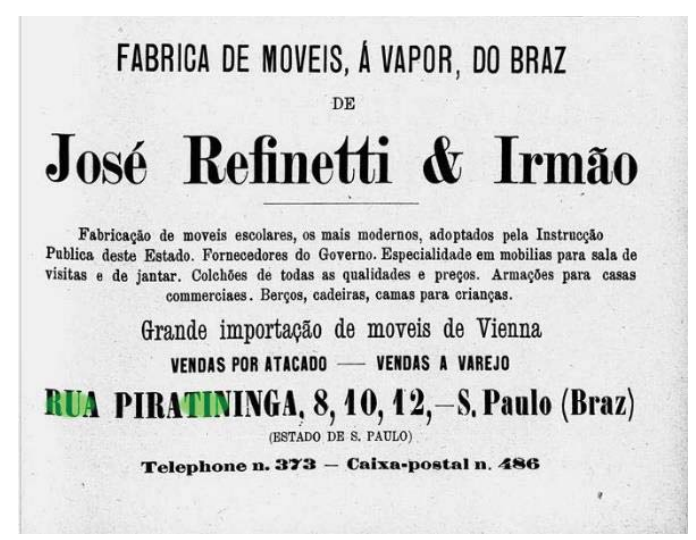

Figura 186: Anúncio da Fábrica de Móveis dos “Irmãos Refinetti”, do Almanaque Laemmert, em 1901. Acervo: Hemeroteca Digital Brasileira.

Móveis de madeira não eram uma exclusividade da fábrica dos Irmãos Reffinetti, pois, o próprio Almanaque Laemmert, que anunciava propagandas da firma, também anunciava sobre outros espaços que se dedicavam à produção moveleira no Brás. Se nos atentarmos para as ruas que trabalham com o entalhe de madeira e a produção de móveis, podemos verificar que esta produção estava espalhada sobre todo Brás, com a Avenida Celso Garcia detendo ao menos um terço das carpintarias e marcenarias. Curioso notar que, em contraponto, as lojas de móveis e colchões estavam em sua maioria na Avenida Rangel Pestana, com metade das 32 localizadas por nós.

\begin{tabular}{|c|c|c|}
\hline \multicolumn{3}{|c|}{$\begin{array}{l}\text { Relação dos estabelecimentos comerciais do Brás } \\
(1897-1915)\end{array}$} \\
\hline ESTABELECIMENTO COMERCIAL & \multicolumn{2}{|c|}{$\begin{array}{l}\text { QUANTIDADE LEVANTADA EM CADA } \\
\text { UMA DAS RUAS }\end{array}$} \\
\hline \multirow[t]{13}{*}{ Carpintarias e marcenarias } & Ruas & Quantidade \\
\hline & Almirante Barroso & 1 \\
\hline & Carneiro Leão & 1 \\
\hline & Celso Garcia & 7 \\
\hline & Concórdia, Largo da & 2 \\
\hline & Euclides da Cunha & 1 \\
\hline & Fernandes Silva & 2 \\
\hline & Gasômetro & 3 \\
\hline & Maria Marcolina & 1 \\
\hline & Miler & 1 \\
\hline & Piratininga & 1 \\
\hline & Visconde de Parnaíba & 1 \\
\hline & TOTAL & 21 \\
\hline \multirow[t]{5}{*}{ Móveis e colchões } & Ruas & Quantidade \\
\hline & Celso Garcia & 8 \\
\hline & Concórdia, Largo da & 1 \\
\hline & Gasômetro & 2 \\
\hline & Maria Marcolina & 2 \\
\hline
\end{tabular}




\begin{tabular}{|l|l|l|}
\hline \multirow{2}{*}{ Serrarias } & Piratininga & 2 \\
\cline { 2 - 3 } & Rangel Pestana & 16 \\
\cline { 2 - 3 } & Visconde de Parnaíba & 1 \\
\cline { 2 - 3 } & TOTAL & 32 \\
\hline \multirow{n}{*}{} & Ruas & Quantidade \\
\cline { 2 - 3 } & Celso Garcia & 1 \\
\cline { 2 - 3 } & Concórdia, Largo da & 1 \\
\cline { 2 - 3 } & Gasômetro & 8 \\
\cline { 2 - 3 } & Henrique Dias & 1 \\
\cline { 2 - 3 } & Monsenhor Andrade & 4 \\
\cline { 2 - 3 } & TOTAL & 15 \\
\hline
\end{tabular}

Tabela 16: "Relação dos estabelecimentos comerciais do Brás especializados no ramo madeireiro (1897-1915)", elaborada pelo autor com base no Almanak Laemmert.

O caso das serrarias, com suas produções voltadas ao processo de corte das madeiras não pode ser considerado preponderante no eixo das avenidas Rangel Pestana e Celso Garcia, mas, o maior número delas encontrava-se na rua do Gasômetro (8 das 15 localizadas), rua que até os dias atuais se coloca no cenário paulistano como especializada no comércio de madeiras. A rua Monsenhor Andrade com 4 destas serrarias aos poucos se especializa e se afirma como mais uma voltada à produção em larga escala.

Como já abordado, figuras dos setores médios como Palaride Mortari fizeram suas pequenas fortunas a partir da diversificação de capitais, neste caso com armazéns, fábricas de sabão e até serrarias (ver figura 175). Outro personagem já abordado, José Monteiro Pinheiro, investidor do ramo imobiliário que possuía uma grande casa na Avenida Celso Garcia, também era proprietário de uma serraria na avenida supracitada número 110. Com projeto assinado em 1908 pelo construtor Adalberto Bueno, a serraria ocupava uma extensa faixa no interior e na testada do lote (figura 187). Sete anos depois, a serraria seria expandida, ocupando boa parte da totalidade do lote, agora com uma cocheira projetada por Accacio de Villalva, espaço que serviria como local de repouso aos animais que transportariam as madeiras dali (figura 188). 


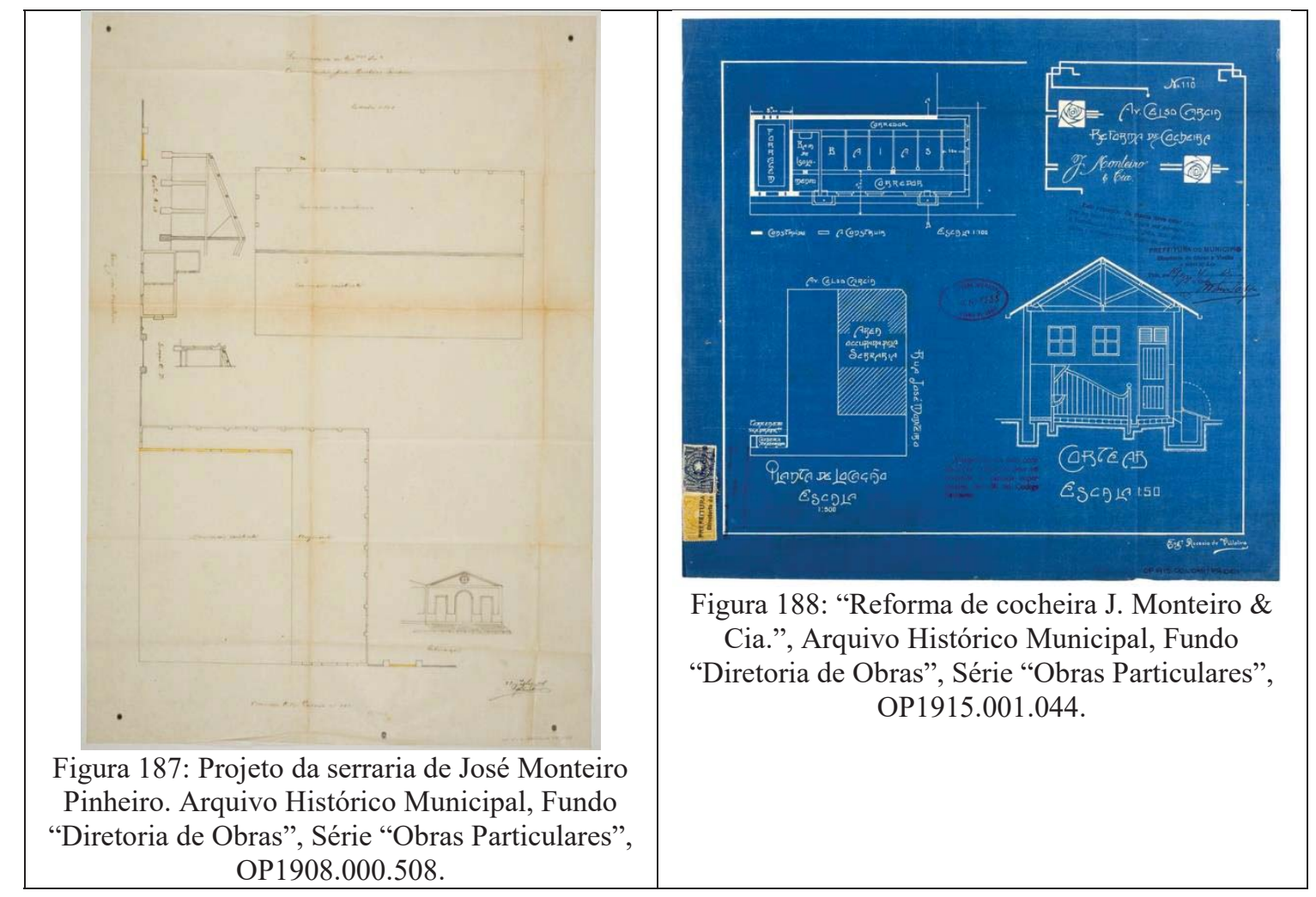

Pouco depois de concluídas as obras, a Companhia Light and Power entrou com um pedido de licença para um desvio na serraria de José Monteiro Pinheiro, desapropriando parte do terreno a fim de que facilitasse a implantação de um dos trilhos dos seus bondes que faria terminal nas proximidades da rua José Monteiro (figura 189).

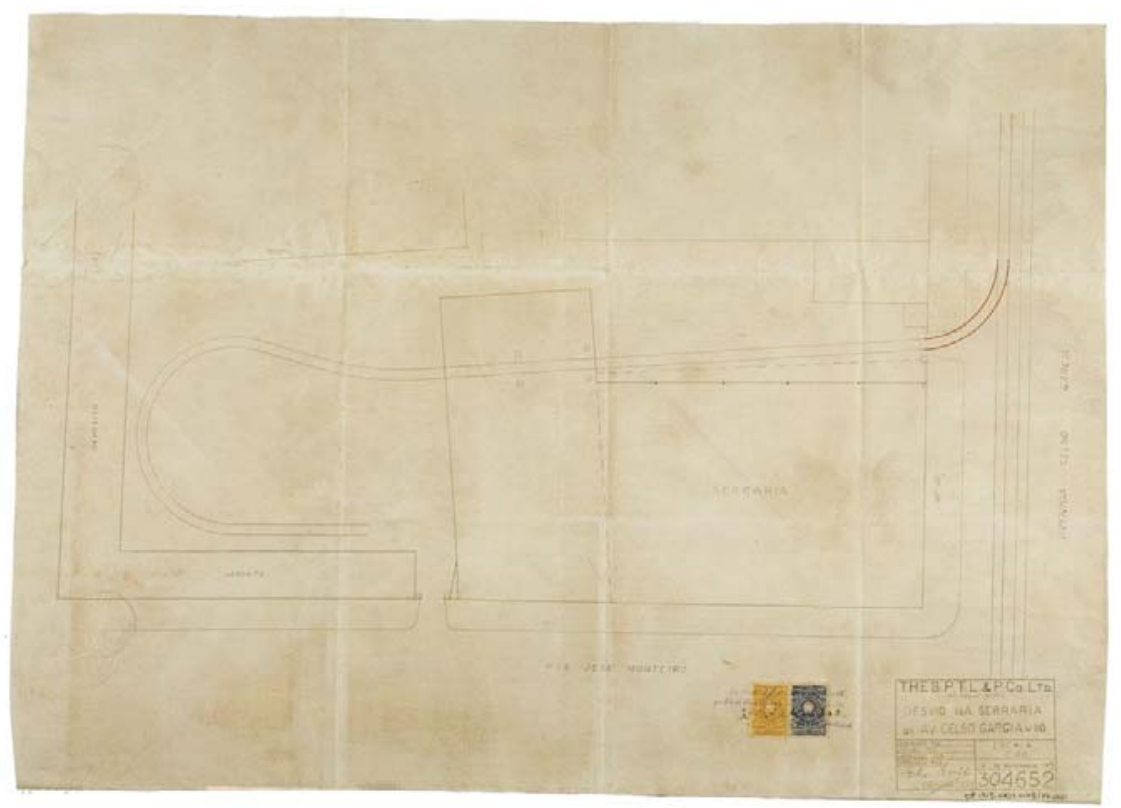

Figura 189: Desvio na serraria da Avenida Celso Garcia, 110. Arquivo Histórico Municipal, Fundo "Diretoria de Obras", Série “Obras Particulares", OP1915.001.045. 
A Serraria Santa Isabel, anunciada nas páginas da edição de 1911 do Almanak Laemmert como a "Serraria de Castro Mendes" na avenida Celso Garcia número 254, registra na Série Obras Particulares algumas mudanças a partir do ano de 1912, como a construção de uma cocheira (figura 190) e um grande barracão que possa comportar as novas instalações produtivas (figuras 191 e 192).

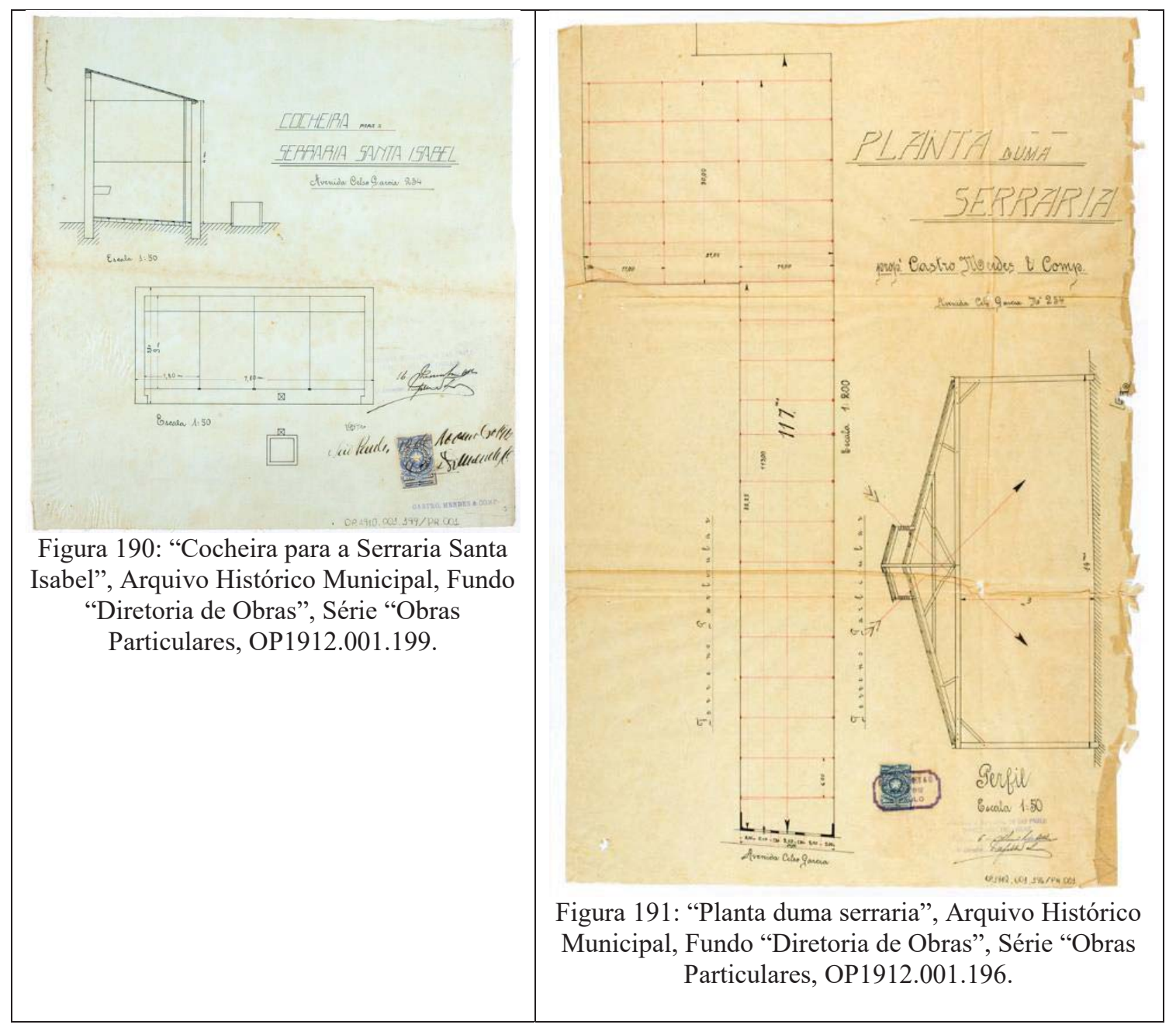




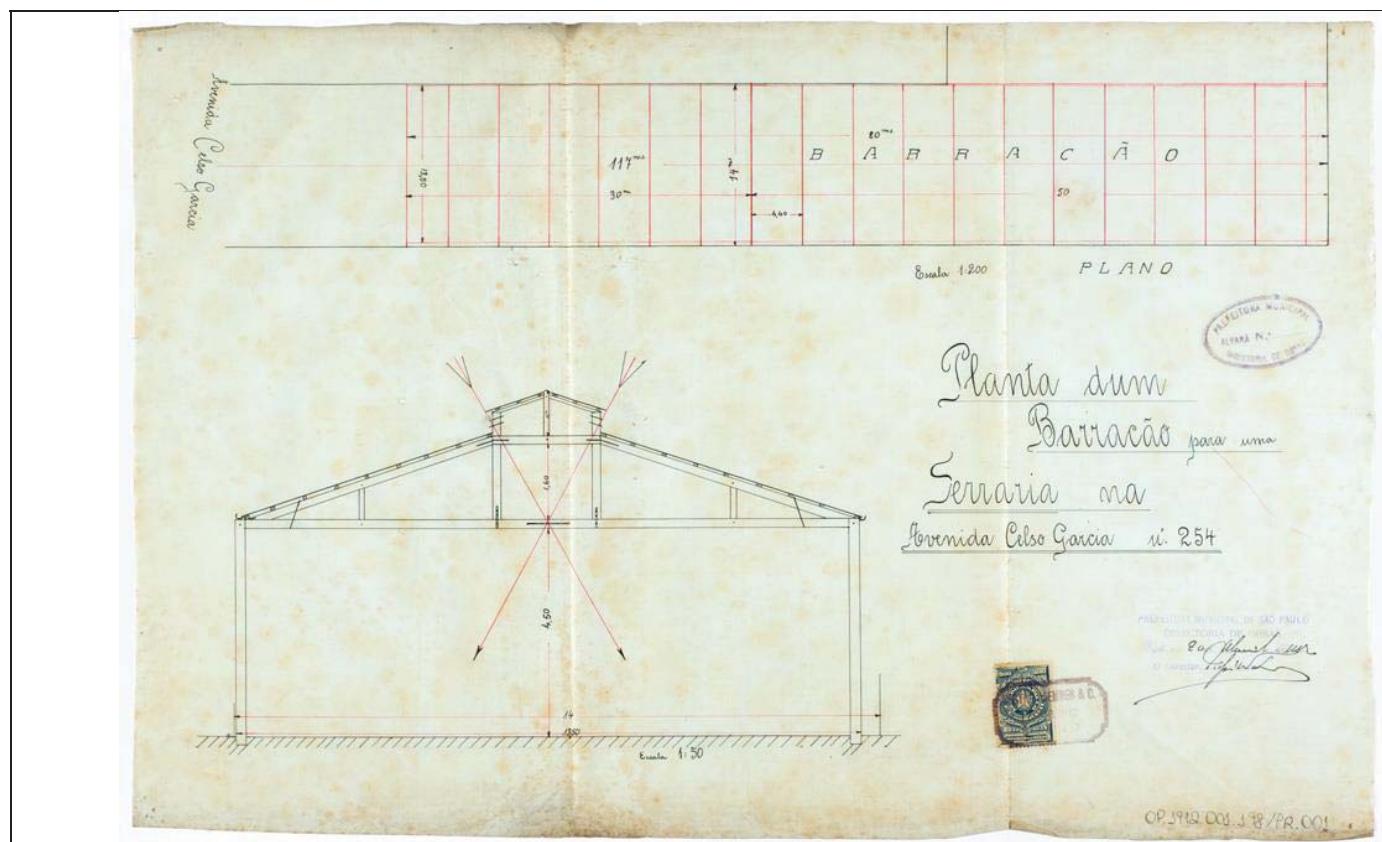

Figura 192: "Planta dum barracão para uma serraria na Avenida Celso Garcia n 254", Arquivo Histórico Municipal, Fundo “Diretoria de Obras”, Série “Obras Particulares, OP1912.001.198.

Este processo de formação de uma porção da cidade especializada no ramo da construção civil, pode-se dizer que é visível no Brás, onde se nota a presença de muitas fábricas e lojas destinadas à venda de artigos da construção e reforma de imóveis e de artigos industriais, com fábricas especializadas na produção de canos, tintas, escadas, parafusos, vidros, louças, porcelanas, cristais, maquinários, ferragens, ladrilhos, mosaicos, fundição e funilaria.

\begin{tabular}{|c|c|c|}
\hline \multicolumn{3}{|c|}{$\begin{array}{l}\text { Relação dos estabelecimentos comerciais do Brás especializados no ramo da } \\
\text { construção civil (1897-1915) }\end{array}$} \\
\hline ESTABELECIMENTO COMERCIAL & \multicolumn{2}{|c|}{$\begin{array}{l}\text { QUANTIDADE LEVANTADA EM } \\
\text { CADA UMA DAS RUAS }\end{array}$} \\
\hline \multirow{13}{*}{$\begin{array}{l}\text { Materiais para construção, ferragens, } \\
\text { ladrilhos, mosaicos, vidros }\end{array}$} & Ruas & Quantidade \\
\hline & Almirante Barroso & 1 \\
\hline & Bresser & 1 \\
\hline & Celso Garcia & 11 \\
\hline & Concórdia & 2 \\
\hline & Concórdia, Largo & 1 \\
\hline & Gasômetro & 4 \\
\hline & Gomes Cardim & 1 \\
\hline & Martim Afonso & 1 \\
\hline & $\begin{array}{l}\text { Monsenhor } \\
\text { Andrade }\end{array}$ & 2 \\
\hline & Oriente & 1 \\
\hline & Piratininga & 3 \\
\hline & Rangel Pestana & 25 \\
\hline
\end{tabular}




\begin{tabular}{|l||l|l|}
\hline \multirow{2}{*}{ Louças, porcelanas, cristais } & Ruas & Quantidade \\
\cline { 2 - 3 } & Bresser & 1 \\
\cline { 2 - 3 } & Celso Garcia & 6 \\
\cline { 2 - 3 } & Gasômetro & 1 \\
\cline { 2 - 3 } & Maria Marcolina & 2 \\
\cline { 2 - 3 } & Rangel Pestana & 1 \\
\cline { 2 - 3 } & $\begin{array}{l}\text { Visconde de } \\
\text { Parnaíba }\end{array}$ & 3 \\
\hline
\end{tabular}

Tabela 17: "Relação dos estabelecimentos comerciais do Brás especializados no ramo da construção civil (1897-1915)", elaborada pelo autor com base no Almanak Laemmert.

Fundada em 1891, em dez anos a Casa Helvetia contava com duas unidades, uma na rua Visconde Rio Branco número 49, e outra na Avenida Rangel Pestana número 92. O Almanaque Laemmert anuncia que em 1914 possuíam outra unidade, na rua Doutor Pedro Vicente, número 2. Comercializava ladrilhos em cimento e mosaico, pias, banheiros e latrinas, pedras para calçamento e para móveis, bem como artefatos funerários, executando inclusive obras para o Palácio do Governo e para a Secretaria da Polícia, Secretaria da Agricultura, Teatro Santana, para as Escolas Normais, Politécnica, Prudente de Morais e do Brás, ao Hospital Militar, Hospital dos Alienados, Jardim de Infância, Estação da Luz e de Santos, Jurí de Campinas, Liceu de Artes e Ofícios, Igreja do Sagrado Coração de Jesus, a Praça do Comércio de Santos, Grupo Escolar de Campinas, à Santa Casa de Bragança. Em 1901 empregava 50 homens estrangeiros. ${ }^{312}$

Já a Cristalaria Germânia, fundada em 1890 por Luiz de Souza Lima, na rua Martim Afonso, 11, nas proximidades da Avenida da Intendência, em 1901, era pertencente à Conrado Sorgenicht \& Comp., vidraria conhecida pela execução de vitrais de inúmeros edifícios da cidade de São Paulo, como os do Mercado Municipal, da Faculdade de Direito do Largo São Francisco e da antiga Escola Politécnica (Edifício Ramos de Azevedo).

Heloisa Barbuy coloca que esta e outras vidrarias ganharam espaço no comércio paulistano, competindo de par e passo com a enxurrada de importados que adentrava no comércio,

“ocupavam a faixa dos produtos utilitários fornecidos por atacado, como garrafas para fábricas de bebidas e vidros para estabelecimentos farmacêuticos, e não ainda, a faixa voltada para o consumo burguês de varejo, na qual o artigo

${ }^{312}$ Idem, pág. 106 e 107. 
estrangeiro reinava, com todas as conotações de modernidade de que se revestia" 313 .

Bandeira Júnior relata em 1901 sobre a cristalaria, de que

“os seus artigos são todos de primeira necessidade, não só no que diz respeito ao meio doméstico, como ao commercio, com especialidade ás pharmacias e drogarias e a modicidade dos preços torna-os de facillima acquisição. Em muitos objectos a perfeição nada deixa a desejar, em outros, o fabrico si não é perfeito, não é máu, principalmente comparando o seu custo com o similar estrangeiro.

Nosso escritor ainda coloca que na fábrica trabalhavam 50 homens, sendo 30 brasileiros; 16 mulheres, das quais 10 eram brasileiras, e 44 meninos (34 nascidos em território nacional), evidenciando o alto número de imigrantes que trabalhava na fábrica. Fato interessante de se notar é que neste mesmo endereço também funcionou outra vidraria, fundada por Alexandre Bekmer, e que contava com um motor de 4 cavalos, máquina completa de latas, moinho para carvão, repizadeira e prensa litográfica, empregando dois homens e três crianças nacionais, dois homens, duas mulheres e três crianças estrangeiras. ${ }^{314}$

A partir do Almanak Laemmert produzimos uma tabela que organiza os estabelecimentos comerciais do Brás dedicados à fundição e funilaria, maquinários e serralheria, ou seja, aos estabelecimentos que trabalhavam com a metalurgia e seus moldes, produzindo peças e artefatos para uso residencial e industrial, e com os profissionais que atuavam com chapas metálicas em máquinas e peças variadas.

\begin{tabular}{|c|l|l|}
\hline $\begin{array}{c}\text { Relação dos estabelecimentos comerciais do Brás especializados no ramo da fundição } \\
\text { e funilaria }\end{array}$ \\
\hline ESTABELECIMENTO COMERCIAL & \multicolumn{2}{|c|}{$\begin{array}{r}\text { QUANTIDADE LEVANTADA EM } \\
\text { CADA UMA DAS RUAS }\end{array}$} \\
\hline \multirow{2}{*}{ Fundição e funilaria } & Ruas & Quantidade \\
\cline { 2 - 3 } & Carneiro Leão & 3 \\
\cline { 2 - 3 } & Celso Garcia & 6 \\
\cline { 2 - 3 } & Concórdia, Largo da & 1 \\
\cline { 2 - 3 } & Correia de Andrade & 1 \\
\cline { 2 - 3 } & Gasômetro & 3 \\
\cline { 2 - 3 } & Lucas, Beco do & 2 \\
\cline { 2 - 3 } & Maria Marcolina & 3 \\
\cline { 2 - 3 } & Martim Burchard & 1 \\
\hline
\end{tabular}

313 BARBUY, Op. Cit., pág. 152 e 153.

${ }^{314}$ BANDEIRA JÚNIOR, Op. Cit., pág. 44 e 46. 


\begin{tabular}{|l|l|l|}
\hline \multirow{4}{*}{ Maquinário } & Monsenhor Andrade & 2 \\
\cline { 2 - 3 } & Paulo Afonso & 1 \\
\cline { 2 - 3 } & Rangel Pestana & 5 \\
\cline { 2 - 3 } & Visconde de Parnaíba & 1 \\
\cline { 2 - 3 } & TOTAL & 29 \\
\hline \multirow{n}{*}{ Serralherias } & Ruas & Quantidade \\
\cline { 2 - 3 } & Celso Garcia & 1 \\
\cline { 2 - 3 } & Martim Burchard & 1 \\
\cline { 2 - 3 } & Monsenhor Andrade & 1 \\
\cline { 2 - 3 } & Rangel Pestana & 7 \\
\cline { 2 - 3 } & TOTAL & 10 \\
\hline & Rua & Quantidade \\
\cline { 2 - 3 } & Celso Garcia & 2 \\
\cline { 2 - 3 } & TOTAL & 2 \\
\hline
\end{tabular}

Tabela 18: "Relação dos estabelecimentos comerciais do Brás especializados no ramo da fundição e funilaria (1897-1915)", elaborada pelo autor com base no Almanak Laemmert.

Um dos estabelecimentos mapeados por nós remonta ao ano de 1897, quando a Fábrica de Pregos Ipiranga foi fundada por Herman, Stolz \& Comp., produzindo 1 milhão e duzentos mil kilos anuais de pregos, marca numérica que o estabelecimento localizado na Avenida Martin Burchard (número 11) ostentava, além de deter o monopólio de produção estadual, visto ser a única em São Paulo que podia contar com um motor de 25 cavalos, 25 máquinas para fazer pregos, duas máquinas para furar, uma máquina para tornear, seis para limpar os pregos e duas serras circulares. ${ }^{315}$

Em torno do ramo da fundição, um dos grandes empreendimentos que teriam destaque no cenário paulistano seria o da Fundição de Ferro e Bronze Craig \& Martins. George Craig \& Julio Martins que fundaram o quarto estabelecimento de fundição no Estado de São Paulo, em 1895, na rua Monsenhor Andrade número 92 e contaram, até o ano de 1901 com máquinas para furar, tornear, limiar, cortar, pençar e forjar ${ }^{316}$, atendendo essencialmente ao mercado agrícola que se expandia rumo ao oeste paulista.

Tendo fabricado as ferragens do Teatro Santana e as caixas automáticas para os serviços de higiene na cidade de Jau, a fundição empregava uma média de 100 operários, em sua maioria estrangeiros. Segundo Michel Deliberali Marson, em 1922 a fundição recebeu duas medalhas de ouro ao participar da Exposição Internacional da Independência

\footnotetext{
315 Idem, pág. 61 e 62.

${ }^{316}$ Idem, pág. 83.
} 
do Brasil: uma por sua máquina para massas alimentícias e outra pelas máquinas para fabrico de papelão. ${ }^{317}$

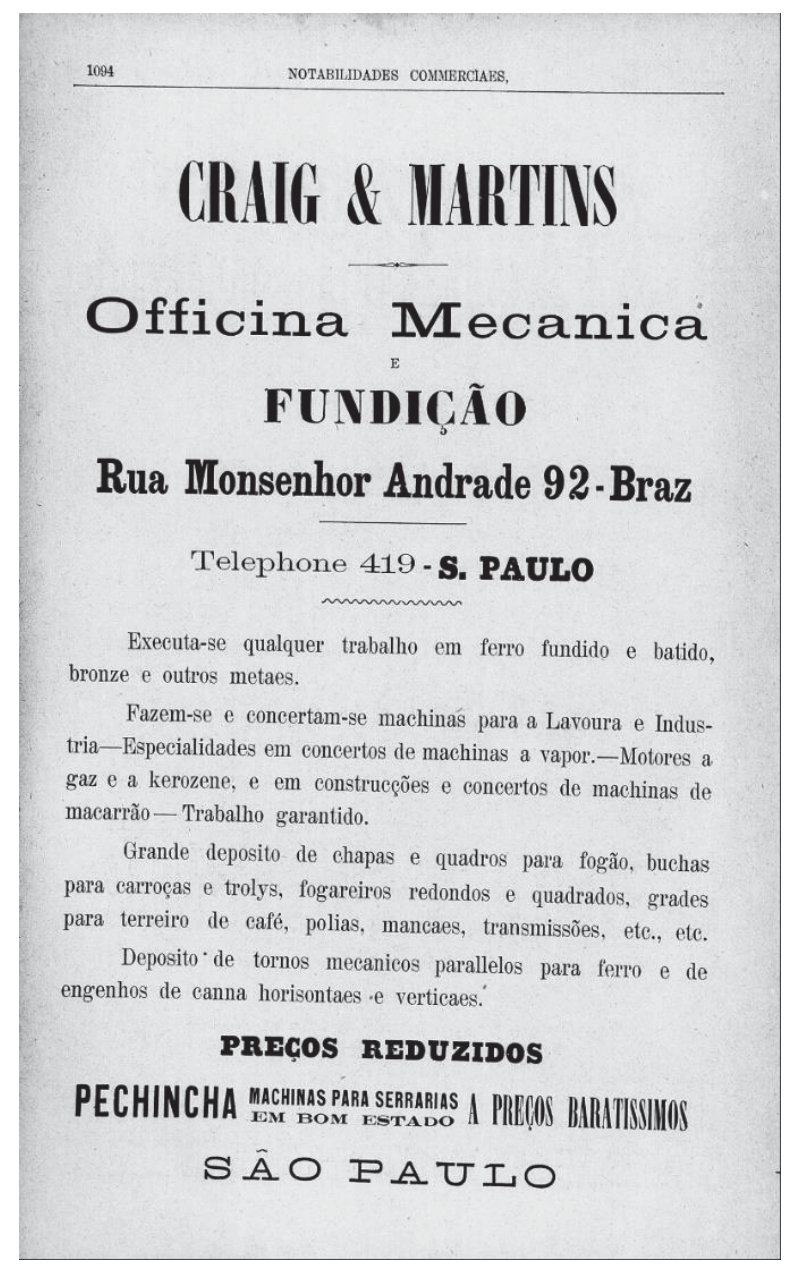

Figura 193: Anúncio da Fundição "Craig \&Martins”, contida no Almanaque Laemmert de 1901. Acervo: Hemeroteca Digital Brasileira.

A Grande Fundição do Braz era outro empreendimento que marcava a paisagem. Fundada em 1892, na rua Correia de Andrade número 14 pelo Tenente Coronel Francisco Amaro, o edifício ocupava uma área de 4000 metros quadrados, podendo contar tanto no seu interior como externamente por linhas de trilhos e vagonetes que permitiam o transporte das matérias primas e produtos lá fabricados.

Dedicada aos processos de fundição de ferro e bronze, como a "fabricação de máquinas inteiras, como peças para máquinas de toda a natureza (...) objetos de arte, de ornamentação", empregava aproximadamente 100 funcionários, a maioria estrangeiros, os

\footnotetext{
${ }^{317}$ MARSON, Michel Deliberali. Origens e evolução da indústria de máquinas em São Paulo, 1870-1960. Tese (Doutorado em Economia). Faculdade de Economia, Administração e Contabilidade. São Paulo: Universidade de São Paulo, 2012, pág. 191.
} 
quais construíam as mais diversas máquinas que podiam atender a produção agrícola ou industrial (figuras 194 e 195). Em 1918 consolidava sua atuação, produzindo artigos de utilidade cotidiana, essencialmente produtos de higiene, como pias, banheiras e vasos sanitários (figuras 199, 200 e 201).

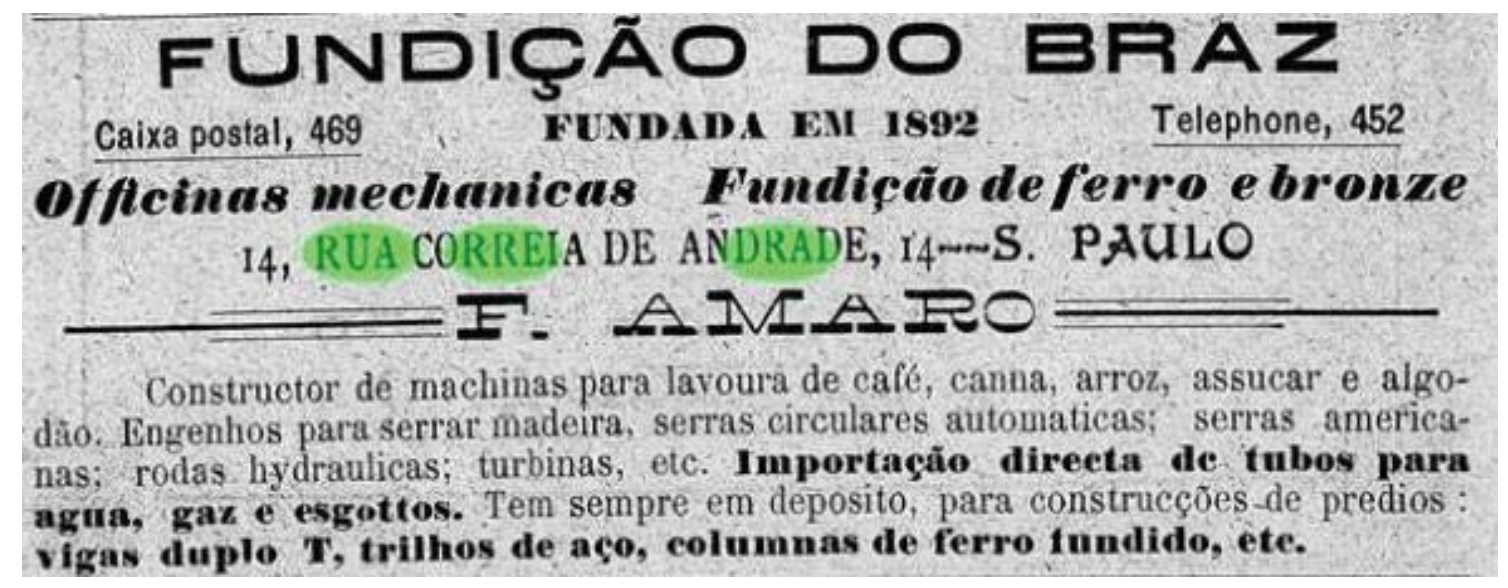

Figura 194: Anúncio da "Fundição do Braz" no Almanaque Laemmert, edição de 1908. Acervo: Hemeroteca Digital Brasileira.

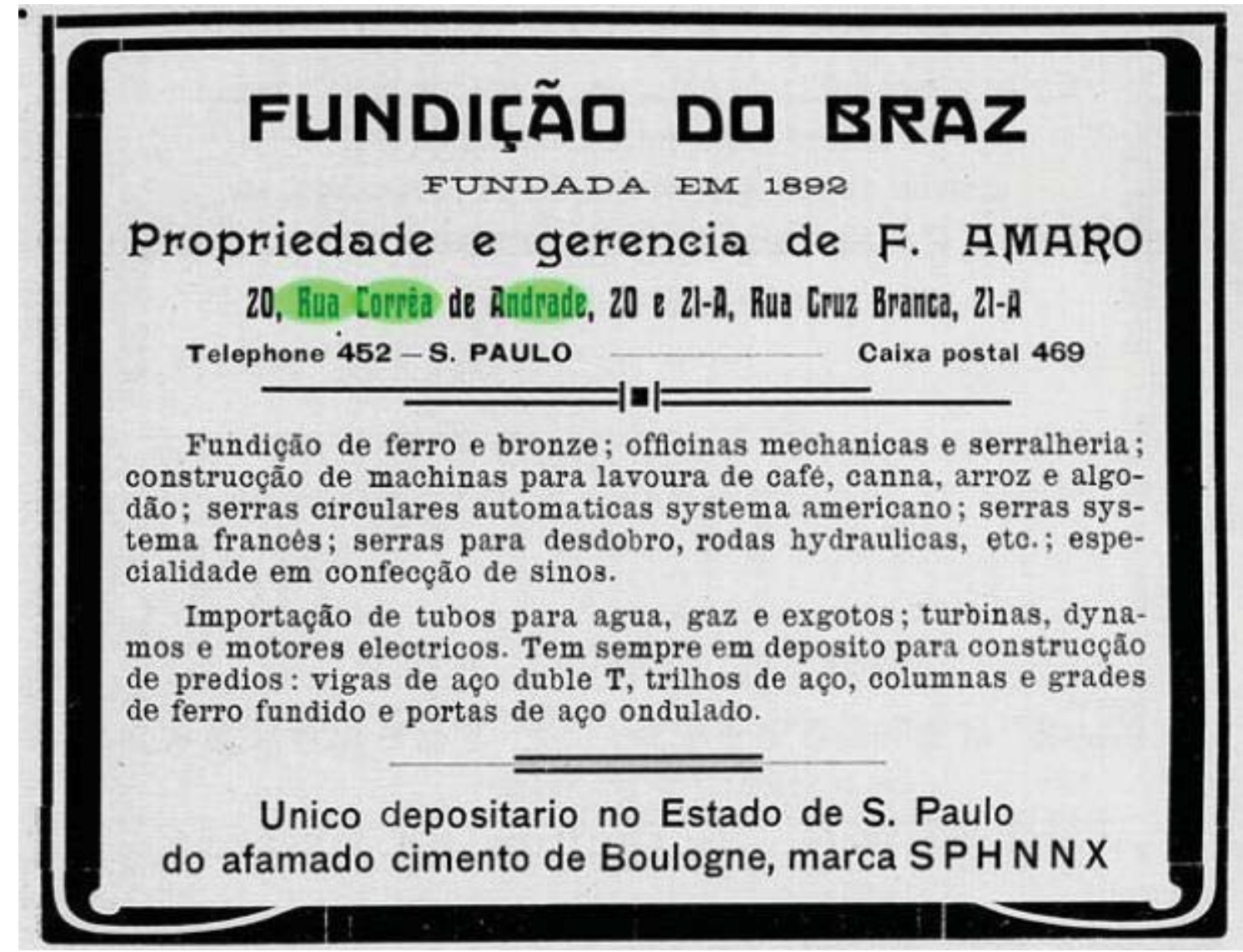

Figura 195: Anúncio da "Fundição do Brás" no Almanaque Laemmert, edição de 1909. Acervo: Hemeroteca Digital Brasileira. 
Beatriz Küh, evidencia que a origem de muitas das estruturas metálicas das construções paulistas foi importada, dado que a siderurgia nacional estava num processo de desenvolvimento neste período, apesar de existirem fundições que já exprimiam sua importância localmente, como a Fundição do Brás, que posteriormente passou a ser denominada Companhia Metalúrgica e Importadora Paulista. Segundo o livro Impressões do Brazil no Século Vinte, "a partir de 1910 [tronou-se] propriedade de uma sociedade anônima organizada pelo Sr. Coronel Francisco Amaro (...), no Brás, o bairro industrial da Capital do Estado de São Paulo." ${ }^{318}$ O livro pesquisado por Kühl ainda confere outras informações acerca da antiga Fundição do Brás, como o emprego de 150 a 180 operários,

\footnotetext{
"no fabrico constante de máquinas para a lavoura de café, arroz, cana e algodão, serras francesas e americanas, fundição de sinos e peças de ferro para construção e ornamentação de prédios, turbinas, comportas, tubos e materiais para serviços sanitários, vagões para estradas de ferro, etc. Construíram estas oficinas as pontes e tubos condutores de água do Cabuçu e Guarahú, a fachada artística da Gazeta de Notícias, do Rio de Janeiro, as estruturas metálicas do Palacete Briccola, Hotel d'Oeste, Teatro Colombo, as colunas artísticas do Teatro Municipal, diversos elevadores, polias de 3 metros de diâmetro para a fábrica de tecidos Votorantim, material rodante para a linha férrea da Cantareira e tantas obras artísticas e de grande importância fundidas em ferro e em bronze."1319
}

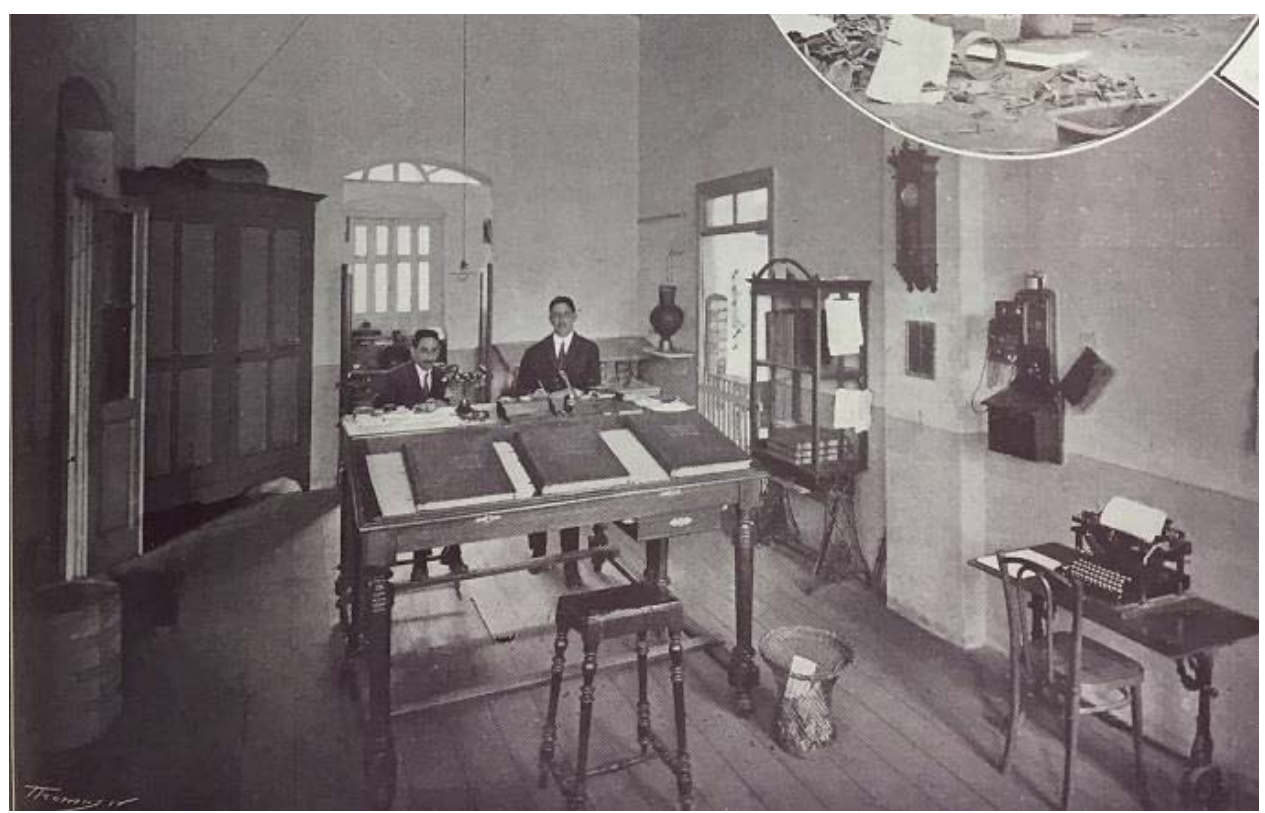

Figura 196: Escritório da "Fundição do Brás", publicado originalmente em Societé de Publicité SudAméricaine, Monte Domecq’ \& Cie. O Estado de S. Paulo. Barcelona: Estabelecimento Graphico Thomaz, 1918, pág. 359.

\footnotetext{
${ }^{318}$ KÜHL, Beatriz Mugayar. Arquitetura do ferro e arquitetura ferroviária em São Paulo: reflexões sobre sua preservação. São Paulo: Ateliê Editorail, 1998, pág. 116.

${ }^{319}$ Impressões do Brazil no século XX, apud, KÜHL, 1998, pág. 117
} 


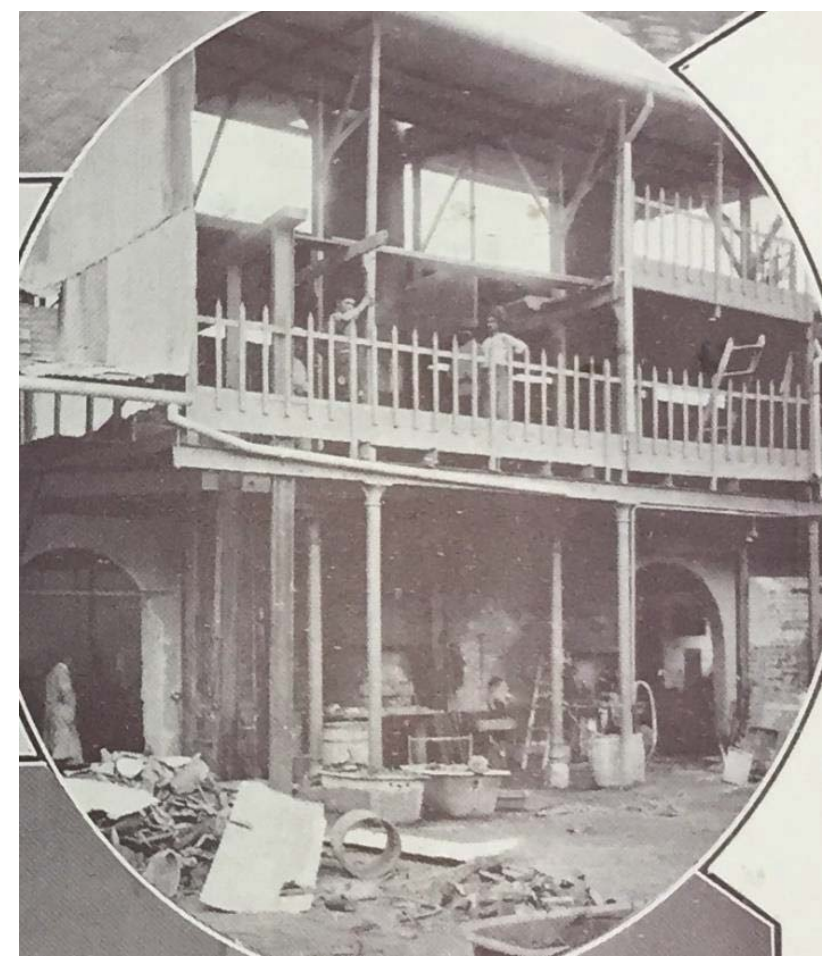

Figura 197: Funcionários em trabalho na "Fundição do Bráz", Societé de Publicité Sud-Américaine, Monte Domecq’ \& Cie. O Estado de S. Paulo. Barcelona: Estabelecimento Graphico Thomaz, 1918, pág. 359.

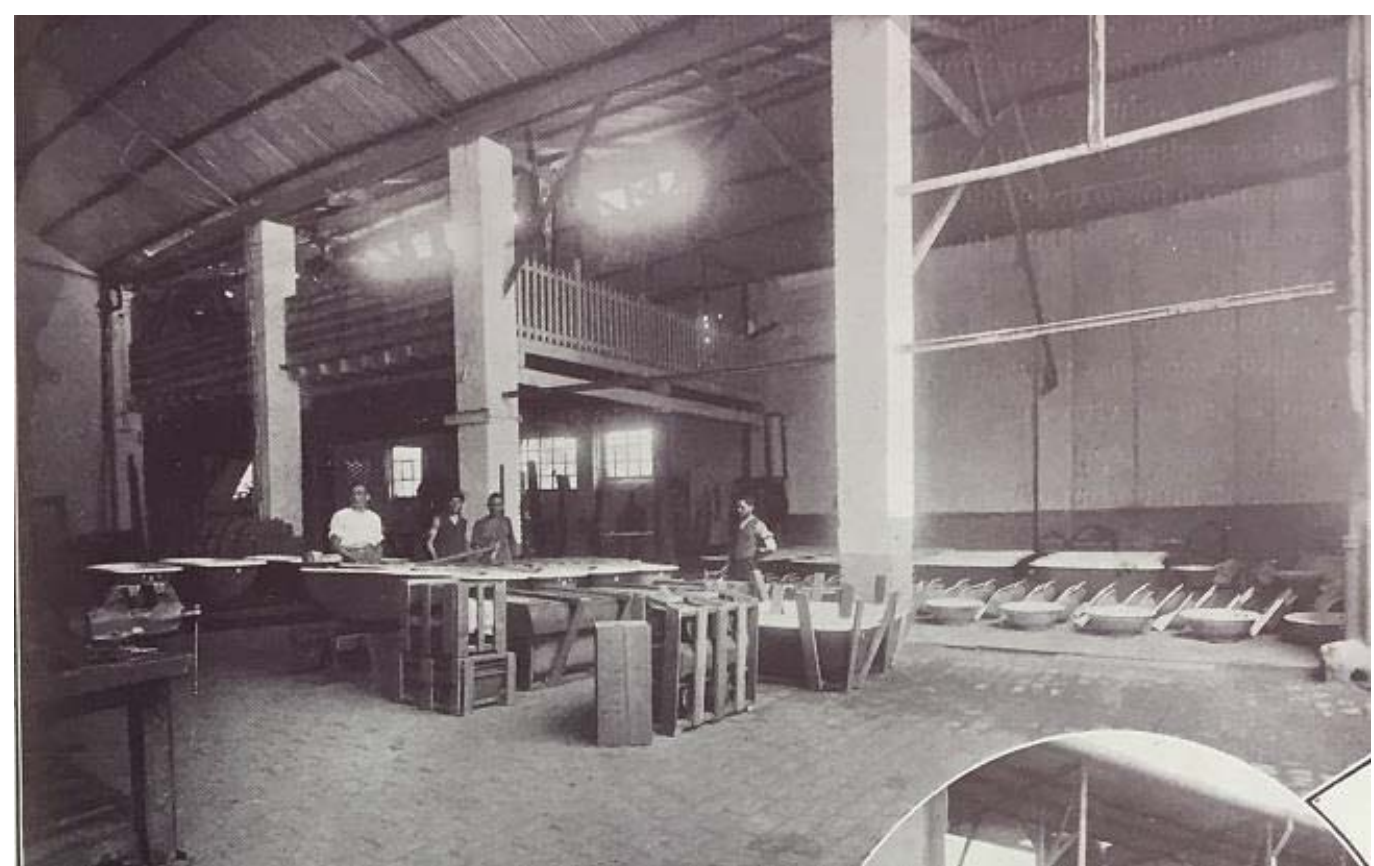

Figura 198: "Funcionários da "Fundição do Bráz" em trabalho, Societé de Publicité Sud-Américaine, Monte Domecq’ \& Cie. O Estado de S. Paulo. Barcelona: Estabelecimento Graphico Thomaz, 1918, pág. 359. 


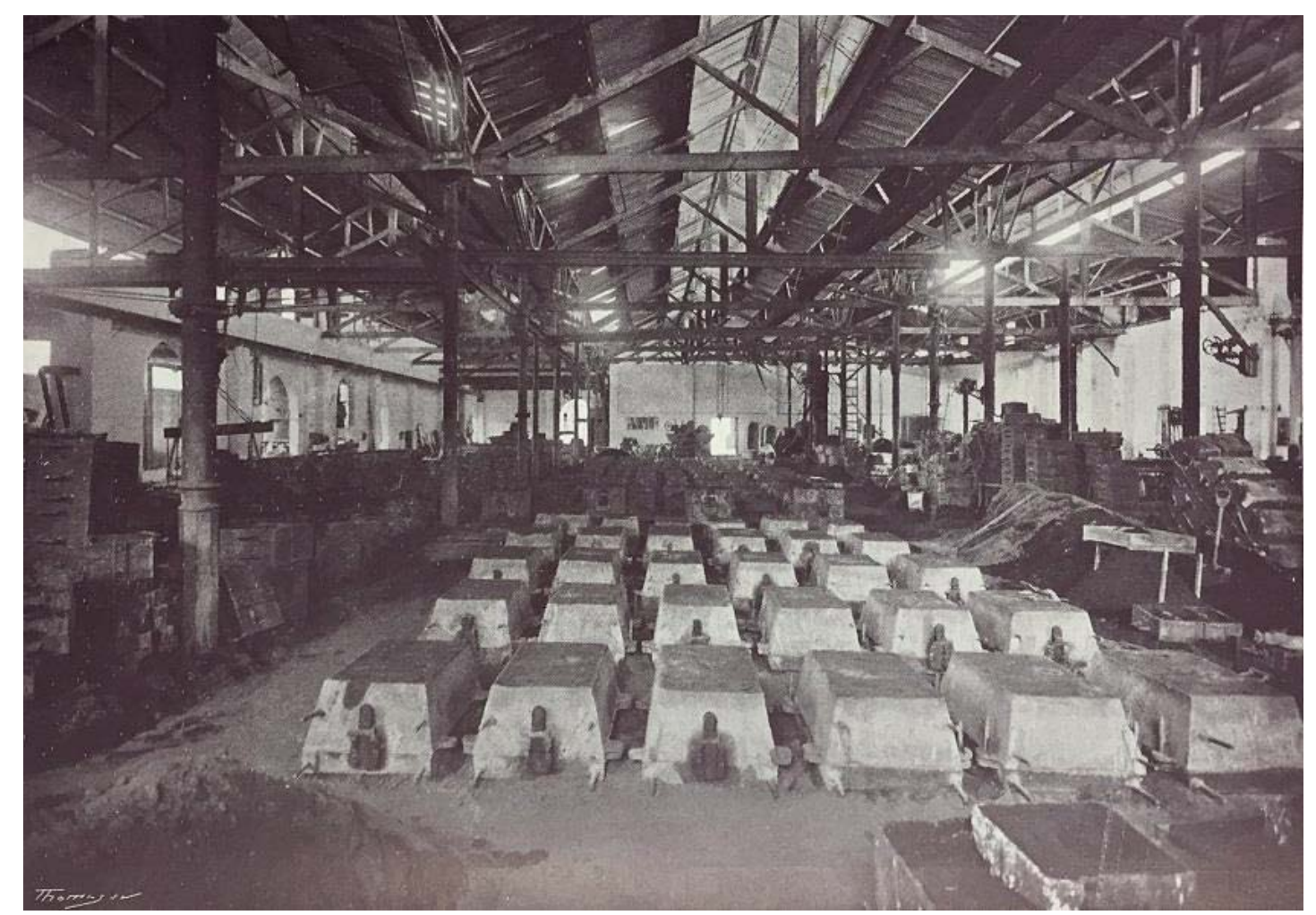

Figura 199: Depósito da fábrica de ferro fundido e esmaltado da "Fundição do Bráz", Societé de Publicité Sud-Américaine, Monte Domecq’ \& Cie. O Estado de S. Paulo. Barcelona: Estabelecimento Graphico Thomaz, 1918, pág. 358.

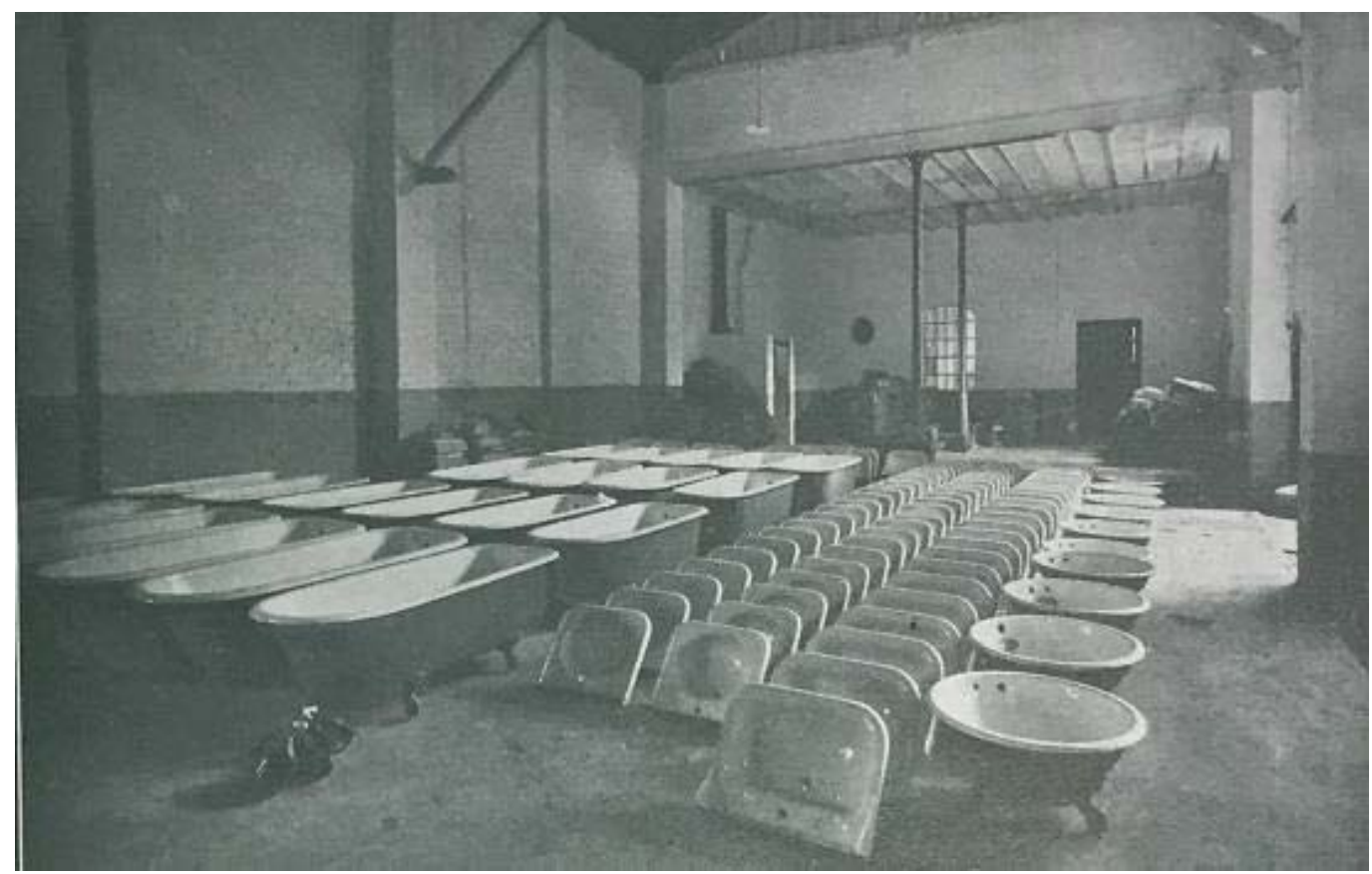

Figura 200: Depósito da fábrica de ferro fundido e esmaltado da "Fundição do Bráz", Societé de Publicité Sud-Américaine, Monte Domecq’ \& Cie. O Estado de S. Paulo. Barcelona: Estabelecimento Graphico Thomaz, 1918, pág. 357. 


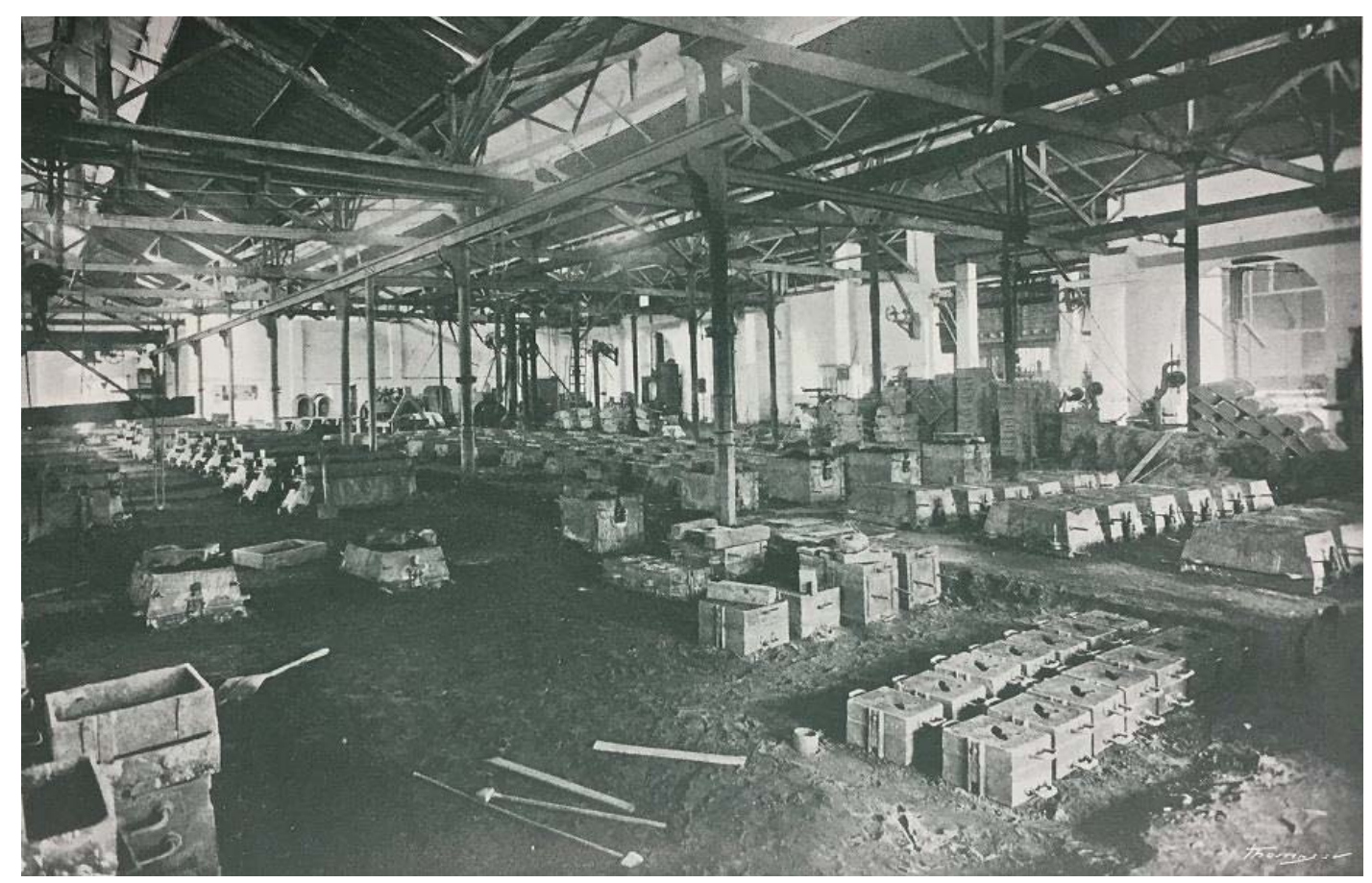

Figura 201: Interior da fábrica de ferro fundido e esmaltado da "Fundição do Bráz", Societé de Publicité Sud-Américaine, Monte Domecq' \& Cie. O Estado de S. Paulo. Barcelona: Estabelecimento Graphico Thomaz, 1918, pág. 356.

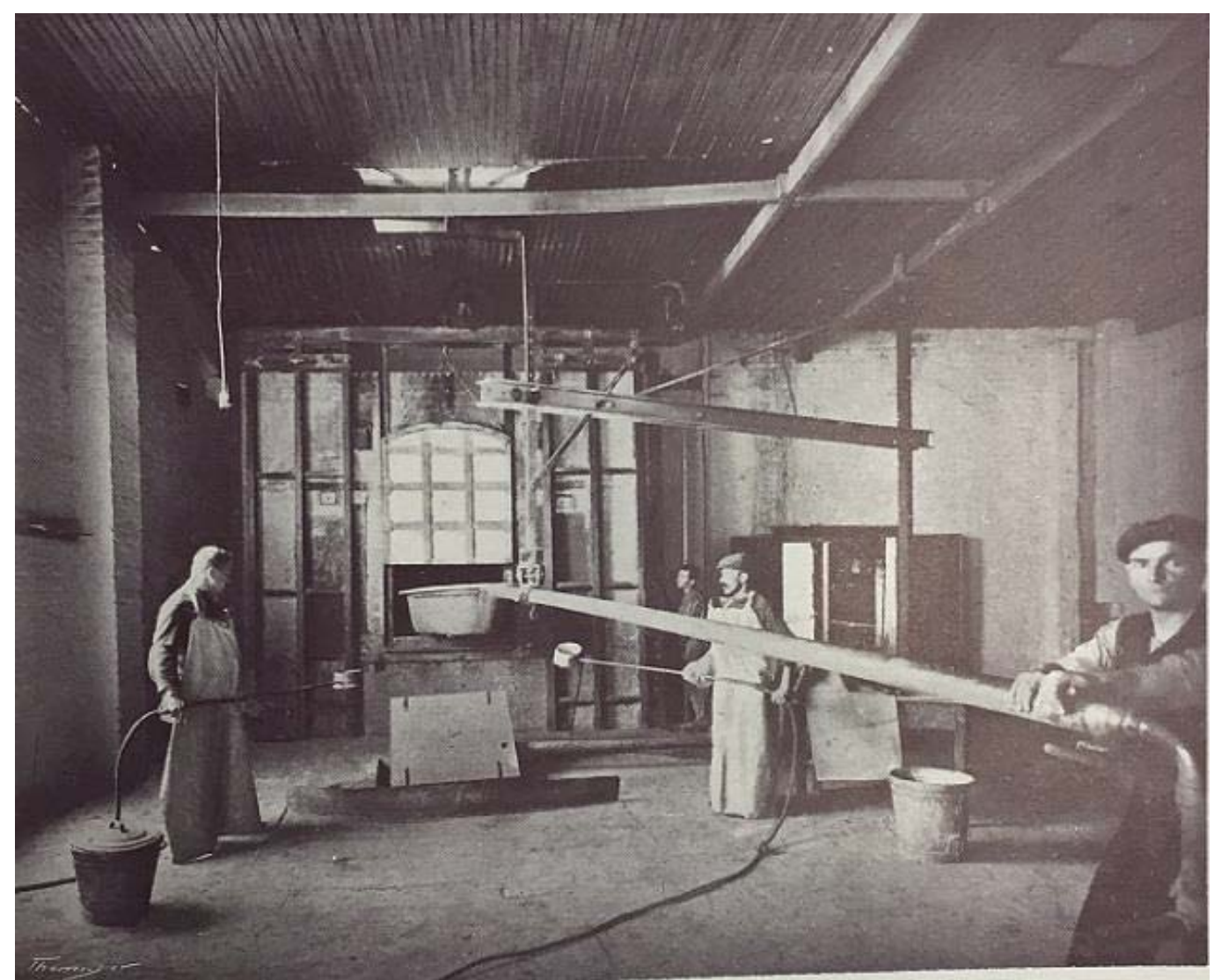

Figura 202: Operários trabalhando nos fornos de esmaltação da "Fundição do Bráz", Societé de Publicité Sud-Américaine, Monte Domecq’ \& Cie. O Estado de S. Paulo. Barcelona: Estabelecimento Graphico Thomaz, 1918, pág. 355. 


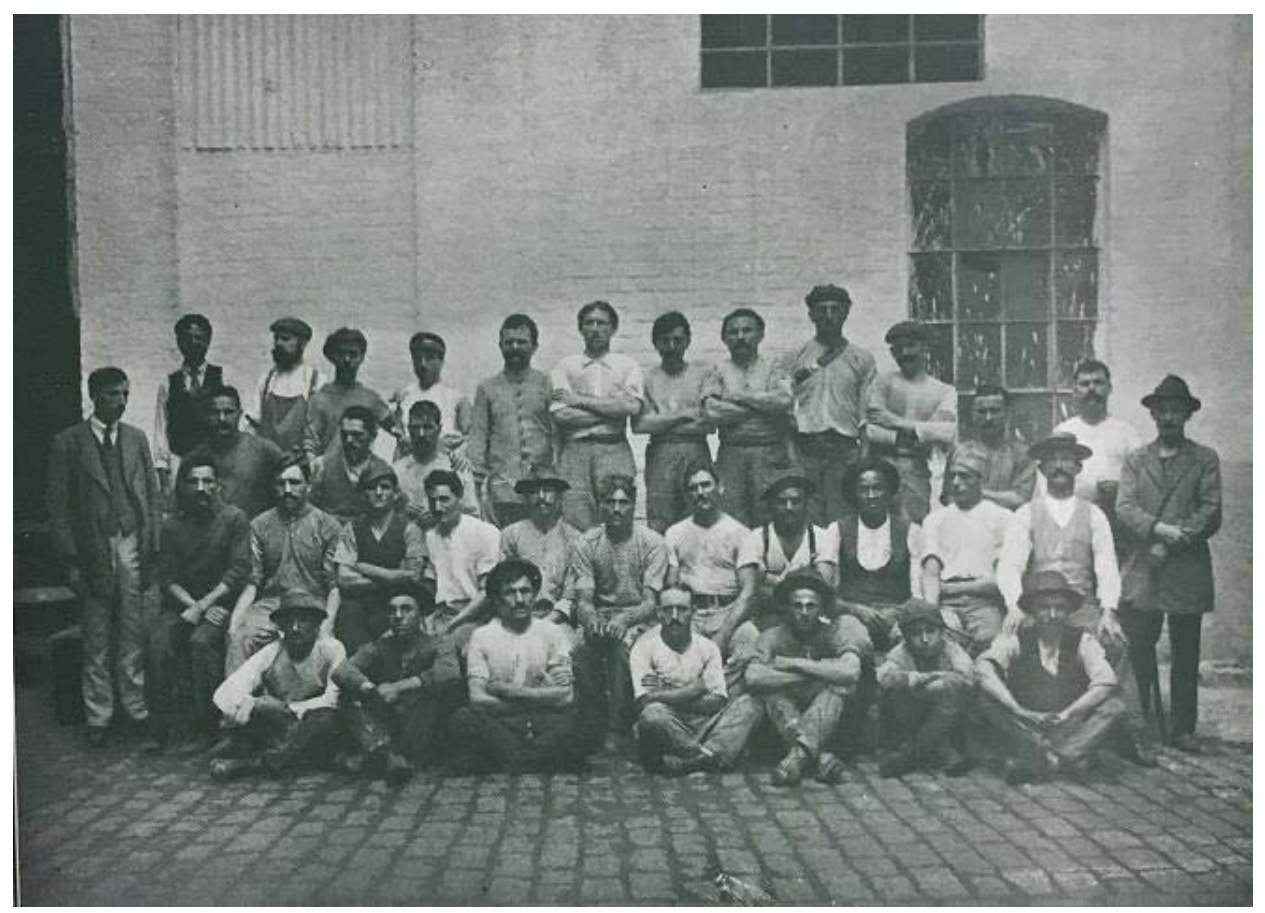

Figura 203: Operários da “Fundição do Bráz”, Societé de Publicité Sud-Américaine, Monte Domecq' \& Cie. O Estado de S. Paulo. Barcelona: Estabelecimento Graphico Thomaz, 1918, pág. 360.

Outras funilarias desempenhavam papel semelhante no bairro, como a Mechanica a Vapor Paulista, fundada em 1893 na rua Almirante Wandenkolk número 17, que contava com uma máquina de força de seis cavalos, 3 prensas grandes, 20 máquinas diversas, tendo uma litografia que podia imprimir em folhas ou latas, em cobre, latões ou zinco, como caixas, latas, pratos, banheiros, vasilhames em geral de folha de flandres, cobre, zinco e metal sem solda, empregando 20 homens nacionais e estrangeiros ${ }^{320}$.

A Companhia Mechanica Importadora de S. Paulo, fundada em 1890 por Alexandre Siciliano, Joaquim Franco de Camargo e Candido Franco de Lacerda, foi considerada por Bandeira Júnior como "um dos mais importantes estabelecimentos industriais da América do Sul”, visto que sua oficina mecânica atendia na rua do Triunfo, 37 a 41, e no Brás nas ruas Monsenhor Andrade e Américo Brasiliense, ocupando uma área de 30.000 metros quadrados, com mais de 600 operários $^{321}$, produzindo inclusive o forno da Pizzaria Castelões na rua Jairo Góis (figura 160).

Alfredo Moreira Pinto confere o mesmo tamanho do terreno para a oficina, informando que também era limitada pelos armazéns do Pari e pelos novos edifícios da

\footnotetext{
${ }^{320}$ BANDEIRA JUNIOR, Op. Cit., pág. 185.

${ }^{321}$ Idem, pág. 146
} 
Alfândega de São Paulo, com seus fornos e "máquinas alimentadas por um motor à vapor da casa inglesa Robey", com força de 16 cavalos, operada por 80 trabalhadores. ${ }^{322}$

A outra oficina era destinada à produção de café, "oficinas, montadas segundo as normas mais rigorosas que a hygiene e a sciencia aconselham, altas, bem arejadas, claras, ventiladas, pudemos apreciar de perto quanto progresso na indústria da ferraria teem alcançado as nações mais adeantadas, como Inglaterra, a Belgica, os Estados Unidos, a Allemanha." "323. Já os armazéns guardavam ferro, aço, madeiras, e eram servidos por trilhos da São Paulo Railway, "o que facilita enormemente o transporte dos vagões e augmenta de modo extraordinário o valor do estabelecimento" além de ali serem guardados os materiais importados "do estrangeiro enquanto não os encontra no nosso paiz; o deposito de madeiras, por exemplo, na maior parte, é representado por produtos nacionaes"324 (figuras 204, 205, 206 e 207).

Alfredo Moreira Pinto relata que, na unidade da rua do Triunfo, os operários trabalham 54 horas por semana, com salários que variavam de 450 a $1 \$ 000$ por hora de serviço.

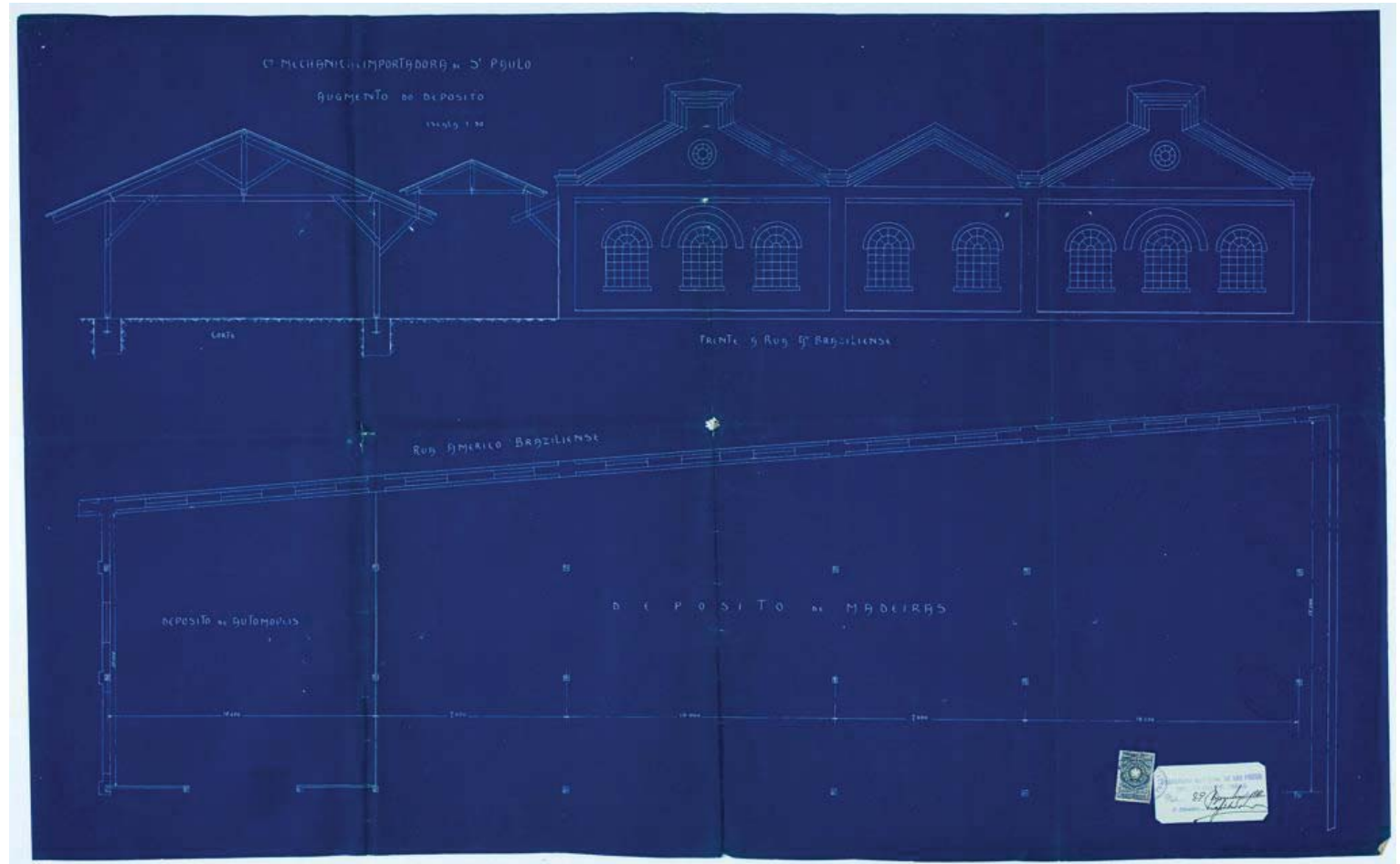

Figura 204: "Cia. Mechanica e Importadora de S. Paulo - Aumengto do depósito", Arquivo Histórico Municipal, fundo "Diretoria de Obras", série "Obras Particulares, OP1911.002.467.

\footnotetext{
322 PINTO, Op. Cit., pág. 212.

${ }^{323}$ Idem, pág. 213

${ }^{324}$ Idem.
} 


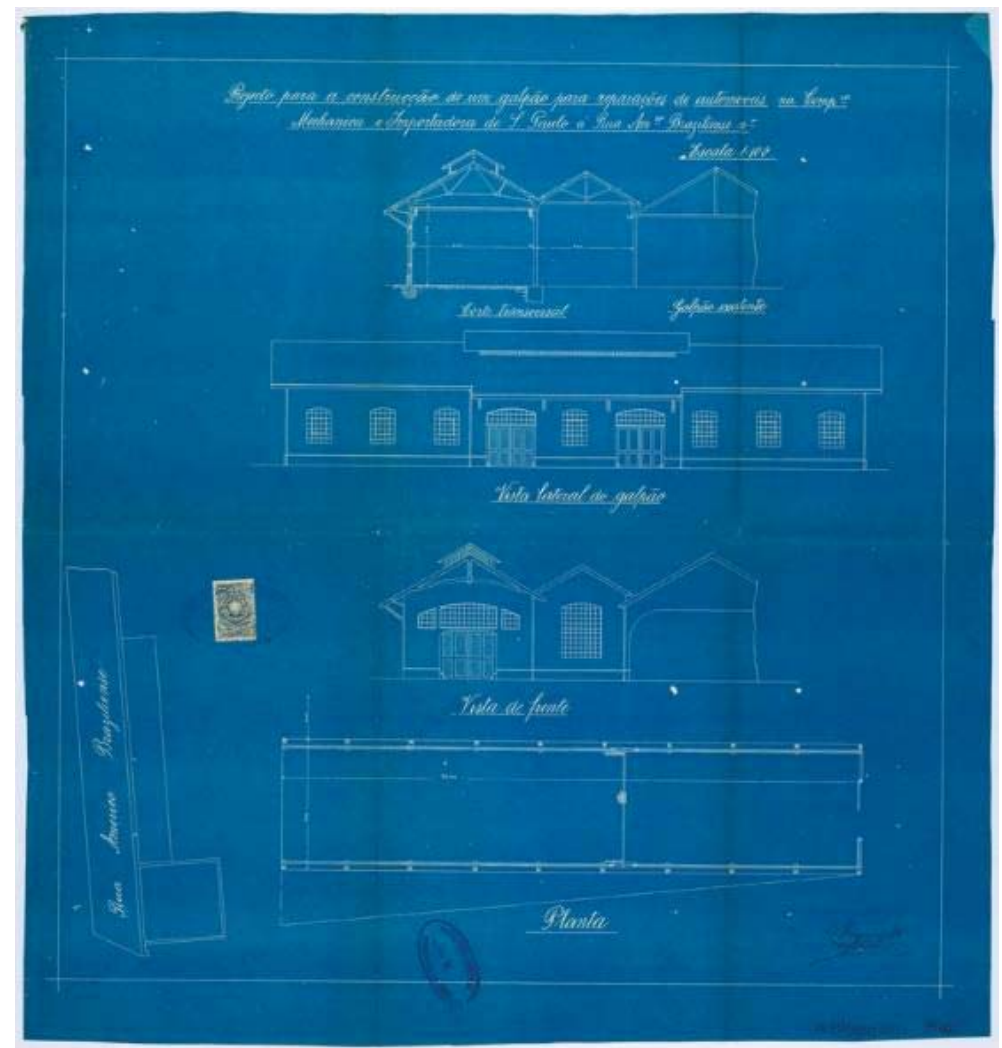

Figura 205: "Projecto para a construção de um galpão para reparações de automóveis da Companhia Mecânica e Importadora de S. Paulo à Rua Américo Brasiliense", Arquivo Histórico Municipal, Fundo "Diretoria de Obras", Série "Obras Particulares, OP1911.000.124

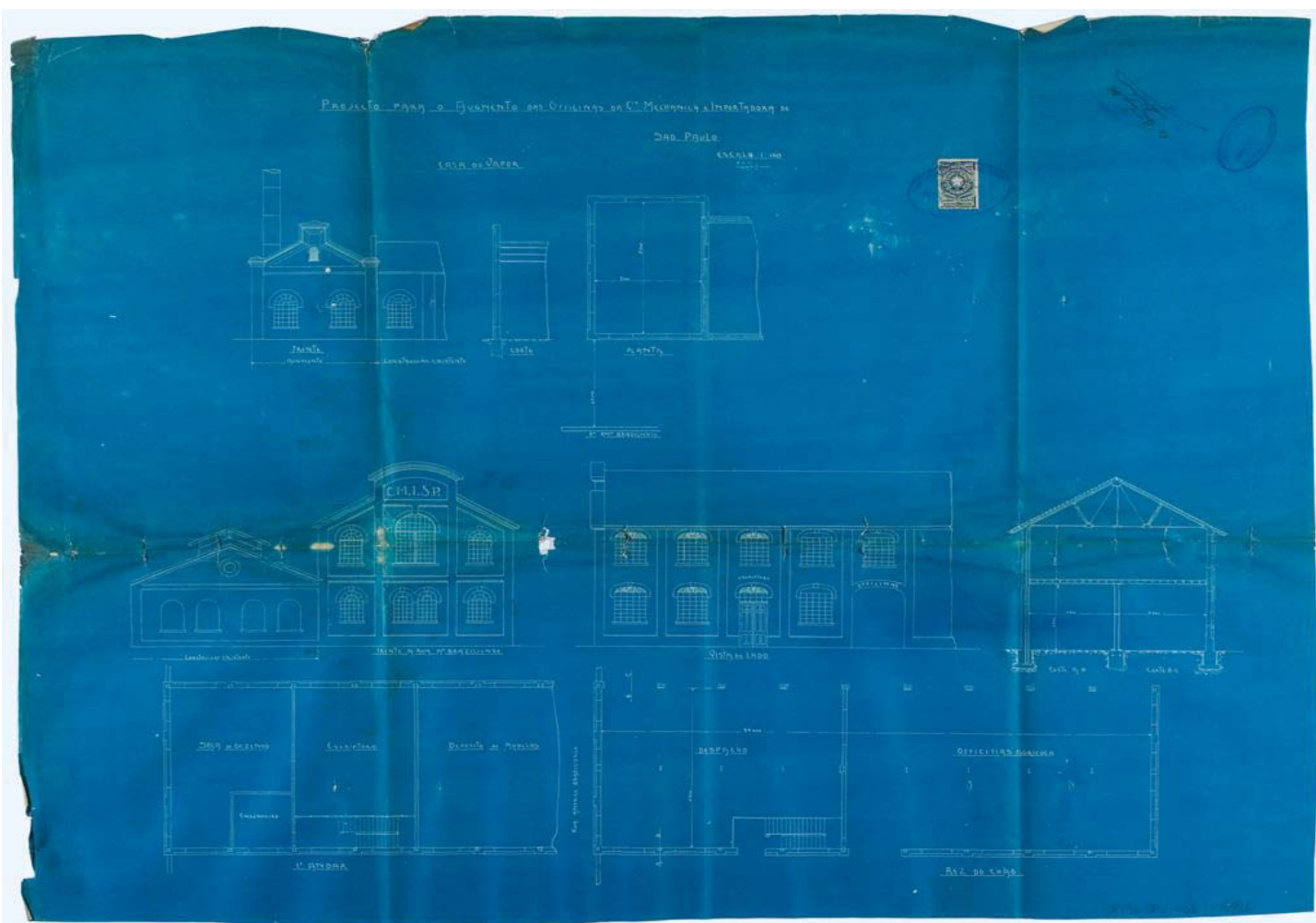

Figura 206: "Projecto para o aumengto das oficinas da Cia. Mechanica e Importadora de São Paulo.", Arquivo Histórico Municipal, fundo "Diretoria de Obras", série "Obras Particulares OP1911.002.468 


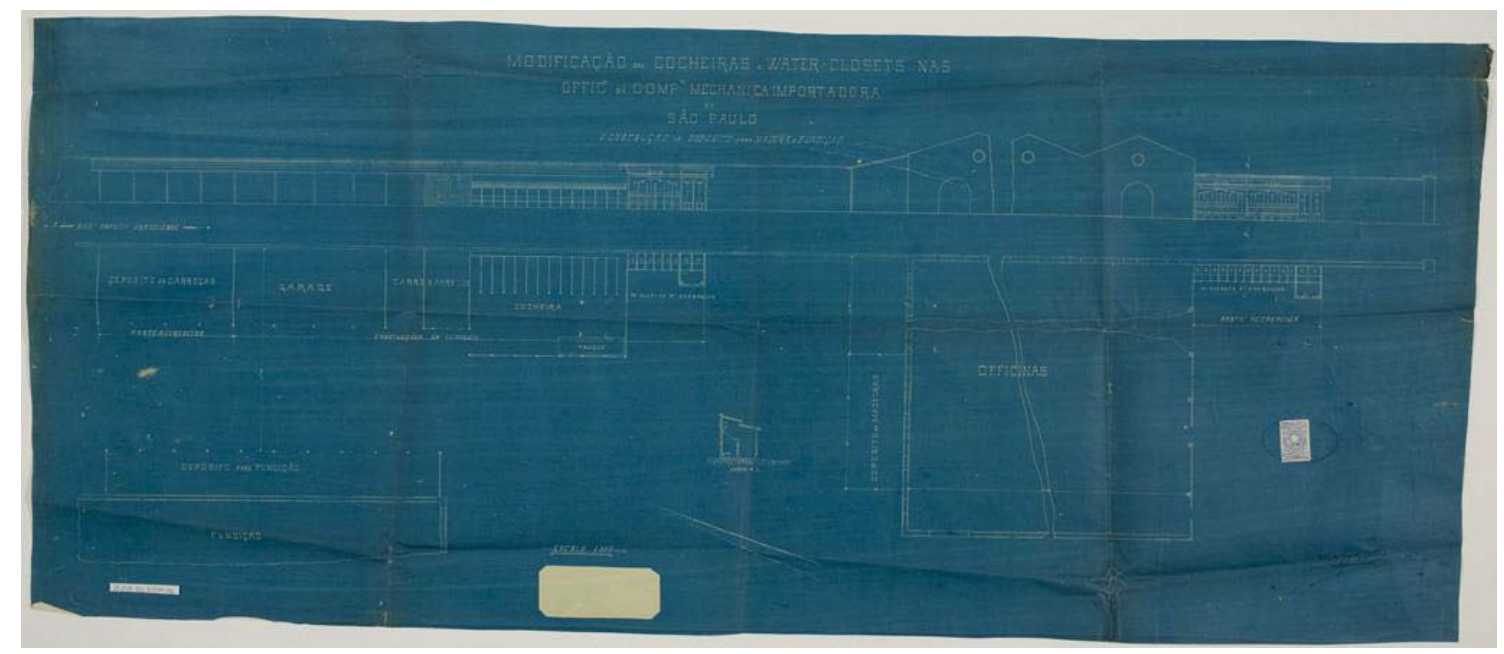

Figura 207: "Modificação em cocheiras e water closets nas offic da Compa Mechanica Importadora de São Paulo. Construção de depósito para (...) e fundição", Arquivo Histórico Municipal, Fundo "Diretoria de Obras”, Série “Obras Particulares, OP1908.001.358.

Tais empreendimentos, quando analisados em conjunto, nos permitem entrever questões antes não colocadas pela historiografia, como sua implantação num determinado espaço que envolveu uma série de dispositivos da passagem do século XIX e o começo do século XX, como o aumento populacional da cidade e o seu consequente consumo de bens primários, além de um aumento dos setores médios que aos poucos consumiam uma série de produtos que dificilmente os setores mais pobres da cidade de São Paulo conseguiriam consumir. São as louças de ferro esmaltadas decorando (e sendo utilizadas) nos banheiros de casas como as de José Monteiro Pinheiro, de dona Leonor Monteiro da Silva e do arquiteto João Grass; são os móveis dos Irmãos Refinetti que estão nas salas e quartos de muitas das casas da rua Bresser; são os vidros da Cristalaria Germânia que fazem as janelas das casas em série e diversas outras residências do Brás.

Ao mesmo tempo, podemos perceber que tais empreendimentos, trazem consigo uma dinâmica dos modos de uso do espaço e seu entorno. Os estabelecimentos que dedicamse às atividades de funilaria e pintura, e construção civil, estão intimamente ligados aos armazéns e da rua Concórdia e às fábricas da rua Monsenhor Andrade, polarizando diversos botequins e pequenos comércios que suprem necessidades dos milhares de operários que ali trabalham. 
Uma das preocupações centrais do governo Republicano, fora o de promover reformas no sistema educacional do país, buscando encontrar meios de promover uma maior ampliação dos ideais positivistas e liberais, bem como separar o ensino público das mãos da Igreja Católica. Reformas como as de Benjamin Constant (1890); o Código Epitácio Pessoa (1901); a Reforma Rivadávia Correa (1911); Reforma Carlos Maximiliano (1915); e a Reforma João Luiz Alves/Rocha Vaz (1925), estiveram preocupadas essencialmente em organizar o ensino secundário.

Nessa linha, o Estado de São Paulo (que capitaneava boa parte dos ideais republicanos nacionais) passou a fomentar a criação de uma série de instituições que versavam do ensino básico ao superior, como a criação de grupos escolares, escolas técnicas e profissionais, e de nível superior (o que não significava uma proposta ou ação de universalização do ensino). Instituições como a Escola Politécnica (surgida em 1893), o Museu Paulista (de 1895) e a Escola de Farmácia (de 1905), passaram a integrar o quadro oficial de pesquisas que respaldassem o Estado de São Paulo no rol científico, produzindo uma série de investigações que trouxessem à tona o desenvolvimento local.

Sob a mesma ideologia nasce a Escola Normal Caetano de Campos, instalada na Praça da República desde 1894 como sede dos programas de ensino básico da capital e de formação de formação de professores. Diversas regiões da cidade receberiam escolas voltadas ao ensino básico, e o Brás passaria a contar com algumas destas instituições.

O Primeiro Grupo Escolar do Braz foi criado em 1898 na Avenida Rangel Pestana, em frente ao Largo do Brás e à Igreja Matriz do bairro, atendendo uma média de 700 a 800 alunos de ambos os sexos. Projetado pelo escritório do arquiteto Francisco de Paula Ramos de Azevedo, o edifício se destacava pela monumentalidade no período, dispondo de 16 salas de aula, sendo o maior prédio escolar do período depois da Escola Normal, na Praça da República $^{325}$.

${ }^{325}$ WOLFF, Silvia Ferreira Santos. Escolas para a República: Os primeiros passos da arquitetura das escolas públicas paulistas. São Paulo: Edusp, 2010, pág. 177. 


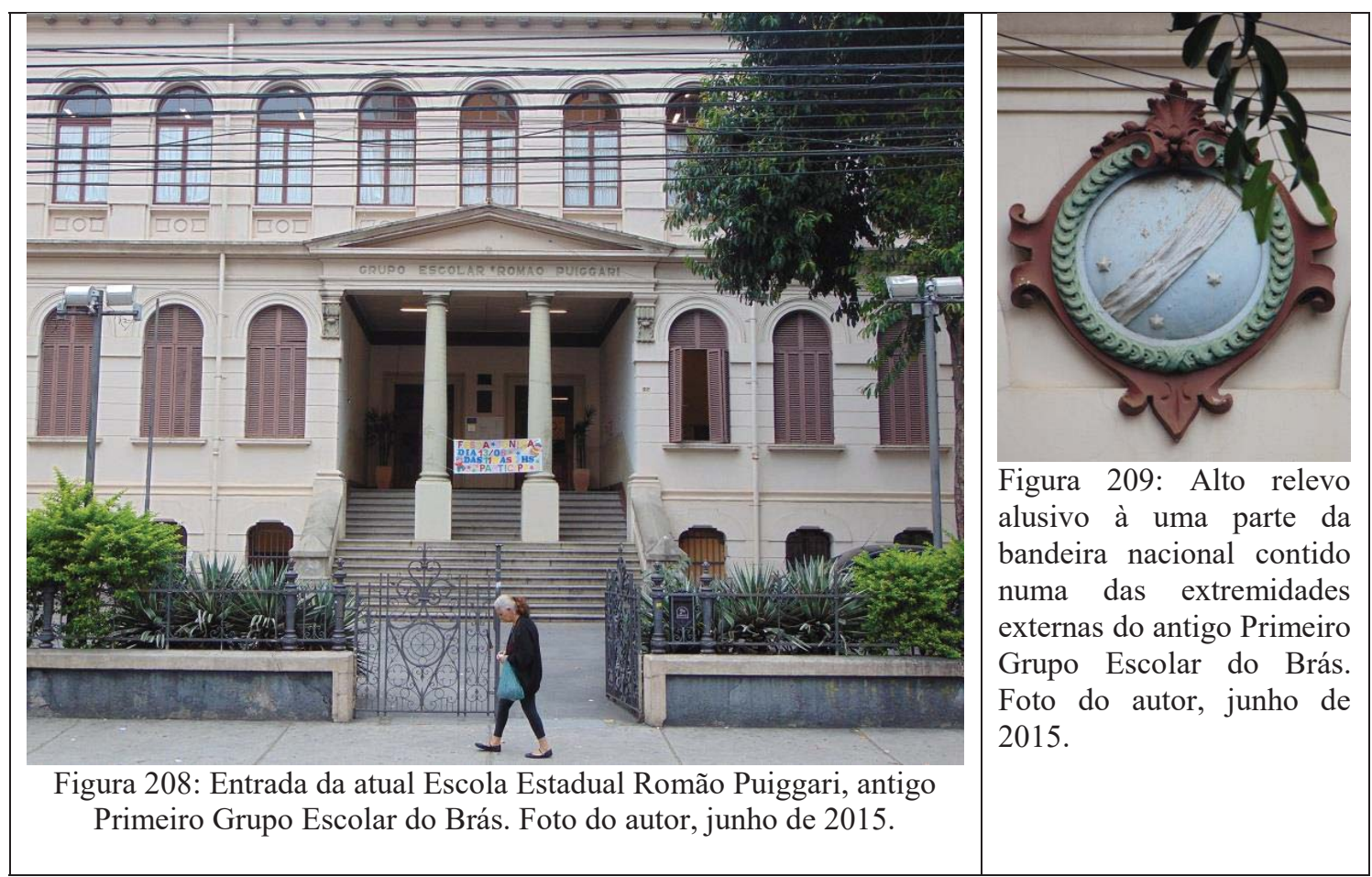

Outros dois grupos escolares foram instalados no bairro: o Segundo Grupo Escolar do Brás, inaugurado em 1896 apenas para o público masculino num prédio adaptado da Avenida Intendência número 12, e o Terceiro Grupo Escolar do Brás, inaugurado em 1898 como seção feminina, e a partir de 1906 abrangendo os dois sexos. Neste mesmo edifício tem início a Escola Normal do Brás, que seria transferida para um edifício próprio apenas em 1913, na avenida Rangel Pestana (figura 206).

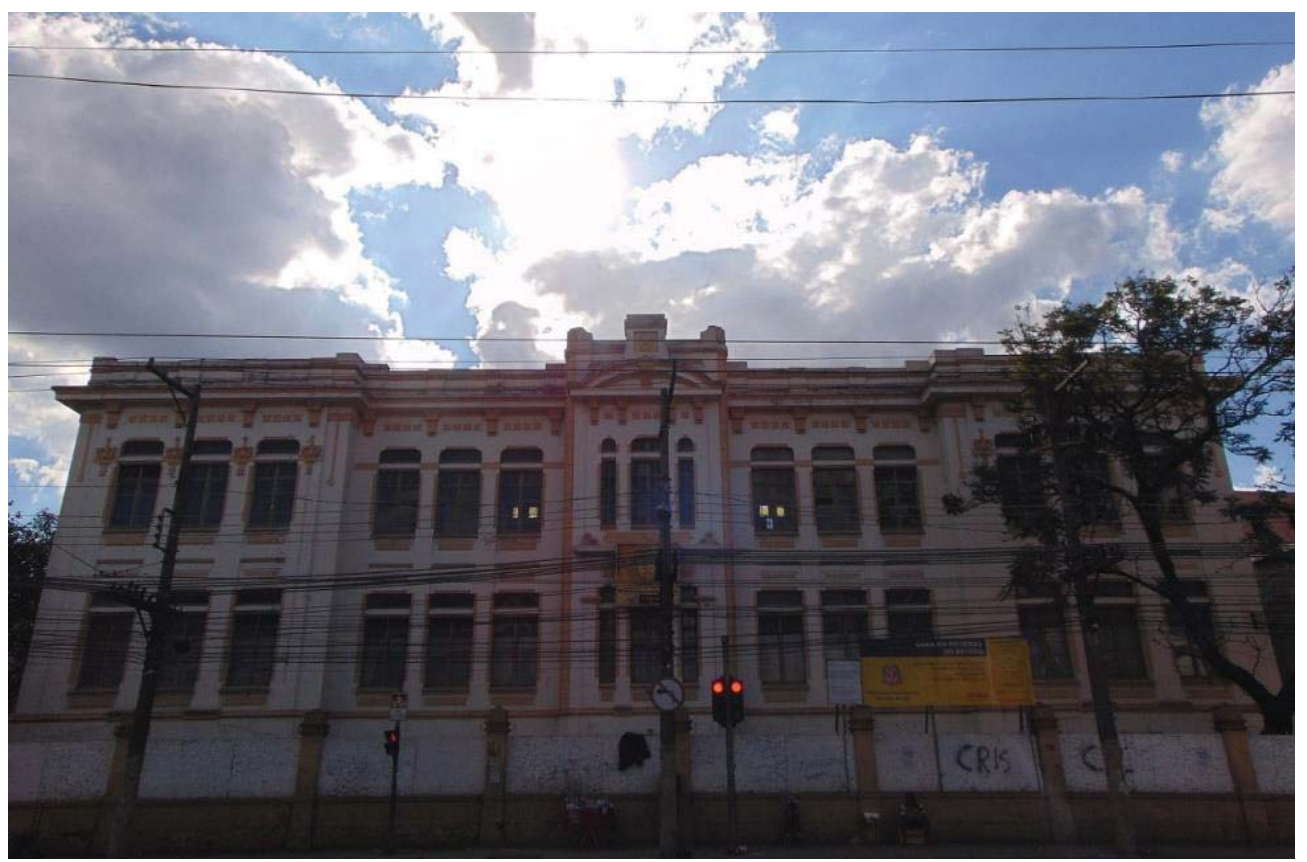

Figura 210: Antigo edifício da Escola Normal do Brás, atual sede da São Paulo Escola de Teatro. Foto do autor, junho de 2015. 
Duas escolas técnicas são criadas no Brás em 1911, pensadas na formação de um quadro técnico especializado no ensino das artes e ofícios, e visando a qualificação dos setores médios e baixos para o mercado de trabalho na indústria e comércio, como o gerenciamento e organização de tarefas nas diversas fábricas e serviços públicos. Divididas por sexos, a Escola Profissional Masculina foi instalada na rua Miler número 4, o governo estadual cria duas escolas técnicas, divididas segundo os sexos: uma masculina, instalada na rua Miler número 4, com atenção às artes industriais como arcenaria, serralheria, pintura, mecânica e o comércio. Já a Escola Profissional Feminina esteve localizada na rua Monsenhor Andrade número 120, tendo como eixo a economia doméstica e atividades manuais, como rendas, bordados, costura e confecção de chapéus, tendo como alegoria no alto do edifício nada menos que uma roca de fiar ${ }^{326}$.

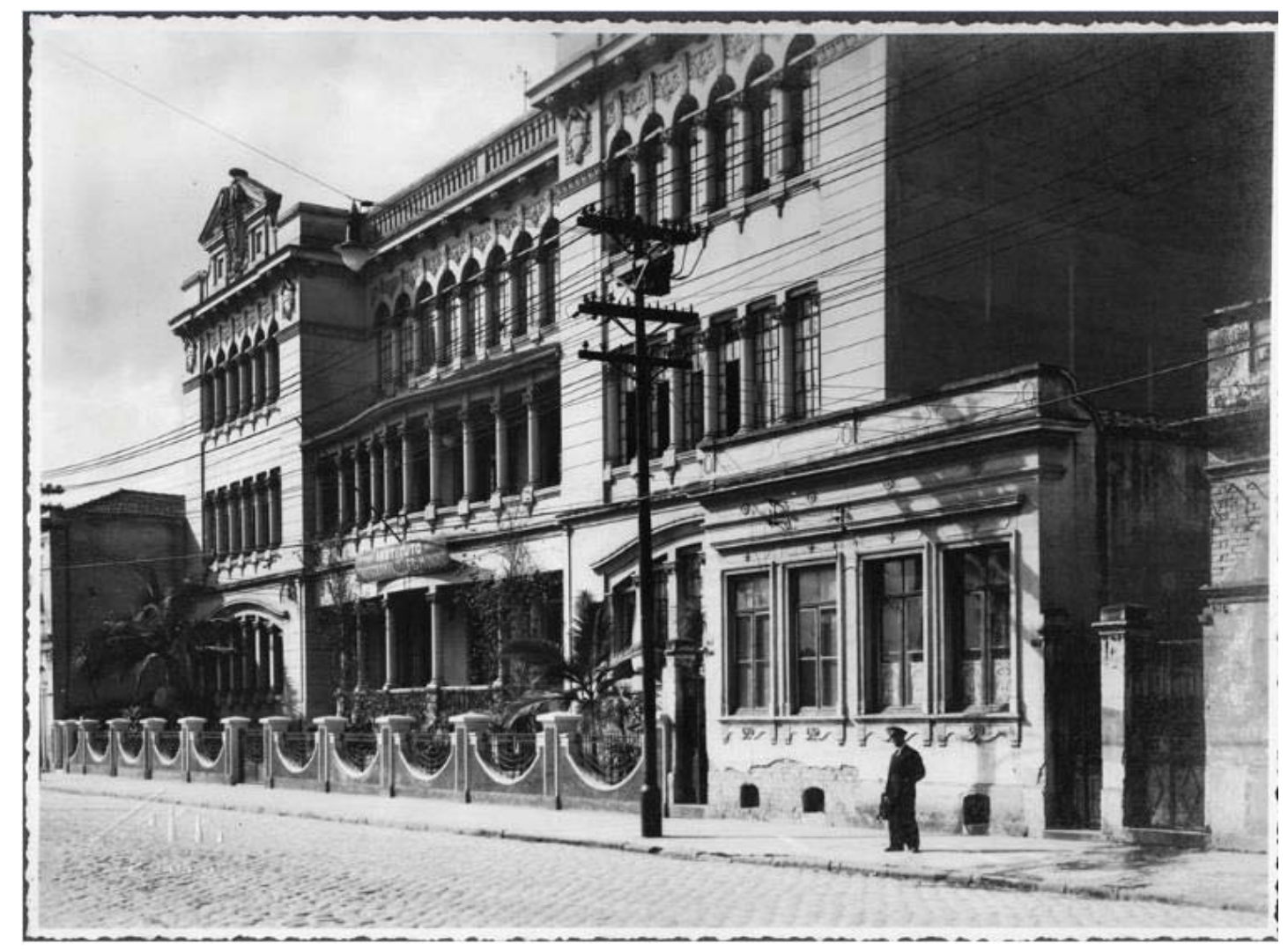

Figura 211: A Escola Profissional Feminina do Brás em 1940. Acervo Fotográfico do Arquivo Histórico Municipal. 


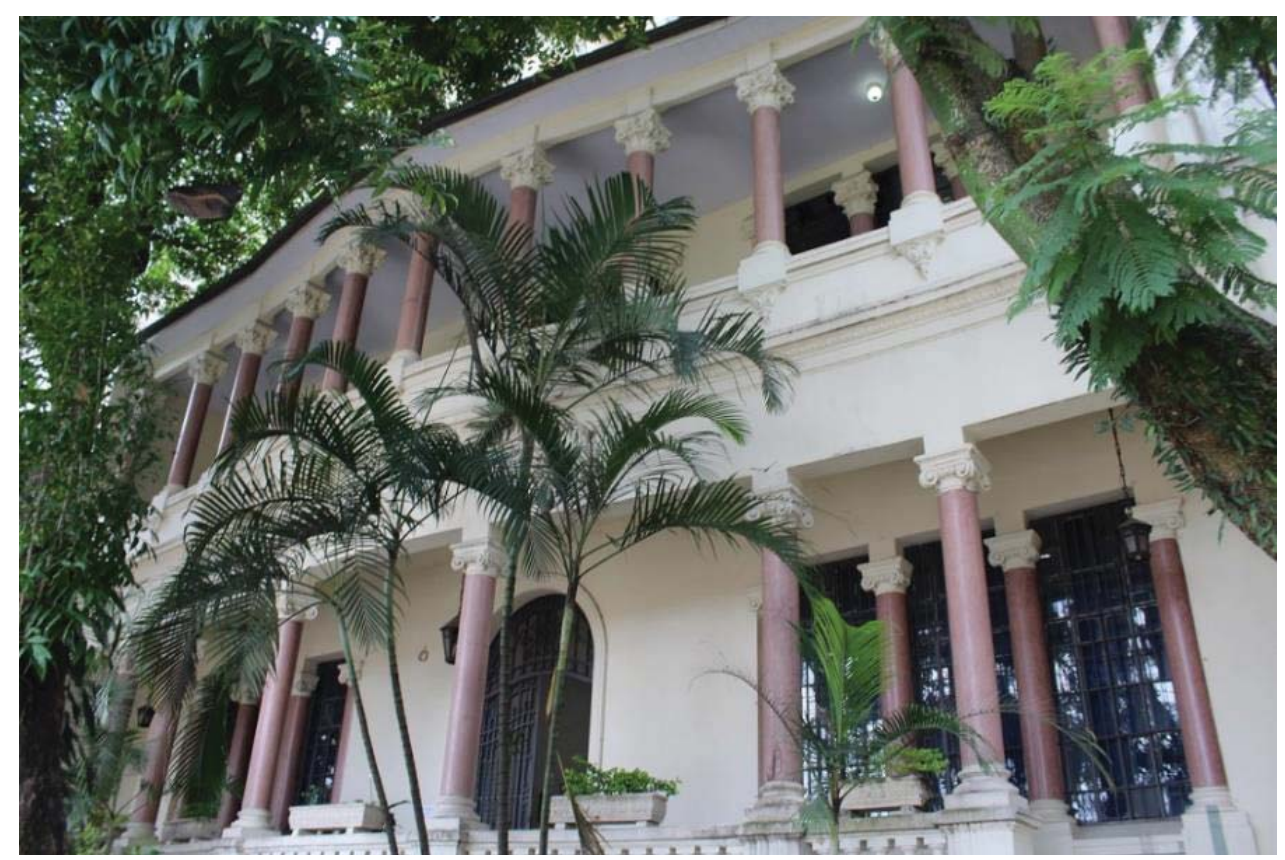

Figura 212: Antigo edifício da Escola Profissional Feminina do Brás, atual Escola Técnica Estadual Carlos de Campos. Foto do autor, janeiro de 2017.

Em paralelo ao surgimento destas instituições públicas, uma série de escolas privadas surgiram, especialmente no em torno do ensino básico, médio e técnico. A partir do levantamento das diferentes instituições escolares presentes no Brás no Almanak Laemmert, mapeamos um conjunto expressivo de escolas italianas (afirmação que se deu a partir da análise dos nomes das mesmas e dos seus respectivos responsáveis legais) espalhadas em diversas ruas do bairro. Do levantamento, elaboramos a seguinte tabela contendo o endereço da escola, o seu nome, além do responsável pela instituição no ano que pesquisamos no almanaque:

\begin{tabular}{|c|c|c|c|}
\hline \multicolumn{4}{|c|}{ Distribuição dos estabelecimentos educacionais do Brás (1897-1916) } \\
\hline \multicolumn{4}{|c|}{ INSTITUIÇÕES PÚBLICAS } \\
\hline Endereço & Instituição & Responsável & $\begin{array}{c}\text { Ano de Publicação } \\
\text { no Almanaque }\end{array}$ \\
\hline $\begin{array}{c}\text { Avenida Rangel } \\
\text { Pestana, s/n }\end{array}$ & $\begin{array}{c}\text { Primeiro Grupo } \\
\text { Escolar do Braz }\end{array}$ & $\begin{array}{c}\text { Romão Puiggari (residia na } \\
\text { rua Maria Antonia, 59) / } \\
\text { Gabriel Ortiz }\end{array}$ & $1904 / 1914$ \\
\hline $\begin{array}{c}\text { Avenida Intendência, } \\
\text { 12; Almirante Barroso, } \\
3\end{array}$ & $\begin{array}{c}\text { Segundo Grupo } \\
\text { Escolar do Braz }\end{array}$ & $\begin{array}{c}\text { João Mário de Freitas Brito } \\
\text { / Raphael de Moraes Lima }\end{array}$ & $1904 / 1914$ \\
\hline $\begin{array}{c}\text { Rua Celso Garcia, s/n; } \\
\text { em frente à rua do } \\
\text { Hipódromo }\end{array}$ & $\begin{array}{c}\text { Terceiro Grupo } \\
\text { Escolar do Braz / } \\
\text { Escola Normal do Braz }\end{array}$ & $\begin{array}{c}\text { Diretor Arthur Goulart } \\
\text { Penteado / Arthur de } \\
\text { Cunha Gloria }\end{array}$ & 1904,1914 \\
\hline Rua Miler, 4 & $\begin{array}{c}\text { Escola Profissional } \\
\text { Masculina da Capital } \\
\text { do Estado de S. Paulo }\end{array}$ & & 1913,1914 \\
\hline
\end{tabular}




\begin{tabular}{|c|c|c|c|}
\hline $\begin{array}{l}\text { Rua Monsenhor } \\
\text { Andrade, } 120\end{array}$ & $\begin{array}{c}\text { Escola Profissional } \\
\text { Feminina da Capital do } \\
\text { Estado de S. Paulo }\end{array}$ & & 1913 \\
\hline $\begin{array}{l}\text { Avenida Rangel } \\
\text { Pestana }\end{array}$ & $\begin{array}{c}\text { Escola de Comércio do } \\
\text { Braz }\end{array}$ & $\begin{array}{c}\text { Diretor Dr. João O. Lima } \\
\text { Pereira }\end{array}$ & 1914 \\
\hline \multicolumn{4}{|c|}{ INSTITUIÇÕES PRIVADAS ITALIANAS } \\
\hline Endereço & Instituição & Responsável & $\begin{array}{l}\text { Ano de Publicação } \\
\text { no Almanaque }\end{array}$ \\
\hline Rua Assunção, 7 & Escola Flano Giora & Diretor Crescenzio Ottavio & 1913 \\
\hline Rua Assunção, 79 & Escola Dante Alighieri & Diretor Luigi Basile & 1914,1915 \\
\hline Rua Carneio Leão, 40 & Escola Aurelio Yofll & Dona Carolina Limoncelli & $1913,1914,1915$ \\
\hline $\begin{array}{l}\text { Rua Carneiro Leão, } \\
183\end{array}$ & $\begin{array}{c}\text { Escola Francesco } \\
\text { Petrarca }\end{array}$ & Dona Antonietta Maffei & 1913,1914 \\
\hline $\begin{array}{l}\text { Rua do Gasômetro, } \\
164\end{array}$ & $\begin{array}{l}\text { Instituto Brasile Gia } \\
\text { Dante Alighiere }\end{array}$ & & $1913,1914,1915$ \\
\hline Rua Luiz Gama, 132 & $\begin{array}{l}\text { Escola Cesare } \\
\text { Lombruso }\end{array}$ & Diretora Severina Fantatto & 1913,1914 \\
\hline $\begin{array}{l}\text { Rua Maria Marcolina, } \\
2\end{array}$ & Escola Studio e Lavoro & Diretor Salomano Rosio & 1913,1914 \\
\hline $\begin{array}{l}\text { Rua Maria Marcolina, } \\
\qquad 79\end{array}$ & $\begin{array}{l}\text { Escola de Ensino } \\
\text { Primário Edmondo de } \\
\text { Amicis (publicado } \\
\text { como "Amiers") }\end{array}$ & $\begin{array}{c}\text { Amelia Galessini } \\
\text { (residente na mesma rua, } \\
\text { número 19) }\end{array}$ & $1913,1914,1915$ \\
\hline $\begin{array}{l}\text { Rua Monsenhor } \\
\text { Anacleto }\end{array}$ & Escola Italia & Magdalena Balone & $1913,1914,1915,1916$ \\
\hline $\begin{array}{l}\text { Rua Monsenhor } \\
\text { Andrade, } 48\end{array}$ & Escola Marianoella & Nicola Di Genaro & $1913,1914,1915,1916$ \\
\hline Rua Piratininga, 138 & $\begin{array}{l}\text { Escola Vincenzo } \\
\text { Globerti / Instituto } \\
\text { Maria de Loretto }\end{array}$ & $\begin{array}{c}\text { Francesco Autico / Orsola } \\
\text { Autico }\end{array}$ & $1913,1914,1915$ \\
\hline $\begin{array}{l}\text { Avenida Rangel } \\
\text { Pestana, } 1\end{array}$ & $\begin{array}{c}\text { Escola Estanislau } \\
\text { Derosa } \\
\end{array}$ & & 1901 \\
\hline $\begin{array}{l}\text { Avenida Rangel } \\
\text { Pestana, } 110\end{array}$ & $\begin{array}{l}\text { Escola Guglielmo } \\
\text { Ferraro } \\
\end{array}$ & $\begin{array}{c}\text { Diretora Dona Cancettina } \\
\text { D'Amelia }\end{array}$ & 1914 \\
\hline Rua Sayão Lobato, s/n & $\begin{array}{l}\text { Escola Principesca } \\
\text { Iolanda } \\
\end{array}$ & Diretor Francesco Fatica & $1913,1914,1915$ \\
\hline $\begin{array}{l}\text { Rua Visconde de } \\
\text { Parnaíba, } 115\end{array}$ & Escola Italiana & Diretora Thereza Santi & $1913,1914,1915$ \\
\hline $\begin{array}{l}\text { Rua Visconde de } \\
\text { Parnaíba, }\end{array}$ & Escola Bruno Serale & & 1914,1915 \\
\hline
\end{tabular}

Tabela 19: "Distribuição dos estabelecimentos educacionais do Brás (1901-1916)", elaborada pelo autor

com base no Almanak Laemmert.

Considerando a expressividade das escolas italianas listadas, procuramos compreender sua espacialização e entender as razões que estavam por trás nos nomes atribuídos a cada uma delas. Entendemos que os nomes atribuídos não são meras homenagens, mas demarcam a identidade de um povo em sua afirmação, de modo que se 
coloque em disputa a memória coletiva daqueles que estão inseridos em determinado tempo e espaço.

A rememoração de determinados agentes do passado de um povo, vai de encontro às afirmações de Jacques le Goff, o qual enxerga que a memória moderna remonta ao período da Revolução Francesa, e ao longo do século XIX estabeleceu contatos com o mundo da política, da sensibilidade e do folclore ${ }^{327}$, num processo de afirmação e consolidação das nações diante do mundo, em que os franceses rememoram a revolução de julho de 1789; os estados do norte dos Estados Unidos festejam o Memorial Day; os alemães criando museus pelo país; na Itália a criação de um museu nacional ${ }^{328}$. Ademais, nestes dois últimos países a questão se tornava muito mais complexa, pela própria unificação de seus reinos ser realizada apenas em finais do século XIX, e a discussão sobre o nacionalismo se acirrar sobremaneira em torno do seu povo.

São as "comunidades imaginadas" que percorrem estes povos e seus governos, criando uma série de dispositivos que os unifiquem, como a criação de símbolos pátrios (bandeiras, hinos), o louvor ao exército, a busca por uma ancestralidade histórica que dê sentido e coesão aos seus diferentes agentes, além da criação de uma como uma língua nacional que unifique todos aqueles que fazem parte do mesmo grupo nacional ${ }^{329}$. Estamos tratando de uma época em que diversos intelectuais se debruçam sobre o passado para conferir autenticidade e identidade ao seu povo, ao mesmo tempo em que havia um mundo de migração em massa ${ }^{330}$ e aos poucos a ““"nacionalidade” se tornava uma verdadeira rede de relações pessoais e não uma comunidade imaginária. ${ }^{331}$

No que toca às diversas comunidades italianas estabelecidas no Brasil, é de se destacar que a chamada "italianidade" se desenrolou essencialmente devido à "colônia italiana" ser bastante fragmentada e relativamente heterogênea, o que pode ser compreendido a partir das diferenças linguísticas, costumes e espaços de inserção social ${ }^{332}$, por isso '“[...] as hipóteses favoráveis à formação de 'baluartes da italianidade' partiam de

\footnotetext{
${ }^{327}$ LE GOFF, Jacques. História e memória. Campinas: Editora da Unicamp, 2013, pág. 424.

${ }^{328}$ Idem, pág. 425.

${ }^{329}$ ANDERSON, Benedict. Comunidades imaginadas: reflexões sobre a origem e a difusão do nacionalismo. São Paulo: Companhia das Letras, 2008. O historiador confere em sua obra um amplo debate acerca do nacionalismo e suas conexões com o surgimento das nações modernas ao longo do século XIX.

${ }^{330}$ HOBSBAWM, Eric. A era dos impérios, 1875-1914. São Paulo: Paz e Terra, 2010, pág. 238; 245.

${ }^{331}$ Idem, pág. 245. Extenso é o debate historiográfico sobre as origens do nacionalismo ao longo do século XIX, não existindo um consenso sobre ele ter surgido das massas populares ou a partir dos governos que criavam mecanismos de unificação entre a população. Ver: também e RANGER, Terence (org.). A invenção das tradições. Rio de Janeiro: Paz e Terra, 1984. Nações e nacionalismos desde 1780: programa, mito e realidade. São Paulo: Paz e Terra, 1990.

332 BAO, Carlos Eduardo. "A invenção da italianidade no Brasil: contribuição para um olhar descontínuo". Anais do XXVIII Simpósio Nacional de História. Florianópolis, 2015, pág. 8
} 
premissas absolutamente inexistentes e irrealizáveis, ou seja, da negação e qualquer tipo de conflito no seio da colônia" ${ }^{333}$. É a imprensa, as comunidades religiosas e as escolas que seriam alguns dos espaços formadores desta unificação da "comunidade" italiana no Brasil.

Das instituições privadas italianas do Brás mapeadas por nós no Almanak Laemmert, procuramos separá-las em dois grupos "históricos": as escolas que tinham como nome personagens que remontavam à uma ideia de "ancestralidade" italiana ou de referência ao país (Escola Dante Alighieri, Escola Francesco Petrarca, Escola Itália, Escola Italiana, Escola Studio e Lavoro), e as escolas que faziam referência a personagens de um "passado recente", vividos entre o final do século XIX e o começo do XX (Escola Flano Giora, Escola Aurelio Yofll, Escola Cesare Lombruso, Escola de Ensino Primário Edmondo de Amiers, Escola Marianoella. Escola Vincenzo Globerti / Instituto Maria de Loretto, Escola Estanislau Derosa, Escola Guglielmo Ferraro, Escola Principesca Iolanda, Escola Bruno Serale $)^{334}$.

As escolas do grupo que remetiam à "ancestralidade italiana", contavam com dois poetas conhecidos: Dante Alighieri, autor da Divina comédia, e Francesco Petrarca, inventor do soneto. Nascidos da região da Toscana (respectivamente das cidades de Florença e Arezzo), foram considerados como símbolos do processo de unificação dos diversos reinos da Península Itálica no final do século XIX, servindo de referência para uma padronização da língua nacional, visto a infinidade de dialetos falados na península e o novo país procurar sua unificação por meio da língua.

Acreditamos que a comunidade italiana residente no Brás tenha escolhido o nome destes dois personagens não como uma simples rememoração dos seus antigos vilarejos e cidades italianas, mas como uma ação da afirmação da "italianidade" em curso, de procurar a partir de símbolos já identificados como próprios “da Itália”, formarem uma comunidade mais forte e que garantisse unidade, haja vista a exploração que muitos passavam em fábricas e pela indiferença da população paulistana do período, visto estarem

\footnotetext{
"defrontados com jornadas de dez, quatorze ou dezesseis horas de trabalho, preferencialmente propostos a mulheres e crianças, salários congelados, custo de vida e alugues em escalada permanente e completo desamparo legal, sua vida nas cidades pouco diferia das fazendas de que se haviam esquivado. Mais do que o
}

\footnotetext{
333 TRENTO, Angelo. Do outro lado do Atlântico: um século de imigração italiana no Brasil. São Paulo, SP: Nobel: Instituto Italiano di Cultura di San Paolo: Instituto Cultural Ítalo Brasileiro, 1988, pág. 159, Apud BAO, Op. Cit., pág. 10 .

${ }^{334}$ Alguns personagens não encontramos referências suficientes para que pudéssemos aferir informações.
} 
mito de Babel, nessa ordem de metáforas, São Paulo para estes grupos evocaria o Cativeiro da Babilônia".335

Não podemos negar que a escolha dos nomes de Francesco Petrarca e Dante Alighieri para escolas não contenha teores e anseios do nacionalismo da época, até porque a Itália ainda vivia um processo de unificação, e muitos dos que imigraram para São Paulo vivenciaram em sua terra natal questões que envolviam o incentivo ao amor pela pátria. Assim, não é fortuito reunirmos neste grupo de escolas outras duas: a Escola Itália, numa clara alusão ao sentimento do país, e a Escola Studio e Lavoro (Estudo e Trabalho), que evocava ao espírito de progresso que rondava o mundo capitalista desde a segunda metade do século XIX com o progresso científico tecnológico da Segunda Revolução Industrial.

Os nomes das demais escolas também estavam inseridos no discurso cientificista do oitocentos, com personagens italianos que atuaram num contexto temporal mais próximo dos imigrantes que se estabeleciam no Brasil, possivelmente vindo a memória de muitos dos moradores e descendentes italianos de São Paulo. Cesare Lombroso (1835-1909), nome da escola localizada na rua Luiz Gama número 132, foi o médico criador da chamada antropologia criminal, "argumentava ser a criminalidade um fenômeno físico e hereditário e, como tal, um elemento objetivamente detectável nas diferentes sociedades" ${ }^{336}$. Suas teorias procuravam compreender o "criminoso nato", e ganhavam espaço nas faculdades de Medicina e Direito de todo o Brasil, especialmente com seus ideários de "medidas de segurança" os quais argumentavam recuperar o delinquente a partir de um tratamento compulsório. Para Lombroso, "o crimonoso representava o retorno à selvageria" 337 , tecendo aproximações com as teorias Darwinistas e de outros cientistas do século XIX.

Já Edmondo de Amicis foi um escritor e militar italiano (1846-1908), conhecido por ter escrito o livro Coração, o qual tinha como um dos seus principais objetivos a criação de uma identidade nacional e cultural para a Itália recém-criada, a partir do retrato do cotidiano de uma escola pública para meninos na Itália,

\footnotetext{
“cujo objetivo é fortalecer o espírito cívico ou as virtudes morais, apelando para o sentimentalismo do leitor e por um otimismo distante da realidade. A intenção do autor é fazer com que o leitor sinta-se um personagem do texto, identificando-
}

\footnotetext{
335 SEVCENKO, Op. Cit.,pág. 39.

336 SCHWARCZ, Op. Cit., pág. 65.

${ }^{337}$ Idem, pág. 216.
} 
se com os personagens e com os eventos cotidianos narrados, para melhor apreender as mensagens morais e cívicas valoradas. ${ }^{338}$

Tanto na Itália como em vários outros países (incluindo o Brasil), o livro foi adotado durante vários anos.

Sobre a escola da rua Piratininga número 132, a homenagem à Vincenzo Gioberti (1801-1852) presumimos que se refira ao fato deste filósofo e político italiano ter escrito uma das obras que fundamentaram a Unificação Italiana, Dei primato morale e civili dei italiani, escrita em 1842, e que ia de encontro aos anseios de valorizar a ideia de nação italiana, procurando "afirmar em sua obra a existência de um primado civil dos italianos sobre a Europa. A primazia da península sobre o restante do continente evidenciava-se, para o filósofo piemontês, na instituição eclesiástica, a qual, a partir de sua sede em Roma, dirigia culturalmente a civilização cristã" 339 . Desta forma, sob o discurso religioso, garantiria a Itália o papel de civilizador dos povos, por sediar a Igreja Católica.

Poucas foram as referências às figuras de Gugliemo Ferraro e Princesa Iolanda. Enquanto o primeiro pode ter sido um dirigente positivista do Partido Socialista Italiano ${ }^{340}$, Iolanda de Saboya era a filha mais velha do rei da Itália, Vitor Emanuel III, homenageando em 1914 a escola da rua Sayão Lobato quando contava com apenas 12 anos de idade. Sobre os demais nomes que homenageiam as escolas (Marionella, Maria de Loretto, Estanislau Derosa, Flano Giora, Aurelio Yofll e Bruno Serale), não dispomos de informações.

Podemos perceber que as homenagens conferidas ao grupo de italianos do final do século XIX é intrinsicamente ligado às questões políticas, econômicas e sociais que a Itália vinha passando (Unificação, crise agrária, intensa emigração). Podemos trazer em perspectiva que o grupo de italianos (e pensando numa escala macro, dos demais imigrantes estabelecidos na cidade), formava um grupo homogêneo, de modo que nem todos possuíam as mesmas ideologias e equiparações sociais.

No caso das escolas italianas por nós abordadas, estas são escolas voltadas aos setores médios italianos residentes no Brás, que podiam arcar com o pagamento de uma mensalidade e ao mesmo tempo identificar-se simbolicamente com os anseios e propostas vividas pela comunidade italiana espalhada fora do país de origem. Daí adotarem nomes de

338 BASTOS, Maria Helena Camara. "A educação do caráter nacional: leituras de formação". Revista Educação e Filosofia. V. 12; n. 23; 1998, pág. 695.

339 BIANCHI, Alvaro. MUSSI, Bianca. "Il príncipe e seus contratempos: De Sancts, Croce e Gramsci", In: Revista Brasileira de Ciência Política, nº12. Brasília, set. - dez. 2013, pág. 13.

${ }^{340}$ MARTINS, Francisco Marcos. "Gramsci, filosofia e educação", Práxis Educativa, Ponta Grossa, v. 8, n. 1, p. 13-40, jan./jun. 2013, pág. 25. 
personalidades que estiveram envolvidos nos processos políticos do Risorgimento, e que estavam em sintonia com outras questões discutidas na época, como a publicação de livros para crianças a fim de incentivar o nacionalismo ou espelharem-se em metodologias de compreensão social que na realidade excluíam o outro, com olhares de indiferença, tal como principiavam as ideias de Cesare Lombroso.

Não podemos afirmar que toda a comunidade italiana do Brás fosse pertencente aos setores médios, mas colocá-los como unicamente pobres e operários reduzia o fato destes também terem participado do processo de construção da cidade. Como visto anteriormente, muitos dos sobrenomes de pessoas que financiavam os sobrados da rua Bresser na avenida Celso Garcia eram de estrangeiros. Enquanto Maura Véras pontua que dos grupos italianos que se instalaram no Brás, os vênetos e napolitanos ocupavam um destaque ${ }^{341}$, Susana Ribeiro acrescenta que os bareses passaram a residir nas imediações do Mercado Central, vizinhos às ruas do Gasômetro, Luca, Alfandega e Álvares de Azevedo, ocupando-se com o comércio cerealista. Já os napolitanos estariam concentrados nas ruas Caetano Pinto, Carneiro Leão, Piratininga e imediações, trabalhando em ofícios diversos como os ramos da carpintaria e construção civil" ${ }^{342}$, ruas que apresentaram um destacado número de cortiços no primerio capítulo.

O processo de "italianidade" de parte dos setores médios do Brás, vai ao encontro do que os próprios paulistas viviam no momento: um processo de afirmação diante da nação, com a eleição de um símbolo do passado que conferisse autenticidade ao dinamismo que o estado e a cidade vinham passando momento. A figura do bandeirante serviu para tal propósito, de modo que sua construção histórica nos diversos espaços intelectuais ali situados (Museu Paulista, Academia de Direito, Instituto Histórico e Geográfico de São Paulo, dentre outros), procuravam identificar o paulista (no) dos anos iniciais do século XX ao bandeirante do período colonial. Nas palavras de Danilo Ferreti, este é um processo de construção da chamada "paulistanidade" 343.

Os setores médios italianos que podiam contar com recursos suficientes, além de arcar com as escolas, podiam ser atendidos por uma série de estabelecimentos comerciais que se dedicaram à venda de produtos e objetos escolares. Interessante notar que dos 6 equipamentos encontrados, 4 deles ficavam na Avenida Rangel Pestana, muito próximo das escolas citadas anteriormente, atendendo inclusive as escolas públicas do bairro. Tais

${ }^{341}$ VÉRAS, Maura Pardini Bicuro. "Cortiços no Brás: velhas e novas formas de habitação popular na São Paulo industrial. Análise Social, Vol. XXIX (127), 1994, pág. 66.

${ }^{342}$ RIBEIRO, Op. Cit, pág. 30.

${ }^{343}$ FERRETI, Danilo José Zioni. A construção da paulistanidade. Identidade, política e historiografia em São Paulo (1856-1930). Tese (Doutorado em História). São Paulo: Universidade de São Paulo, 2010. 
estabelecimentos podem ser vislumbrados no mapa Escolas e estabelecimentos de venda de objetos escolares do Brás, elaborado por nós com base no processamento dos dados apresentados até aqui.

\begin{tabular}{|l|l|l|l|}
\hline \multicolumn{3}{|c|}{ Lojas especializadas em objetos escolares do Brás (1906-1914) } \\
\hline Rua Celso Garcia, 18 & $\begin{array}{l}\text { Objetos escolares } \\
\text { escritórios, livraria }\end{array}$ & $\begin{array}{l}\text { DiretorRodolpho } \\
\text { Cumino }\end{array}$ & 1914 \\
\hline $\begin{array}{l}\text { Rua do Gasômetro, } \\
106\end{array}$ & Objetos escolares & Diretor Miguel Lafeu & 1909 \\
\hline $\begin{array}{l}\text { Avenida Rangel } \\
\text { Pestana,136 }\end{array}$ & Objetos escolares & Martin Sale & 1908 \\
\hline $\begin{array}{l}\text { Avenida Rangel } \\
\text { Pestana, 143 }\end{array}$ & Objetos escolares & Humberto Calandrini & 1908 \\
\hline $\begin{array}{l}\text { Avenida Rangel } \\
\text { Pestana, 156B }\end{array}$ & Objetos escolares & Gordon \& Geller & 1906 \\
\hline $\begin{array}{l}\text { Avenida Rangel } \\
\text { Pestana, 156C }\end{array}$ & Objetos escolares & Heitor \& Alves & 1908 \\
\hline
\end{tabular}

do Almanak Laemmert. 


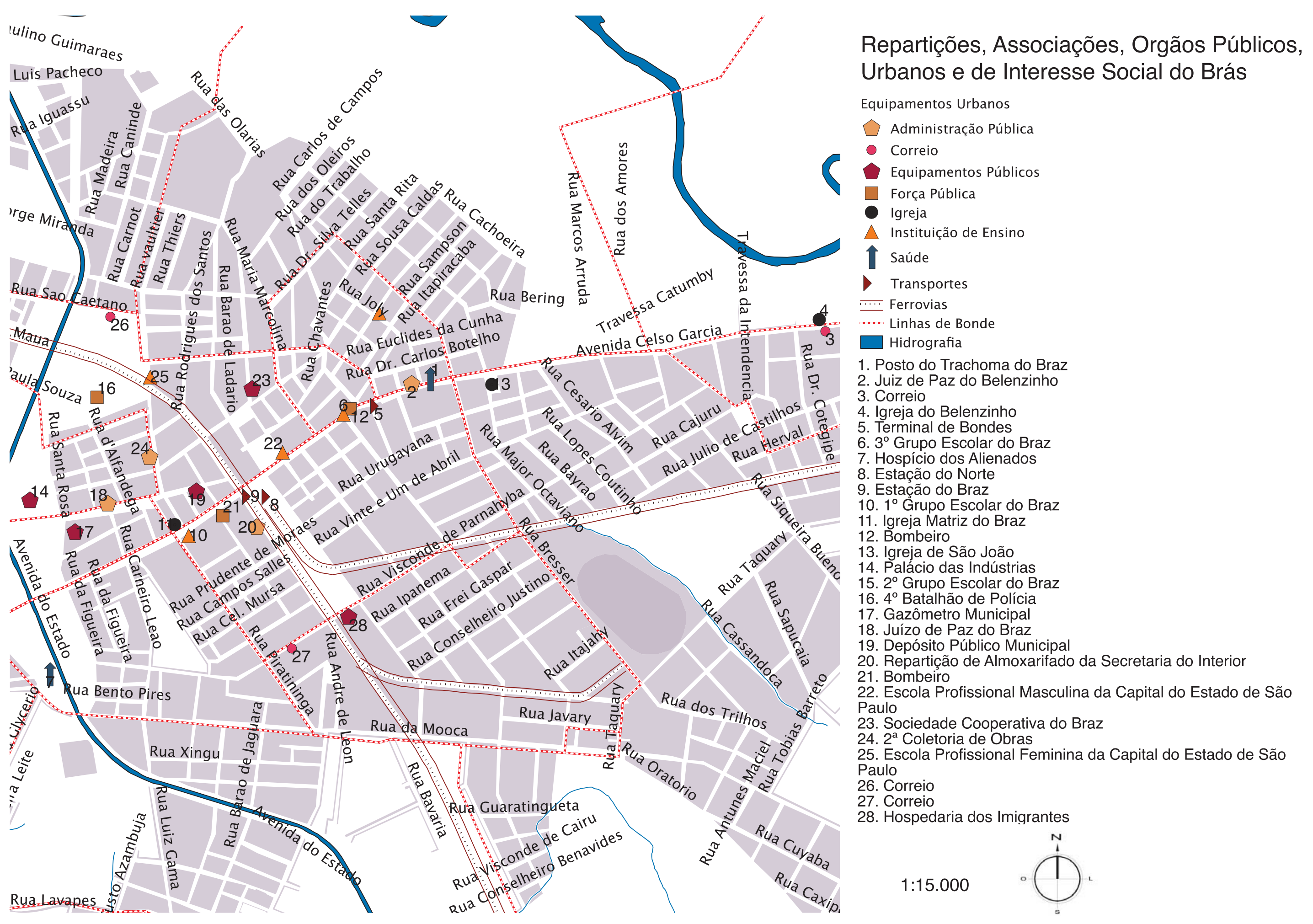


3.11 Equipamentos urbanos e entretenimentos modernos: os estabelecimentos de interesse social, o Teatro Colombo, cinemas e fotografias

À medida que São Paulo crescia em número de residências e novos moradores, a demanda por serviços públicos como o transporte, educação e saúde aumentava gradativamente. No ano de 1902 São Paulo já contava com pelo menos 286.000 habitantes, e o bairro do Brás com $68.790^{344}$, ou seja, quase $25 \%$ de toda a população da cidade habitava um único bairro, o que explica a alta concentração de moradias oficializadas, bem como a ampla rede comercial existentes especialmente nas ruas que passavam os bondes.

O bairro do Brás passou a concentrar uma ampla rede de serviços que realizavam o atendimento à sua população. A partir da análise cartográfica (em especial da Planta Industrial e Commercial da Cidade de São Paulo, e da Planta da Cidade de São Paulo levantada pela Divisão Cadastral, e na leitura do Almanak Laemmert alguns destes estabelecimentos foram citados, o que redundou na elaboração da tabela 21 e do mapa Repartições, Associações, Órgãos Públicos, Urbanos e de Interesse Social do Brás.

\begin{tabular}{|c|c|c|}
\hline \multicolumn{3}{|c|}{ Estabelecimentos de interesse social do Brás } \\
\hline ESPAÇO & ENDEREÇO & $\begin{array}{c}\text { REFERÊNCIA } \\
\text { Almanack } \\
\text { Laemmert }\end{array}$ \\
\hline Teatro Colombo & Largo da Concórdia & 1908 \\
\hline Segunda Coletoria de Obras & Rua Monsenhor Andrade, 57 & 1913 \\
\hline $\begin{array}{c}\text { Repartição de Almoxarifado da } \\
\text { Secretaria do Interior - } \\
\text { Depósito }\end{array}$ & Rua Domingos Paiva, 59 & 1913 \\
\hline $\begin{array}{c}\text { Gasômetro Municipal } \\
\text { Hospício dos Alienados / }\end{array}$ & Rua do Gasômetro & \\
Guarda Cívica Municipal ${ }^{345}$ & Avenida do Estado (antes \\
rua do Hospício) & \\
\hline $\begin{array}{c}\text { Juízo de Paz do Braz } \\
\text { Estação do Norte / Estação } \\
\text { Pedro II }\end{array}$ & $\begin{array}{c}\text { Rangel Pestana } \\
\text { do Gasômetro, 43 }\end{array}$ & 1913,1914, \\
\hline Juiz de Paz do Belenzinho & Avenida Celso Garcia, 139 & \\
\hline Depósito Público Municipal & Rua do Gasômetro, 158 & 1913,1915 \\
\hline Telef. 771 & 1915 \\
\hline Bombeiro & $\begin{array}{c}\text { Estação do Norte - Martin } \\
\text { Burchard, 10 - Telef. 81 }\end{array}$ \\
\hline \multicolumn{2}{|c}{} \\
\hline
\end{tabular}

${ }^{344}$ Com base nas informações do Annuario Estatístico Estadual de 1902.

${ }^{345}$ Apesar de estar localizado na região administrativa do centro, o Hospício (e posterior Guarda Cívica) fora alvo de intensos debates em torno da urbanização da Várzea do Carmo. 


\begin{tabular}{|c|c|c|}
\hline Bombeiro & $\begin{array}{c}\text { Avenida Rangel Pestana, } \\
285 \text { - Telef. } 508 \\
\end{array}$ & \\
\hline $\begin{array}{c}\text { Sociedade Cooperativa } \\
\text { Beneficente do Braz }\end{array}$ & Rua Miler, 38 & 1914,1915 \\
\hline Correio & $\begin{array}{c}\text { Alfredo Danise - Avenida } \\
\text { Intendência, } 232 \\
\end{array}$ & 1909 \\
\hline Correio & $\begin{array}{l}\text { Manoti João - Visconde de } \\
\text { Parnaíba, } 62\end{array}$ & 1909 \\
\hline Correio & $\begin{array}{l}\text { Palucieno Antonio - São } \\
\text { Caetano, } 230\end{array}$ & 1909 \\
\hline $\begin{array}{l}\text { Deposito Estadual do Trabalho / } \\
\text { Imigração }\end{array}$ & $\begin{array}{c}\text { Visconde de Parnaíba, } 238 \text { - } \\
\text { Telef. } 206 \text { e } 2068\end{array}$ & $\begin{array}{c}1913 \\
1914,1915 \\
\end{array}$ \\
\hline Escola Profissional Feminina & $\begin{array}{l}\text { Rua Monsenhor Andrade, } \\
\text { esquina rua Oriente }\end{array}$ & 1914 \\
\hline Escola Profissional Masculina & Rua Miler,4 & $1913 / 1914$ \\
\hline Primeiro Grupo Escolar do Brás & $\begin{array}{l}\text { Rangel Pestana (em frente à } \\
\text { Igreja) }\end{array}$ & $1904 / 1914$ \\
\hline Segundo Grupo Escolar do Brás & $\begin{array}{l}\text { Entre a rua Almirante } \\
\text { Barroso e Mendes Junior }\end{array}$ & $1904 / 1914$ \\
\hline $\begin{array}{l}\text { Terceiro Grupo Escolar do Brás } \\
\text { / Escola Normal }\end{array}$ & $\begin{array}{l}\text { Rangel Pestana, em frente a } \\
\text { rua do Hipódromo }\end{array}$ & $1904 / 1914$ \\
\hline Escola de Comércio do Brás & Avenida Rangel Pestana & 1914 \\
\hline Palácio das Indústrias & Parque Dom Pedro II & \\
\hline Matriz do Braz & $\begin{array}{l}\text { Rangel Pestana, } 149 \text { (entre } \\
\text { as ruas Monsenhor Andrade } \\
\text { e Jairo Gois) }\end{array}$ & 1914 \\
\hline Igreja de São João & $\begin{array}{c}\text { Largo Senador Moraes } \\
\text { Barros }\end{array}$ & \\
\hline Igreja São José & Largo de São José & \\
\hline Posto do Trachoma do Braz & Intendência, 99 & 1914 \\
\hline Subdelegacia da $5^{\text {a }}$ Parada & $\begin{array}{c}\text { Avenida Celso Garcia, s/n } \\
\text { Telef. } 2113 \\
\end{array}$ & 1914 \\
\hline Juiz de Paz do Belenzinho & $\begin{array}{c}\text { Avenida Celso Garcia, } 139 \text { - } \\
\text { Telef. } 769\end{array}$ & 1914 \\
\hline Igreja Belenzinho & Avenida Celso Garcia, 483 & 1914 \\
\hline Igreja São João & $\begin{array}{l}\text { Avenida Celso Garcia - } \\
\text { Largo do Marco }\end{array}$ & 1914 \\
\hline Igreja São Jose & Largo São Jose & 1914 \\
\hline $\begin{array}{c}4^{\circ} \text { Batalhão de Polícia (Quartel } \\
\text { da Alfândega Antiga) }\end{array}$ & $\begin{array}{c}\text { Rua Américo Brasiliense } \\
\text { Telef. } 1321\end{array}$ & 1913,1914 \\
\hline Terminal Bondes & $\begin{array}{c}\text { Início da Celso Garcia, } \\
\text { esquina da rua José de } \\
\text { Alencar } \\
\end{array}$ & \\
\hline $5^{\circ}$ Batalhão de Policia & Quartel da Alfandega Antiga & 1915 \\
\hline
\end{tabular}

Tabela 21: "Estabelecimentos de interesse social do Brás surgidos até 1915", elaborada pelo autor com base na Planta Industrial e Commercial da Cidade de São Paulo [c. 1911], e a Planta da Cidade de São Paulo levantada pela Divisão Cadastral de 1916, bem como nos anúncios do Almanak Laemmert. 


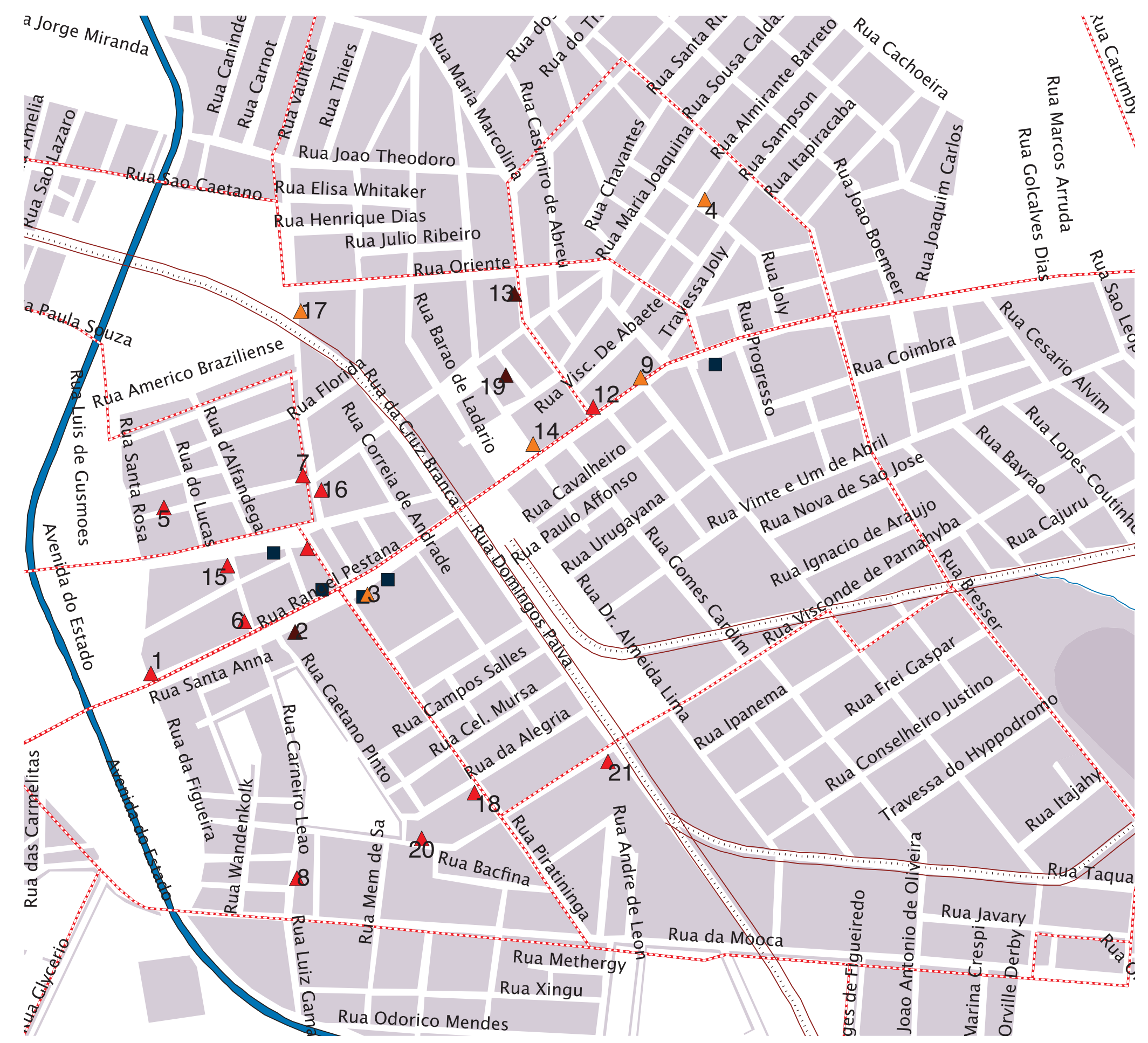

Escolas e estabelecimentos de venda de objetos escolares do Braz Escolas

A Italiana tipo I

- Italiana tipo II

$\triangle$ Pública

- lojas de materiais escolares

… Ferrovias

$-\infty$ Linhas de Bonde

Hidrografia

1. Escola Estanislau Derosa

2. Escola Guglielmo Ferraro

3. $1^{\circ}$ Grupo Escolar do Braz

4. $2^{\circ}$ Grupo Escolar do Braz

5. Escola Flano Giora

6. Escola Aurélio Yofll

7. Escola Dante Alighieri

8. Escola Francesco Petrarca

9. $3^{\circ}$ Grupo Escolar do Braz

10. Instituto Gia Dante Alighieri

11. Escola Cesare Lombroso

12. Escola Studio e Lavoro

13. Escola de Ensino Primário Edmondo de Amicis

14. Escola Profissional Masculina da

Capital do Estado de S. Paulo

15. Escola Italia

16. Escola Marianoella

17. Escola Profissional Feminina da

Capital do Estado de São Paulo

18. Escola Vincenzo Globerti/Instituto

Maria de Loretto

19. Escola Italiana

20. Escola Italiana

21. Escola Bruno Serale

$1: 10.000$<smiles>NC12CCCCCC1CCCC2</smiles>

Mapa construído a partir da Planta da Cidade de São Paulo de 1916 (APESP), localização de endereços e numeração da Planta Cadastral e Commercial da Cidade de São Paulo de 1911 (Museu Paulista), vetores de arruamento, hidrografia e ferrovias do Grupo Himaco, listas das escolas citadas Almanak Laemmert (Hemeroteca Digital). 
Os estabelecimentos acima descritos fornecem um panorama dos usos que a população estabelecida no Brás e de outros bairros da cidade podiam usufruir. Além das escolas públicas mencionadas anteriormente, os serviços de transporte se mostram abundantes $^{346}$, e as igrejas ocupam um destaque na vida social e urbana, destacando-se muitas vezes na paisagem local.

Espaços dedicados a questões voltadas ao campo da segurança pública como postos policiais e bombeiros se encontram bem distribuídos pelo bairro, e àqueles ligados à saúde se restringem ao Hospício dos Alienados (na margem oposta do rio) e ao Posto do Trachoma. Este último nos chamou a atenção, e pudemos verificar que possivelmente tratase de um posto provisório do Serviço Sanitário Estadual, instalado apenas em 1914 na Avenida Celso Garcia número 99 como forma de controle e monitoramento da doença no bairro. "O tracoma ou conjuntivite granulosa é uma enfermidade oftálmica contagiosa que causou grande número de enfermos no interior do Estado de São Paulo no período compreendido entre o final do século XIX e primeiras décadas do século XX" ${ }^{\text {347 }}$, estando intimamente ligada como uma "doença do imigrante", visto o intenso número destes que se estabeleciam na cidade e traziam consigo muitas outras doenças que encontravam um ambiente propício para sua propagação. A instalação do posto possui relação direta com a manutenção da salubridade urbana, capitaneada em grande parte por médicos que atuavam nestes espaços, formando uma classe profissional "preocupada com as questões da cidade e o seu saneamento" ${ }^{348}$.

A procura por espaços dedicados ao lazer ganhava força. Não eram mais as procissões, demais festas e eventos religiosos que possuíam a exclusividade na organização da vida daqueles que moravam em São Paulo no começo do século XX, novas demandas e anseios se faziam presentes, e muitos desejavam a experiência de viver a cidade que estava

\footnotetext{
${ }^{346}$ Apesar de ainda serem insuficientes para a população ali estabelecida, conforme atestam muitos dos debates na Câmara Municipal envolvendo o vereador Celso Garcia na luta pela ampliação dos horários e das redes de bonde por exemplo.

347 LUNA, E. J. A epidemiologia do tracoma no Estado de São Paulo. Dissertação (Mestrado em Ciências Médicas)-Universidade Estadual de Campinas - Unicamp, Campinas, 1993; RIBEIRO, M. A. História sem fim: Um inventário da saúde pública, São Paulo, 1880- 1930. Tese (Doutorado em Economia do Instituto de Economia) - Universidade Estadual de Campinas, Campinas, 1991; TELAROLLI JR. R. Poder e Saúde: as epidemias e a formação dos serviços de saúde em São Paulo. São Paulo: Editora da Universidade Paulista, 1996, Apud: LÓDOLA, Soraya. "O tracoma em viagem pelos trilhos da economia: uma análise sobre a primeira comissão de tratamento e profilaxia do tracoma em São Paulo no início do século XX", In: Anais Eletrônicos do $15^{\circ}$ Seminário Nacional de História da Ciência e da Tecnologia. Florianópolis: Universidade Federal de Santa Catarina, nov. 2016. Disponível em: http://www.15snhct.sbhc.org.br/trabalho/view?ID TRABALHO=1545 >>, acesso em 27 de janeiro de 2017. ${ }^{348}$ CAMPOS, Cristina. "Biografias profissionais de médicos e engenheiros como fonte para a história da cidade e do urbanismo". FARIA, Rodrigo de. CERASOLLI, Josianne (orgs.). Urbanistas e urbanismo no Brasil: entre trajetórias e biografias. São Paulo: Alameda, 2014, pág. 210.
} 
se transformando. É o Teatro Politema, o São José, Boa Vista, Apolo, o Cassino Antárctica, São Paulo, Palace Theatre, São Pedro, Variedades ${ }^{349}$, além do Teatro Municipal construído no Anhangabaú que proporcionam parte do lazer da cidade nas primeiras décadas do século $\mathrm{XX}$

Ernani Silva Bruno nos dá uma ideia dos novos aparelhos teatrais instalados na cidade nas primeiras décadas do século XX: são exemplo dessa cidade desejosa de mais espaços destinados ao lazer e entretenimento pode ser observada com o Teatro Colombo, instalado nas antigas dependências do Mercado Municipal do Brás de 1897, no Largo da Concórdia, foi inicialmente transformado em 1906 em casa de diversões com projeto do arquiteto Augusto Fried ${ }^{350}$, e certamente sua remodelação se deu pela ação e envolvimento do vereador Celso Garcia junto com a comunidade do bairro (figura 209). O arrendatário, o coronel Pedro França Pinto, conseguiu o uso do imóvel por 20 anos, e dois anos depois, em 1908, “o prefeito Barão Raimundo Duprat eleva de vinte para trinta anos o prazo de arrendamento do antigo mercado do largo da Concórdia" 351 . O prédio retangular remodelado, tinha 30 metros de frente por 20 de fundo, com um total de $1.500 \mathrm{~m}^{2}$ de área edificada, custando Rs2:000\$000 (dois contos de réis) no primeiro ano, passando a seis no segundo.

\footnotetext{
349 BRUNO, Op. Cit, pág. 1294-1295.

${ }^{350}$ Grande parte das informações sobre o Teatro Colombo foram baseadas no "Inventário dos espaços de sociabilidade cinematográfica da cidade de São Paulo (1895-1929)”, organizado pelo historiador José Inacio de Melo e Souza, e encontram-se disponíveis em: $<$ http://www.arquiamigos.org.br/bases/cine3p/historico/00002.pdf $>>$, acesso em 01/03/2017.

${ }^{351}$ Notícia do jornal O Estado de S. Paulo, edição de 11 de agosto de 1972.
} 


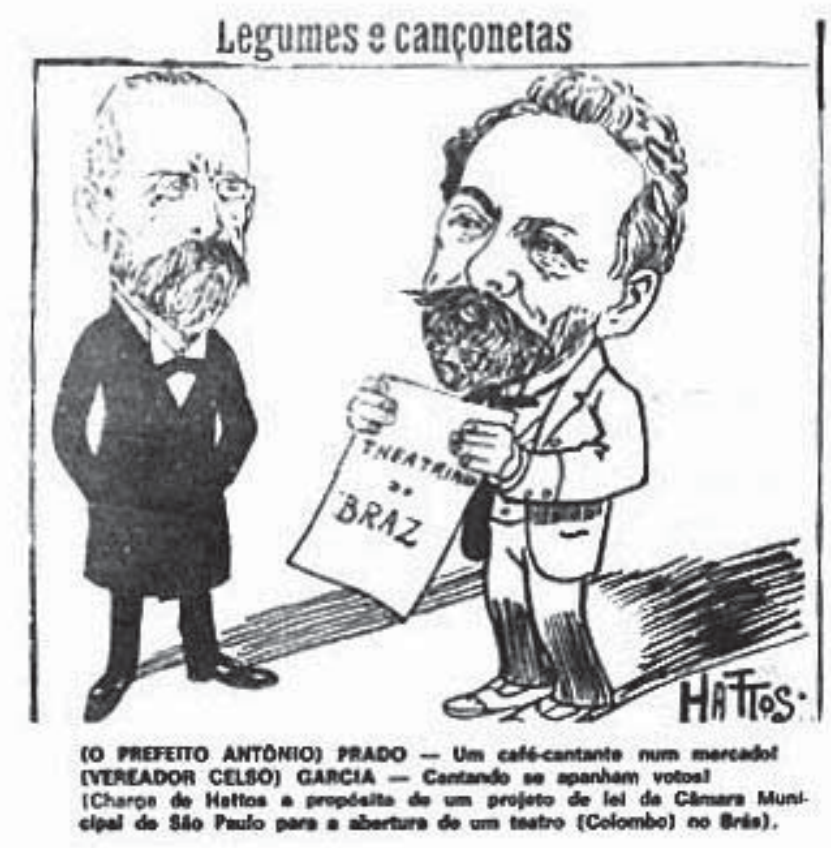

Figura 213: Charge satirizando a instalação do Teatro Colombo envolvendo o vereador Celso Garcia e o prefeito Antônio Prado. ARAÚJO, Vicente de Paula. Salões, circos e cinemas de São Paulo, p.117. Apud: "Inventário dos espaços de sociabilidade cinematográfica da cidade de São Paulo (1895-1929)"

Sua sala de espetáculos construída em forma de ferradura (figura 210) tinha capacidade para 1.968 espectadores, divididos em 38 camarotes (cinco lugares), 24 frisas (cinco lugares), 750 cadeiras na plateia, três arquibancadas com 216 lugares cada uma (648 lugares) e mais 260 pessoas em pé nas duas filas atrás das arquibancadas. Tanto o palco como os camarins foram pensados de modo que formassem um bloco destacado do restante do edifício (figura 211). Segundo o historiador José Inacio de Melo e Souza, todo o mobiliário do Teatro Colombo foi importado da Áustria, sendo fabricado pela empresa Thonet, e o teto da plateia era decorado com um azul celeste e uma vistosa alegoria. No lado oposto ao palco ficava um bar e restaurante de grandes dimensões ${ }^{352}$. Sua inauguração ocorreu em 20 de fevereiro de 1908, às 20h50, com a presença do prefeito Antonio Prado que junto da plateia pôde assistir à apresentação da Companhia Dramática Italiana de Antonio Bolognesi, o drama "Maria Antonieta" de Paolo Giocometti, financiada por Manuel Ballesteros. 


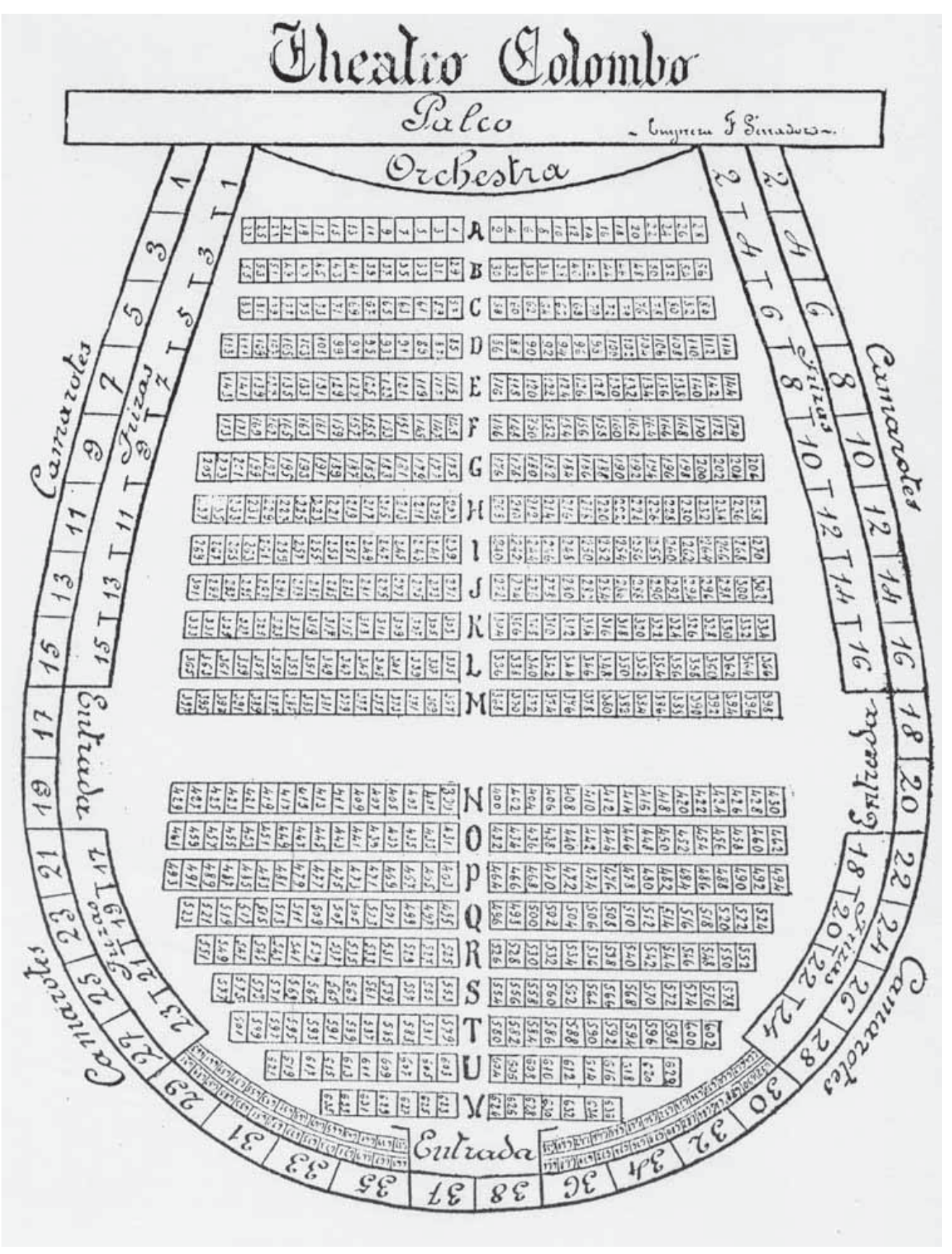

Figura 214: Palco e plateia do Teatro Colombo. Fonte: KUHL, Beatriz Mugayar. Contribuição para o estudo da evolução da edificação teatral na cidade de São Paulo. Apud: "Inventário dos espaços de sociabilidade cinematográfica da cidade de São Paulo (1895-1929)”. 


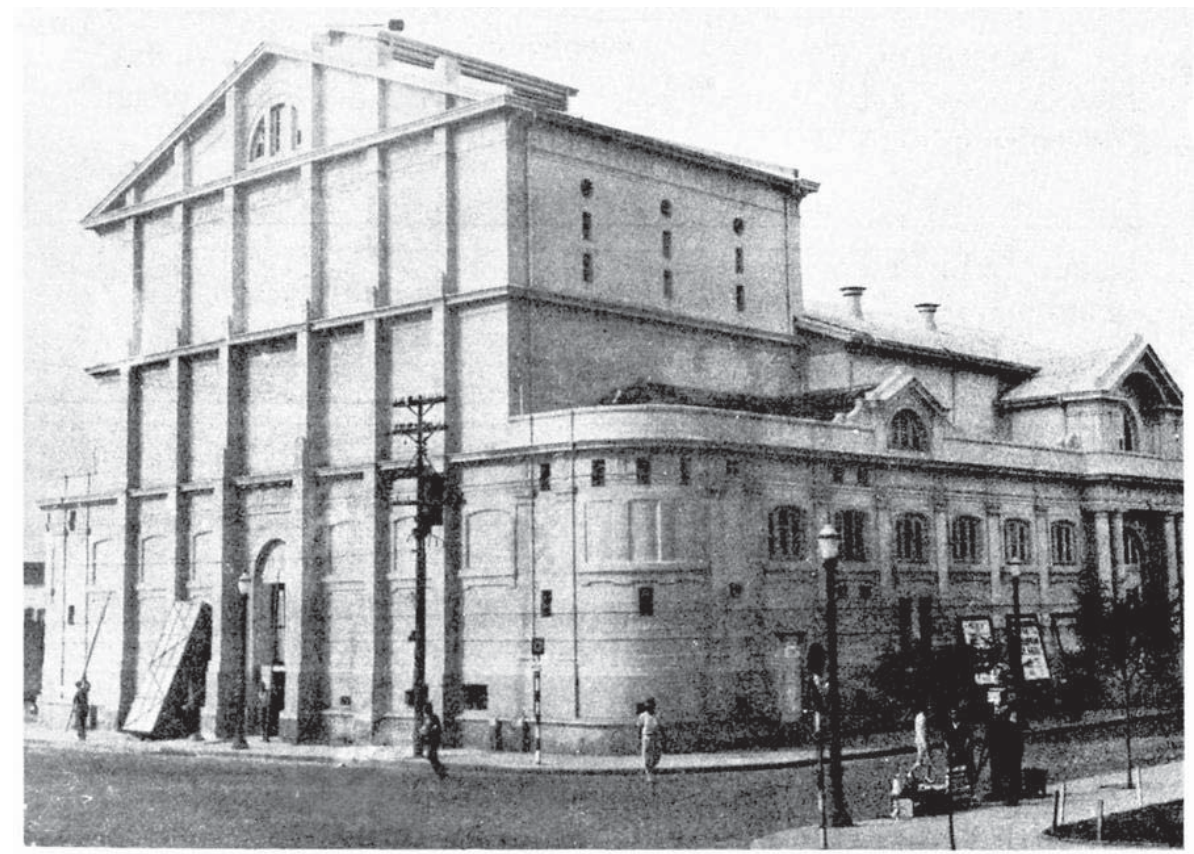

Figura 215: Foto da caixa do teatro nos anos 1950-60. REALE, Ebe. Brás, Pinheiros, Jardins, p.48, Apud, "Inventário dos espaços de sociabilidade cinematográfica da cidade de São Paulo (1895-1929)".

A partir de 5 de 1908, Francisco Serrador, um empresário espanhol proprietário de hotéis, cassinos, teatros e cinemas espalhados por várias cidades brasileiras (como o Rio de Janeiro, Curitiba e São Paulo), arrenda o Teatro Colombo até 1911, quando o repassou para a Empresa Gomes da Silva, época em que também eram exibidas sessões de cinema Richbourg (figura 212).

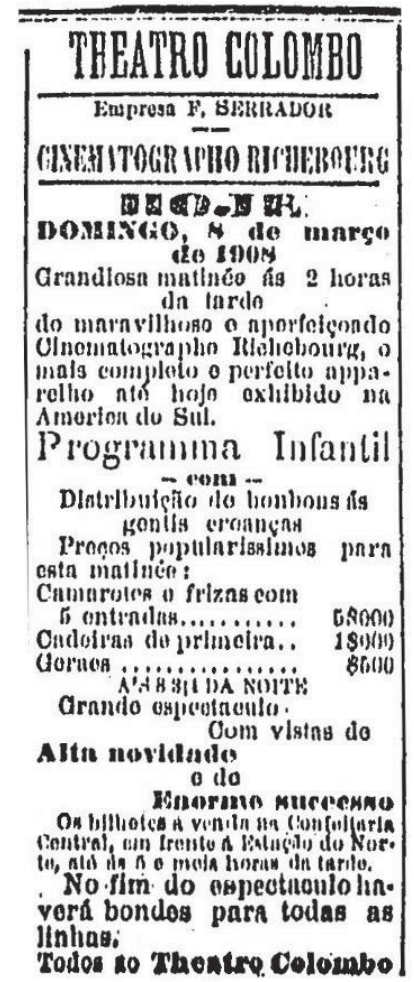

Figura 216: Anúncio do Teatro Colombo no jornal O Estado de S. Paulo, edição de 08 de março de 1908, Apud, "Inventário dos espaços de sociabilidade cinematográfica da cidade de São Paulo (1895-1929)". 
Desde 1913 o teatro passou a se utilizar de um acumulador próprio de corrente de energia, assim como o Teatro Politeama na porção central da cidade. Em 1914 passou por intensas reformas, quando ganhou uma nova pintura e iluminação por arco na fachada principal do edifício (figura 213).

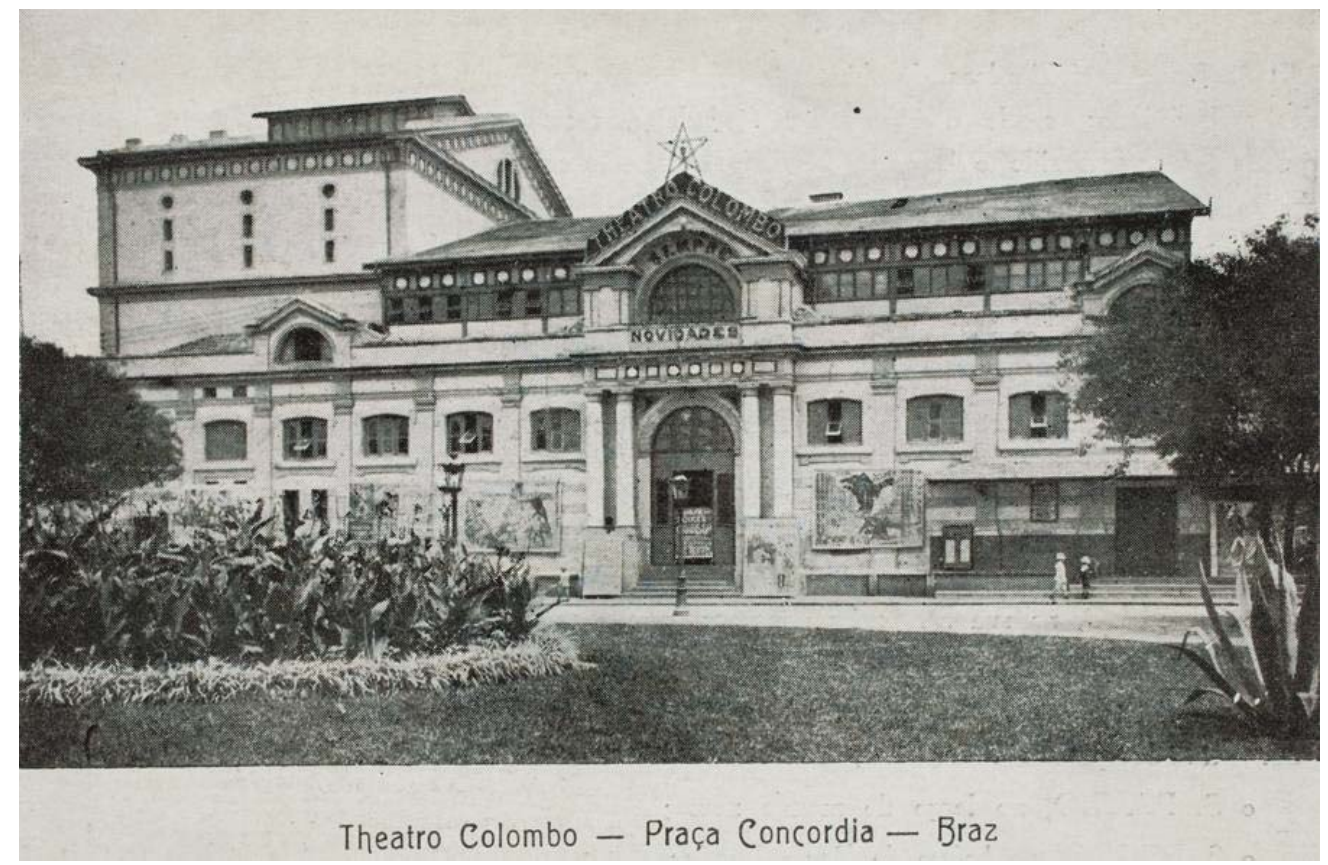

Figura 217: Fachada do Teatro Colombo na década de 1920 com os arcos voltaicos instalados em 1914. Fonte "A Capital paulista: comemorando o Centenário da Independência, p.57”, Apud, "Inventário dos espaços de sociabilidade cinematográfica da cidade de São Paulo (1895-1929)".

José Inácio de Melo e Souza relata que quando São Paulo ganhou uma legislação específica para os cinemas e teatros em 1916, o engenheiro José de Sá Rocha chegou a vistoriar o Teatro Colombo, declarando que a

Casa construída especialmente para teatro, no lugar do antigo mercado, semelhantemente ao que aconteceu com o Teatro S. Paulo já referido. Os serviços a fazer aqui podem ser os seguintes: fixar as cadeiras da plateia ao piso, e dar às filas o espaçamento mínimo de $80 \mathrm{~cm}$, observando igualmente as larguras determinadas para as passagens; tornar incombustíveis as escadas de acesso para os camarotes; melhorar as condições da cabine, que é de madeira e imperfeitamente forrada de asbesto. Uma das escadas de acesso para as galerias está trancada, convindo que seja tornada livre, para poder servir de saída. ${ }^{353}$

353 SOUZA, José Inacio de Melo. Op. Cit. 
Mais uma vez realocado, agora sob a administração da empresa de João de Castro e Cia. (por um período de sete anos), sofreu uma extensa reforma em 1917, no qual foi construída uma

\begin{abstract}
"[...] passagem de 2 metros de largura no plano dos camarotes, passagem esta feita em balanço, de acordo com a planta. A retificação da linha exterior de divisa dos camarotes e frisas dá lugar à criação de quatro pequenos vestíbulos contrapostos às frisas e outros quatro em correspondência, contrapostos aos camarotes, conforme a planta. O número de lugares novos é de 144 no plano da plateia e de 212 no dos camarotes" 354 (figura 214).
\end{abstract}

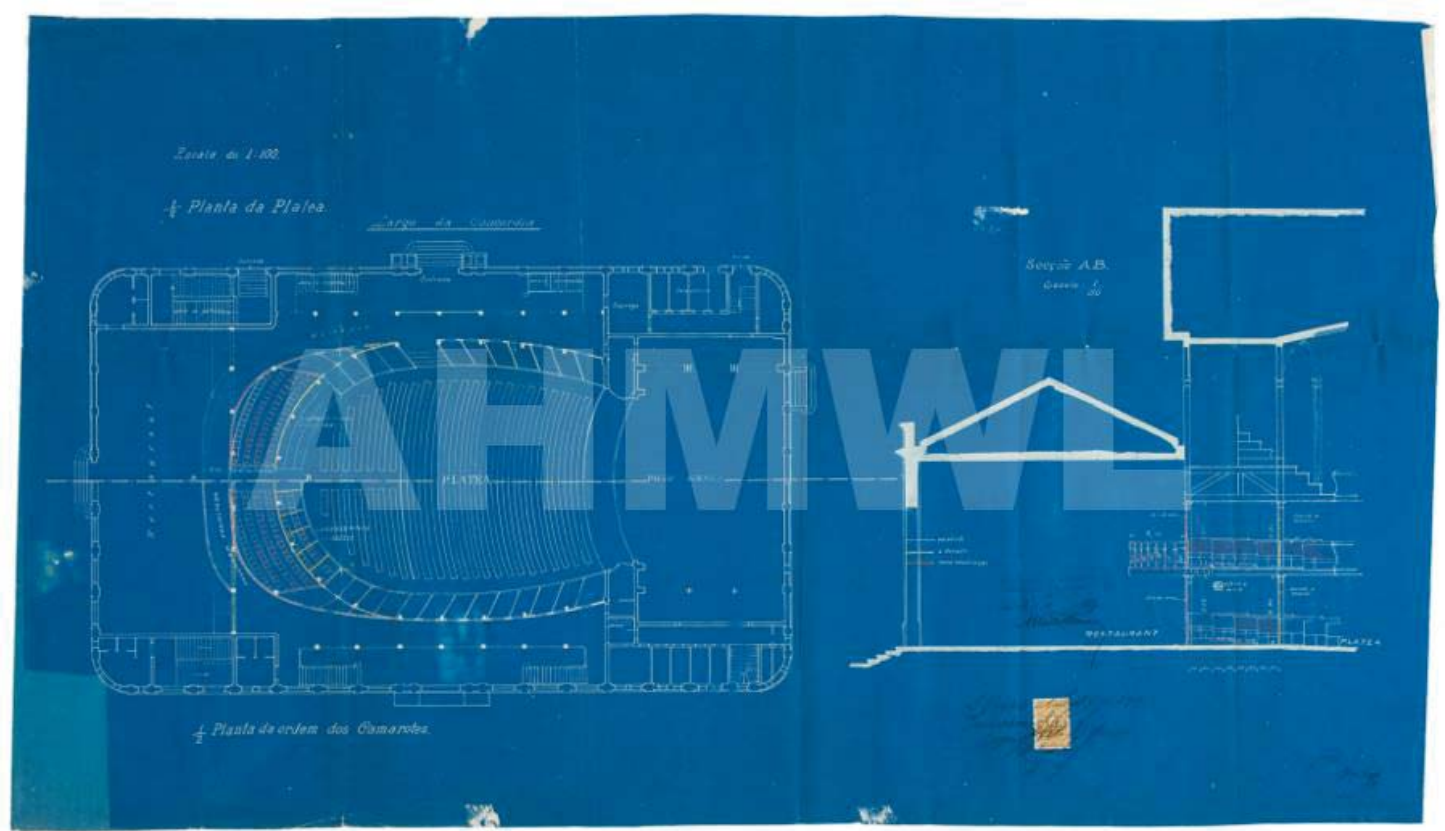

Figura 218: A reforma dos camarotes do Teatro Colombo, Apud, "Inventário dos espaços de sociabilidade cinematográfica da cidade de São Paulo (1895-1929)".

Com o fim do contrato original, a Prefeitura notificou os herdeiros de Pedro França Pinto para assim retomar o prédio, o que só ocorreu em 1950, quando Abílio Peixe retirou todas as benfeitorias existentes no teatro, sendo alvo de um novo processo, no qual teve de devolver todos os pertences.

Reaberto em 10 de julho de 1952 sob direção do Departamento Municipal de Cultura, permaneceu até 1957 quando foi novamente fechado por falta de segurança. José Inacio relata que o jornal $O$ Estado de São Paulo anunciava as possíveis ameaças de demolição, depois de ser incluído no traçado viário da Radial Leste, além de torcedores de futebol (durante a época da Copa do Mundo de 1966) prometerem queimar o teatro, motivo que infelizmente não dispomos de maiores informações. Um princípio de incêndio ocorreu

\footnotetext{
354 Alvará de licença e memorial descritivo datado de 30 de outubro de 1917, disponível no "Inventário dos espaços de sociabilidade cinematográfica da cidade de São Paulo (1895-1929)”.
} 
na manhã de 17 de julho de 1966, quando um colchão pegou fogo no teatro vazio. Dois dias depois, às 16h30, um novo incêndio voltou a queimar o Teatro Colombo, que não se salvou, restando apenas suas paredes (figuras 219 e 220).

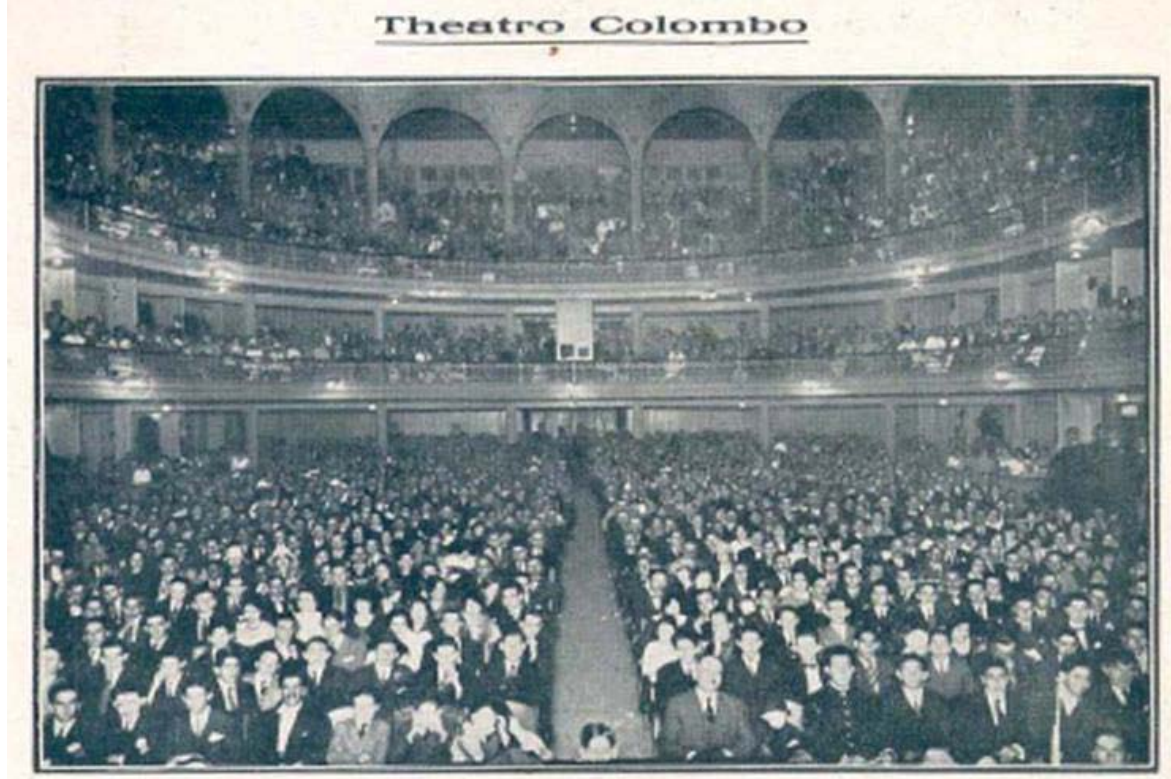

Aspocto do Theatro Colombo, a nusta e aprociada casa de dirvorsobs da Emporesa jallo de Castro, transóor. dando do espectadores em uma das ufilmas reeilas aif rowilisadas com grande successo.

Figura 219: Plateia do Teatro Colombo em 1921. Fonte: Revista A Cigarra, (169): 29, 1/10/1921, Apud, "Inventário dos espaços de sociabilidade cinematográfica da cidade de São Paulo (1895-1929)".

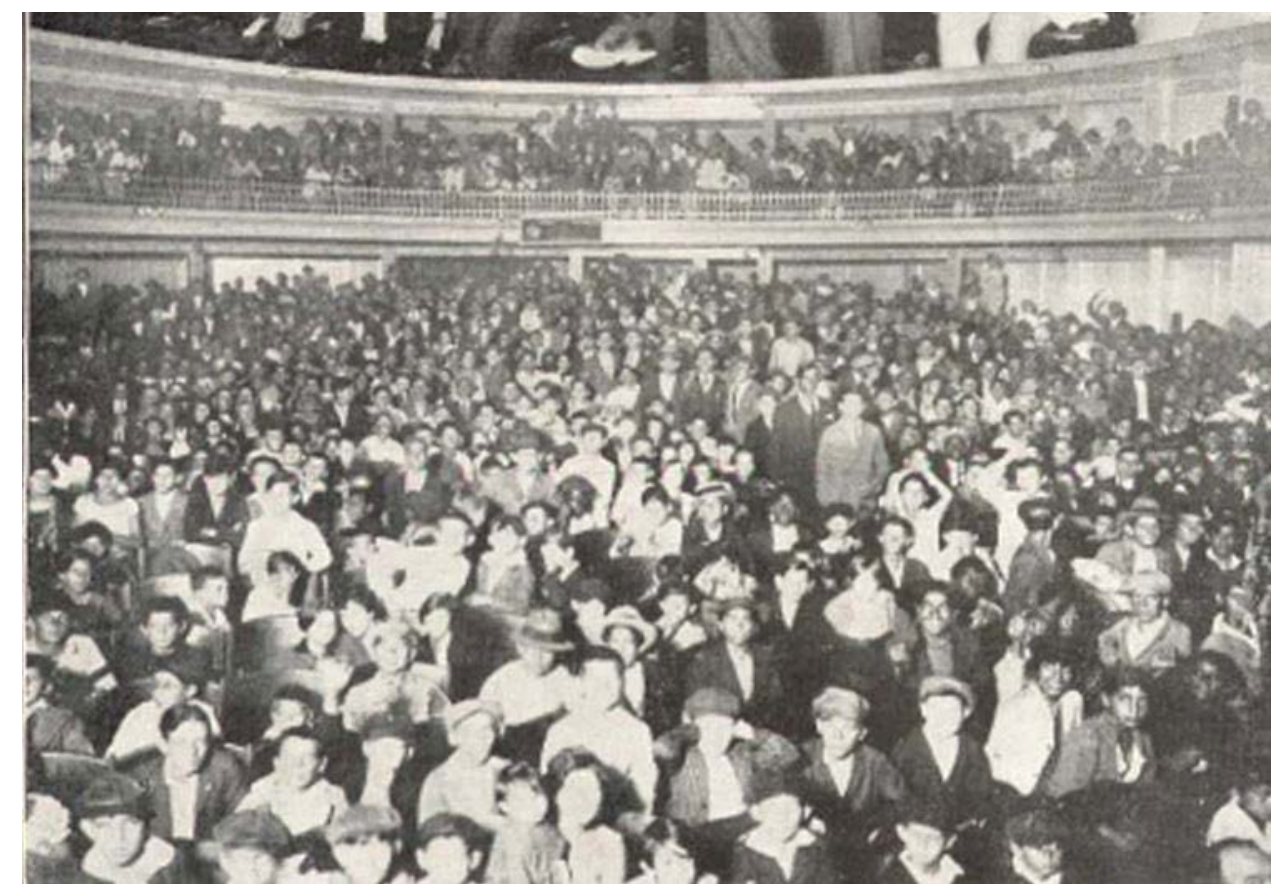

Figura 220: Plateia do Teatro Colombo em 1928. Fonte: Revista A Cigarra, (316): 25, jan.1928, Apud, "Inventário dos espaços de sociabilidade cinematográfica da cidade de São Paulo (1895-1929)". 


\section{THEATRO GOLOMBO}

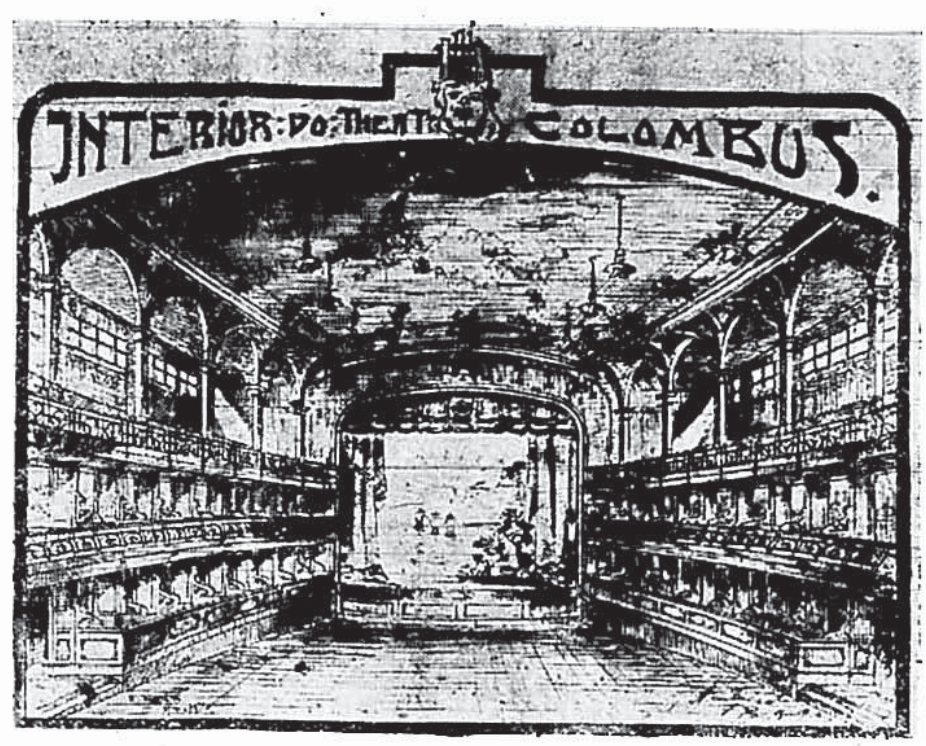

Figura 221: Interior do Teatro Colombo em 1908, Fonte: Jornal O Estado de S. Paulo, 21/2/1908, p.5, Apud, "Inventário dos espaços de sociabilidade cinematográfica da cidade de São Paulo (1895-1929)".

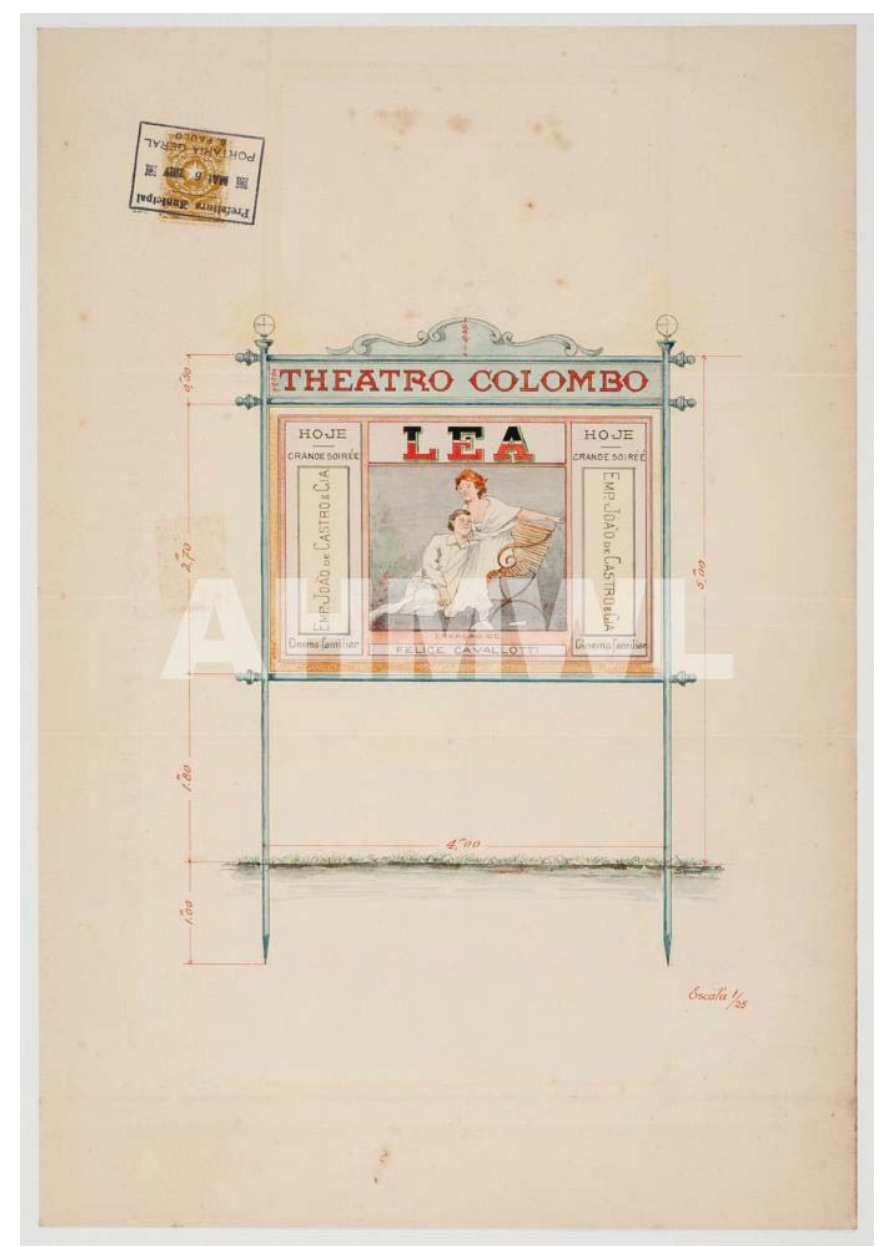

Figura 222: Proposta de placar para anúncio do Teatro Colombo.

Fonte: Grupo Polícia Administrativa e Higiene, caixa 302, AHMWL, Apud, "Inventário dos espaços de sociabilidade cinematográfica da cidade de São Paulo (1895-1929)". 


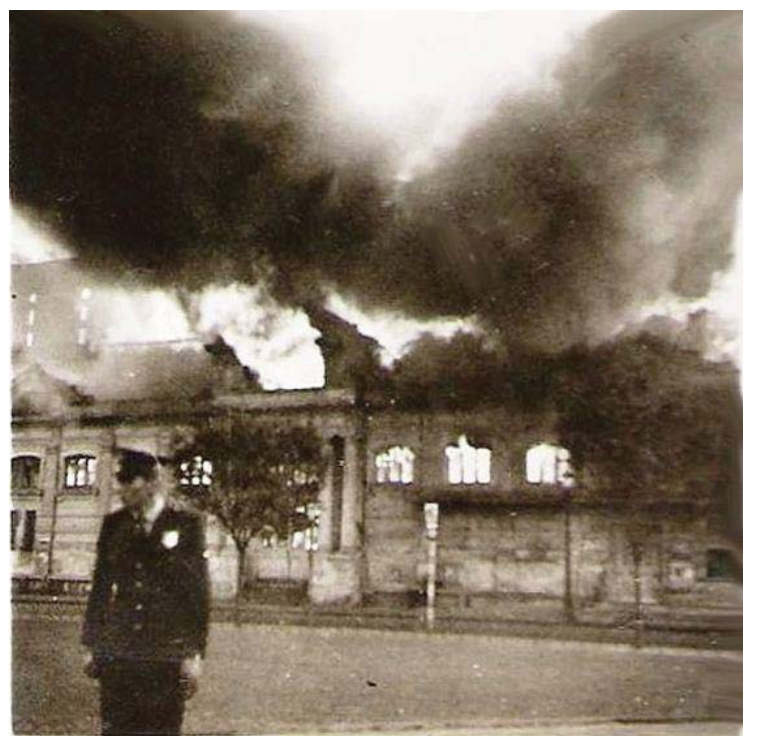

Figura 223: O incêndio do Teatro Colombo. Fonte: https://br.pinterest.com/pin/548805904570138227/

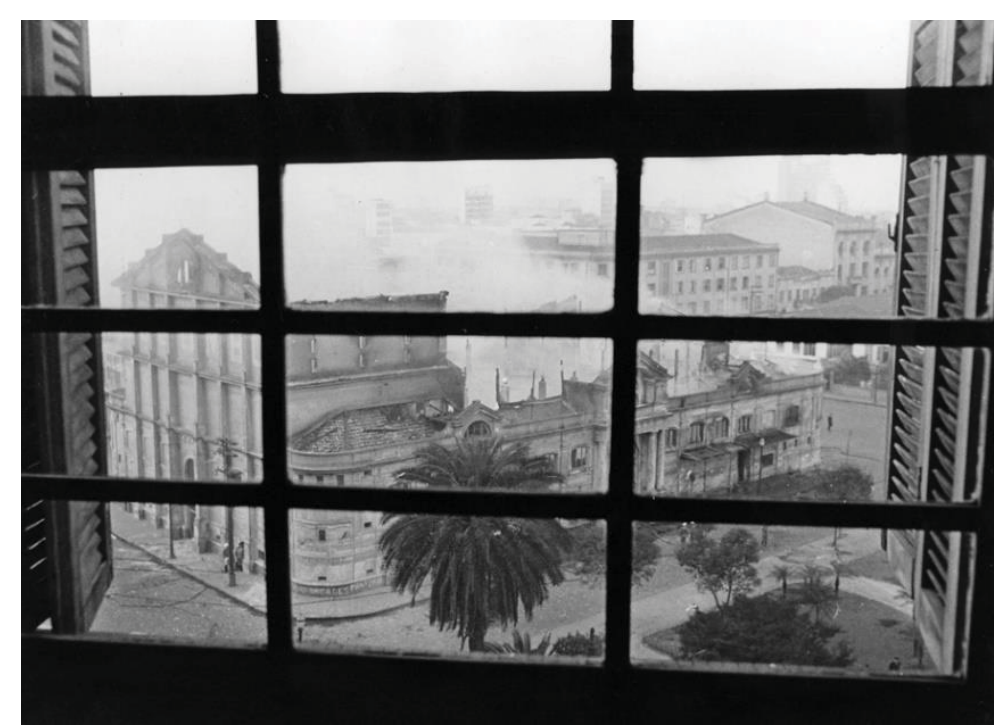

Figura 224: O final do incêndio do Teatro Colombo, com o que restou de suas paredes. Fonte: Jornal $O$ Estado de S. Paulo, edição de 21 de julho de 1966. Apud, "Inventário dos espaços de sociabilidade cinematográfica da cidade de São Paulo (1895-1929)".

O Teatro Colombo cumpria uma importante função de entretenimento à cidade de São Paulo, exibindo espetáculos de companhias e artistas nacionais e internacionais. Contudo, o público local não o tinha como um exclusivo espaço de lazer. Além do Teatro Colombo, em nossas pesquisas realizadas no Almanak Laemmert, combinada com os pedidos de construção e reforma da Série Obras Particulares, nos deparamos com um expressivo número de cinemas espalhados por diferentes ruas do Brás. 


\begin{tabular}{|c|c|c|c|}
\hline \multicolumn{4}{|c|}{ Pedidos de licença para construção ou reforma de cinemas no Brás (1910-1915) } \\
\hline $\begin{array}{l}\text { PEDIDO DE } \\
\text { LICENÇA }\end{array}$ & ENDEREÇO & PROPRIETÁRIO & REFERÊNCIA \\
\hline $\begin{array}{l}\text { Reabertura do } \\
\text { Cinema Celso Garcia }\end{array}$ & $\begin{array}{l}\text { Avenida Celso } \\
\text { Garcia, } 44 \text { e } 46 . \\
\text { No Almanaque } \\
\text { Laemmert consta } \\
\text { como número } 40\end{array}$ & $\begin{array}{l}\text { Arthur de Lima } \\
\text { Pereira }\end{array}$ & $\begin{array}{l}\text { OP1915.001.035 } \\
\text { Almanak Laemmert } \\
1914\end{array}$ \\
\hline $\begin{array}{l}\text { Reconstrução da } \\
\text { fachada de um } \\
\text { cinema - Antigo } \\
\text { Cinema Belém } \\
\text { transformado no } \\
\text { Theatro Melitta }\end{array}$ & $\begin{array}{l}\text { Avenida Celso } \\
\text { Garcia, } 360\end{array}$ & Antonio Gadotti & OP1914.001.164 \\
\hline $\begin{array}{l}\text { Construção de um } \\
\text { barracão para } \\
\text { cinematógrafo - } \\
\text { Cinema Belém }\end{array}$ & $\begin{array}{l}\text { Avenida Celso } \\
\text { Garcia, } 328 \text { e rua } \\
\text { Belém, } 25\end{array}$ & Martello e Cia? & OP1910.000.628 \\
\hline $\begin{array}{l}\text { Construção de um } \\
\text { barracão para } \\
\text { cinematógrafo }\end{array}$ & $\begin{array}{l}\text { Rua Henrique Dias, } \\
44 \text {, esquina com a } \\
\text { rua Rodrigues dos } \\
\text { Santos }\end{array}$ & Gioielli e Baptista & OP1911.001.759 \\
\hline $\begin{array}{l}\text { Projeto de um } \\
\text { cinema }\end{array}$ & $\begin{array}{l}\text { Avenida Rangel } \\
\text { Pestana, } 148\end{array}$ & Luciano di Fiori & OP.1911.002.941 \\
\hline $\begin{array}{l}\text { Projeto de um } \\
\text { cinema - } \\
\text { Brás Bijou Cinema }\end{array}$ & $\begin{array}{l}\text { Avenida Rangel } \\
\text { Pestana, 139. No } \\
\text { Almanaque } \\
\text { Laemmert de } 1914 \\
\text { consta como número } \\
141 .\end{array}$ & Luciano di Fiori & $\begin{array}{l}\text { OP.1912.003.600 } \\
\text { Almanack Laemmert, } \\
\text { 1913,1914,1915 }\end{array}$ \\
\hline $\begin{array}{lr}\text { Projeto } & \text { para } \\
\text { construção de um } \\
\text { cinema com palco } \\
\text { para orquestra }\end{array}$ & $\begin{array}{l}\text { Rua São Caetano, } \\
226\end{array}$ & Henrique Romeu & OP.1913.004.598 \\
\hline $\begin{array}{l}\text { Projeto de um } \\
\text { anfiteatro - } \\
\text { Ideal Cinema (1914) }\end{array}$ & $\begin{array}{l}\text { Rua do Gasômetro, } \\
\text { 47. No Almanaque } \\
\text { Laemmert consta } \\
\text { como números } 35 \text { e } \\
37\end{array}$ & $\begin{array}{l}\text { Fernando e Luiz } \\
\text { Thadeu / Projeto de } \\
\text { Fernando Simões } \\
\text { Prop: Companhia } \\
\text { Cinematográfica } \\
\text { Brasileira (1913) }\end{array}$ & $\begin{array}{l}\text { OP1911.001.585 } \\
\text { Almanak } \quad \text { Laemmert } \\
\text { de } 1913\end{array}$ \\
\hline $\begin{array}{l}\text { Cinema } \\
\text { Oriente }\end{array}$ & Rua Oriente, 41 & & $1913,1914,1915$ \\
\hline $\begin{array}{ll}\text { Eros Theatro } & - \\
\text { Cinematógrafo } & \mathrm{e} \\
\text { Variedades } & \end{array}$ & Rua Piratininga, 95 & Ferdinando Taddeo & 1913,1914 \\
\hline Cinema Piratininga & $\begin{array}{l}\text { Rua Piratininga, } \\
118\end{array}$ & Francisco Taddeo & 1913,1914 \\
\hline Central Cinema & $\begin{array}{l}\text { Avenida Rangel } \\
\text { Pestana, } 122\end{array}$ & $\begin{array}{l}\text { Companhia } \\
\text { Cinematográfica } \\
\text { Brasileira }\end{array}$ & 1914 \\
\hline
\end{tabular}

Tabela 22: Pedidos de licença para construção ou reforma de cinemas no Brás (1910-1915), elaborada pelo autor com base no Almanak Laemmert, disponível na Hemeroteca Digital Brasileira, e na Série Obras Particulares do Arquivo Histórico Municipal. 
Os anúncios do Almanak Laemmert nos revelaram estabelecimentos tidos como "fotografias e aparelhos para cinematógrafos", que à primeira vista podem ser simples extensões dos cinemas anteriormente apresentados. Mas se analisarmos seus respectivos endereços, e cotejarmos com os proprietários, verificaremos que se tratam de lugares diferentes, apesar da relativa proximidade.

\begin{tabular}{|l|l|l|l|}
\hline \multicolumn{4}{|c|}{ Fotografias e aparelhos para cinematógrafos do Brás (1908-1914) } \\
\hline ESTABELECIMENTO & ENDEREÇO & PROPRIETÁRIO & REFERÊNCIA \\
\hline $\begin{array}{l}\text { Fotografias e aparelhos } \\
\text { para cinematógrafos }\end{array}$ & $\begin{array}{l}\text { Avenida Celso } \\
\text { Garcia, 145 }\end{array}$ & Secondo Biola & 1910 \\
\hline $\begin{array}{l}\text { Fotografias e aparelhos } \\
\text { para cinematógrafos }\end{array}$ & $\begin{array}{l}\text { Avenida Celso } \\
\text { Garcia, 200 }\end{array}$ & Henrique Clareto & 1908 \\
\hline $\begin{array}{l}\text { Fotografias e aparelhos } \\
\text { para cinematógrafos }\end{array}$ & $\begin{array}{l}\text { Avenida Celso } \\
\text { Garcia, 213 }\end{array}$ & $\begin{array}{l}\text { Manoel } \\
\text { Andrade }\end{array}$ & 1908 \\
\hline $\begin{array}{l}\text { Fotografias e aparelhos } \\
\text { para cinematógrafos }\end{array}$ & Rua Oriente, 106 & Rosato Augusto & 1914 \\
\hline $\begin{array}{l}\text { Fotografias e aparelhos } \\
\text { para cinematógrafos }\end{array}$ & $\begin{array}{l}\text { Rua Piratininga, } \\
27\end{array}$ & Celestino Pesca & 1910 \\
\hline $\begin{array}{l}\text { Fotografias e aparelhos } \\
\text { para cinematógrafos }\end{array}$ & $\begin{array}{l}\text { Avenida Rangel } \\
\text { Pestana, 116 }\end{array}$ & Fratelli Meglino & 1908 \\
\hline
\end{tabular}

Tabela 23: Fotografias e aparelhos para cinematógrafos do Brás (1908-1914), organizada pelo autor com base no Almanak Laemmert.

Podemos perceber que estes espaços não apenas forneciam produtos aos cinemas, mas atrelavam ao comércio a fotografia, uma novidade que aos poucos passa a se popularizar entre as populações das cidades ditas "modernas". Da junção destes diferentes documentos, elaboramos o mapa Diversões e Lazer: Cinemas, Teatros e Fotografias, que traz em perspectiva a distribuição destes estabelecimentos pelo bairro do Brás até o ano de 1915. Interessante notar que grande parte destes espaços de sociabilidade encontravam-se em vias de grande circulação, como o eixo das Avenidas Rangel Pestana e Celso Garcia, e em outras onde o bonde passava, como a rua Piratininga e a rua Santa Rosa. 


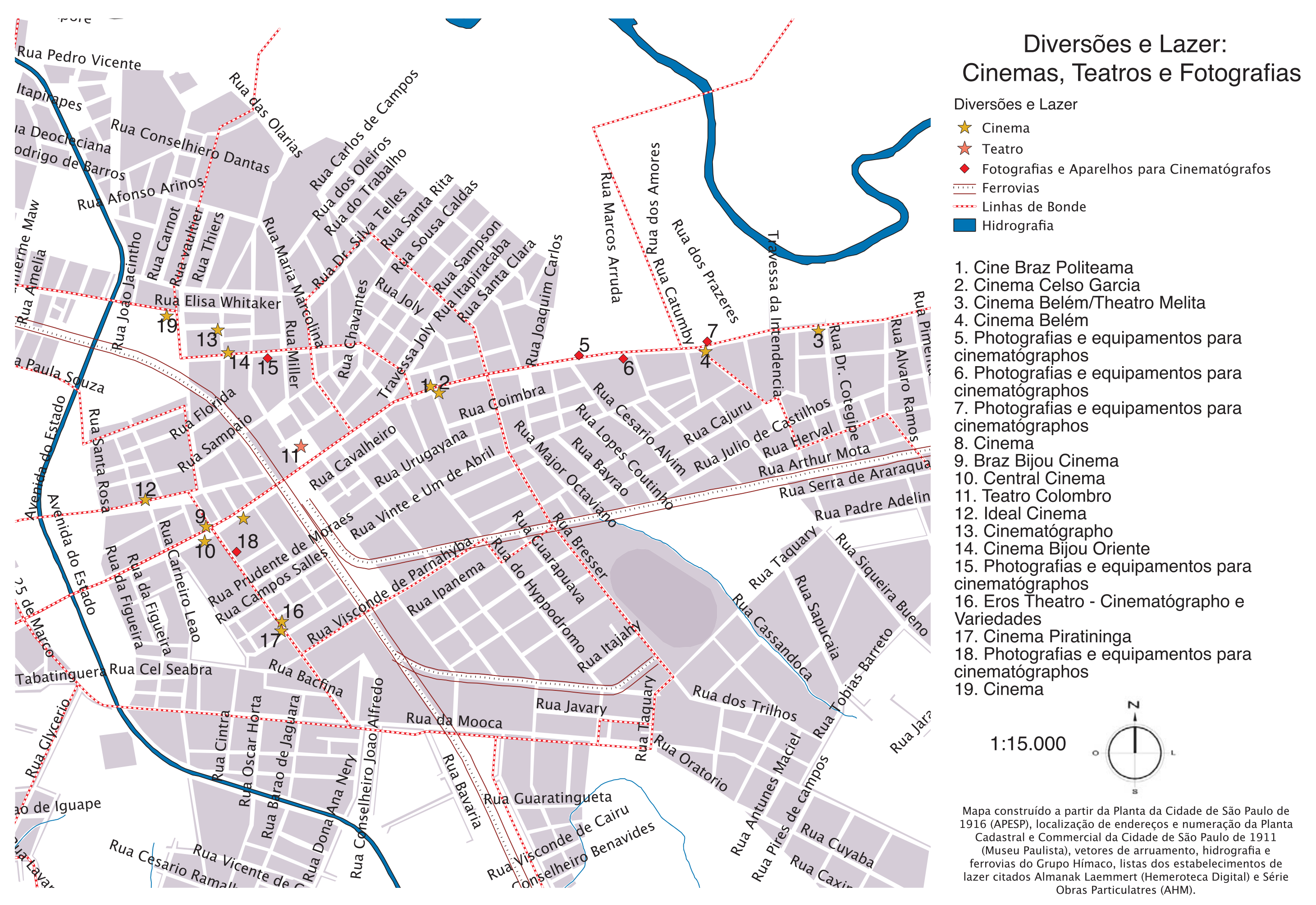




\section{Canclusãa}

Ao descobrirmos que Inácio de Araújo, Maria Domitila, Caetano Pinto, Celso Garcia, dentre muitos outros e outras personagens foram moradores do Brás e hoje conferem nomes à uma imensidade de ruas do bairro, podemos perceber que a atenção aos fios e os rastros do presente nos permite desvendar uma série de questões acerca do passado, sobretudo quando analisadas a partir da História da Urbanização.

Esses personagens estiveram envolvidos e ativamente inseridos no processo de mudanças que a cidade de São Paulo vinha passando desde o último quartel do século XIX, estabelecendo laços de sociabilidade e de interesses diversos, os quais versavam sobre a política e economia, mas também sobre diversões, alimentação e em torno do mundo da habitação só para elencarmos alguns dos temas. Podemos perceber que o processo de urbanização do Brás, converge com uma história de personagens que atuaram sobre o bairro, e mantinham laços que se desdobravam para além da localidade, com regiões adjacentes.

O processo de formação do bairro se explica em grande parte por não ser um bairro formado a partir de um único loteamento, mas por solicitações diversas que encaminham seus pedidos à Intendência Municipal e posterior Prefeitura a fim de que sejam demarcados os alinhamentos dos seus terrenos, desenhando o traçado de muitas ruas do bairro. Este conjunto de mudanças na superfície do Brás, em parte é também compreendida pela própria dinâmica que o centro da cidade passava, com seu reordenamento urbano, a construção de novas edificações, instalação de equipamentos como linhas de bonde, a linha férrea, a chegada da luz elétrica, servindo também como espaço para armazenamento de muitos destes equipamentos e da instalação de diversos grupos nacionais e imigrantes que se instalavam na cidade em busca de melhores condições de vida.

Equipamentos como o Gasômetro, a Hospedaria dos Imigrantes e o Palácio das Indústrias marcaram a paisagem juntamente com fábricas de grande porte, como as das Indústrias Reunidas Francisco Matarazzo, a Alpargatas e as fábricas ligadas a Armando Álvares Penteado, contudo, não seriam o maior número de construções tidas pelo Brás, um bairro na qual se espraiaram diversas residências que variavam do perfil mínimo, a 
palacetes, de casas em série à vilas operárias. Pudemos trazer em pauta o bairro oficial, sem nos determos em tipologias tidas como clandestinas, como os cortiços, que também perfaziam parte da paisagem do bairro, mas que não pode ser entendida como a preponderante.

Nos primeiros anos do século XX, pode-se constatar que o Brás não era um bairro homogêneo em sua dimensão da tessitura urbana, mas que congregava uma série de tipologias construtivas, essencialmente no que toca às formas de morar. Predominaram em determinadas ruas as casas com perfil mínimo de três cômodos voltadas para operários, pequenos vendedores, trabalhadores, técnicos, dentre outros. Percebemos que conforme o número e tamanho de cômodos aumentava, maior o poder aquisitivo da população que podia adquirir. Desta forma, pudemos inferir que no Brás, os setores médios tiveram uma grande participação, em casas que versavam não apenas pelo perfil mínimo estabelecido por lei, mas com casas que continham dois quartos, uma varanda e cozinha, por exemplo.

Com o material processado das Obras Particulares pudemos entrever uma série de vilas construídas não por empresários fabris, como por muito tempo pontuou a historiografia, mas por pessoas ligadas diretamente com o mercado imobiliário rentista, os quais alugavam e vendiam estas casas que continham pátio e entrada comum aos seus habitantes. Da mesma forma, é de se destacar a própria composição das vilas, em que na frente da rua ficavam as maiores casas, quando não atreladas à algum tipo de comércio, e nos fundos a vila propriamente, com casas um pouco menores.

Essencialmente o Brás não fora um bairro horizontal também, pois o número de sobrados foi muito grande em determinadas vias para além da avenida Rangel Pestana, principalmente naquelas em que o bonde passava, permitindo que seus usuários vislumbrassem o bairro que crescia juntamente da cidade. Da mesma forma, casas com porões altos "imitavam" os sobrados, simbolizando uma questão de status daqueles que lá moravam, visto que ao menos na aparência não seriam simples casas.

Tampouco podemos perceber que o bairro fora exclusivamente residencial, visto a infinidade de comércios que se destacavam em torno das ruas Maria Marcolina, Bresser, do Gasômetro e do eixo formado pelas avenidas Rangel Pestana e Celso Garcia. São armazéns de secos e molhados, próximos de açougues, quitandas e padarias, sendo que se os usuários e moradores do bairro andassem um pouco mais encontrariam relojoarias, 
lojas para compra de materiais escolares ou artigos para reforma e construção. Um bairro que formou um comércio local e atendia àqueles que lá estavam, bem como outros que vinham de diferentes bairros da cidade.

Este deslocamento da cidade também só pode ser explicado pela presença das linhas de bonde, que apesar de serem uma constante luta dos moradores e do vereador Celso Garcia a fim de que se expandisse suas linhas e os horários de atendimento, o transporte dava a tônica para a existência de muitos dos comércios que se estabeleciam em suas proximidades, permitindo que aquele que estivesse de passagem pelo bairro, pudesse usufruir dos serviços ali existentes.

Os bondes explicam a própria dinâmica da cidade em princípios do século XX, ao distribuírem a população que desejava deslocar-se para outros pontos, mas conferiam também uma escala da produção residencial, onde nas ruas em que passava ou em suas proximidades, maiores eram as residências, como o caso da rua João Boemer paralela à rua Bresser, a qual contava com bondes, e ambas continham um elevado número de residências voltadas aos setores médios.

Os cinemas foram os grandes divertimentos para o bairro, distribuídos essencialmente em ruas “acima” do eixo das avenidas Rangel Pestana e Celso Garcia, mas também nestas vias, mas não foram os únicos estabelecimentos que garantiam a diversão para os moradores do Brás, pois o Teatro Colombo significou ser um estabelecimento que rompia as fronteiras do bairro, trazendo pessoas de diferentes outros pontos da cidade, com suas atrações de músicos, cantores e artistas internacionais.

A localização de muitos desses comércios também não era fortuita, pois muito se explica por estarem nas cercanias de outros estabelecimentos, como no caso de botequins e bilhares estarem muito próximos, quando não nas mesmas ruas e de frente aos complexos fabris, servindo aos operários e demais funcionários que ali trabalhavam. $\mathrm{O}$ mesmo com relação aos armazéns de secos e molhados, distribuídos entre as ruas que concentravam elevado número de residências, e às lojas de materiais escolares, próximas das diversas escolas, como as fundadas pela comunidade ítalo-brasileira.

Sobre as escolas é de se destacar que elas demonstram ser um exemplo de uma comunidade de descendentes ou de próprios imigrantes que se estabelecem na cidade e ali congregam o saber de sua origem, como a língua e costumes, servindo possivelmente como espaço de reuniões. Ademais, o bairro não se mostrou como exclusivamente 
italiano, mas contava com uma comunidade expressiva de portugueses, espanhóis, sírios, turcos, alemães, belgas, franceses e até hermanos argentinos. O que mais nos chama a atenção, fora o fato do número de óbitos daqueles que moravam no Brás não ser de nenhum grupo imigrante, mas de brasileiros, muitos deles oriundos de outras cidades e estados do país, nos auxiliando a compreender os deslocamentos de tais grupos que se dão conjuntamente à chegada de outros grupos nacionais na cidade, entre finais do século XIX e começo do XX.

Apesar de conter toda esta dinâmica, o Brás enfrentava uma série de problemas como ruas ainda serem macadamizadas, enquanto outras já contavam com paralelepípedos; o fato das inundações ainda serem correntes; além da exploração a que muitos estavam submetidos nas fábricas e em outros estabelecimentos, o que explica em parte o elevado número de greves e manifestações que surgem no bairro ainda em princípios do século XX.

O bairro do Brás congregava assim a dualidade de ser um bairro central, pois contava com serviços de diversas naturezas, mas também um espaço de subúrbio, pois a população ali residente não necessariamente trabalhava nas suas redondezas, mas distribuía-se para outras regiões da cidade. Além do mais, a tônica da distribuição dos impostos entre a cidade parece-nos ter sido muito desigual. Os relatórios de prefeitos e as falas dos vereadores demonstraram que a região, apesar de ser a que mais contribuía com impostos, era a que menos recebia incentivos de retorno.

Sobre os memorialistas não pretendíamos excluir as suas falas, mas incorporá-las e entendê-las no momento de sua produção, feita a partir da primeira metade do século XX, procurando tecer relações com o próprio processo de urbanização do bairro e da cidade nesta época. Eles confeririam uma visão do bairro que nem sempre fora possível corroborar, como um espaço não aprazível, sujo, e que antes continha apenas chácaras, em detrimento da existência de comércios e serviços que também puderam ser mapeados no final do oitocentos. Ernani Silva Bruno, que apesar de ter construído uma memorável obra sobre a cidade de São Paulo nos festejos do IV Centenário, merece uma crítica mais aprofundada em torno de sua produção, a fim de localizarmos seus laços com a elite intelectual do começo do século XX, bem como seu discurso continuar a ser reiterado como oficial da cidade que se desenvolveu a partir do último quartel do século XIX. 
Muitas das questões propostas por nós, infelizmente não puderam ser respondidas, haja vista o corpus documental por nós trabalhado não permitir que pudéssemos aferir conclusões em torno de temas que estiveram envoltos sobre a urbanização do Brás. Ainda assim, colocamos como indagações futuras uma melhor compreensão da existência e distribuição dos cortiços sobre o bairro; das relações entre os setores médios com os setores mais altos; ou mesmo da participação dos setores mais baixos no processo de produção do Brás, que não se encerra naqueles que privilegiamos para este estudo.

Ademais, muito daquilo que fora construído na região do Brás, Belenzinho, Móoca, Pari, Tatuapé e Penha, no começo do século XX ainda persiste na materialidade, servindo de exemplo para uma das passagens mais emblemáticas de Carlo Ginzburg em seu clássico Mitos, emblemas, sinais, o qual nos orienta a ficarmos “centrado[s] sobre os resíduos, sobre os dados marginais, considerados reveladores" 355 . Estes dados marginais são casas mínimas hoje habitadas por imigrantes bolivianos e haitianos; são os sobrados que continuam a ter uma função mista, mas que se especializaram em determinados gêneros de consumo; são os remanescentes dos edifícios fabris, que aos poucos dão lugar à grandes depósitos, e que aos poucos são destruídos. Estes espaços não desapareceram em sua totalidade, permanecem sob a paisagem do bairro, e contam uma história de contradições do processo de urbanização de uma cidade como São Paulo. A arquitetura que ali persiste só poderá ser resguardada por um meio: o conhecimento histórico e educacional da importância destes espaços para a sociedade paulistana.

${ }^{355}$ GINZBURG, Carlo. Mitos, emblemas, sinais: morfologia e história. São Paulo: Companhia das Letras, 2014, pág. 149. 


\section{Referências billiagráficas}

AMARAL, Maria Vicentina de Paula do. A dinâmica dos nomes da cidade de São Paulo (1554-1897). São Paulo: Annablume, 1997.

ANDERSON, Benedict. Comunidades imaginadas: reflexões sobre a origem e a difusão do nacionalismo. São Paulo: Companhia das Letras, 2008.

ANDRADE, Margarida Maria de. Bairros além Tamanduateí: o imigrante e a fábrica no Brás, Móoca e Belenzinho. Tese (Doutorado em Geografia). Faculdade de Filosofia, Letras e Ciências Humanas. São Paulo: Universidade de São Paulo, 1991.

ANDREW, George Reid. Negros e brancos em São Paulo (1888-1988). São Paulo: Edusc, 1998.

ATIQUE, Fernando. Memória moderna: a trajetória do Edifício Esther. São Paulo: RiMa / Fapesp, 2004.

. Arquitetando a "Boa-Vizinhança": a sociedade urbana do Brasil e a recepção do mundo norte-americano, 1876-1945. Doutorado em Arquitetura e Urbanismo. São Paulo: FAUUSP, 2007.

AZEVEDO, Aroldo de. A cidade de São Paulo: Estudos de geografia urbana. V. 3. São Paulo: Companhia Editora Nacional, 1958.

AZEVEDO, Elciene. Orfeu de carapinha: a trajetória de Luís Gama na imperial cidade de São Paulo. Campinas: Editora da Unicamp, 1999.

BARBUY, Heloisa. A Cidade-exposição: Comércio e Cosmopolitismo em São Paulo, 1860-1914. São Paulo: Editora da Universidade de São Paulo, 2006.

BANDEIRA JUNIOR, Antonio Francisco. A indústria no Estado de São Paulo em 1901. São Paulo: Typ. do Diario Official, 1901.

BAO, Carlos Eduardo. "A invenção da italianidade no Brasil: contribuição para um olhar descontínuo". Anais do XXVIII Simpósio Nacional de História. Florianópolis, 2015.

BARROS, Liliane Schrank Lehmann de. MOIZO, Rosana Pires Azanha. "Formação administrativa da cidade de São Paulo, 1554-1954”. In: Revista do Arquivo Municipal, V. 199. São Paulo: Departamento do Patrimônio Histórico, 1991. 
BASTOS, Maria Helena Camara. "A educação do caráter nacional: leituras de formação". Revista Educação e Filosofia. V. 12; n. 23; 1998.

BIANCHI, Alvaro. MUSSI, Bianca. "Il príncipe e seus contratempos: De Sancts, Croce e Gramsci”, In: Revista Brasileira de Ciência Política, nº12. Brasília, set. - dez. 2013. BLAJ, Ilana. A trama das tensões: o processo de mercantilização de São Paulo Colonial (1681-1721). São Paulo: Humanitas / FAPESP, 2002.

BLAY, Eva Alterman. Eu não tenho onde morar: vilas operárias na cidade de São Paulo. São Paulo: Nobel, 1985.

BONDUKI, Nabil. Pioneiros da habitação social. v.1 São Paulo: Editora Unesp, 2014. BORIN, Monique Felix. A Barra Funda e o fazer da cidade: experiências da urbanização em São Paulo (1890-1920). Dissertação (Mestrado em História), Faculdade de Filosofia, Letras e Ciências Humanas, Universidade de São Paulo, São Paulo, 2014.

BORREGO, Maria Aparecida de Menezes. A teia mercantil: negócios e poderes em São Paulo Colonial, 1711-1765. São Paulo: Alameda, 2010.

BRESCIANI, Maria Stela. “As sete portas da cidade". Revista Espaço e Debates, no 34, 1991. - FAU.

Historiografia brasileira em perspectiva. In: FREITAS, Marcos Cezar de (Org.). Historiografia brasileira em perspectiva. Rio de Janeiro: Contexto, 1998.

. "História e Cidade". In: OLIVEIRA, Lúcia Lippi (org.). Cidade: História e desafios. Rio de Janeiro: Editora Fundação Getúlio Vargas, 2002.

BRITO, Mônica Silveira. Modernização e tradição: urbanização propriedade imobiliária e crédito hipotecário em São Paulo, na segunda metade do século XIX. São Paulo: FFLCH (Tese de Doutorado em Geografia Humana), 2006

A participação da iniciativa privada na produção do espaço urbano: São Paulo, 1890-1911. São Paulo: FAUUSP, 2008.

BRUNO, Ernani da Silva. História e Tradições da Cidade de São Paulo. São Paulo: Comissão do IV Centenário da Cidade de São Paulo. Livraria José Olympio Editora, 1954.

BUENO, Beatriz Piccolotto Siqueira. Aspectos do mercado imobiliário em perspectiva histórica. São Paulo (1809-1950). 2a edição. São Paulo: Edusp, 2016. 
. Aspectos do Mercado Imobiliário em Perspectiva Histórica. São

Paulo (1809-1950). São Paulo: FAUUSP, 2008.

. "A cidade como negócio: mercado imobiliário em São Paulo no século XIX”. In: FRIDMAN, Fania; ABREU, Mauricio. (Org.). Cidades latinoamericanas: um debate sobre a formação de núcleos urbanos. Rio de Janeiro: Casa da Palavra, 2010.

. São Paulo: um novo olhar sobre a história: a evolução do comércio de varejo e as transformações da vida urbana. São Paulo: Via das Artes, 2012. . In: João Marcos Lopes e José Lira (orgs.) Memória, Trabalho e Arquitetura. São Paulo: Editora da Universidade de São Paulo, 2013.

CALABI, Donatella. História do urbanismo europeu: questões, instrumentos, casos exemplares. São Paulo: Perspectiva, 2015.

CAMPOS NETO, Cândido Malta. Os rumos da cidade. Urbanismo e modernização em São Paulo. São Paulo: Editora SENAC, 2002.

CAMPOS, Cristina de. São Paulo pela lente da higiene. As propostas de Geraldo Horácio de Paula Souza para a cidade (1925-1945). São Paulo: Fapesp / Rima, 2002.

. Ferrovias e saneamento em São Paulo: o engenheiro Antonio Francisco de Paula Souza e a construção da rede de infraestrutura territorial e urbana paulista. Tese (doutorado) - FAUUSP, São Paulo, 2007.

- "Biografias profissionais de medicos e engenheiros como fonte para a história da cidade e do urbanismo". In: Urbanistas e urbanismo no Brasil: Entre trajetórias e biografias. Organização Rodrigo de Faria, Josianne Cerasoli. São Paulo: Alameda, 2014.

CARONE, Edgar. A evolução industrial de São Paulo (1889-1930). São Paulo: Editora SENAC, 2001.

CORREIA, Telma de Barros. "De Vila operária a cidade-companhia: as aglomerações criadas por empresas no vocabulário especializado e vernacular". Revista Brasileira de Estudos Urbanos e Regionais. № 4 / maio, 2011. 
CARVALHO, Clara Cristina Valentin Anaya de. Os setores médios e a urbanização de São Paulo: Vila Mariana, 1890-1914. Dissertação (Mestrado em História), Escola de Filosofia, Letras e Ciências Humanas, Universidade Federal de São Paulo, Guarulhos, 2016.

CARVALHO, Cristina Leite. Dentistas práticos no Brasil: História de exclusão e resistência na profissionalização da odontologia brasileira. Tese de doutorado em Saúde Pública. Rio de Janeiro: Escola Nacional de Saúde Pública Oswaldo Cruz, 2003.

CHALHOUB, Sidney. Cidade febril: cortiços e epidemias na Corte imperial. São Paulo: Companhia das Letras, 1996.

CORDEIRO, Simone Lucena (org.). Os cortiços de Santa Ifigênia: sanitarismo e urbanização. São Paulo: Imprensa Oficial, 2010.

COSTA, Luiz Augusto Maia. O moderno planejamento territorial e urbano em São Paulo: a presença norte-americana no debate da formação do pensamento urbanístico paulista 1886-1919. São Paulo: FAUUSP (Tese de Doutorado em Arquitetura e Urbanismo), 2005.

DAECTO, Marisa Midori. Comércio e vida urbana na cidade de São Paulo (18891930). São Paulo: Editora SENAC, 2002.

DIAS, Maria Odila Leite da Silva. Quotidiano e poder em São Paulo no século XIX. São Paulo: Brasiliense, 1995.

Divisão administrativa e divisas municipaes do Estado de S. Paulo. São Paulo: Typ. Mont' Alverne, 1908.

FABRIS, Annateresa (org). Ecletismo na Arquitetura Brasileira. São Paulo: Nobel, 1987.

FARIA, Rodrigo de. CERASOLLI, Josianne (orgs.). Urbanistas e urbanismo no Brasil: entre trajetórias e biografias. São Paulo: Alameda, 2014.

FERLA, Luis. Feios, sujos e malvados sob medida: a utopia médica do biodeterminismo, São Paulo (1920-1945). São Paulo: Alameda, 2009.

FERREIRA, Antonio Celso. A epopeia bandeirante: letrados, instituições, invenção histórica (1870-1940). São Paulo: Editora Unesp, 2002. 
FERRETI, Danilo José Zioni. A construção da paulistanidade. Identidade, política e historiografia em São Paulo (1856-1930). Tese (Doutorado em História). São Paulo: Universidade de São Paulo, 2010.

FISCHER, Sylvia. Os arquitetos da Poli: ensino e profissão em São Paulo. São Paulo: Edusp, 2005.

FONTES, Paulo. Um Nordeste em São Paulo: Trabalhadores migrantes em São Miguel Paulista (1945-66). Rio de Janeiro: Editora FGV, 2008.

FRANCO, Herta. Modernização e melhoramentos urbanos em São Paulo: a gestão do presidente de província João Theodoro (1872-1875). São Paulo: FAUUSP (Tese de Doutorado em Arquitetura e Urbanismo), 2002.

GENNARI, Luciana Alem. As casas em serie do Brás e da Mooca: um aspecto da constituição da cidade de São Paulo. Dissertação (Mestrado), Faculdade de Arquitetura e Urbanismo da Universidade de São Paulo. São Paulo: FAUUSP, 2005.

O lugar da casa na cidade: Rio de Janeiro na Belle Époque. Tese (Doutorado em Arquitetura e Urbanismo). Rio de Janeiro: Universidade Federal do Rio de Janeiro, 2013.

GITAHY, Maria Lúcia Cayra. (org.). Desenhando a cidade do século XX. São Paulo: Rima, 2005.

GLEZER, Raquel. Chão de terra e outros ensaios sobre São Paulo. São Paulo: Alameda, 2007.

GREGORY, Ian e ELL, Paul. Historical GIS. Cambridge: Cambridge University Press, 2007.

História Geral da Civilização Brasileira. Direção de Bóris Fausto, Introdução geral de Sérgio Buarque de Holanda. T.3: O Brasil republicano. Rio de Janeiro: Bertrand Brasil, 2006.

HOBSBAWM, Eric. A era dos impérios, 1875-1914. São Paulo: Paz e Terra, 2010. . Nações e nacionalismos desde 1780: programa, mito e realidade.

São Paulo: Paz e Terra, 1990. 
HOMEM, Maria Cecília Naclério. Palacete paulistano: o processo civilizador e a moradia da elite do café (1867-1914-18). Tese (doutorado em Arquitetura e Urbanismo). Faculdade de Arquitetura e Urbanismo da Universidade de São Paulo. São Paulo, 1992. KOB, Edgar. "Como a cerveja se tornou bebida brasileira". In: Revista do Instituto Histórico e Geográfico Brasileiro. Ano 161, n. 409, out./dez. 2000

KÜHL, Beatriz Mugayar. Arquitetura do ferro e arquitetura ferroviária em São Paulo: reflexões sobre sua preservação. São Paulo: Ateliê Editorial, 1998.

KOWARICK, Lúcio \& ANT, Clara. "Cem anos de promiscuidade: o cortiço na cidade de São Paulo”. In: KOWARICK, Lúcio. As lutas sociais e cidade: São Paulo passado e presente. Rio de Janeiro: Paz e Terra, 1988.

LE GOFF, Jacques. História e memória. Campinas: Editora da Unicamp, 2013.

Leis e resoluções da Câmara Municipal da capital do Estado de S. Paulo de 29 de setembro de 1892 a 30 de dezembro de 1893. São Paulo: Typ. Official, s/d

LEMOS, Carlos. Cozinhas, etc. São Paulo: Perspectiva, 1978.

Alvenaria burguesa. Breve história da arquitetura residencial de tijolos em São Paulo a partir do ciclo econômico liderado pelo café. 2. ed. ver. Ampl. São Paulo, Nobel, 1989.

. História da casa brasileira. São Paulo: Contexto, 1996.

. "Os primeiros cortiços paulistanos". In: SAMPAIO, Maria Ruth

Amaral de. Habitação e cidade. São Paulo: Laboratório de Programação Gráfica da FAUUSP, 1998.

. A República ensina a morar (melhor). São Paulo: Hucitec, 1999.

LEPETIT, Bernard. Por uma nova história urbana. São Paulo: Edusp, 2016.

LÓDOLA, Soraya. "O tracoma em viagem pelos trilhos da economia: uma análise sobre a primeira comissão de tratamento e profilaxia do tracoma em São Paulo no início do século XX”, In: Anais Eletrônicos do $\mathbf{1 5}^{\circ}$ Seminário Nacional de História da Ciência e da Tecnologia. Florianópolis: Universidade Federal de Santa Catarina, nov. 2016. 
LODY, Jorge. Arquitetura e cidade: obras particulares em São Paulo, 1906-1915. Tese (Arquitetura e Urbanismo), Faculdade de Arquitetura e Urbanismo da Universidade de São Paulo, São Paulo, 2015.

LOVE, Joseph. A locomotiva: São Paulo na federação brasileira - 1889/1937. Rio de Janeiro: Paz e Terra, 1982.

LUNA, E. J. A epidemiologia do tracoma no Estado de São Paulo. Dissertação (Mestrado em Ciências Médicas) - Universidade Estadual de Campinas - Unicamp, Campinas, 1993.

LUNÉ, Antônio José Batista de. Almanak da Província de São Paulo para 1873. São Paulo: Imprensa Oficial do Estado; Arquivo do Estado, 1985.

LUZ, Nicia Vilela. A luta pela industrialização do Brasil (1808-1930). São Paulo: DIFEL, 1960.

MARINS, Paulo César Garcez. "Habitação e vizinhança: limites da privacidade no surgimento das metrópoles brasileiras”. In: História da vida privada no Brasil. V. 3. São Paulo: Companhia das Letras, 1999.

MARSON, Michel Deliberali. Origens e evolução da indústria de máquinas em São Paulo, 1870-1960. Tese (Doutorado em Economia). Faculdade de Economia, Administração e Contabilidade. São Paulo: Universidade de São Paulo, 2012.

MARQUES, Abílio A. S. Indicador de São Paulo administrativo, judicial, industrial, profissional e comercial para o ano de 1878. São Paulo: Imprensa Oficial do Estado; Arquivo do Estado, 1985.

MARTINS, Francisco Marcos. "Gramsci, filosofia e educação”. Práxis Educativa, Ponta Grossa, v. 8, n. 1, p. 13-40, jan./jun. 2013.

MELOSI, Martin V. The Sanitary City: Urban Infrastruture in America from Colonial Times to the Present. Baltimore/London: The Johns Hopkins University Press, 2000.

MORSE, Richard. De comunidade a metrópole: a biografia de São Paulo. São Paulo: Comissão dos Festejos do IV Centenário da Cidade de São Paulo, 1954.

MONTELEONE, Joana. Sabores urbanos - alimentação, sociabilidade e consumo: São Paulo, 1828-1910. São Paulo: Alameda, 2015. 
MOURA, Carlos Eugênio Marcondes de (Org.). Vida cotidiana em São Paulo no século XIX: memórias, depoimentos, evocações. São Paulo: Editora UNESP, 1999.

NASCIMENTO, Flávia Brito do. Entre a estética e o hábito: o Departamento de Habitação Popular (Rio de Janeiro, 1946-1960). Rio de Janeiro: Secretaria Municipal das Culturas, Coordenadoria de Documentação e Informação Cultural, Gerência de Informação, 2008.

NOBLE, David F. America by Design. Science, Tecnology, and the Rise of Corporate Capitalism. Oxford: Oxford University Press, 1979.

OLIVEIRA, Maria Luiza Ferreira de. Entre a casa e o Armazém: relações sociais e experiência da urbanização, 1850-1900. São Paulo: Alameda, 2005.

. "Em casas térreas com alcovas. Formas de morar entre os setores médios em São Paulo, 1875 e 1900”. Anais do Museu Paulista, São Paulo. N. Sér. v. 8/9. p. 55-76 (2000-2001). Editado em 2003

. "O registro dos limites da cidade: imagens da Várzea do Carmo no século XIX”. Anais do Museu Paulista, N. Sér. v. 6/7, (1998-1999), editado em 2003. PARETO JÚNIOR, Lindener. O cotidiano em construção: os "práticos licenciados" em São Paulo. Dissertação (Mestrado em Arquitetura e Urbanismo), São Paulo: Faculdade de Arquitetura e Urbanismo da Universidade de São Paulo, 2011.

Joaquim Cavalheiro: um "arquiteto-construtor" no Brás e na Mooca. São Paulo: Cultura Acadêmica, 2015.

. Pândegos, rábulas, gamelas: Os construtores não-diplomados entre a engenharia e a arquitetura, 1890-1960. Tese (Doutorado em Arquitetura e Urbanismo). São Paulo: Faculdade de Arquitetura e Urbanismo da USP, 2016.

PENTEADO, Jacob. Belenzinho, 1910: retrato de uma época. São Paulo: Carrenho Editorial / Narrativa Um, 2003.

PERROT, Michelle. Os excluídos da história: operários, mulheres e prisioneiros. Rio de Janeiro: Paz e Terra, 2006.

PASSOS, Maria Lúcia Perrone. Desenhando São Paulo: mapas e literatura, 1877- 1954. São Paulo: Senac: Imprensa Oficial, 2009. 
PERROT, Michelle. Os excluídos da história: operários, mulheres e prisioneiros. Rio de Janeiro: Paz e Terra, 2006.

PINTO, Alfredo Moreira Pinto, A cidade de S. Paulo em 1900: Impressões de viagem. Rio de Janeiro: Imprensa Nacional, 1900.

PICCINI. Andrea. Cortiços na cidade: conceito e preconceito na reestruturação do centro urbano de São Paulo. São Paulo: Annablume, 1999.

PIRES, Walter. Configuração territorial, urbanização e patrimônio: Colônia da Glória (1876-1904). Dissertação (Mestrado em Arquitetura e Urbanismo) - Faculdade de Arquitetura e Urbanismo, Universidade de São Paulo, São Paulo, 2003.

. "Arquivo Aguirra. Fonte documental sobre a formação territorial de

São Paulo”. Anais do Museu Paulista. São Paulo. N. Sér. v. 10/11. p. 61-78 (20022003).

RANGER, Terence (org.). A invenção das tradições. Rio de Janeiro: Paz e Terra, 1984.

REALE, Ebe. Brás, Pinheiros, Jardins: três bairros, três mundos. São Paulo: Pioneira; Ed. Da Universidade de São Paulo, 1982.

REIS Filho, Nestor Goulart. São Paulo: Vila, Cidade, Metrópole. São Paulo: Bank Boston, 2004.

Quadro da Arquitetura no Brasil. São Paulo: Perspectiva, 1970.

. "Habitação popular no Brasil 180-1920”. In: Cadernos de Pesquisa do LAP. Nº 02. São Paulo: FAUUSP, set. /out. 1994.

. São Paulo: Vila, Cidade, Metrópole. São Paulo: Bank Boston, 2004.

Dois séculos de projetos no Estado de São Paulo. São Paulo: Imprensa Oficial do Estado, 2010. Vols. 1-3.

REIS, Philippe Arthur dos. "O passado servindo aos anseios do presente: Orville Derby e a historiografia bandeirante". Epígrafe, V. 1, nº $1,2014$.

. "Novos olhares sobre a urbanização e expansão da cidade de São

Paulo: o bairro do Brás entre a passagem do século XIX para o XX”. Anais do XXIII

Encontro Estadual de História. Assis, 2016. 
- (org.) Passeando pelas Ruas: Reflexões sobre o patrimônio paulistano. São Paulo: Passeando pelas Ruas, 2017.

RIBEIRO, M. A. História sem fim: Um inventário da saúde pública, São Paulo, 18801930. Tese (Doutorado em Economia do Instituto de Economia) - Universidade Estadual de Campinas, Campinas, 1991.

RIBEIRO, Suzana Barretto. Italianos do Brás: Imagens \& Memórias (1920- 1930). Dissertação (Mestrado em Multimeios). Instituto de Artes da Unicamp. Campinas: Universidade Estadual de Campinas, 1994.

RIBEIRO, Vanessa Costa. Várzea do Carmo a Parque Dom Pedro II: de atributo natural a artefato. Décadas de 1890 a 1950. Dissertação de Mestrado (História). São Paulo: FFLCH, 2012.

RODRIGUES, Jaime. "Da "chaga oculta" aos dormitórios urbanos: notas sobre higiene e habitação operária na São Paulo de fins do século XIX”. In: CORDEIRO, Simone Lucena (org.). Os cortiços de Santa Ifigênia: sanitarismo e urbanização. São Paulo: Imprensa Oficial, 2010.

ROLNIK, Raquel. A cidade e a lei: legislação, política urbana e territórios na cidade de São Paulo. São Paulo: Studio Nobel: Fapesp, 1997.

RUFINONI, Manoela Rossinetti. Preservação e restauro urbano: intervenções em sítios históricos industriais. São Paulo: Fap-Unifesp: Edusp, 2013.

SAES, Décio. Classe Média e política na Primeira República Brasileira: (18891930). Petrópolis: Vozes, 1975.

SALMONI, Anita. e DEBENEDETTI, Emma. Arquitetura italiana em São Paulo.

São Paulo: Perspectiva, 1981.

SAMPAIO, Maria Ruth (Org.). Habitação e cidade. São Paulo: FAU-USP; FAPESP, 1998.

A promoção privada de habitação econômica e a arquitetura

moderna 1930-1964. São Paulo: Rima/ Fapesp, 2002.

SANTOS, Fábio Alexandre. Domando águas: salubridade e ocupação do espaço na cidade de São Paulo, 1875-1930. São Paulo: Alameda, 2011. 
SCHNECK, Sheila. Formação do bairro do Bexiga em São Paulo: loteadores, proprietários, construtores, tipologias edilícias e usuários (1881-1913). Dissertação (Mestrado em Arquitetura e Urbanismo), Faculdade de Arquitetura e Urbanismo, Universidade de São Paulo, São Paulo, 2010.

SCHWARCZ, Lilia Moritz. O espetáculo das raças: cientistas, instituições e questão racial no Brasil- 1870-1930. São Paulo: Companhia das Letras, 1993.

SCHWARZ, Roberto. "Autobiografia de Luiz Gama". Revista Novos Estudos. CEBRAP. N. 25, out/1989.

SEVCENKO, Nicolau. Orfeu extático na metrópole: São Paulo, sociedade e cultura nos frementes anos 20. São Paulo: Companhia das Letras, 1992.

SILVA, Maria Elisângela da. Práticas de apropriação e produção do espaço em São Paulo: a concessão de terras municipais através das Cartas de Datas (1850-1890). Dissertação (Mestrado em Arquitetura e do Urbanismo). São Paulo: FAUUSP, 2012.

SILVA, Rodrigo da. Sobre taipas e textos: um estudo sobre as narrativas a respeito da cidade de São Paulo (1772 a 1953). São Paulo: Alameda, 2013.

SOUSA, Diógenes. Cidade e cerveja: Companhia Antarctica Paulista e Urbanização em São Paulo. Dissertação (Mestrado em Urbanismo). Pontifícia Universidade Católica de Campinas. Campinas, 2017.

SOUZA, José Inacio de Melo. Inventário dos espaços de sociabilidade cinematográfica da cidade de São Paulo (1895-1929). Disponível em: http://www.arquiamigos.org.br/bases/cine.htm

TELAROLLI JR. R. Poder e Saúde: as epidemias e a formação dos serviços de saúde em São Paulo. São Paulo: Editora da Universidade Paulista, 1996.

TOLEDO, Benedito Lima de. São Paulo: três cidades em um século. São Paulo: Duas cidades, 1983.

Álbum iconográfico da Avenida Paulista. São Paulo: Ex- Libris/João Fortes Engenharia, 1987.

Anhangabaú. São Paulo: FIESP, 1989. 
Paulo. São Paulo, Empresa das Artes, 1996.

TONAKI, Luciana Lepe. A Companhia Nitro Química: indústria e vila operária em São Miguel Paulista. Dissertação (Mestrado), Instituto de Arquitetura e Urbanismo de São Carlos, Universidade de São Paulo, São Carlos, 2013.

TORRES, Maria Celestina Teixeira Mendes. O bairro do Brás. Série História dos bairros de São Paulo. São Paulo: Oficina da Gráfica Municipal, 1969.

TRENTO, Angelo. Do outro lado do Atlântico: um século de imigração italiana no Brasil. São Paulo, SP: Nobel: Istituto Italiano di Cultura di San Paolo: Instituto Cultural ítaloBrasileiro, 1988.

UNZELTE, Celso (org.). A família Bresser na história de São Paulo. São Paulo: Campo Visual, 2003.

VÉRAS, Maura Pardini Bicuro. "Cortiços no Brás: velhas e novas formas de habitação popular na São Paulo industrial”. Análise Social, Vol. XXIX (127), 1994.

VARELLA, Drauzio. Nas ruas do Brás. São Paulo: Companhia das Letras, 2000.

VILLARDAGA, José Carlos. São Paulo no império dos Felipes: conexões na América meridional (1580.1640). São Paulo: Intermeios, 2014.

WOLFF, Silvia Ferreira Santos. Escolas para a República: Os primeiros passos da arquitetura das escolas públicas paulistas. São Paulo: Edusp, 2010.

WOODS, Mary N., From Craft to Profession. The Practice of Architecture in Nineteenth- Century America. Berkeley/Los Angeles/London, University of California Press, 1999.

ZUCCONI, Guido. A cidade do século XIX. São Paulo: Perspectiva, 2009. 


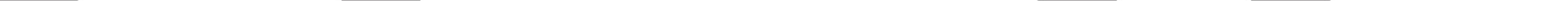




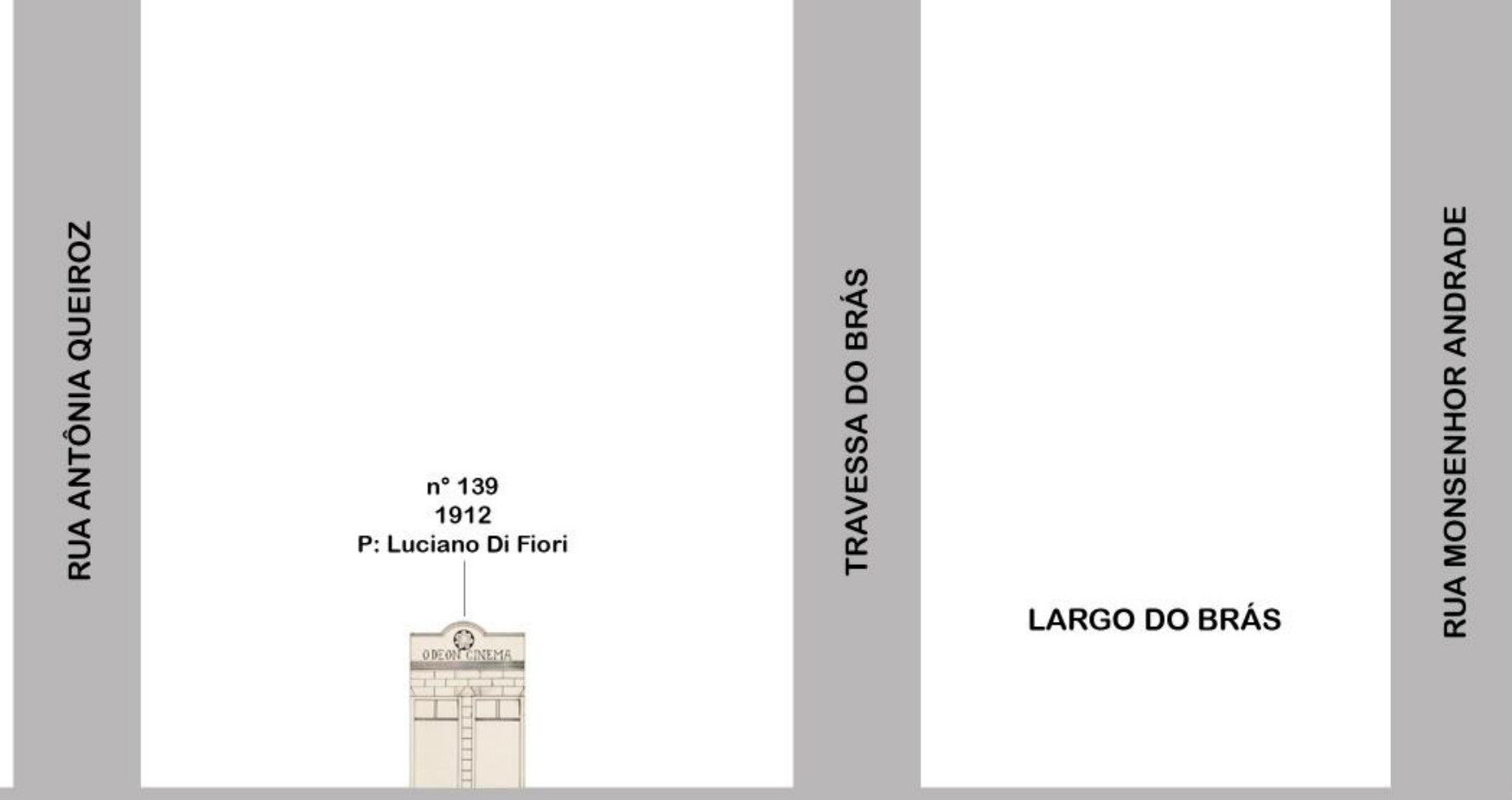

\section{AVENIDA RANGEL PESTANA}

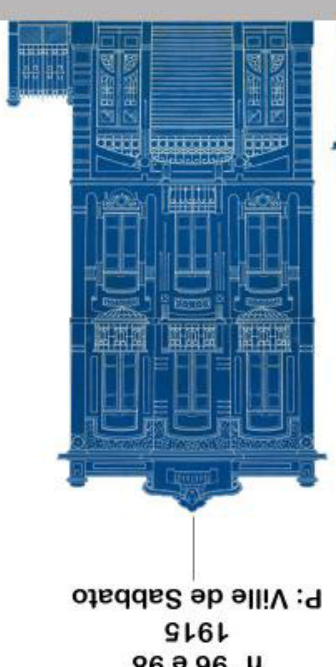

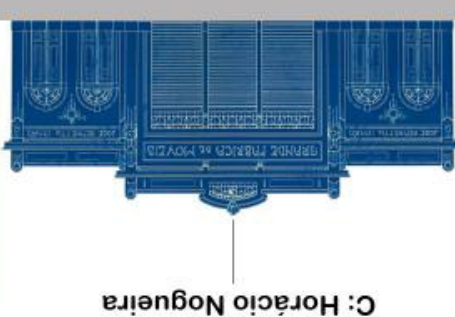

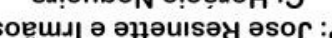

$$
\text { EL6L }
$$

柾

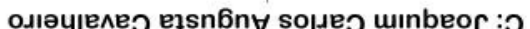
ep!əu| $\forall$ әр ou!uınłes :d

$$
\text { ZL6L }
$$



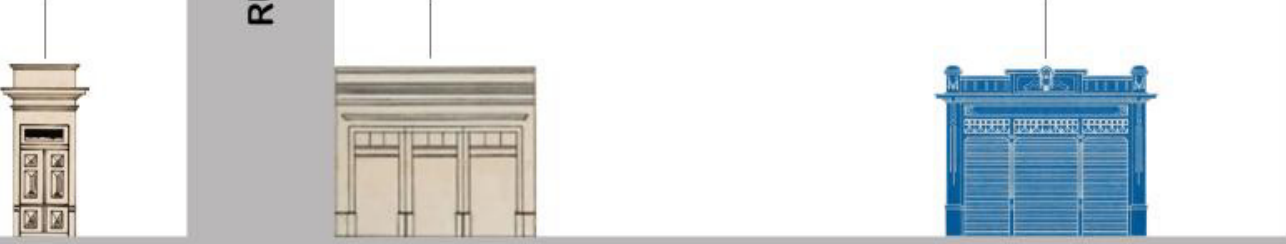

AVENIDA RANGEL PESTANA

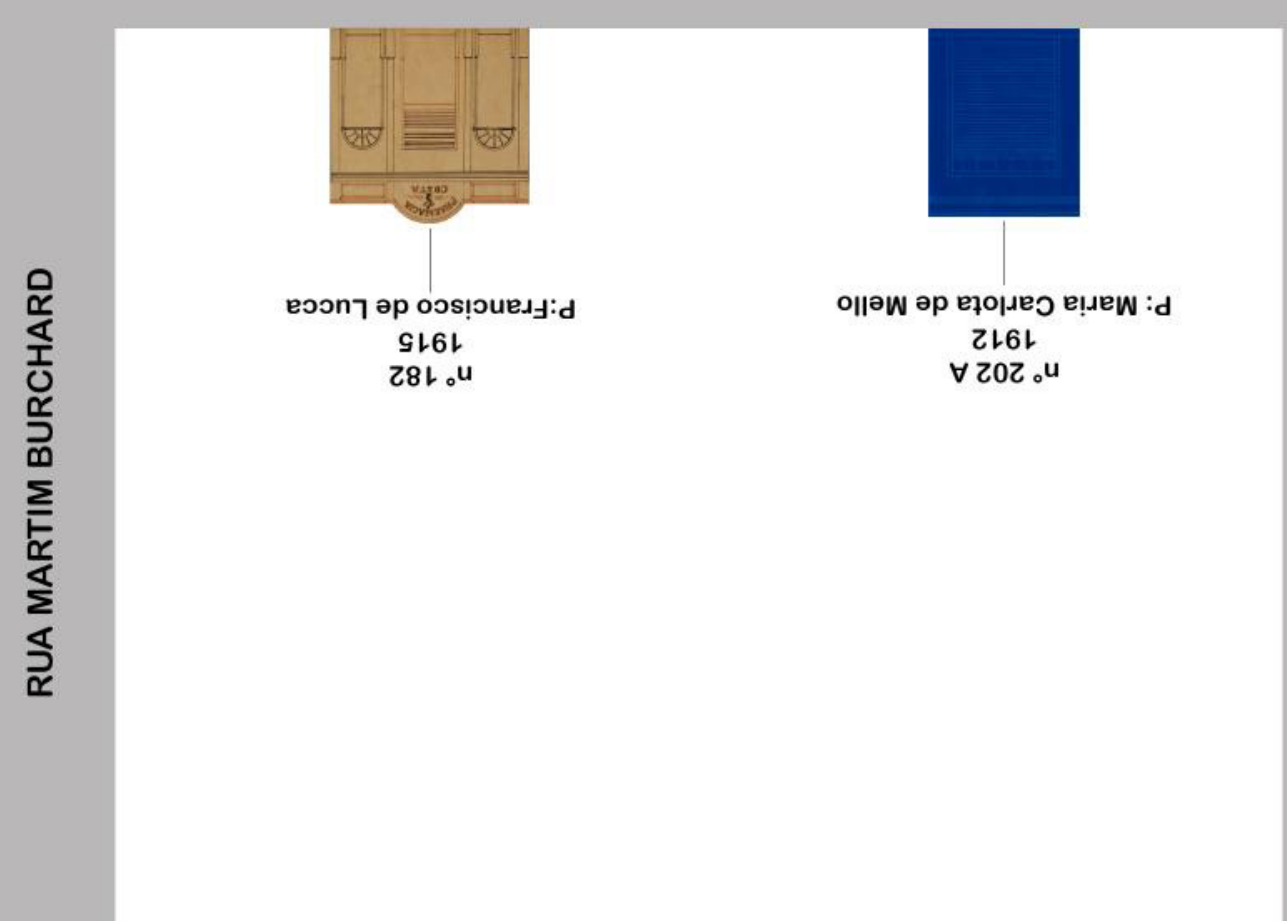

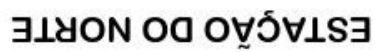




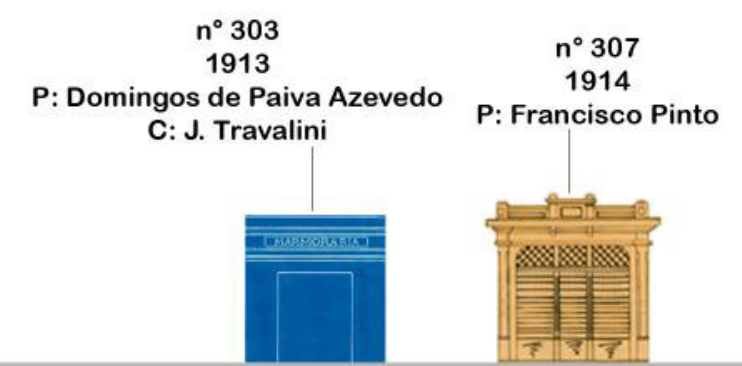

\section{AVENIDA RANGEL PESTANA}
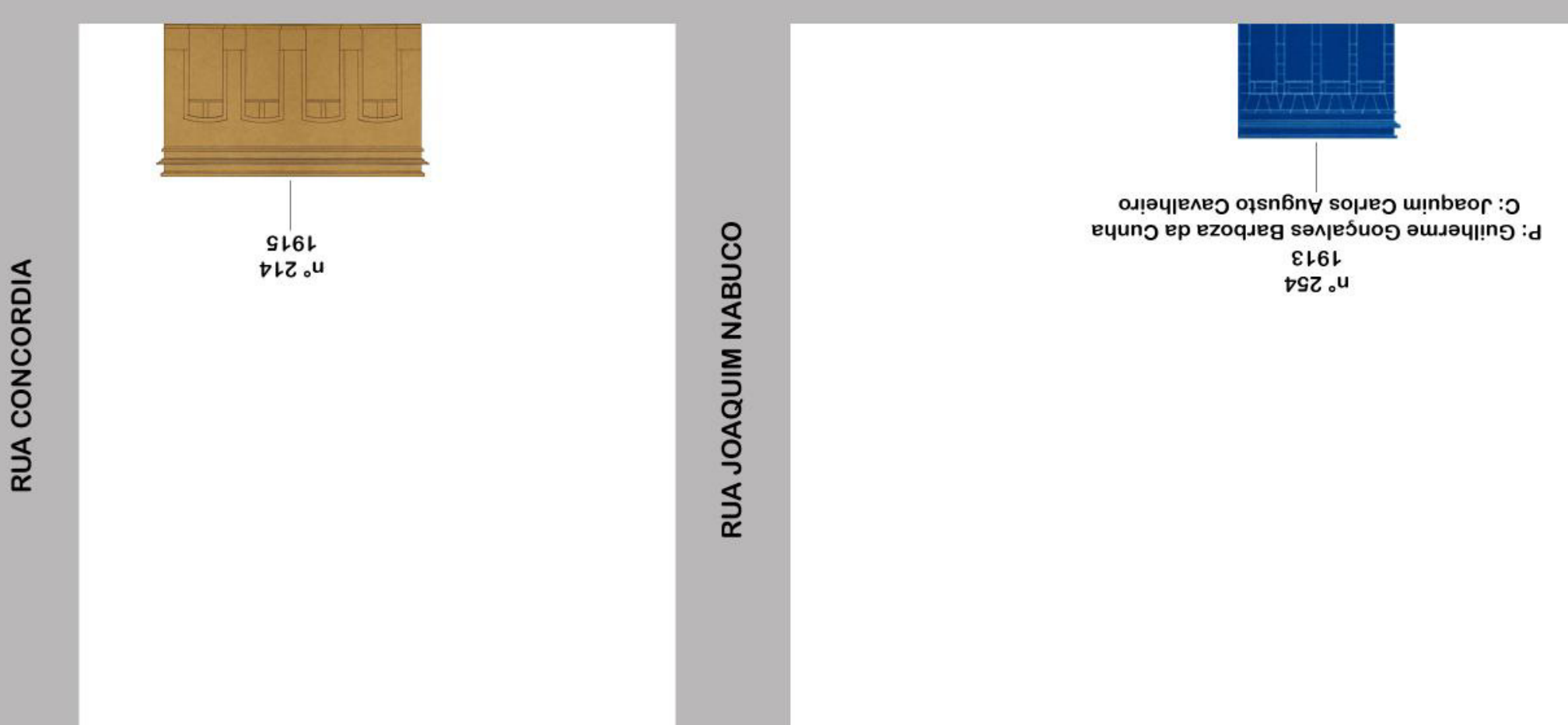


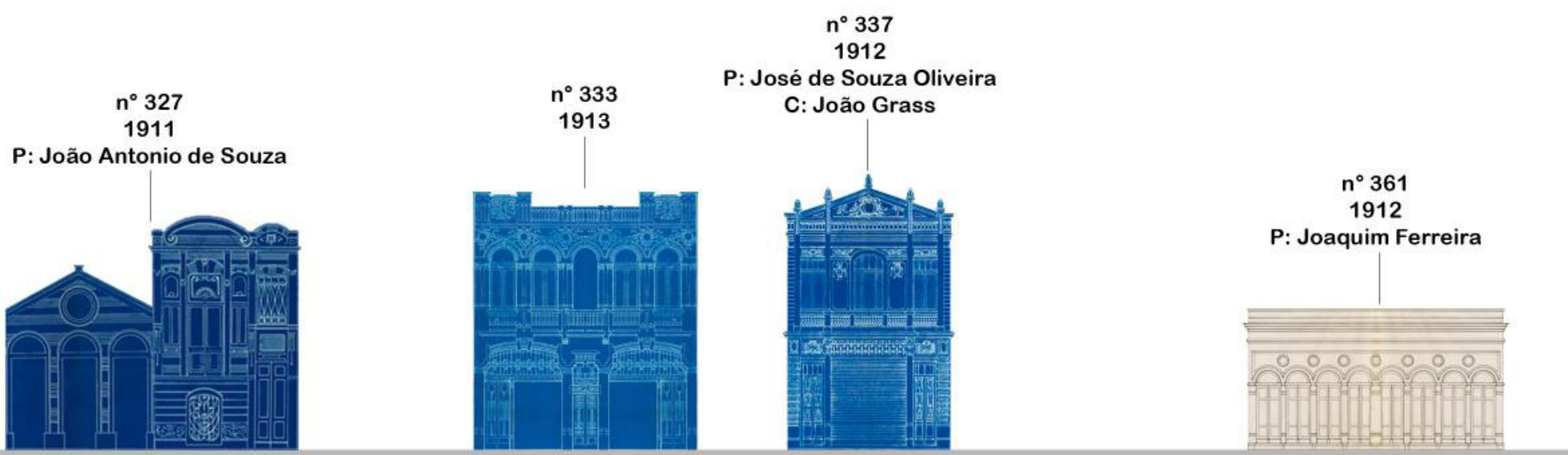

\section{AVENIDA RANGEL PESTANA}

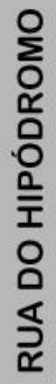

ęsoo oos!̣ouedy oluoguy :d SL6L 
$n^{\circ} 37$

1912

P: Domingos Consiglio

n'39 A

1915 P: Companhia Nacional P: Raphael Avino de Tecidos de Juta

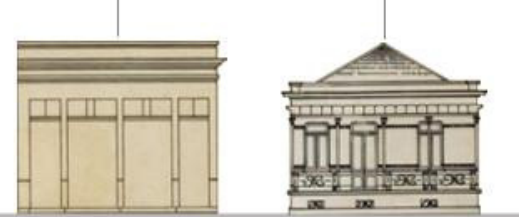

1911

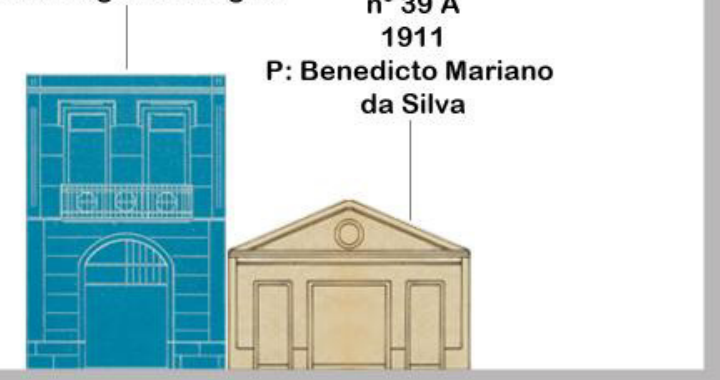

AVENIDA CELSO GARCIA
ఫ্

$n^{\circ} 77$ P: Armindo Ancke

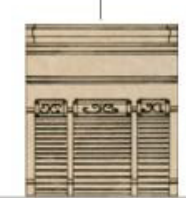

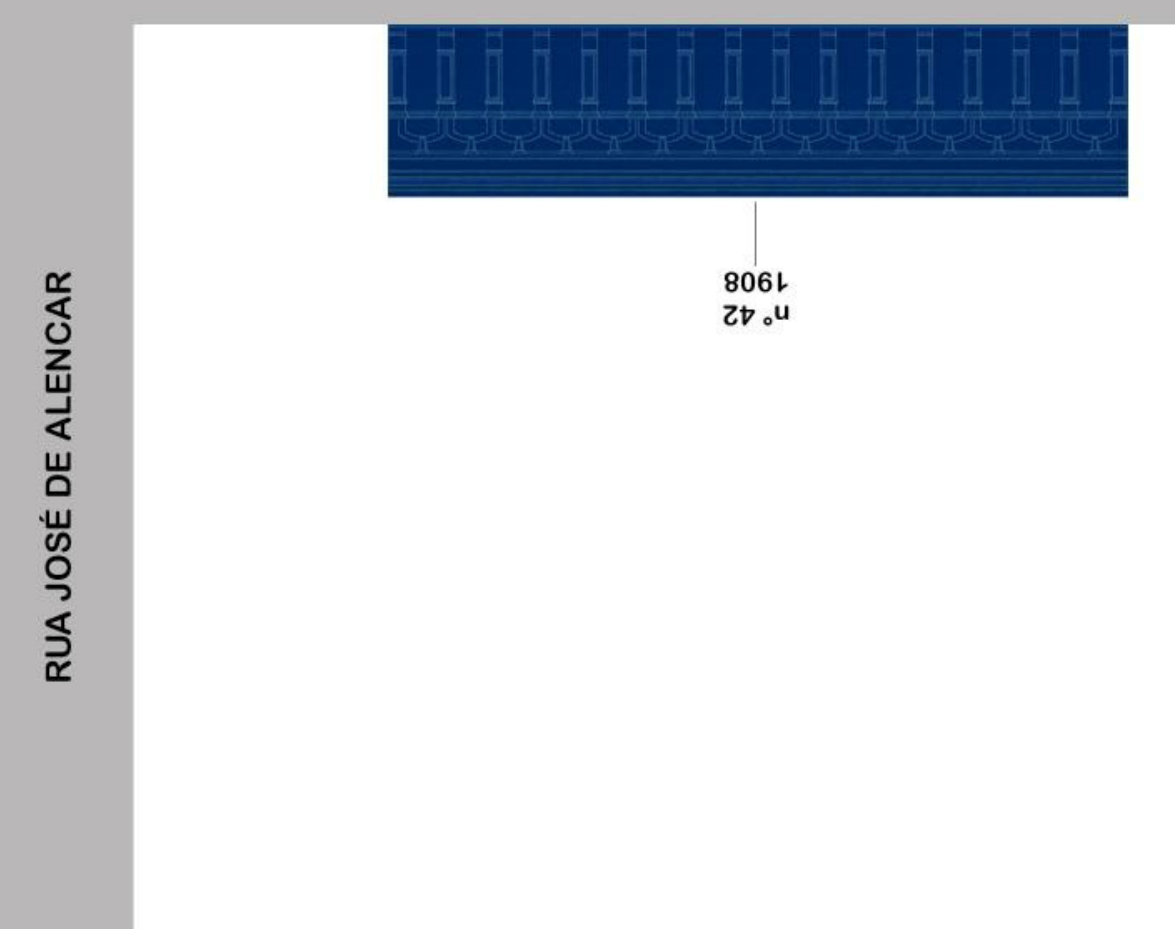

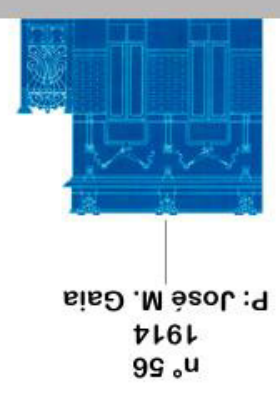




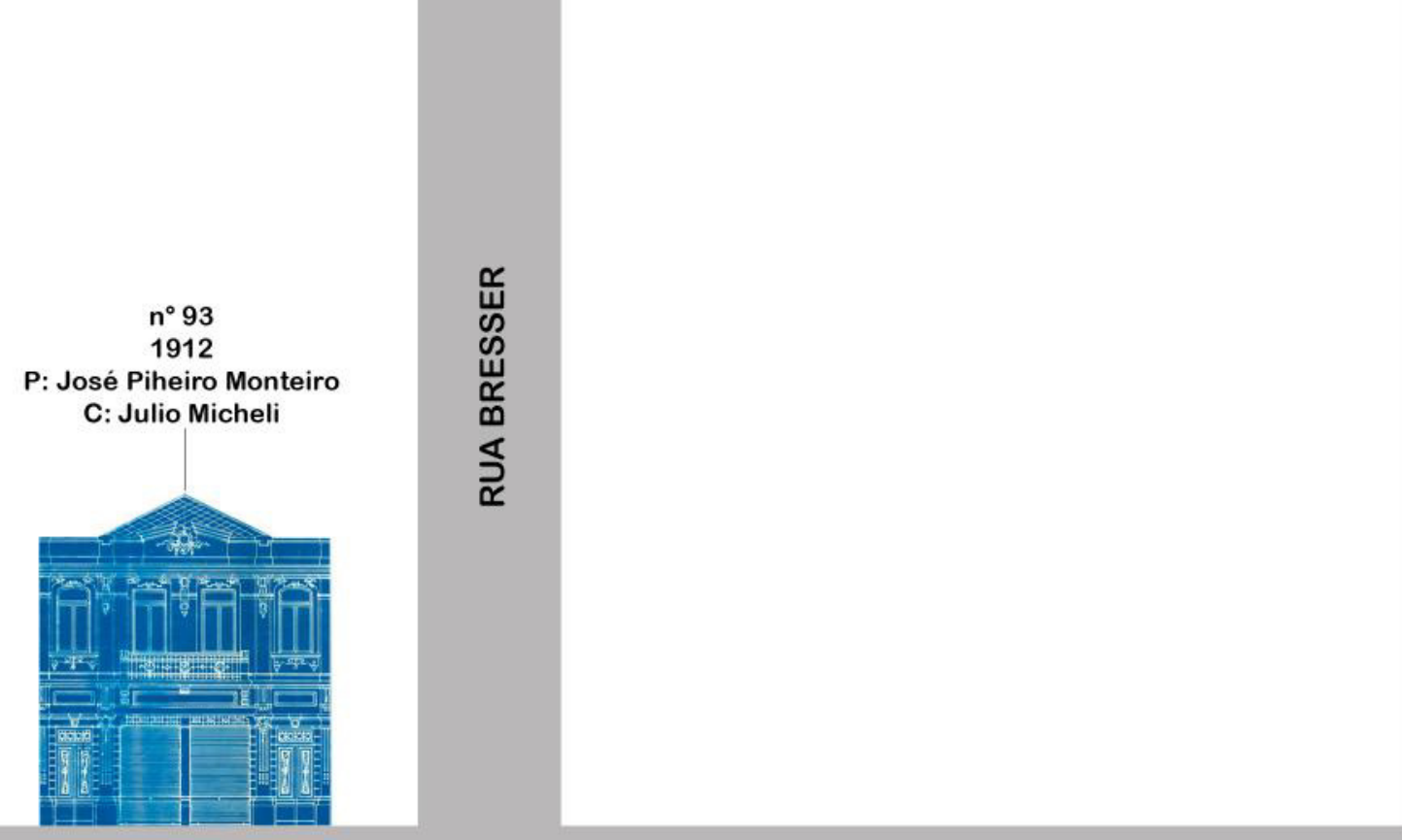

\section{AVENIDA CELSO GARCIA}
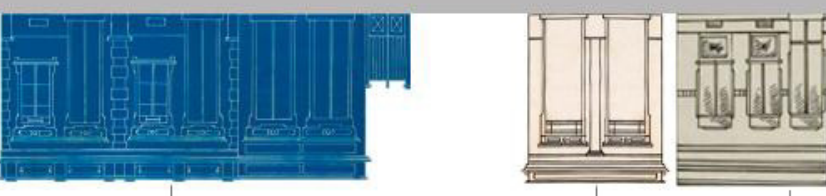

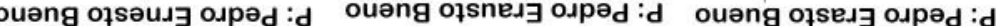

$$
\text { ZL6L }
$$

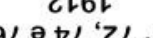

EL6

SL6t

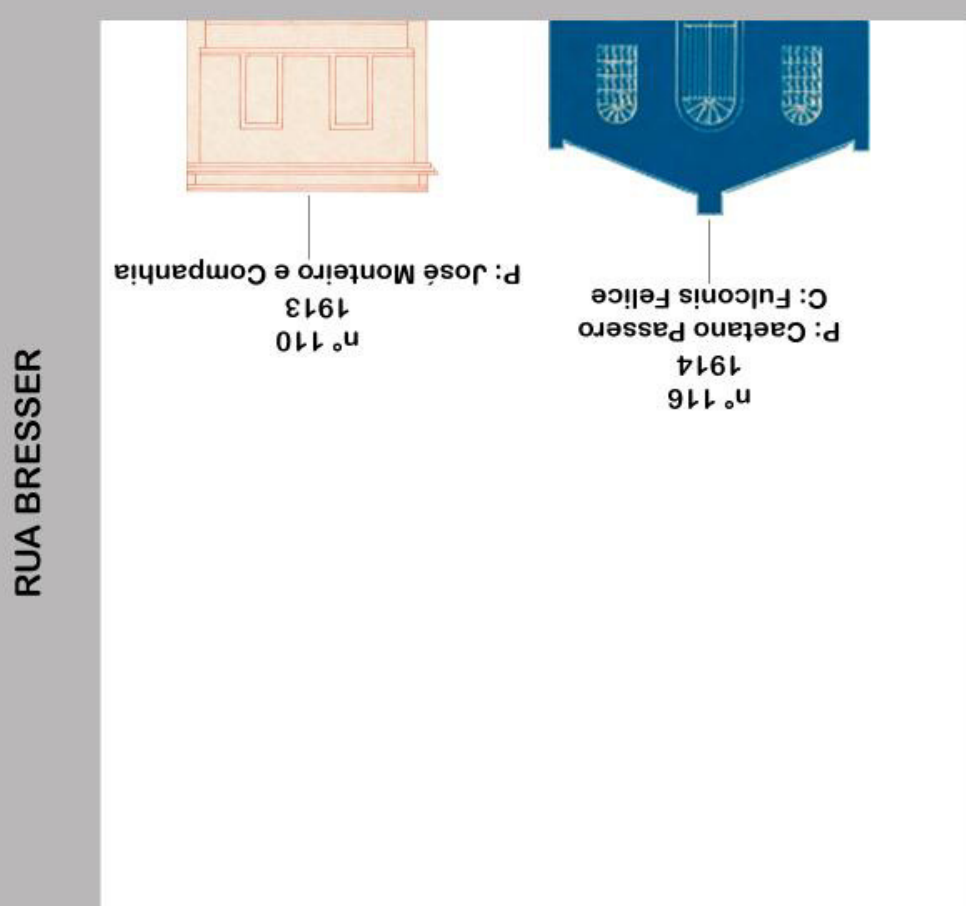

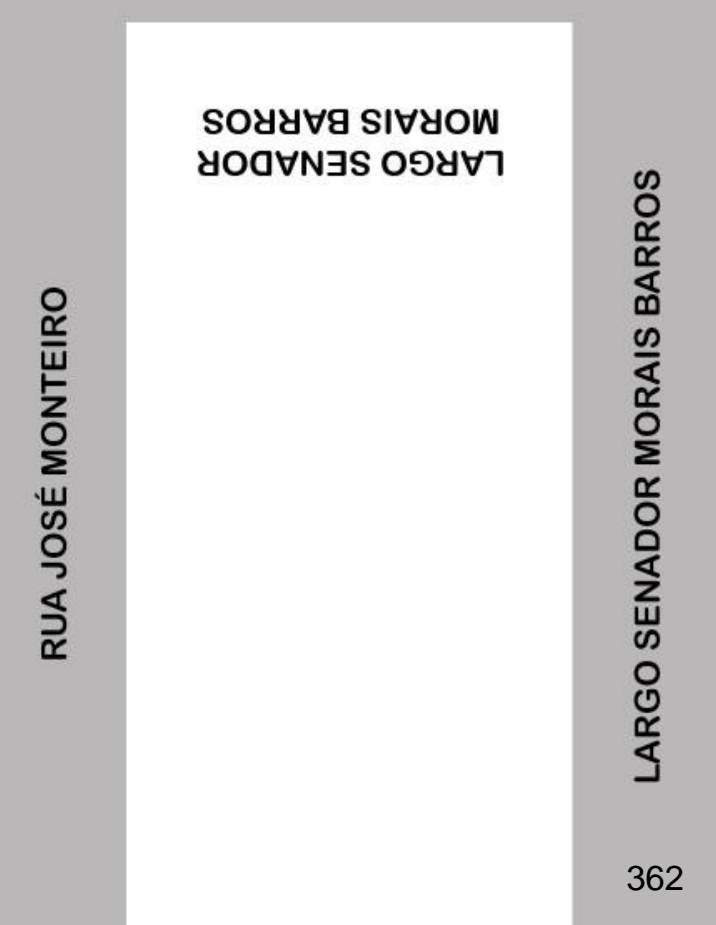


n०149

1913

: Mendonça Bravo e Companhia

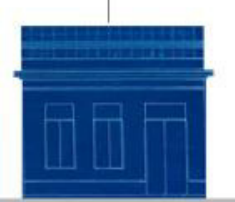

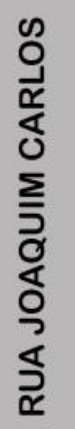

$n^{\circ} 155$

P: João Cardoso Primo

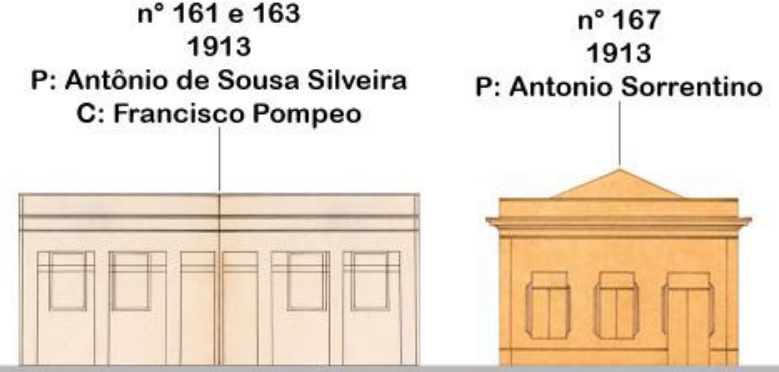

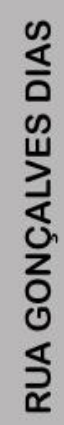

$n^{\circ} 197$ P: José Troise

\section{AVENIDA CELSO GARCIA}
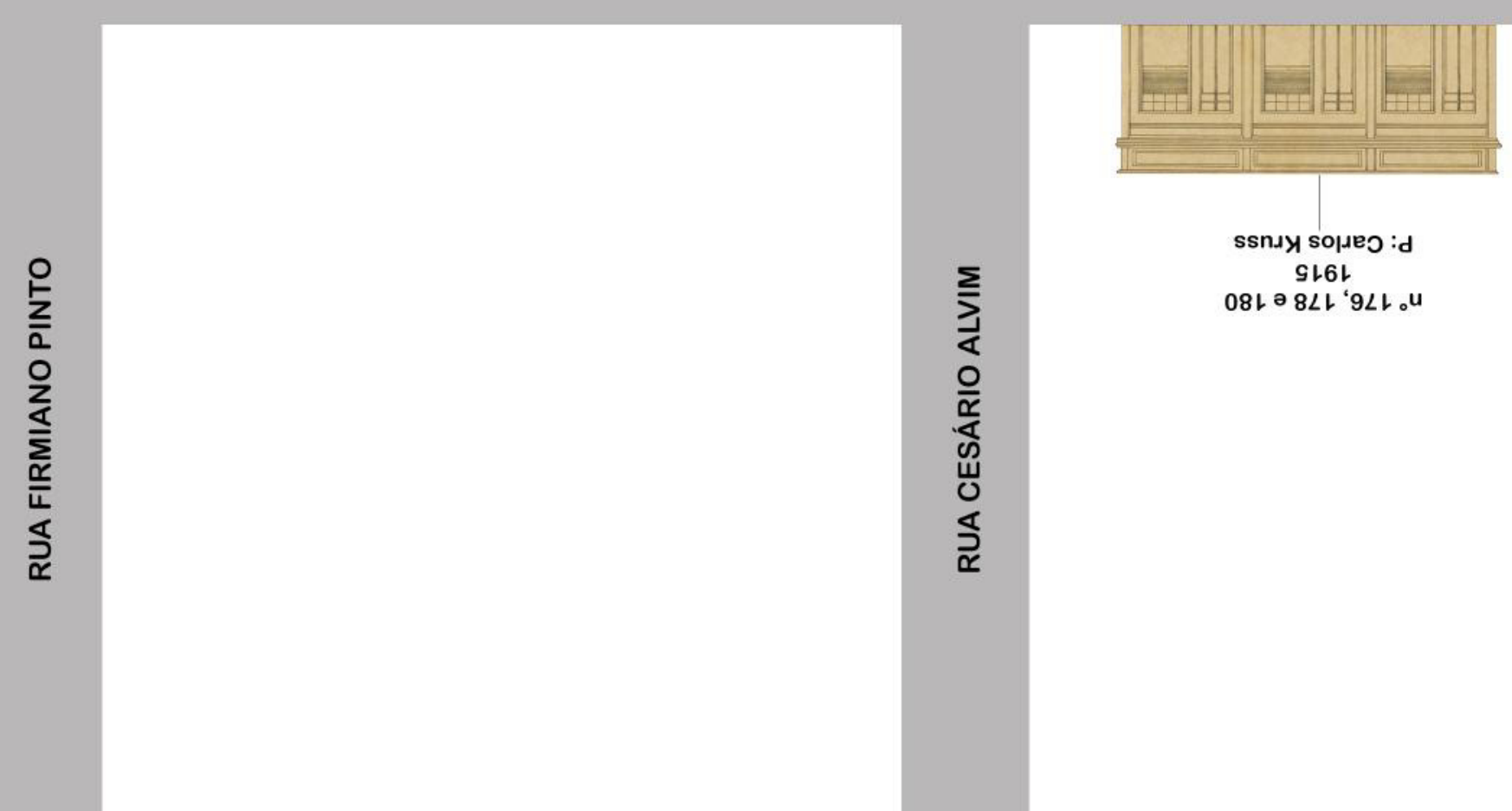

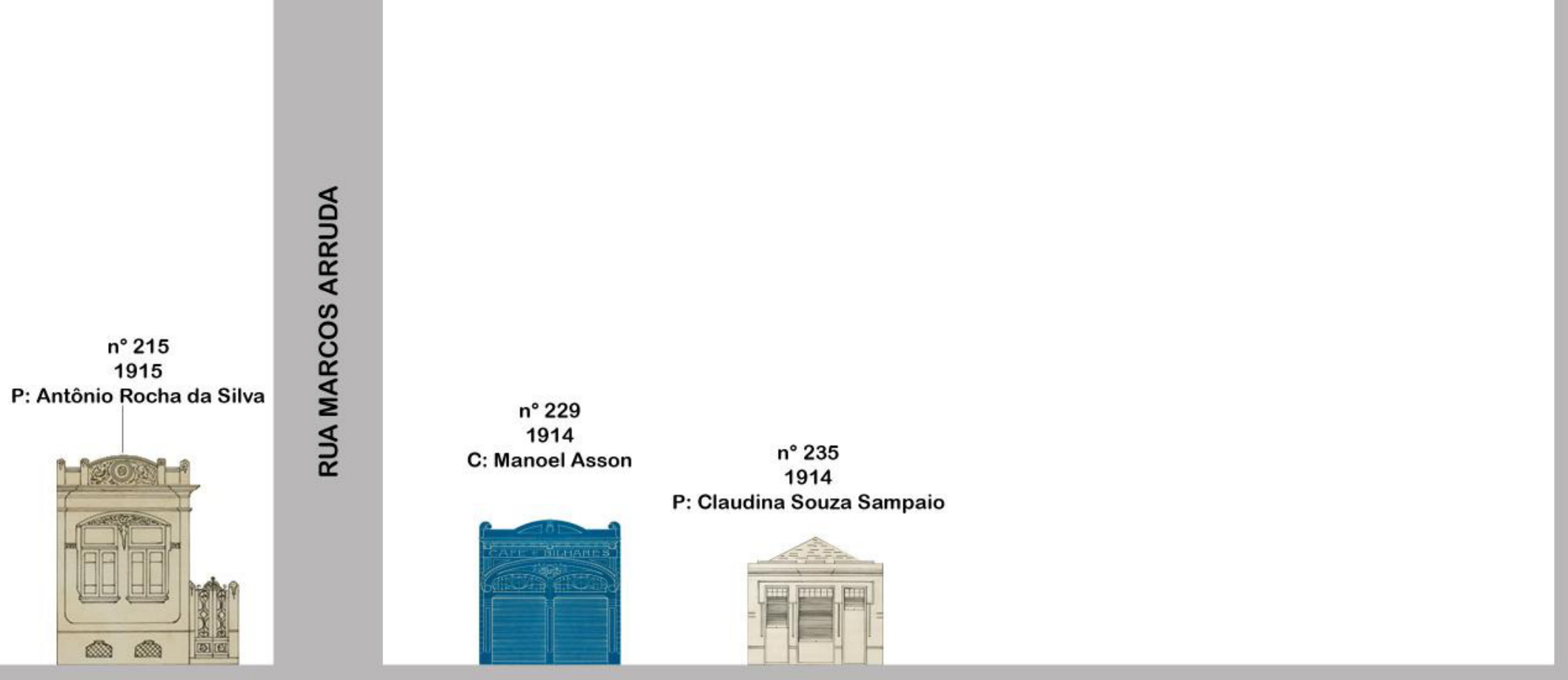

\section{AVENIDA CELSO GARCIA}
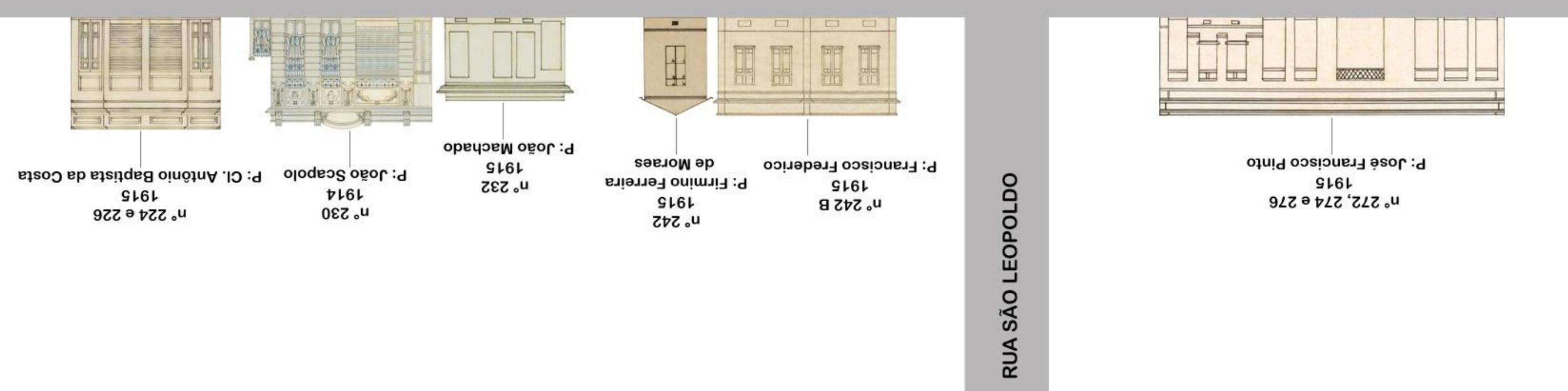
$n^{\circ} 303$ e 305

1915

P: Joaquina Francisca P: Joaquina Francisca de Paiva

de Paiva
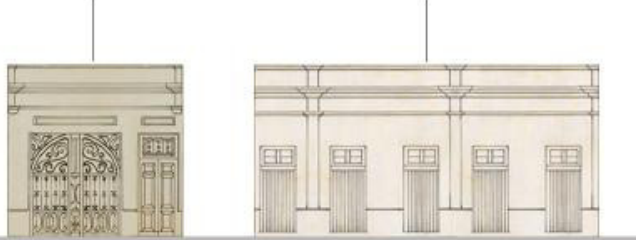

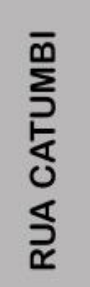

$n^{\circ} 311$ e 317

1915

P: Manoel Ramos Marques

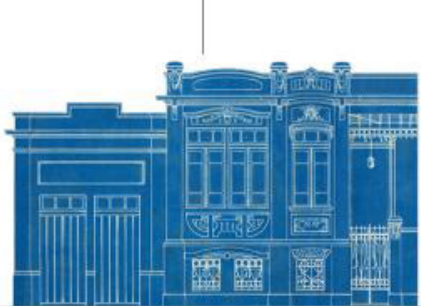

AVENIDA CELSO GARCIA

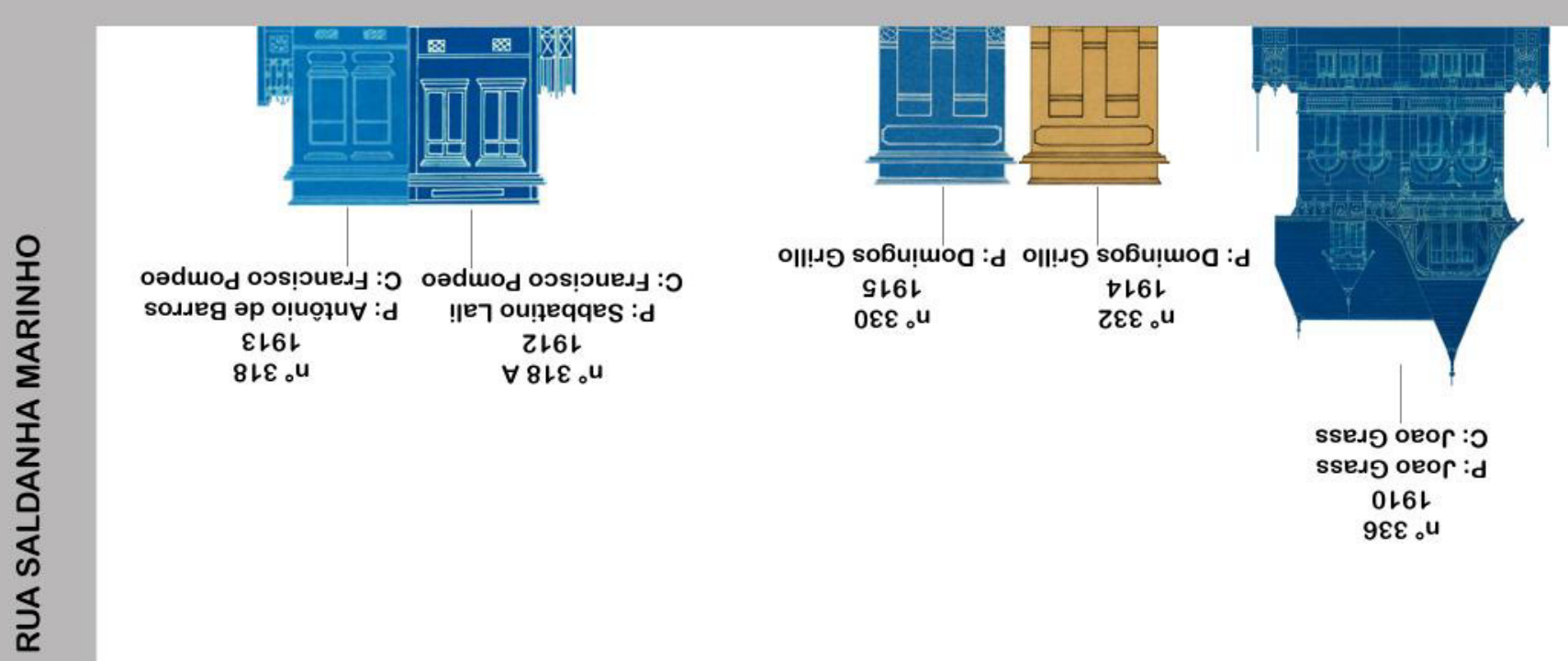



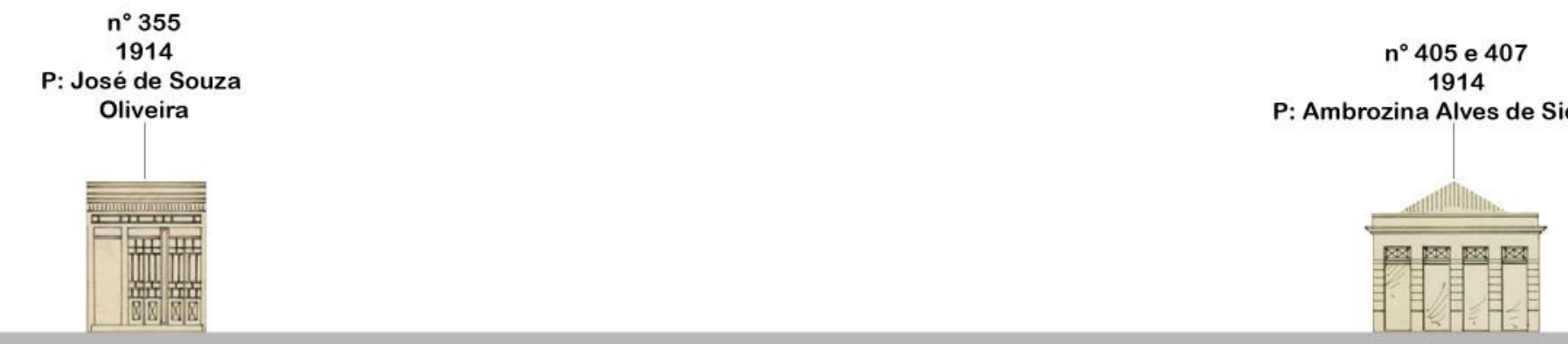

\section{AVENIDA CELSO GARCIA}
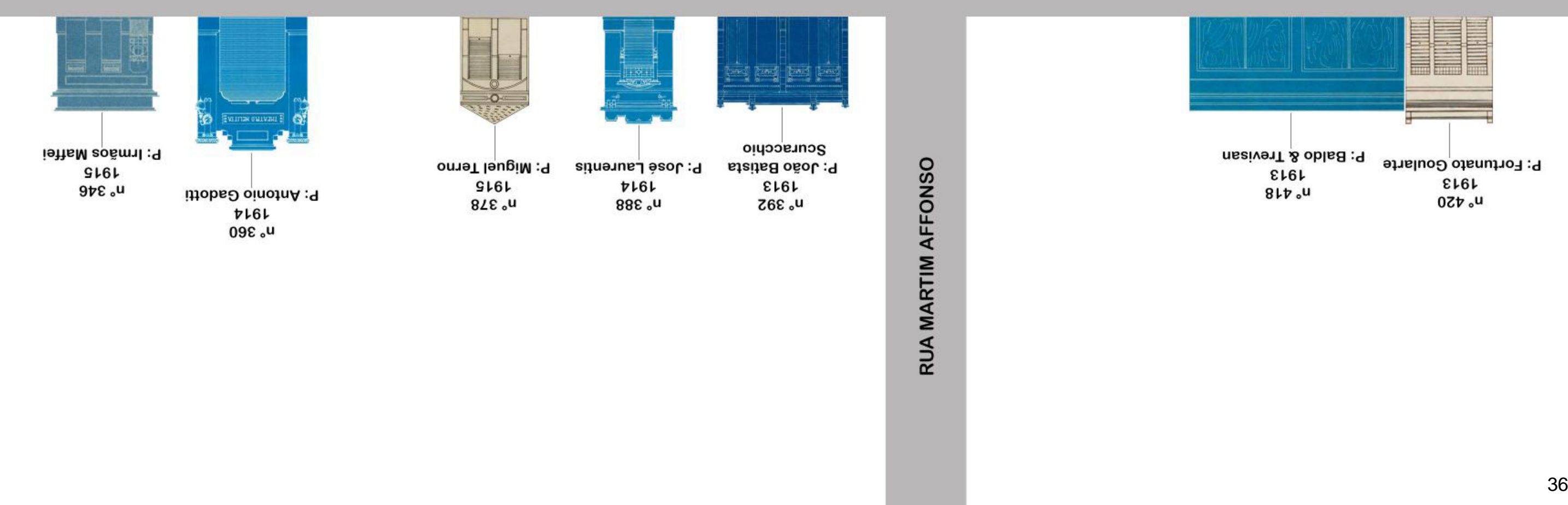


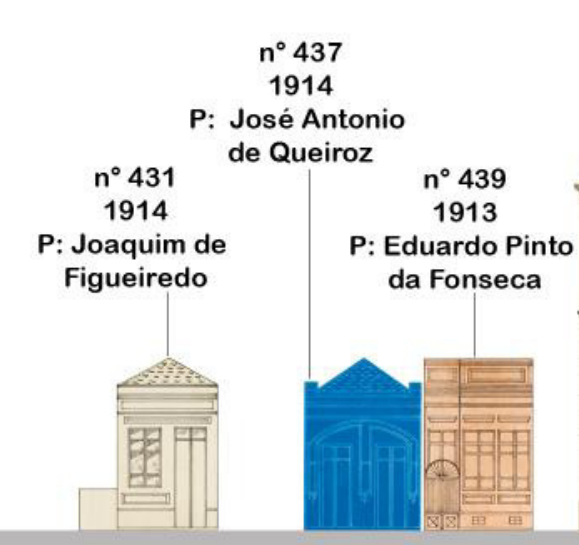



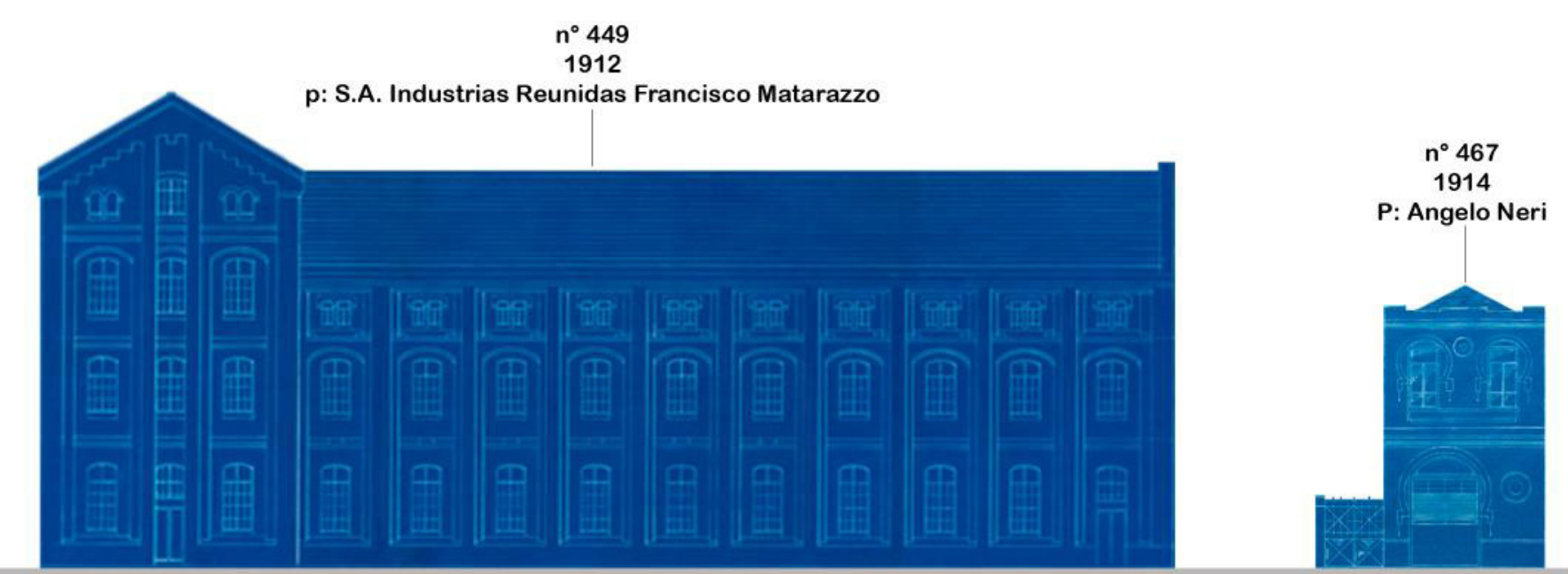

INSTITUTO DISCIPLINAR

\section{AVENIDA CELSO GARCIA}
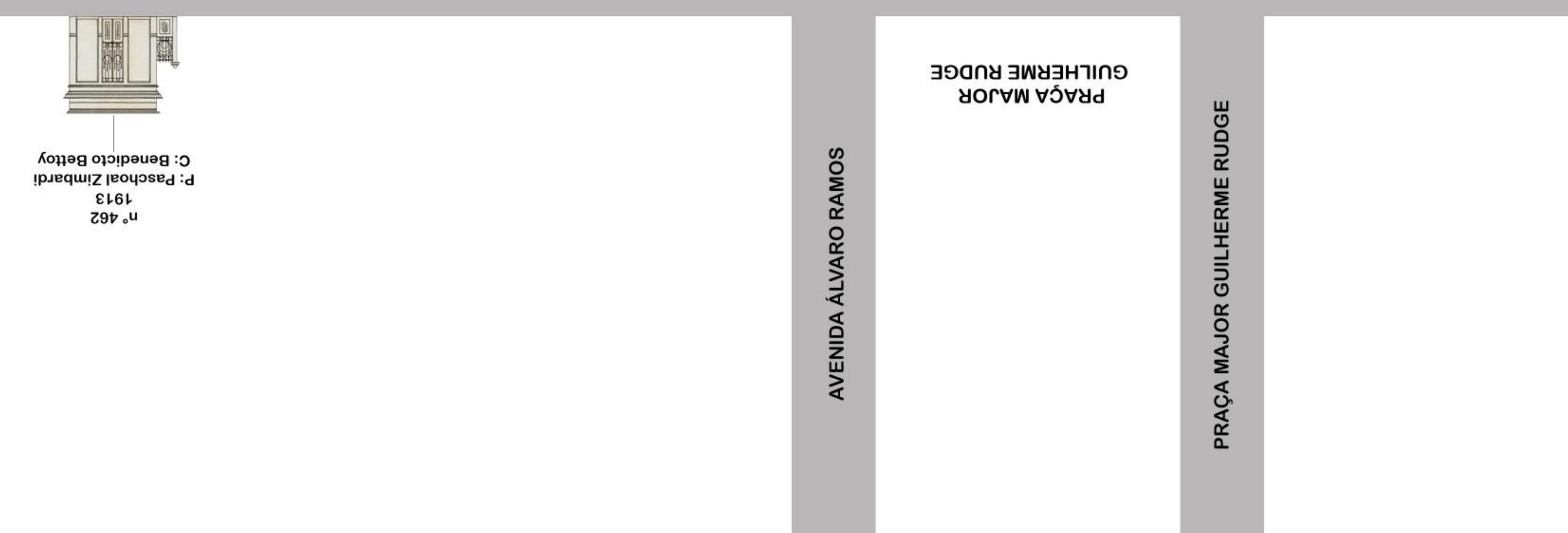


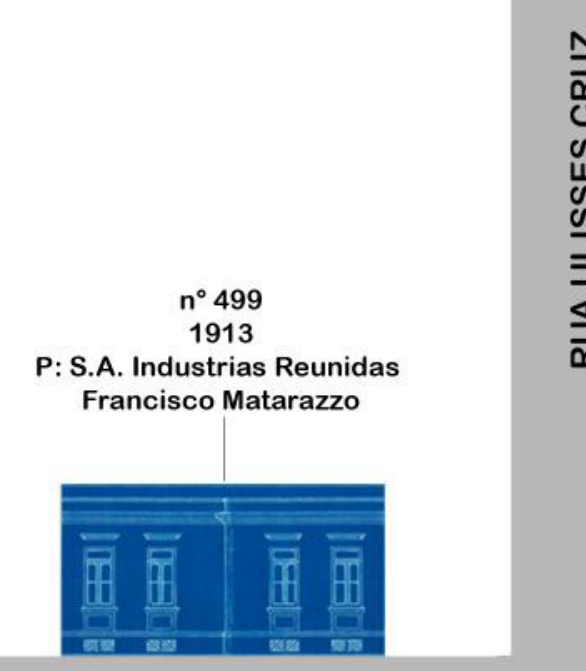

\section{AVENIDA CELSO GARCIA}

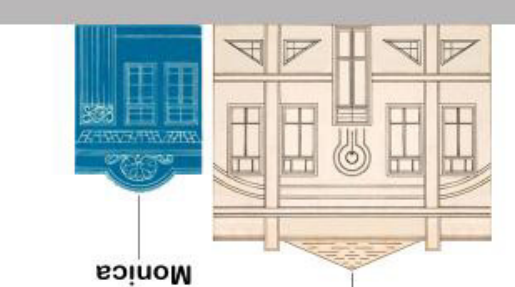

E\|əo osuoH $\forall: d$

EL6L

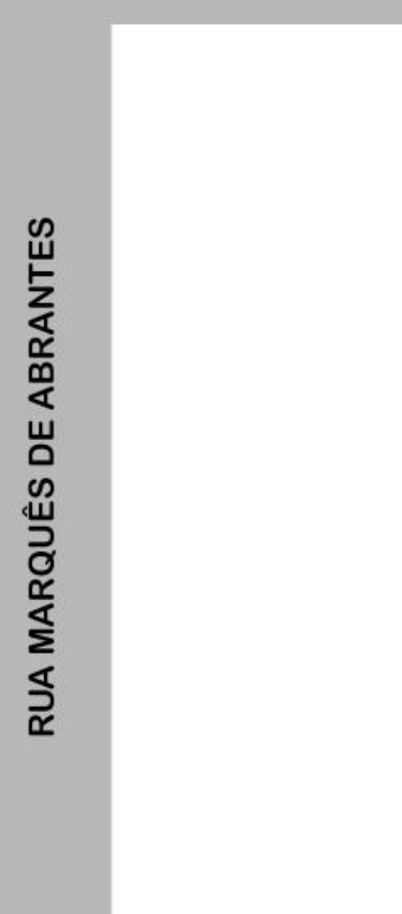

esoqueg sobu!moo :d EL6เ

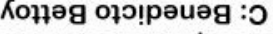

opseuseg jəeydey :d

EL6L 


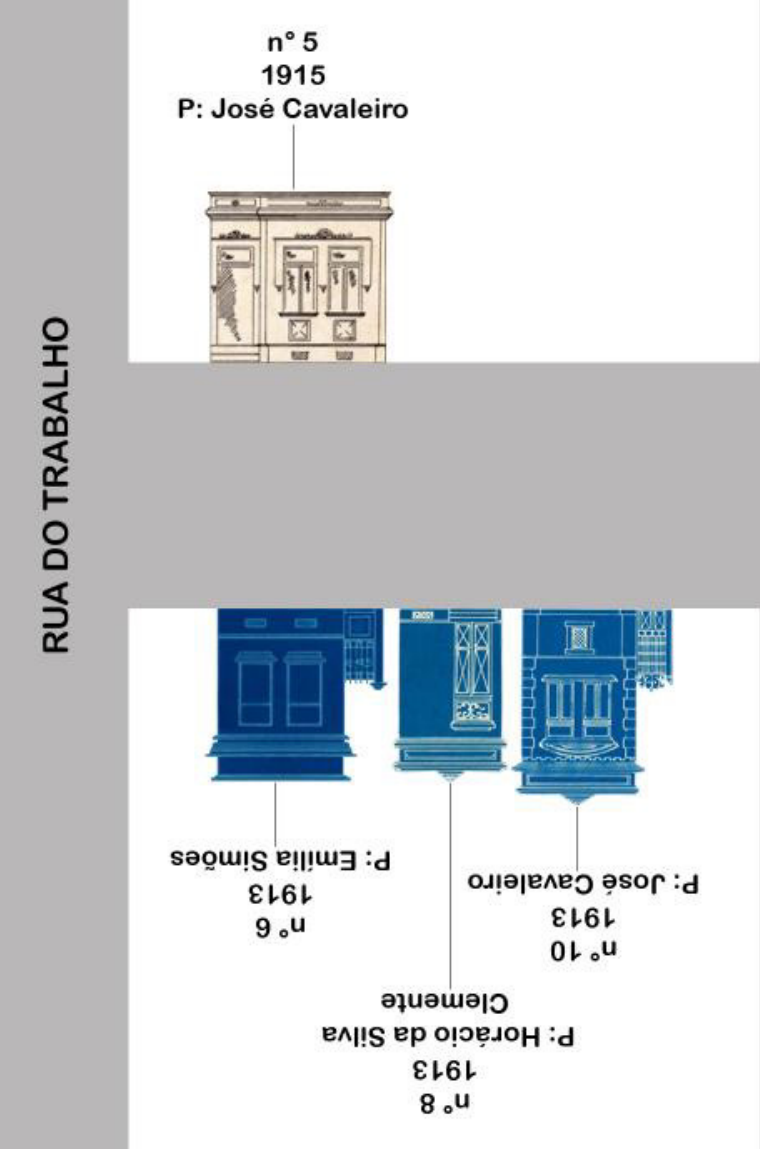

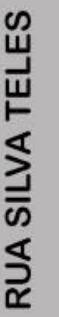

$n^{\circ} 55$

P: Francisco Maria Pardal
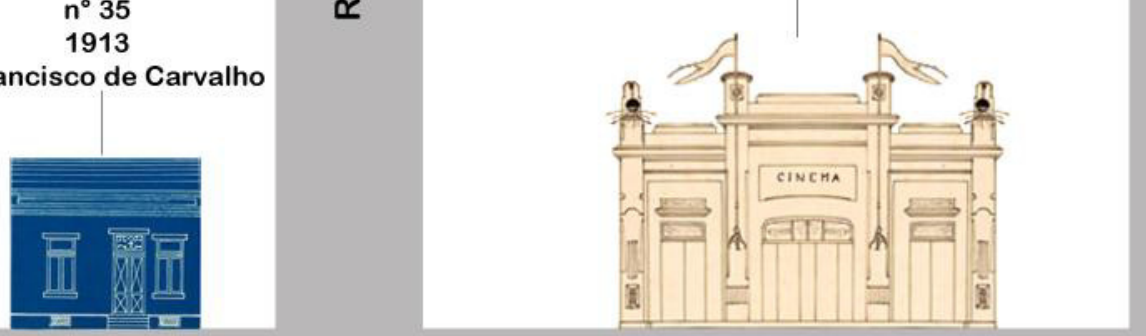

\section{RUA BRESSER}

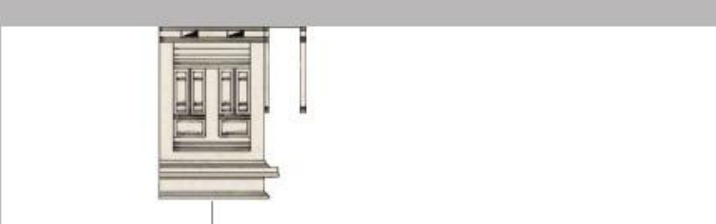

оч|елде әр ןоouew :d

$$
\text { SL6 }
$$




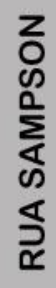

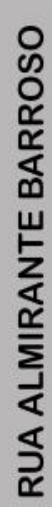

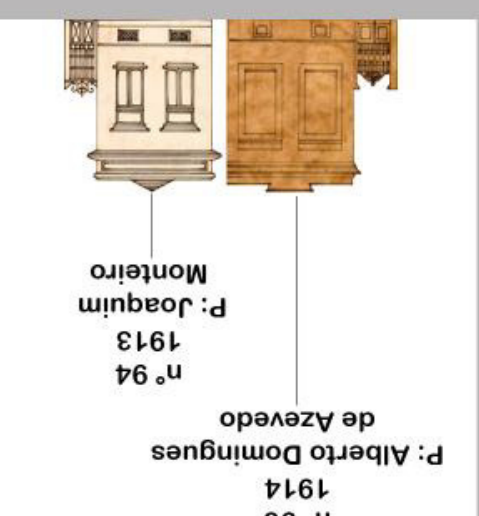

tᄁt6!

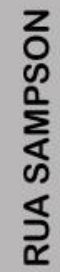

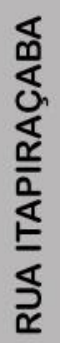
P: Charles Weiler

onstantin

$n^{\circ} 125$

P: Manoel Ferreira
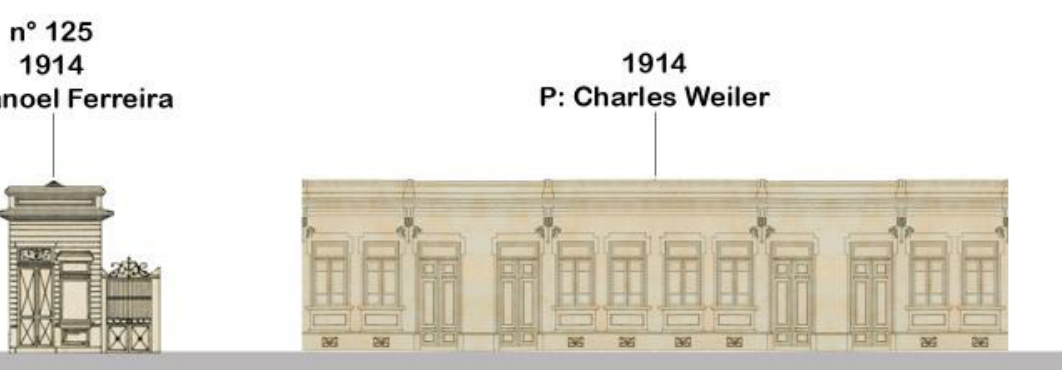

RUA BRESSER

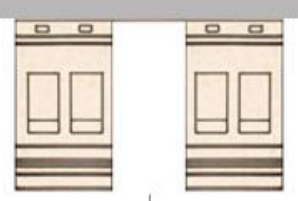

Eג!̣ı!!IO solues sop |ney : eu! 7 eNI!S ep u!nbeor :d

$$
\text { tL6 }
$$

カtト əてtレ。U

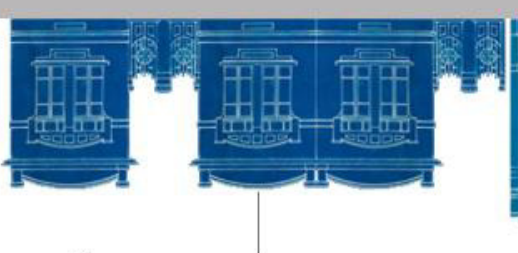

Kqn!ej sajeos орлејәр $\forall$ eu! 7 в

$$
\text { EL6L }
$$

ZSL。U

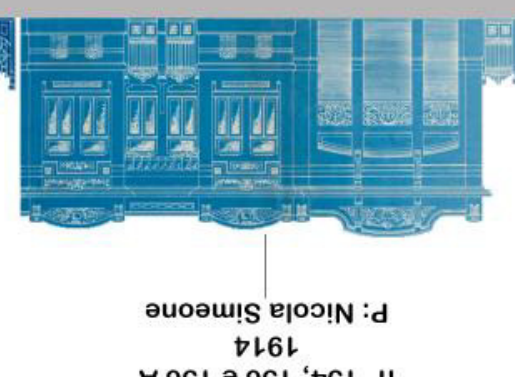

$\forall 9 S$ ə $9 G L$ ' $\forall G L_{0} \mathrm{U}$

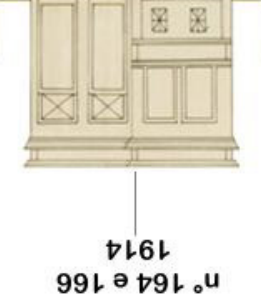

$99 L$ ə $จ 9$ 。

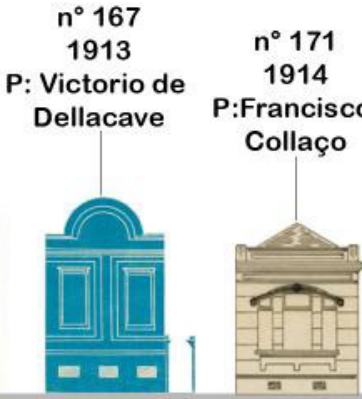



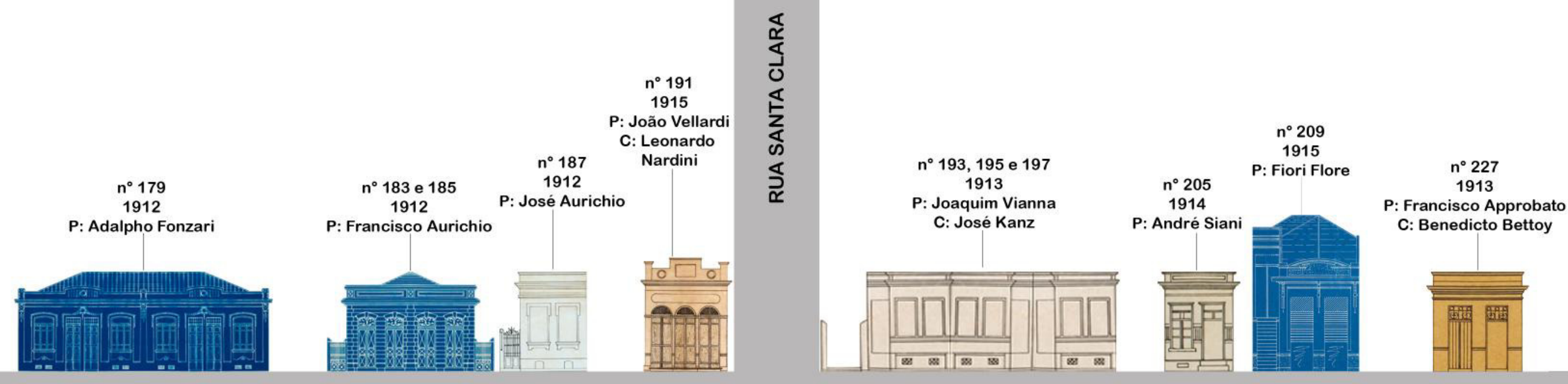

\section{RUA BRESSER}

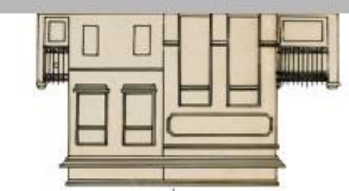

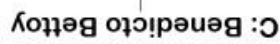

o!̣o! jeoyosed :d

$$
\text { tr6L }
$$

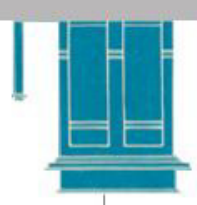

оu!|олsә ор|еләэ :d

$$
\text { tᄂ6L }
$$

06 ou essə। $z ! n \cap 7: d$

0ᄂ6L

96เ ə จ6เ'Z6เ。u

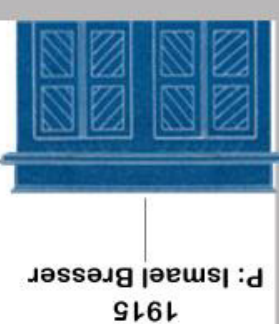

SL6L 


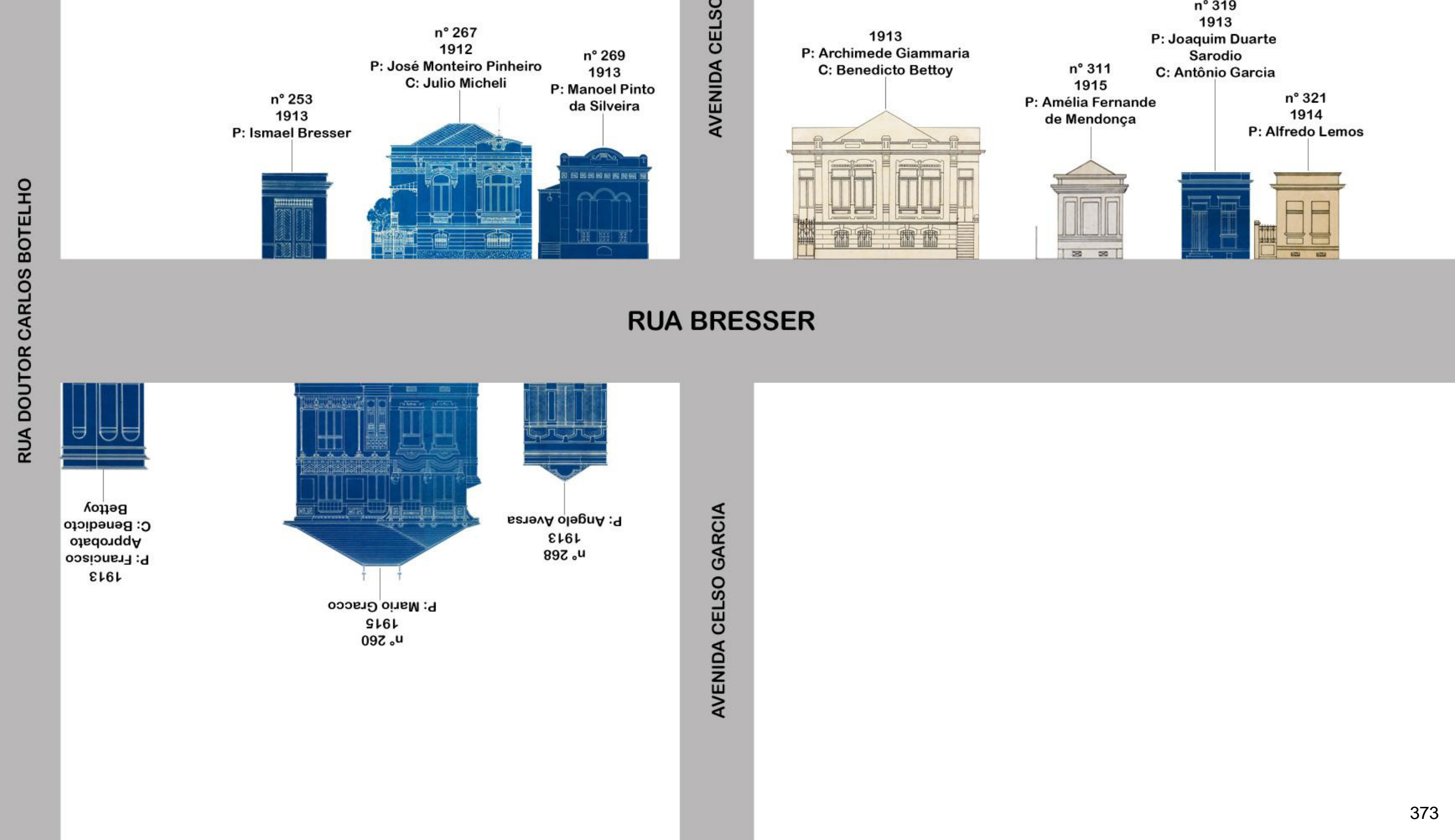




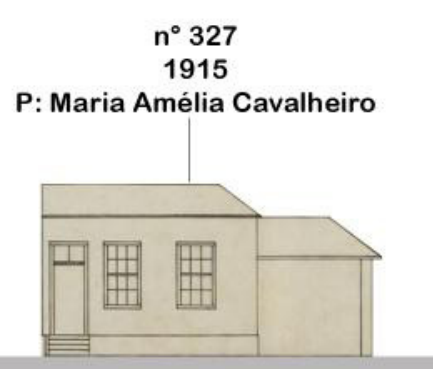

\section{RUA BRESSER}

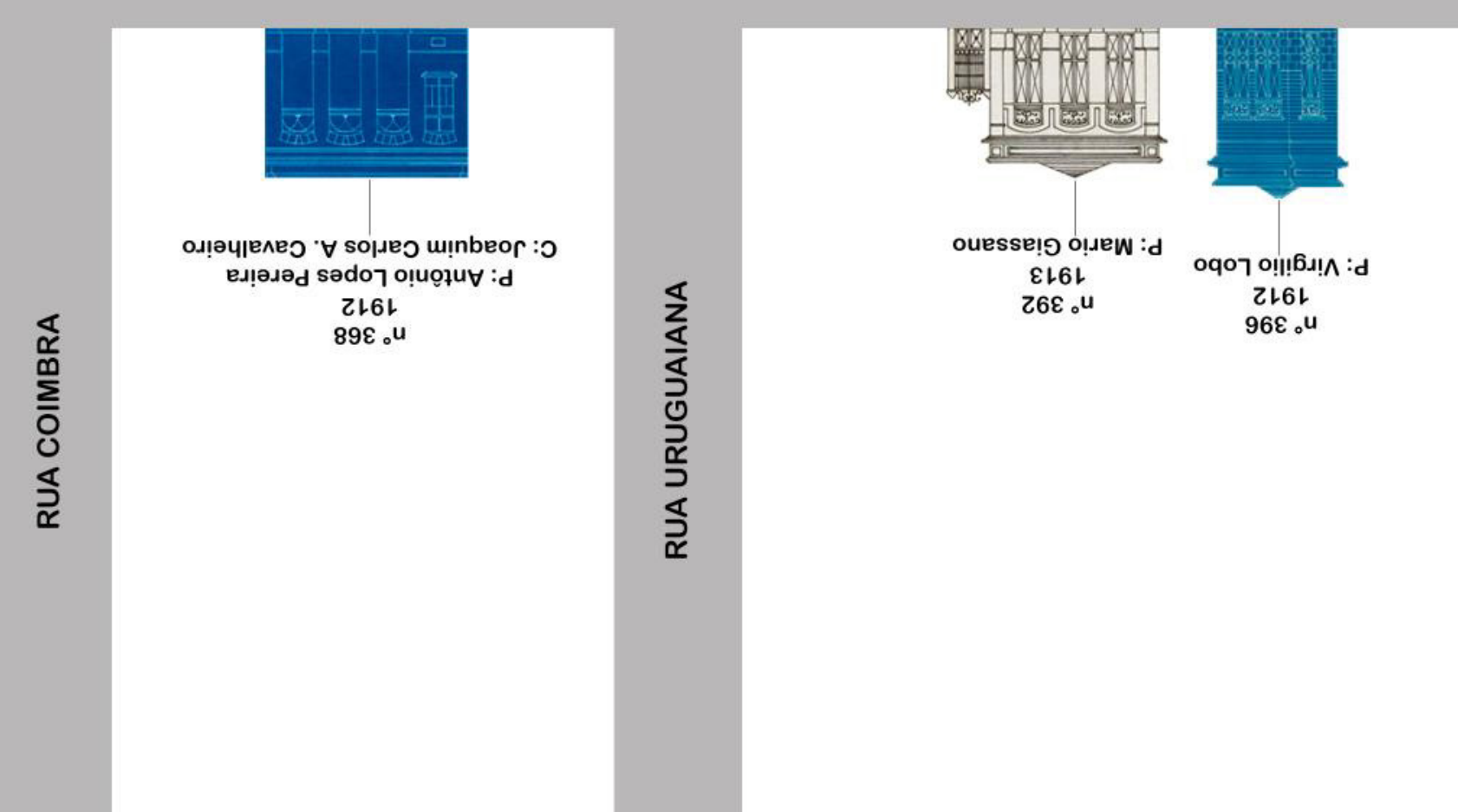


$n^{\circ} 433$

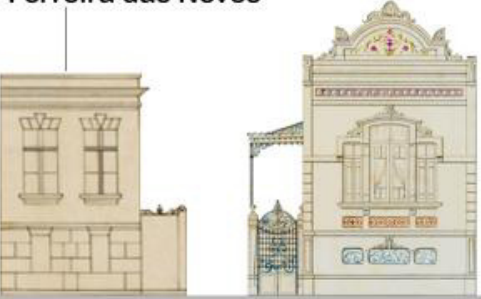

José Antônio de Souza Marquez

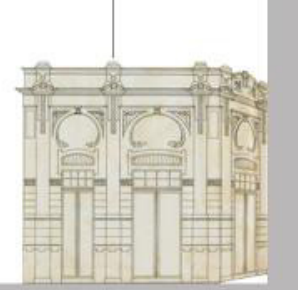

P: Leone Sonsini

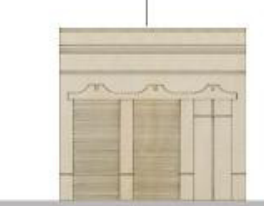

P: Joaquim Pereira

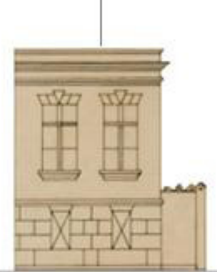

\section{RUA BRESSER}

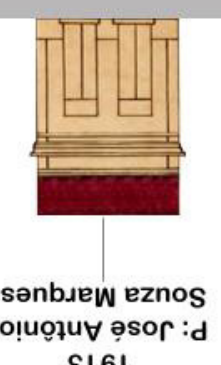

ọuogu $\forall$ ọsor :d

Eเ6L

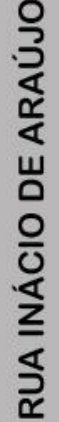
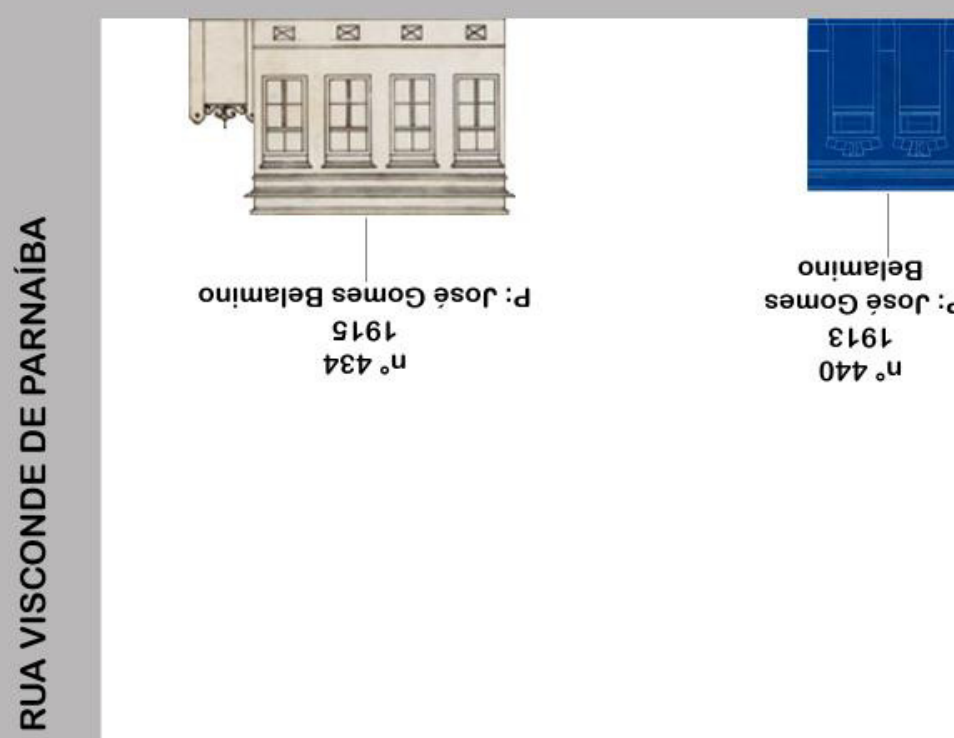

ou!mejəg

$$
\text { EL6เ }
$$




\section{RUA BRESSER}

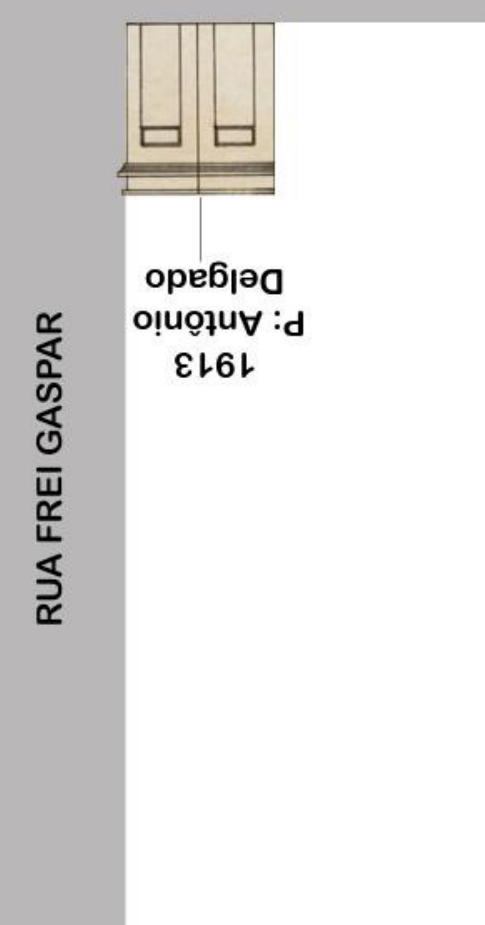
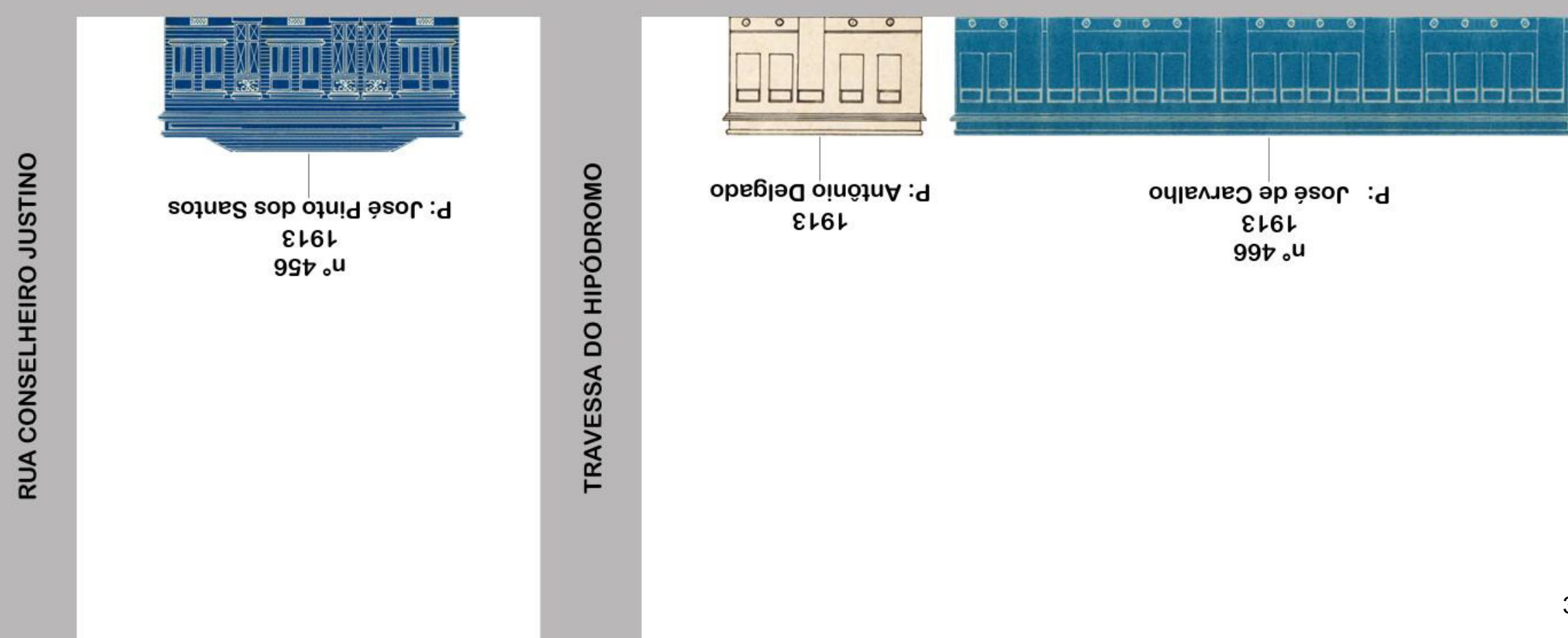


\section{RUA BRESSER}

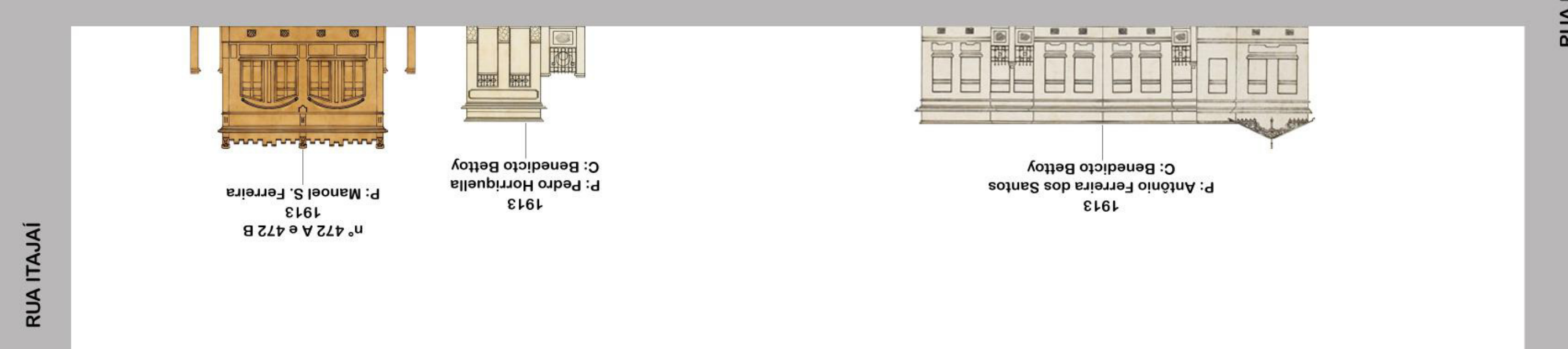




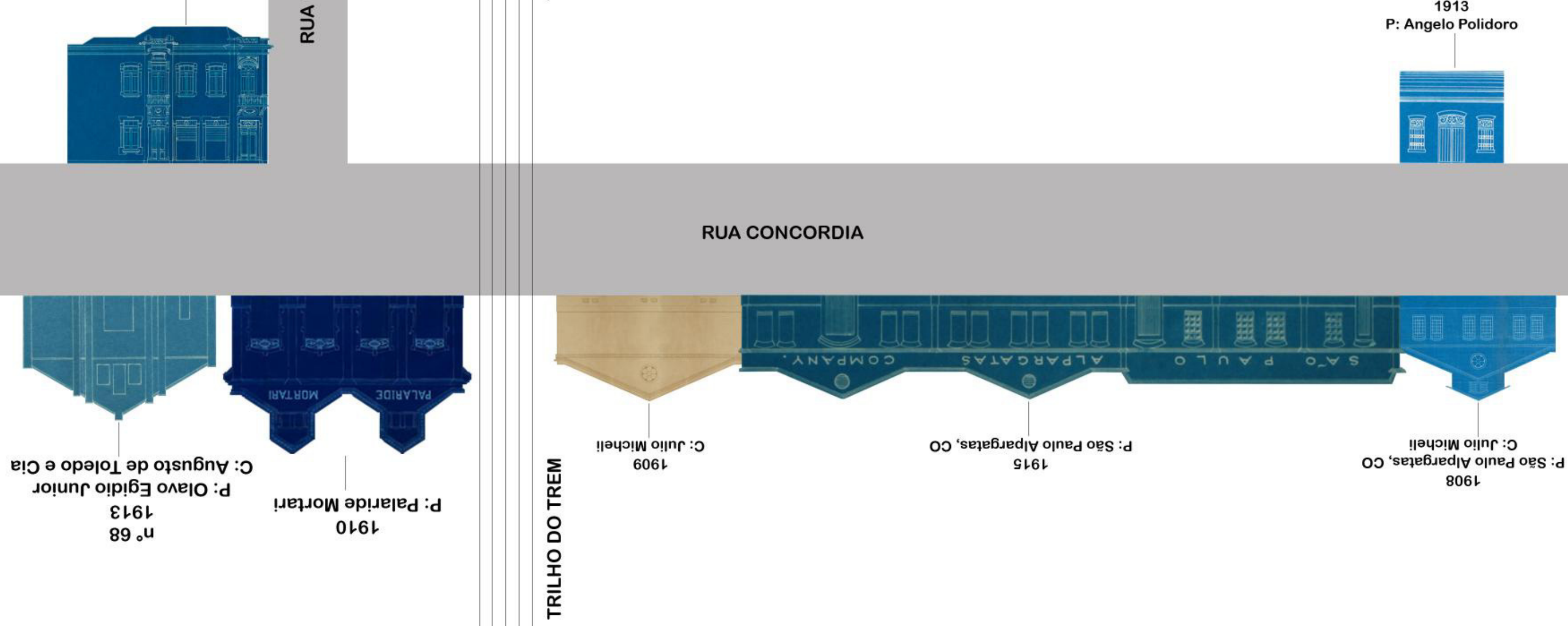
$n^{\circ} 215-217$

1913

$$
\begin{gathered}
n^{\circ} 179 \\
1913
\end{gathered}
$$

1914

P: Antonio Mariano de Camargo

$n^{\circ} 213$

P: Leonor Monteiro da Silva

P: André Padilha

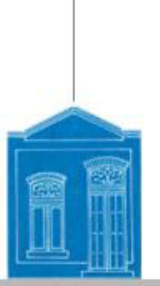

1915

P: Leonor Monteiro da Silva
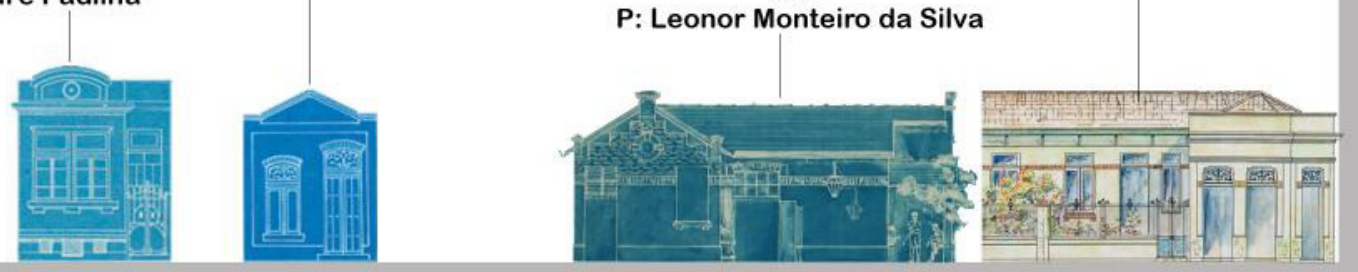

RUA CONCORDIA

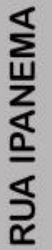

$\mathrm{n}^{\circ} 241$

P: Elessio Andreon

C: Benedicto Bettoy

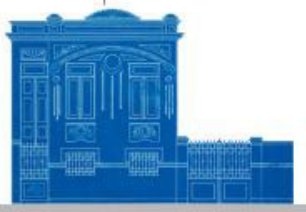

$n^{\circ} 283$

1914

P: Julia Licardi

C: Francisco Di Pale

$$
n^{\circ} 269
$$

1915

P: João Kubenik
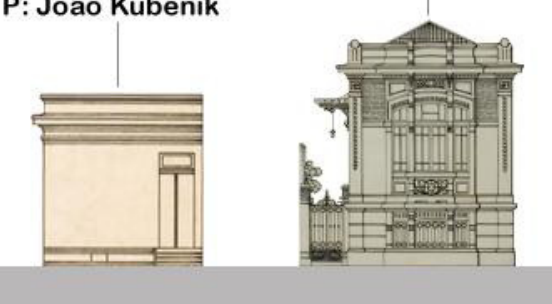

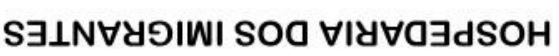





\section{RUA MARIA MARCOLINA}

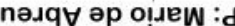$$
\text { SL6L }
$$

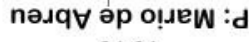

$$
\text { SL6L }
$$

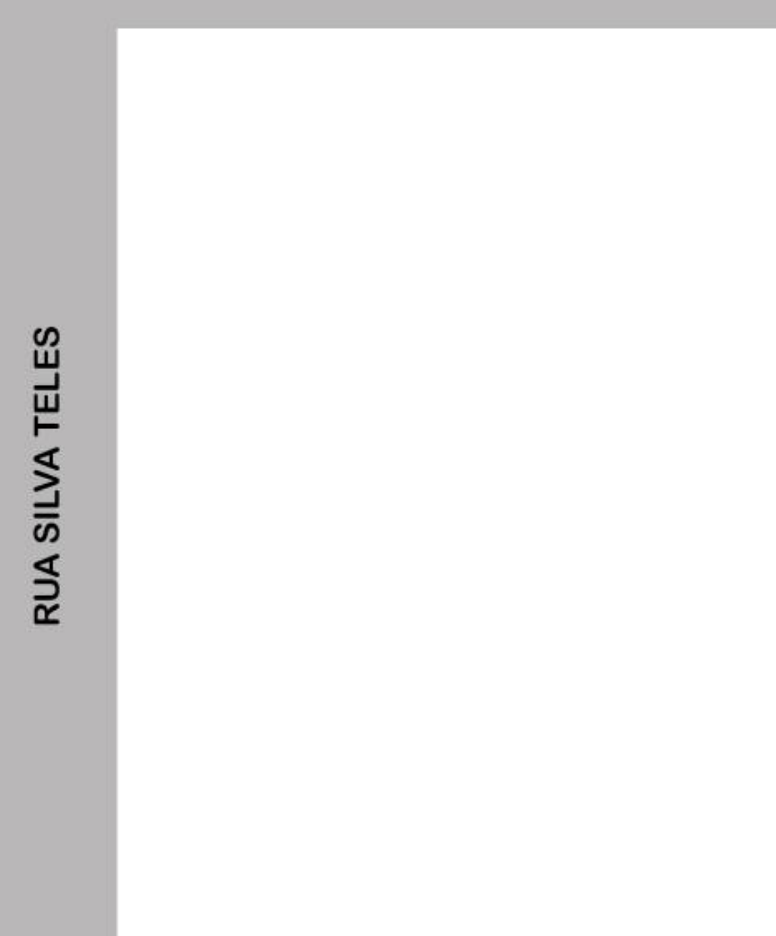




\section{$\mathrm{n}^{\circ} 39$}

P. Rosa 1913

$$
\begin{aligned}
& \text { Gomes } \\
& \text { Coma de }
\end{aligned}
$$

$n^{\circ} 45$

1914

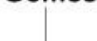

P: José Villa

e Irmão

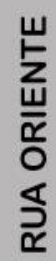
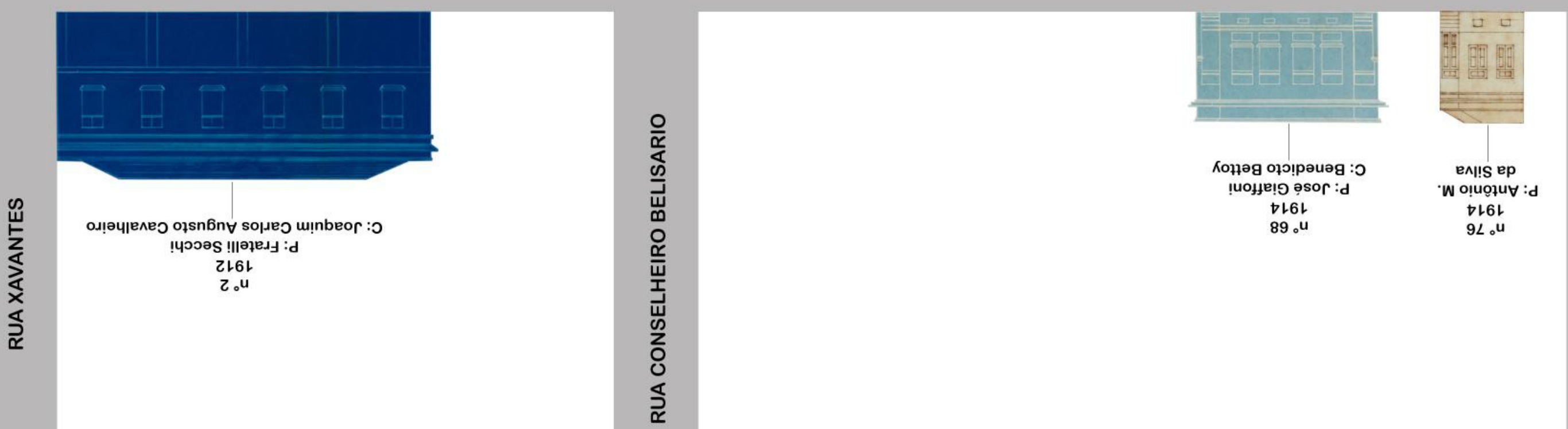


\section{RUA MILLER}

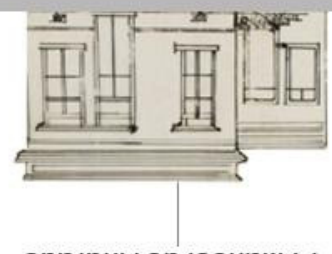

әрелpu $\forall$ әр ןәоиеW :d †L6L
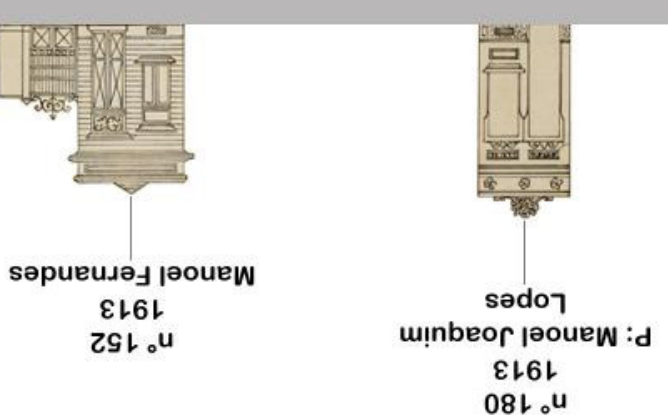

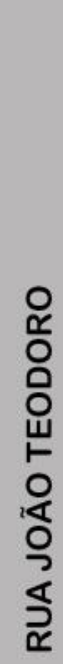

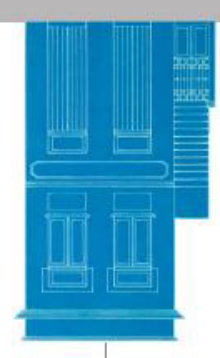

орәләz $\forall$ әр е!леW :

tL6L
$\mathrm{ZOZ}$ 。u

$\mathrm{zOz} \mathrm{u}$

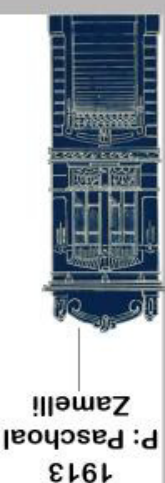

